\title{
De hygienisten : artsen, staat en volksgezondheid in Nederland, 1840-1890
}

Citation for published version (APA):

Houwaart, E. S. (1991). De hygienisten : artsen, staat en volksgezondheid in Nederland, 1840-1890.

[Doctoral Thesis, Maastricht University]. Rijksuniversiteit Limburg.

https://doi.org/10.26481/dis.19910412eh

Document status and date:

Published: 01/01/1991

DOI:

10.26481/dis.19910412eh

Document Version:

Publisher's PDF, also known as Version of record

\section{Please check the document version of this publication:}

- A submitted manuscript is the version of the article upon submission and before peer-review. There can be important differences between the submitted version and the official published version of record.

People interested in the research are advised to contact the author for the final version of the publication, or visit the DOI to the publisher's website.

- The final author version and the galley proof are versions of the publication after peer review.

- The final published version features the final layout of the paper including the volume, issue and page numbers.

Link to publication

\footnotetext{
General rights rights.

- You may freely distribute the URL identifying the publication in the public portal. please follow below link for the End User Agreement:

www.umlib.nl/taverne-license

Take down policy

If you believe that this document breaches copyright please contact us at:

repository@maastrichtuniversity.nl

providing details and we will investigate your claim.
}

Copyright and moral rights for the publications made accessible in the public portal are retained by the authors and/or other copyright owners and it is a condition of accessing publications that users recognise and abide by the legal requirements associated with these

- Users may download and print one copy of any publication from the public portal for the purpose of private study or research.

- You may not further distribute the material or use it for any profit-making activity or commercial gain

If the publication is distributed under the terms of Article $25 \mathrm{fa}$ of the Dutch Copyright Act, indicated by the "Taverne" license above, 


\section{DE HYGIENISTEN}

\section{ARTSEN, STAAT EN VOLKSGEZONDHEID \\ IN NEDERLAND 1840-1890}

\section{PROEFSCHRIFT}

ter verkrijging van de graad van doctor aan de Rijksuniversiteit Limburg te Maastricht, op gezag van de Rector Magnificus, Prof.Mr. M.J. Cohen, volgens het besluit van het College van Dekanen, in het openbaar te verdedigen op vrijdag, 12 april 1991 om 16.00 uur

door

EDUARD SIMON HOUWAART 
Niets uit deze uitgave mag worden verveelvoudigd en/of openbaar gemaakt door middell van druk, fotokopie, microfilm of op welke andere wijze ook, zonder voorafgaande schriftelijke toestemming van de auteur. 
Promotores

Prof.Dr. A.M. Luyendijk-Elshout

Prof.Dr.Ir. G.H. de Vries

\section{Co-promotor}

Dr. A.H.M. Kerkhoff

\section{Beoordelingscommissie}

Prof.Dr. H.A.M.J. ten Have (voorzitter)

Dr. J. Dekker

Prof.Dr. P. Kooij (Rijksuniversiteit Groningen)

Prof.Dr. H. Philipsen

Prof.Dr. F. Sturmans 

De eerste plannen voor dit boek dateren uit het voorjaar van 1981, toen Dick Willems, Henk Havinga en ik een historisch onderzoek uitvoerden naar de politieke opvattingen van geneeskundigen. We hadden onze medische studie bijna afgerond en vroegen ons af, of geneeskundigen in Nederland hun vak ooit hadden gebruikt om politieke hervormingen tot stand te brengen. Aanleiding was het artikel '1848 und die Nicht-Entstehung der Sozialmedizin' van de wetenschapsonderzoeker Gernot Böhme, waarin werd gesteld dat in Duitsland in de negentiende eeuw artsen met behulp van de geneeskunde een democratische en rechtvaardige samenleving wilden vestigen. Het leek ons aannemelijk dat in Nederland artsen op vergelijkbare wijze politiek actief zijn geweest. We voelden ons tevens betrokken bij het internalisme-externalisme debat in de wetenschapsgeschiedenis, en wilden weten of Böhme gelijk had met zijn stelling dat politieke en sociale factoren richting hebben gegeven aan cognitieve ontwikkelingen in de medische wetenschap. We hoopten bovendien dat historisch onderzoek van de geneeskunde ons inzicht kon geven in de voor- en nadelen van de geneeskunde die wij in onze studie hadden leren kennen. Met steun van Prof.Dr. H.H.W. Hogerzeil, hoogleraar in de sociale geneeskunde in Groningen, resulteerde het onderzoek in een rapport over de sociale geneeskunde in Nederland in de tweede helft van de negentiende eeuw. We hadden maar zeer ten dele antwoord op onze vragen gekregen, maar er was wel een basis gelegd voor een systematisch historisch onderzoek naar het verband tussen medische wetenschap en politiek in de vorige eeuw.

Prof.Dr. D. de Moulin, hoogleraar in de geschiedenis der geneeskunde in Nijmegen, speelde een belangrijke rol bij mijn beslissing de huisartsgeneeskunde op te geven en dit onderzoek verder vorm te geven. Hij stelde mij in de gelegenheid de dissertatie te schrijven die voor u ligt. Vanaf 1983 heeft hij mijn eerste schreden op het pad van de professionele medische geschiedschrijving begeleid. Ik heb daarbij mogen profiteren van zijn grote kennis op het terrein van de medische geschiedenis. Helaas kan hij als gevolg van een tragisch ongeval niet meer als promotor optreden.

Prof.Dr. A.M. Luyendijk-Elshout toonde zich bereid de begeleiding over te nemen, en Prof.Dr.Ir. G. de Vries stemde erin toe als tweede promotor op te treden. Hierdoor wist ik mij verzekerd van de kritische begeleiding van een ervaren medisch-historica en een scherpzinnig wetenschapsonderzoeker. Voor hun stimulerende commentaar op eerdere versies van dit boek ben ik hen zeer erkentelijk, vooral ook omdat het onderzoek zich reeds in een vergevorderd stadium bevond toen zij besloten als promotor op te treden.

Dit onderzoek kon slechts plaatsvinden door de medewerking en steun van vele mensen. Toon Kerkhoff was vanaf het begin bij mijn onderzoek betrokken. Als een gedreven sociaal-geneeskundige wees hij mij telkens op het belang van het onderzoek voor de versterking van de identiteit van de huidige sociale geneeskunde. Zijn grondige tekstkritiek en onze - soms nachtelijke - discussies over de sociale geneeskunde en de epidemiologie sterkten mij in de overtuiging dat de sociale geneeskunde van fundamenteel belang is geweest voor de verbetering van de volksgezondheid, en tevens een onmisbare schakel vormt tussen medische theorie en maatschappijtheorie, tussen geneeskunst en politiek. Zijn enthousiasme voor de sociale geneeskunde heeft hij op mij weten over te dragen, wat naar ik hoop dit boek ten goede is gekomen. 
Pieter Caljé heeft een essentiële rol gespeeld bij het bepalen van de betekenis van de hygiënisten voor de politieke geschiedenis van Nederiand, en voor de negentiende-eeuwse ontwikkelingen in de gezondheidszorg. Zijn analyserend vermogen en suggesties voor verder onderzoek zijn onmisbaar geweest voor het verkrijgen van inzicht in de hoofdlijnen en de nuances van de politieke en sociale stromingen in de negentiende eeuw. Ik dank hem voor zijn waardevolle inbreng.

Mevr. A.S. Ali Cohen-Vos verleende welwillend haar medewerking door mij een groot aantal boeken en handschriften uit de nalatenschap van Levy Ali Cohen - een vooraanstaand hygiënist uit de vorige eeuw - tijdelijk ter beschikking te stellen. Hierdoor was ik in staat de ontwikkeling van de hygiënisten op de voet te volgen. Voor het belangeloos uitlenen van het kostbare bronnenmateriaal ben ik haar zeer erkentelijk.

Frank van Vree, Ida Stamhuis, Annemarie Mol, Maarten Doorman en Patrick Everard hebben het manuscript of delen daarvan gelezen en van vele kanttekeningen voorzien. Hun correcties hebben de interne consistentie en de leesbaarheid van het boek aanzienlijk vergroot. Tot slot dank ik Mevr. A.A.G. Ham voor haar hulp bij het opsporen van biografische gegevens van artsen en Hilary Marland voor haar correcties van de Engelstalige samenvatting, en dank ik Yvonne Voogt en Anja Servais voor het vele typewerk dat zij nauwgezet hebben verricht. 


\section{INLEIDING}

1 Het onderzoek

Het programma van de Nederlandse hygiënisten

De Nederlandse hygiënisten in Europees verband

2 Epidemiologie in de negentiende en in de twintigste eeuw 4

3 De geschiedschrijving van de openbare hygiëne in Nederland $\quad 7$

4 Afbakening van het onderzoeksthema $\quad 8$

\section{HOOFDSTUK 1}

Gezondheidszorg en onderzoek naar volksziekten onder het bestuur van koning Willem I

1 Nederland als eenheidsstaat

De Noordelijke en Zuidelijke Nederlanden verenigd

2 De geneeskundige staatsregeling van 1818

Het Geneeskundig Staatsbestuur

De medische beroepsgroep na 1818

3 Besmettelijke ziekten

De koepokinenting

Het quarantainereglement van 1805

4 De gezondheidszorg na 1818

De geneeskundige hulpverlening

De commissies van toevoorzicht

Gebrek aan leiding

Politiek onvermogen

5 Geneeskundige opvattingen over gezondheid en ziekte

Praktische en theoretische geneeskunde

Het humanistisch gezondheidsmodel

Gezondheidsleer en beschaving

Aetiologische modellen

Ziektekarakter

Constitutio en miasma

Contagium

6 Wetenschappelijk onderzoek naar volksziekten

De organisatie van het onderzoek

Methoden van onderzoek

Medische geografie

Historische pathologie

Medische topografie

7 De stad als ziektefactor

Berusting onder de geneeskundigen 


\section{HOOFDSTUK 2}

Het streven naar een sterk geneeskundig staatsbestuur

1 Nationale herleving $\quad 52$

2 De maatschappelijke positie van geneeskundigen 53

Onvrede van medici

De staatscommissie van 1841

Verbreding van de oppositie

Een Maatschappij of een congres van geneeskundigen ?

3 De staatscommissie van 1848

De oprichting van de Nederlandsche Maatschappij tot bevordering der Geneeskunst

4 Botsende idealen

Obstructie van minister Thorbecke

Verdeeldheid onder de geneeskundigen

\section{HOOFDSTUK 3}

\section{De hygiënisten en de 'maatschappelijke toestand'}

1 De opkomst van de hygiënische beweging

Frankrijk en Engeland

Nederland en Duitsland

2 Politieke reacties in Frankrijk en Duitsland

3 De hygiënisten in Nederland

Positivistische idealen

Politieke dilemma's

De Gemeentewet

De liberale staatsonthouding

\section{HOOFDSTUK 4}

\section{De hygiënisten en de cholera}

1 De cholera-epidemie van 1832

De reactie van de overheid

Onenigheid over de quarantaine

Het onderzoek van de regeringscommissie

Het beleid van de minister van Binnenlandse Zalken

2 De cholera als miasmatisch-contagieuze ziekte

De cholera-epidemie van 1848-1849

Een nieuwe besmettingshypothese

Quarantaine of sanitaire hervormingen

3 Een nieuwe infectietheorie

De smetstof in het darmkanaal

De bodemtheorie van Max von Pettenkofer

Nederlandse artsen en de bodemtheorie

Cholera als collectief probleem

4 Een zaak van nationaal belang, 1865-1875

De rapporten van het Geneeskundig Staatstoezicht

Het neocontagionisme 
Oppositie van Mulder

De drinkwatercommissie

5 Bodemtheorie versus drinkwatertheorie

Von Pettenkofers afwijzing van een monocausale verklaring

Het onderzoek naar de kwaliteit van drinkwater

6 Het zoeken naar de materies morbi

Drie microbiologische theorieen

De specificiteit van micro-organismen in twijfel getrokken

Het ontstaan van de bacteriologie

Het Geneeskundig Staatstoezicht en de bacteriologie

\section{HOOFSTUK 5}

\section{Statistiek en openbare gezondheidsleer}

1 Van historische pathologie naar kwantitatief onderzoek

De NMG-commissie voor volksziekten

Sociale sterfteverschillen

Fysiologische geneeskunde, pathologische anatomie en empiricisme

Een njeuwe ziekteclassificatie

2 De mogelijkheden van de statistiek

De ontwikkeling van de bevolkingsstatistiek

De betekenis van Quetelet

3 De nauwkeurigheid van de sterftecijfers

Ongestandaardiseerde sterftecijfers

De gebrekkige registratie

4 Het onderzoeksprogramma van de hygiënisten

Het lotelingenonderzoek

De ontwikkeling van het lokalisme

Het NMG-plan voor de geneeskundige plaatsbeschrijving

Sociale sterfteverschillen en openbare hygiëne

'Sociale welstand' in Amsterdam

De eerste sterfte-atlas

\section{HOOFDSTUK 6}

\section{Politieke impasse}

1 Tussen liberaal en conservatief

Moeilijkheden bij de afdeling Medische Politie

Thorbeckes persoonlijke adviseurs

Het tegenspel van de conservatieven

2 De eerste pogingen tot sanitaire hervormingen

De gemeentelijke gezondheidscommissies

Enkele lokale verbeteringen

3 De politieke onhaalbaarheid van de ontwerpen van 1848

4 De koerswijziging van de Maatschappij

5 Toenemende invloed van liberale geneeskundigen 
s 


\section{Het onderzoek}

\section{Het programma van de Nederlandse hygiënisten}

In de negentiende eeuw vond in tal van Europese landen een debat plaats over de vraag hoe het uitbreken van epidemieën - pokken, cholera of tyfus - kon worden voorkomen. Daarin kreeg geleidelijk de gedachte dat bestrijding van dergelijke ziekten een zaak van algemeen belang was meer erkenning: overheid en burgerij moesten gezamenlijk zorgen voor een goede openbare hygiëne. De voorgestelde maatregelen omvatten de invoering van een vaccinatieprogramma, verbetering van het drinkwater en de voeding, verbetering van de volkshuisvesting en bestrijding van de verontreiniging van bodem, water en lucht.

In sommige landen groeide de groep van voorstanders van zulke maatregelen uit tot een beweging van sanitaire hervormers. Geneeskundigen, ingenieurs, onderwijzers, juristen en economen probeerden de verantwoordelijke politici over te halen tot het nemen van hygiënische maatregelen. Van hygiënisten kan men voor het eerst spreken in Frankrijk en Engeland in de jaren 1830-1850. Deze hygiënisten streefden naar de oprichting van permanente, wetenschappelijke instellingen ter bevordering van de volksgezondheid. $\mathrm{Zij}$ ijverden bovendien voor een gezondheidspolitiek gebaseerd op democratische principes en op initiatieven van de bevolking zelf. Het voorgestelde beleid week naar vorm en methode sterk af van de autoritaire en paternalistische politiek van gezondheidsbevordering die in de meeste landen van Europa sinds het midden van de achttiende eeuw onder de noemer medische politie was gevoerd.

Vanaf 1850 zien we ook in Nederland hygiënisten optreden. Aanvankelijk waren dit vooral geneeskundigen, pas later ook ingenieurs, onderwijzers en ambtenaren. Zij wilden een nieuw gezondheidsbeleid dat - naar buitenlands voorbeeld - was gericht op professionalisering en verwetenschappelijking van de openbare gezondheidszorg. In een periode van ongeveer veertig jaar hebben zij 'objectivering' van de volksgezondheid en sanitaire hervormingen nagestreefd.

De hygiënisten vertegenwoordigden een duidelijk herkenbare, politiek-wetenschappelijke stroming. Deze stroming en de manier waarop zij een debat over de gezondheidstoestand van het volk in zijn geheel tot stand bracht, vormen het onderwerp van deze studie. Beschreven wordt wanneer en hoe de hygiënisten zich gaan onderscheiden van andere geneeskundigen. Dit is niet van de ene dag op de andere gebeurd, maar geleidelijk in een proces van sociale differentiatie binnen de totale groep van geneeskundigen. De groep in wording vormde de context waarin het politiek-wetenschappelijke gedachtengoed zich uitkristalliseerde. Het ontstaan van het hygiënisch gedachtengoed en van de sociale groep van hygiënisten vond dus gelijktijdig plaats. In deze studie worden enkele factoren beschreven die dit proces van differentiatie richting hebben gegeven. Zo zal aandacht worden besteed aan de politieke veranderingen in de jaren veertig en vijftig, aan de kwestie van de armoede en aan de verschijning van de cholera, de nieuwe 'gesel des tijds' die zoveel tijdgenoten angst inboezemde. 
Vanzelfsprekend is ook nagegaan wie de betrokken geneeskundigen waren, waar zij leefden en werkten en welke functies zij bekleedden.

Uit een beschrijving van bovengenoemde onderwerpen zou men gemakkelijk kunnen afleiden dat de hygiënisten dertig jaar lang hebben gestreden voor verbetering van de volksgezondheid en dat zij deze verbetering door een hervorming van de openbare gezondheidszorg tot stand wilden brengen. Dit is echter een even voor de hand liggende als onvolledige conclusie. Bekijkt men de gebeurtenissen in de periode 1850-1880 nauwkeuriger en betrekt men de voorgaande periode bij zijn beschouwingen, dan wordt al snel duidelijk dat het in deze periode nog lang geen uitgemaakte zaak was wat onder volksgezondheid en openbare hygiëne moest worden verstaan. De hygiënisten spraken weliswaar met grote regelmaat over de openbare hygiëne en de volksgezondheid, maar zij moesten aan deze begrippen nog inhoud geven. 'Volksgezondheid' en 'openbare hygiëne' maakten niet reeds deel uit van de realiteit toen de hygiënisten op het toneel verschenen. In dit boek wordt betoogd dat de redenering moet worden omgekeerd: men raakte pas door het optreden van de hygiënisten vertrouwd met de volksgezondheid en de openbare hygiëne.

Naarmate de hygiënisten zich duidelijker als groep manifesteerden, kreeg een nieuw domein van politiek handelen en wetenschappelijk onderzoek vastere vorm - het domein dat zij als 'algemeene gezondheidstoestand' of 'volksgezondheid' omschreven. In dit domein waren de onderwerpen die in de eerste helft van negentiende eeuw een rol in de gezondheidsdiscussie hadden gespeeld anders geordend dan tot dusverre gebruikelijk was geweest. Wat vóór 1850 in het centrum van de politieke en wetenschappelijke belangstelling stond, werd nu tot de periferie van het veld voor beschouwingen gerekend. Omgekeerd kregen onderwerpen die aanvankelijk nauwelijks werden bestudeerd, veel meer aandacht.

Zo vormde een epidemie in de vroege negentiende eeuw vooral de uitdrukking van verstoringen in de evenwichten van het natuurlijk milieu, terwijl na 1850 een epidemie als teken van een verkeerde organisatie van de samenleving werd opgevat. De ziekten zelf werden anders gedefinieerd en geclassificeerd, en de gezondheidstoestand van de bevolking werd volgens nieuwe methoden gemeten. Waar men eerst een epidemie met behulp van wettelijke verordeningen en politie-toezicht bestreed, daar verwachtte men na 1850 het meeste heil van collectieve voorzieningen, zoals riolering en waterleiding. Beperkte de medicus zich bij een epidemie in de eerste helft van de negentiende eeuw voornamelijk tot hulpverlening en nabeschouwingen, volgens de nieuwe maatstaven was het zijn taak de ontwikkeling van preventieve technieken op collectief niveau en de reorganisatie van de sociale omgeving te coördineren. In het verlengde hiervan stelde men aan de organisatie van de medische stand andere eisen.

De volksgezondheid en de openbare hygiëne waren dus niet een gegeven, maar ontstonden in wisselwerking met inspanningen van hygiënisten gericht op de opbouw van een nieuwe onderzoekspraktijk, en van nieuwe organisatorische structuren in de gezondheidszorg. In dit boek wordt onderzocht met welke politieke en wetenschappelijke argumenten de hygiënisten het debat over de volksgezondheid entameerden. Welke maatschappelijke verschijnselen vertaalden zij in termen van medische wetenschap en gezondheidspolitiek? Bijzondere aandacht wordt aan de statistiek geschonken. Besproken wordt wat de hygiënisten onder statistiek verstonden en welke verwachtingen zij ervan hadden, hoe de opbouw van het statistisch onderzoek is verlopen, waarin het succes van dit 
onderzoek school en welke invloed de statistiek op het denken over de gezondheidstoestand van de bevolking heeft uitgeoefend.

Het ontstaan van de 'volksgezondheid' omvatte niet alleen conceptuele en wetenschappelijke veranderingen. Er waren ook politieke consequenties aan verbonden. Bevordering van de volksgezondheid hield volgens de hygiënisten in dat de rijksoverheid een andere positie in de gezondheidszorg moest innemen. Verder moest de gezondheidszorg zelf anders worden opgezet en moest de burgerij bij het uitstippelen van het gezondheidsbeleid worden betrokken. De medische beroepsgroep diende bij dit laatste een vooraanstaande positie te krijgen. Het programma van de hygiënisten was dus voor een niet onaanzienlijk deel politiek van karakter. Het speelde ipso facto een rol in de politieke verhoudingen na 1850 .

In deze studie wordt nagegaan hoe de hygiënisten in het aanvankelijk door conservatieven en liberalen, later door liberalen en confessionelen beheerste politieke krachtenveld hebben geprobeerd hun voorstellen aanvaard te krijgen. De studie laat zien dat de groep hygiënisten een exponent van de liberale stroming was, maar dat men desondanks niet kan concluderen dat de groeiende invloed van de liberalen onverdeeld gunstig heeft gewerkt op de uitvoering van het hygiënisch hervorningsprogramma.

\section{De Nederlandse hygiënisten in Europees verband}

In Frankrijk en Engeland waren al vanaf 1830 de hygiënisten actief. Door hun toedoen zijn in de jaren dertig en veertig overheidsinstellingen in het leven geroepen, die leiding gaven aan de hervorming van de openbare hygiëne. Spoedig daarna werd de statistische methode van onderzoek op ruime schaal toegepast, en werden in verschillende steden nieuwe technieken op het gebied van waterhuishouding, afvalverwerking en volkshuisvesting toegepast. Vanaf 1840 vonden ook in België soortgelijke ontwikkelingen plaats.

Toen in Nederland de hygiënisten ten tonele verschenen, had men in bovengenoemde landen dus al meer dan tien jaar ervaring met wetenschappelijke en politieke vernieuwingen op het terrein van de volksgezondheid. De conclusie echter dat Nederland wat betreft de zorg voor de volksgezondheid achter was gebleven bij de omringende landen, lag omstreeks 1850 niet zo voor de hand als men wellicht zou denken. Veel tijdgenoten keken met wantrouwen naar de politieke en sociale veranderingen die in de voorgaande decennia in Frankrijk en Engeland hadden plaatsgevonden. Zij spraken niet van een achterstand, eerder benadrukten zij het eigen karakter van de Nederlandse gezondheidszorg. Voor de hygiënisten daarentegen stond het vast dat Nederland zo snel mogelijk het voorbeeld van Frankrijk en Engeland moest volgen. Nauwgezet bestudeerden zij alles wat zich in deze landen na 1830 op het terrein van de volksgezondheid had afgespeeld. Tegelijkertijd probeerden zij aansluiting te vinden bij eigentijdse ontwikkelingen in de landen waar volgens hen de 'beschaving' verder was voortgeschreden dan in hun eigen land.

Deze studie laat zien dat de hygiënisten voor een aantal lastige problemen kwamen te staan, juist doordat zij aan de hervormingen in Engeland, Frankrijk en later ook Duitsland een voorbeeld namen. Om aansluiting te vinden bij de hervorming van de gezondheidszorg in andere landen moesten zij in relatief korte tijd hun positie bepalen ten opzichte van onderzoeksmethoden en van 
technologische vernieuwingen die volop in ontwikkeling waren. Tegelijkertijd moesten zij rekening houden met de wetenschappelijke en sociale tradities in eigen land, en vooral met beperkingen op organisatorisch, technisch en financieel terrein.

Meer nog dan op wetenschappelijk en technologisch terrein, moesten de hygiënisten in de politiek een eigen weg vinden. Het centralisme van het Franse en Pruisische landsbestuur was volkomen vreemd aan het Nederlands staatsbestel dat in de grondwet van 1848 was vastgelegd. Zelfs het Engelse model van openbare gezondheidszorg berustte teveel op staatsinterventie om in Nederland op brede steun te kunnen rekenen. Daar kwam nog bij dat Engelse en Franse hygiënisten - soms tegen wil en dank - steun kregen van 'trade unions' respectievelijk socialistische groeperingen. In Nederland ontbrak het tot 1880 aan een linkse stroming van betekenis. Deze verschillen in politieke omstandigheden dwongen de hygiënisten het politieke programma van de Engelse en Franse hygiënisten telkens op zijn haalbaarheid te toetsen. Zij moesten het omvormen tot een eigen politiek programma, dat aansloot bij het Nederlands staatsrecht en de Nederlandse politieke verhoudingen.

De hygiënisten beschouwden deze omvorming overigens niet als een beperking van hun politielse mogelijkheden. Integendeel, Nederland moest weliswaar aansluiting vinden bij andere beschaafde naties, maar dat betekende niet dat elke ontwikkeling in het buitenland navolging verdiende. Nederland behoorde zijn eigen politieke oplossingen te vinden, passend bij de Nederlandse instellingen en 'volksaard'. In hun opvattingen klinkt het besef door dat het geestelijk klimaat in Nederland vanaf het einde van de jaren veertig geleidelijk ging beheersen, het besef namelijk dat de Nederlandse gemeenschap, na de mislukte vereniging met België, de staatkundige stagnatie in de jaren dertig en de nationale identiteitscrisis in de jaren veertig, met de grondwet van 1848 eindelijk de staatsvorm had gevonden die bij haar paste. ${ }^{l}$

In dit boek wordt beschreven door welke politieke en wetenschappelijke ontwikkelingen in de omringende landen de Nederlandse hygiënisten zijn beinvloed. Verder komt aan de orde waarom de hygiënisten een eigen weg naar een nieuw gezondheidsbeleid hebben gezocht. Waar nodig, zal worden aangegeven welke gevolgen het verschil in politieke en sociaal-economische omstandigheden tussen Nederland en de omringende landen heeft gehad voor het karakter van de Nederlandse beweging van hygiënisten.

\section{Epidemiologie in de negentiende en in de twintigste eeuw}

De kern van de politiek-wetenschappelijke denkbeelden van de hygiënisten bestond uit de opvatting dat de 'volksziekten uitdrukking zijn van het gestoorde leven der Maatschappij'. ${ }^{2}$ Een uitgebreid vocabulaire moest dit uitgangspunt in de algemene ziekteleer verankeren. Men sprak over de 'openbare gezondheidsleer', de 'leer der hygiëne' of de 'hygiënische wetenschap'. Daarmee doelde men op een breed veld van onderzoek, waartoe in ieder geval ook de studie van de volksziekten behoorde. Een enkele keer gebruikte men voor dit laatste ook de term 'epidemiologie'. ${ }^{3}$ Daarnaast kenden de hygiënisten een 'toegepaste wetenschap', aangeduid met de term 'algemene of openbare gezondheidsregeling' of ook wel 'medicina politica'. Deze wetenschap moest leren wat de staat kan en moet doen ter handhaving van de gezondheid van de burgers. 
De begrippen zijn nooit bijzonder scherp gedefinieerd geweest. De hygiënist L. Ali Cohen zag als belangrijkste taak van de openbare gezondheidsleer de 'beoefening van de geschiedenis der beschaving van de menschheid in het algemeen, en van die der volks- en andere ziekten en hare bestrijding in het bijzonder'. De medicus G.E. Voorhelm Schneevoogt noemde in 1861 als fundament van de nieuwe wetenschap het inzicht dat te veel mensen onnodig sterven en dat hygiënische maatregelen een vermindering van de sterfte teweeg hadden gebracht. In het Handboek voor openbare gezondheidsregeling uit 1872, wordt in het geheel geen definitie van het vakgebied gegeven. En de Amsterdamse hoogleraar in de hygiëne A.H. Israëls omschreef de nieuwe wetenschap als 'de leer van de voorwaarden van de gezondheid van de menschelijke maatschappij'. 'De gezondheidsleer', zo vervolgt hij, 'stelt den loop en den gang der functiën van het menschelijk leven als bekend, maar leert, van welke voorwaarden die functiën afhangen, welke invloeden daarop inwerken en hoe die functiën. moeten geschieden'. Hij had een onderwijsprogramma ontwikkeld waaruit blijkt hoe ver de hygiënisten hun kennis wilden laten reiken: 'geschiedenis der hygiëne, geschiedenis der physieke ontwikkeling des menschdoms, physiologie der menschelijke maatschappij, meteorologie, chronische eigenschappen van de dampkring, en de invloeden die deze samenstelling kunnen wijzigen, epidemische ziekten, voeding, dranken, lichaamsbeweging, hygiëne der geslachtsdrift, huisvesting, en medico-politische wetgeving'. ${ }^{6}$ In de openbare gezondheidsleer liepen dus twee onderzoeksgebieden vloeiend in elkaar over. De nieuwe weteņschap bestudeerde ziekte èn gezondheid. Ze bestudeerde het de verspreiding van volksziekten en de loop van epidemieën, maar ook de middelen ter bevordering van de gezondheid.

Hoe verschillend de omschrijvingen ook waren, over enkele wezenlijke kenmerken van de openbare gezondheidsleer was men het eens.

1. De leer biedt inzicht in de wijze waarop een ziekte zich verbreidt, wanneer deze eenmaal is ontstaan. Zij kan echter geen uitspraak doen over het 'ziektebeginsel' (het ziekmakende agens) en de pathogenese van de ziekte. Zij laat dus de vraag onbeantwoord hoe en waarom een ziekte ergens ontstaat.

2. $\mathrm{Zij}$ onderzoekt alles wat de hygiëne betreft in samenhang met onderzoek naar de heersende ziekten; zij geeft aan welke gunstige effecten te verwachten zijn van hygiënische maatregelen op de gezondheid. $\mathrm{Zij}$ leert dus hoe de gezondheid kan worden bevorderd.

3. De belangrijkste 'hulpwetenschap' die de hygiënische wetenschap ten dienste staat is de statistiek, dat wil zeggen 'de kennis van de krachten der natuur en van den menschelijken arbeid, die in een gegeven maatschappelijken kring werkzaam zijn, van de resultaten dezer werking voor de maatschappij en van de vaste verschijnselen die zich daarbij openbaren'. De statistiek probeert 'uit de geregelde opmerking en voortdurende vergelijking van zekere feiten, die zich telkens en regelmatig voordoen, bepaalde wetten te leeren kennen op het gebied van het physische of maatschappelijke leven (..). Haar grondslag ligt in de feiten, en de meest positieve uitdrukking dier feiten is het cijfer"?

- Korte levensschetsen van de belangrijkste hygiënisten treft men aan in Bijlage 1. De biografische gegevens van geneeskundigen die betrokken zijn geweest bij de verbetering van de openbare hygiëne of bij het onderzoek naar de volksgezondheid, staan vermeld in Bijlage 2. 
In deze omschrijving van 'openbare gezondheidsleer' zitten elementen van de tegenwoordige descriptieve en analytische epidemiologie, maar ook van het onderzoek ten behoeve van het gezondheidszorgbeleid dat sommige epidemiologen de laatste twintig jaar tot hun vakgebied zijn gaan rekenen. ${ }^{8}$ Tussen deze elementen maakten de hygiënisten echter geen duidelijk onderscheid. Om in dit boek toch een differentiatie te kunnen aanbrengen tussen bijvoorbeeld een theorie over volksziekten en een theorie over de inrichting van de gezondheidszorg, zal ik in het vervolg de studie van de volksziekten en de kennis over de aetiologie van deze ziekten aanduiden met de term leer der volksziekten.

Waarom gebruik ik de term 'leer der volksziekten' en niet de term 'epidemiologie' die tegenwoordig wordt gehanteerd? Daar zijn twee redenen voor. Om te beginnen kwam de term 'epidemiologie' vóor 1900 nauwelijks in het medisch vocabulaire voor, en toen de term éénmaal in zwang was geraakt, verwees hij naar een wetenschappelijke discipline die in haar onderzoeksobject en methoden volstrekt nieuw was. Epidemiologie stond na 1900 voor een subwetenschap binnen het grotere geheel van de gezondheidsleer of de hygiënische wetenschap. In zijn Voordrachten over de gezondheidsleer omschreef de Amsterdamse hoogleraar in de hygiëne R.H. Saltet in 1913 de hygiëne als de 'wetenschap, die oorzaken van ziekte opspoort en de middelen aangeeft om deze te bestrijden'. Over de epidemiologie stelde hij: 'De epidemiologen bestudeeren [..] den loop der besmettelijke ziekten, zij nemen kennis van al wat de pathologie leert over den aard en de oorzaken dezer aandoeningen; zij trachten op te sporen hoe de smetstof verspreid wordt om, met deze kennis toegerust, het binnendringen in den mensch tegen te gaan. Ook het gebruik van profylactica (kinine bij malaria, koepokstof bij pokken, inenting tegen cholera, hondsdolheid, pest, febris typhoidea, paratyphus) en de regeling hiervan worden meestal tot hun taak gerekend'. ${ }^{10}$ We mogen hieruit opmaken dat na 1900 de gezondheidsleer zich dus niet richtte op alles wat de gezondheid bevordert, maar op de aetiologie en de preventie van ziekten. Tegelijkertijd stond de epidemiologie geheel in het teken van de bacteriologie. Epidemiologie was dus synoniem met de leer van de verbreidingswijze van besmettelijke ziekten.

Op soortgelijke wijze zijn de begrippen epidemie en epidemische ziekte in betekenis veranderd. In de negentiende eeuw reserveerde men de uitdrukking 'epidemische ziekte' voor ziekten die als niet-besmettelijk werden gezien en steeds in de vorm van een epidemie optraden. Ziekten die men als besmettelijk beschouwde, werden contagieuze ziekten genoemd. Deze zouden via een smetstof van een ziek op een gezond persoon worden overgedragen, maar zich niet altijd in de vorm van een epidemie voordoen.

$\mathrm{Na} 1900$ hanteerden de epidemiologen deze indeling niet meer. Voor hen ging het bij een epidemische ziekte of een epidemie juist altijd om een besmettelijke ziekte; een ziekte die door een bacterie werd veroorzaakt en die zich daarom via contactinfecties, besmette levensmiddelen of besmet water en lucht kon verspreiden. Een epidemie omschreef men nu als 'het plotseling optreden van een vele mensen gelijktijdig aantastende besmettelijke ziekte'.

Hoewel deze definities van meet af aan en herhaaldelijk om haar bacteriologische vertekening zijn bekritiseerd, is de omschrijving van het vakgebied zoals Saltet die had gegeven, tot in de jaren vijftig van onze eeuw in de geneeskunde dominant gebleven. Daarna werd de epidemiologie in toenemende mate bepaald door het zogenaamde multifactoriële model of risicofactoren-model, dat Amerikaanse onderzoekers in de jaren vijftig en zestig ter verklaring van cardiovas- 
culaire aandoeningen hebben ontwikkeld. ${ }^{\text {I }}$ Ander onderzoek uit de jaren vijftig, gericht op het verband tussen roken en longkanker, heeft bovendien uitgemaakt dat controlegroepen onontbeerlijk zijn voor statistische analyses in de epidemiologie. Sindsdien beperkt epidemiologisch onderzoek zich niet meer tot besmettelijke ziekten. Bij een epidemie kan het sinds de jaren vijftig dan ook weer om niet-besmettelijke aandoeningen gaan, zoals het hartinfarct of bronchitis. Anderzijds is de term epidemiologie een synoniem geworden voor risico-analyses en cohort- en dubbelblind-onderzoek. Zonder kennis van steekproefgedrag en toetsingsprocedures is epidemiologisch onderzoek niet meer mogelijk.

Een tweede reden om de term epidemiologie niet te gebruiken, is dat het begrip epidemiologie - mede door de gecompliceerde geschiedenis van het vakgebied - tegenwoordig niet helder is gedefinieerd. Epidemiologen hebben de laatste 25 jaar heel verschillende definities van hun vakgebied gegeven. Bovendien zijn sommigen van hen herhaaldelijk van standpunt veranderd. ${ }^{12}$ Het is dus niet duidelijk welke epidemiologie teruggaat op de periode die in deze studie is beschreven.

Om een associatie met de twintigste-eeuwse epidemiologie te voorkomen en om niet verwikkeld te raken in het contemporaine debat tussen epidemiologen, is gekozen voor de term 'leer der volksziekten'. Daar komt bij dat de term "voor de gehele bestudeerde periode $(1800-1890)$ kan worden gebruikt.

\section{De geschiedschrijving van de openbare hygiëne in Nederland}

Over de geschiedenis van de openbare hygiëne is reeds het een en ander bekend. Een algemeen overzicht van de geschiedenis van de (openbare) gezondheidszorg in Nederland in de periode 1200-1960 is gegeven door J.K. van der Korst. ${ }^{13} \mathrm{D}$. Cannegieter heeft de wetgeving sinds 1795 uitvoerig besproken, terwijl A. Querido vooral de geschiedenis van het in 1865 ingestelde Geneeskundig Staatstoezicht heeft behandeld. ${ }^{14}$ Ook in Staat en Gezondheidszorg van P. Juffermans komen enkele passages voor over de rol van de overheid in Nederland in de negentiende eeuw op het terrein van de openbare gezondheidszorg. ${ }^{15}$ Verder heeft J.A. Verdoorn geschreven over het 'Gezondheidswezen' in Amsterdam in de negentiende eeuw. ${ }^{16}$ Enigszins vergelijkbaar met het boek van Verdoorn zijn de studies van D. Bosschaert en W. Romijn over respectievelijk de stad Utrecht en het verband tussen welvaart en volksgezondheid. ${ }^{17} \mathrm{H}$. Festen besteedt in zijn boek over de geschiedenis van de Nederlandsche Maatschappij tot bevordering der Geneeskunst enige aandacht aan discussies die in de Maatschappij over de openbare hygiëne hebben plaatsgevonden, terwijl A.H. Bergink de bijzondere betekenis van de arts S.Sr. Coronel voor deze discussies heeft beschreven. ${ }^{18}$ Ten slotte zijn vooral de laatste jaren talrijke studies van de lokale geschiedenis van de openbare hygiëne verschenen en zijn tevens verschillende aspecten van de geschiedenis van de openbare hygiëne onderzocht. Choleraepidemieën en lokale politiek, de geschiedenis van de waterbeheersing, van bouw- en woningverordeningen en van de niet-industriële vervuiling zijn slechts enkele onderwerpen uit de lange reeks van de meest recente publicaties.

Anders dan in Engeland, Frankrijk en Duitsland is in Nederland echter tot op heden geen studie verschenen, waarin de geschiedenis van het sociaal-medisch onderzoek en die van de openbare gezondheidszorg in hun onderlinge samenhang wordt beschreven. In bovengenoemde publikaties krijgt het onderzoek naar de volksziekten in de negentiende eeuw bovendien slechts incidenteel aandacht. 
De theoretische samenhang binnen de enorme hoeveelheid publikaties van geneeskundigen over de volksgezondheid heeft daardoor niet de belangstelling gekregen die ze verdient. De onderhavige studie beoogt deze lacune te vullen.

Het geraadpleegde bronnenmateriaal bestaat uit medische tijdschriften, handboeken en monografieën uit de periode 1840-1900. Verder is gebruik gemaakt van de Verslagen van het Geneeskundig Staatstoezicht in de periode 1865-1890, alsmede van het archief van het ministerie van Binnenlandse Zaken, afdeling Medische Politie en het archief van de Nederlandsche Maatschappij tot bevordering der Geneeskunst. Beide archieven zijn aanwezig in het Algemeen Rijksarchief in Den Haag. Studies over de geschiedenis van volksziekten en openbare hygiëne op plaatselijk niveau vormden eveneens een belangrijke bron van informatie. ${ }^{19}$

\section{Afbakening van het onderzoeksthema}

Gekozen is voor het beschrijven van de geschiedenis van de groep hygiënisten. De studie volgt de gedachtenontwikkeling en de activiteiten van de betrokken geneeskundigen 'op de voet'. Dat wil zeggen dat zij is geschreven vanuit het perspectief van die geneeskundigen. Uitgaande van de ideologische en wetenschappelijke standpunten in de periode 1840-1890 kunnen vervolgens de methodologische, technische en politieke problemen worden besproken die de geneeskundigen op hun weg tegen kwamen.

Het nadeel van deze vorm van geschiedschrijving is dat een scheiding wordt aangebracht tussen de groep hygiënisten enerzijds en de 'buitenwereld' anderzijds. De hygiënisten worden gedurende veertig jaar op de voet gevolgd: zij maken plannen, organiseren zich, boeken successen en incasseren tegenslagen. De 'omgeving' van de hygiënisten daarentegen wordt in deze studie zeer beperkt geëxploreerd. De omgeving heeft af en toe het karakter van het decor in een stuk, dat ten opzichte van de historische werkelijkheid een onnatuurlijke stabiliteit krijgt toebedeeld. Een consequentie van de gekozen werkwijze is bijvoorbeeld dat de oppositie tegen de plannen van de hygiënisten af en toe naar de achtergrond verdwijnt.

Een andere beperking betreft de onderwerpen waarvoor de hygiënisten belangstelling hadden. Zo zijn de prostitutie, de verkoop van geneesmiddelen en de bestrijding van kwakzalverij buiten beschouwing gelaten. Ook de vraag in hoeverre de hygiënisten erin zijn geslaagd de gezondheidscultuur te veranderen, wordt niet in haar volle omvang behandeld. In deze studie worden enkele deelonderwerpen besproken, zoals de veranderingen in de medische wetgeving, de opvattingen van de geneeskundigen, het ontstaan van nieuwe overheidsinstellingen en de concrete maatregelen ter bevordering van de openbare hygiëne. Deze onderwerpen zijn overigens niet willekeurig gekozen. De hygiënisten hebben er altijd hoge prioriteit aan gegeven.

Ten slotte wil ik nog eens benadrukken dat de studie geen overzicht beoogt te geven van de hygiënische beweging in haar totaliteit. Zoals gezegd, ook vertegenwoordigers uit andere beroepsgroepen behoorden immers tot deze beweging.

De onderzochte periode ligt tussen 1800 en 1890 , met het accent op de jaren 1840-1880. In deze periode speelden aanvankelijk de geneeskundige wetten van 1818 een belangrijke rol, omdat deze wetten het handelen van de geneeskundi- 
gen en de overheid alsmede het gezondheidsdebat bijna vijftig jaar hebben bepaald. In 1865 kwamen nieuwe geneeskundige wetten tot stand, die de rest van de negentiende eeuw van kracht zijn gebleven. Deze wetten vormden het juridisch kader waarbinnen de hygiënisten na 1865 hebben gewerkt.

Om drie redenen is het jaar 1890 als terminus ad quem gekozen. Ten eerste vonden in de jaren tachtig ideologische veranderingen en politieke verschuivingen plaats. Door deze veranderingen nam het vertrouwen af in het in de jaren vijftig opgestelde, sterk liberaal getinte hervormingsprogramma van de hygiënisten af. Ten tweede is de vigerende aetiologische theorie in de jaren tachtig door de opkomst van de bacteriologie naar de achtergrond verdrongen. Ten derde overleden de meeste hygiënisten omstreeks 1890. Een nieuwe generatie hygiënisten diende zich pas enkele jaren later aan. 
4 


\section{Gezondheidszorg en onderzoek naar volksziekten onder het bestuur van koning Willem I}

Nadat het aantal inwoners van het huidige Nederlandse grondgebied ongeveer 150 jaar stabiel was gebleven, begon vanaf 1800 de bevolking te groeien. In 1800 telde Nederland iets meer dan 2 miljoen inwoners, in 1830 was het inwonertal ruim 2,5 miljoen en in 1850 was dit getal ruim 3 miljoen. De bevolkingsgroei was geheel te danken aan een geboorte-overschot van jaarlijks bijna tien per duizend inwoners. Dit geboorte-overschot was een gevolg van de sterke stijging van het aantal geboorten; de sterfte bleef in de eerste helft van de negentiende eeuw onveranderd op een hoog niveau.

Voor het landelijk totaal lag de sterfte tussen 25 en 31 voor iedere 1000 inwoners. In sommige jaren konden deze cijfers nog aanzienlijk hoger liggen, zoals in 1807 en 1826 toen epidemieën met hoge sterfte heersten, en in de jaren 1846-1848. Er bestonden grote regionale verschillen. De hoogste sterfte was geconcentreerd in de westelijke provincies (Zeeland, Noord- en Zuid-Holland), waar het sterfteniveau gewoonlijk tussen 30 en $350 / 00$ lag. Veel lager lag dat in de rest van het land $(20-250 / 00){ }^{I}$

De oorzaak van deze hoge sterfte was de slechte gezondheidstoestand van de bevolking. Allerlei 'koortsende' ziekten heersten endemisch en ook tuberculose kwam veel voor. Verder zorgden mazelen, kinkhoest en difterie voor een constant aantal dodelijke slachtoffers en leed een belangrijk deel van de bevolking aan kwalen ten gevolge van chronische voedingsdeficiënties. Daar kwam nog bij dat de bevolking met onregelmatige onderbreking door epidemieën werd getroffen. In de jaren 1815-1840 deden zich drie roodvonk-epidemieën en vier pokken-epidemieën voor. Ook epidemieën van koortsende ziekten - men moet daarbij in de eerste plaats denken aan malaria en tyfus abdominalis - traden regelmatig op. Een zeer boosaardige epidemie (waarschijnlijk een combinatie van tyfus en malaria) deed zich in 1826-1827 voor, met name in de provincies Groningen, Friesland en Noord-Holland. Ten slotte moeten de cholera-epidemieën van 1832 en 1848-1849 worden genoemd. De meeste slachtoffers van deze ziekten vielen onder de armen, maar in feite was het voor iedereen die in de eerste helft van de negentiende eeuw leefde een ongezonde tijd met veel risico's en een geringe kans op het bereiken van een hoge leeftijd. ${ }^{2}$

Ook al waren ziekten zo alomtegenwoordig, dat zij nauwelijks te bestrijden leken, toch bestonden op maatschappelijk en individueel niveau tal van voorschriften die de gevaren voor de gezondheid moesten verkleinen. Deze waren voor een niet onbelangrijk deel het produkt van een eeuwenoude geneeskundige traditie van ziektebestrijding, soms echter waren zij pas na 1800 in maatschappelijke praktijken opgenomen.

In dit inleidende hoofdstuk wordt geschetst hoe de Nederlandse overheid en de geneeskundige stand in de jaren 1800-1840 hebben getracht de gevaren voor de gezondheid te verkleinen en de ziektebestrijding te organiseren. Ik beperk me daarbij tot de structuren en praktijken op het terrein van de volksgezondheid, die nog lang na 1850 hun invloed hebben doen gelden, en die ook voor de 
beweging van hygiënisten van belang zijn geweest. Allereerst worden de organisatie en het functioneren van de gezondheidszorg in de jaren 1800-1840 besproken. Vervolgens komen geneeskundige opvattingen over gezondheid en ziekte aan bod. Ten slotte wordt een overzicht gegeven van het wetenschappelijk onderzoek naar volksziekten.

\section{Nederland als cenheidsstaat}

Met de vestiging in 1795 van de Bataafse Republiek kwam voorgoed een einde aan de Republiek der Zeven Verenigde Nederlanden, de statenbond waarin de gewesten en de steden in belangrijke opzichten autonoom waren geweest. Onder de Bataafse Republiek (1795-1806), het Koninkrijk Holland (1806-1810) en het Napoleontische Frankrijk (1810-1813) voltrok zich de overgang naar de moderne eenheidsstaat. De gewestelijke soevereiniteit werd afgeschaft. Er kwam eenheid van staatsburgerschap, eenheid van bestuur, beleid en rechtspraak. Deze beginselen werden vastgelegd in een grondwet, in belasting- en onderwijswetten, in een strafwetboek en een burgerlijk wetboek. Het herstel van de onafhankelijkheid en de proclamatie van het Koninkrijk der Nederlanden in 1813 zijn het sluitstuk van deze overgang. De verworvenheden van de Bataafse omwenteling vormden het fundament van de nieuwe eenheidsstaat die onder leiding van koning Willem I vorm zou krijgen.

Het ontstaan van de eenheidsstaat heeft ook voor de gezondheidszorg verstrekkende gevolgen gehad. Het beginsel dat de staat op dit gebied een eigen, onvervreemdbare taak te vervullen had, raakte in de Bataafs-Franse periode algemeen aanvaard, zij het dat over de grenzen van die taak diepgaande meningsverschillen bleven bestaan.

De Bataafse hervormers, onder wie zich een aanzienlijk aantal geneeskundigen bevond, stonden sterk onder invloed van verlichte denkbeelden uit Frankrijk, Engeland en Duitssprekende landen, waar talrijke publicaties over de zorg van de staat voor de volksgezondheid en voor het milieu van mens en dier waren verschenen. ${ }^{3} \mathrm{Zo}$ was het na 1779 verschenen System einer vollständigen medicinischen Polizey van de hand van de Oostenrijkse arts J.P. Frank een belangrijke inspiratiebron voor de medische hervormers in de Bataafs-Franse tijd. Frank, stadsarts te Bruchsal en na 1795 directeur van het 'Allgemeines Krankenhaus' in Wenen, had in zijn zesdelige werk alle terreinen van het sociale leven beschreven waarop de staat regulerend moest optreden om de gezondheid van de onderdanen te bevorderen. Hij achtte het noodzakelijk dat de rijksoverheid medisch geschoolde politie-ambtenaren in dienst nam om de kwaliteit van bodem, water en lucht, van de verzorging van de armen en van de geneeskundige hulpverlening te bewaken. $\mathrm{Zij}$ zouden krachtig tegen de kwakzalverij moeten optreden en de inrichting van woningen, werkplaatsen, hospitalen, gevangenissen en begraafplaatsen dienen te bepalen.

De Bataafse hervormers hebben in de geest van Franks werk getracht een stelsel van medische politie in te voeren. $\mathrm{Zij}$ wilden een nationale gezondheidsraad en een centraal toezicht op de gast- en krankzinnigenhuizen in het leven roepen, en een woningbouwwet en landelijke richtlijnen voor de geneeskundige armenverzorging tot stand brengen. Voorts stelden zij een wet op het landelijk invoeren van identieke registers van huwelijken, geboorten en sterfte voor om de ontwikkeling van een medische statistiek mogelijk te maken. ${ }^{5}$ 
Een zeer belangrijk desideratum was de reorganisatie van de medische beroepsgroep. De eeuwenoude collegia medica en chirurgijnsgilden dienden te worden afgeschaft. Daarvoor in de plaats moesten instellingen komen die een actieve gezondheidspolitiek gingen voeren. Een landelijke wet op de uitoefening der geneeskunde moest de geneeskundige hulp op het platteland regelen en de kwakzalverij aan banden leggen. Met behulp van deze wet zou tevens de medische opleiding moeten worden verbeterd en zouden de examens van degenen die niet aan een hogeschool waren opgeleid voor het gehele land gelijkgesteld moeten worden. Alleen het met goed gevolg afleggen van deze examens of het behalen van de doctorstitel aan een hogeschool mocht voortaan toegang tot de praktijk verlenen.

De hervormers wilden tevens dat er een geneeskundig bestuursapparaat kwam, waarvan de functionarissen aan de hand van een medisch wetboek zouden toezien op het doen en laten van alle burgers, inclusief de geneeskundigen. Overtreders van de wet moesten door hen bij de rechter worden aangegeven en streng worden gestraft. De Bataafse hervormers hadden de verwachting dat deze medische politie-ambtenaren in de toekomst zouden zorgen voor uitbreiding van het medisch wetboek met nieuwe verordeningen, in het bijzonder op het gebied van de openbare hygiëne.

Van de meeste plannen is niets terecht gekomen. Hoewel de unitaristische krachten in Den Haag in kwesties zoals financiën, leger en onderwijs sterker bleken dan de federalistische oppositie in de provincies en de steden, lukte het op het gebied van de welvaarts- en gezondheidspolitiek niet een nationaal beleid tot stand te brengen. Wat de hervormers van de gezondheidszorg uiteindelijk bereikten, droeg in veel opzichten de sporen van een moeizaam tot stand gekomen compromis en vertoonde ook niet de samenhang die de hervormers zich hadden voorgesteld. ${ }^{6}$

In de jaren 1804-1806 werd de geneeskundige hulpverlening door middel van een geneeskundige staatsregeling onder het gezag van de landelijke regering geplaatst. De bevoegdheden van de geneeskundigen, de chirurgijns (voortaan heelmeesters genoemd) en tal van andere geneeskunstbeoefenaars waren nu bij wet vastgelegd. Tevens kwam een einde aan het bestaan van de plaatselijke collegia medica en de chirurgijnsgilden. Deze beroepsorganisaties hadden vóór 1795 in de steden de alleenheerschappij over de praktijkuitoefening van de geneeskundigen en over de opleiding en examinering van chirurgijns en apothekers. $\mathrm{Zij}$ werden vervangen door 'plaatselijke commissies van toevoorzigt', die nog slechts hadden toe te zien op de opleiding van heel- en vroedmeesters, apothekers en vroedvrouwen.

Het toezicht op de praktijkuitoefening en de examinering van de heelmeesters was voortaan opgedragen aan 'departementale commissies van toevoorzigt en onderzoek' die door de minister werden benoemd. Het was een verbetering dat hiermee ook de geneeskundige hulpverlening op het platteland onder toezicht kwam te staan. Tot de taak van de departementale commissies behoorde verder het toezien op de handel in geneesmiddelen. Zij kregen daarvoor de beschikking over de Pharmacopoea Batava, het in 1805 gepubliceerde voorschriftenboek dat voor de gehele Republiek geldig was. ${ }^{7}$ Behalve het examineren van leerlingheelmeesters en het visiteren van apothekerswinkels, moesten de commissies de minister op de hoogte houden van de gezondheidstoestand in het departement en aan hem advies uitbrengen over eventueel te nemen maatregelen. 
Ook de preventie en de bestrijding van besmettelijke ziekten (met name pest en pokken) kregen aandacht van de regering. In 1805 werden alle provinciale en plaatselijke quarantainebepalingen uit de voorgaande eeuw door een landelijke regeling vervangen. De rijksoverheid kreeg hiermee het recht om langs de gehele kust binnenkomende schepen te weren, wanneer de verdenking bestond dat op deze schepen een besmettelijke ziekte heerste.

De regering in Den Haag heeft verschillende malen bij de plaatselijke besturen aangedrongen op een verbetering van de bestrijding van pokken. In 1801 nam het Uitvoerend Bewind een besluit om de algemene verspreiding van de inenting met 'kinderpokstof' (de variolatie) te stimuleren, met name onder de klasse der behoeftigen en op het platteland. De variolatie werd sinds 1750 in verschillende streken van het land met wisselend succes toegepast. De methode was echter omstreden. Uit vrees voor schadelijke bijwerkingen was het in enkele steden zelfs verboden de variolatie toe te passen. Het besluit van 1801 maakte deze verboden weliswaar ongedaan, maar het legde niemand de verplichting op zich te laten inenten. Wel werden armendokters verplicht bedeelden gratis in te enten wanneer er een pokkenepidemie was uitgebroken. Verder kregen de regenten van weeshuizen de bevoegdheid om weeskinderen jonger dan twaalf jaar te laten inenten als er direct gevaar voor een epidemie bestond. Gemeentebesturen werden opgeroepen inentingslokalen in te richten; als de pokken uitbraken konden plattelandsgemeenten die verstoken waren van medische hulp op kosten van de overheid een inenter krijgen, mits de ingezetenen daar prijs op stelden. Om verspreiding van de ziekte tegen te gaan, mochten pokkenlijders of personen die niet ingeënt waren, niet naar andere plaatsen worden vervoerd, zolang ze besmet waren. In dit verband kregen de gemeentebesturen de opdracht streng op te treden tegen met pokken besmette bedelaars en landlopers. ${ }^{8}$

Als gevolg van het besluit van 1801 hebben verschillende plaatselijke commissies van toevoorzicht en gemeentebesturen zelf het initiatief genomen om de inenting tegen pokken te bevorderen. De genomen maatregelen hadden dikwijls betrekking op inenting met 'kinderpokstof', maar ook het inenten met koepokstof (vaccinatie) vond plaats. Het besluit riep overigens op om de vaccinatie - in 1798 door de Engelse arts E. Jenner voor het eerst beschreven - op haar betrouwbaarheid te testen. ${ }^{9}$ Een decreet van koning Lodewijk Napoleon op 25 november 1808 verscherpte de pokkenbepalingen nog enigszins: kinderen die miet ingeënt waren, mochten niet op school komen wanneer een pokkenepidemie dreigde. Maar van een landelijke inentingsplicht is het vóór 1814 niet gekomen. ${ }^{18}$

Ten slotte dient ook de ontwikkeling van de bevolkingsstatistiek te worden genoemd, waarvoor vooral de geneeskundigen onder de Bataafse hervormers hebben gepleit. Zij wilden voor het gehele land uniforme gemeentelijke bevolkingsregisters in het leven roepen, waarin geboorte en sterfte gedifferentieerd naar leeftijd, huwelijkse staat, sexe en beroep waren opgetekend. ${ }^{11}$ Met behulp van de daardoor verkregen kennis van de omvang en de samenstelling van de bevolking zou men het ontstaan van volksziekten in de toekomst beter kunnen onderzoeken. Hun pogingen zijn echter zonder succes gebleven. Wèl vond in 1795 een volkstelling plaats, waarvan de resultaten een jaar later zijn gepubliceerd. Pas in 1811, na de inlijving van het Koninkrijk Holland bij Frankrijk, werd besloten tot het invoeren van de Burgerlijke Stand. Alle gemeenten waren voortaan verplicht doop, huwelijk en sterfte van iedere inwoner in de registers 
van de Burgerlijke Stand bij te houden. ${ }^{12}$ Maar van de totstandbrenging van een geboorte-, sterfte-, en doodsoorzakenstatistiek, zoals de Bataafse hervormers hadden gewild, was niets in het Franse besluit terug te vinden.

\section{De Noordelijke en Zuidelijke Nederlanden verenigd}

Bij het herstel van de onafhankelijkheid in november 1813 en de samenvoeging van de Noordelijke en Zuidelijke Nederlanden in 1814 werd de eenheidsstaat die in de Bataafs-Franse tijd was opgebouwd gehandhaafd. De grondwet van 1815 bepaalde dat de Koning als soeverein het beginsel van de centrale overheid vorm gaf. De Koning kreeg dan ook een grote uitvoerende macht toebedeeld. Op het gebied van de wetgeving was de macht van de Koning eveneens groot. Wetsvoorstellen moesten weliswaar door de Staten-Generaal worden goedgekeurd, maar leden van de Eerste Kamer werden door de Koning zelf voor het leven benoemd, terwijl de toegang tot de Tweede Kamer waarin men voor een provincie werd gekozen, in de praktijk door zijn goeverneurs werd bepaald. De invloed van het parlement op de begroting was beperkt door het systeem van de tienjaarlijkse begroting en de afwezigheid van het recht tot amendement. Het parlement had meer een ondersteunende dan een controlerende functie.

Het was van het begin af aan duidelijk dat het Verenigd Koninkrijk nog veel moeilijkheden had te overwinnen, voordat Noord en Zuid tot én natie zouden zijn omgevormd. In het Zuiden verzette de katholieke kerk zich heftig tegen de 'liberale' grondwet en er bestond veel wantrouwen tegenover de bedoelingen van de Koning bij de opbouw van het regeringsapparaat. In het Noorden stuitte de regering op onverschilligheid van de elite, die slechts bereid was haar te steunen zolang zij de specifieke Noordelijke tradities en belangen verdedigde. ${ }^{13}$ Bovendien was het Koninkrijk in de beginjaren economisch zwak.

Deze omstandigheden hebben de Koning er niet van weerhouden om zijn beleid volledig op de eenwording van Noord en Zuid te richten. Zijn industrieen handelspolitiek, de hervormingen die hij in het onderwijs en de rechterlijke macht doorvoerde, zijn poging om het 'Nederduitsch' als unificerend middel te gebruiken en zijn ambtenarenbeleid stonden geheel in het teken van de 'amalgamering' van de beide rijksdelen.

Het streven na 1815 naar voortzetting van de Bataafse politiek gold ook voor de geneeskundige wetgeving. Nadat de regeling van 1806 door een ambtelijke commissie vrijwel ongewijzigd was overgenomen, werd deze in 1818 voor het gehele Koninkrijk ingevoerd. Ook de quarantaineregeling en de bepalingen met betrekking tot de Burgerlijke Stand bleven van kracht. Alleen op het terrein van de pokkenbestrijding vond een verandering plaats. In 1814 werd een wet op de koepokinenting van kracht, die de plaatselijke inentingsregelingen verving. In de volgende paragrafen zullen deze regelingen in detail worden besproken. Bijzonderheden over de Zuidelijke Nederlanden zullen daarbij buiten beschouwing blijven. 


\section{Het Geneeskundig Staatsbestuur}

In de Wet op de uitoefening der Geneeskunde van 12 maart 1818 en het daarbij behorende uitvoeringsbesluit van hetzelfde jaar werd de totstandkoming en de werking van de provinciale en plaatselijke commissies van geneeskundig onderzoek en toevoorzigt vastgelegd. ${ }^{14}$ De commissies moesten bestaan uit 'kundige en ervaren mannen in elk vak der Geneeskunde', door de Kroon benoemd. Hun algemene taak was toe te zien op de naleving van medische wetten en verordeningen, en de kwaliteit van de geneeskundige hulpverlening te waarborgen. Desgevraagd dienden zij de minister, Gedeputeerde Staten, de gerechtshoven en de burgemeesters desgevraagd van advies.

Provinciale commissies hadden als bijzondere taak de medische beroepsgroep te 'besturen' door toe te zien op de uitoefening der geneeskunst. Zij namen ook de examens af van zogenaamde niet-gegradueerde (niet gepromoveerde) geneeskunstbeoefenaars: zij die hun opleiding niet aan een hogeschool hadden gevolgd en die stads-, plattelands- of scheepsheelmeester, vroedmeester, apotheker, oogmeester, tandmeester en drogist of kruidenverkoper wilden worden. Behalve het afleveren van behoorlijke getuigschriften aan deze groep van kunstbeoefenaars en het waken over de juiste uitoefening van de geneeskundige vakken, moesten de provinciale commissies de bekwaamheid onderzoeken van degenen die zich als geneeskunstbeoefenaar in de provincie wilden vestigen. Ook was het de leden van de provinciale commissies opgedragen te letten op de 'geneeskundige verzorging der armen, vooral op het platteland en in kleine steden, ten einde van zoo verre dienaangaande provinciale voorzieningen mogten vereischt worden, daartoe de noodige voordragten aan de Gedeputeerde Staten intezenden'. ${ }^{15}$ Met het oog daarop moesten de provinciale commissies de Gedeputeerde Staten adviseren over de inrichting van het medisch onderwijs in de steden voor de vorming van goede heelmeesters. Over de taak van de provinciale commissies met betrekking tot de algemene gezondheidstoestand stond in de wet niet meer vermeld dan dat zij waakzaam dienden te zijn bij het ontstaan van epidemieën. De commissies hadden niet de bevoegdheid om iets te veranderen aan situaties die voor de volksgezondheid bedreigend waren.

De provinciale commissies moesten op zijn minst vier maal per jaar bijeenkomen. Jaarlijks moest een verslag, vergezeld van de verslagen van de plaatselijke commissies in de provincie plus een overzicht van de koepokinentingen, door iedere provinciale commissie bij de minister worden ingediend. Wanneer de minister het nodig oordeelde, kon hij een vergadering van alle voorzitters van de provinciale commissies uitschrijven.

Plaatselijke commissies van toevoorzicht bestonden in steden waar vier of meer medicinae of chirurgiae doctores (aan de hogeschool van Leiden, Utrecht of Groningen gepromoveerde geneeskundigen) waren gevestigd. Deze commissies moesten toezicht houden op de plaatselijke geneeskundige en hygiënische verordeningen, op de uitoefening der geneeskunst en de winkels van apothekers. Van hen werd tevens verwacht dat zij de noodzakelijke maatregelen bij het uitbreken van een epidemie namen.

De staatsregeling had een centralistisch karakter. De commissies van toevoorzicht stonden onder het gezag van de minister van Binnenlandse Zaken. De 
plaatselijke commissies waren ondergeschikt aan de provinciale commissies. Een actieve bevordering van de volksgezondheid werd van de plaatselijke commissies niet verwacht; in de taakomschrijving was hierover niets opgenomen. Het was de commissies zelfs uitdrukkelijk verboden op eigen gezag verordeningen op de openbare hygiëne uit te vaardigen of aan het stadsbestuur aan te bieden. ${ }^{16}$ Twee commissarissen voor Geneeskundige Zaken, eén voor de Noordelijke en eén voor de Zuidelijke Nederlanden, stonden tot 1825 de minister in zijn taak bij. $\mathrm{Na}$ dat jaar was er voor het gehele Rijk nog slechts één geneeskundige ambtenaar die de minister van advies moest dienen. De commissarissen en de commissies van toevoorzicht vormden te zamen het Geneeskundig Staatsbestuur.

\section{De medische beroepsgroep na 1818}

Met de invoering van de geneeskundige staatsregeling was tevens de samenstelling van de medische beroepsgroep voor lange tijd vastgelegd. ${ }^{17}$ Tot 1865 - toen de wet van 1818 door vier nieuwe wetten werd vervangen - was de overgrote meerderheid van de geneeskundigen niet-universitair gevormd. Een kleine minderheid, de zogenaamde gegradueerde geneeskundigen of doctores, was aan een hogeschool opgeleid.

De groep van ongegradueerde geneeskunstbeoefenaars bestond uit verschillende subgroepen. De belangrijkste was de groep van stads- en plattelandsheelmeesters, van wie laatstgenoemden op het platteland en in daarmee gelijkgestelde kleine steden de bevolking geneeskundige hulp verleenden. Deze groep bestond in het begin van de negentiende eeuw nog ten dele uit personen die in de achttiende eeuw als chirurgijn hun opleiding hadden genoten, ten dele uit heelmeesters die bij deze voormalige chirurgijns het vak hadden geleerd. Zij baseerden hun heelkundige praktijk volgens vaste traditie op ervaringskennis. Door ondervinding en bestudering van ervaringen van anderen hadden zij zich vertrouwd gemaakt met de behandeling van fracturen, dislocaties, liesbreuken, tetanus en dergelijke. Hetzelfde gold voor technieken als het aderlaten, het leggen van 'Spaansche vliegen', het zetten van bloedzuigers, lavementen en koppen en het aanleggen van verbanden. Hoewel het toedienen van medicamenten niet tot hun eerste taak behoorde, beschikten zij over empirische kennis van de werking van geneesmiddelen, zoals kwik, jodium, levertraan en opium.

In 1823 werd bepaald dat deze heelmeesters een opleiding van vier jaar aan nog op te richten klinische scholen dienden te hebben gevolgd, voordat zij een examen bij een proviciale commissie van geneeskundig toevoorzicht mochten afleggen. Hiermee werd de lacune in de wetgeving gevuld die sinds 1798 - toen de gilden als opleidingsinstituut werden opgeheven - had bestaan. In 1806 en 1818 was immers wel de examinering, maar niet de opleiding van de ongegradueerde stand in wettelijke voorschriften vastgelegd. De toelatingseisen voor de klinische scholen waren bescheiden: men moest zestien jaar of ouder zijn, behoorlijk kunnen lezen en schrijven en van onbesproken gedrag zijn. ${ }^{18}$ Als gevolg van het besluit van 1823 werden in verschillende steden (Amsterdam, Rotterdam, Middelburg, Haarlem, Hoorn, Alkmaar) klinische scholen opgericht. Aan deze scholen werden voortaan ook de vroedmeesters en vroedvrouwen opgeleid. ${ }^{19}$ 
Een poging om de kennis van met name de plattelandsheelmeesters te vergroten, was de oprichting in 1823 van het Practisch Tijdschrift voor de Geneeskunde. Elke aflevering van dit tijdschrift - één van de meest succesvolle medische periodieken van voor 1850 - bestond gewoonlijk uit vele pagina's vullende casuistische mededelingen. Het tijdschrift bevatte tevens artikelen uit het buitenland, die door een uit doctores bestaande redactie in het Nederlands werden vertaald. Theoretische artikelen bijvoorbeeld op het terrein van de pathologie werden zelden opgenomen. ${ }^{20}$

Een kleine groep ongegradueerden bestond uit abituriënten van 's Rijkskweekschool voor Militaire Geneeskundigen te Utrecht. Verder waren er nog zogenaamde scheepsheelmeesters, die na een korte praktische vooropleiding op de vaart en een examen bij een provinciale commissie van geneeskundig toevoorzicht tot de praktijk werden toegelaten.

Een minderheid van de geneeskundigen was opgeleid aan eén der hogescholen (Utrecht, Leiden, Groningen), volgens de regeling die in 1815 bij de Wet op het Hooger Onderwijs was getroffen. Alvorens tot de eigenlijke studie in de geneeskunde te worden toegelaten, dienden de studenten een vooropleiding te volgen die werd afgesloten met examens in de wis- en natuurkunde, de kruid- en scheikunde en in de Latijnse en Griekse letterkunde en de logica. ${ }^{21}$ Daarop volgde twee jaar universitair onderwijs, waarin de nadruk eerder op 'literarische studiën' dan op handvaardigheid lag. De denkbeelden van Boerhaave en zijn opvolger Gaubius op het terrein van bijvoorbeeld de fysiologie, pathologie en diëtetiek hadden daarbij nog weinig van hun autoriteit verloren.

Onderwijs in de praktische geneeskunde ('praktische studiën') vond plaats in de vorm van colleges, gelegenheid tot zelfstandig onderzoek van patiënten was er nauwelijks. Ten behoeve van het aanschouwelijk onderwijs beschikten de faculteiten over een kabinet van anatomische en pathologische preparaten en over een verzameling van heel- en verloskundige instrumenten. Alle examens en zelfs een deel van de colleges geschiedden in het Latijn. Ter afsluiting van de doctoraal-studie moest men twee ziektegevallen of twee aforismen van Hippocrates uitleggen. Op het doctoraal examen volgde de promotie, waarna men als medicinae doctor toegang tot de geneeskundige praktijk kreeg. Door het afleggen van aanvullende examina en de verdediging van theses kon men daarna nog de graad behalen van chirurgiae doctor of artis obstetriciae doctor. ${ }^{22}$

Zoals vanouds, vestigden de meeste doctores zich na hun promotie in de steden. ${ }^{23} \mathrm{Zij}$ begonnen hun loopbaan vaak als armendokter, maar probeerden zo spoedig mogelijk een eigen praktijk onder de meer welgestelden op te bouwen. Hun therapeutisch arsenaal bestond uit versterkende dranken, het laten aanleggen van warme kruiken of koude omslagen; verder het voorschrijven van warme of koude baden eventueel met genezende stoffen in het badwater. Desnoods schreven doctores geneesmiddelen voor om het natuurlijk genezingsproces te ondersteunen. Meer ingrijpende vormen van therapie, zoals aderlaten of koppen zetten, lieten zij door anderen uitvoeren.

De bevoegdheden van de verschillende geneeskunstbeoefenaars waren in Wet van 1818 vastgelegd. ${ }^{24}$ De strikte scheiding die in voorgaande eeuwen tussen inwendige geneeskunde, heelkunde en verloskunde had bestaan was voor het grootste deel gehandhaafd. Bovendien was gestreefd naar een evenwichtige verdeling van bevoegdheden van de academisch gevormde medici enerzijds en de heelmeesters en apothekers anderzijds. Het uitoefenen van de inwendige geneeskunde was slechts toegestaan aan personen die op een hogeschool de 
graad van medicinae doctor hadden verkregen. Anderzijds mochten alleen doctores chirurgiae en stads- en plattelandsheelmeesters de heelkunde uitoefenen. Bovendien was het de medicinae doctores, die de (inwendige) geneeskunde praktizeerden, niet toegestaan tegelijkertijd de heel-, vroed- of artsenijmengkunde uit te oefenen, ook niet als zij in deze vakken een diploma hadden behaald. Deze bepaling was mede bedoeld om de nering van heelmeesters en apothekers te beschermen tegen de concurrentie van de doctores medicinae, die sinds de achttiende eeuw in aantal waren toegenomen. ${ }^{25}$

Voor het platteland golden enkele uitzonderingsbepalingen. Op het platteland was het doctores die in meerdere vakken een diploma hadden behaald, wel toegestaan de genees-, heel- en vroedkunde tegelijkertijd uit te oefenen en geneesmiddelen aan hun patiënten te leveren. ${ }^{26}$ Omgekeerd was het aan heelmeesters die zich ten plattelande vestigden toegestaan in 'haastige en gevaarlijke toevallen' inwendige ziekten te behandelen en de beginselen der artsenijmengkunde toe te passen. ${ }^{27}$

Tussen de drie groepen heelkundigen was een hiërarchie aangebracht. De doctor chirurgiae werd als de meest deskundige beschouwd, dan kwam de stadsheelmeester en ten slotte de plattelandsheelmeester. De plattelandsheelmeester mocht bijvoorbeeld geen levensbedreigende ingrepen doen, zoals 'breuksnijding, steensnijding, panboring, afzetten van ledematen'. In dergelijke gevallen moest hij met spoed een doctor chirurgiae of een stadsheelmeester te hulp roepen. Voor de stadsheelmeester gold ongeveer hetzelfde, alleen hij mocht deze ingrepen wel zelf uitvoeren, zij het in tegenwoordigheid van een collega-heelmeester. Voor zowel de stads- als plattelandsheelmeester gold dat hij alleen in die provincie mocht praktizeren, waar hij bij de provinciale commissie van geneeskundig toevoorzicht examen had afgelegd. De doctor chirurgiae daarentegen mocht praktiseren waar hij wilde. Wat betreft de verloskunde bestonden er soortgelijke verschillen in bevoegdheden tussen vroedvrouw, vroedmeester en doctor artis obstetriciae.

Overigens werd dit formele onderscheid tussen gegradueerde en ongegradueerde medici en tussen genees- en heelkundigen in de praktijk steeds minder toegepast. Al sinds het midden van de achttiende eeuw zochten chirurgijns toenadering tot de academische geneeskunde en waagden geneeskundigen zich steeds vaker op het terrein van de heel- en verloskunde. Als gevolg daarvan werden na 1800 in tal van steden genootschappen opgericht, waar niet alleen doctores chirurgiae en heelmeesters gezamenlijk de beoefening van de heelkunde bespraken, maar ook medicinae doctores en chirurgiae doctores steeds nauwer samenwerkten. Verschillende genootschappen gaven in de eerste helft van de negentiende eeuw tijdschriften uit waarin zowel de theoretische als de praktische geneeskunde aan bod kwamen. ${ }^{28}$ Uiteindelijk werd in 1838 het in de wet gemaakte onderscheid tussen inwendige geneeskunde, heelkunde en verloskunde ongedaan gemaakt. ${ }^{29}$ Het duurde echter tot 1865 voordat ook de scheiding tussen academisch en niet-academisch gevormde medici zou verdwijnen. 


\section{De koepokinenting}

Een preventieve maatregel die over het algemeen als een belangrijke aanvulling op het hygiënisch toezicht van het Geneeskundig Staatsbestuur werd gezien, was de koepokinenting. Een voorlopig besluit in 1814 bepaalde dat kinderen van armlastigen voortaan verplicht moesten worden gevaccineerd; de armen werden bedreigd met intrekking van de bedeling als zij hun kinderen niet lieten vaccineren. Variolatie werd alleen nog bij wijze van uitzondering toegestaan. ${ }^{30}$ De armbesturen kregen de verantwoordelijkheid voor de vaccinatie, die kosteloos werd uitgevoerd. De gemeentebesturen dienden erop toe te zien dat de armbesturen hun taak deugdelijk uitvoerden. Geneeskundigen hadden de plicht gevallen van de 'kinderziekte' bij de plaatselijke commissie van geneeskundig toevoorzicht of het gemeentebestuur te melden, waarna degene die aan deze ziekte leed, geïsoleerd moest worden verpleegd. Met het besluit werd een reglement voor het opstellen van een ziekte- en sterftestatistiek van pokken van kracht.

De voorschriften uit 1814 werden in 1818 uitgebreid met de bepalingen dat geneeskundigen verplicht waren de kinderen een bewijs van inenting mee te geven, en dat kinderen uit een gezin of wonend in een huis waar pokken heerste de toegang tot iedere vorm van onderwijs moest worden ontzegd. ${ }^{31}$ Deze laatste bepaling onderging in 1823 nog een uitbreiding: kinderen werden niet meer tot het lager onderwijs toegelaten, tenzij ze een door een vaccinateur ondertekend 'pokkenbriefje' konden tonen. ${ }^{32}$ Naar aanleiding van dit voorschrift stelden de meeste provinciebesturen reglementen op ter bevordering van de koepokinenting. Om het aantal besmettelijke ziekten verder terug te dringen, droegen enkele provinciebesturen de onderwijzers in het lager onderwijs op, ook kinderen met besmettelijke huidziekten zoals mazelen en roodvonk de toegang tot de school te ontzeggen. ${ }^{33}$ De landelijke vaccinatieplicht voor kinderen in het lager onderwijs bleef tot 1857 gehandhaafd, toen de nieuwe Wet op het Lager Onderwijs de verplichting ongedaan maakte.

$\mathrm{Na} 1814$ groeide het aantal vaccinaties gestaag en leek het vaccinatieprogramma een succesvolle toekomst tegemoet te gaan. Genootschappen ter bevordering van de koepokinenting (Amsterdam, Rotterdam, Haarlem) wierven fondsen voor de aanschaf van koepokstof en prezen de voordelen van de vaccinatie aan onder de bevolking. Maar na een aantal jaren kwamen er moeilijkheden. De koepokstof werd uit het buitenland geïmporteerd en vervolgens via de arm-op-arm methode gebruikt en bewaard. De werkzaamheid van de entstof nam daardoor op den duur zodanig af, dat ingeënten in tijden van een pokkenepidemie even zeer konden worden aangetast als de niet-ingeënten. Na een aanvankelijk daling nam het aantal pokkengevallen in de jaren twintig weer toe. Men moest bij de arm-op-arm methode altijd bedacht zijn op overbrenging van ziekten, zoals syfilis en andere huidziekten, en de bewerking met onsteriele instrumenten kon tot erisypelas (wondroos) en flegmone (celweefselontsteking met ettering) leiden. Ten slotte was de beschikbaarheid van de humane lymfe afhankelijk van het aantal gevaccineerden, waardoor men tijdens een epidemie vaak niet meteen aan de plotseling gestegen vraag kon voldoen. 
Een tweede middel van de overheid om de verspreiding van besmettelijke ziekten tegen te gaan, was het uitvaardigen van quarantainebepalingen en het inrichten van een sanitair cordon. Het doel ervan was het beperken of zelfs stilleggen van verkeer dat ons land binnenkwam. Zowel de quarantaine als het sanitair cordon behoorden in Europa reeds eeuwenlang tot de vaste gewoonten van plaatselijke, regionale en landelijke overheden om de bevolking te beschermen tegen besmettelijke ziekten die van buiten de grenzen via scheepvaart of handelsverkeer over land konden worden geïmporteerd. In de vijftiende eeuw waren quarantaine en sanitair cordon alleen tegen de verspreiding van de pest gericht, later werden dezelfde voorzorgsmaatregelen ook toegepast op de gele koorts en in de negentiende eeuw tevens op de aziatische cholera. ${ }^{34}$

De Nederlandse quarantainebepalingen stonden geformuleerd in een Algemeen Reglement dat - het is reeds vermeld - het Staatsbewind van de Bataafse Republiek in 1805 had uitgevaardigd. ${ }^{35}$ Het Reglement moest de bevolking bescherming bieden tegen met name de pest en de gele koorts.

De procedure voor de inwerkingstelling van de bepalingen zag er gewoonlijk als volgt uit. Bij berichten van bijvoorbeeld de diplomatieke dienst over het heersen van een besmettelijke ziekte in een bepaald land, kon de minister van Marine dat land besmet of 'verdacht' verklaren. Dit betekende dat een schip afkomstig uit zo'n land bij het binnenvaren van de territoriale wateren door de marinecommandant van de dichtsbijzijnde havenplaats diende te worden aangehouden. De gezagvoerder van het vaartuig moest vervolgens een 'gezondheidsbrief', afgegeven in het land van herkomst, aan de commandant kunnen tonen. Bemanning en lading werden geïnspecteerd, alvorens het schip de haven van bestemming mocht binnenlopen. De beoordeling van de gezondheidsbrief en de gezondheidstoestand aan boord lag in handen van één van de zeventien door de overheid aangestelde geneeskundige 'visiteurs'. Bleken er naar de mening van de visiteur aanwijzingen te bestaan voor de aanwezigheid van een besmettelijke ziekte aan boord, dan diende het schip voor een bepaalde periode in één van de speciaal daarvoor aangewezen quarantaineplaatsen voor anker te gaan. Wieringen en Tiengemeten bijvoorbeeld waren zulke ankerplaatsen.

De quarantaine was van het 'observatieve' type: de gehele bemanning moest ter observatie aan boord blijven, in afwachting van het eventueel uitbreken van de ziekte. De achterliggende gedachte was dat het gedwongen verblijf aan boord van de opvarenden gedurende een bepaalde periode een eventueel latent aanwezige ziekte de tijd gaf zich te manifesteren. Het infectueuze materiaal dat door personen of goederen uit een besmet gebied was meegebracht zow zijn schadelijke eigenschappen door 'verdamping' verliezen.

Gezonde opvarenden moesten dus aan boord blijven, totdat zij niet meer als dragers van de smetstof beschouwd werden. De duur van de quarantaine stond gelijk aan de incubatietijd van de ziekte waartegen de maatregel was gericht. Voor de pest was een incubatietijd van 10 tot 15 dagen vastgesteld, voor de gele koorts 15 tot 17 dagen. Bleken opvarenden reeds bij aankomst of gedurende de quarantaine aan pest of gele koorts te lijden, dan werden schip en lading met ontsmettingsmiddelen (dampen van zoutzuur, water en zeep of ongebluste kalk) bewerkt. ${ }^{36}$ 


\section{De geneeskundige hulpverlening}

Ondanks alle pogingen in de voorgaande decennia om het verlenen van medische hulp te professionaliseren, bleef het eeuwenoude diffuse netwerk van halfen niet-professionele hulpverleners na 1818 bestaan. Naast een nog maar nauwelijks afgegrensde medische beroepsgroep boden tal van andere groepen in de samenleving, zoals marktkooplieden, winkeliers en rondreizende genezers, hun diensten aan bij de bestrijding van ziekte en ander lichamelijk ongemak. Het medisch consumptiepatroon van de bevolking werd dan ook niet zozeer bepaald door het bestaan van de verschillende soorten geneeskundigen of door het verschil in sociale status tussen die geneeskundigen. Het vormde veeleer een weerspiegeling van de diensten die zowel erkende als niet-erkende hulpverleners aanboden. Welke vorm van hulp men inriep, zal dan ook hebben afgehangen van de kwaal, de woonplaats, de sociale groep waartoe men behoorde en het soort hulpverleners waarmee men bekend was.

De Nederlandse medische historiografie biedt weinig inzicht in deze aspecten van de medische praktijk, aangezien deze vrijwel uitsluitend de geschiedenis van de legale hulpverleners beschrijft. De hulpverleners die geheel of gedeeltelijk buiten de wet werkten, blijven doorgaans onbesproken. Onze kennis van het medisch consumptiepatroon van de bevolking is daarom beperkt. In recent verschenen studies van het brede scala van hulpverleners in de achttiende en negentiende eeuw, wordt geprobeerd hierin enige verandering te brengen. ${ }^{37}$ Het blijkt dat de geneeskundige hulpverlening en het consumptiepatroon tot ver in de negentiende eeuw complexe verschijnselen zijn geweest. Dergelijke studies maken tevens duidelijk dat bij de huidige stand van onderzoek de geneeskundige hulpverlening in Nederland in de vroege negentiende eeuw niet op een afgewogen wijze kan worden samengevat. We zullen ons daarom in het vervolg beperken tot een bespreking van de belangrijkste vertegenwoordigers van de legale hulpverleners, de wettelijke bepalingen met betrekking tot de geneeskunde en de instanties die geneeskundige hulp of financiële steun bij ziekte verleenden. Daarbij kan een onderscheid worden gemaakt tussen geneeskundige hulpverlening aan personen die daarvoor betaalden en geneeskundige hulpverlening aan armen.

Voor degenen die niet in onderstand verkeerden, bestond er maar eén gezondheidsvoorziening, namelijk de dienstverlening van de geneeskunstbeoefenaars: arts, apotheker, vroedvrouw en tandmeester. Geneeskundige hulp werd verleend aan hen die daarvoor zelf betaalden of aan leden van ziekenfondsen. Een deel van deze ziekenfondsen, ook wel geneeskundige sociëteiten of ziektebussen genaamd, stamde uit de achttiende eeuw. Een ander deel was opgericht na de opheffing in 1798 van de gilden en de daarmee verbonden gildebussen voor onderling hulpbetoon. De fondsen functioneerden op commerciële basis en werden niet door de overheid gecontroleerd. Bij de commerciële fondsen heersten niet zelden wantoestanden zoals slechte medische verzorging, het gebruik van minderwaardige medicamenten, het bestaan van veel te grote fondspraktijken, financiële fraude en ongebreideld winstbejag. ${ }^{38}$

De geneeskundige verzorging van de armen was geheel anders georganiseerd. Deze maakte deel uit van een stelsel van armenzorg dat grotendeels onder het 
bestuur van plaatselijke kerkgenootschappen stond. Een klein deel van de armenzorg kwam voor rekening van de gemeenten. De diaconieën hadden ten behoeve van de geneeskundige verzorging van de armen, vaak tegen een zeer geringe vergoeding, zogenaamde armendoctoren in dienst die de behoeftige gratis hulp verstrekten. In de meeste steden waren van gemeentewege ook stadsdoctoren aangesteld, bedoeld voor de geneeskundige hulp aan de stadsbedeelden. De armen mochten pas de hulp van een armen- of stadsdoctor inroepen nadat zij van een zogenaamde wijkmeester, wiens taak het was de bedeelden op fraude en wangedrag te controleren, een schriftelijk bewijs van armlastigheid hadden ontvangen.

Naast deze geneeskundige voorzieningen voor de thuiszittende armen, bestond er in de steden een groot aantal verzorgingsinstellingen die voor het merendeel door de diaconieën - vaak met subsidie van de gemeente - werden geëxploiteerd: godshuizen waar ouden van dagen werden verpleegd, weeshuizen, bedelaarsgestichten en gasthuizen. Daarnaast bestonden er ook openbare gasthuizen, waarvan de kosten geheel voor rekening van de gemeente kwamen. Deze gasthuizen waren dikwijls niet meer dan interneringsplaatsen voor zieke armen die geen mogelijkheden tot huisvesting en ziekenverzorging hadden. Vanwege de zeer onhygiënische toestanden die er heersten, liet de burger zich niet dan in uiterste nood in deze tehuizen opnemen. Ook de toelating tot eén van de gasthuizen kon slechts op vertoon van een briefje van de wijkmeester geschieden.

Tijdens de voorbereiding van de geneeskundige staatsregeling in de jaren 18151818 hebben de ambtenaren van het ministerie van Binnenlandse Zaken de geneeskundige zorgverlening door de armbesturen, en ook de gast- en godshuizen en het krankzinnigenwezen buiten beschouwing gelaten. De Koning had namelijk het voornemen om deze terreinen in de gezondheidszorg door middel van bijzondere wetten onder staatsbestuur te brengen. Met name de armenzorg en het krankzinnigenwezen wenste hij ingrijpend te veranderen.

Het bleek echter dat de kerk en de regenten die traditioneel verantwoordelijk waren voor de gasthuizen, de krankzinnigengestichten en de armenzorg zich heftig tegen deze plannen verzetten. Voorstellen van de regering zorgden steevast voor een jarenlang politiek en juridisch steekspel tussen deze bestuursklasse en de vorst. Deze strijd eindigde soms onbeslist, maar werd ook dikwijls door de Koning verloren. Zo heeft de Koning van 1818 af geprobeerd radicale hervormingen door te voeren in het krankzinnigenwezen, maar moest hij na langdurig verzet van regenten en provinciale besturen de hervormingen uiteindelijk aan het initiatief van de lagere overheid en particulieren overlaten. Pas in $1841 \mathrm{kwam}$ de eerste krankzinnigenwet tot stand. ${ }^{39}$

Een van de belangrijkste aspecten van de geringe staatsinvloed in de gezondheidszorg is dat de geneeskundige armenzorg na 1815 grotendeels in particuliere handen bleef. De Grondwet van 1815 beschouwde het armbestuur en de opvoeding van arme kinderen als een zaak van aanhoudende zorg van de regering. Voor de Koning heeft deze bepaling altijd betekend dat de vorst voor een doelmatige armenzorg had te zorgen en tevens het recht op armenzorg moest garanderen. Hij heeft dan ook geprobeerd de armenzorg onder staatsbestuur te brengen. Dit is hem echter niet gelukt, wederom door het verzet van de regenten en de kerk. In 1818 werd de Wet op de domicilie van onderstand van kracht, waarin de rol van de rijksoverheid bij de armenzorg tot een minimum was beperkt. ${ }^{40}$ 
Deze wet riep een stelsel van armenzorg in het leven, dat in principe aan een ieder die in werkelijke nood verkeerde onderstand garandeerde. Deze hulp aan de armen, in de vorm van levensmiddelen, kleding, turf, kraamgeld en doodskisten, werd bekostigd door de kerkelijke instellingen van een gemeente of door de gemeente, waar de behoeftige was geboren. In de praktijk waren de meeste armen op de steun van de diaconieën aangewezen. Alleen de armen aan wie geen der diaconieën onderstand verleende, konden een beroep doen op de gemeentelijke armenzorg.

Dankzij de Wet op de domicilie van onderstand konden de kerkelijke armbesturen vrijwel zonder toezicht van de overheid blijven functioneren. De Koning en zijn ministers hebben in de jaren twintig nog diverse malen geprobeerd een grotere controle over de honderden armbesturen die ons land kende te krijgen, maar zij zijn daar nooit in geslaagd. Wel kwam het voor dat een gemeentebestuur subsidies aan een diaconie verleende en in ruil daarvoor inzicht in de administratie en controle op de begroting van het armbestuur eiste. ${ }^{4 l}$

Samenvattend kan worden gesteld, dat de kosten van de curatieve gezondheidszorg voor rekening van particuliere, veelal kerkelijke instellingen kwamen. De kerk zorgde ervoor dat de welgestelden zich aan hun plicht jegens de ${ }^{\prime}$ armen hielden en beheerde een omvangrijk, wettelijk gesanctioneerd stelsel van armenzorg waartoe ook de geneeskundige hulpverlening aan armen behoorde. Onder leiding van de burgerij hielden deze instellingen een filantropisch en paternalistisch zorgsysteem in stand, dat voor het armste deel van de bevolking de geneeskundige verzorging garandeerde. Dit systeem was decentraal georganiseerd.

\section{De commissies van toevoorzicht}

Ook in een ander opzicht mislukte de centralisering van de gezondheidszorg. De commissies van geneeskundig toevoorzicht hebben hun taken - adviseren van de overheid bij de bevordering van de volksgezondheid en toezien op de uitoefening der geneeskunst - niet naar behoren kunnen vervullen.

Van de uitvoering van de eerste taak is weinig terecht gekomen, omdat niet duidelijk was tot wie de commissies zich moesten richten. Volgens de geneeskundige staatsregeling moesten de plaatselijke commissies zich in de eerste plaats tot de provinciale commissies wenden. Deze dienden op hun beurt de minister van Binnenlandse Zaken van eventuele problemen op de hoogte te stellen. De stadsbesturen evenwel gingen ervan uit dat het hùn taak was voorschriften op medisch-hygiënisch gebied te maken - een begrijpelijke veronderstelling, want de zorg voor de openbare hygiëne behoorde al eeuwen tot de verantwoordelijkheid van de stadsbesturen. Maar deze verantwoordelijkheid noch die van de minister was vastgelegd. ${ }^{42}$

Onder deze omstandigheden waren de adviezen van de commissies weinig effectief. Voorstellen aan de minister bereikten nooit de gemeentebesturen. Verzoeken die de plaatselijke commissies op eigen gezag tot de stadsbesturen richtten, misten hun uitwerking. In de praktijk deden de besturen namelijk niet veel meer dan het bekrachtigen van verordeningen uit de Bataafse tijd of het toevoegen van enkele bepalingen daaraan. Maar de verordeningen werden op grote schaal overtreden, omdat geen effectieve controle op de naleving ervan bestond. Voor het overige beperkte de activiteit van de plaatselijke overheid op 
het gebied van de openbare en algemene gezondheidszorg zich tot een 'crisisbeleid': de beheersing van brood- en waterprijzen in tijden van schaarste en de inrichting van kleine hospitalen tijdens het uitbreken van een epidemie.

De plạatselijke commissies van geneeskundig toevoorzicht hebben in de jaren 1818-1840 weinig kunnen ondernemen tegen het gebrek aan initiatief dat burgemeester en wethouders op het gebied van de openbare hygiëne aan de dag legden. Geleidelijk aan verdween alle werkzaamheid op dit terrein. Omdat de leden van de commissies dikwijls nog een eigen praktijk moesten voeren, konden ze er ook niet de tijd insteken die hier eigenlijk voor nodig was. Mede hierdoor gingen de commissieleden hun aanstelling meer en meer als een erebaantje beschouwen. ${ }^{43}$

Het zou in overeenstemming zijn geweest met de politiek van de Koning, als het ministerie van Binnenlandse Zaken de gemeentelijke overheden had opgedragen de openbare hygiëne te verbeteren. Maar het is wel zeker dat dit nooit is overwogen, omdat staatsinterventie in de gemeentelijke politiek telkens op grote weerstanden stuitte. De lokale verhoudingen veranderden onder het bewind van koning Willem I nauwelijks, en voorzover de staat wel intervenieerde, was een groeiende oppositie tegen de centrale overheid het gevolg. Zowel de regentengeslachten als de burgerlijke hervormers hielden vast aan hun oude rechten en het eigen recht te regeren tegenover de soevereiniteitsaanspraken van de Koning. ${ }^{4}$ De enige keer dat de rijksoverheid de stadsbesturen zonder tegenstand voorschriften kon opleggen, was in 1831 tijdens de choleraepidemie.

Met het werk van de provinciale commissies was het op den duur even somber gesteld. De provinciale besturen en gerechtshoven toonden weinig belangstelling voor de mening van de medische colleges. In de jaarverslagen van Gedeputeerde Staten stond nauwelijks iets vermeld over de gezondheidstoestand van de bevolking. Aan de verplichting vier maal per jaar bijeen te komen, werd ook steeds minder voldaan en de rapporten van de commissies verdwenen jaren achtereen onbesproken in de archieven van het ministerie van Binnenlandse Zaken. Dit versterkte de neiging van de commissies om zich steeds meer bezig te houden met provinciale en plaatselijke belangen en minder met problemen van nationale aard. Op den duur was nauwelijks nog sprake van overleg tussen de verschillende provinciale commissies, hetgeen met name het tegengaan van de verspreiding van besmettelijke ziekten van de ene provincie naar de andere ernstig heeft geschaad.

De tweede vorm van toezicht - het toezien op de uitoefening van de geneeskunst - was ook al weinig effectief. Tegen het voorschrift voor de gegradueerden zich te beperken tot eén tak van de geneeskunde werden ongestraft vele overtredingen gemaakt. Ook de scheiding tussen de in- en uitwendige geneeskunst bleek in de praktijk moeilijk te handhaven. De verplichting van heelmeesters, vroedmeesters en vroedvrouwen om in geval van grote ingrepen respectievelijk problemen bij de partus hulp van een doctor in te roepen, werd dikwijls niet nagekomen. Onwetendheid, maar ook afgunst, broodnijd en de kans om op fouten te worden gewezen, speelden hierbij een rol. Verder waren vooral op het platteland vele soorten onbevoegde geneeskunstbeoefenaars werkzaam, zoals barbiers, aderlaters, lavementzetters, elixerverkopers (polaks) en magnetiseurs. Enerzijds was het aantal aanklachten wegens een overtreding van de regeling der bevoegdheden bij de provinciale commissies aanzienlijk. Anderzijds konden de commissies nauwelijks optreden tegen deze contraventies omdat de 
zogenaamde 'Instructies', waarin de bevoegdheden van de verschillende beroepsbeoefenaars stonden opgesteld, nooit in het Staatsblad waren gepubliceerd en dus rechtskracht misten. ${ }^{45}$ Mochten zij ooit zelf iemand aanklagen, dan geschiedde dat vrij willekeurig. Bovendien legden de provinciale commissies de regeling der bevoegdheden dikwijls verschillend uit en waren examens bij de ene commissie minder zwaar dan bij de andere.

Ten slotte was het onderwijs aan de klinische scholen, waarop de provinciale commissies toezicht moesten houden, met uitzondering van dat in Amsterdam en Rotterdam ronduit slecht. Er waren soms maar twee lectoren per school, die meestal ook nog een drukke praktijk hadden. Overigens was het met het onderwijs aan de hogescholen niet veel beter gesteld. Het kwam voor dat op geen der hogescholen onderricht werd gegeven in therapie, percussie en auscultatie, psychiatrie, huidziekten en leer der verbanden. Er bestond weinig gelegenheid tot het leren gebruiken van thermometer en microscoop en tot praktische oefeningen aan het ziekbed. Het laat zich raden dat de ondoelmatige organisatie van de geneeskundige hulpverlening, het gebrekkige toezicht op de kunstuitoefening en de onderlinge concurrentie tussen geneeskundigen het geringe aanzien van geneeskundigen in de hand werkten.

\section{Gebrek aan leiding}

De leiding van het Geneeskundig Staatsbestuur, i.c. de minister en zijn ambtenaren, heeft in de jaren 1818-1840 weinig gedaan om aan deze toestand een eind te maken. De taken van de commissarissen voor geneeskundige zaken op het ministerie - vóor 1850 waren er nooit meer dan twee - waren in feite veel te omvangrijk om goed leiding te kunnen geven. Volgens de 'Instructie voor de commissarissen tot de zaken der geneeskunde', die overigens ook nooit in het Staatsblad is gepubliceerd, waren zij belast 'met de zorg en het toezigt over alles, wat een onmiddellijken invloed heeft op bewaring, bevordering en herstelling van de gezondheid der Inwoners'. Zij moesten tevens gebreken in het geneeskundig onderwijs en de geneeskundige staatsregeling uit de weg ruimen, toezien op de handhaving van bestaande wetten en zich op de hoogte stellen van veranderingen en ontdekkingen op medisch terrein in binnen- en buitenland. Verder waren zij verantwoordelijk voor de gezondheid van slachtvee en voor de gezondheidstoestand in gasthuizen en gevangenissen, waarin zij eventueel poolshoogte moesten nemen. Ook behoorden zij tijdens een epidemie de nodige maatregelen te nemen en werd van hen verwacht dat zij een geneeskundige statistiek opmaakten uit de gegevens die door de provinciale commissies naar het ministerie werden opgestuurd.

Deze opdrachten konden met de beschikbare mankracht onmogelijk naar behoren worden uitgevoerd, zeker niet toen na 1825 nog maar één medisch ambtenaar, de arts F.J. van Maanen, op de afdeling Geneeskundige Staatsregeling van het ministerie van Binnenlandse Zaken overbleef. Van Maanen was in 1822 tot commissaris voor de Geneeskundige Staatsregeling in de Noordelijke Nederlanden benoemd, nadat de hofarts jhr. P.J. Groen van Prinsterer deze functie had neergelegd. ${ }^{47} \mathrm{Hij}$ werd daarmee de tweede man op de afdeling Geneeskundige Staatsregeling, naast de Leuvense hoogleraar F.J. Harbaur die sinds 1815 de geneeskundige zaken voor de Zuidelijke Nederlanden behartigde. $\mathrm{Na}$ het overlijden van Harbaur in 1824 werd er geen nieuwe commissaris benoemd en stond Van Maanen er alleen voor. Vier jaar later werd hij tot 
'inspecteur-generaal voor de burgerlijke geneeskundige dienst' benoemd, maar reeds in 1831 volgde de opheffing van de afdeling Geneeskundige Staatsregeling als gevolg van reorganisaties en bezuinigingen op het Departement. Het geneeskandig bestuur viel sindsdien onder het beheer van de afdeling Binnenlands Bestuur van het ministerie. Van Maanen werd benoemd tot raadadviseur, een functie die hij tot 1848 is blijven vervullen. ${ }^{4}$ Volgens Cannegieter was Van Maanen weliswaar een scherpzinnig en zeer belezen man, maar vond hij door zijn vele liefhebberijen en de grote rol die hij in de society speelde geen tijd om zich met hart en ziel aan zijn taak te wijden. Hij was een goed ambtenaar, maar geen doorzetter en zeker geen stimulerend figuur. ${ }^{49}$

De gevolgen van het falen van de leiding van het Geneeskundig Staatsbestuur waren ernstig. De in opzet voor het gehele land geldende staatsregeling werd per provincie steeds vaker verschillend uitgelegd, zonder dat hiertegen vanuit het ministerie iets werd gedaan. Van de jaarlijkse vergaderingen van minister en voorzitters van de provinciale commissies kwam niets terecht, waardoor de ontwikkeling van een gezondheidsbeleid volledig tot stilstand kwam. Zelfs het Koninklijk Besluit van 15 juli 1818 (Stb. 30), waarin de aanstelling van gerechtelijke geneeskundigen was verordonneerd, werd niet uitgevoerd: tot 1843 was nog niet één gerechtelijk arts benoemd. De gerechtelijke geneeskunde - een van de oudste vormen van vervlechting tussen geneeskunde en overheid - raakte er volledig door in het slop. ${ }^{50}$

Toch kon het Geneeskundig Staatsbestuur soms goed functioneren. Dit blijkt uit gebeurtenissen tijdens een koortsepidemie die in 1826 in de provincies Groningen, Friesland en Noord-Holland veel slachtoffers maakte. Uit het hele land kwamen toen geneeskundigen de in allerijl opgerichte plaatselijke noodcomités te hulp om deze catastrofe het hoofd te bieden. Het Geneeskundig Staatsbestuur bleek op dat moment opmerkelijk slagvaardig. Wat tevens opvalt is het grote aantal (statistische) gegevens over de sterfte dat na 1826 door toedoen van leden van de commissies van toevoorzicht bekend werd gemaakt. ${ }^{51}$

Mogelijk vormden de koortsepidemie en het grote aantal publicaties daarover de aanleiding voor het initiatief van de minister van Binnenlandse Zaken P.L.J. Servais van Gobbelschroy om de voorzitters van de provinciale commissies in 1828 in Den Bosch bijeen te roepen. ${ }^{52}$ Een andere reden voor de convocatie van de voorzitters kan zijn geweest, dat de Zuidnederlander Gobbelschroy sinds zijn benoeming in 1825 tot minister van Binnenlandse Zaken pogingen in het werk stelde zijn Departement te moderniseren en doelmatiger te organiseren. ${ }^{53}$

Onder leiding van Van Maanen vergaderde men twee weken over de vraag hoe het Geneeskundig Staatsbestuur kon worden verbeterd. De voorzitters verkeerden in de unieke positie 'en bloc' voorstellen tot verbetering van het staatsbestuur te kunnen indienen. Van dit laatste kwam echter niets terecht. Men was niet in staat een gezamenlijke mening naar voren te brengen en beperkte zich tot het aanbrengen van enkele kleinere aanpassingen. Wat een aanzet tot een beter systeem van medische politie had kunnen worden, ging de jaren daarop volledig verloren in het politieke rumoer rond de afscheiding van België. ${ }^{54}$ De eerste cholera-epidemie in Nederland in 1832 leidde nog tot een kortstondige opleving van de activiteiten, maar daarna keerde men terug in dezelfde berustende toestand. 
In de jaren dertig vernemen we weinig van de activiteiten van de commissies van geneeskundig toevoorzicht. Het ontbreken van perspectief op verbetering en de algemene politieke en financiële malaise in deze jaren maakten het Geneeskundig Staatsbestuur krachteloos.

\section{Politiek onvermogen}

Wanneer we de gezondheidszorg in de eerste veertig jaar van de negentiende eeuw nog eens in haar geheel bezien, dan valt ons een merkwaardig samenspel van centraal gezag en plaatselijke zelfstandigheid op. De geneeskundige staatsregeling was tot stand gekomen vanuit de veronderstelling dat de gezondheid van de burgers en de welvaart van het land het meest gebaat zijn bij een centraal geleide gezondheidspolitiek. Het Geneeskundig Staatsbestuur was dan ook hiërarchisch opgezet, met de Koning aan het hoofd. Het gezag van dit bestuur strekte zich weliswaar niet verder uit dan de medische stand en de uitoefening der geneeskunst, maar het bestaan ervan alleen al liet voortdurend de mogelijkheid open om in de toekomst de gezondheidszorg onder centraal bestuur te plaatsen. Op deze mogelijkheid werd door de commissies van toevoorzicht ook herhaaldelijk gewezen, en dan dacht men met rname aan de besmettelijke ziekten en de gerechtelijke geneeskunde. ${ }^{5 s}$

De maatschappelijke praktijk bewoog zich echter in tegenovergestelde richting. De bestrijding van ziekten was lokaal of regionaal georganiseerd en vond in de meeste gevallen zonder enige staatsbemoeienis plaats. De geneeskundige zorg voor de armen was grotendeels in handen van de diaconieën, terwijl de zorg voor de rest van de bevolking aan het vrije spel der maatschappelijke krachten was overgelaten. Meer dan de helft van de geneeskundigen werd opgeleid aan onderwijsinstellingen die onder de provinciale verantwoordelijkheid vielen, de gasthuizen waren geheel en al een plaatselijke aangelegenheid, en op het gebied van de openbare hygiëne waren de verantwoordelijkheden zelfs helemaal niet vastgelegd. Daar kwam bij dat de commissies van toevoorzicht op den duur alleen nog maar oog hadden voor de problemen in hun eigen ressort.

$\mathrm{Na} 1818$ bestond in het Koninkrijk dus enerzijds een decentraal functionerende, particularistische gezondheidszorg, anderzijds een hiërarchisch opgezet geneeskundig staatsbestuur waarvan de gremia zonder veel onderling overleg hoofdzakelijk bezig waren aan hun administratieve verplichtingen te voldoen. Er bestonden met andere woorden onduidelijke politieke verhoudingen in de gezondheidszorg. De regering had kunnen besluiten hieraan een eind te maken door het staatsgezag in de gezondheidszorg wezenlijk te versterken. Dit laatste zou volledig in overeenstemming zijn geweest met het staatkundig bestel van die dagen en zeker ook met de wijze waarop de Koning de staatkundige verhoudingen interpreteerde. Zo had de minister allereerst actief leiding kunnen geven aan de commissies van geneeskundig toevoorzicht: de voorzitters van de provinciale commissies regelmatig bijeenroepen, knelpunten op het gebied van de bevoegdheden oplossen, het toezicht op de handel in geneesmiddelen verscherpen. Het Geneeskundig Staatsbestuur had kunnen worden uitgebouwd door de geneeskundige armenzorg en de ziekenfondspraktijken onder staatstoezicht te plaatsen, de sterfteregistratie te verbeteren, voorschriften op het gebied van de openbare hygiëne uit te vaardigen en de controle op het medisch onderwijs te verscherpen. Ook uitbreiding van het aantal geneeskundige ambtenaren zou veel hebben verbeterd. 
Dergelijke maatregelen zijn nooit genomen; ten dele omdat de kerkgenootschappen hervormingen in de armenzorg op alle mogelijke manieren hebben tegengewerkt, ten dele wegens geldgebrek. De onmacht van het landsbestuur was echter bovenal het gevolg van de telkens terugkerende politieke problemen die de Koning ondervond bij zijn poging de Noordelijke en de Zuidelijke Nederlanden tot én natie te verenigen. In het Noorden was in het algemeen weinig sympathie voor het streven van de Koning, terwijl in het Zuiden het wantrouwen tegen de Koning telkens weer de kop op stak. Toen het de Koning in de jaren twintig toch leek te lukken om Noord en Zuid te verenigen, groeide in het Zuiden de aanhang van de liberalen en keerde een deel van de bevolking zich tegen de gecentraliseerde en 'despotische' macht. Voorstanders van een parlementair stelsel met vrije verkiezingen sloten na 1825 zelfs een verbond met de katholieken die altijd al tegen de Grondwet van 1815 hadden geageerd. ${ }^{56}$

De moeilijkheden tussen Noord en Zuid ondermijnden de slagvaardigheid van het ministerie van Binnenlandse Zaken - het ministerie van waar de initiatieven voor verbetering van de gezondheidszorg moesten komen. Men is daar tussen 1815 en 1830 voortdurend op zoek geweest naar de juiste organisatievorm. De inrichting van het departement stuitte nu eens op bezwaren uit het Zuiden, dan weer uit het Noorden (vooral de afdelingen onderwijs en rechterlijke macht vormden inzet van vele geschilpunten). De ene reorganisatie had zich nog maar nauwelijks voltrokken, of de volgende diende zich reeds aan. Ten slotte werden de reorganisaties abrupt onderbroken, toen eind augustus 1830 de Belgische Opstand uitbrak. ${ }^{57}$ Het zal duidelijk zijn, dat onder deze omstandigheden geen doeltreffend gezondheidsbeleid van de grond kon komen.

De staatkundige geschiedenis is in de jaren dertig bepaald door de weigering van de vorst te berusten in de afscheiding van België. De ontwikkelingen op het departement van Binnenlandse Zaken werden in de jaren dertig beheerst door een verzwakking van het ambtenarenapparaat, bezuinigingen en wederom reorganisaties. ${ }^{58}$ Pas in 1839 , na de ondertekening door Willem I van de '24 artikelen' van Londen, kwam een einde aan de volhardingspolitiek. De herziening van de Grondwet die in dat jaar eveneens haar beslag kreeg, had weinig om het lijf, maar de Koning voelde weinig lust tot verder regeren. In 1840 deed hij vrijwillig en als een verbitterd man afstand van de troon.

\section{Geneeskundige opvattingen over gezondheid en ziekte}

\section{Praktische en theoretische geneeskunde}

Terwijl het opleiden van heelmeesters het aantal 'practici' in de gezondheidszorg op peil moest houden, stelde men zich in het hoger onderwijs ten doel de studenten 'tot eenen geleerden stand in de maatschappij voor te bereiden'. "s9 In tegenstelling tot de studenten aan de klinische scholen moesten de aanstaande doctores dan ook een groot deel van hun studietijd wijden aan de bestudering van fysiologische en pathologische theorieën uit de achttiende en vroege negentiende eeuw. Zij hadden bovendien het voorrecht om de geschiedenis van de geneeskunde en medische teksten uit de oudheid te bestuderen. Zij behoorden de achtergronden en de werking van het Geneeskundig Staatsbestuur te 
kennen en dienden tevens veel aandacht te besteden aan klassïeke en literaire vorming.

Het in het onderwijs gemaakte onderscheid tussen practici en theoretici was in de dagelijkse praktijk van de medici weliswaar aan het vervagen, maar had niettemin tot gevolg dat het theoretisch erfgoed van de geneeskunde vooral het terrein van de doctores was. Dit effect werd versterkt door het feit dat de wetenschappelijke teksten nog vaak in het Latijn waren gesteld en de heelmeesters deze taal niet beheersten.

Aangezien de leer der volksziekten tot het theoretisch deel van de geneeskunde behoorde, kwamen de geneeskundigen die epidemieën beschreven en mogelijke oorzaken opspoorden vrijwel zonder uitzondering uit de groep van doctores. Beschouwingen over de gezondheidstoestand van de bevolking waren altijd van hun hand. Deze doctores - niet meer dan enkele tientallen - domineerden met andere woorden de discussie in de geneeskundige stand over de (preventie van) volksziekten. $\mathrm{Zij}$ bepaalden, als lid van een commissie van toevoorzicht of van een geleerd genootschap, het geestelijk klimaat waarin het gezondheidsbeleid van de overheid werd besproken.

Zoals we zullen zien, drongen de nieuwe opvattingen die in Engeland en Frankrijk na 1820 op het terrein van de natuurwetenschap, de geneeskunde en de politieke filosofie opgeld deden, tot 1840 in het geheel niet in de beschouwingen van de Nederlandse geneeskundigen door. De doctores stelden zich vooral de Duitse geneeskunde ten voorbeeld, met name het daarin sterk vertegenwoordigde en enigszins fantasieloze eclecticisme. Huizinga schreef in 1914 dat de meeste Nederlandse geneeskundigen wel op de hoogte waren van de verschillende medische systemen die in de vroeg negentiende-eeuwse geneeskunde een rol speelden, maar deze zelden aanvaardden. $\mathrm{Zij}$ namen uit de vaak tegenstrijdige systemen slechts over wat zij juist vonden. Doordrongen van de beginselen van Hippocrates streefden zij er volgens Huizinga naar ervaring en theorie voorzichtig in evenwicht te brengen. ${ }^{6}$

Ook nieuwe stromingen in de politieke filosofie - positivisme en liberalisme kregen vóór 1840 geen aanhang van betekenis onder de geneeskundigen. Voor iedere doctor die over volksziekten schreef, vormde de bestaande standenmaatschappij, het gevestigde politieke systeem en de cultuur van de hogere burgerij het uitgangspunt van zijn beschouwingen. Uitgaand van een mengeling van verlichtingsidealen en classicistische cultuuropvattingen analyseerde hij het verband tussen ziekte en armoede en gaven zij de bevolking voorlichting over de wijze waarop men zijn gezondheid kon bewaren.

Waarom de medische theorie in Nederland betrekkelijk immuun voor verandering is gebleven, valt bij de huidige stand van historisch onderzoek moeilijk te zeggen. Mogelijk stond het systematische karakter van de nieuwe maatschappijen wetenschapstheorieën te ver af van het voorzichtige eclecticisme van de Nederlandse geneeskundigen. Een andere reden kan zijn dat het in de beslotenheid van de traditioneel ingestelde en relatief kleine academische wereld vrijwel onmogelijk was met de bestaande denkschema's en gewoonten te breken. ${ }^{62}$ Men moet echter aannemen dat de conservatieve trek in de medische theorie niet alleen aan een behoudende opstelling van de medici kan worden toegeschreven. Ook de organisatie van het Geneeskundig Staatsbestuur, het mislukken van de centralisatiepolitiek van de Koning en de geringe financiële middelen waarover hogescholen beschikten, belemmerden de geneeskunde in haar ontwikkeling. Doordat de invoering van nieuwe technieken in het wetenschappelijk onderzoek 
werd verhinderd, konden achttiende-eeuwse denkbeelden onverminderd blijven bestaan . en was in wetenschappelijk opzicht zelfs sprake van enige terugval. In de volgende drie paragrafen wordt besproken welke gevolgen dit voor de leer der volksziekten heeft gehad.

\section{Het humanistisch gezondheidsmodel}

De gezondheid van de mens berustte volgens de geneeskunde in de eerste helft van de negentiende eeuw op de vervulling van drie voorwaarden. De eerste is een juiste inrichting van de structurele en functionele componenten die het menselijk lichaam constitueren. Het ging hier om de aangeboren lichamelijke gesteldheid en om de onwillekeurige processen in het lichaam, waar de mens geen invloed op kan uitoefenen. De tweede voorwaarde is een juiste beheersing van lichaamsfuncties, waar de mens tot op zekere hoogte wel invloed op kon uitoefenen. Met een verstandig dieet, een regelmatige afwisseling van rust en beweging, en beteugeling van de hartstochten kan de mens zijn lichaam in een ideale staat van functioneren houden. Dit verschaft hem de mogelijkheid zich met succes te weren tegen de altijd werkzame invloeden van het natuurlijk milieu, zoals koude, warmte en droogte. Deze invloeden zouden hem onvermijdelijk te gronde richten, wanneer zij onbelemmerd op het lichaam kunnen inwerken. De gezondheid van het individu hing dus af van de mate waarin hij in staat is de inwerking van de 'buitenwereld' (de Natuur) op zijn lichaam te modificeren, zodanig dat de juiste condities voor een gezond leven voortbestaan. Op de derde voorwaarde - optimale omstandigheden in het leefmilieu - heeft de mens weer veel minder greep. Weliswaar kan hij zijn directe omgeving enigszins naar eigen inzicht inrichten, maar in het milieu worden de omstandigheden door natuurkrachten bepaald waarop hij geen vat heeft.

Omgekeerd kunnen een verkeerde verzorging van het lichaam of bepaalde extreme omstandigheden in het natuurlijk milieu de normale wisselwerking tussen het menselijk organisme en de omgevende natuur verstoren. In dat geval raakt het harmonisch samenspel der lichaamsfuncties verloren, waardoor allerlei schadelijke stoffen zich in het lichaam ophopen of een ziekte van buitenaf bezit neemt van het lichaam.

Dit gezondheidsmodel ging terug tot de geneeskunde uit de klassieke oudheid. Nadat humanistische geleerden in de vijftiende en zestiende eeuw de antieke denkbeelden tot nieuw leven hadden gewekt, kreeg het model de betekenis van een rationele ordening van terreinen waar de mens vrij is om te kiezen hoe hij het 'goede leven' in het algemeen en zijn gezondheid in het bijzonder kan nastreven. De Grieks-Romeinse diëtetiek - de leer van het goede leven - ging vervolgens als een gezondheidsleer, die voorschreef hoe men zijn gezondheid kon bewaren, een integrerend deel vormen van het beschavingsideaal van de middengroepen in de samenleving. ${ }^{63}$

\section{Gezondheidsleer en beschaving}

Het uitgangspunt van de gezondheidsleer is dat men zijn gezondheid kan bewaren door het in acht nemen van een aantal vaste leefregels. Het gaat daarbij om een juiste beheersing van de zogenaamde res non-naturales: lucht, eten en drinken, bewegen en rust, slapen en waken, uit- en afscheidingen en gemoedsaandoeningen. Beheersing betekende volgens de gezondheidsleer niets 
anders dan dat men in alles matigheid moet betrachten en dat men zo veel mogelijk de natuur moest volgen. Men moest bijvoorbeeld juist zoveel eten en drinken, dat opname en afscheiding in evenwicht blijven. Een gezond leven bestaat verder uit een evenwichtige verdeling tussen werken en rusten, tussen prikkeling en rust van de geest. Ook is het nodig te leven volgens het ritme van de natuur, door een ordelijk slaap- en waakpatroon aan te houden en dient men een zindelijk en nijver bestaan te leiden. Alleen volstrekte gemoedsrust en harmonie van het lichaam kunnen een lang en gezond leven garanderen.

Maakt men echter geen goed gebruik van de res non-naturales, dan leeft men tegengesteld aan de natuur en zijn disharmonie van het lichaam, en ziekte het gevolg (res contra naturam). De beschrijving van ongezond gedrag, zoals overmatig alcoholgebruik, een zittende leefwijze, in bed lezen en nachtbraken, het toelaten van sterke hartstochten, overspel en masturbatie, vormde een essentieel bestanddeel van de gezondheidsleer. Staan matigheid, kuisheid, zelfbeheersing, redelijkheid en werkzaamheid voor gezondheid, het tegendeel van deze gedragsvormen staat voor ziekte: onmatigheid, onkuisheid, controleverlies, dwaasheid, morsigheid en werkeloosheid. Of zoals de arts J.J. Pennink in 1828 in zijn Gezondheidsleer voor het volk de gehele leer samenvatte: 'Beschaving, matigheid en deugd zijn de grondzuilen [van gezondheid], terwijl onmatigheid, loszinnigheid en verkeerdheden onze gezondheid zoowel als ons karakter bederven. De mensch moet nimmer slaaf van kwade aanwensels en hebbelijkheden worden, maar tijdig de sprekende stem der Natuur, der rede en van den Godsdienst opvolgen, en zich niets gewennen dan aan matigheid voor zijn natuurlijk, gelijk aan deugd voor zijn zedelijk leven. Zoo zal de jeugd welopgevoed, en zullen goede burgers voor den Staat gevormd worden'. ${ }^{6}$

De regels van de gezondheidsleer vormen een onderdeel van een groter geheel van gedragscodes die zich - zoals de socioloog Norbert Elias heeft laten zien - in West-Europa sinds de zestiende eeuw hebben ontwikkeld als gevolg van een verandering van het sociale gedrag in burgerlijke en, in Frankrijk, ook in hoofse kringen. ${ }^{55}$ Naarmate de burgerij (kooplieden, de vrije beroepen, schoolmeesters, intellectuelen en ambtenaren) maatschappelijk sterker werd, ontwikkelde zij zelfbewuster haar eigen levensstijl, gebaseerd op de betrachting van deugden, zoals matigheid, redelijkheid, vlijt, rechtvaardigheid en vaderlandsliefde. ${ }^{66}$ Arbeid en opvoeding golden in dit ideaal als de wezenskenmerken van het burgerlijk leven. Arbeid onderscheidde de burgerstand van de adel, die verstoken was van koopmansgeest en buiten het economische leven stond. Door opvoeding grensde de stedelijke burgerij zich af van de boeren en de onderste lagen van de maatschappij, die in onwetendheid leefden en allerlei irrationele denkbeelden en praktijken erop nahielden. Arbeid en opvoeding gaven de burgerij een plaats in de maatschappelijke hiërarchie.

In de achttiende eeuw krijgt gezondheid een belangrijke rol in dit normen- en waardenstelsel te spelen. Gezondheid wordt toegeschreven aan een regelmatige levenswijze, een nijver en rechtschapen bestaan, een gelukkig gezinsleven, lichaamshygiëne en juiste voedingsgewoonten. Men beschouwde gezondheid ook als een voorwaarde voor individueel geluk en succes. Alleen een gezond mens, wiens organen, krachten en functies zich in evenwicht bevonden, kan zijn plaats in de burgerlijke samenleving op juiste wijze innemen en kan zijn capaciteiten aanwenden voor het welzijn van het geheel en zichzelf. De leer van de res nonnaturales verschafte dit burgerlijk streven naar gezondheid en hygiëne een 
coherente basis. De leer voorzag niet alleen in de behoefte aan gesystematiseerde kennis ter behoud van een gezond en gelukkig leven. Ze sloot ook aan bij de rationalistische levensbeschouwing van de burgerij door de mens als een wezen op te vatten dat zijn gedrag door kennis kon laten leiden. ${ }^{67}$

In de tweede helft van de achttiende eeuw benadrukte men meer het universele karakter van de burgerlijke normen en waarden. In een stortvloed van geschriften werd deze algemene geldigheid door een voorlichtingsbeweging onder de aandacht van de bevolking gebracht. De belangrijkste exponent van deze beweging was in Nederland de in 1784 opgerichte Maatschappij tot Nut van 't Algemeen. Volgens het Nut was de welvaart van een volk illusoir zonder spreiding van kennis en goede zeden onder alle burgers. Ook godsdienst, verlicht door de rede, was onmisbaar voor het maatschappelijk welzijn. Het Nut streefde dan ook naar verbreiding van nuttige kennis en deugd onder 'de handwerkende landgenooten' door het uitgeven van geschikte lectuur voor de lagere standen te stimuleren en het verbeteren van het (volks)onderwijs. Het Nut poogde met andere woorden de gehele natie te mobiliseren voor een beschavingsideaal, waarin de aanwezigheid van rede, nuttige kennis en deugd bij de gehele bevolking noodzakelijk werd geacht voor het welvaren van het land.

Uit de studie naar culturele genootschappen in Nederland in de periode 17501815 van de historicus Mijnhardt blijkt, dat na 1800 enkele accentverschuivingen in het beschavingsideaal van het Nut optreden. Beklemtoonde het Nut vóor 1795 zijn onafhankelijke karakter en vermeed het ook expliciet al te veel samenwerking met de overheid, daarna raakte het Nut meer en meer met de overheid verstrengeld. Begonnen als 'exponent van een culturele revolutie', werd het Nut - zo stelt Mijnhardt - vooral na 1813 propagandist van een nationale cultuur. Men wilde de tegenstellingen van voor 1795 doen vergeten en een nieuw eenheidsbesef kweken. ${ }^{68}$ De verbreiding van redelijkheid, deugd en orde kwam in het teken te staan van het harmonisch functioneren van de standenstructuur. Door beoefening van de deugd zouden wederzijds respect, rechtvaardigheid, vriendelijkheid en tolerantie de toon aangeven. ${ }^{69}$ Daarbij werden ook de risico's van volksvoorlichting regelmatig onder de loupe genomen. De Nutsidealen mochten niet leiden tot standsverwisseling. De maatschappelijke orde zoals die was, moest blijven bestaan. Het verschil in rang en stand in de maatschappij werd zelfs noodzakelijk geacht ter bevordering van het algemeen volksgeluk. Ook de gedachte dat de verschillen in stand door goddelijke wijsheid waren ingesteld, floreerde. ${ }^{70}$

Hoewel in principe voor iedereen bedoeld, richtte de voorlichting zich hoofdzakelijk op de volksklasse. Deze vormde een weinig nauwkeurig omschreven groep, bestaande uit bedelaars, bedeelden, losse en ongeschoolde arbeiders, dienstboden, kleine boeren, zeelieden, soldaten, handwerkslieden, kleine neringdoenden, weduwen, wezen en ouderen. Het beeld van de beheerste en beschaafde mens werd door de voorlichters wel het minst bij deze groepen aangetroffen. In brochures en op Nutsbijeenkomsten werd er telkens op gewezen dat de cultuur en de levensstijl van de volksklasse zich door bandeloosheid, ongebondenheid en tomeloosheid kenmerkten.

Deze zogenaamde ontaarde vorm van vrijheid werd als een permanent gevaar voor de maatschappijke orde gevoeld, maar ook verantwoordelijk gesteld voor de wijdverbreide armoede onder de volksklasse. De volksklasse kon daarom niet aan haar lot worden overgelaten. De vervanging van de volkscultuur door een beschaafde en verlichte levensstijl zou heilzaam zijn voor de gehele samenleving 
en de armoede in de toekomst helpen voorkomen. Zo pleitte men voor de vervanging van volksfeesten door stichtelijke toespraken en gekuiste volkszang. Ook trachtte men huiselijkheid en 'stil vriendenverkeer' te bevorderen. Men bond de strijd aan met de straatzangers en hun 'walgelijke rijmproducten' en er werd een concurrerend repertoire van volksliederen gecomponeerd ter zuivering van de volkszang. Het Nut gaf volksromans met een zedelijke strekking uit en handboeken voor kinderopvoeding en huishoudkunde om de volksklasse op weg te helpen naar verstand, deugd en orde. Vanzelfsprekend werd veel aandacht aan de bevordering van het volksonderwijs besteed. Daar kregen de kinderen van de volksklasse les in geschiedenis, natuurkunde en geografie en bracht men hen het bestaan van God, zelfkennis van lichaam en geest en de plichten van hun stand bij.

Hoe groot het aandeel van geneeskundigen in de voorlichtingsbeweging is geweest, is niet met zekerheid te zeggen. Evenmin is duidelijk hoe sterk burgerij en geneeskundigen zijn beïnvloed door de in het buitenland opkomende gezondheidsbeweging, met haar bad- en wascultuur, haar voorschriften voor gezonde kleding en voorliefde voor gymnastische oefeningen. Systematische studies op dit gebied zijn nog niet verschenen. Het lijkt echter onwaarschijnlijk dat in Nederland een gezondheidsbeweging van dezelfde omvang heeft bestaan als bijvoorbeeld in Duitsland. Terwijl in Duitsland telkens nieuwe tijdschriften, brochures en gezondheidscatechismussen het licht zagen, hield in Nederland een in 1822 opgericht gezondheidsblad met aandacht voor opvoeding en een gezonde levensstijl het niet langer dan drie jaar vol. ${ }^{71}$ Tekenend is ook dat het beroemde, in 1796 verschenen boek over de gezondheidsleer van de hand van de Duitse arts C.W. Hufeland - Die Kunst das menschliche Leben zu verlängernpas in 1828 in een Nederlandse bewerking door de Maatschappij tot Nut van 't Algemeen is uitgegeven (het eerder genoemde Gezondheidsleer voor het volk).

Niettemin zijn er voldoende aanwijzingen dat ook in Nederland geneeskundigen systematisch hebben bijdragen aan het levend houden van de burgerlijke gezondheidsmoraal. Zo publiceerden geneeskundigen tijdens een epidemie altijd talrijke pamfletten en brochures, waarin de bekende leefregels nog eens onder de aandacht van de bevolking werden gebracht. Ook schreven geneeskundigen meer dan eens op bestraffende toon over de leefwijze van zowel de aristocratie als de volksklasse. ${ }^{72}$ De geneeskundigen versterkten bovendien de negatieve beeldvorming van de volksklasse, door deze als bijzonder ziektegevoelig af te schilderen. Armoede, irrationaliteit en gebrek aan morele orde zouden de volksklasse zelfs tot de natuurlijke voedingsbodem van gevaarlijke ziekten hebben gemaakt. Niet zelden identificeerden geneeskundigen dan ook 'typische' ziekten van de armen, die vervolgens gewoonlijk aan alcoholmisbruik, sexuele ongeremdheid of onzindelijkheid werden toegeschreven.

\section{Aetiologische modellen}

In de achttiende eeuw komt een ander aspect van het klassieke gezondheidsmodel in het centrum van de filosofische en wetenschappelijke belangstelling te staan: de betekenis van het natuurlijk milieu voor de fysiologie van mens en dier. Men wilde de taal van de natuur begrijpen, niet om een volledige controle over alle natuurprocessen mogelijk te maken, maar om in harmonie met de onvermijdelijke invloeden van de natuur te kunnen leven. Deze invloeden vormen de uitdrukking van vaste en voorspelbare natuurwetten. Het lot van de mensheid 
is daarom deze wetten te kennen en te trachten deze te gehoorzamen. Tegen deze achtergrond ontwikkelden geleerde genootschappen - op basis van klassieke teksten - een wetenschappelijke theorie over causale verbanden tussen veranderingen in het natururlijk milieu en het ontstaan van ziekten.

Sindsdien was het wetenschappelijk denken over volksziekten gestructureerd volgens twee naast elkaar bestaande theoretische modellen, die elk een eigen leer van ziekte-oorzaken vertegenwoordigde. Het eerste model moest een verklaring bieden voor de zogenaamde epidemische ziekten. Hiertoe werden tal van koortsende ziekten gerekend, bijvoorbeeld de 'gal- en tusschenpoozende koortsen'. Het tweede model had betrekking op de contagieuze ziekten, zoals pest, gele koorts, pokken, mazelen en cholera.

De reden voor dit onderscheid lag in het telkens waargenomen verschil in verspreidingspatroon van de beide typen volksziekten. In een verslag uit 1826 van de Commissie van geneeskundig Toevoorzicht in Groningen wordt dit verschil als volgt onder woorden gebracht: '(Besmettelijke of contagieuze ziekten) ontstaan meestal in eén enkel huis, en kruipen vandaar, zonder de bewoners van zekere klei- (kalk-, veenaardige, zandige of andere) gronden, omdat zij daarop gevestigd zijn, te verschoonen, allengs voort, en breiden zich langzamerhand uit tot die huizen, wijken, vlekken, steden - en ook tot die alléén - welker bewoners in onmiddellijke of middellijke aanrijking zijn met hen, die aan de besmettelijke ziekte lijden (..) Het tegenovergestelde heeft plaats bij heerschende niet besmettelijke ziekten. Dezelve beginnen bijna gelijktijdig in onderscheidene landen, zelfs zonder eenige verkeering van de gezonden en de zieken, dikwerf verbazend snel onder de inwoners dier plaatsen, alwaar de oorzaken der ziekte aanwezig zijn, en verschoonen intusschen geheel en al de ver afgelegene, en nog voor zekere tijd de naderbij gehuisveste bewoners van die streken, in welke de oorzaken dier ziekte ontbreken." 73

De twee aetiologische modellen boden allerminst sluitende verklaringen voor het verschil in verspreiding van respectievelijk de epidemische en contagieuze ziekten. Zoals veel tijdgenoten zich ook wel bewust waren, ging het veeleer om twee denkrichtingen, beide met een eigen logica en bijbehorend empirisch vastgesteld feitenmateriaal. Het is niet eenvoudig de complexe en veelzijdige ontwikkeling, zoals de vroege negentiende eeuw op dit terrein te zien geeft, in het kort te behandelen. Toch zal worden getracht deze ontwikkeling te reconstrueren, en wel aan de hand van een bespreking van de begrippen ziektekarakter, constitutio, miasma en contagium.

\section{Ziektekarakter}

Wanneer het harmonisch samenspel van lichaamsfuncties verstoord was, konden allerlei schadelijke stoffen zich in het lichaam ophopen. De ziekteverschijnselen die hiervan het gevolg konden zijn, werden door de vroeg negentiende-eeuwse Nederlandse geneeskunde uitvoerig beschreven (nosografie). Zo lette men op verkleuringen van de huid, krampen in buik of ledematen, pijn, tongbeslag, onregelmatige of zwakke pols en benauwdheidsverschijnselen. De aard van de eventueel aanwezige koorts (acuut, derde- en vierdedaags koortsen), buikloop of bloedspuwing werd beschreven. Daarnaast stelde men nog vast of de verschijnselen chronisch of acuut waren. Bij overleden patiënten verrcihtte men soms ook pathologisch-anatomisch onderzoek. 
Om orde te kunnen aanbrengen in deze ziekteverschijnselen - zij konden in alle mogelijk combinaties optreden - werd gebruik gemaakt van een stelsel van ziektecategorieën, zogenaamde klassen en ziektekarakters. Zo stelde de Nijmeegse arts A. Moll in zijn in 1826 gepubliceerde Handboek over de medische semiologie, dat de ziekten in vijf klassen waren in te delen, namelijk koortsen, ontstekingen, bloedstortingen, zenuwaandoeningen en algemene ziekten met motorische gebreken. ${ }^{74}$ Elke klasse was onderverdeeld in ziektekarakters, die elk een specifieke uitingsvorm van de ziekte vertegenwoordigde. De ziekteverschijnselen werden dus op basis van uitwendig vast te stellen overeenkomsten bij een bepaalld ziektekarakter ingedeeld. Het ziektekarakter gaf bijvoorbeeld aan of sprake was van koorts met maag-darmverschijnselen of van koorts met een aandoening van de luchtwegen.

Het classificeren en catalogiseren van ziektebeelden was al in in de zeventiende eeuw door de Engelse arts Thomas Sydenham aanbevolen als de beste methode om de oorzaken van ziekten te achterhalen. Volgens hem was onderzoek aan het ziekbed de basis van de geneeskunde: de arts moest de ziekte van punt tot punt beschrijven, zoals de schilder zijn object beschrijft. Vervolgens moest hij die classificeren op dezelfde wijze als de botanicus de planten in genera en species indeelde. ${ }^{75}$ Geïnspireerd door Sydenham publiceerde $F$. Boissier De Sauvages in 1732 zijn Nouvelles Classes des Maladies, waarin hij een groot aantal klassen en typen ziekten onderscheidde. Later heeft het classificatiesysteem nog tal van veranderingen ondergaan. Tot het midden van de negentiende eeuw is het onderbrengen van ziekten in klassen en ziektekarakters een gangbare praktijk gebleven.

\section{Constitutio en miasma}

De gedachte achter het classificeren was dat ziekten bepaalde entiteiten zijn, die onafhankelijk van het individu kunnen voorkomen en als vijandige wezens bezit nemen van het menselijk lichaam. Het spectrum van voorkomende ziekten, onderverdeeld in ziektekarakters, was afhankelijk van de natuurlijke gesteldheid, zoals ook de samenstelling van het plantenrijk afhankelijk was van de seizoenswisselingen en de verschillen in klimaat. Ziekten werden dus ontologisch gedefinieerd; zij maakten een kenmerkende ontwikkeling in de tijd door, met fasen van groei, bloei en afsterven.

Deze 'natuurlijke historie' van ziekten vatte men samen met het begrip constitutio - een begrip dat al sinds Hippocrates werd gebruikt, maar in de zeventiende en achttiende eeuw een centrale plaats in de leer der volksziekten innam. De constitutio stond voor het algemene beeld van de ziektevormen, zowel wat de ziektevormen die aan de 'bloei' van het ziektekarakter waren voorafgegaan, als wat de aard van het ziektekarakter zelf betreft. Men nam aan, dat de constitutio de mens voor sommige ziekten vatbaarder maakte, en deze ziekten snel of langzaam deed ontstaan.

Men onderscheidde een constitutio endemica, annua en epidemica. De constitutio endemica omvatte ziekten die kenmerkend waren voor een bepaald gebied op aarde. Zo werd struma als een typisch plaatsgebonden ziekte beschouwd. De constitutio annua stond in verband met de afwisseling van de jaargetijden. Croup en andere acute aandoeningen van de ademhalingsorganen bijvoorbeeld werden epidemisch bij koud weer met aanhoudende noordoostelijke wind en diarrhee en ander buiklijden juist bij zeer warm weer. De belang- 
rijkste invloed op de volksgezondheid echter werd de constitutio epidemica (stationaria) genoemd. Deze constitutio kon jaren achtereen 'ontstekingachtig' of 'galachtig' zijn. Men sprak dan van een constitutio epidemica (stationaria) inflammatoria of biliosa. Dit aanhoudende algemene ziektekarakter kon invloed uitoefenen op het gehele beeld van de voorkomende ziekten, of deze nu sporadisch, endemisch dan wel epidemisch optraden.

Men nam aan dat de laatstgenoemde constitutie het resultaat was van kosmische invloeden, uitgeoefend door bijvoorbeeld de stand der hemellichamen, en tellurische invloeden die uitgingen van bepaalde nog onbekende processen in het binnenste van de aarde. Kosmische invloeden konden atmosferische veranderingen veroorzaken, terwijl tellurische invloeden de lucht konden besmetten met schadelijke dampen, ook wel effluvia, emanaties of miasmata genoemd. ${ }^{76}$ Deze dampen zouden vooral ontstaan op plaatsen met rottende organische stoffen, zoals moerassen.

Het samenspel van atmosferische en tellurische veranderingen kon binnen één mensenleven de constitutio epidemica vele malen van karakter doen veranderen, waardoor ook het spectrum van ziektebeelden telkens een geheel ander aanzien kreeg. Nu eens stonden koortsende ziekten met dysenterie of exantheem op de voorgrond, dan weer overheersten de intermitterende koortsen. De epidemische constitutie kon zo ongunstig zijn, dat zich een epidemie van bijvoorbeeld tyfeuze koortsen ontwikkelde.

\section{Contagium}

Met het bovenbeschreven aetiologische model meende men op den duur de 'heersende ziektegesteldheid' te kunnen verklaren. In de vroeg-negentiendeeeuwse geneeskunde hanteerde men echter voor het ontstaan en de verspreiding van de zogenaamde contagieuze ziekten een afzonderlijke verklaring. Van deze ziekten nam men al sinds de zestiende eeuw aan dat zij alleen door een 'contagium' of 'smetstof' van een ziek op een gezond persoon konden worden overgedragen. ${ }^{77}$ Aanvankelijk rekende men vooral de syfilis en de pest tot deze ziekten, maar later werden ook schurft, pokken, gele koorts, mazelen en 'inheemsche cholera' als contagieuze ziekten beschouwd.

De theorie van het contagionisme - de gedachte dat besmetting veroorzaakt werd door onzichtbare ziektekiemen - werd in de zeventiende en in de eerste helft van achttiende eeuw door veel natuuronderzoekers verdedigd. ${ }^{78}$ Hoewel ze daarna een groot deel van haar aanhang kwijt raakte, bleven vele geneeskundigen tot in het begin van de negentiende eeuw ervan overtuigd dat boven genoemde ziekten zich via een contagium verspreidden. Overigens waren de tijdgenoten zich ervan bewust dat het bestaan van een smetstof nog nooit was aangetoond. Men nam eenvoudig aan dat bepaalde ziekten via een smetstof van de ene persoon op de andere werden overgebracht. Samengevat volgde men voor een contagieuze ziekte de volgende redenering:

1. De oorzaak van de ziekte is een smetstof. Deze smetstof is waarschijnlijk een anorganisch gif of een organische substantie, vergelijkbaar met de kiem van een plant of mogelijk een parasiet. ${ }^{79}$

2. Het bewijs voor het bestaan van de smetstof is weliswaar nog niet geleverd, maar de wetenschap zal de stof in de toekomst ongetwijfeld aantonen. 
3. De smetstof kan alleen via direct contact tussen personen of tussen personen en goederen worden overgebracht. Onder direct contact kan soms ook worden verstaan de aanwezigheid van een patiënt in de onmiddellijke omgeving.

4. De smetstof kan zich alleen in de ruimte verplaatsen, wanneer besmette personen zich in de ruimte verplaatsen of wanneer besmette goederen in de ruimte worden verplaatst.

5 . Omdat de smetstof zich alleen via personen of goederen kan verplaatsen, en alleen via direct contact van de ene persoon op de andere persoon kan worden overgebracht, is de 'reis' die de ziekte aflegt van persoon naar persoon, van huis naar huis, van stad naar stad, ja zelfs van land naar land in beginsel volledig te beschrijven.

6. Het wetenschappelijk onderzoek naar contagieuze ziekten moet daarom bestaan uit een gedetailleerde beschrijving van de route die de ziekte aflegt. Deze beschrijving kan de vorm hebben van een 'journaal' of van een plattegrond waarop de marsroute van de smetstof van dag tot dag staat aangegeven. ${ }^{80}$

7. De verspreiding van de ziekte kan worden verhinderd door een verbod op verplaatsing van (mogelijk) besmette personen en goederen.

In de eerste decennia van de negentiende eeuw werd deze redenering steeds vaker als speculatief van de hand gewezen, ten dele doordat het empiricisme in de geneeskunde de overhand had gekregen, ten dele omdat het uitbreken van de eerste cholera-epidemie (1831) er niet mee kon worden verklaard.

Om te beginnen was het tot dusverre niemand gelukt om het bestaan van smetstoffen aan, te tonen. Noch scheikundige proefnemingen met lichaamsvloeistoffen, besmet materiaal, lucht en water, noch botanisch-microscopisch onderzoek hadden overtuigende bewijzen opgeleverd voor het bestaan van contagia. Denkbeelden over de aard van de smetstof (anorganisch of organisch), de levenscyclus (zichzelf reproducerend organisme of spontaan voortkomend uit rottend materiaal) en de pathofysiologische werking in het menselijk lichaam (aantasting zenuwstelsel of parasitair) bleven louter theoretische constructies. Juist dit laatste begon in de medische wereld rond 1800 weerstanden op te roepen. Men wilde elke speculatieve theorie uitbannen door slechts van 'feiten' uit te gaan. ${ }^{8 t}$

In de tweede plaats toonden meer gedetailleerde waarnemingen aan dat lang niet alle patiënten die aan een 'contagieuze ziekte' leden, contact hadden gehad met besmette personen of goederen. Dit kon in de ogen van de tijdgenoten slechts twee dingen betekenen: het onderzoek naar de route die de ziekte had afgelegd was niet goed uitgevoerd, of de ziekte was niet contagieus. Het eerste standpunt werd door de contagionisten verdedigd. Zij gaven zich veel moeite om van ieder slachtoffer van een epidemie alle contacten na te gaan. De zogenaamde telluristen of miasmatici huldigden het tweede standpunt. Volgens hen moest het bestaan van het contagium naar het rijk der fabelen worden verwezen, niet alleen omdat contagia nog nooit waren waargenomen, maar vooral omdat vaker bleek dat de verspreiding van zogenaamde contagieuze ziekten atypisch verliep. Zo verspreidden de gele koorts en de cholera zich niet van persoon naar persoon, maar ontstonden deze ziekten op verschillende plaatsen tegelijkertijd, zonder dat tussen deze plaatsen verkeer had plaatsgevonden. ${ }^{82}$ De miasmatici waren van mening dat deze ziekten tot de epidemische ziekten moesten worden gerekend. Alleen geologisch onderzoek van het aardoppervlak, chemisch onderzoek van lucht en water en analyse van de klimatologische gesteldheid (temperatuur, luchtdruk, vochtigheidsgraad en windrichting) konden in samen- 
hang met onderzoek naar de leefomstandigheden de oorzaak van deze ziekten ophelderen. In hoofdstuk 4 zal nader op deze discussie tussen contagionisten en miasmatici worden ingegaan.

\section{Wetenschappelijk onderzoek naar volksziekten}

\section{De organisatie van het onderzoek}

Volksziekten werden in Nederland zowel door de provinciale commissies van toevoorzicht bestudeerd als door de verschillende wetenschappelijke genootschappen die het land kende. Een deel van deze genootschappen was in de tweede helft van de achttiende eeuw door intellectuelen, vertegenwoordigers van de vrije beroepen en kleine kooplieden opgericht ter bevordering van maatschappelijke hervormingen en van het verzamelen van kennis tot nut van het vaderland. ${ }^{83}$ De Hollandsche Maatschappij der Wetenschappen en het Provinciaal Utrechts Genootschap voor Kunsten en Wetenschappen bijvoorbeeld behoorden tot deze categorie. Het andere deel bestond uit genootschappen of leesgezelschappen ter bevordering van de geneeskunde of heelkunde. $\mathrm{Zij}$ waren na 1800 ontstaan, vooral in plaatsen waar een universiteit of een klinische school stond. ${ }^{84}$

De provinciale commissies waren verplicht ieder jaar een verslag van de heersende ziekten op te stellen en dit bij minister van Binnenlandse Zaken in te dienen. De gedachte was dat de minister zo op de hoogte van ontwikkelingen in de volksgezondheid bleef en desgewenst maatregelen kon treffen tegen bedreigingen van de volksgezondheid.

In theorie betekende deze regeling een grote verandering ten opzichte van de voorgaande periode. Het wetenschappelijk onderzoek was nu landelijk georganjseerd en de onderzoeksresultaten werden op een vast punt verzameld en geanalyseerd, bijvoorbeeld op de jaarlijkse vergaderingen van minister en voorzitters van de provinciale commissies. Dit maakte uitwisseling van gegevens mogelijk, wat de ontwikkeling van het wetenschappelijke onderzoek ten goede zou komen.

In de praktijk echter is hier niets van terecht gekomen. Zoals eerder is vermeld, zijn de rapporten van de commissies nooit bewerkt op het ministerie. Evenmin zijn de conclusies van het onderzoek ooit in een landelijke vergadering van commissievoorzitters besproken. De onderzoeksresultaten zijn bovendien nooit openbaar gemaakt, waardoor deze ook geen rol hebben gespeeld in de wetenschappelijke discussie. Daarom is het Geneeskundig Staatsbestuur nooit geworden wat het beoogde te zijn, namelijk het centrum van wetenschappelijk onderzoek naar volksziekten. De voortgang van het onderzoek was met andere woorden net als vóór 1818 afhankelijk van initiatieven van de eerder genoemde genootschappen of van individuele leden van de commissies van toevoorzicht. 
Er zijn in de periode na 1800 verschillende methoden van onderzoek naar de 'heersende ziekten' te onderscheiden. Drie daarvan zullen in het kort worden besproken: de medische geografie, de historische pathologie en de geneeskundige plaatsbeschrijving.

\section{Medische geografie}

Een veel toegepaste methode van onderzoek was de medische geografie. Met behulp van deze methode bestudeerden doctores de spreiding van alle op aarde voorkomende ziekten en probeerden zij de eigenschappen van deze ziekten te verklaren vanuit geografische en klimatologische factoren. De geografisch verschillende ontwikkeling van ziektevormen werd 'geografische pathologie' genoemd. $^{85}$

De medische geografie is in de achttiende eeuw tot ontwikkeling gekomen, toen bovengenoemde geleerde genootschappen in hun streven naar het verzamelen van nuttige kennis de verspreidingsmechanismen van volksziekten - in het bijzonder koortsende ziekten - wilden ophelderen. De aandacht van de medischgeografen ging vooral uit naar de klimatologische omstandigheden waaronder volksziekten voorkwamen. Maar men hield ook rekening met het type beschaving waarin de bestudeerde ziekten zich voordeden. De medische geografie bracht de doctores bovendien voor de eerste keer in de geschiedenis in contact met de wereld van bedelaars, fabrieksarbeiders en gevangenen, voor wie vervuiling in de straten en ondervoeding normale verschijnselen waren. ${ }^{86}$

De medisch-geografische koortsliteratuur, inclusief de sociale implicaties ervan, heeft zulk een grote invloed op de Europese artsen uitgeoefend, dat zij gerust aan het begin van de ontwikkeling van de openbare gezondheidszorg kan worden geplaatst. ${ }^{87}$ In Engeland bijvoorbeeld, waar de medische geografie sterk kwantitatief van karakter was, ontwikkelden artsen voor de verschillende gebieden van het land een 'scale of salubrity', aan hand waarvan de verlichte regering de welvaart van de onderdanen zou moeten vaststellen en de gezondheidstoestand van het land zou moeten bevorderen. ${ }^{88} \mathrm{Op}$ het Europese continent, vooral in landen waar de 'staatenkunde' of 'Kameralwissenschaften' - de studie van de bronnen van welvaart met veel aandacht voor demografische en geografische thema's - tot ontwikkeling waren gekomen, gaven regeringen steeds vaker de opdracht tot medisch-geografisch onderzoek. Zo werden in Pruisen ambtenaren met de beschrijving van de heersende ziekten en van de leefomstandigheden van de bevolking belast. ${ }^{89}$ Ook in de Zeven Verenigde Nederlanden zagen medisch-geografische studies het licht, zij het dat deze niet op last van de regering werden geschreven. In de Republiek stimuleerden vooral particuliere, geleerde genootschappen, zoals de Hollandsche Maatschappij der Wetenschappen en de Natuur- en Geneeskundige Correspondentie Sociëteit het onderzoek naar volksziekten. ${ }^{90}$

$\mathrm{Na} 1800$ maakte de medische geografie in Engeland en Frankrijk een andere ontwikkeling door dan die in de Duitstalige gebieden en Nederland. In de eerstgenoemde landen ging het getal en de rekenkunde een grote rol in de medische geografie spelen. Dit werd bevorderd door het feit dat bevolkingsstatistiek in deze landen tot ontwikkeling was gekomen. De Franse en Engelse geografen gaven zich ook rekenschap van de samenhang tussen het mortali- 
teitspatroon en de sociale veranderingen in hun tijd. ${ }^{91}$ In de Duitse en de Nederlandse medische geografie daarentegen werd over het algemeen weinig met numerieke gegevens gewerkt. Bovendien stond in de Duitse en Nederlandse publikaties het fysisch-geografisch determinisme op de voorgrond: ecologische variabelen bepaalden het ziekte- en sterftepatroon, terwijl de sociale en demografische verhoudingen statisch werden opgevat.

Het kwalitatieve karakter van de Nederlandse medische geografie werd in de hand gewerkt, doordat het landsbestuur onder Willem I er niet in slaagde de initiatieven van de Bataafse hervormers op demografisch terrein uit te werken, en een deugdelijke bevolkingsstatisitek tot stand te brengen. Na het herstel van de onafhankelijkheid behield het Franse besluit tot invoering van de Burgerlijke Stand ongewijzigd - dus zonder bepalingen die een geboorte- en sterftestatistiek mogelijk maakte - zijn wetsgeldigheid. Daardoor zijn de omvang van de totale Nederlandse bevolking, het aantal inwoners per provincie en gemeente, de leeftijdsopbouw van de populatie en de grootte van de migratie jarenlang onbekend gebleven. ${ }^{92}$ Alleen in Amsterdam, Den Haag en enkele kleinere gemeenten werden ook de doodsoorzaken opgetekend. De aangifte daarvan vond meestal niet door een arts, maar door een leek plaats. ${ }^{93}$

Op initiatief van de minister van Binnenlandse Zaken Van Gobbelschroy werd in 1826 de beoefening van de statistiek weliswaar enigszins geïnstitutionaliseerd, maar de statistische overzichten die in de jaren daarop het licht zagen, waren slechts gedeeltelijk numeriek van aard. De opgaven van de bevolking in het Konipkrijk gedurende de jaren 1815-1824, met tabellen betreffende geboorte, huwelijk, echtscheidingen en sterfte voor elke provincie, bevatten bovendien niet de rekenkundige bewerkingen die toen al bekend waren (gemiddelde levensduur, levensverwachting, relatieve sterfte). ${ }^{94}$ In opdracht van de minister werd vanaf 1826 tevens een Jaarboekje uitgegeven, waarin tal van statistische opgaven stonden vermeld. Het Jaarboekje, waarvan het laatste in 1849 verscheen, stond onder redactie van R. Lobatto, adviseur voor maten en gewichten bij het ministerie van Binnenlandse Zaken. Hij stelde in de jaren dertig en veertig pogingen in het werk om de 'politieke rekenkunde' meer bekendheid te geven. Het hoofdstuk statistiek van de jaarboekjes bevatte voornamelijk Nederlands demografisch materiaal en verder een door Lobatto zelf vervaardigde 'Wet van sterfte' van de stad Amsterdam, opgesteld naar het voorbeeld van de Brusselse hoogleraar in de wis- en natuurkunde L.A.J. Quetelet. Maar Lobatto was een witte raaf in de Nederlandse demografische wetenschap: van een rekenkundige bevolkingsstatistiek was in Nederland vóór 1840 verder weinig te merken.

Een andere poging om de bevolkingsstatistiek tot ontwikkeling te brengen, was het uitschrijven van volkstellingen. Vanaf 1829 vond iedere tien jaar een volkstelling plaats. ${ }^{96}$ Hierdoor kwamen voor het eerst in de geschiedenis van het Koninkrijk gegevens beschikbaar over de naam, de ouderdom, de geboorteplaats, het geslacht, de burgerlijke staat, de godsdienst en het beroep van iedere ingezetene in het land. Maar ook deze poging is van geringe betekenis voor de medische geografie geweest. De uitkomsten van de volkstellingen zijn vóór 1850 nooit afzonderlijk verschenen, maar stonden na 1831 voor een deel wel in het Jaarboekje van Lobatto afgedrukt. ${ }^{97}$ Het duurde tot 1849 , voordat genoemde gegevens permanent werden bijgehouden in de bevolkingsregisters, die in dat jaar voor elke gemeente verplicht werden gesteld. Artsen waren daardoor in 
eerste helft van de negentiende eeuw niet in staat om het ontstaan van volksziekten te onderzoeken op basis van numerieke gegevens en een rekenkundige bewerking daarvan.

In de Nederlandse medische geografie stonden in de eerste decennia van de negentiende eeuw vooral de streken in de belangstelling, waarvan men wist dat er een hoge sterfte was. Zeeland was zo'n streek (de 'Zeeuwsche koortsen' waren berucht), maar ook polder- en moerasgebieden elders in het land kregen veel aandacht van medici. In de ogen van de tijdgenoten hadden de vele inpolderingen die in het begin van de vorige eeuw plaatsvonden tot gevolg, dat de bevolking van de omliggende dorpen jarenlang werd blootgesteld aan pathogene atmosferische omstandigheden van de naburige drassige polders. De Goudse arts W.F. Büchner verklaarde in 1826 het feit dat de koortsen in Alkmaar minder slachtoffers maakten dan in Hoorn bijvoorbeeld als volgt: 'De uit zee waaijende winden ververschen en zuiveren de lucht te Alkmaar aanhoudend, maar over de lage en moerassige, pas drooggemaakte gronden heenstrijkende, en met derzelve uitwasemingen vermengd, alvorens zij Hoorn, of andere zijden van Noord-Holland bereiken, worden ze voor die steden verderfelijk, en voeren de stoffelijke oorzaken voor ziekten aan. 98

Op soortgelijke wijze werd een epidemie van 'tusschenpoozende koortsen' geanalyseerd, die in het noorden en het westen van het land in 1826 veel slachtoffers had gemaakt. De vraag waarom de epidemie in het noorden en westen van het land wel en elders niet was uitgebroken en waarom sommige delen van het noorden meer dan andere waren getroffen, bracht vele pennen in beweging. Zo verklaarde de geneesheer J. Banga uit Franeker - een uitgesproken bewonderaar van Sydenham - in zijn veel geroemde Verhandeling over de epidemische ziekte van 1826 de epidemie uit de 'gevestigde ziektegesteldheid' van de getroffen gebieden: koortsen waren kenmerkend voor 'alle moerassige gedeelten der aan zee gelegen Nederlandsche provinciën'. ${ }^{99}$ De heftigheid en het verspreidingspatroon van de epidemie was volgens Banga te wijten aan overstromingen in 1825 en de weersgesteldheid van de zomer en nazomer van 1826 , die droog en warm waren met weinig wind. Het feit dat de epidemie op sommige plaatsen uitzonderlijk veel slachtoffers had geëist, was het gevolg van lokale of 'voorbeschikkende en opwekkende' oorzaken, zoals armoede en gebrek aan goed drinkwater. In de stad Groningen waren vele doden te betreuren vanwege de 'morzigheid der straten; eene van water ontbloote met alle onreinheid vervulde en ondragelijke stank verwekkende gracht; armoede door het steeds verminderen van werk, het verval der fabrieken, van den koophandel; slegt en gemeen voedsel...' Daardoor waren vooral onder de 'geringe burgerklasse, kinderen, vrouwen en bejaarden' veel slachtoffers te betreuren. ${ }^{100}$

De wijze waarop Banga de epidemie analyseerde, kan model staan voor die van al zijn tijdgenoten. Beschouwingen over de klimatologische en geografische gesteldheid, aangevuld met meer of minder expliciete verwijzingen naar de leefomstandigheden van de bevolking, werden tot in de jaren veertig algemeen gezien als het beste analytisch instrumentarium bij het onderzoek naar volksziekten. $^{101}$ 
Terwijl in Engeland en Frankrijk de medische geografie steeds meer in het teken kwam te staan van kwantiteit en sociaal-politieke kwesties, greep men in Duitsland en Nederland dus juist terug op het oude streven van Sydenham om een natuurlijke historie van ziekten te ontwikkelen. De 'nieuwe' werkwijze, die de historische pathologie werd genoemd, kende vooral in Duitsland in de jaren 1820-1840 vele beoefenaars, maar zij is ook in Nederland tot in de jaren vijftig toegepast. ${ }^{102}$

De verschijning van ziektebeelden stond volgens de historische pathologie in verband met een evolutionair proces in de natuur of bijzondere gebeurtenissen in de geschiedenis van de mensheid. Om deze verbanden nader te kunnen onderzoeken, moesten zo veel mogelijk historische feiten worden verzameld. Deze verzameling zou de historisch-pathologen in staat stellen een 'historia morborum' te ontwerpen, waarmee zij het bestaan van bepaalde ziekten wilden verklaren en tevens de verwantschap tussen de verschillende ziektebeelden aan het licht wilden brengen. Daartoe werden de ziektebeelden ondergebracht in ziektekarakters die nu eens als 'gastrisch-bilieus', dan weer als 'catarrhaal' of 'catarrhaal-rheumatisch tot sthenisch' werden omschreven. Zo kwam men tot de vaststelling van de 'constitutio epidemica' van een bepaald jaar. Deze constitutio bracht men vervolgens in verband met de stand van de thermometer en de barometer en met de windrichting van het ogenblik. ${ }^{103}$

Dit onderzoek ging hand in hand met een analyse van de pathogenese van de ziekten. Het 'wezen der ziekte' kon worden ontdekt door de systematische vergelijking van de verschijningsvormen van ziekten. Ziekten werden uitvoerig onderzocht op hun verschillen en overeenkomsten met aandoeningen die in voorgaande jaren en zelfs in voorgaande eeuwen door artsen waren beschreven. Het herhalen van dergelijk comparatief historisch onderzoek zou volgens de historisch-pathologen steeds betere definities van ziekten opleveren. De geneeskunde zou daarmee een objectieve basis voor haar handelen verkrijgen. Zo'n historische analyse moest ook duidelijk maken, hoe veranderingen in de natuurlijke gesteldheid van een land de verschijningsvorm en de virulentie van ziektekarakters konden wijzigen. Een bepaald ziektekarakter kon door klimatologische veranderingen zo op de voorgrond treden, dat ziekteverschijnselen die tot een ander ziektekarakter behoorden volledig werden 'onderdrukt'. Zo kon een epidemie van febris intermittens het aantal gevallen van tyfus sterk doen dalen.

De kennis van de pathogenese van ziekten was binnen de historische pathologie dus voor een belangrijk deel gebaseerd op de geschiedenis van de ziekten. De historisch-pathologen meenden dat deze geschiedenis objectieve wetmatigheden kende, waardoor hun onderzoek uiteindelijk tot 'natuurwetenschappelijke zekerheid' over het ontstaan van ziekten zou leiden. Daarom hadden zij ook de verwachting dat ze op den duur het ontstaan, het beloop en de opeenvolging van epidemieën met dezelfde nauwkeurigheid konden voorspellen als waarmee astronomen het tijdstip van een zonsverduistering berekenden.

Ook all klonken er soms geluiden dat het gezien de geschiedenis van een bepaalde ziekte 'verre het menschelijke vermogen te boven gaat de ziekte te stuiten', over het algemeen waren de geneeskundigen van mening dat de resultaten van de historische pathologie de mensheid in staat zouden stellen zich te verdedigen tegen ziekten die de natur nu eenmaal met zich meedroeg. ${ }^{105} \mathrm{Zo}$ stelde men voor om gebieden die volksziekten konden herbergen, af te scher- 
men van gezonde delen van het land, bijvoorbeeld door de beplanting in de polders zo in te richten dat zij als 'slagboom' tegen moerasdampen kon dienen. Ook werden ruime, luchtige huizen met de gevel afgewend van schadelijke winden aanbevolen. Men zocht naar 'algemeene middelen om den dampkring goed te houden', zodat een barrière tussen gezonde en ongezonde streken kon worden opgeworpen. In de ongezonde gebieden zelf wilde men een verbetering in het afwateringssysteem aanbrengen of dijken aanleggen om overstromingen te voorkomen. ${ }^{106}$ Bij het voorkómen van epidemische ziekten lag de nadruk dus op het aanpassen aan de eisen van de natuur, niet op het veranderen van de natuur of het wegnemen van de ziekten zelf.

\section{Medische topografie}

Een derde methode van onderzoek was de medische topografie of de geneeskundige plaatsbeschrijving. Een topografie was een zo volledig mogelijke beschrijving van een stad of een dorp om het spectrum van ziektebeelden te verklaren. De methode was al door Hippocrates aangeprezen als het beste middel voor een arts om de gezondheid van een bevolking ter plaatse te leren kennen. In de achttiende eeuw herontdekten Engelse en Franse legerartsen, die in opdracht van de overheid naar de oorzaken van de hoge sterfte in de krijgsmacht zochten, deze methode van onderzoek. In hun rapporten over de garnizoensplaatsen analyseerden ze het klimaat, de watervoorziening, de bodemgesteldheid en de voeding van de soldaten, en schetsten zij de invloed ervan op de gezondheid van de soldaten. ${ }^{107} \mathrm{Na} 1770$ volgden de gezondheidsdiensten van de Oostenrijkse, Pruisische en Russische legers met topografieën van garnizoensplaatsen. Tegen het einde van de achttiende eeuw raakte de topografische methode ook in de burgermaatschappij bekend, doordat militairgeneeskundigen na hun ontslag uit de dienst of terugkeer uit de koloniën geneeskundige plaatsbeschrijvingen van hun woonplaatsen gingen publiceren. ${ }^{108}$

Door de opkomst van de topografie is het begrip gezondheidsleer, opgevat als leefregels ter beheersing van de res non-naturales, uitgebreid tot een collectieve gezondheidsleer van een bevolking als geheel. In de topografie werden de ligging van de verschillende wijken, hun vochtigheid en belichting, de beluchting van de gehele stad, riolerings- en afwateringsstelsel, de situering van kerkhoven en demografische gegevens besproken. Met andere woorden in de topografie werd de infrastructuur van een stad geanalyseerd en tot object van medische zorg gemaakt. Tegelijk zagen de opstellers van een topografie het als hun taak de vorst ervan te overtuigen dat hij voor de gezondheid van zijn onderdanen een verlicht, op rationele kennis gebaseerd gezondheidsbeleid moest voeren. Rede, wetenschap en techniek zouden de stad in de toekomst herscheppen tot het prototype van een beschaafde, gelukkige en welvarende samenleving.

In de Republiek der Zeven Verenigde Nederlanden werden de buitenlandse plaatsbeschrijvingen vaak snel na verschijning vertaald, en gelezen door artsen die zich inspanden een breder publiek met de denkbeelden van de Verlichting bekend te maken. ${ }^{109}$ Toch verschenen er in de Republiek in de achttiende eeuw geen oorspronkelijke garnizoens- of plaatsbeschrijvingen, vooral omdat er in het Staatse leger voór 1793 geen geneeskundige dienst van enige omvang bestond. Ook in de jaren 1800-1840 vond de topografie in Nederland nauwelijks toepassing. De enige topografie van betekenis was in deze periode de geneeskundige plaatsbeschrijving van Amsterdam van de hand van de arts C.J. Nieuwenhuys. ${ }^{110}$ 
In dit werk, verschenen in twee delen in de jaren 1816-1820, werden behalve de geografische, klimatologische en maatschappelijke omstandigheden, alle voorkomende ziekten alsmede de demografische ontwikkelingen (bevolkingsgroei, aantal huwelijken, geboorten en sterfgevallen) gedetailleerd besproken.

Dat voor 1840 slechts één uitgewerkte analyse van de volksgezondheid in een stad is verschenen, heeft ongetwijfeld te maken met het ontbreken van een deugdelijke bevolkingsstatistiek, en ook met het feit dat onderzoek uitdrukkelijk niet tot de taken van de plaatselijke commissies van toevoorzicht werd gerekend. Toch verklaren beide factoren het ontbreken van dergelijke analyses niet volledig. Geneeskundigen hadden immers, net als bij de beoefening van de medische geografie, zelf het initiatief kunnen nemen om de volksgezondheid in hun woonplaats in kaart te brengen. Daarom lijkt de hypothese gerechtvaardigd dat geneeskundigen in de jaren 1800-1840 weinig belangstelling voor eigen topografisch onderzoek hadden. Daarvoor kunnen wetenschappelijke en politieke redenen worden aangevoerd, die in de volgende paragraaf worden besproken.

\section{De stad als ziektefactor}

\section{Verstoring van de natuurlijke evenwichten}

Vanuit het gezichtspunt van de ecologisch ingestelde geneeskunde was de stad een bron van ziekten en van verval van lichaamskrachten, omdat nagenoeg alle natuurlijke voorwaarden voor een gezond leven ontbraken. In de medische literatuur van voor 1840 worden talloze voorbeelden gegeven om aan te tonen dat de stad als zodanig eigenlijk een anomalie in de natuur is. De waterhuishouding van bodem en oppervlaktewater in de stad bijvoorbeeld raakte gemakkelijk verstoord door grote droogte of zware regenval, waardoor de inwoners regelmatig met een tekort aan drinkwater of ondergelopen straten en woningen te kampen hadden. Fris en helder drinkwater - éen van de belangrijkste door de natuur gegeven middelen om gezond te blijven - was in de stad slechts in geringe hoeveelheden aanwezig, waardoor de meeste stadsbewoners voor hun drinkwater op de vervuilde grachten en sloten waren aangewezen. Geneeskundigen toonden zich ook allerminst gelukkig met de oprichting van fabrieken, zoals loodwitmakerijen, katoendrukkerijen en lijmmakerijen, die immers de natuurlijke gesteldheid van bodem en oppervlaktewater aantastten. Men meende dat de gezondheid van de stadsbewoners werd ondermijnd door schadelijke dampen, die vanuit de grachten opstegen of vanuit omliggende moerasgebieden met de wind werden meegevoerd en in de nauwe straten en stegen bleven hangen. Altijd dreigde het gevaar dat de vervuilde stadslucht de uitwaseming ontregelde van schadelijke stoffen via de huid - volgens de artsen naast de ontlasting en urinelozing de belangrijkste fysiologische weg waarlangs het menselijk lichaam zich van schadelijke stoffen ontdeed. $\mathrm{Er}$ bevonden zich bovendien zieken en 'morsige lieden' in de stad die met de lucht die zij uitademden de atmosfeer bedierven. Door de luchtverontreiniging kon de dampkring in de stad gemakkelijk met ziekmakende, organische bestanddelen 'geanimaliseerd' raken, hetgeen het uitbreken van een epidemie tot gevolg kon hebben. 
Illustratief voor deze sombere visie op het stadsleven is de in 1827 gepubliceerde beschrijving van de situatie in Amsterdam door G.J. Mulder, die een jaar in de hoofdstad had gepraktiseerd. Na een schets van de verstoring van het natuurlijk milieu in fysisch en chemisch opzicht, stelde hij enigszins berustend vast: "Wien bevreemdt het (...), dat het bij elkander wonen van vele menschen zeer nadeelig is, en dat Amsterdam in dit opzigt ver te stellen is achter plaatsen waar minder menschen vergaderd zijn? Is dit nu in het algemeen den dampkring nadeelig, het is dit in het bijzonder voor het regenwater, hetwelk bij het vallen, in droppelen verdeeld, hier altijd door zulk eenen dampkring moet doortrekken, eer het in de vergaderbakken opgezameld en tot gebruik gebezigd wordt. Deze schadelijke uitvloeiselen worden niet weinig, vermeerderd door de onreinigheden van vele menschen, welke hun lichaam, in plaats van het behoorlijk te zuiveren, laten verstikken onder de voortbrengselen van hun beroep enz., zoodat men bijna de kleur der huid niet meer weet te onderscheiden." 112

Ook de levenswandel van de stadsbewoner werd in de medische literatuur afgeschilderd als strijdig met de natuur. Pennink stelde in zijn Gezondheidsleer voor het volk vast dat de stadsbewoner voor de hoeveelheid en de hoedanigheid van zijn voedsel allang niet meer 'de natuur volgde': de rijke stedeling at te veel, de arme te weinig, terwijl van beiden de voeding eenzijdig was. Het stadsleven was volgens Pennink evenmin bevorderlijk voor een gezonde lichaamsbeweging: er werden voor de gezondheid schadelijke beroepen uitgeoefend en de veel voorkomende werkloosheid en 'leeggang' in de steden had de bevolking in ernstige mate 'verwekelijkt'. Werkloosheid bracht bovendien voor de maatschappij nutteloze en schadelijke lieden voort.

Aan het ongezonde leefklimaat in de stad viel volgens de geneeskundigen weinig te veranderen. Het beste wat de stadsbewoner kan doen, is zo dikwijls mogelijk het platteland opzoeken, waar de natuur nog ongerept is en 'waar vrije lucht, bestendige bewegingen, eenvoudige spijzen en regelmatige levenswijze zich van zelve aanbieden, terwijl de onschuld der zeden bewaard blijft tegen de verleidingen der steden." 113 Daar kan men ook een voorbeeld nemen aan het leven van de landman, wiens frisse natuurlijke leven schril afsteekt tegen het muffe, kunstmatige leven van de stadsmens.

Bij Mulder en Pennink, en ook in verhandelingen over de ziektegesteldheid van andere medici, werd het stadsleven als ongezonder dan het plattelandsleven afgeschilderd, maar er werd niet met cijfers aangetoond dat de gezondheid van de stedelingen werkelijk zoveel slechter was dan die van de boerenbevolking. De sombere visie op de stad als leefmilieu was ook niet zozeer gebaseerd op systematisch onderzoek naar de volksgezondheid, als wel op een medisch axioma dat al vanaf de achttiende eeuw opgell deed, namelijk dat de beschaving de 'moderne' mens ver van zijn natuurlijke toestand had gebracht. Hierdoor was de mens het slachtoffer van een groot aantal ziekten geworden. 114

Het beschavingsbegrip van sommige geneeskundigen vertoonde met andere woorden sterke rousseau-ïstische trekken. Of, zoals Pennink het kernachtig samenvatte, 'sterk en gezond van ligchaam, vrolijk en onberoerd van geest, kwam de mensch uit de hand zijner Schepper. Al spoedig schijnt zijn gestel meer verweekt te zijn geworden, terwijl hij door de maatschappelijke zamenleving, en allerlei ziekte-aanbrengende dwalingen in zijn leefwijze, aanmerkelijk van zijn oorspronkelijk bestaan verwijderd is. 115 De enige juiste methode om de moderne mens van zijn kwalen af te helpen, was volgens Pennink hem ertoe te brengen volgens de regelen der natuur te leven. Men moest een voorbeeld 
nemen aan de oude grieken, die in hun streven naar het goede leven en naar schoonheid hun roem te danken hadden aan een evenwichtige ontwikkeling van lichaam en geest. ${ }^{116}$ Waar de verlichtingsdenkers uit de achttiende eeuw in wetenschap, techniek en maatschappelijke vooruitgang geloofden en tevens trots waren op de Europese cultuur, daar legden Pennink en andere medici dus juist de nadruk op de perverterende kant van cultuur en op de redelijkheid en de schoonheid van de natuur. Dit, te zamen met de idee dat de stad als zodanig een verwerpelijk produkt van de menselijke beschaving was, gaf weinig aanleiding om de gezondheidstoestand van de stadsbevolking te analyseren.

\section{Berusting onder de geneeskundigen}

De geringe belangstelling van de medici voor de infrastructuur en de demografische kenmerken van de stad was niet alleen het gevolg van het medisch pessimisme over het stadsleven en de voorliefde voor het landleven. Ook politieke en economische factoren speelden een rol.

In economisch opzicht verkeerden de Nederlandse steden sinds de achttiende eeuw in een crisis. Van sommige steden was het inwonertal geslonken, soms zo sterk dat hele straten onbewoond waren. Vooral de meer gegoeden waren naar het platteland getrokken. In 1815 gaven steden als Haarlem, Leiden, Den Haag, Enkhuizen en Gouda door achterstallig onderhoud, leegstand, afbraak van percelen en zelfs pleinen en straten een bouwvallige aanblik. 117

Vóór 1830 was het de politiek van de Koning om het Zuiden te industrialiseren en in het Noorden de handel en de landbouw te stimuleren. Na de afscheiding van België in 1830 beschikten de Noordelijke Nederlanden mede als gevolg van deze politiek niet meer over een levensvatbare economische basis: de bevolking in de steden verarmde in snel tempo. De trek naar de steden vanuit economische motieven was daardoor in de eerste helft van de negentiende eeuw in de Noordelijke Nederlanden een vrijwel onbekend verschijnsel. Terwij1 sommige steden in Engeland, Frankrijk en Zuid-Nederland na 1800 groeiden, nam het aantal inwoners in de grootste steden in Noord-Nederland enigszins af. $\mathrm{Na} 1830$ kenden de steden nauwelijks enige economische en sociale dynamiek. Onder dergelijke omstandigheden lag topografisch onderzoek niet voor de hand. Er viel weinig maatschappelijke ontwikkeling te bespeuren en alles leek bij het oude te blijven, terwijl een plaatsbeschrijving juist was bedoeld om verbetering van de stedelijke infrastructuur te bewerkstelligen.

Maar ook de politieke verhoudingen in de steden werkten niet in het voordeel van de artsen die een dergelijke analyse hadden willen publiceren. Tot 1851 , het jaar van de nieuwe Gemeentewet van Thorbecke, werden leden van de gemeenteraad voor het leven verkozen. Verantwoording behoefde niet te worden afgelegd en de beraadslagingen waren geheim. Door het zeer beperkte censuskiesrecht was een groot deel van de burgerij (de lagere standen in hun geheel) uitgesloten van politieke invloed op het lokaal bestuur. Het stedelijk politiek bestel was niet meer dan wat Thorbecke in 1847 'een wonderlijk mengsel van oude familie-aristocratie en nieuwe, fransch administratieve gedweeheid' noemde. ${ }^{118}$ Het zou zinloos geweest zijn om geneeskundige plaatsbeschrijvingen te publiceren, waarin geneeskunde en politiek zo duidelijk waren vervlochten. De politieke structuur van de stad maakte dat iedere poging tot verandering van de bestaande toestand gedoemd was te mislukken. 
Eén keer leek de indolentie in de steden doorbroken te worden, toen in 1831 en 1832 op last van de minister van Binnenlandse Zaken overal in het land gemeentelijke choleracommissies werden opgericht om een dreigende choleraepidemie het hoofd te bieden. ${ }^{119}$ In verschillende gemeenten kwam een discussie op gang over eventueel te nemen politie-maatregelen inzake de openbare reinheid; toen in 1833 de cholera eenmaal geweken leek, werden de choleracommissies opgeheven en keerde de gebruikelijke bestuurlijke rust en gezapigheid terug. De door sommigen voorgestelde structurele maatregelen om een herhaling van de cholera te voorkomen, zoals het terugdringen van de vervuiling van de openbare weg of toezicht op de verkoop van levensmiddelen, maakten geen enkele kans bij de gemeentelijke bestuurscolleges in deze jaren.

De achtergrond hiervan laat zich niet moeilijk vaststellen. Ziekten als tyfus en cholera waren een probleem van de armen. En problemen van de armen werden als eigen aan de mindere stand gezien. ${ }^{120}$ De volksziekten waren naar de mening van de regenten en de gegoede burgerij het gevolg van een onzedelijke en onhygiënische levenswandel, en niet van de staat waarin de openbare hygiëne verkeerde, hoezeer ook sommige artsen dat laatste bestreden. De bestrijding van volksziekten maakte, samen met het beheer van de gasthuizen en de verstrekking van geneesmiddelen, deel uit van de armenzorg. En daarin heerste de politiek van het allernoodzakelijkste en filantropie en paternalisme. De (geneeskundige) hulpverlening was er niet alleen op gericht de ergste nood van de arme te lenigen en hem te helpen zijn levenswandel te veranderen, maar ook om hem deugd en plichtsgevoel te bij te brengen, zodat hij zich voegde naar de autoriteiten en de plichten van de stand waarin hij geboren was.

Een dergelijke visie op de volksgezondheid, voortkomend uit de vrees de standsverschillen te doorbreken, stond een verbetering van de algemene gezondheidstoestand en van de leefomstandigheden van de lagere standen in de weg. Hoewel het weinigen was ontgaan, dat de slechte levenscondities van grote delen van de bevolking de hevigheid van epidemieën bevorderde, verhief slechts een enkeling zijn stem tegen het voortbestaan van de armoede. Van een breed protest van medische zijde was in deze jaren geen sprake. Dit bevestigt het beeld dat historici van Nederland in deze periode hebben geschetst en dat ook op de geneeskundigen van toepassing is: er waren geen groepen eerzuchtige intellectuelen die de Romantiek als wapen leerden gebruiken. Er was geen actieve en haar plaats zoekende middenklasse, waarvan intellectuelen konden beweren de representanten te zijn. ${ }^{122}$ Zoals we zullen zien, zal pas met de komst van de hygiënisten het conservatisme onder de geneeskundigen plaatsmaken voor sociaal-utopische en democratische denkbeelden die in Frankrijk en België reeds in de jaren dertig bestonden.

Samenvattend kunnen we zeggen, dat tussen 1800 en 1840 het gezondheidsbeleid van de regering in theorie was gebaseerd op het beginsel van centralistisch landsbestuur, maar dat in de praktijk lokale bestuursorganen en particuliere instanties in de gezondheidszorg de dienst uitmaakten. De geneeskundige staatsregeling die in de Bataafs-Franse tijd tot stand was gekomen, beloofde de aanzet te zijn voor een gezondheidszorg onder staatsbeheer. Tijdens het bestuur van koning Willem $I$ is getracht onderdelen van de gezondheidszorg onder controle van de rijksoverheid te krijgen. Deze pogingen kenmerkten zich echter door politiek onvermogen; ten eerste doordat de Koning er niet in slaagde een krachtige eenheidsstaat op te bouwen, ten tweede doordat de lokale elites en de 
kerkgenootschappen zich sterk tegen de soevereiniteitsaanspraken van de Koning hebben verzet.

De armenzorg - één van de peilers van de gezondheidszorg - is daarom altijd een lokale, veelal kerkelijke aangelegenheid gebleven. De openbare gezondheidszorg heeft de rijksoverheid aan de plaatselijke besturen overgelaten. Aan de bevordering van de statistiek is men nauwelijks toegekomen en er is weinig gedaan voor het medisch onderwijs. Ten slotte zijn de gasthuizen onder beheer van de lokale notabelen gebleven. Zelfs als het uitdrukkelijk de verantwoordelijkheid van de minister van Binnenlandse Zaken was om regulerend op te treden, bijvoorbeeld inzake de bevoegdheden van geneeskundigen, werden de zaken op hun beloop gelaten. Van de top van het Geneeskundig Staatsbestuur ging weinig uit, waardoor het stelsel van commissies van toevoorzicht op den duur functioneerde als een onsamenhangend verband van medische gezelschappen.

De maatschappelijke invloed van de geneeskundige stand is in dit hoofdstuk niet systematisch onderzocht. Er zijn echter aanwijzingen dat deze niet groot is geweest. Het beleid in de curatieve gezondheidszorg (gasthuizen, geneeskundige armenzorg, ziekenfondsen) werd in de meeste gevallen bepaald door leden van de plaatselijke elite en door commerciële instellingen. Op het terrein van de openbare gezondheidszorg oefenden medici evenmin veel invloed uit, en voor de gerechtelijke geneeskunde bestonden zelfs in het geheel geen institutionele banden tussen geneeskunde en overheid. Wel lijken geneeskundigen een rol te hebben gespeeld in het deel van de burgerij dat zich sinds de achttiende eeuw inspande voor de opvoeding van de arme volksklasse. $\mathrm{Zij}$ legden zich vooral toe op de verbreiding van adviezen voor een gezonde leefwijze.

Het ontbreken van een sterk centraal gezag heeft ook gevolgen voor het onderzoek naar volksziekten gehad. Er bestond geen wetenschappelijk debat op nationaal niveau, waarin de lokale onderzoekingen systematisch met elkaar werden vergeleken. Het onderzoek was vrijwel geheel op regionale en lokale gezondheidsproblemen - meestal epidemieën - gericht.

In het onderzoek maakte men een onderscheid tussen contagieuze en epidemische ziekten. Contagieuze ziekten zouden door een smetstof via direct contact van een ziek op een gezond persoon worden overgedragen. Epidemische ziekten hadden hun oorsprong in de constitutio epidemica, het algemene beeld van ziektekarakters. De constitutio was het resultaat van atmosferische veranderingen en schadelijke dampen in de lucht (miasmata), die op hun beurt waren terug te voeren op klimatologische invloeden en nog onbekende processen in het binnenste van de aarde.

Het onderzoek zelf bestond uit medisch-geografische en historisch-pathologische studies. Daarin werden hoofdzakelijk de klimatologische en geografische factoren geanalyseerd die voor de constitutio epidemica van belang waren. De methode waarin geneeskunde en politiek het meest waren vervlochten, namelijk de medische topografie, is (op één uitzondering na) niet toegepast. Geneeskundigen beschouwden het stadsleven als fundamenteel ongezond. Het beste wat men kon doen was zo dikwijls mogelijk het platteland opzoeken, om daar op krachten te komen. Topografisch onderzoek had onder de gegeven politieke verhoudingen ook weinig nut. Een groot deel van de burgerij, inclusief de medici, was uitgesloten van politieke invloed. Een kritische analyse van de gezondheidsvoorzieningen in de stad zou in Nederland vór 1840 weinig steun hebben gekregen. 


\section{Het streven naar een sterk geneeskundig staatsbestuur}

Indien de Staat verpligt is zorg te dragen voor den openbaren gezondheidstoestand der ingezetenen, behoren iedere plaats, iedere inrigting, gesticht of gebouw, iedere wijze der uitoefening van beroep, die met den openbaren gezondheidstoestand in verband staat (...) tot het domain public en moeten zij te allen tijde toegankelijk en keurbaar zijn voor die wettelijk aangestelde personen, welke de Staat met het toezigt over den openbaren gezondheidstoestand belast heeft (..) Persoonlijke vrijheid is eene vrijheid in en niet buiten of tegenover den Staat.

\section{J.P. Heije, 1843}

Aan het eind van de jaren dertig deed de organisatie van de gezondheidszorg nog maar weinig denken aan de oorspronkelijke doelstellingen van de Bataafse hervormers: overheidszorg voor de gezondheid van de burgers, uniformering van de reglementen voor de geneeskundige praktijk en een centraal geneeskundig bestuur. De onverschilligheid van de verantwoordelijke autoriteiten ten aanzien van de volksgezondheid en de concurrentie tussen de geneeskunstbeoefenaars zijn reeds als oorzaak genoemd. Daarnaast was het medisch onderwijs aan de hogescholen sterk achterop geraakt bij dat in het buitenland, terwijl het wetenschappelijk onderzoek en de oprichting en verbetering van klinieken werden belemmerd door chronisch geldgebrek.

Enkele jaren eerder had een aantal hoger geplaatste medici - leden van provinciale commissies, lectoren van klinische scholen en hoogleraren - geprobeerd de minister te bewegen verbeteringen aan te brengen, maar een werkelijke gedachtenwisseling met de minister, laat staan een openbare discussie over het gezondheidsbeleid kwam niet tot stand. De meeste geneeskundigen namen bovendien een afwachtende houding aan.

In dit hoofdstuk wordt beschreven hoe geneeskundigen een actievere houding jegens het regeringsbeleid aannamen. Eerst zal de kritiek worden besproken die geneeskundigen in de eerste helft van de jaren veertig op het regeringsbeleid hebben uitgeoefend. Vervolgens wordt beschreven, hoe de medici na 1845 besloten een onafhankelijke landelijke organisatie van geneeskundigen in het leven te roepen, toen de regering niet bereid of in staat bleek, aan die kritiek tegemoet te komen. 


\section{Nationale herleving}

De volhardingspolitiek van Willem I had voor het land rampzalige gevolgen gehad. Internationaal was Nederland in aanzien gedaald, en de financiële gevolgen van de politiek hadden het land op de rand van bankroet gebracht. De financiële crisis leidde bij de doorgaans volgzame Staten-Generaal uiteindelijk in 1839 tot verzet tegen de begrotingspolitiek van de Koning. Het resultaat van dit verzet was onder meer dat een verdrag met België werd gesloten en dat diverse ministeries na 1840 meer greep op 's rijks financiën kregen.

De oppositie tegen de Koning kwam van de hogere burgerij, de bankiers en de handelshuizen in Holland, in het bijzonder in Amsterdam. In economisch opzicht was deze oppositie liberaal, in politiek opzicht wilde zij evenwel niet verder gaan dan een beperkte grondwetswijziging. Zowel bij de oppositie als bij de regering leefde de angst dat elke ingreep in het staatkundig stelsel krachten zou losmaken die men niet kon beheersen. Voor de middengroepen der burgerij brachten de veranderingen in 1840 daarom nauwelijks enige verbetering in hun maatschappelijke positie.

Nog een tweede groep kwam onder invloed van de nationale crisis in beweging. Veel leden van de lagere en midden-burgerij, wier maatschappelijke positie op kennis was gebaseerd, hadden de gevolgen van de financiële situatie waarin het land verkeerde, aan den lijve ondervonden. ${ }^{\prime}$ Zo werd het vak van onderwijzer slecht betaald. Het werk was zwaar door de soms zeer grote klassen, de opleiding in het lager en technisch onderwijs was van slechte kwaliteit en ver achtergebleven bij het buitenland. ${ }^{2}$ Ook een groot deel van de ambtenaren ontving een gering salaris. De betere posten waren voorbehouden aan leden van de aristocratische elite. ${ }^{3}$ Tot de getroffen groepen behoorden eveneens de civiele ingenieurs en de geneeskundigen. De ingenieurs hadden door het uitblijven van industriële vernieuwing en de bijbehorende constructiewerken (weinig stoomwerktuigen, geen mechanisering van de landbouw, geen gas- en waterleidingen, terugval in weg- en waterbouwkunde, geen spoorwegen) geen uitzicht op een maatschappelijke carrière. ${ }^{4}$ De geneeskundigen hadden hun inkomen geleidelijk achteruit zien gaan door de geringer wordende financiële armslag van de armbesturen en de onderlinge concurrentie.

De lage beloningen en de weinig florissante arbeidsmarkt maakten samen met de politieke discussies na 1839 onder dit deel van de bevolking iets los. De abdicatie van de Koning in 1840, gevolgd door de troonsbestijging door Willem II, wekte verwachtingen omtrent politieke vernieuwingen. De invoering van ministeriële verantwoordelijkheid in de vorm van het contraseign had een ruimere vrijheid van spreken mogelijk gemaakt: eventuele kritiek raakte niet meer direct de Koning. Bovendien had de Koning de conservatieve minister van Binnenlandse Zaken $\mathrm{H}$. baron Merkus de Kock vervangen door de gematigd liberale W.A. baron Schimmelpenninck van der Oye van der Poll, die als TweedeKamerlid het autocratisch bewind van Willem I herhaaldelijk had bestreden. Zijn benoeming wekte de indruk van een hervormingsgezindheid van Willem II. In intellectuele kringen legde men de nadruk op culturele regeneratie door naar verwetenschappelijking te streven. In dit kader sloten meerdere beroepsgroepen zich aaneen om hun vakgebied te vernieuwen en het daardoor tevens te verheffen. Verheffing van de intellectuele beroepen lag in het verlengde van het streven naar nationale herleving. 
Voor deze groepen was het literaire tijdschrift De Gids een centraal punt. Dit blad, in 1837 door E.J. Potgieter opgericht, had zich ondanks een beperkte oplage tot een toonaangevend blad ontwikkeld. Het tijdschrift, geboren uit onvrede met de bestaande literaire tijdschriften die 'traag, nalatig en partijdig' waren, moest volgens de redacteuren Potgieter en Bakhuizen van den Brink een meer wetenschappelijke literaire kritiek nastreven. Alleen dan kon een beoordeling van letterkundige werken 'vooruitgang' betekenen, een veel gebruikt begrip in De Gids. In het proza en de boekbesprekingen van beide redacteuren voerde nationalisme de boventoon. $\mathrm{Zij}$ stelden de Hollandse zeventiende eeuw als voorbeeld: de degelijke werkzaamheid, de karaktervastheid, en de creativiteit in kunst en wetenschappen; eigenschappen die naar hun mening haaks stonden op de middelmatigheid en het statische karakter van de eerste decennia van de negentiende eeuw. Vooral Potgieter uitte in verscheidene prozastukken zijn kritiek op de lamlendigheid en de middelmatigheid van zijn tijd.

Al spoedig kwamen kwamen vele terreinen van wetenschap en kunst aan de orde. Recensenten besteedden aandacht aan zojuist verschenen werken op het gebied van letterkunde, rechten, taalkunde, sterrenkunde, geschiedenis, geneeskunde, filosofie, economie, wis- en natuurkunde. Deze recensenten schuwden niet nieuwe en moderne wetenschappelijke opvattingen te bespreken, en zich daar tegenover open op te stellen. Ook op het gebied van de wetenschap moesten recensies bijdragen aan de 'vooruitgang'.

Na $1840 \mathrm{kwam}$ in De Gids meer aandacht voor de liberale politiek, de handel, het armenvraagstuk, maar ook voor concrete politieke zaken zoals de grondwetsherziening en de herziening van het staatsbestel. In recensies van de werken van de liberale Leidse hoogleraar Thorbecke kon De Gids zijn opvattingen over vooruitgang en vrijheid van beginsel expliciet maken. Hier zag de overwegend liberale Gids-redactie een politieke vertaling van datgene wat ze nastreefde: vrijheid van denken die leidde tot ontplooiing en vooruitgang. ${ }^{5}$

In de jaren veertig drong het streven naar nationale herleving en verwetenschappelijking door in andere sectoren van de samenleving. In 1841 werd het Tijdschrift woor Staathuishoudkunde als forum voor economische, sociale en politieke vraagstukken opgericht. Allerlei vakorganisaties werden opgericht, zoals de Nederlandsche Maatschappij ter bevordering der Pharmacie (1842), het Nederlandsch Onderwijzersgenootschap (1844), het Historisch Genootschap (1845) en de Maatschappij ter bevordering van de Veeartsenijkunde (1846). Vanaf 1846 werden jaarlijks 'landhuishoudkundige' congressen georganiseerd. De nationale crisis van de jaren dertig en de neergang van de intellectuele beroepen lagen aldus ten grondslag aan de opkomst van een nieuwe, veelal academisch gevormde groep liberale burgers als een nieuwe klasse in een oude gemeenschap.

\section{De maatschappelijke positie van geneeskundigen}

\section{Onvrede onder de medici}

Uit onvrede over de falende wetgeving en het dalende aanzien van de medische stand traden een aantal jonge medici in de openbaarheid en leverden onomwonden kritiek op de gezondheidszorg. De Amsterdamse medicus J.P. Heije gaf 
tussen 1838 en 1840 als eerste een tijdschrift uit dat grotendeels gewijd was was aan de geneeskundige staatsregeling: Wenken en Meeningen omtrent Geneeskundige Staatsregeling en Algemeene Geneeskunde. Over zijn motieven liet hij weinig misverstand bestaan: 'Een schande is het dat niets gedaan wordt tot voorkoming of stuiting der syphilis, een schande voor de kunst dat kwakzalverij, ongeoorloofde praktijk schaamteloos het hoofd opsteken, dat de Commissiën voor Geneeskundig Toevoorzigt voor het kwaad terugdeinzen ook wegens het weinig omschreven zijn van hun werkkring; dat wij niets van den gang der epidemische en endemische ziekten, niets over het toe- of afnemen der bevolking, niets van de resultaten der vaccinatie, niets van openbare geneeskundige inrichtingen afweten.' 6

In 1841 richtte Heije een nieuw tijdschrift op, het Archief voor Geneeskunde (1841-1846), dat inhoudelijk niet veel van Wenken en Meeningen verschilde. Het jaar daarop verscheen op initiatief van de Amsterdamse arts J. van Geuns, de kleinzoon van de beroemde achttiende-eeuwse medisch hervormer Matthias van Geuns, het tijdschrift Bijdragen tot Geneeskundige Staatsregeling (1842-1845). Naast deze tijdschriften zagen in het begin van de jaren veertig nog talrijke losse publikaties over de geneeskundige staatsregeling het licht.

De meeste auteurs waren jonge, aan de hogeschool opgeleide, praktiserende geneeskundigen. Zij hadden geen deel gehad aan de totstandkoming van de Wet van 1818, maar hadden wel te maken met de gevolgen ervan. Enkelen maakten studiereizen naar het buitenland, waar zij nieuwe diagnostische methoden leerden kennen en moderne ontwikkelingen op het gebied van de medische wetgeving. Een betrekkelijk groot aantal van hen was afkomstig uit Amsterdam, zoals de energieke Heije en zijn vriend G.E. Voorhelm Schneevoogt, die in 1840 tot eerste geneesheer van het Buitengasthuis was benoemd, Van Geuns, en D.J.A. Arntzenius die in 1832 naam had gemaakt als lid van de regeringscommissie tot onderzoek van de cholera in Duitsland. Heije, Van Geuns en Voorhelm Schneevoogt maakten deel uit van de groep intellectuelen rond het tijdschrift De Gids. Heije publiceerde gedichten in De Gids; hij behoorde tot de romantische generatie van Nicolaas Beets en Arnout Drost. Met de laatste had Heije in de jaren dertig geprobeerd een doorbraak van de nieuwe literaire praktijk en een nieuwe literaire kritiek te bewerkstelligen. ${ }^{7}$ Van Geuns was in 1838 tot de redactie van het tijdschrift toegetreden, Voorhelm Schneevoogt volgde hem in $1846{ }^{8}$ Buiten Amsterdam waren het vooral de flamboyante Mulder, in 1840 tot hoogleraar in de chemie te Utrecht benoemd en een autoriteit op zijn vakgebied, en J.N. Ramaer, eerste geneesheer van het provinciaal krankzinnigengesticht te Zutphen, die van zich deden spreken.

Deze geneeskundigen deden op gezondheidkundig gebied wat Potgieter en anderen op literair gebied deden. Zij verbraken de stilte rond het gezondheidsbeleid door de misstanden in de gezondheidszorg openlijk aan de kaak te stellen. Hun kritiek presenteerden zij als wetenschappelijk en onpartijdig. Hun doel was een fundamentele hervorming van het medisch onderwijs en een goed functionerend Geneeskundig Staatsbestuur, ingericht volgens het model dat de Bataafse hervormers aan het einde van de achttiende eeuw hadden opgesteld. Daarnaast eisten zij een grotere zeggenschap van geneeskundigen in de gezondheidszorg. Dan zou ook in de geneeskunde een 'nationale herleving' tot stand gebracht worden.

De ernstigste klachten richtten zich tegen het theoretisch karakter van het academisch onderwijs en het lage wetenschappelijk peil van het onderwijs aan 
de klinische scholen. Volgens Amtzenius, die in de Bijdragen enkele malen de toestand van het medisch onderwijs besprak, leverde het academisch onderwijs onvolwaardige geneeskundigen af, omdat de aankomende doctores nauwelijks gelegenheid tot praktische oefening aan het ziekbed hadden. In de klinieken bestond bovendien weinig verscheidenheid in ziekten dat de studenten getoond werd, en gelegenheid om zich voor te bereiden op de behandeling van krankzinnigen was er niet. Demonstraties van heel- en verloskundige operaties waren uitzondering en, onderwijs in de kennis der oogziekten werd evenmin gegeven. De examens werden volgens Arntzenius gekenmerkt door 'lauwheid, partijdigheid en toegeeflijkheid'. Ook op de klinische scholen werd kritiek geleverd. Volgens Voorhelm Schneevoogt stelden de toelatingseisen en de opleiding aan deze scholen zo weinig voor dat 'de eerste de beste boeren-kinkel, wien men eerder den ploeg dan het anatomisch scalpel in de hand zou geven, of de eerste de beste kruijersjongen, wiens brein men eerder met boodschappen, dan met physiologische data behoorde te vervullen eraan kon voldoen'. ${ }^{10}$

Het Geneeskundig Staatsbestuur schoot volgens de critici eveneens op een groot aantal punten tekort: het overschrijden van de in de wet vastgelegde bevoegdheden van de geneeskunstbeoefenaars werd door de commissies van toevoorzicht oogluikend toegestaan, soms overtraden commissieleden zelf de geldende bepalingen, de bestrijding van de kwakzalverij was onvoldoende, de geneesmiddelenverstrekking was - wegens gebrek aan toezicht - in handen van ondeskundigen geraakt en het toezicht op de hygiëne in de gestichten en openbare gebouwen, op de verkoop van levensmiddelen en op de koepokinenting werd verwaarloosd. " De rechterlijke macht - mede verantwoordelijk voor de handhaving van de geneeskundige wetten - had niets gedaan om aan deze misstanden een eind te maken, aldus de klacht van deze artsen.

Volgens Van Geuns, die in 1842 een knappe analyse van het Geneeskundig Staatsbestuur publiceerde, hadden de commissies van geneeskundig toevoorzicht de situatie voor een groot deel aan zichzelf te danken. ${ }^{12}$ De examinering van heelmeesters door de provinciale commissies was naar zijn mening beneden peil, en er bestond aanwijsbare bevoordeling van bepaalde kandidaten. Leden van een plaatselijke commissie van toevoorzicht waren bovendien niet zelden ook lid van een provinciale commissie, hetgeen volgens Van Geuns tot een ontoelaatbare vermenging van functies leidde, en corrumperend werkte. De provinciale commissies hadden zich in de loop der tijd volledig buiten spel laten zetten: de klinische scholen waren in de jaren twintig buiten hen om tot stand gekomen en stonden nauwelijks onder hun zorg, ondanks desbetreffende bepalingen in de wet. Ook bij de verbeteringen in het krankzinnigenwezen hadden deze commissies volgens Van Geuns geen rol van betekenis gespeeld.

Een ander kritiekpunt was de totale afwezigheid van openbaarheid van bestuur: de activiteiten van het geneeskundig bestuur waren gehuld in een 'nevel der geheimzinnigheid', waardoor allerlei gebreken onbesproken bleven en ieder inzicht bij de geneeskundigen in bijvoorbeeld het vóórkomen van epidemieën en de resultaten van de vaccinatie ontbrak. Het gevolg van dit alles was, volgens genoemde artsen, dat de geneeskundige stand nauwelijks aanzien bij het publiek genoot, en er ook bij de regering weinig vertrouwen in de capaciteiten van de medici bestond.

In de ogen van Van Geuns, Ramaer, Mulder en anderen die in het begin van de jaren veertig hun kritiek op het geneeskundig bestuur formuleerden, viel er echter maar een hoofdoorzaak van de malaise in de gezondheidszorg aan te 
wijzen: de staat, van 'wie alle hoogere zedelijke invloed uitging', was ernstig in gebreke gebleven. In het bijzonder het departement van Binnenlandse Zaken had zijn plicht verzuimd om de 'materiële belangen' van de bevolking te beschermen en haar 'verstandelijke ontwikkeling' te bevorderen. ${ }^{13}$ Genoemde artsen meenden dat de reeds ten tijde van de Bataafse Republiek voorgestelde, maar nooit gerealiseerde gezondheidspolitiek nu eindelijk tot stand gebracht moest worden door het Geneeskundig Staatsbestuur centralistischer in te richten en met meer macht te bekleden.

Een voorwaarde voor de verhoging van het aanzien van de stand was een ingrijpende hervorming van het medisch onderwijs. Elke geneeskundige in opleiding diende voortaan hetzelfde onderwijs te volgen met ruime aandacht voor praktische oefening aan het ziekbed en voor de naturirwetenschappen. De examens moesten door een staatscommissie, bestaande uit onafhankelijke geneeskundigen, worden afgenomen en niet meer door de hoogleraren en de provinciale commissies van toevoorzicht.

Alle werkzaamheden van het Geneeskundig Staatsbestuur moesten openbaar zijn. Nieuw was het voorstel om een nationale vergadering van professoren, doctores, hoofdofficieren van gezondheid en apothekers als adviserend orgaan binneh het Geneeskundig Staatsbestuur in het leven te roepen. De leiding van deze vergadering zou door de Koning moeten worden benoemd. Dit toekomstige 'hoofdbestuur' moest binnen het kader van het departement van Binnenlandse Zaken worden belast met de behandeling van geneeskundige zaken. Dit voorstel illustreert hoe men een grotere werkzaamheid van geneeskundigen in het kader van een autocratisch bestuur dacht te kunnen verwezenlijken. ${ }^{14}$

\section{De staatscommissie van 1841}

De critici hadden hun hoop gevestigd op een staatscommissie die in november 1841 door minister Schimmelpenninck in het leven was geroepen om een herziening van de Wet van 1818 voor te bereiden. ${ }^{15}$ De talrijke klachten van medici in de jaren dertig aan het adres van het ministerie, en de verzoeken van de Eerste en Tweede Kamer om de medische wetgeving grondig op lacunes en ondoelmatigheden te onderzoeken, hadden hem tot dit besluit gebracht. Daarnaast was de definitieve erkenning van de afscheiding van België een goede aanleiding om de geneeskundige staatsregeling, die in 1818 immers voor zowel de Noordelijke als de Zuidelijke Nederlanden was opgesteld, te herzien.

Tot de leden van de staatscommissie behoorden, behalve de raadadviseur Van Maanen als voorzitter, de Leidse hoogleraar in de heelkunde J.C. Broers, de Amsterdamse hoogleraar in de anatomie W. Vrolik en F.S. Alexander, hoofd van de militair-geneeskundige school te Utrecht; alsmede de Groningse oudhoogleraar in de obstetrie en chirurgie P. Hendriksz, die in 1832 met Arntzenius een regeringsrapport over de cholera had opgesteld en in de omgeving van Den Haag een oogheelkundige praktijk voerde, de Zwolse arts I. van Deen, bekend om zijn onderzoek naar de fysiologie der zenuwbanen en behandelend geneesheer van het Tweede-Kamerlid Thorbecke, en ten slotte Heije als secretaris zonder stemrecht. Op Van Deen na waren er geen leden van de provinciale commissies in de staatscommissie opgenomen. De minister had de staatscommissie met opzet zo samengesteld, omdat hij een onafhankelijk advies wilde -een standpunt dat heel wat ongenoegen bij de leden van de verschillende commissies van toevoorzicht veroorzaakte. 
In april 1842 kwam de commissie met haar rapport. Over de doelstellingen bij een herziening van de medische wetgeving was de commissie het eens: de eenheid van stand moest worden bevorderd, verbetering van het medisch onderwiis was noodzakelijk en er moest een krachtiger geneeskundig bestuur komen. De meningen verschilden echter over de middelen om deze doelstellingen te bereiken. Een meerderheid, bestaande uit Van Maanen, Broers, Vrolik en Alexander, stelde de geleidelijke afschaffing voor van de plattelandsheelmeesters met behoud van een stand van niet-gegradueerden in de steden, alsmede de invoering van staatsexamina voor alle geneeskundigen. ${ }^{16}$ Daarmee moest de medische hulp op het platteland voortaan van dezelfde kwaliteit zijn als in de stad.

Voor wat betreft het medisch onderwijs bleven Van Maanen c.s. in vage termen steken. Weliswaar moest er in de toekomst slechts én type 'geneeskundige school' komen, waar doctores en stadsheelmeesters in zeven respectievelijk vier jaar werden opgeleid, maar de vraag of deze scholen de drie medische faculteiten moesten vervangen, lieten zij onbeantwoord.

Inzake het geneeskundig bestuur - dus het toezicht op de geneeskundigen en de openbare hygiëne - stelden deze commissieleden een uitbreiding voor van het geneeskundig bestuur met provinciale en gemeentelijke autoriteiten, zoals de gouverneur van de provincie, de procureur-generaal van het provinciaal gerechtshof en de hoofdingenieur van waterstaat van een provincie. Op landelijk niveau moest een raad van algemeen geneeskundig bestuur met de minister als voorzitter komen, opdat 'de zoo zeer miskende geneeskundige stand behoorlijk in den Staat worde vertegenwoordigd [..] ten einde voor al hetgeen de geneeskundige staatsregeling, de behoefte en belangen der wetenschap en den gezondheidstoestand betreft, voorstellen aan de Hooge Land's Regering te doen, en daar op al de punten, deze beide onderwerpen betreffende, te adviseren'. Tevens wensten Van Maanen c.s.de plaatselijke commissies van toevoorzicht te vervangen door kantonartsen, die moesten toezien op de uitoefening van de plaatselijke praktijk, gerechtelijke schouwingen moesten verrichten en verder tot taak hadden 'het voordragen en ten uitvoer brengen van maatregelen tegen de verspreiding van de syphilitische en andere besmettelijke ziekten". 7

Het standpunt van de minderheid, Hendriksz, Van Deen en Heije, week op drie belangrijke punten af. Ten eerste voldeed volgens hen niet één van de bestaande faculteiten en klinische scholen aan 'hetgeen de wetenschap verlangt', noch kon het bestaande onderwijs ooit 'tot gevoegzame hoogte opgevoerd worden'. 'Opheffing dus van alle die inrigtingen, welke nimmer aan het doel, waartoe zij bestemd zijn, zullen kunnen beantwoorden', zo concludeerde de minderheid. ${ }^{18} \mathrm{Er}$ diende slechts é́n klasse van geneeskundigen te be- staan, liefst opgeleid aan éen geneeskundige school, en wel bij voorkeur in Amsterdam. De examens zouden door een staatscommissie moeten worden afgenomen.

Ten tweede zag de minderheid niets in een versterking van het Geneeskundig Staatsbestuur door er nog meer notabelen in op te nemen. Hendriksz, Van Deen en Heije waren van mening dat het falen van het Geneeskundig Staatsbestuur vooral een gevolg was van het feit dat het toezicht was opgedragen aan commissies in plaats van aan individuen die persoonlijk verantwoording aan de minister schuldig waren. Het voorstel van de meerderheid zou het euvel van de gezapig werkende commissies niet wegnemen. Daarom moest uitvoering van de maatregelen, uitgaande van de minister of het geneeskundig bestuur, geheel in 
handen worden gelegd van 'op zich zelven staande en persoonlijk verantwoordelijke individus'!

Hendriksz, Van Deen en Heije wilden in tegenstelling tot de andere commissieleden de ambtenaren van het geneeskundig bestuur vergaande bevoegdheden geven. Deze moesten worden belast met het toezicht op levensmiddelen en bij lijkschouwingen optreden als 'regter-commissaris in geneeskundige zaken'. ${ }^{20} \mathrm{Zij}$ dienden gekend te worden in de bouw en inrichting van openbare gebouwen, en zouden zij ieder gasthuis of krankzinnigengesticht en elke school of fabriek op eigen initiatief mogen inspecteren. Bij het constateren van gebreken was het hun taak voorstellen aan burgemeester en wethouders te doen. Heije verdedigde in het Archief voor Geneeskunde deze voorstellen met de opmerking dat de overheid alleen ernst kon maken met verbetering van de gezondheidstoestand door geneeskundige ambtenaren vergaande bevoegdheden te geven, desnoods ten koste van de persoonlijke vrijheid en de onschendbaarheid van het eigendom. ${ }^{2 .}$

Ten slotte wilden Hendriksz, Van Deen en Heije dat gekozen gewestelijke raden in plaats van benoemde commissies het toezicht op de geneeskundige praktijk zouden gaan uitoefenen. Aan het hoofd van deze gewestelijke raden moest een landelijke - eveneens gekozen - wetenschappelijke raad komen te staan. 'Zullen (...) de geneeskunst-oefenaren hunne belangen vooral wat het disciplinair gezag betreft, geheel en onbepaald aan zulk een ligchaam toevertrouwen, zoo moet het hen ook waarlijk vertegenwoordigen, dat is, zoo moet het door hen gekozen zijn', aldus de minderheid. ${ }^{22}$

De inzichten van de commissie als geheel waren dus wat betreft de verhouding tussen stand en staat niet strijdig met de grondslagen van het uit de Bataafse Republiek stammende geneeskundig bestuur: men zag het uit commissies en individuele personen opgebouwde geneeskundig bestuur - bedoeld om alles wat de ontwikkeling van de medische wetenschap, de uitoefening van het geneeskundig beroep en de openbare gezondheidszorg betrof, te controleren en in de gewenste richting te sturen - als een integraal onderdeel van het staatsbestel. De meerderheid was daarbij van mening dat de belangen van de medische beroepsgroep moesten worden behartigd door een landelijke raad, waarvan de leden door de Koning waren benoemd. De minderheid stond een democratischer geneeskundig bestuur voor: de leden van de gewestelijke raden behoorden te worden gekozen door de praktijkvoerende geneeskundigen in het land. De landelijke wetenschappelijke raad zou worden samengesteld uit gedeputeerden van de gewestelijke raden. Op deze wijze was openbaarheid van handelen gegarandeerd, waardoor de geneeskundige rijksorganen niet meer konden vervallen tot colleges, waarin jarenlang dezelfde incompetente personen zitting hadden. Dit denkbeeld van een gekozen geneeskundig staatsbestuur bleef de discussie tot ver in de jaren vijftig beheersen, zoals we zullen zien.

De uitspraken van de staatscommissie brachten grote beroering in geneeskundige kringen. Hoogleraren verzetten zich tegen de instelling van een staatscommissie voor geneeskundige examens en tegen het idee dat de opleiding in Amsterdam zou moeten worden gevestigd. Enkele van hen keerden zich tegen wat zij als een aantasting van het academisch karakter van het medisch onderwijs zagen. Daarbij moest vooral de minderheid in de staatscommissie het ontgelden. De Groningse hoogleraar in de obstetrie en pathologie J. Baart de la Faille meende dat 'alleen aan universiteiten den jongeling (...) gelegenheid tot harmonische ontwikkeling van kracht en veelzijdige vorming (wordt) gegeven; dáár alleen is doelmatig gezorgd voor alle mogelijke vakken van menschelijke 
kennis; dáár alleen wandelt hij op klassieke bodem en schept uit zuivere bron van Wetenschap en Kunst, al wat hij nodig heeft voor het practisch leven'. Voor de aankomende medicus was 'het levende woord, de bezielende voordracht van den leraar' van groter belang dan het zien van een groot aantal patiënten, waaraan de hervormers zo hechtten. ${ }^{23}$ Volgens de Leidse hoogleraar C. Pruys van der Hoeven zouden de voorgestelde geneeskundige scholen slechts zeer eenzijdige medici zonder enig karakter afleveren. De bestaande academische opvoeding had juist het voordeel dat men 'behoed blijve voor die bekrompen manier van zien, welken aan menschen, die zich uitsluitend aan een vak van studie toewijden, eigen is, en hen te dikwijls verleidt, om hun vak als het non plus ultra van menschelijke kennis en zichzelve als de uitverkorenen des menschdoms te beschouwen'. ${ }^{24}$ Terwijl de critici kennis, eigen waarneming en praktische oefening voorop stelden, legden de hoogleraren de nadruk op traditie, vorming van de persoonlijkheid en humanistische waarden.

Anderen vonden de minderheid te ver gaan in haar streven naar eenheid van stand, en meenden dat een tweede stand op enigerlei wijze moest worden gehandhaafd. Een 'klasse' van niet-gegradueerden moest blijven voortbestaan, daar de universitair opgeleide medici niet geschikt waren voor een praktijk onder het mindere volk en of op het platteland, dan wel nooit voldoende talrijk zouden zijn om het platteland toereikend van hulp te voorzien. ${ }^{25}$ De corporatistische grondslagen van het geneeskundig staatsbestuur werden echter door niemand bestreden.

Het wetsontwerp van minister Schimmelpenninck, was ongetwijfeld als een compromis tussen de verschillende partijen in het debat bedoeld. Juist om die reden echter liet het allerlei problemen onopgelost. ${ }^{26}$ Evenals de minderheid van de staatscommissie wilde de minister dat voortaan slechts én klasse van geneeskundigen zou worden opgeleid. Maar in tegenstelling tot de minderheid verbond hij dit voorstel niet met een plan voor ingrijpende hervormingen in het medisch onderwijs - één van de belangrijkste eisen van de critici. Integendeel, hij had op het punt van het onderwijs juist de zijde van de hoogleraren gekozen: iedereen die de genees-, heel- en verloskunde gezamenlijk of afzonderlijk wilde uitoefenen, was verplicht zijn opleiding aan één van de hogescholen te volgen. Het onderwijssysteem op de faculteiten bleef onveranderd, en staatsexamina wees de minister van de hand.

Terwijl velen het onderwijs aan de hogescholen als verouderd beschouwden en sommigen het zelfs geheel afgeschaft wilden zien, zag de minister dus tedenen om de medische faculteiten het alleenrecht op de opleiding tot geneeskundige te geven. Of de drie faculteiten wel in staat waren om met de bestaande onderwijsvoorzieningen voldoende artsen af te leveren, moest in de toekomst blijken. Mogelijk vond de minister dit geen urgent probleem, waarschijnlijker is echter dat hij niet over de financiële middelen beschikte om de onderwijscapaciteit van de faculteiten te vergroten.

Op het terrein van het Geneeskundig Staatsbestuur volgde de bewindsman in grote lijnen de adviezen van de meerderheid van de staatscommissie. In de door hem voorgestelde provinciale en plaatselijke raden van geneeskundig toevoorzicht zouden voortaan ook de gouverneur, de procureur-generaal, respectievelijk de burgermeester (eventueel wethouder of raadslid), de officier van justitie en de commissaris van politie zitting moeten hebben. Alle overige voorstellen van de staatscommissie (landelijke raad van geneeskundigen, kantonartsen, gekozen Geneeskundig Staatsbestuur) wees hij van de hand. Op het gebied van de 
openbare hygiëne stelde hij evenmin wetswijzigingen voor.

Kort samengevat kwam het ontwerp van de minister neer op een versterking van de positie van het hoger onderwijs ten koste van de klinische scholen, het onveranderd laten van het hoger onderwijs zelf en uitbreiding van het aantal notabelen in het Geneeskundig Staatsbestuur.

De meeste reacties op het wetsontwerp waren negatief. De hervormers keerden zich vanzelfsprekend tegen het voorstel, maar ook in de Tweede Kamer rezen vele bezwaren, onder meer tegen de voorgestelde afschaffing van de klinische scholen en het feit dat het toezicht niet aan personen was opgedragen. Ook het ontbreken van een regeling voor de gerechtelijke geneeskunde ontmoette veel kritiek in de Kamer. ${ }^{27}$ Met grote meerderheid werd het ontwerp door de Kamer verworpen. Schimmelpenninck kreeg niet de mogelijkheid een nieuw voorstel in te dienen, want in 1846 trad hij af. Hij had 'vrijzinniger' voorstellen aangaande de regeling van het kiesrecht ingediend dan de koning wilde goedvinden.

Het ministerie van Binnenlandse Zaken werd de jaren daarop geleid door conservatieve ministers, van wie men geen enkele hervorming hoefde te verwachten. De departementale bemoeienis met de geneeskundige staatsregeling bereikte een dieptepunt in 1848, toen de raadadviseur Van Maanen eervol werd ontslagen. Zijn functie werd overgenomen door de secretaris-generaal $\mathrm{mr}$. C. Vollenhoven, op dat moment de hoogste functionaris op het ministerie. ${ }^{28}$ Gevolg was, dat er vanaf dat moment in het geheel geen medisch geschoold ambtenaar meer op het departement werkzaam was ten behoeve van geneeskundige zaken. ${ }^{29}$

Omstreeks 1845 leek dus alles bij het oude te blijven. De poging van Heije en anderen om het Geneeskundig Staatsbestuur te verbeteren, was mislukt. De hervormers konden nu twee dingen doen: wachten tot de minister van Binnenlandse Zaken bereid was de discussie over de gezondheidszorg te heropenen wat de geneeskundigen in de voorgaande twee decennia hadden gedaan; of zelf het initiatief nemen en in navolging van andere begroepsgroepen een eigen organisatie oprichten om zo meer invloed te kunnen uitoefenen. Heije, volgens wie het streven naar vrijheid en vooruitgang niet meer was tegen te houden, koos voor het laatste. Hij staakte de uitgave van het Archief. Het had naar zijn mening geen zin meer nog langer dezelfde argumenten te herhalen. In het laatste nummer van het tijdschrift plaatste hij een oproep aan alle geneeskundigen om zich aaneen te sluiten en in vereniging verbetering van de wetgeving van de regering te eisen. ${ }^{30}$

\section{Verbreding van de oppositie}

Heije voelde zijn tijd goed aan. Overal in het land morden de geneeskundigen over het weinige dat werd gedaan ter verbetering van de gezondheidszorg. Daarnaast had Heije een juiste beoordeling gemaakt van de veranderde politieke gezindheid van de geneeskundigen. Nu de regering niet tot hervormingen bereid leek, namen de medici zelf het initiatief.

De eerste tekenen van verandering werden zichtbaar in de medische genootschappen die in de loop van de jaren twintig en dertig in de steden waren opgericht. Gegradueerde geneeskundigen en ook enkele stadsheelmeesters kwamen in deze genootschappen bijeen voor de bespreking van geneeskundige onderwerpen. De zorg in deze kring over de ondoelmatige organisatie van de 
geneeskundige hulpverlening en het geringe maatschappelijke aanzien dat daarvan het gevolg was, werd na 1840 met steeds luider stem onder woorden gebracht. In de genootschappen raakten de wetenschappelijke activiteiten op de achtergrond en kwamen discussies over beroepsbelangen op de voorgrond te staan.

In de genootschappen werd geklaagd over de schaarste aan middelen in het medisch onderwijs, de totale afwezigheid van natuurwetenschappelijke instituten en het geringe aantal ziekenhuizen die bovendien veelal ontoereikend waren ingericht. De deplorabele staat waarin de geneeskunde als vakgebied verkeerde was in deze jaren echter niet de enige zorg van medici. In de genootschappen werd ook gesproken over de geringe financiële vooruitzichten en de slechte arbeidsvoorwaarden van geneeskundigen. Met name voor jonge geneeskundigen was het moeilijk om een behoorlijk bestaan op te bouwen. Zij beschikten niet over een eigen praktijk en waren voor inkomen en praktijkervaring op een betrekking bij een geneeskundige armendienst of een ziekenfonds aangewezen. Het was evenwel lastig om een betrekking bij een armendienst of een fonds te bemachtigen, doordat enerzijds het aantal geneeskundigen in de jaren dertig sterk was toegenomen en anderzijds de armendiensten en fondsen fors op hun uitgaven bezuinigden. ${ }^{32}$ Als men het toch tot armen- of busdokter had weten te brengen, waren de werkomstandigheden slecht. Gedwongen door de scherpe concurrentie hielden de ziekenfondsen de vergoedingen van de busdokters laag. Tegelijkertijd werd het aantal fondspatiënten per geneeskundige vergroot. Er was veel kritiek van geneeskundigen op de fondspraktijken. Maar tegen het winstbejag van de fondsdirecties kon niets worden gedaan, zolang in de wet niets was geregeld op het gebied van ziekenfondsen. Dat de staatscommissie van 1841 een dergelijke wet niet had voorgesteld, was voor velen een grote teleurstelling geweest.

Ook bij de geneeskundige armendiensten verslechterde de positie van de geneeskundigen. Tegenover de geringer wordende financiële armslag van de armbesturen stond een toenemende werkdruk van de armenartsen als gevolg van de groei van het aantal bedeelden na 1834 - het jaar waarin dit aantal een laagtepunt had bereikt. In 1830 werd $10 \%$ van de bevolking bedeeld, in 1848 ongeveer $16 \%$, ofwel een half miljoen op drie miljoen inwoners. In NoordHolland ontving in dat jaar bijna een kwart van de bevolking steun. Het ging om mensen die over het algemeen wel werkten, maar die te weinig verdienden om zich met name in bijzondere omstandigheden te kunnen redden.

Zowel degenen die een beroep op de armenzorg deden als de geneeskundigen kregen met een bezuinigingsbeleid van de armbesturen te maken. Op vergoedingen voor medicijnen werd fors beknibbeld en de armbesturen gingen strenger toezien op de aanvragen voor bijstand. De vergoedingen voor geneeskundigen werden gelijk gehouden, ondanks de toename van de hoeveelheid werk en de geldontwaarding in Nederland. ${ }^{34}$ De armbesturen bleken pas na langdurig aandringen bereid extra geneeskundigen - vaak slechts op basis van een tijdelijk contract - aan te trekken om de groeiende hoeveelheid werk het hoofd te bieden. De wijze waarop de doctores hun patiënten behandelden werden strenger gecontroleerd of armbesturen zochten goedkopere behandelmethoden buiten de behandelend geneeskundige om. Ziekenhuisopname kon pas plaats vinden na toestemming van het College van diakenen.

Een ander probleem dat nijpender werd naarmate het aantal bedeelden toenam, was het volledig langs elkaar heen werken van de verschillende armbe- 
sturen in de steden. Elk armbestuur had zijn eigen geneesheer, heelmeesters, vroedvrouwen en apothekers en zijn eigen reglementen. Verzoeken van geneeskundigen om de hulpverlening per wijk en niet per gezindte te organiseren, zoals bij het uitbreken van een epidemie gebeurde, werden steevast van de hand gewezen. Diaconieën gingen soms zelfs zover, dat zij onderlinge afspraken van armendoctores over de verdeling van patiënten verboden. ${ }^{35}$

De misstanden in de gezondheidszorg waren groot genoeg om de geneeskundigen landelijk in beweging te brengen. Vór 1845 ontbrak het de geneeskundigen echter nog aan richtinggevende politieke ideeën. Vooral onder de gegradueerden in de steden bestond de overtuiging dat verandering noodzakleijk was, maar in welke richting deze verandering moest gaan was allerminst duidelijk. Er was eerder sprake van een mentaliteitsverandering, met name in de medische genootschappen, dan van politiek engagement. Een alternatief voor het Geneeskundig Staatsbestuur, bijvoorbeeld een onafhankelijke, landelijke organisatie van geneeskundigen, was een nauwelijks besproken onderwerp. De geneeskundigen kwamen pas in beweging in de jaren 1845-1850, toen onder invloed van de staatkundige ideeën van Thorbecke een proces van politieke bewustwording in gang werd gezet.

Thorbecke had het 'doctrinair liberalisme' als politieke verwoording van het streven van de middengroepen in de jaren veertig een consistente vorm gegeven. Door zijn toedoen herleefde de oppositie na 1840. Thorbecke nam in de jaren veertig een aanmerkelijk radicaler standpunt in dan de gematigd-liberale oppositie van 1840. Naar zijn opvatting was de natie in verval geraakt en was het moment voor herstel gekomen. Dit laatste was mogelijk, als de staatsinrichting grondig werd herzien. De geschiedenis toont, aldus Thorbecke, dat de staat zich onvermijdelijk onwikkelt in de richting van een rechtsgemeenschap, door alle leden van die gemeenschap gezamenlijk in het leven geroepen en bestuurd: de staat 'wil gemeentelijke zelfregulering worden, rustende op gemeene regeerbevoegdheid der leden, met uitsluiting van voorregt'. ${ }^{36}$ Het staatsbestel had zichzelf overleefd omdat het geen mogelijkheden liet tot vruchtbare ontwikkeling van wetgeving en bestuur. Onder het 'landsvaderlijk' bestuur van de Koning hadden de burgers te weinig zeggenschap in het landsbestuur, waardoor de staat niet op 'nationale kracht' berustte. En zonder zo'n hoog ontwikkelde nationale kracht kon geen staat bewaard blijven, zo had de geschiedenis aangetoond. Alleen een staatsinrichting die een 'bron van ontwikkeling' vormt, is historisch gezien de juiste.

Thorbecke stelde kortom dat de Nederlandse staatsinrichting en de Grondwet ingrijpend moesten worden herzien, wilde de Nederlandse staat recht van bestaan behouden. Terwijl de bestaande Grondwet 'volkskracht buiten sloot', moest een nieuwe grondwet garanties bieden voor een 'oneindig grotere medewerking der burgerij aan de overheidsinstellingen dan tot dusver het geval was geweest'. Deze medewerking - door Thorbecke in 1844 met de term 'staatsburgerschap' betiteld - was hèt kenmerk van de negentiende eeuw op staatkundig gebied, en een dwingende opgave voor een ieder die het voortbestaan van de natie ter harte ging.

Thorbeckes concrete programmapunten waren ontleend aan het bijna twintig jaar eerder in Frankrijk ontwikkelde liberalisme: een parlementaire regering, ministeriële verantwoordelijkheid, algemeen kiesrecht in fasen te verwezenlijken, 
vrijheid van drukpers en vrijheid van vereniging. Zijn eerste poging om als Tweede-Kamerlid in 1844 een radicale grondwetsherziening te laten aannemen, kreeg slechts de steun van negen kamerleden die bekendheid behielden als de Negenmannen. De gematigd-liberale oppositie onthield haar steun aan Thorbecke, omdat zij aan de standenstructuur van de Nederlandse samenleving vasthield en deze zelfs wilde versterken. Bij de gevestigde orde ontstond een ware 'Thorbecke-fobie', met als gevolg dat Thorbecke in 1845 niet in de Tweede Kamer werd herkozen. De voorstanders van een radicale grondwetsherziening bleven evenwel regelmatig met elkaar in contact; zij vonden vooral steun bij enkele gelijkgestemde bladen als de Arnhemsche Courant, De Gids, het Handelsblad en de in 1844 opgerichte Nieuwe Rotterdamsche Courant.

Thorbeckes voorstellen hadden een katalyserende werking op het optreden van de medici. De politieke strubbelingen in de Tweede Kamer en de groeiende aandacht voor de grondwetsherziening werkten na 1845 in de discussies van de geneeskundigen door. Het beginsel van vrijheid, eigen initiatief en staatsburgerschap gaf langzaam maar zeker richting aan het handelen van de leden der medische gezelschappen. De roep om openbaarheid van bestuur klonk luider. Aan het gezondheidsdebat, tot dusverre slechts in beperkte kring gevoerd, moest iedere geneeskundige kunnen deelnemen. Tegelijkertijd lieten de geneeskundigen hun afwachtende houding varen. Tussen de genootschappen in de steden groeiden de contacten en van verschillende zijden gingen stemmen op om geneeskundigen in een landelijke organisatie te verenigen.

\section{Een Maatschappij of een congres van geneeskundigen ?}

Toch was het in die eerste jaren van politieke bewustwording niet onmiddellijk duidelijk hoe de geneeskundigen zich landelijk moesten manifesteren om hun eisen kracht bij te zetten. Moest men eenmaal per jaar een geneeskundig congres organiseren, zoals in het begin van de jaren veertig was voorgesteld? of was het beter een vrije en onafhankelijke vereniging van blijvende aard op te richten?

Een congres zou naar het voorbeeld van een geneeskundig congres, dat in 1845 in Parijs had plaatsgevonden, de regering gevraagd en ongevraagd van advies kunnen dienen. De Franse regering had het bijeenroepen van het congres, door ongeveer tweeduizend geneeskundigen bijgewoond, niet alleen goedgekeurd, zij had ook verklaard dat zij met het opstellen van wetsontwerpen zou wachten, totdat de geneeskundigen hun wensen kenbaar hadden gemaakt. ${ }^{37}$

Verschillende geneeskundigen in Nederland hoopten dat de regering het Franse voorbeeld zou volgen. Sommigen geloofden zelfs dat een congres kon uitgroeien tot een nationale vergadering van geneeskundigen, met als taak om een vernieuwd geneeskundig staatsbestuur kritisch te volgen. Een nationale vergadering zou tevens de ambtenaren van het staatsbestuur kunnen voordragen.

De voorstanders van een vereniging stond echter iets geheel anders voor ogen. Volgens hen zou een vereniging naar het voorbeeld van de in 1822 opgerichte 'Verein Deutscher Naturforscher und Aerzte' zelfstandig initiatieven moeten nemen op het terrein van de medische wetenschap, de beroepsbelangen en de openbare hygiëne. De vereniging zou moeten bestaan uit plaatselijke afdelingen met een eigen bestuur. Het landelijk bestuur moest door de leden van de afdelingen worden gekozen. ${ }^{38}$ 
Ramaer nam het initiatief tot de oprichting van een vereniging. Als secretaris van de Geneeskundige Kring te Zutphen verstuurde hij in 1847 brieven naar talrijke hem bekende medici, waarin hij pleitte voor de oprichting van een 'Algemeene Nederlandsche Maatschappij van Geneeskundigen'. Met zoveel woorden stelde Ramaer dat de weg die de geneeskundigen in Frankrijk hadden ingeslagen in Nederland onbegaanbaar was, omdat hier geen politiek centrum als Parijs bestond en omdat gelet op de onverschilligheid van de meeste geneeskundigen een congres onvoldoende bezoekers zou trekken. Ramaer wist de oprichting van geneeskundige kringen elders in het land te bevorderen en vele bestaande genootschappen te bewegen zich bij zijn initiatief aan te sluiten. In juli 1847 besloot de kring Zutphen, op voorstel van Ramaer, de genootschappen uit te nodigen afgevaardigden te kiezen voor een landelijke vergadering. Op de uitnodiging werd positief gereageerd door geneeskundigen in Groningen, Arnhem, Zuidbroek, Rotterdam, Leiden, Den Haag, Nijmegen, Meppel, Amsterdam en door de verloskundigen in Utrecht.

Maar Ramaers plan werd niet overal enthousiast ontvangen. Sommige geneeskundigen waren bevreesd voor tweespalt in hun genootschap, wanneer men zich met politieke onderwerpen zou inlaten. Anderen voelden meer voor het organiseren van een geneeskundig congres, waar ook geneeskundigen die niet van een genootschap lid waren, aanwezig konden zijn. ${ }^{39}$ Een grote tegenslag voor Ramaer was de weigering van Mulder om het voorzitterschap van de nieuwe maatschappij op zich te nemen. Ook deze had, zo zou spoedig blijken, meer vertrouwen in het uitschrijven van een geneeskundig congres.

Hoe groot het aantal tegenstanders van Ramaers plan was, blijft onduidelijk. Evenmin is bekend wie als eerste is begonnen met het dwarsbomen van Ramaers initiatief. In elk geval kwam het door Ramaer afgewezen denkbeeld van een geneeskundig congres weer in de belangstelling toen de arts N.B. Donkersloot begin 1848 in zijn Geneeskundige Courant een oproep richtte aan alle 'genees-, heel-, verlos-, schei- en artsenijmengkundigen' in Nederland, om deel te nemen aan een landelijk congres. Men kon 'geheel voor zich zelven verschijnen, of als afgevaardigde van het eene of andere Genootschap, van de eene of andere Vereeniging, Hooge School, Athenaeum of Klinische School'. 40

De oproep kwam politiek gezien op zeer beladen moment. De dag tevoren, 27 februari, was in Nederland de val van de monarchie in Frankrijk bekend geworden. Dit bericht veroorzaakte niet alleen grote ontsteltenis bij politieke kringen in Den Haag (in het bijzonder bij de Koning), maar wekte onder liberalen ook de hoop dat in Nederland de politieke hervormingen niet langer te stuiten zouden zijn. Een maand na de oproep werd bekend dat Duitse geneeskundigen een congres in Pruisen hadden belegd om veranderingen in het regeringsbeleid af te dwingen.

Deze omstandigheden vormden een gunstige voedingsbodem voor initiatieven als die van Donkersloot. Aan zijn oproep om zich bij de redactie van de Geneeskundige Courant op te geven werd van vele zijden gehoor gegeven. Wekelijks werden de namen van 'adhaerenten' in de kolommen van de Courant vermeld. Geneeskundigen die aanvankelijk hun medewerking aan Ramaer hadden toegezegd, besloten de oproep van Donkersloot te volgen. Ramaer zag zich gedwongen zijn pogingen een Maatschappij op te richten te staken. Hij besloot zelfs op uitnodiging van de Geneeskundige Courant mee te werken aan de voorbereiding van het congres. Op 21 mei werd een 'commissie tot inleiding van het geneeskundig congres' opgericht. Daarin treft men vele bekenden aan, 
zoals Mulder die voorzitter was, Van Deen, Van Geuns, Heije, Voorhelm Schneevoogt en Donkersloot; terwijl Ramaer secretaris van de commissie was. Er waren ook enkele nieuwe gezichten: F.C. Donders, de om zijn fysiologisch onderzoek vermaarde leerling van Mulder en kort tevoren tot buitengewoon hoogleraar in Utrecht benoemd; de Haagse arts J.C.G. Evers, bekend als redacteur van het tijdschrift Boerhaave (1839-1848), en de Groningse arts L. Ali Cohen, een begaafd leerling van de botanicus-geoloog Th. van Swinderen en Baart de la Faille. Ali Cohen genoot landelijke bekendheid dankzij de uitgave van het Statistisch-Geneeskundig Jaarboekje (1847-1852). ${ }^{41}$

In de zomer van 1848 besloot de commissie inderdaad een congres te organiseren, en stelden Heije en Evers een wetsontwerp op het geneeskundig staatsbestuur op dat daar moest worden besproken. Het ontwerp was vrijwel identiek aan het minderheidsrapport van Hendriksz, Van Deen en Heije uit 1842. Voor klein een deel was het ontwerp ontleend aan plannen die geneeskundigen in Pruisen tijdens de maart-revolutie hadden opgesteld. ${ }^{42}$ Korte tijd later - van 11 juli tot 26 juli - beraadslaagden de commissieleden over een aangepaste tekst van de hand van Voorhelm Schneevoogt en Heije. In hun voorstel werd voor het eerst getracht de diverse aspecten van het geneeskundig staatsbestuur (toezicht op de uitoefening der geneeskunst en op de openbare hygiëne, de examens en de regeling der bevoegdheden) in enkele afzonderlijk wetsontwerpen te regelen. ${ }^{43}$

\section{De staatscommissie van 1848}

De voorbereidingen van het congres werden doorkruist door de gevolgen van de drastisch gewijzigde politieke situatie. $\mathrm{Na}$ de bekendwording van de politieke omwenteling in Frankrijk en de vergaande concessies van de Duitse vorsten aan de liberale oppositie, liet de koning, onder de indruk van deze onheilspellende berichten, weten bereid te zijn de liberalen tegemoet te komen. Hij benoemde een aantal vroegere Negenmannen en de Amsterdamse liberale advocaat $D$. Donker Curtius in een commissie tot herziening van de grondwet.

De commissie, met Thorbecke als voorzitter, was binnen enkele maanden met haar werkzaamheden gereed. Het kabinet met de liberale minister J.M. de Kempenaer op Binnenlandse Zaken kon al in juni 1848 de grondwetswijzigingen van de commissie Thorbecke bij de Tweede Kamer ter behandeling indienen. In het najaar van 1848 werd de nieuwe Grondwet in een bijzondere vergadering van de Staten-Generaal aangenomen. Daarmee kwam een einde aan een lange, tot 1780 teruggaande crisis van de Nederlandse staat. Thorbecke had de staat nu een duidelijke vorm gegeven, door de positie van de koning in de constitutie en de verhouding tussen rijksoverheid en andere overheidsorganen expliciet vast te leggen. Hij had bovendien de 'medewerking van de burgers aan de overheidsinstellingen' tot beginsel van de constitutie gemaakt.

De vooruitzichten op blijvende en fundamentele politieke hervormingen leken groot, toen minister De Kempenaer op 25 juli een staatscommissie instelde met als doel de regering nog voor het eind van het jaar te adviseren aangaande herziening van de geneeskundige staatsregeling. Tot leden werden benoemd mr. H. van Sonsbeeck als voorzitter, en Mulder, Baart de la Faille, de Leidse hoogleraar in de pathologie en therapie G.C.B. Suringar, J. van Geuns, vanaf 1846 hoogleraar in de pathologie en forensische geneeskunde aan het Athenae- 
um Illustre in Amsterdam en C.B. Tilanus. De laatste was hoogleraar in de heelen verloskunde aan de klinische school te Amsterdam en voorzitter van het eerbiedwaardige Genootschap ter bevordering van de Heel- en Geneeskunde. Ook mr. J. de Bosch Kemper, advocaat-generaal van het Provinciaal Gerechtshof in Noord-Holland werd benoemd, maar zag van het lidmaatschap af. In zijn plaats kwam de gematigd liberale politicus mr. M.H. Godefroi uit Amsterdam.

Op 30 juni 1849 kon de commissie haar rapport aan De Kempenaer overhandigen. Voor het eerst werd getracht de geneeskundige zaken door middel van vijf afzonderlijke wetsontwerpen te regelen. ${ }^{45}$ Het Wetsontwerp op het geneeskundig staatsbestuur vertoonde een grote gelijkenis met dat in het minderheidsrapport van 1842. Aan het hoofd van het geneeskundig bestuur stond een directeur-generaal. Onder hem waren de provinciale en arrondissementsartsen. Alleen de directeur-generaal was ambtenaar in volledige dienst. De staatscommissie wilde het toezicht op de uitoefening der geneeskunst en op de openbare gezondheid geheel in handen leggen van individuen, die in bijzondere gevallen van commissies richtlijnen kregen. De bestaande provinciale en plaatselijke commissies van toevoorzicht moesten worden opgeheven. De staatscommissie sprak de verwachting uit dat de 'openbare geneesheren' in de komende jaren konden beschikken over nieuwe medische politiewetten, bijvoorbeeld op de verkoop van levensmiddelen en de hygiëne in openbare gebouwen. Voorts was de commissie van mening dat de geneeskunstbeoefenaars hun vertegenwoordigers in het staatsbestuur zelf moesten kiezen in de vorm van getrapte verkiezingen en met een,soort passief censuskiesrecht. Wat de vertegenwoordiging betreft werd de oprichting van een 'Academie voor Geneeskunde' aanbevolen, waarin hoogleraren en hogere ambtenaren van het geneeskundig staatsbestuur zitting zouden hebben. De academie moest dienen als vertegenwoordigend lichaam van de medici, ter behartiging van de beroepsbelangen en ter bevordering van de medische wetenschap. Opnieuw werd dus geopteerd voor een wet die het bestuur van de medische beroepsgroep in handen van overheidsorganen legde.

Met betrekking tot de geneeskunstbeoefening stelde de commissie twee afzonderlijke wetten voor. Apothekers mochten slechts medicijnen verstrekken op doktersvoorschrift. Bovendien werden ze aan het toezicht van geneeskundige ambtenaren onderworpen. Van alle beoefenaren eiste men bekendheid met de gehele geneeskundige wetenschap. Obstetrici en chirurgen zouden dezelfde opleiding als medicinae doctores moeten krijgen. De opleiding en toelating van de vroedvrouwen kwam eveneens onder staatstoezicht. De commissie ging niet zover als de minderheid van de commissie uit 1841 door slechts één klasse van geneeskundigen te verlangen: in kleinere en armere gemeenten op het platteland zag men voldoende behoefte aan een 'klasse van minder gevormde heelmeesters'. Zij moesten worden opgeleid door dezelfde hoogleraren als alle andere geneeskundigen, maar de aan hun gestelde eisen konden minder zwaar zijn. Ten slotte bracht de staatscommissie een advies met betrekking tot het geneeskundig onderwijs uit en presenteerde zij een wetsontwerp op de geneeskundige examens. $\mathrm{Zij}$ stelde de opheffing van de klinische scholen voor, met uitzondering van die te Amsterdam. Daar zag men juist goede mogelijkheden de medische studenten klinische ervaring op te laten doen. De examens die toegang tot de medische opleiding gaven en de examens aan het eind van de opleiding dienden door staatscomissies te worden afgenomen. ${ }^{46}$

Minister De Kempenaer kon zich met de voorgestelde hervormingen verenigen en bood de wetsontwerpen voor onderzoek bij de Raad van State aan. Daarmee was de eerste werkelijke stap op weg naar hervormingen gezet. Het doel van de 
voorgestelde hervormingen was de centrale leiding en de corporatistische structuur van het geneeskundig staatsbestuur te versterken. Een verbetering was de gedachte dit bestuur niet meer te belasten met de examinering van de nietacademisch gevormde geneeskundigen, en het toezicht op de uitoefening der geneeskunst en de openbare hygiëne aan individuen op te dragen. De drie medische faculteiten en de klinische school in Amsterdam kregen het monopolie op de opleiding van geneeskundigen.

\section{De oprichting van de Nederlandsche Maatschappij tot bevordering der Genees- kunst}

$\mathrm{Na}$ de instelling van de staatscommissie deed Ramaer, secretaris van de commissie tot inleiding van het geneeskundig congres, een opmerkelijke stap. Hij liet de Geneeskundige Courant meedelen, dat besloten was het congres uit te stellen teneinde het rapport van de staatscommissie af te kunnen wachten. Te zelfder tijd vatte hij zijn oorspronkelijke plan voor de oprichting van een maatschappij voor de geneeskunst weer op. Drie weken na het afzeggen van het geneeskundig congres, volgde op zijn initiatief de bijeenkomst ter oprichting van een maatschappij in Amsterdam. Afgevaardigden uit zestien steden, onder wie Evers, Voorhelm Schneevoogt en Ali Cohen, waren aanwezig. De bijeenkomst gaf de aanzet tot de oprichting en eerste algemene vergadering van de Nederlandsche Maatschappij tot bevordering der Geneeskunst in oktober 1849 te Arnhem. ${ }^{47}$ De vraag of de Maatschappij namens alle geneeskundigen mocht spreken, of dat er nog een congres moest worden gehouden waar ook alle niet-leden van de NMG zich konden uitspreken over de voorstellen van de staatscommissie, liet men op deze vergadering bewust onbeantwoord, ongetwijfeld om de tegenstellingen rond deze kwestie niet te zeer op de spits te drijven.

Zo bestonden in de jaren 1848-1849 twee landelijke initiatieven: een opgeschort geneeskundig congres en een Maatschappij met algemene vergaderingen en wetenschappelijke secties. Elk van de initiatieven vertegenwoordigde een andere opvatting over de politieke organisatie van de gezondheidszorg. Een congres was bedoeld om zo veel mogelijk geneeskundigen te verenigen. Een dergelijk congres zou onder leiding van Mulder wensen op het gebied van de medische wetenschap, de geneeskundige hulpverlening, de medische wetgeving en de medische politie moeten opstellen. Het bestuur van het congres zou vervolgens in overleg moeten treden met de leiding van het Geneeskundig Staatsbestuur.

De oprichting van de Maatschappij had niet tot doel individuele geneeskundigen bijeen te brengen, maar geneeskundigen in plaatselijke afdelingen te organiseren. Het idee was dat de afdelingen zelf het aanzien van de medische stand moesten hooghouden door hun wetenschappelijke activiteiten, door de geneeskundige hulpverlening te reorganiseren en erop toe te zien dat collega's de goede naam van de stand niet schaden. Een democratisch gekozen landelijk bestuur coördineerde deze activiteiten. Dit bestuur moest tevens met de regering onderhandelen over een wetgeving die een goede uitoefening van de geneeskunst en een ontplooiing van de Maatschappij kon garanderen. 


\section{Obstructie van minister Thorbecke}

Op het moment dat de staatscommissie haar rapport aan minister De Kempenaer aanbood, was het al duidelijk dat het zittende kabinet een fiasco zou worden. De nieuwe Grondwet was inmiddels een feit en de liberalen hadden bij de eerste rechtstreekse verkiezingen van de Tweede Kamer een eclatant succes behaald. Zij stonden uitermate kritisch tegenover het kabinet Donker CurtiusDe Kempenaer, dat Thorbecke niet in zijn midden had willen opnemen. In het najaar van 1849 moest het kabinet zijn ontslag indienen en er volgde een moeizame formatie, die uiteindelijk op 1 november tot de benoeming van Thorbecke tot minister van Binnenlandse Zaken leidde.

Het bleek al snel dat Thorbecke, met zijn uitgesproken opvattingen over de nieuwe Grondwet, ook een nieuwe geneeskundige staatsregeling naar liberale geest wilde opstellen. In 1850 liet hij weten verschillende bezwaren tegen het rapport te koesteren. Op het advies inzake het geneeskundig onderwijs na wilde, hij het voorlopig niet openbaar maken om zijn handen vrij te houden. De staatscommissie en enkele leden van de Tweede Kamer drongen op openbaarmaking aan, maar de minister verklaarde eerst met een door hem gekozen afvaardiging van de staatscommissie te willen spreken over eventuele wijzigingen in de wetsvoorstellen. Naar zijn zeggen had hij twee leden van de staatscommissie, de hoogleraar Tilanus en mr. M.H. Godefroi, daartoe reeds bereid gevonden. $\mathrm{Na}$ beraad besloot een meerderheid van de staatscommissie niet op deze uitnodiging in te gaan.

Vooral Godefroi betreurde dit besluit. Hij was in februari 1849 door het district Amsterdam in de Tweede Kamer gekozen en had zich daarna voor de getrouwe naleving van de Grondwet van 1848 ingezet. Deze constitutioneel ingestelde parlementariër had wel met de minister willen onderhandelen. ${ }^{49}$ Mulder daarentegen ontstak in grote woede over de gang van zaken. Hij verweet Thorbecke politieke sabotage en voelde zich bovendien op schandelijke wijze gepasseerd, omdat de minister hem niet in de genoemde afvaardiging had willen opnemen. Bij de opening van de tweede algemene vergadering van de NMG in 1850, zei vice-voorzitter Mulder daarover: 'Zoo verre mij bekend is, zijn er noch bij de Hooge Regeering, noch in de Tweede Kamer der StatenGeneraal lieden, die in staat zijn (de geneeskundige wetten) geheel en grondig te beoordeelen. Zullen die verordeningen zonder een goed onderzoek in het leven worden geroepen; worden ingediend door een bestuur dat ze niet kan toetsen, worden aangenomen door de Staten-Generaal die ze niet beoordelen kan; dan staat het te wachten, dat die arbeid der Staatscommissie - al is haar eenig streven geweest om aan de behoefte van de Geneeskundigen in Nederland te voldoen - toch niet voldoen zal. De deskundigen behoorden den Staat te besturen. Gij M.H.! zijt hierin de deskundigen; Uw oordeel, eerlijk en met nauwgezetheid opgemaakt, na een grondig en uitvoerig onderzoek, moet tot wet verheven worden. Nevens de Staten-Generaal, is de Maatschappij der Geneeskunde de Staten-Speciaal'. ${ }^{\text {so }}$

Het ging Mulder hier om meer dan alleen de vergadering moed in te spreken. $\mathrm{Hij} \mathrm{had,} \mathrm{zo} \mathrm{was} \mathrm{toen} \mathrm{al} \mathrm{duidelijk,} \mathrm{zeer} \mathrm{persoonlijke} \mathrm{opvattingen} \mathrm{over} \mathrm{wat} \mathrm{de}$ juiste regeringsvorm was. Mulder haatte de grondwetswijziging van 1848 , omdat deze 'Rome begunstigde en omdat zij aan den vorst, die kordaat kon zijn, de 
leiding van den staat ontnam en haar in handen gaf van een redekavelend, door partijmacht gespleten, in machteloze wettenmakerij zijn krachten verkwistend Parlement'. ${ }^{s P}$ Mulder was orangist en royalist en wenste geen enkele omwenteling, ook niet de beste, omdat de omverwerping van het bestaande gezag op geen enkele wijze aanvaardbaar was. Mulders ideaal was een eenhoofdig bestuur, dat door deskundigen ter zijde werd gestaan. De bureaucratie moest worden afgeschaft met behoud van alleen de uiterst noodzakelijke administratie. De Koning zou dus met volledige macht regeren, terwijl in technische aangelegenheden deskundigen geraadpleegd moesten worden. Het door koning Lodewijk Napoleon ingestelde Koninklijk Instituut voor Wetenschappen, Letterkunde en Schoone Kunsten leek hem hiervoor het meest geschikt.

Het zal duidelijk zijn wat Mulder bedoelde met de NMG als 'Staten-Speciaal'. Hij borduurde voort op het eerder besproken initiatief voor een geneeskundig congres, dat een legislatieve functie had moeten krijgen onder het oppergezag van de koning, waarbij de ministeriële verantwoordelijkheid tot een minimum moest worden beperkt. Ook de door de staatscommissie voorgestelde 'Academie voor Geneeskunde', bestaande uit hoogleraren en hogere geneeskundige ambtenaren vormde een concretisering van Mulders ideaal. Deze plannen zag Mulder door toedoen van Thorbecke mislukken. Vanaf dat moment zou Mulders gehele politieke streven worden beheerst door het verlangen om Thorbecke als politicus afbreuk te doen. Mulders standpunt was overigens niet uitzonderlijk. Sinds 1814 werden ambtenaren in de eerste plaats als 'dienaren des Konings' beschouwd. Herhaaldelijk was in de jaren dertig en veertig op het ministerie van Binnenlandse Zaken al het voorstel besproken de bureaucratie te verkleinen en slechts een klein aantal ambtenaren aan te stellen dat goed voor zijn diensten betaald zou moeten worden. ${ }^{52}$

Naar de mening van Thorbecke kon regeren pas concreet gestalte krijgen in het parlement, dat in zijn ogen zeker geen spreekbuis van de volkswil (of Mulders 'wil van de geneeskundigen') was. De minister was voorstander van een scheiding van staat en maatschappij op het gebied van godsdienst, het onderwijs, de wetenschap en het economische leven. Dat staat en maatschappij in het verleden samenvielen, had juist geleid tot willekeurig staatsgezag, gevormd door de vrij afgesloten groep aristocraten. De staat mocht zich slechts met de maatschappij bemoeien om de politieke en burgerlijke vrijheden (actief en passief stemrecht respectievelijk vrijheid van godsdienst, wetenschap en economie) te waarborgen en voor iedereen bereikbaar te maken. 'Ziehier het eigen gebied, de ware taak van de staat. De overheid heeft zoodanige orde van samenleving, waarin vrije menschelijke ontwikkeling mogelijk worde, in te rigten en te onderhouden; niet die ontwikkeling zelve te besturen'. ${ }^{3}$

Overtuigd als hij was van de juistheid van deze staatsopvatting, moest Thorbecke wel met een staatscommissie in conflict komen die geneeskundige ambtenaren en justitie vergaande bevoegdheden wilde geven in alles wat de volksgezondheid raakte. De minister was van mening dat de medische beroepsgroep dezelfde rechten en plichten diende te hebben als alle 'andere standen' in de samenleving. Een apart overheidsapparaat, bestaande uit artsen, ambtenaren en juristen, dat tot taak had de geneeskundigen te besturen en de bellangen van de medische wetenschap te behartigen, wees hij daarom af. De artsen moesten voortaan hun eigen 'bestuur' vormen, los van iedere overheidsbemoeienis, waardoor de 'vrije menschelijke ontwikkeling" ook ten aanzien van de geneeskundigen mogelijk werd. $\mathrm{Er}$ moesten weliswaar geneeskundige ambtenaren komen om toe te zien op de naleving van de medische wetgeving en om de 
minister te adviseren, maar deze behoorden niet eigenmachtig verordeningen uit te vaardigen of als 'commissarissen van politie' op te treden, zoals de staatscommissie had voorgesteld. In tegenstelling tot de staatscommissie meende Thorbecke dat het bestraffen van overtredingen op geneeskundig gebied tot de taak van politie en justitie behoorde en niet tot die van bijzondere medische politieambtenaren. Alleen de gewone justitiële autoriteiten moesten opdracht kunnen geven tot huiszoeking en confiscatie van een corpus delicti, bijvoorbeeld wanneer de openbare hygiëne in het geding was. ${ }^{54}$ Thorbecke was bovendien tegen het aanstellen van gerechtelijke geneeskundigen, zoals de staatscommissie had voorgesteld. Volgens hem moest de rechter niet de mogelijkheid tot vrije keuze worden ontnomen. Daarom wenste Thorbecke de voorstellen van de staatscommissie eerst beoordeeld te zien door ambtenaren van zijn ministerie. Terecht beriep hij zich daarbij op zijn ministeriële verantwoordelijkheid, die bij de grondwetsherziening was ingevoerd.

$\mathrm{Na}$ de rede van Mulder in 1850 ging een delegatie van de NMG, bestaande uit Voorhelm Schneevoogt en Heije (Donders zou ook meegaan, maar meldde zich op het laatste moment ziek), op audiëntie bij Thorbecke. De delegatie betreurde de weigering van de minister het rapport van de staatscommissie openbaar te maken en vroeg om een spoedige indiening van de wetsvoorstellen. In zijn antwoord zei Thorbecke te hopen dat hij het komende parlementaire jaar de wetsvoorstellen kon indienen, maar hij wist nog niet of hij het rapport openbaar zou maken.

Het ging echter anders dan de minister wilde. De staatscommissie weigerde met Thorbecke te onderhandelen en vroeg, op voorstel van de voorzitter, ontslag. Hierop kon Thorbecke niets anders doen dan de commissie ontbinden. ${ }^{36}$ Vervolgens maakte hij aan het eind van 1851 het gehele rapport openbaar. Al met al was Thorbecke geen stap dichter bij een geneeskundige staatsregeling gekomen die zijn instemming had.

\section{Verdeeldheid onder de geneeskundigen}

Ondertussen was in de NMG een discussie over de staatsregeling op gang gekomen, die tot grote verdeeldheid leidde. In 1851 bleek de Maatschappij anders over de toekomst van het geneeskundig onderwijs te denken dan de staatscommissie. Daar kwam bij dat men het onderling niet eens kon worden over de vraag of er volledige eenheid van stand moest komen. ${ }^{57}$

De verdeeldheid nam nog toe. Toen Mulder zag dat de NMG geen actie tegen Thorbecke wilde ondernemen, nam hij in het najaar van 1851 een opmerkelijk initiatief, namelijk het bijeenroepen van de commissie tot inleiding van het geneeskundig congres te Arnhem: dezelfde commissie die door de oprichting van de Maatschappij in 1849 overbodig leek geworden. Mulder wilde blijkbaar buiten de NMG-top om de oppositie van de 'Staten-Speciaal' tegen Thorbecke voortzetten. Ten slotte was nog niet éénderde van Nederlands geneeskundigen in de NMG georganiseerd en leek een gerede kans op succes te bestaan. Maar de actie van Mulder werd een mislukking, want alleen hijzelf, zijn discipel Donders en de hoofdredacteur van de Geneeskundige Courant, Donkersloot, waren aanwezig op de uitgeschreven bijeenkomst. De overigen hadden afgezegd
of ontslag uit de commissie genomen.

Op deze vergadering zette Mulder de reden van het congres nog eens uiteen: 'Nimmer heeft de natie in den laatsten tijd, in grooteren dommel verkeerd dan 
thans. Nimmer heeft zij minder zelfstandigheid aan de dag gelegd, nimmer meer slaafs de mening van één persoon aangekleefd.' Als snerende opmerking aan het adres van de NMG voegde hij er aan toe dat een openbaar congres meer 'levendigheid en meer waarheid geeft dan een lijst van meeningen van Afdeelingen der Maatschappij, hoe goed die ook tot één geheel vereenigd zijn. ${ }^{59} \mathrm{De}$ drie besloten door te gaan en een oproep tot steun aan het congres in de Geneeskundige Courant te plaatsen. ${ }^{60}$

Buiten noch binnen de NMG kreeg deze oproep voldoende steun. In de NMG vroeg alleen de afdeling Dordrecht zich af of men zich niet moest aansluiten bij het congres, omdat daar immers apothekers en ongeorganiseerde geneeskundigen ook aanwezig konden zijn. Men zou dan met één stem kunnen spreken. ${ }^{6 l}$ Maar het bestuur van de NMG zag er niets in, en besloot om als in het jaar tevoren het advies over het geneeskundig onderwijs was besproken, nu het gehele rapport van de staatscommissie aan de leden voor te leggen.

Opnieuw traden er talrijke meningsverschillen tussen de Maatschappij en de staatscommissie aan het licht. Zo was men in meerderheid voor een absolute eenheid van stand en tegen 'geneesmeesters', die de staatscommissie wilde. Ook was men pertinent tegen allerlei strafbepalingen voor medici, zoals door de staatscommissie werd voorgesteld. ${ }^{62}$ Daarnaast bleek de NMG ook intern zeer verdeeld; zo zeer zelfs dat de Algemene Vergadering in 1852 geen nieuwe discussie wilde voeren, omdat dit de tegenstellingen te zeer zou aanscherpen. Het schriftelijke rapport dat de NMG Thorbecke aanbood, was uiteindelijk zo tegenstrijdig en inconsistent dat het onmogelijk als richtsnoer voor het beleid van de minister kon dienen.

Bij alle onenigheid was één ding duidelijk geworden: Mulders plan voor een geneeskundig congres had geen kans van slagen. De mislukking van Mulders actie had twee oorzaken die voor de komende jaren van fundamentele betekenis zouden blijken.

Ten eerste bleek dat zijn voormalige geestverwanten zich van hem hadden afgewend. Zij deelden de politieke denkbeelden van Mulder niet, maar er speelden ook persoonlijke motieven mee. Voor Voorhelm Schneevoogt, Heije en Ramaer zou deelneming aan het congres gelijk staan met het uit handen geven van hun leidende positie. Van Geuns hoopte op een universitaire status van de Klinische School in Amsterdam - iets waartegen Mulder de grootst mogelijke bezwaren had. Bovendien was Van Geuns het met Thorbecke eens dat het Koninklijk Instituut vervangen moest worden door een nieuwe instelling met een meer natuurwetenschappelijk karakter, waartegen Mulder zich ook al heftig verzette. In 1852 werd Van Geuns door Thorbecke tot de eerste voorzitter van de nieuwe Koninklijke Akademie van Wetenschappen benoemd. ${ }^{63}$ Thorbecke had bovendien Van Deen aan zich verplicht door hem tot hoogleraar in de fysiologie in Groningen te benoemen. Dankzij deze benoeming was Van Deen niet alleen 's lands eerste hoogleraar in de fysiologie, maar ook de eerste joodse hoogleraar in Nederland.

Ali Cohen ten slotte verdedigde - overigens anoniem - in de Nieuwe Rotterdamsche Courant Thorbeckes beleid ten aanzien van het rapport van de staatscommissie. Hij bestreed het idee van Mulder dat de conclusies van de staatscommissie op een geneeskundig congres moesten worden behandeld, alvorens deze werden voorgelegd aan de minister en de koning. Ali Cohen betoogde dat dit moest gebeuren door 'de, door het gouvernement erkende, Nederlandsche Maatschappij ter bevordering der Geneeskunst, die kwantitatief ongeveer een 
derde van de Nederlandsche geneeskundigen, kwalitatief zeker het beste en bevoegdste gedeelte omvatte'. Mulder vertrouwde de NMG blijkbaar niet, zo oordeelde Ali Cohen. Dat was echter geen reden een congres bijeen te roepen, daar dit de situatie rond de herziening van de geneeskundige staatsregeling alleen maar verwarrender zou maken. Bovendien zou een dergelijk congres zeker niet alle geneeskundigen in Nederland vertegenwoordigen.

De tweede oorzaak van Mulders debâcle hing samen met een schisma in de medische pers. Toen in 1847 de Geneeskundige Courant door Donkersloot werd opgericht, leek het er even op dat deze de belangrijkste spreekbuis van de medische oppositie zou worden. In 1850 traden de Amsterdamse geneeskundigen Penn en Israëls tot de redactie toe. ${ }^{65}$ Beide artsen waren actief betrokken geweest bij de oprichting van de NMG en speelden een belangrijke rol in de Amsterdamse afdeling van de Maatschappij. Penn had samen met onder anderen het Tweede-Kamerlid Godefroi, in 1847 het Algemeen Ziekenfonds voor Amsterdam opgericht, omdat volgens hem de bestaande commerciële 'ziekenbussen' geen enkel oog hadden voor de belangen van arts en patiënt. Israëls had zojuist een onderzoek naar de kindersterfte in Amsterdam afgesloten. Hij was reeds jarenlang bevriend met Ali Cohen, die hem gedurende zijn studie in Groningen met de geschiedenis van de gëneeskunde bekend had gemaakt.

Penn en Israëls hadden echter andere opvattingen over de redactionele en politieke koers van de krant dan Donkersloot. Al snel bleek dat de onenigheid zo groot was, dat beide medici samen met enkele andere Amsterdammers een eigen tijdschrift oprichtten, namelijk het Nederlandsch Weekblad voor Geneeskundigen (1851-1856). ${ }^{66}$ In 1852 trad de Amsterdamse arts J. Zeeman, al op jeugdige leeftijd bekend om zijn onderzoek naar volksziekten, tot de redactie toe. Dit weekblad was heel anders van opzet dan de Geneeskundige Courant. Het bestond voor een groot deel uit klinisch-wetenschappelijke bijdragen. De redacteuren van het Weekblad namen, evenals Ali Cohen al eerder had gedaan in het door hem sinds 1849 geleide Nieuw Practisch Tijdschrift voor de Geneeskunde (1849-1856), in de jaren vijftig afstand van de voorstellen van de staatscommissie van 1848 .

In een periode van slechts enkele jaren was een politieke richting binnen de medische beroepsgroep ontstaan die kritisch stond ten opzichte van de plannen van de staatscommissie en bovendien geen steun wilde verlenen aan radicale tegenstanders van Thorbecke. De aanhangers van deze richting hadden zich georganiseerd in de NMG. De standpunten van de woordvoerders vonden hun weg naar de geneeskundigen via het Weekblad voor Geneeskundigen, het Nieuw Practisch Tijdschrift voor de Geneeskunde en het tijdschrift van de NMG. Onder de woordvoerders bevonden zich geneeskundigen die verder wilden gaan dan alleen de reorganisatie van de geneeskundige hulpverlening en van het medisch onderwijs. Zij wilden het eigen initiatief waarvoor de NMG wenste op te komen, een krachtige impuls geven door het opzetten van een ambitieus programma ter verbetering van de volksgezondheid. Het programma moest iedereen dezelfde kans op gezondheid geven, de nationale welvaart bevorderen en tevens leiden tot een op liberale leest geschoeide gezondheidszorg. Deze geneeskundigen en dit programma vormen het onderwerp van de volgende hoofdstukken. 
Samenvattend kunnen we stellen dat in de jaren 1845-1850 de geneeskundigen zelf het initiatief tot veranderingen namen. Daarbij kwamen twee verschillende politieke opvattingen tegenover elkaar te staan. Er waren medici die vasthielden aan hun oorspronkelijke hervormingsvoorstellen uit het begin van de jaren veertig. Zij zagen hun voorstellen in 1849 door een staatscommissie uitgewerkt in de vorm van vijf wetsontwerpen. Daarnaast waren zij voorstander van een congres waar door alle geneeskundigen de wetsontwerpen en andere onderwerpen van medisch belang moesten worden besproken. Een bestuur van dit congres moest de minister en de leiding van het Geneeskundig Staatsbestuur adviseren.

Daartegenover kwamen geneeskundigen te staan die voor de rijksoverheid juist een veel beperktere rol in de gezondheidszorg zagen weggelegd dan tot dusverre het geval was geweest. Deze snel aan invloed winnende medici waren voorstander van een onafhankelijke organisatie van geneeskundigen die zelfstandig initiatieven moest nemen ten behoeve van de ontwikkeling van de medische wetenschap en de verbetering van de openbare hygiëne. Een jaar na de oprichting van de Nederlandsche Maatschappij tot bevordering der Geneeskunst in 1849 bleek ongeveer een derde van alle geneeskundigen deze visie te delen. Twee jaar na de opriciting werd bovendien duidelijk dat de leden tal van bedenkingen hadden tegen de wetsontwerpen van de staatscommissie.

Van een serieuze concurrentie tussen de liberale artsen van de Maatschappij en de voorstanders van een congres is nooit sprake geweest. Toen Mulder en enkele anderen uit protest tegen de weigering van minister Thorbecke om de plannen van de staatscommissie uit te voeren, het congres in 1851 wilden organiseren, bleek de meerderheid van de NMG niet bereid daaraan mee te werken. Ook de steun van de ongeorganiseerde medici was te klein voor het organiseren van een congres.

Het mislukken van het congres gaf Thorbecke de gelegenheid om zonder al te grote druk van buitenaf de voorstellen van de staatscommissie in zijn richting bij te stellen. Daarnaast maakte de discussie over het congres en over de voorstellen van de staatscommissie duidelijk dat Thorbecke kon rekenen op steeds openlijker steun van de artsen in de NMG. Zoals uit de volgende hoofdstukken zal blijken, wilde de NMG een gezondheidspolitiek op liberale grondslag. 
i 


\section{De hygiënisten en de 'maatschappelijke toestand'}

Wij weten thans, dat zekere maatschappelijke toestanden, dat wetten, staatsinrigtingen en vooral financiële maatregelen, die de grondbezittingen, de geheele productie en belastingen betreffen, van veel meer belang zijn voor het voorkomen of uit de weg ruimen der hevigste ziekten, dan de geheele eigenlijk gezegde geneeskunde.

\section{L.J. Egeling, 1859}

De staatkundige denkbeelden van Thorbecke hadden bij geneeskundigen een proces van politieke bewustwording op gang gebracht. Steeds meer geneeskundigen kwamen tot de overtuiging dat zij zelf het initiatief tot bevordering van de volksgezondheid moesten nemen. $\mathrm{Zij}$ wilden los van de bestaande commissies van geneeskundig toevoorzicht en onafhankelijk van directieven van de rijksoverheid hun belangen verdedigen. De oprichting van de NMG was een eerste uiting van dit streven.

De politieke bewustwording hield echter meer in dan een groeiende waardering voor het eigen initiatief. De NMG-leden wensten ook een gezondheidsbeleid dat - naar buitenlands voorbeeld - was gericht op verbetering van de levensomstandigheden van de bevolking. Een deel van deze leden ging zich na 1850 onderscheiden van andere geneeskundigen, doordat zij zich op de verbetering van de openbare hygiëne gingen toeleggen.

In dit hoofdstuk wordt beschreven hoe deze hygiënisten zich het verband tussen maatschappij en geneeskunde voorstelden. Na een korte bespreking van de hygiënische beweging in het buitenland van voor 1850 , wordt de invloed van een nieuwe richting in de natuurwetenschap en de politieke filosofie - het positivisme - behandeld. Tot slot wordt de positie die de hygiënisten innamen binnen de doctrinair-liberale stroming in algemene termen geschetst.

\section{De opkomst van de hygiënische beweging}

\section{Frankrijk en Engeland}

In de jaren twintig en dertig van de vorige eeuw maakte het intellectuele leven in Frankrijk en Engeland grote veranderingen door. In deze landen werd heftig gedebatteeerd over de vraag, hoe het sociale leven het best kon worden onderzocht en aan gezondheidsbevorderende maatregelen kon worden onderworpen. In Frankrijk traden de sociaal-theoretici op de voorgrond, die zich ten doel hadden gesteld de sociale verhoudingen in een maatschappijtheorie te vatten. Daarbij hebben vooral Saint-Simon en Comte ieder op hun eigen wijze Franse geneeskundigen geinspireerd tot theorievorming over de sociale betekenis van 
de geneeskunde. ${ }^{\prime}$ Onder hen bevond zich bijvoorbeeld de orthopedist J.R.G. Guérin, aan wie de vinding van het begrip 'médecine sociale' wordt toegeschreven. Tijdens de revolutie van 1848 werkten hij en vele andere geneeskundigen mee aan de totstandkoming van politieke en sociale hervormingen. ${ }^{2}$

Toch stonden de meeste sociaal-theoretici in de dagelijkse praktijk betrekkelijk ver af van de grote hygiënische beweging die Frankrijk in de periode 1820-1850 kende. ${ }^{3}$ De meeste geneeskundigen zochten naar mogelijkheden de geneeskunde te hervormen tot een praktische wetenschap van de openbare hygiëne, en waren minder geïnteresseerd in ingrijpende politieke veranderingen. Dit waren medici als Parent-Duchâtelet, Lévy en Villermé. Zij hadden in Frankrijk en daarbuiten naam gemaakt door hun verhandelingen over de levensomstandigheden van de arbeidende klasse, de hygiëne in gevangenissen en andere onderwerpen op het terrein van de volksgezondheid. Ook dient de lijfarts van koning Louis Philippe, C.C.H. Marc te worden genoemd. Hij richtte in 1829 het in heel Europa vermaarde tijdschrift Annales d'hygiène publique et médecine légale op. Deze geneeskundigen verlangden hervormingen van het bestuursapparaat dat onder Napoleon in het leven was geroepen om de openbare hygiëne te verbeteren, maar sindsdien ondoelmatig had gefunctioneerd. Ook de talrijke hygiënische wetten en verordeningen die im het begin van de eeuw waren uitgevaardigd, hadden volgens hen weinig verbetering van de volksgezondheid gebracht.

In 1820 - nog ten tijde van de Restauratie - was de Académie Royale de Médecine' opgericht, met vier permanente commissies die elk een onderdeel van de openbare gezondheidszorg tot werkterrein had. Twee jaar later kwam de Conseil Supérieur de Santé tot stand die landelijk hygiënisch toezicht moest uitoefenen. Tegen het einde van de jaren twintig verschenen in het hele land stedelijke gezondheidsraden. Na de revolutie van 1830 hadden de hygiënisten, onder wie zich ook een aanzienlijk aantal farmaceuten, ingenieurs, architecten en ambtenaren bevond, hun hoop gericht op de liberale politicus en historicus François Guizot, de man aan wie Thorbecke een voorbeeld zou nemen. Zij ondersteunden het streven van Guizot naar industrialisering en economische vooruitgang. Villermé werd zelfs voorzitter van de door Guizot in 1832 in ere herstelde Académie des sciences morales et politiques, het forum voor de aanhangers van de liberale politieke economie. ${ }^{4}$ Maar tegelijkertijd wensten de hygiënisten de economische vooruitgang gepaard te zien gaan met een politiek van sociale rechtvaardigheid: de functie van sanitaire politie van voorheen moest worden uitgebreid tot sociale en sanitaire hervormingen ('assainissement'). Met dat doel voor ogen moest de regering een gecentraliseerde, nationale bureaucratie in het leven roepen, met behulp waarvan professionele hygiënisten het leven van dag tot dag konden volgen en de gebeurtenissen met betrekking tot de openbare gezondheid konden registreren. De medicus-hygiënist moest op deze wijze een intermediair tussen de verlichte staat en het dagelijkse leven vormen.

De opvatting van de medici-hygiënisten over 'civilisatie' was vergeleken bij de voorgaande periode volkomen veranderd. Geneeskundigen, die waren opgegroeid met het rousseauïstisch denkbeeld dat beschaving ziekten voortbrengt, geloofden inmiddels dat vooruitgang (industrialisering, verstedelijking) niet zonder meer tot aantasting van de volksgezondheid hoefde te leiden, als deze maar tot stand werd gebracht op geleide van een 'positieve', op feiten gebaseerde maatschappijwetenschap. In het bijzonder met behulp van de statistiek - de positieve sociale wetenschap bij uitstek - kon het veranderingsproces worden beheerst en konden de oude klassentegenstellingen kunnen worden opgeheven. 
De bestaande onderzoekstechnieken

waren voor dit doel ongeschikt. Niet de medische geografie - de bestudering van klimatologische en geografische factoren, maar de analyse van het proces van civilisatie in de steden moest het uitgangspunt voor het terugdringen van de hoge sterfte en van de epidemieën zijn. De medicus diende zich slechts bezig te houden met het verzamelen en ordenen van empirische feiten. Hij moest zich beperken tot het beschrijven van relaties tussen waarneembare grootheden, zoals het aantal zieken, de spreiding van ziekten, pathologisch-anatomische afwijkingen en de chemische samenstelling van water, bodem en lucht. Niet de beschrijving van de natuurlijke historie der ziekten, maar de numerieke methode - het onderbrengen van in getallen uitgedrukte gegevens inzake leeftijd, geslacht, aantal geboorten, sterfte, ziekte, lichaamslengte en - gewicht en voeding in tabellen, alsmede het berekenen van gemiddelden per bevolkingsgroep - moest de ontwikkelingen in de volksgezondheid overzichtelijk en beheersbaar maken. ${ }^{5}$ Een lange reeks publikaties over de gevolgen van de industriële ontwikkeling voor mens en milieu en over de levensomstandigheden in gevangenissen en in de arme wijken van Parijs was het directe gevolg van deze nieuwe wetenschappelijke belangstelling.

Ook in Engeland werd het intellectuele klimaat gekenmerkt door de opkomst van nieuwe sociale theorieën en socialistische agitatie. Van grote invloed zijn de denkbeelden van de theoreticus Jeremy Bentham geweest. Hij had met zijn sociaal-utilitaristische denkbeelden benadrukt dat de staat tot taak had de burgers een zo groot mogelijk geluk te verschaffen door de veiligheid te handhaven, bestaansmiddelen te verschaffen, rijkdom te beschermen en de gelijkheid te bevorderen.

De Engelse geneeskundigen namen een positie in die vergelijkbaar is met die van hun Franse collega's. Mede naar aanleiding van de cholera-epidemie van 1831-1832 wisten sanitaire hervormers zoals Chadwick, Southwood Smith, beiden aanhangers van Benthams denkbeelden, en Farr het vraagstuk van de 'Condition of England' tot een van de belangrijkste discussiepunten van de jaren dertig en veertig te maken. ${ }^{6}$ Op voorstel van Chadwick, geen arts maar advocaat en lid van de Poor Law Commission die op de uitvoering van de armenwet moest toezien, werd in de General Registration Act van 1836 niet alleen de registratie van geboorte en sterfte, maar ook die van de doodsoorzaken opgenomen. Reeds enkele jaren later publiceerde Chadwick een rapport, waarin hij het statistische verband aantoonde tussen de sanitaire condities van verschillende sociale klassen enerzijds en hun respectievelijke levensverwachting anderzijds. Dit rapport vormde de directe aanleiding voor de instelling van een staatscommissie in 1844 die plannen voor de riolering, herinrichting van straten, sanitaire voorzieningen en aanleg van parken in de steden moest opstellen. In hetzelfde jaar werden in Londen ook minimumeisen voor huurwoningen opgesteld, en in 1846 volgde een verbod op de verhuur van kelderwoningen.

Chadwick ontwikkelde ook een statistisch model, waarmee de steden en 'provincies' naar graden van gezondheid konden worden ingedeeld. Elke stad of 'provincie' beschikte in dit model over een eigen gezondheidsthermometer of biometer die de mortaliteit van een bepaald jaar aangaf. Farr, tussen 1839 en 1880 secretaris van het bureau dat aan de Registration Act uitvoering moest geven, verbeterde in de jaren veertig naar het voorbeeld van Villermé de mathematische bewijsvoering van de statistiek die door Chadwick was ontwikkeld. Hij verdedigde onder andere de stelling dat naarmate de bevolkingsdichtheid toeneemt ook de sterfte toeneemt, tenzij zich veranderingen in de sanitaire 
omstandigheden van de bevolking voordeden. Evenals Chadwick wilde Farr de statistiek in de vorm van een socio-biologische thermometer of biometer bruikbaar maken voor een politiek van sociale rechtvaardigheid. Hij stelde vast dat een sterfte van 17 oer duizend inwoners fysiologisch gezien onvermijdelijk was. Een hoger sterftepercentage kon echter worden uitgedrukt in graden van ongezondheid. Farr ontwikkelde op deze wijze een concreet wetenschappelijk instrument, waarmee lokale autoriteiten kon worden getoond in welke mate hun gemeente ongezond was.

De biometer van Farr werd in 1848 als uitgangspunt van de eerste Public Health Act in Engeland genomen, zij het dat in deze wet niet een sterfte van 17 pro mille, maar het landelijke gemiddelde van 23 pro mille als 'fysiologisch percentage' werd genomen. Was de lokale sterfte hoger dan dit percentage, dan kon een landelijk toezichthoudend orgaan (General Board of Health) door inspecteurs onderzoek laten verrichten naar de sanitaire omstandigheden ter plaatse. Het kon tevens een plaatselijke gezondheidscommissie instellen voor de verbetering van de drinkwatervoorziening, de riolering of voor het opruimen van afval en vuilnisbelten.

\section{Nederland en Duitsland}

Deze ontwikkelingen ontgingen de Nederlandse geneeskundigen aanvankelijk. De Nederlandse leer der volksziekten vertoonde in de periode 1820-1840 grote gelijkenis met die in Duitsland, waar de kwalitatieve statistiek en de historischpathologen het debat over de volksziekten beheersten met hun onderzoek naar epidemische constituties en de natuurlijke historie van ziekten. ${ }^{7} \mathrm{Er}$ bestond in Duitsland noch in Nederland grote belangstelling voor het speuren naar in kwantiteiten uit te drukken medisch-demografische wetmatigheden.

In 1842 publiceerde de Goudse geneesheer Büchner een topografie van zijn woonplaats, waarin voor het eerst de volksgezondheid werd geanalyseerd volgens de methode die door de Franse en Engelse geneeskundigen was ontwikkeld. Büchner had de topografie geschreven op verzoek van de Plaatselijke Commissie van geneeskundig Toevoorzicht, die de oorzaken van de hoge neonatale sterfte in de stad opgehelderd wilde zien. Na de cholera-epidemie van 1832 had Büchner het voorzitterschap van deze commissie op zich genomen en sindsdien had hij vrijwel zonder succes voor betere sanitaire voorzieningen in de stad geijverd. ${ }^{8}$

Het eerste deel van de topografie bevat een beschrijving van de geografische ligging en geologische gesteldheid (veen) van de stad, vervolgens van de waterhuishouding en dampkring, die vanwege het omringende drassige land en de droogmakerijen is 'gemengd met moerasuitwasemingen en gassoorten van schadelijke samenstelling'. 9 Büchner constateerde dat deze factoren niet duidelijk anders waren dan elders. Daarom konden zij volgens hem het relatief hoge percentage der doodgeborenen en de relatief hoge kindersterfte niet verklaren. Om na te kunnen gaan welke factoren wel tot de hoge sterfte hadden geleid, werkte Büchner naar het voorbeeld van de Parijse artsen Benoiston de Chateauneuf en Villermé de bestaande, primitieve demografische gegevens om tot een medisch-statistisch overzicht van de sterfte per sociale klasse. Daaruit bleek zonneklaar dat de hoge sterfte in Gouda het arme deel der bevolking betrof. De oorzaak hiervan moest volgens Büchner worden gezocht in de slechte sanitaire omstandigheden, waaronder de armen moesten leven. De 'meergegoeden' 
beschikten bijvoorbeeld over kwalitatief goed drinkwater, terwijl de 'mingegoeden' hun drinkwater uit de gracht moesten halen. Het feit dat in Gouda de bevolking voor meer dan $26 \%$ uit bedeelden bestond, terwijl het gemiddelde percentage armlastigen in Nederland $11 \%$ was, was volgens Büchner een tweede bewijs voor de stelling dat niet de geografische gesteldheid van de stad, maar de armoede en de slechte sanitaire voorzieningen de oorzaak van de relatief hoge sterfte waren. Büchner kwam concludeerde dat de regering en het bestuur van de stad hun verantwoordelijkheid voor de gezondheid der 'ingezetenen' ernstig moesten nemen door bijvoorbeeld de voedselprijzen te verlagen (verlaging gemeentelijke accijnzen) en maatregelen ter bevordering van de openbare hygiëne te nemen.

In de plaatsbeschrijving van Büchner worden voor het eerst de contouren zichtbaar van wat door Nederlandse medici na 1848 de maatschappelijke toestand wordt genoemd: een verslechterende gezondheidssituatie in de steden, gekenmerkt door een verschil in sterfte tussen arm en rijk. Büchner had op grond van zijn onderzoeksresultaten de stad als (toekomstig) leefmilieu kunnen afwijzen en het leven op het platteland kunnen aanprijzen. Deze vorm van stadsvijandigheid, die onder nogal wat medici voorkwam, wees Büchner echter nadrukkelijk af. De stad als zodanig vertegenwoordigde in zijn ogen weliswaar een voor de gezondheid schadelijk fenomeen, maar zijn boodschap was dat hieraan wat viel te doen, wanneer 'de voortgang en ontwikkeling der natuurkunde door den goede wil erkend wordt'. ${ }^{10}$

Büchner had in Nederland de eerste stap gezet op weg naar een nieuwe benadering van de stedelijke volksgezondheid. Maar de gebeurtenissen op het gebied van de sanitaire hervormingen in het buitenland werden pas goed door de Nederlandse geneeskundigen onderkend, nadat ook in Duitsland geneeskundigen naar Frans voorbeeld een nieuwe gezondheidspolitiek eisten.

In diverse Duitse staten was sinds de jaren twintig onder de intelligentsia en een deel van de bureaucratie een heimelijke sympathie gegroeid voor de Franse doctrinair-liberale beginselen. In liberale en radicaal-democratische gezelschappen treffen we talrijke geneeskundigen aan, die in latere jaren een belangrijke rol in de Duitse geneeskunde zullen spelen: de fysioloog W. Griesinger uit Kiel, na 1865 bekend om zijn hervormingen in de psychiatrie, de eerste joodse privaat-docent (embryologie en cytologie) in Pruisen R. Remak, de fysioloog, zoöloog en radicaal-democraat te Frankfurt $\mathbf{K}$. Vogt en de Heidelbergse anatoom F.G.J. Henle; verder de Berlijnse psychiater R. Leubuscher, de eveneens uit Berlijn afkomstige hygiënist, statisticus en socialist S. Neumann en de prosector aan het Berlijnse militaire hospitaal $\mathrm{R}$. Virchow. Zij keerden zich niet alleen tegen de autocratische bestuursvorm van hun landen en het in hun ogen ondoelmatige overheidsapparaat dat de gezondheidszorg bestuurde ('Medizinische Polizey'), maar ook tegen de gangbare onderzoekstechnieken van de invloedrijke 'Gesellschaft für Naturförscher und Aerzte'.

De beweging was in wetenschappelijk opzicht allerminst homogeen. Weliswaar keerden de hervormers zich zonder uitzondering tegen het ontologisch denken in de geneeskunde, en tegen de historische pathologie die naar hun mening volledig op speculatie waren gebaseerd. En ook was iedereen het er over eens dat de geneeskunde slechts wetenschappelijk was wanneer het vakgebied op directe, 'positieve' waarneming berustte. Maar over de ordeningsprincipes van de waargenomen feiten verschilden de meningen. Virchow vond de tijd niet rijp voor een nieuw geneeskundig stelsel. Hij meende dat 'jetzt nicht der Zeit der 
Systeme ist, sondern die Zeit der Detailuntersuchungen'. Zijn aandacht richtte zich op het microscopisch onderzoek en de pathologische anatomie. " Anderen beschouwden de 'fysiologische' geneeskunde, die elke ziekte als een stoornis in de - volgens vaste natuurwetten verlopende - lichaamsfuncties van de mens zag, als een werkelijk wetenschappelijke geneeskunde. Deze gedeeltelijk onbekende natuurwetten moesten zowel in het menselijk lichaam zelf worden opgehelderd als in het natuurlijk en sociaal milieu waarin de mens leeft. ${ }^{12}$ Ook verwierp niet iedereen het contagionisme. Henle bijvoorbeeld hield vast aan het contagionisme en vernieuwde bovendien de contagionistische theorie door deze met inzichten uit de botanie te verbinden.

In de tweede helft van de jaren veertig eisten echter vooral de politieke verwikkelingen de aandacht op. Toen in de winter van 1847 een vlektyfusepidemie uitbrak in het door hongersnood geteisterde Bovensilezië - een Pruisische provincie waar de bevolking in meerderheid uit Polen bestond - roerde de oppositionele pers zich zo heftig, dat de Pruisische regering de zaak niet op zijn beloop kon laten. $\mathrm{Zij}$ droeg de arts Rudolf Virchow op, om samen met een collega de situatie ter plaatse te onderzoeken. Virchow was nog maar juist met zijn onderzoek gereed, toen in maart 1848 de politieke en sociale ontevredenheid tot een uitbarsting kwam. Onder de leuze 'eenheid en vrijheid' ontketenden radicaal-democratische groepen in diverse Duitse steden een revolutionaire opstand, waaraan talloze geneeskundigen deelnamen. Ook Virchow sloot zich direct na zijn terugkeer uit Silezië aan bij de opstand in Berlijn. Hij weigerde zijn onderzoeksbevindingen aan de Pruisische regering kenbaar te maken, omdat hij er van overtuigd was dat deze regering spoedig omver geworpen zou worden. Virchow richtte met Leubuscher het tijdschrift Die medicinische Reform op. Voor hen was 'der große Kampf der Kritik gegen die Autorität, der Naturwissenschaft gegen das Dogma' eindelijk begonnen. ${ }^{13}$ Het tijdschrift publiceerde een jaar lang de hervormingsgezinde denkbeelden van geneeskundigen en bracht verslag uit van de vele congressen en vergaderingen waarop de medische hervormingen werden besproken.

In het tijdschrift en op de medische congressen werd het constitutionele recht van de individuele burger op een gezond leven benadrukt. De taken van een democratisch gekozen regering ten opzichte van de sociale ellende en de volksziekten moesten door vrije en natuurwetenschappelijk gevormde geneeskundigen - als advocaten der armen - omschreven worden, aldus de opstandige geneeskundigen. ${ }^{14}$

Met dat doel voor ogen zochten Neumann en Virchow naar een nieuw uitgangspunt voor de leer der volksziekten. Zij maakten een onderscheid tussen 'natuurlijke' en 'kunstmatige' volksziekten. Natuurlijke volksziekten (dysenterie, intermitterende koorts, pneumonie) waren er naar hun mening altijd geweest als gevolg van het feit dat de bevolking zich onvoldoende beschermde tegen bijvoorbeeld klimatologische veranderingen. Kunstmatige volksziekten daarentegen (tyfus, ziekten als gevolg van ondervoeding, tuberculose) waren een produkt van bepaalde ontwikkelingen in de moderne maatschappij: '(sie) sind vielmehr Attribute der Gesellschaft, Produkte der falschen oder nicht auf alle Klassen verbreiteten Kultur; sie deuten auf Mängel, welche durch die staatliche und gesellschaftliche Gestaltung erzeugt werden und treffen daher auch vorzugsweise diejenigen Klassen, welche die Vorteile der Kultur nicht mitgenießen.' ${ }^{\$}$ Hiermee plaatsten Neumann en Virchow de geneeskunde voor wat betreft de belangrijkste volksziekten binnen de sociale en politieke context, en wel in een 
formulering die hier en daar bijna woordelijk van Villermé lijkt te overgenomen. ${ }^{16}$

Dat gebrek aan 'beschaving' als oorzaak van volksziekten moest worden gezien, ging in feite terug op de burgerlijk-humanistische opvatting, dat de armen door hun onredelijke en daarmee onnatuurlijke levenswijze gevoeliger voor ziekten zijn. Nu echter gebruikten de Duitse artsen deze vaststelling als een politiek wapen, als een instrument voor positivistische en radicaal-democratische hervormingen. Ziekten waren geen attributen van de volksklasse, maar van een onbeschaafde maatschappij. De achttiende-eeuwse verlichtingsidealen, gericht op maatschappelijke vooruitgang, op de ontwikkeling van wetenschap en techniek en op de vestiging van een rechtvaardige samenleving, klonken duidelijk door in het beschavingsbegrip van de Duitse geneeskundigen.

Dit blijkt ook uit het beroemd geworden verslag van Virchow over de tyfusepidemie in Silezië. Zes maanden na zijn onderzoek, en nadat een militaire actie de opstand in Silezië had neergeslagen, besloot Virchow zijn bevindingen alsnog bij de Pruisische regering in te dienen. In zijn verslag legde Virchow de schuld voor de epidemie volledig bij de regering. Hij haalde menige Engelse en Franse onderzoekingen aan, om aan te tonen dat alleen een sociale en politieke emancipatie van de burgerij en de arme volksmassa dergelijke rampen in de toekomst konden voorkomen. 'Volle und unumschränkte Demokratie' en 'Bildung mit ihren Töchtern Freiheit und Wohlstand' waren daarom volgens Virchow de pijlers van een goed gezondheidsbeleid. ${ }^{17}$ Het waren beginselen waaraan hij zijn leven lang heeft vastgehouden. Zo trad Virchow vanaf 1861 op als woordvoerder van de 'Fortschrittspartei' die de Duitse eenheid en de vestiging van een constitutionele monarchie nastreefde. Als liberale democraat heeft hij vanaf de jaren zeventig bovendien geopponeerd tegen de naar diens mening absolutistische politiek van Bismarck. ${ }^{1}$

\section{Politieke reacties in Frankrijk en Duitsland}

Het moet in de jaren veertig geleken hebben alsof de meeste tegenstanders van het oude bewind, van gematigd hervormingsgezind tot uiterst links, het eens waren over de toekomstige politieke en maatschappelijke ontwikkelingen. In deze jaren vonden liberalen en socialisten elkaar in kritische beschouwingen van de maatschappelijke toestand, waarbij de aantasting van de volksgezondheid als één van de voornaamste misstanden werd genoemd. ${ }^{19}$ In hun afkeer van de gevolgen van de industrialisatie, urbanisatie en armoede verschilden de geneeskundigen niet van bijvoorbeeld Friedrich Engels die zijn sociale kritiek onderbouwde met de resultaten van sociaal-medisch onderzoek. Virchow zag alle critici schouder aan schouder staan: 'überall wo die Sache des Volkes war, standen auch die Ärzte unter den hervorragenden Führern ... Die Buchez, die Récourt, die Trélat, die Ducaux, diese ehrenhaften Republikaner de la veille, übernahmen die Leitung der höchsten Staatsgeschäft in Frankreich. Nees van Esenbeck, Jacoby, D'Ester traten in das vorderste Glied der äussersten Linken bei uns. Vogt, Löwe, Von Calbe, selbst Eisenmann kämpften in Frankfurt, Löhner, Goldmark, Fishhof in Wien für das Volk. ${ }^{20}$ Er kwam echter spoedig een eind aan de euforie. Zowel in Frankrijk als Duitsland haalde het mislukken van de revolutie van 1848 de vaart uit de hervormingsbeweging. Bovendien zaaiden de opkomst en de repressie van het socialisme zaaiden verdeeldheid in 
de eerst zo eensgezinde beweging.

In Frankrijk werd de Tweede Republiek na een staatsgreep omgevormd tot een keizerrijk onder leiding van Napoleon III, warin het economisch liberalisme aan kracht won en democratische rechten werden beperkt. De socialisten moesten zich uit de actieve poltiek terugtrekken en vele radicale geneeskundigen verdwenen voor lange tijd naar de achtergrond. Artsen zoals Villermé pasten zich aan de nieuwe politieke verhoudingen aan. Parijs onderging in de jaren vijftig onder leiding van Haussmann een complete gedaanteverandering: armenwijken werden opgeruimd, riolering en waterleiding werden aangelegd en er kwam een stelsel van boulevards tot stand die lucht en licht tussen de nieuwe woonblokken brachten. Niet het radicaal-liberale model, dat sanitaire, sociale en politieke hervormingen verbond, maar het autoritair-technocratische model, waarvan in Nederland Mulder een vertegenwoordiger was, bepaalde de verdere politieke ontwikkelingen. Hierin was voor sociale en politieke hervormingen geen plaats. Integendeel, de hervormingen in de steden, zoals Haussmann die in Parijs doorvoerde, kwamen de armen niet ten goede. Velen werden door de projecten van Haussmann naar de stadsgrenzen verdrongen, waar zij opnieuw in krotten moesten leven. De machteloosheid van de sanitaire hervormers ten opzichte van de snelle kapitalistische expansie en de daarmee gepaard gaande sociale ontwrichting, alsmede de opkomst van het socialisme deden het hervormingsprogramma van de hygiënisten in de jaren zeventig ten slotte uit het centrum van de politieke belangstelling verdwijnen. ${ }^{21}$

In Duitsland was de beweging al eerder op dood spoor terechtgekomen. Nadat de Pruisische regering in 1849 met millitair geweld de orde had hersteld, trad een fase van repressie in, waarin het steeds moeilijker werd politiek actief te zijn. Bovendien raakte de oppositie verdeeld in liberalen die een constitutionele monarchie naar Brits voorbeeld wensten en op een compromis met de adel aanstuurden, in radicaal-democraten met doctrinair-liberale beginselen en in socialisten die later de klassenstrijd in hun vaandel voerden. Virchow distantieerde zich van de socialistische opvattingen van onder anderen Neumann, Remak en Leubuscher, die nog enige tijd successen boekten met de 'Gesundheitspflegeverein" als onderdeel van de communistisch geinspireerde Berlijnse 'Arbeiterverbruderung". ${ }^{22}$ Liberaal georiënteerde medici zoals Virchow raakten geïsoleerd. Enerzijds werden żij heftig bekritiseerd door hun radicale collega's, anderzijds werden zij vanwege hun democratische op- vattingen door de politieke leiders gewantrouwd. De beweging viel uiteen. Midden 1849 hief Virchow Die medicinische Reform op. Van medische hervormingen kwam vooralsnog niets terecht. Virchow c.s. trokken zich terug uit de actieve politiek en legden zich toe op het wetenschappelijk werk. Door de toenemende repressie belandden hervormingsgezinde geneeskundigen - Vogt en Griesinger bijvoorbeeld - in de gevangenis of zagen zij zich gedwongen te emigreren. ${ }^{23}$ Virchow verloor zijn betrekking van prosector en privaat-docent, waarna hij naar Würzburg vertrok. In 1856 keerde hij terug naar Berlijn, waar hij tot hoogleraar in de pathologische anatomie was benoemd.

Niet de sociale pathologie met al haar politieke implicaties van Virchow en Neumann, maar de 'bodemtheorie' van de hoogleraar in de hygiëne $M$. von Pettenkofer met haar technocratische aanpak van de volksgezondheid zou na 1850 de ontwikkelingen in de leer der volksziekten bepalen. Deze zag niet zozeer sociale factoren alswel fysisch-geografische factoren als voornaamste oorzaken van volksziekten. Dit wordt nader besproken in hoofdstuk 4 . 


\section{De hygiënisten in Nederland}

De gebeurtenissen in Duitsland in 1848 maakten diepe indruk op de Nederlandse geneeskundigen, die verwikkeld waren in discussies over de herziening van de medische wetgeving en bezig waren zich landelijk te verenigen. Als door een schok wakker geschud, begonnen zij buitenlandse sociaal-medische publikaties te vertalen en te bespreken. Het debat over de volksziekten kreeg ook in Nederland onmiskenbaar het karakter dat het jaren tevoren al in Engeland en Frankrijk had. In kringen van de nog prille Nederlandsche Maatschappij tot bevordering der Geneeskunst werd de kwestie van de openbare hygiëne één van de belangrijkste discussiepunten.

De directe aanleiding vormde het uitbreken van een cholera-epidemie in Nederland - enkele maanden na de bekendwording van de revolutionaire gebeurtenissen in Duitsland. De geneeskundigen stonden evenals ten tijde van de epidemie in 1832 machteloos tegenover de cholera. Maar anders dan in 1832 leidden hun, medisch gezien ontmoedigende ervaringen thans niet tot berusting en pessimisme, maar tot politieke agitatie dat steunde op een nieuw zelfvertrouwen. Met name de armendoctores zagen, als lid van de plaatselijke choleracommissies de fatale gevolgen van de epidemie; zij hadden tevens de kritische geest van hun buitenlandse collega's overgenomen. $\mathrm{Zij}$ hadden de overtuiging dat volksziekten konden worden voorkomen door een hervorming van de politieke en sociale verhoudingen. Ali Cohen, in wiens Nieuw Practisch Tijdschrift voor de Geneeskunde de Duitse invloed en de nieuwe oriëntatie op de openbare hygiëne sterk naar voren kwamen, schreef in dit verband dat 'de waarheid, dat ziekten als de cholera arme-lui's ziekten zijn, bewijst, dat het in de magt staat van de menschelijke maatschappij, ook dezen verschrikkelijke vijand zo niet magteloos, dan toch oneindig minder gevaarlijk te maken."24

\section{Positivistische idealen}

Nederlandse geneeskundigen waren weliswaar beïnvloed door de Duitse hervormingsbeweging, hun verlangens stelden zij echter in veel minder heftige bewoordingen. Zij koesterden zeker geen revolutionaire plannen. Hun sociale betrokkenheid kenmerkte zich door ingetogenheid en afstandelijkheid, eerder dan door emotionele verbondenheid met de levensomstandigheden van de onderste lagen der bevolking. Anders ook dan bij hun Duitse en Franse collega's vonden radicaal-democratische geluiden geen enkel gehoor bij de Nederlandse geneeskundigen.

Toch bestonden er fundamentele overeenkomsten tussen de maatschappelijke oriëntatie van de Nederlandse hygiënisten en die van hun buitenlandse collega's. Ze beschouwden de samenleving als een organisme, waarin consensus de grondslag van de sociale orde is en waarin ideeën de sociale werkelijkheid bepalen. Het was hun stellige overtuiging dat deze ideeën voortaan 'positief'-wetenschappelijk van aard waren. De politieke en sociale veranderingen van 1848 hadden een nieuw tijdperk ingeluid, waarin de 'positieve' wetenschappen oplossingen zouden bieden voor maatschappelijke problemen. Deze wetenschappen waren, volgens de medici, vrij van apriori-kennis en beperkten zich tot het verzamelen en ordenen van kennis over natuur en maatschappij. Met een zo beknopt mogelijke beschrijving van de waarnemingen zou men op den duur regelmaat in 
de natuurlijke en maatschappelijke verschijnselen aan het licht brengen. Daarmee zou de mogelijkheid ontstaan deze verschijnselen te voorspellen. Met andere woorden de positieve wetenschappen stelden de mens in staat zich optimaal in zijn omgeving te oriënteren en zich aan die omgeving aan te passen.

Een dergelijke, met de maatschappij innig verbonden wetenschap kon met de bijbehorende technologie een rechtvaardige samenleving tot stand brengen, waarin de oude tegenstellingen tussen de standen waren opgeheven. Wanneer ook de geneeskunde werd omgevormd tot een positieve, voor de maatschappij nuttige wetenschap, dan kwam - zo meenden de hygiënisten - een eind aan het onvermogen van de geneeskunde om iets tegen de volksziekten te doen. Bovendien kon men dan de maatschappij zodanig inrichten dat alle burgers ongeacht hun afkomst een gelijke kans op gezondheid hadden.

Inzicht in de sociale en biologische regelmaat van het menselijk bestaan zou dus zowel tot een concrete verbetering van de bestaansvoorwaarden leiden als tot saamhorigheid tussen 'arbeiders' en 'kapitalisten'. Door de organisatie van de maatschappij op positief-wetenschappelijke grondslag kon er een nieuwe mens worden geboren: 'Het zal geschieden, zoodra men (...) meer algemeen zal hebben leeren inzien, hoe met de toename en uitbreiding der beschaving ook de gezondheidstoestand toeneemt en zich uitbreidt, en hoe met elken vooruitgang op de baan van kennis en beschouwing, noodwendig ook gepaard gaat eene weldadige verbetering van het lichamelijke bestaan des menschengeslachts', zo hield Ali Cohen in een lezing zijn gehoor van natuur- en geneeskundigen voor. ${ }^{25}$ Over de grondslagen van zo'n samenleving zou vanzelf overeenstemming worden bereikt, wanneer de toepassing van de positieve kennis over het menselijk bestaan maar voldoende werd gestimuleerd. De Leidse hoogleraar in de pathologie, antropologie en geschiedenis der geneeskunde C. Pruys van der Hoeven drukte zich daarover rond 1850 als volgt uit: 'Vroeg of laat moet zij [= de wetenschap] zich sociaal maken, moet zij communistisch worden, en de wetenschappelijke aristocratie zich democratiseren. De wetenschap, of liever het wetenschappelijk element als bestanddeel der maatschappij, moet haar geheel doordringen, moet zich door haar heen verspreiden, het moet niet uitsluitend eigendom van een bijzonder, bevoorregten stand zijn; maar het moet zich aan alle standen mededeelen en over het geheele huishouden van de Staat uitstrekken, het moet deszelfs materieelen, intellectueelen en moreelen welstand meer en meer bevorderen en vervolmaken. 26

De kennismaking van de Nederlandse geneeskundigen met het positivisme was in theoretisch opzicht nogal oppervlakking. Zij citeerden weliswaar herhaaldelijk uit geschriften van positivistische artsen uit Frankrijk of Duitsland, maar ze hadden nauwelijks belangstelling voor de filosofische en maatschappijtheoretische grondslagen van het positivisme. Originele aanvullingen of interpretaties moesten van hen niet worden verwacht. Zij maakten vertalingen en compilaties van de in het buitenland opgestelde theorieën die hun dagelijkse praktijk enigszins richting gaven of legitimeerden. Een uitzondering vormde Pruys van der Hoeven. Hij was een man van groot gezag in de medische wereld en een erkend tegenstander van het opkomend natuurwetenschappelijk reductionisme in de geneeskunde, en van het in zijn ogen overdreven vertrouwen van artsen in geneesmiddelen. Tussen 1851 en 1854 publiceerde hij het vierdelig boekwerk Anthropologisch Onderzoek, waarin hij de achttiende-eeuwse traditie van de hygiëne trachtte te verbinden met het positivisme van August Comte.

Pruys van der Hoeven begon zijn boek met zijn bewondering te uitten voor de 
Weense arts Frank. Frank was naar zijn mening de onbetwistbare grondlegger van de hygiêne, omdat hij als eerste de maatschappelijke waarde van de geneeskunde had geformuleerd. Voor Franks systeem van medische politie was, volgens Pruys van der Hoeven, echter een nieuwe historische fase aangebroken. Het Franse positivisme had namelijk uitgewezen dat er grote ontwikkelingsmogelijkheden voor de mens in het verschiet lagen, mits de in de politiek, de wetenschap en de bij het volk levende speculatieve opvattingen over natuur en maatschappij werden vervangen door nuchtere en wetenschappelijke inzichten van specialisten en vaklieden, van 'én raad van positieve filosofen en sociologen als opperste instantie van het geestelijk leven en opvoeding. ${ }^{, 27}$ Deze vaklieden en specialisten, waartoe ook de geneeskundigen zich moesten rekenen, zouden duidelijk moeten maken hoe mens en maatschappij deel uitmaakten van één groot natururlijk organisme. De Franse sociaal-theoretici, en vooral de Brusselse hoogleraar Quetelet hadden volgens Pruys van der Hoeven inmiddels aangetoond dat de maatschappij, evenals de hemellichamen, werd 'voortbewogen' door natuurwetten, waarvan men de bewegingen kon berekenen en tot het voordeel van de mensheid kon aanwenden. ${ }^{28}$

Het positivisme sloot volgens Pruys van der Hoeven uitstekend aan bij de opvattingen van Virchow. Nadat de positieve sociologie het menselijk bestaan had leren kennen als een volledig door natururwetten beheerst proces, had Virchow treffend de betekenis hiervan voor de medische wetenschap geformuleerd: het doel van de medische wetenschap was 'te weten, welke veranderingen het lichaam ondergaat bij verandering van de voorwaarden des levens. Ziekte is eene veranderde rigting der levensbeweging: het plaatselijk ziek zijn is stoornis der normale voedingsprocessen. Volksziekten zijn het gevolg van veranderde natuurtoestanden, of van veranderde levenswijs'. De taak van de geneeskunde was daarom 'het maatschappelijke zoo te verbeteren, dat zij de hindernissen die de geregelde vervulling der levensprocessen en levensverrichtingen in den weg staan, leert opheffen en aldus eigendom wordt van het algemeen'. ${ }^{29}$

Pruys van der Hoeven wilde met zijn Anthropologisch Onderzoek, dat hij schertsend het 'novum organum medicinae' noemde, de studenten van zijn tijd laten zien, dat de medische praktijk in de toekomst in hoofdzaak een hygiënische praktijk zou zijn. Tegelijk wilde hij de stadsdoctores het vertrouwen in eigen kunnen teruggeven door hen voor te houden, dat de medicus de verbindende schakel vormt tussen de wetenschappelijke organisatie van de samenleving en de biologische bestaansgrond van de mens. ${ }^{30}$ Volgens Pruys van der Hoeven dienden zij te beseffen dat er een historische ontwikkeling gaande was in de richting van vrijheid en een verlichte maatschappij en dat zij deel uitmaakten van een burgerlijke beweging die in Parijs in 1848 was ontstaan en zich inmiddels in geheel Europa had laten gelden.

Wat dit betreft verschilde hij principieel van mening met Mulder, de andere 'ideoloog' onder de medici. Mulder wilde de maatschappelijke en politieke positie van een kleine groep deskundigen zeker stellen, maar de standenmaatschappij niet wezenlijk veranderen. Daarom ageerde hij scherp tegen de grondwetsherziening van 1848. Pruys van der Hoeven zag daarentegen juist in de emancipatie van de burgerij en de opheffing van de standenmaatschappij de motor van de vooruitgang. Hij formuleerde op elegante wijze zijn instemming met de toegenomen maatschappelijke invloed van de burgerij: 'Die burgerstand of middenklasse is de verbindende schakel tusschen beide uitersten der maatschappij: nijverheid, volksvlijt, handel, vrijheid zijn wij haar verpligt. Volkszeden 
en volksdeugden en volkskarakter moet men bij haar vooral bestuderen. Even verwijderd van het onbeschaafd gemeen, als van de door weelde ontzenuwde grooten, is zij de zenuw en kracht van den staat, het magtig en stevig orgaan, waarop alles afstuit, en van waar alles uitgaat. Bij haar berust de sens commun, het commun esprit, rationaliteit, gezond verstand, burgerzin. $\mathrm{Zij}$ is het meest vrij van de erfelijke en aangeboren vooroordelen, costumes en gezetheden, en het minst onderhevig aan bijgeloof en dweperij. Bij iedere omwenteling heeft zij in crediet gewonnen, en iedere poging tot vooruitgang is eene toenadering tot den middelstand der maatschappij'. ${ }^{39}$ De burgerij in het algemeen en de geneeskundigen in het bijzonder moesten de historische taak op zich nemen om de maatschappij te leiden naar een toekomst 'vol kracht en leven, geluk en menschlievendheid'. De grondwetswijziging van 1848 zal in de ogen van Pruys van der Hoeven ongetwijfeld een vooruitgang hebben betekend, ook al moet worden betwijfeld of hij veel waardering voor Thorbecke als persoon, en voor sommige van diens handelingen kon opbrengen.

Anthropologisch Onderzoek oogstte veel lof in geneeskundige kring. De hoogleraar bleek de behoefte onder de praktizerende geneeskundigen goed te hebben aangevoeld. De nogal pessimistische kijk op de mogelijkheden van de geneeskundige therapie, de wijdse perspectieven van de hygiëne, gecombineerd met liberale beginselen raakten de gevoelens van de ontevreden medicinae doctores in de steden op de juiste plek.

In tal van artikelen klonken de opvattingen van Pruys van der Hoeven door. De Arnhemse medicus S.P. Scheltema noemde zijn bewondering voor 'die man' onbegrensd. Hij zelf zou maar liever met zijn werk stoppen, wanneer hij zich alleen maar met 'zieke individuen' moest bezighouden. ${ }^{32}$ Volgens Israëls, die in de beoefening van de geschiedenis der geneeskunde een leerling van Pruys van der Hoeven mag worden genoemd, leerde de geschiedenis hoe 'elke epidemie ons therapeutisch handelen bespotte, beschimpte en hoe alleen hygiënische maatregelen vrucht droegen en zegen aanbrachten." ${ }^{33}$ Egeling, een leerling van Pruys van der Hoeven, en behalve stadsgeneesheer eerste geneesheer aan het Elisabeth-gasthuis en docent aan de klinische school in Haarlem, herhaalde in 1858 nog eens de woorden van Pruys van der Hoeven dat maatschappelijke verbeteringen de volksziekten beter bestreden dan de 'geheele eigenlijke geneeskunde'. ${ }^{34}$ De Haagse geneesheer L.H. Verwey, die korte tijd als adviseur van Thorbecke dienst had gedaan, betrok Pruys van der Hoeven in 1853 bij de uitgave van het eerste tijdschrift in Nederland dat geheel aan de openbare hygiëne was gewijd: Tijdschrift voor algemeene Gezondheidsregeling en Geneeskundige Politie (1853-1854). Het hygiënistisch tijdschrift Schat der Gezondheid, dat van 1858 tot 1865 verscheen, en waaraan een groot aantal hygiënisten meewerkte, voerde als motto een citaat uit Pruys van der Hoevens werk, dat duidelijk moest maken dat de waarde van de geneeskunde niet lag in het genezen van zieken of het ontdekken van kwalen, maar in het waken over de gezondheid der maatschappij. Nog in 1867 citeerde de Haagse hygiënist C.P. Pous Koolhaas hem - ook hij was een leerling van Pruys van der Hoeven - in het voorwoord van het Tijdschrift voor Gezondheidsleer met de volgende woorden: 'ik zag mij verplaatst onder een ander menschengeslacht. Onder hen geen zieken, noch gebrekkigen, noch zwakken. Frischheid, gezondheid en kracht straalden van aller gelaat. Tevredenheid en geluk verhelderden hun wezentrekken. De vrede op aarde scheen weder gekeerd'. ${ }^{35}$

Het is duidelijk welke grote verwachtingen men van de geneeskunde had, als 
die zich maar op de openbare hygiëne toelegde. De geneeskunde zou zelfs kunnen bijdragen tot het herstel van de oude glorie van de Nederlandse natie. ${ }^{36}$ 'Mogt eens, door haren invloed, door haren macht, het Nederlandsche volk zich weer tot zijn vroegere grootheid verheffen', aldus Voorhelm Schneevoogt in De Gids. ${ }^{37}$ Voorwaarde was wel dat de openbare hygiëne op wetenschappelijke wijze werd bestudeerd. Een nieuwe wetenschap, aangeduid als openbare gezondheidsleer, moest steunen op de in de achttiende eeuw ontwikkelde topografische methode en op de wetenschap van het sociale leven: de statistiek. De statistiek kon met natuurwetenschappelijke zekerheid de vaste betrekkingen aantonen tussen sociale en sanitaire misstanden enerzijds en hoge sterfte en volksziekten anderzijds. Had men eenmaal met behulp van de plaatsbeschrijving de misstanden nauwkeurig geanalyseerd, dan kon de gezondheidsleer de noodzakelijke technische oplossingen aandragen voor de hygiënische problemen in de samenleving. Zo moest de geneeskunde tot een techniek van de gezondheid voor de gehele bevolking worden omgevormd - een techniek waarmee de verantwoordelijke autoriteiten in staat waren een effectief gezondheidsbeleid te voeren.

Het vooruitzicht op de ontwikkeling van deze nieuwe wetenschap bracht tal van medicinae doctores in de steden tot het systematisch verzamelen van feiten over de 'maatschappelijke toestand'. $\mathrm{Zij}$ gingen als hygiënisten een nieuwe loopbaan tegemoet. Alleen onder hun leiding, zo meenden zij, kon de gezondheid van de bevolking - de algemene gezondheidstoestand of de volksgezondheid - wezenlijk worden verbeterd. Onder hen bevonden zich Penn, Zeeman, Israëls uit Amsterdam, Pous Koolhaas uit Den Haag, Egeling uit Haarlem en Ali Cohen uit Groningen. Het zijn slechts enkelen van de vele geneeskundigen die zich vanaf de jaren vijftig hebben ingezet voor de bestrijding van sociale en sanitaire misstanden.

Zo was in Nederland, bijna twintig jaar nadat in Frankrijk en Engeland de hygiënisten ten tonele waren verschenen, een groep geneeskundigen ontstaan, die de zorg voor de openbare hygiëne wilde professionaliseren, en zich met dat doel voor ogen ging specialiseren in de openbare gezondheidsleer. Deze geneeskundigen waren allen beinvloed door het positivisme met zijn utiliteitsbeginsel, organische maatschappij-opvatting en gerichtheid op het verzamelen en ordenen van feiten. De Duitse of Franse radicaal-democratische opvattingen uit de jaren veertig hadden op hen geen invloed uitgeoefend; de hygiënisten waren voorstander van een beperkte democratisering op sociaal en politiek terrein. Zij verlangden vooral de oprichting van medisch-wetenschappelijke instellingen die regering en burgerij een oriëntatiemiddel konden bieden in de complexe en onzekere wereld van sociale misstanden en ziekten. Maatschappelijke vooruitgang lag in het verlengde van hun eigen sociale en politieke emancipatie.

Deze emancipatie verliep in Nederland anders dan in omringende landen. Nederland kende in tegenstelling tot Engeland en Frankrijk vóór 1870 geen industrie van betekenis, waardoor de economische en sociale verhoudingen relatief langzaam veranderden. Bovendien kreeg het hygiënisme in Frankrijk en Duitsland onder een centralistisch en autoritair landsbestuur vaste vorm, terwij] de Nederlandse hygiënisten hun programma ontwikkelden tegen de achtergrond van een succesrijke ontplooiing van de liberaal-democratische staat. Daarom wordt in het kort bespreken hoe zowel de relatief starre sociale verhoudingen als het succes van de doctrinair liberalen het Nederlandse hygiënisme een eigen karakter hebben geven. 
De Nederlandse hygiënisten vertoonden wat betreft hun object van onderzoek (het ongezonde leefklimaat en de sociale sterfteverschillen in de steden), hun wetenschappelijke methoden (plaatsbeschrijving en statistiek) en hun doelstellingen (sanitaire hervormingen) grote gelijkenis met hun buitenlandse collega's. $\mathrm{Zjj}$ meenden dat het hygiënisch hervormingsprogramma dat in de Engelse en Franse steden in praktijk werd gebracht, ook in de Nederlandse steden moest worden uitgevoerd. Men kan zich afvragen, waar deze gedachte op was gebaseerd. De situatie in Nederland week namelijk nogal af van die in de omringende landen. In Engeland had de sanitaire beweging haar oorsprong in de groei van de steden en de industrialisatie, in Frankrijk maakte zij deel uit van een veel bredere beweging voor modernisering van het sociale en economisch leven. De groei van de steden in Nederland daarentegen kwam na 1870 eerst aarzelend op gang, om pas in de periode 1880-1900 door te zetten. Ook de groei van het inwonertal van steden met meer dan 20.000 inwoners begon pas nà 1870 . Alleen Arnhem, Tilburg en Schiedam hadden al eerder een forse groei doorgemaakt. ${ }^{38}$ Er vond in de jaren vijftig weliswaar een opleving van de Nederlandse economie plaats, maar deze was veeleer het gevolg van vermeerderde handel en opbloei van landbouw en veeteelt en dan industrialisatie. ${ }^{39}$

Dat de sanitaire problematiek in de steden toch groot genoeg was om een wetenschap van de openbare hygiëne te rechtvaarigden, had dan ook te maken met andere, deels specifieke, omstandigheden. Er bestond in de Hollandse steden een chronisch tekort aan kwalitatief goed drinkwater als gevolg van de eigenaardige bodemgesteldheid in het westen (kleigrond en verzilting). Epidemieën verspreidden zich er snel als gevolg van de hoge bevolkingsdichtheid in de steden in het Westen, en de niet-industriële vervuiling van oppervlaktewater, bodem en openbare weg nam gestaag toe. Deze relatief ongunstige natuurlijke gesteldheid en demografische omstandigheden gaven de sanitaire problematiek in de steden als het ware een modern aanzien, zonder dat er moderne oorzaken waren aan te wijzen. ${ }^{40}$

Door deze bijzondere omstandigheden hadden de sanitaire hervormers in Nederland voor 1870 nauwelijks belangstelling voor de typische sociale kwesties van de Engelse en Franse hygiënisten. Met de problemen van een industrieel proletariaat hadden de Nederlandse geneeskundigen lange tijd niets van doen. Die kregen pas in de jaren zestig en zeventig enige aandacht, toen in Nederland de industrialisering aarzelend op gang kwam. Daardoor ontbrak

het besef dat specifieke sociaal-economische factoren de gezondheid van de 'handwerksman' beïnvloedden, waardoor het onderzoek na 1850 vrijwel uitsluitend op de fysisch-geografische kenmerken van de stad gericht was. De artsen wilden met dergelijk onderzoek aantonen, dat de sterfte hoger was naarmate de plaatselijke sanitaire omstandigheden slechter waren. Dit verklaart enigszins waarom het hygiënisme in Nederland geen radicale vleugel heeft ontwikkeld, en waarom na 1850 de sociaal-conservatieve ideeën van de Duitse hygiënist Von Pettenkofer aanhang verwierven onder de hygiënisten.

\section{Politieke dilemma's}

\section{De Gemeentewet}

De staatkundige hervormingen die minister Thorbecke tussen 1848 en 1853 doorvoerde, gaven de geneeskundigen de mogelijkheid hun positivistische 
idealen in een praktische politiek om te zetten. Van direct politiek belang voor de geneeskundigen waren de door Thorbecke gerealiseerde Kieswet van 1850 en Gemeentewet van 1851 . Vór 1848 was het stemrecht gebaseerd op de hoogte van de personele en grondbelasting. Met de Kieswet van 1850 was echter bepaald dat het stemrecht voor de Tweede Kamer en de Provinciale Staten ook gold voor hen die patent-belasting (een soort bedrijfsbelasting) betaalden. Deze verruiming van het censuskiesrecht kwam een deel van de geneeskundigen, en meer in het algemeen de kleine burgerij in de steden ten goede. ${ }^{41}$ Maar het was vooral de Gemeentewet van 1851 die tegemoet kwam aan de wensen van de hygiënisten. ${ }^{42}$

De nieuwe Gemeentewet bepaalde dat eens in de twee jaar een derde deel van de leden van de gemeenteraad moest aftreden. Door geheime, rechtstreekse verkiezingen moest dat deel worden aangevuld. Gemeentebesturen werden verplicht ieder jaar verslag van hun activiteiten te doen, en de beraadslagingen waren openbaar. De wet bepaalde de rechten en plichten van het gemeentebestuur, waaronder die met betrekking tot de volksgezondheid. Stond het de gemeenten voorheen vrij al of niet verordeningen te maken, nu werden bepaalde taken expliciet aan het gemeentebestuur opgedragen. Volgens artikel 134 van de wet kon de gemeenteraad iedere voorziening treffen die hij vond passen in de 'huishouding der gemeente'. Artikel 135 stipuleerde dat de raad verordeningen in het belang der openbare orde, zedelijkheid en gezondheid moest opstellen. Artikel 179 stelde het toezicht op de 'publieke gezondheidsdienst' onder burgemeester en wethouders, terwijl in artikel 205 was bepaald dat de kosten van de plaatselijke gezondheidspolitie op de begroting moesten worden gebracht.

Deze bepalingen in de Gemeentewet, gecombineerd met openbaarheid van bestuur en rechtstreekse verkiezingen, gaven de geneeskundigen de mogelijkheid om wezenlijke invloed uit te oefenen op het bestuur van de steden. De mogelijkheid ontstond om beleidsinstrumenten te ontwikkelen voor de verbetering van de 'maatschappelijke toestand', zo luidde het oordeel van de hygiënisten. De hoop de gezondheidspolitiek van de gemeenten definitief in een andere richting te sturen, bracht de hygiënisten in diverse steden ertoe hun politieke activiteiten in kieskringen te vergroten, of zich kandidaat te stellen voor de gemeenteraad. Onder het motto 'dat alles gewonnen kan worden, zoo de deskundigen zich voornemen, zich uit hun midden door hen zelf te vertegenwoordigen', probeerden geneeskundigen een zetel in de gemeenteraad te bemachtigen, omdat burgemeester en wethouders op het gebied van armenzorg, medische politie en openbare hygiëne 'desonkundig' waren.

Toch waren de hygiënisten niet onverdeeld gelukkig met de Gemeentewet, althans niet met de wijze waarop deze in de liberale partij werd geïnterpreteerd. Hoewel zij het alleen maar eens konden zijn met Thorbeckes bedoeling om met de Gemeentewet overmatige bemoeienis van de rijksoverheid met het lokaal bestuur te voorkomen, meenden zij ook dat volledige staatsonthouding inzake de volksgezondheid moest worden afgewezen. En wel om twee redenen.

Ten eerste sloot de Gemeentewet de totstandkoming van landelijke medische politiewetgeving, zoals door de geneeskundige staatscommissie van 1848 was bepleit, vrijwel uit. Thorbecke wees er telkens weer op dat het 'onverantwoordelijk van het Gouvernement zou zijn, zich te stellen in de plaats van de gemeentebesturen, zoolang deze niet getoond hadden dat zij verzuimden te doen hetgeen hun pligt is." Dit betekende dat de hygiënisten noodgedwongen waren 
aangewezen op wat de gemeentebesturen bereid waren te ondernemen. De vraag waarvoor de hygiënisten zich vrijwel direct geplaatst zagen, was hoe voor het gehele land een uniforme aanpak van de sanitaire misstanden en de daarmee samenhangende volksziekten kon worden gerealiseerd. De Gemeentewet bood daarvoor geen enkele mogelijkheid en het systeem van provinciale en plaatselijke commissies van toevoorzicht kon dit evenmin bewerkstelligen. De rijksoverheid moest volgens de hygiënisten daarom zorg dragen voor een aantal landelijke richtlijnen, bijvoorbeeld met betrekking tot de volkshuisvesting, de pokkenvaccinatie, de inrichting van openbare gebouwen en de drinkwatervoorziening.

In de tweede plaats bracht de Gemeentewet gedurende de eerste twintig jaar na haar invoering niet de politieke verschuivingen in de gemeenten teweeg, waarop de hygiënisten hadden gehoopt. Hoewel in de jaren vijftig enige geestverwante liberalen en ook medici in verschillende gemeenteraden zitting namen, behielden degenen die voór de invoering van de Gemeentewet reeds lid van de gemeenteraad waren over het algemeen hun positie na 1851 . Veel gemeenteraden bleven nog lange tijd bestaan uit vertegenwoordigers van de financiële toplaag van de kiesgerechtigden, die niet meer dan $19 \%$ van de mannelijke bevolking van 23 jaar en ouder uitmaakten. Kooplieden, juristen en renterfiers waren in de meerderheid. Pas in de loop van de jaren zestig kon het gebeuren dat geneeskundigen, bekend om hun kritiek op de sanitaire toestanden in hun woonplaats, tot lid van de gemeenteraad werden gekozen. Kennelijk stemden de kiezers liever op vertrouwde gezichten binnen de kiesvereniging en eerder op basis van de persoonlijke status of het beroep van de kandidaat, dan op basis van politieke overtuigingen. De burgerij was met andere woorden in meerderheid niet erg gevoelig voor het verkiezingsthema 'volksgezondheid'.

\section{De liberale staatsonthouding}

Naarmate het duidelijker werd dat van de lokale besturen geen wezenlijke verandering in het gezondheidsbeleid te verwachten viel, gingen de hygiënisten het beginsel van de volledige staatsonthouding in twijfel trekken. Ali Cohen sneed de kwestie in 1852 aan: 'Voorzeker de aanleidende oorzaken, waardoor epidemieën als wij er eene in 1848 en 1849 hebben beleefd en zijn doorgeworsteld [..] dien graad van boosaardigheid kunnen verkrijgen en die uitbreiding erlangen, zijn geene zaken, waarop 't laissez aller moest worden toegepast. En toch is het zoo, en schijnen er nieuwe epidemieen van zoodanigen aard als nieuwe prikkels van tijd tot tijd noodig om de maatschappij de ogen te openen, den staatsman en staathuishoudkundige onmacht wakker te schudden'. ${ }^{6}$ Ook andere hygiënisten hekelden in de jaren vijftig en zestig het gebrek aan creativiteit van de rijksoverheid om de lokale besturen tot het nemen van maatregelen in de geest van de Gemeentewet aan te zetten. Zij benadrukten de scheppende taak van de staat op het terrein van de openbare hygiëne, en wensten nadere wetgeving of op zijn minst ministeriële druk op de gemeentebesturen, zodat die besturen gedwongen werden naar adviezen van de hygiënisten te luisteren.

Er bestond wat dit betreft weinig overeenkomst met de anti-liberale opvattingen van conservatieven, zoals Mulder. Die wilden immers een centraal geleid en autoritair staatsapparaat in het leven roepen, dat in samenwerking met de rechterlijke macht verordeningen op milieuvervuiling, levensmiddelen, kwakzalverij en dergelijke, moest uitvaardigen en doen naleven. De liberale hygiënisten 
daarentegen stonden niet meer dan een soort 'raamwet' voor die de gezondheidsbepalingen in de Gemeentewet moest preciseren. Zij stelden zich een gang van zaken voor als die in het buitenland, in het bijzonder Engeland en België. De resultaten van de sanitaire hervormers in Engeland waren in de ogen van de Nederlandse geneeskundigen bepaald indrukwekkend: daar had de biometer van Farr de publieke opinie overtuigd van de noodzaak van sanitaire maatregelen, hetgeen onder meer bleek uit de totstandkoming in 1848 van de Public Health Act. Ook in België waren van overheidswege sanitaire hervormingen in gang gezet, en verschenen er landelijke en plaatselijke adviesorganen met betrekking tot de openbare hygiëne (oprichting van Académie Royale de Médecine in 1841, van gemeentelijke gezondheidscomités in 1848, en de instelling van de Conseil Supérieur d'Hygiène Publique in 1849). De gezondheidspolitiek in beide landen toonde naar de mening van de Nederlandse hygiënisten aan, dat rijksbemoeienis met de volksgezondheid goed viel te rijmen met een liberaal staatsbestel.

Met hun 'liberaal interventionisme' vonden de hygiënisten liberale economen, rechtsgeleerden, politici, inclusief Thorbecke, en een groot deel van de liberale aanhang tegenover zich. De liberale partij beroemde er zich juist op dat de staat bescheidener was en dat provincies en gemeenten zelfstandiger waren dan in België. 'Belgisch etatisme' zowel als 'Engelsche despotieke bepalingen' moesten in Nederland worden vermeden, omdat die de gemeentelijke zelfstandigheid te sterk zouden aantasten. De verwachting van de hygiënisten dat de Nederlandse overheid soortgelijke maatregelen als in Engeland of België zou nem, vond weinig begrip bij de liberale voormannen.

Hoe de liberale aanhang over het streven van de hygiënisten dacht, is minder duidelijk. Het liberalisme was gedeeltelijk een emancipatiebeweging van intellectuelen en beoefenaars van de vrije beroepen (waartoe ook de hygiënisten behoorden). Deze groepen konden waarschijblijk wel enige sympathie voor de hygiënisten opbrengen. Een groter deel van de aanhang echter bestond uit leden der gezeten burgerij en uit de middenklasse in het noorden en het oosten van het land, alsmede uit welgestelde boeren in heel Nederland. ${ }^{47} \mathrm{Bij}$ hen zal van positivistische idealen geen sprake zijn geweest. In deze groepen van de bevolking stelde men vooral belang in de opruiming van het protectionisme en de opheffing van de accijnzen, wegens de uiterst hinderlijke belemmering die daarvan uitging voor de handel en het bedrijfsleven. ${ }^{48}$

Het valt gemakkelijk in te zien dat in deze kring het animo voor nieuwe overheidsbemoeienis - nu van hygiënische aard - gering was. De grote belasting van het stedelijk milieu die uitging van het toenemend aantal kleinschalige fabrieken en van de groei in de agrarische sector bracht hierin weinig verandering. Dit blijkt niet alleen uit het geringe electorale succes van de hygiënisten bij de gemeenteraadsverkiezingen. Ook de verslagen van het Geneeskundig Staatstoezicht spreken duidelijke taal: een groot deel van de bevolking werkte niet mee aan de plannen van de hygiënisten of verzette zich tegen de hygiënische maatregelen.

Het feit dat de hygiënisten na 1850 twintig jaar lang op het punt van de staatsonthouding als een kleine minderheidsgroep van 'rekkelijken' telkens het onderspit moesten delven tegenover een meerderheid van 'preciesen' in de liberale partij, stelde de hygiënisten herhaaldelijk voor de vraag in hoeverre zij de liberale opvattingen konden delen zonder te breken met hun streven naar verbetering van de openbare gezondheidstoestand. Het was een dilemma dat in de jaren vijftig en zestig telkens aan de dag trad, maar de hygiënisten in feite de 
gehele negentiende eeuw is blijven achtervolgen. In sommige gevallen leidde dit dilemma tot een kortstondige flirt met de meer verlichte conservatieven, die minder scrupules ten aanzien van staatsinterventie hadden dan de liberalen. 


\section{De hygiënisten en de cholera}

Een wijzer en verlichter geslacht moge, als wij er niet meer zijn, het raadsel ophelderen; zich misschien over onze eenvoudigheid verbazen, totdat eene nieuwe ziekte uit verre landen opgedaagd, nieuwe raadsels en nieuwe teleurstellingen met zich voert.

\section{Pruys van der Hoeven e.a., 1833.}

Het staat well vast dat de gastro-intestinale aandoening, die we tegenwoordig cholera noemen, niet voor 1830 op het Europese vasteland heeft geheerst. ${ }^{I}$ Algemeen wordt 1817 beschouwd als het jaar, waarin een cholera-epidemie in de delta van de Ganges uitbrak, die zich over heel India en vervolgens over het Zuidoost-Azië en het Midden-Oosten uitbreidde. In 1826 volgde een tweede pandemie, die ook naar Europa en het Amerikaanse continent oversloeg. In 1830 bereikte de cholera Moskou en verspreidde zich in twee jaar via St. Petersburg, Polen, Pruisen en Oostenrijk tot in Engeland, Frankrijk, België en Nederland. Een derde pandemie bereikte Rusland in 1847 en maakte vele slachtoffers in heel Europa. De vierde pandemie die in de jaren 1863-1875 woedde was verantwoordelijk voor de laatste grote cholera-epidemie in Nederland van 1866-1867. Ten slotte trad in de jaren 1883-1894 een pandemie op, die was ontstaan in Egypte. Deze eiste in West-Europa veel minder slachtoffers dan de vorige. $\mathrm{Na} 1894$ nam het aantal cholera-gevallen in Europa snel af. ${ }^{2}$

In het vorige hoofdstuk is vermeld, dat naar aanleiding van de cholera-epidemie in 1848-1849 vele geneeskundigen in de Nederlandsche Maatschappij tot bevordering der Geneeskunst zich volledig gingen toeleggen op de kwestie van de openbare hygiëne. Deze geneeskundigen stelden de overheid verantwoordelijk voor de ondoeltreffende bestrijding van de epidemie. In dit hoofdstuk wordt uitvoeriger ingegaan op de betekenis van de cholera voor de beweging van hygiënisten. Daarbij wordt beschreven hoe de hygiënisten het ontstaan en de verbreiding van de cholera verklaarden, en welke bestrijdingsmaatregelen zij voorstelden. Tevens zal de invloed van enkele micro-biologische theorieën op de hygiënische beweging worden besproken.

Wat maakte de betekenis van de cholera zo groot, dat hieraan een afzonderlijk hoofdstuk moet worden gewijd? Allereerst riep geen enkele andere ziekte zoveel emoties op als de cholera. De snelheid waarmee de ziekte dodelijk toesloeg, was uitermate angstwekkend, vooral omdat volledig gezonde, volwassen mannen en vrouwen binnen enkele uren konden sterven, en dat zelfs zonder dat enige tekenen van infecties in de directe omgeving waarneembaar waren. Bovendien waren de symptomen van de ziekte afschuwelijk. De snelle ontwatering van het lichaam leidde ertoe dat de zieke in korte tijd tot een schim van wat hij kort tevoren was ineenschrompelde, terwijl gesprongen haarvaten de huid zwart en blauw deden kleuren. Wanneer we tevens bedenken dat de medici volkomen machteloos stonden, dan wordt begrijpelijk dat het bericht dat in de buurt 
cholera was uitgebroken, iedereen de schrik om het hart deed slaan. De angstgevoelens die de cholera telkens bij de bevolking opriep, hebben er zonder twijfel toe bijgedragen dat de ziekte een zwaar stempel op de discussie over preventie van volksziekten heeft gedrukt.

De cholera is echter om nog een andere reden een belangrijke ziekte geweest. Vanaf het moment dat de 'cholera asiatica' Europa bereikte tot aan het eind van de negentiende eeuw, is zij het onderwerp geweest van heftige wetenschappelijke en politieke controverses over respectievelijk de oorzaak en de bestrijding van de ziekte. ${ }^{3}$ De sterfte als gevolg van de cholera werd een maatstaf voor de doeltreffendheid van het gezondheidsbeleid en voor de validiteit van elke wetenschappelijke theorie over volksziekten. De verschijning van de cholera leidde bovendien tot een wetenschappelijke speurtocht naar de oorzaak van de ziekte. Deze speurtocht beloofde op zijn beurt de sleutel te zijn tot een beter inzicht in een groot aantal andere ziekten en een effectief gezondheidsbeleid.

\section{De cholera-epidemie van 1832}

\section{De reactie van de overheid}

Bij de regeringen en de medici in Midden- en West-Europa ontstond het besef dat er groot onheil op komst was, toen de cholera in 1830 Rusland had bereikt. Begin 1831 stelden de Oostenrijkers aan de grens met Rusland over een lengte van 60.000 kilometer wachthuizen op. Gewapende schildwachten moesten zonodig met geweld onbevoegde grensoverschrijdingen voorkomen. Soortgelijke maatregelen werden ook door Pruisen en Hannover genomen. ${ }^{4}$ Vanuit Frankrijk en Engeland reisden regeringscommissies en individuele artsen naar Rusland en Polen om de aard van de ziekte te onderzoeken en de beste wijze van preventie vast te stellen. Zonder uitzondering keerden de onderzoekers onthutst en verslagen naar hun vaderland terug.

Ook in Nederland was men zich ervan bewust dat er een ramp dreigde. De cholera was sinds het einde van de jaren twintig in toenemende mate onderwerp van medische publikaties, waarin de ziekte als bijzonder ernstig werd afgeschilderd. ${ }^{5}$ De minister van Marine stelde zich op het standpunt dat de cholera gelijkgesteld moest worden met pest en pokken en vaardigde in juni 1831 quarantainebepalingen uit. Hij verklaarde het quarantainereglement van toepassing op alle schepen die vanuit Rusland, Pruisen, Scandinavië en de Hanzesteden de Nederlandse wateren wilden binnenvaren. ${ }^{\circ}$

Op het ministerie van Binnenlandse Zaken maakte men zich eveneens zorgen. Daar beraadslaagde een 'commissie van geneeskundige professoren' over eventueel ter land te nemen maatregelen. Op advies van deze commissie droeg minister Van Doorn van Westcappelle in juli 1831 alle provinciale en plaatselijke commissies van toevoorzicht op maatregelen te nemen voor de opvang en de verzorging van choleralijders. Twee rapporten met analyses en geneeskundige commentaren van de commissie werden in het hele land bij postkantoren en boekhandelaars verkrijgbaar gesteld. ${ }^{7}$ Tevens gaf de minister opdracht toezicht op de stranden in te stellen om contacten tussen kustbewoners en aangespoelde goederen of lijken te voorkomen. ${ }^{8}$ In de maanden daarop stelden bestuurders en 
medici in de steden uitvoerige plannen ter wering van de cholera en voor de opvang van choleralijders op (cholerahospitaal, aanleggen van een voorraad geneesmiddelen, verscherpt toezicht op vlees en vis).

\section{Onenigheid over de quarantaine}

De medische wereld paste in die dagen een betrekkelijk eenvoudige indeling van de meest voorkomende ziekten toe. Deze indeling is, zoals we reeds zagen, grotendeels terug te voeren op een scheiding tussen ziekten met een ecologische aetiologie (epidemische constitutie) en ziekten die via direct contact van persoon op persoon werden overgebracht. Belangrijk bij het maken van dit onderscheid was het verspreidingspatroon van de ziekte: er kon geen sprake van besmettelijkheid zijn, indien een ziekte tegelijkertijd op verschillende, ver van elkaar gelegen plaatsen uitbrak.

In de jaren twintig was deze tweedeling in contagieuze en epidemische ziekten in het buitenland onderwerp van wetenschappelijke discussie. Deze vond aanvankelijk vooral in Frankrijk plaats, naar aanleiding van quarantainemaatregelen van de regering tegen de verbreiding van de gele koorts. Artsen, onder wie vele hygiënisten, bekritiseerden de opvatting dat de gele koorts door een 'contagium vivum' of een 'contagium animatum' werd veroorzaakt. Zij wilden natuurwetenschappelijke zekerheid bereiken door uitsluitend op eigen waarnemingen af te gaan. Naar hun mening was het contagionisme niet meer dan een apriorisme, een bijgeloof waarvoor in een moderne positieve wetenschap geen plaats was. Een (levende) smetstof was immers nog nooit waargenomen, zo stelden deze artsen."

De tegenstanders van het contagium leken het gelijk aan hun zijde te krijgen, toen bleek dat de gele koorts zich ondanks strenge quarantainemaatregelen had verspreid: in 1828 stelde de Franse Académie de Médecine vast dat de gele koorts geen contagieuze ziekte was. ${ }^{10}$ De jaren daarop won het anticontagionisme in Frankrijk veld. Een toenemend aantal artsen beschouwde niet alleen de gele koorts, maar ook de cholera en de tyfus als niet-besmettelijke ziekten. ${ }^{11}$ De invloedrijke fysioloog Magendie sprak in 1831 na een bezoek aan Engeland, waar de cholera was uitgebroken, als zijn overtuiging uit dat de ziekte niet tot de contagieuze aandoeningen behoorde. Deze opvatting werd terstond door andere vooraanstaande geneeskundigen in Parijs overgenomen.

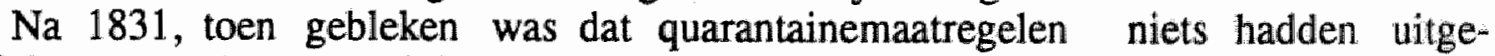
richt tegen de verspreiding van de cholera, beschouwden ook in Engeland en Duitsland steeds meer medici de cholera als een 'epidemische ziekte'. Het feit dat de cholera op verschillende plaatsen tegelijk kon ontstaan, maakte deze overtuiging des te aannemelijker. De regeringen in deze landen daarentegen hielden vast aan de gedachte dat cholera besmettelijk was en dat quarantainemaatregelen dus geboden bleven. Hun liberale tegenstanders verdedigden het anticontagionisme juist, omdat zij de voor de handel zo lastige quarantainemaatregelen afgeschaft wilden zien. ${ }^{12}$

Soortgelijke ontwikkelingen deden zich in Nederland voor. Onmiddellijk na de besluiten van de minister van Marine ontbrandde onder medici en zakenlieden een discussie over nut en noodzaak van de quarantainebepalingen met betrekking tot de cholera. Zo diende de invloedrijke Amsterdamse Kamer van Koophandel een bezwaarschrift bij de koning in, waarin zij erop wees dat stremming van de graanhandel over zee tot 'ontzaglijke verliezen voor den handel', groei 
van werkloosheid en stijging van de broodprijzen zou leiden. Vooral het laatste zou onrust onder de bevolking tot gevolg kunnen hebben, meende de Kamer van Koophandel. ${ }^{33}$ In juli 1831 - dus binnen een maand -bracht de minister van Marine onder druk van de ministers van Binnen- en Buitenlandse Zaken en van Waterstaat, Nijverheid en Koloniën versoepelingen in de bepalingen aan. Er werd voortaan een onderscheid gemaakt tussen schepen komende van 'besmette plaatsen", die veertig dagen in quarantaine moesten blijven, schepen komende van 'suspecte plaatsen', waarvoor een quarantaine van tien dagen gold, en schepen komende van plaatsen ten aanzien waarvan voorzichtigheid was geboden. Voor laatstgenoemde schepen was de duur van de quarantaine slechts drie dagen. 14 Weer een maand later zwakte de minister de verordening verder af. Het lossen van graanschepen uit de Oostzee was nu reeds na tien dagen toegestaan, ook als zij van 'besmette plaatsen' afkomstig waren. ${ }^{15}$

De discussie over de quarantaine verstomde echter allerminst. Sommige geneeskundigen bleven kritiek leveren op de quarantaine die volgens hen als preventief middel niets uithaalde, omdat de cholera geen besmettelijke maar een miasmatische ziekte was. De enige manier om het land van de ziekte te vrijwaren, was volgens de anticontagionistische artsen het op gang brengen van sanitaire hervormingen. Anderen die het contagieuze karakter van de cholera verdedigden, bepleitten juist stringentere quarantainebepalingen of zelfs sluiting van de landsgrenzen.

De minister van Binnenlandse Zaken heeft enige tijd overwogen de landsgrenzen door middel van militaire cordons te sluiten. ${ }^{96}$ Alvorens een dergelijk besluit te nemen, wilde hij eerst een geneeskundig onderzoek naar de aard van de cholera laten plaatsvinden. Hij benoemde in oktober 1831 een regeringscommissie die de ziekte 'in loco', dat wil zeggen in Duitsland, moest onderzoeken. ${ }^{17}$ Deze commissie bestond uit de Groningse hoogleraar Hendriksz, de militairgeneeskundige P.L. Beckers en de Amsterdamse geneesheer Arntzenius. Deze geneeskundigen moesten een antwoord vinden op de vraag of de cholera besmettelijk was en door middel van quarantaine en militaire cordons kon worden bestreden.

\section{Het onderzoek van de regeringscommissie}

De theoretische bagage van de Nederlandse regeringscommissie die naar Duitsland reisde om de aard van de cholera te onderzoeken, bestond dus uit een beproefd ecologisch verklaringsmodel voor volksziekten enerzijds en een overtuigende theorie over besmettelijkheid via direct contact anderzijds. Bovendien had zij te maken met een 'contagionistische' overheid, en internationaal met een wetenschappelijke wereld die naar het anticontagionisme neigde.

De commissie bracht in april 1832 haar rapport uit. $\mathrm{Zij}$ concludeerde op grond van onderzoek in Hamburg en Berlijn dat "de aziatische braakloop zich op eene plaats (kon) ontwikkelen zonder van buiten te zijn ingebragt' en dat 'de wijze van verspreiding niet overeen (komt) met die van contagieuze ziekten'. 'Immers', zo schreef de commissie, 'de aziatische braakloop verschoont vele menschen, niet tegenstaande dezelven in de nauwste gemeenschap met hen die door dezelve zijn aangetast verkeeren'. " Een overtuigend argument tegen besmettelijkheid van de cholera was bovendien dat strenge quarantaine-maatregelen in het buitenland geen enkel effect hadden. De commissie deelde de cholera daarom in bij de epidemische ziekten. 
Zoals eerder vermeld, waren wijzigingen in de epidemische constitutie verantwoordelijk voor het ontstaan van dergelijke ziekten: 'veranderingen in de dampkringslucht hebben dikwijls eenen grooten invloed op het ziekteverloop'. De commissieleden meenden ook dat verstoorde gemoedsaandoeningen, zoals hevige angst, kwaadheid en hysterie, grote invloed hadden op de versrpeiding van de cholera. Over het drinkwater schreven zij: 'bijzondere opmerkzaamheid worde geslagen op de deugdzaamheid van het water in de openbare pompen en bronnen, en op de reiniging derzelven, alsmede op de deugdzaamheid der overige levensmiddelen'. Wat het laatste betreft, men achtte onrijpe vruchten, bedorven vlees en groente gevaarlijk. Kwalitatief slechte voeding kon de lichamelijke gesteldheid ondermijnen en 'voorbeschikkend' werken op het krijgen van de cholera. Als mogelijkheden voor behandeling noemde de commissie het voorschrijven van opium, ijzerpreparaten en ammonium, het toedienen van huidprikkels, het geven van dampbaden en aderlating. De commissie tekende hierbij aan dat niet cén van de genoemde middelen succes had gehad in Duitsland. ${ }^{19}$

De adviezen van de regeringscommissie waren er op gericht de oorzaken van de komende epidemie weg te nemen. Zij stelde voor de straten waar plantaardige en dierlijke 'zelfstandigheden' verzameld werden te reinigen, huizen met veel bewoners te luchten, het grachtwater te verversen en voor een goede riolering te zorgen. De bevolking diende goed te worden voorgelicht over de aard en de gevolgen van de ziekte. ${ }^{20}$ Mocht de cholera onverhoopt ergens uitbreken, dan moest allereerst in elke gemeente een choleracommissie worden opgezet, waarin leden van het plaatselijk bestuur, een geneeskundige en de directeur van de politie zitting hadden. De commissie bepleitte voorts de oprichting van bureaus in de afzonderlijke wijken van grotere steden, waarin een apothekersbediende, een politieman, vier mannelijke en twee vrouwelijke ziekenoppassers en twee dragers werden gestationeerd. Ten slotte beval de commissie de inrichting van speciale cholerahospitalen aan, wat trouwens al in vele steden was gebeurd. ${ }^{21}$

\section{Het beleid van de minister van Binnenlandse Zaken}

Minister Van Doorn volgde het advies van de commissie grotendeels op. Op 5 mei 1832 ging er een ministerieel schrijven uit naar de gouverneurs, dat onder meer bepaalde, dat alle reeds bestaande en nog op te richten plaatselijke choleracommissies onder direct gezag van een provinciale hoofdcommissie, met de gouverneur als voorzitter, kwamen te staan. ${ }^{22} \mathrm{De}$ minister wees op de noodzaak van maatregelen, 'strekkende, om het ontstaan en de verbreiding der Aziatische braakloop tegen te gaan, door het wegnemen of verminderen der oorzaken' en van maatregelen 'strekkende, om aan de lijders een spoedige en doelmatige hulp te kunnen verleenen'. Als gevolg van het laatste deel van de opdracht werden de plaatselijke choleracommissies opgesplitst in een 'curatieve' en een 'preventieve' sectie. Het verslag van de regeringscommissie werd ter 'voorlichting en handleiding' naar de plaatselijke commissies gezonden.

Hoewel de regeringscommissie het nut van quarantainebepalingen niet bewezen achtte, vonden de ministers van Marine en Binnenlandse Zaken het niet raadzaam ze in te trekken. Volgens hen waren deze al zodanig versoepeld, dat zij geen bezwaren meer opleverden voor de handel. Bovendien meenden de ministers dat zij zich moeilijk tegen beschuldigingen van roekeloosheid zouden kunnen verdedigen, wanneer de cholera na afschaffing van de quarantaine 
plotseling zou uitbreken: het publiek geloofde immers nog in de besmettelijkheid ervan. Ten slotte voelden de ministers niet veel voor een beleid dat te zeer zou afwijken van het beleid in de omringende landen. $\mathrm{Zij}$ handhaafden dus de quarantainemaatregelen en wezen zelfs een aantal nieuwe gebieden in Europa aan, die als besmet moesten worden beschouwd. Wat het verkeer te land betreft: reizigers die uit die gebieden afkomstig waren, moesten gezond zijn en meer dan vijftien dagen tevoren zijn vertrokken. ${ }^{23}$ Het moet echter worden betwijfeld of op grond van deze bepalingen ooit een buitenlands schip in quarantaine is geplaatst of dat reizigers van de grenzen zijn geweerd. ${ }^{24}$

$\mathrm{Na}$ de missive van de minister werden in het land de preventieve maatregelen verscherpt. In de meeste gemeenten namen behalve de burgemeester, enkele wethouders, plaatselijke doctores en afgevaardigden van armbesturen en gasthuizen zitting in de choleracommissies. De basismaatregelen waren overal van dezelfde aard, aangezien ze waren 'voorgeschreven' in het rapport van de regeringscommissie: het inrichten van noodhospitalen, het enkele malen per week verversen van grachtwater, verhoogde waakzaamheid met betrekking tot het schoonhouden van straten en grachten, en het graven van speciale 'drekputten'; de verkoop van onrijpe vruchten werd verboden en scholen werden gesloten of regelmatig gelucht. Via pamfletten en affiches werden bij de bevolking leefregels aanbevolen, die vatbaarheid voor de cholera moesten verkleinen. In tal van gemeenten werden aangepaste apotheken ingericht en werd een speciale vorm van ziekenvervoer geregeld. In grotere steden, zoals Rotterdam, werden 'observatieposten' opgericht om de verschijning van de cholera tijdig te kunnen signaleren. In de maanden mei en juni leek men op alles voorbereid. In angstige spanning wachtte men af. ${ }^{25}$

Op 25 juni 1832 werd in Scheveningen het eerste officiële geval van cholera gesignaleerd. De ziekte verspreidde zich vervolgens traag. Pas in de tweede helft van juli bereikte de cholera Den Haag, Katwijk en Rotterdam. Daarna breidde de epidemie zich ineens snel uit naar het midden en noorden van het land. Zoals ook elders in Europa vielen in Nederland de meeste slachtoffers onder de armen. Overal in het land trad het met zoveel zorg opgebouwde hulpverleningsapparaat in werking. Bovendien paste men allerlei contagionistische maatregelen toe, die de verspreiding van het 'choleragif' moesten tegengaan. Op de deuren van huizen, waar cholera heerste, werden plakkaten aangebracht. Voedsel voor bewoners van deze besmette huizen kon het best voor de deur worden neergelegd. 'Chloorberokingen' moesten de 'odor cholericus' in en rond besmette plaatsen neutraliseren. Brieven, afkomstig uit besmette gebieden, moesten het opschrift 'cholera' dragen en met chloordampen worden ontsmet.

Men mag concluderen dat van regeringszijde serieus is getracht met behulp van de beschikbare kennis en middelen de choleradreiging te weren. Maar ondanks alle inspanningen waren de gevolgen van de epidemie rampzalig. Nergens bleken de maatregelen voldoende effect te sorteren. De medici stonden in therapeutisch opzicht volledig machteloos: ongeveer de helft van alle aangetasten stierf. De gegoede burgerij trachtte in de loop van 1832 de ergste nood te lenigen door soep, olie, stro en dekens aan de getroffen gezinnen uit te delen of collectes te organiseren. Pas in $1833 \mathrm{kwam} \mathrm{er}$, plotseling een einde aan de epidemie. Iedereen moest erkennen dat de geneeskundige kennis van de ziekte dramatisch was tekort geschoten. 
In Engeland en Frankrijk veroorzaakte de cholera een schok met blijvende gevolgen voor de politieke en wetenschappelijke wereld. In Engeland leidde het anticontagionisme en het toenemende verzet tegen de quarantaine tot scherpe discussies over de sanitaire toestand van het land. Een tyfusepidemie in 1837 leek de Engelse sanitaire hervormers met hun aandacht voor de vervuiling in de steden gelijk te geven. Het hoogtepunt van het anticontagionisme viel samen met de invoering in 1848 van de Public Health Act, één van de belangrijkste successen van de Engelse sanitaire hervormers. ${ }^{26}$ Frankrijk kende een soortgelijke ontwikkeling. Ook hier ging het toenemend anticontagionisme onder medici gepaard met de opkomst van de hygiënische beweging, die aan het eind van de jaren veertig een nationale gezondheidswetgeving tot stand wist te brengen.

In Nederland verliep de discussie in de jaren dertig geheel anders. De overheid verzuimde de in de jaren 1831-1833 opgedane ervaringen te gebruiken voor de verdere ontwikkeling van een preventief gezondheidsbeleid. Zodra het choleragevaar geweken was, verdween bij de autoriteiten al snel het animo om het medisch politietoezicht op de het stedelijk milieu te verscherpen. De politieke en sociale omstandigheden vormden een belemmering om de preventieve gezondheidspolitiek definitief op te nemen in het bestuurlijk handelen.

De houding van de medische wereld na 1833 kan men tweeslachtig noemen. De ommezwaai van contagionisme naar anticontagionisme, die de regeringscommissie en in haar voetspoor vele andere medici hadden gemaakt, was volkomen identiek aan die van de buitenlandse collega's. Toch kwamen sanitaire hervormingen als alternatief voor quarantaine nauwelijks ter sprake. De discussie bleef beperkt tot de vraag wat de aard en de symptomen van de cholera waren. Niets wijst erop dat de geneeskundigen na 1832 een openbaar debat over de noodzaak van sanitaire hervormingen wilden entameren. Het uitwisselen van standpunten over de cholerakwestie had slechts academische waarde. ${ }^{27}$

\section{De cholera als miasmatisch-contagieuze ziekte}

\section{De cholera-epidemie van 1848-1849}

Ten tijde van de tweede cholera-epidemie, in de jaren 1847-1849, had het anticontagionisme zijn grootste invloed. In Rusland en Oostenrijk werden geen quarantainemaatregelen meer genomen en er werden geen militaire cordons ingesteld. In Engeland en Frankrijk waren de medici inmiddels in grote meerderheid anticontagionistisch. Ook daar werden de quarantainemaatregelen afgezwakt of zelfs afgeschaft. Vooral de sanitaire hervormers, onder wie de leden van de 'General Board of Health' Chadwick en Southwood Smith, propageerden een actief anticontagionistisch beleid: niet quarantainemaatregelen, maar gezonde steden zouden de cholera in de toekomst voorkomen. ${ }^{28}$

In Nederland vielen de eerste slachtoffers van de tweede epidemie in de zomer van 1848. De epidemie duurde tot het voorjaar van 1849. Aanvankelijk nam de Nederlandse regering allerlei quarantainemaatregelen, hoewel de minister van Binnenlandse Zaken De Kempenaer op het standpunt stond dat de cholera niet besmettelijk was. ${ }^{29}$ Op 31 oktober 1848 besloot de regering echter om de quarantainebepalingen op de cholera in te trekken, nadat dit ook elders in Europa was gebeurd. ${ }^{30}$ 
In Nederland raakte nu ook de regering ervan overtuigd dat de cholera niet besmettelijk was. Hierdoor voerde ze een veel minder actief beleid dan in 1832 . Mede als gevolg van de totale afwezigheid van geneeskundige ambtenaren op het departement van Binnenlandse Zaken en de politieke instabiliteit in deze jaren, werd in 1848 geen alternatief beleid voor quarantainebepalingen vastgesteld. Er kwam bijvoorbeeld geen Iandelijke choleracommissie zoals in de jaren 1831-1832. Wel werden evenals in 1831-1832 in de meeste gemeenten plaatselijke choleracommissies ingesteld. Ook werd in vele plaatsen aan de armen brood, turf, kleding en olie uitgedeeld, werden noodhospitalen ingericht en werd door middel van 'chloorberokingen' de lucht in besmette huizen gezuiverd.

Maar de verschillen in beleid van stad tot stad waren nu veel groter dan tijdens de eerste epidemie. Men krijgt de indruk dat de bestuursorganen en de medici nog minder dan in 1831-1832 wisten in welke richting het cholerabeleid moest gaan. Het anticontagionisme zorgde ervoor dat in tal van steden choleralijders niet werden geisoleerd van andere zieken in gasthuizen. In Rotterdam richtte men, anders dan in 1831, geen observatieposten in. In andere steden durfde men toch niet alle contagionistische maatregelen af te schaffen. In verband met mogelijk besmettingsgevaar werden in Groningen de stoffelijke overschotten direct uit de huizen gehaald, op een speciale plaats verzameld en vervolgens snel begraven. Het Groningse stadsbestuur stelde ook 'wakers' aan die moesten rapporteren over de versrpeding van de ziekte.

\section{Een nieuwe besmettingshypothese}

Het beleid verschilde per streek of stad, omdat de verwarring over de aard van de cholera bijzonder groot was. De overheid en een groot deel van de geneeskundigen traden de cholera in 1848 anticontagionistisch tegemoet. Maar bij sommige geneeskundigen ontstond tijdens de epidemie reeds twijfel over de niet-besmettelijkheid van de ziekte. Een van de eersten die het contagieuze karakter van de ziekte niet volledig wilde uitsluiten was de Utrechtse hoogleraar Mulder. In $1848 \mathrm{kwam}$ hij terug op zijn in 1832 ingenomen standpunt dat besmettelijke ziekten tegenover epidemische ziekten staan, en dat de cholera tot de laatste categorie behoorde. Cholera was naar zijn mening wel degelijk besmettelijk, maar op een geheel andere manier dan bijvoorbeeld de pokken of de mazelen. Mulder meende dat 'voor de besmettelijkheid van individu op individu door aanraking geen grond is', omdat ziekenverzorgers en ook hij zelf in 1832 niet door de ziekte waren aangetast, ondanks het feit dat zij vele malen in direct contact met choleralijders hadden gestaan.

Niettemin was Mulder het oneens met uitspraken van de regering, 'dat geneeskundigen meer en meer tot de overtuiging komen: dat de cholera niet tot de besmettelijke ziekten behoort' en 'dat maatregelen van afsluiting daarom niet zijn aan te raden'. ${ }^{\prime \prime}$ Hij achtte de cholera op grond van haar verspreidingswijze na 1847 besmettelijk, hoewel dit niet betekende dat mensen onder alle omstandigheden konden worden besmet. Besmetting was afhankelijk van het plaatselijke ziektekarakter ('constitutio epidemica') of van plaatselijke ziekteoorzaken als vochtige woningen, armoede en opeenhoping van mensen in te kleine vertrekken, want 'effluvia van een cholerazieke verspreiden zich in de lucht en als men onder den invloed ervan komt, kan men choleraziek worden. Cholera brengt cholera voort; daartoe behoeft de afstand niet klein te zijn, zoo als bij roodvonk en pokken; zelfs op grooten afstand verspreidt zij haren invloed. Hoe grooter 
echter die afstand, hoe zwakker die invloed zal zijn' 32 Mulder beschouwde de lucht als medium een ziekmakende stof, die afkomstig is van de choleralijder. De gevaarlijke werking van deze stof was omgekeerd evenredig met de afstand tussen choleralijder en gezonde personen, beweerde Mulder later. Stortregens en sterke wind konden het infectiegevaar verminderen, en ook een juist dieet kon gezonde personen enige bescherming tegen de cholera bieden.

Mulder beschouwde de cholera niet als een contagieuze ziekte. Daar was strikt genomen immers slechts sprake van als de ziekte zich via direct contact tussen mensen verspreidde. Hij verdedigde daarentegen het bestaan van een nieuw type besmettelijkheid, waarbij een anorganisch gif, afgescheiden door de patiënt, zich over een beperkte ruimte door de lucht verspreidt en gezonde personen infecteert. De actieradius van deze 'smetstof' was mathematisch vast te stellen, oordeelde Mulder. Volgens hem betekende de mogelijkheid van besmetting via de lucht, dat sluiting van de landsgrenzen met behulp van quarantainemaatregelen weinig zin had.

Mulders neocontagionistische opvatting was niet nieuw. De Duitse medicus Henle had in 1840 het principiële onderscheid tussen contagium en miasma verworpen. Het verschil tussen de twee ziekmakende 'substanties' was volgens Henle slechts gradueel, daar er twee typen contagia bestonden: vaste en vluchtige. Het eerste type wordt door de huid afgescheiden en door directe aanraking van persoon op persoon overgebracht, zoals bij de pokken. Het tweede type kan via huid en longen direct het lichaam verlaten en de lucht in de omgeving van de patiënt besmetten. Epidemische of miasmatische ziekten kunnen langs laatstgenoemde weg contagieus worden. Anders dan Mulder dacht Henle dat het vluchtige contagium bestond uit een parasitair levend organisme, dat zich buiten het menselijk lichaam op nog onbekende wijze in de atmosfeer of in de bodem vermenigvuldigde. ${ }^{33}$ Henle had zich bij het opstellen van zijn theorie gebaseerd op proefnemingen van zijn vriend Th. Schwann. Deze botanicus ontkende het bestaan van de zogenaamde generatio spontanea, een chemisch proces waarbij levende materie uit anorganische stoffen ontstaat. Schwann beweerde dat zijn experimenten met gisting hadden aangetoond, dat fermentatie en rottingsprocessen niet door de lucht als zodanig, maar door in de lucht levende kiemen ('fungi') werden veroorzaakt. ${ }^{3 / 4}$

Doordat Henle aan het begrip contagium een nieuwe betekenis gaf, kon hij het strikte onderscheid tussen miasma en contagium loslaten en de mogelijkheid verdedigen van het bestaan van een smetstof, die een bepaalde afstand tussen patiënt en gezonde personen kon afleggen zonder zijn ziekmakend vermogen te verliezen. Deze mogelijkheid veronderstelde de aanwezigheid van een medium, waarin de smetstof zich verplaatste. Door tevens het parasitaire karakter van de smetstof te benadrukken, gaf Henle voedsel aan de gedachte dat het contagium niet in de wereld van de chemie maar in die van de biologie moest worden gezocht. Zo identificeerden verschillende onderzoekers in het begin van de jaren veertig met behulp van de microscoop enkele parasieten en pathogene schimmels bij de mens.

Zoals we zullen zien, meenden Engelse onderzoekers in 1849 dat de cholera ook door een fungus werd veroorzaakt. Toch heeft de kiemtheorie van Schwann en Henle in de periode 1840-1870 weinig invloed op het wetenschappelijk denken uitgeoefend. In deze periode was de scheikunde toonaangevend: men trachtte alle levensverschijnselen met behulp van fysische en chemische krachten te verklaren. In dat kader was geen plaats voor biologische denkbeelden over 
zich verplaatsende en zichzelf reproducerende, pathogene micro-organismen. Veel belangrijker voor de discussie over besmettelijke ziekten was de door Henle op theoretische gronden vastgestelde aanwezigheid van een transportmedium van de smetstof. Deze veronderstelling zou in de jaren vijftig en zestig het debat over de aetiologie van de cholera bepalen.

\section{Quarantaine of sanitaire hervormingen}

$\mathrm{Na}$ het uitwoeden van de tweede epidemie volgden de nabeschouwingen. En de twijfels. De belangrijkste vraag was natuurlijk of het juist was geweest niet te handelen in de geest van de quarantainebepalingen van 1805 en 1831. De nieuw aangetreden minister Thorbecke vroeg daarover de mening van het Koninklijk Nederlandsch Instituut van Wetenschappen. Dit gaf in 1850 het advies de quarantaine niet meer toe te passen bij de gele koorts en de cholera. Een op zichzelf staand stelsel van afwering tegen de pest achtte het Instituut evenmin raadzaam. ${ }^{35}$

Thorbecke kwam echter niet toe aan een herziening van de quarantainebepalingen. Pas in 1858 kwamen de ministers Van Tets van Goudriaan (Binnenlandse Zaken) en Lotsij (Marine) naar aanleiding van dit advies met een wetsontwerp dat de quarantainebepalingen van 1805 moest vervangen. ${ }^{36} \mathrm{Zij}$ wilden kennelijk geen standpunt inzake de besmettelijkheid van de verschillende ziekten innemen, want in het ontwerp werden de ziekten waarop de nieuwe bepalingen betrekking hadden, niet genoemd. Deze zouden bij Maatregel van Bestuur worden vastgesteld. Voor de Tweede Kamer was dat reden om het ontwerp al tijdens de voorbehandeling af te wijzen. ${ }^{37}$ Het ongenoemd laten van de ziekten waarop de wet betrekking moest hebben, zou de regering te veel de vrije hand laten.

Bij de voorbehandeling stelden enkele parlementariërs de ministers voor om in navolging van Engeland ook in ons land voortaan alleen schepelingen te isoleren die werkelijk leden aan gele koorts, pest of cholera. Zij wilden bovendien de mening van de ministers horen over de uitkomsten van de internationale sanitaire conferentie die in 1851 op initiatief van de Franse regering bijeen was geroepen om de gezondheidsmaatregelen van de Europese landen op elkaar af te stemmen. ${ }^{38}$ Op deze conferentie, waar Nederland niet was vertegenwoordigd, bleken de standpunten van de aanwezige landen ver uiteen te liggen: de Franse regering wilde de observatieve quarantaine herinvoeren, omdat ze niet gerust was op de veiligheid van de volledig onbeschermde en kwetsbare kustgebieden aan de Middellandse Zee. De Engelsen toonden zich echter felle tegenstanders van dit voornemen, en voelden hoogstens iets voor bepalingen die de isolering van zieke schepelingen reglementeerden. ${ }^{39}$ Het resultaat van de conferentie was, dat een aantal Zuideuropese staten de observatieve quarantaine inzake gele koorts en cholera herinvoerde. In Engeland en Denemarken daarentegen werden de voorschriften geliberaliseerd.

De ministers Van Tets van Goudriaan en Lotsij namen geen standpunt in over de resultaten van de conferentie, ondanks de verzoeken van kamerleden. Evenmin beantwoordden zij het negatieve oordeel van de Kamer. Zij trokken hun wetsontwerp in en lieten de zaak verder rusten. Het onderwerp zou pas in 1863 opnieuw ter tafel komen. 
Het advies van het KNIW en het kamerdebat deden de discussie onder de geneeskundigen over de aard van de cholera oplaaien. Anders dan Mulder en het Instituut stelden de Middelburgse medici J.C. de Man en J.C. van den Broecke zich in 1850 'streng-contagionistisch' op. Naar hun mening kon met de miasmatische theorie niet worden verklaard, waarom de sterfte op de Zeeuwse eilanden ten gevolge van de cholera zowel in 1831-1832 als in 1848-1849, zoveel lager was dan bijvoorbeeld in Amsterdam. De bodem- en luchtverontreiniging was in Zeeland even groot als in Amsterdam en men moest wel heel 'merkwaardige luchtstroomen' veronderstellen om de geringe verspreiding van het choleramiasma in Zeeland via de lucht te verklaren. Atmosferische en tellurische invloeden waren evenmin van belang en epidemisch-constitutionele factoren speelden een ondergeschikte rol: 'De plaatselijke invloeden of andere, met leefwijze en bedrijf samenhangende, zijn geenszins op goede gronden als eerste en voldoende oorzaken voor het ontstaan der cholera aan te wijzen', aldus De Man en Van den Broecke. ${ }^{40}$ Dit gold des te meer, omdat de gezondheidstoestand in Zeeland vóór het uitbreken van de cholera in 1848 in jaren niet zo gunstig was geweest.

Punt voor punt weerlegden De Man en Van den Broecke de door Mulder in 1848 opgestelde theorie over een nieuw type besmettelijkheid. $\mathrm{Zij}$ kwamen tot de conclusie dat overdracht van individu op individu het enige verspreidingsmechanisme van de cholera was. Want 'het is op die plaatsen (..), dat de eerste choleralijders vreemdelingen of personen waren die van plaatsen kwamen, waar de cholera heerschte (..). De cholera is eerst dan in de landelijke gemeenten verschenen, wanneer daaraan een verkeer was voorafgegaan met plaatsen, waar de ziekte zich vertoond had. (...) Men is genoodzaakt aan te nemen, dat de cholera asiatica in Zeeland als eene uitheemsche besmettelijke ziekte ontstaan is, en zich door onmiddellijke of middellijke voortplanting van de eenen op den anderen verspreid heeft. ${ }^{\not I}$ De Man en Van den Broecke accepteerden de mogelijkheid van een nieuw type besmettelijkheid dus niet, en konden daardoor het verspreidingspatroon van de cholera in Zeeland slechts met behulp van de oude opvatting over besmettelijke ziekten verklaren, namelijk overdracht van smetstof door aanraking. Het nemen van quarantainemaatregelen lag binnen deze opvatting vanzelfsprekend voor de hand.

Hoewel de beschouwingen van De Man en Van den Broecke indruk maakten, kozen de meeste artsen de zijde van Mulder. In het Nederlandsch Lancet, het tijdschrift waarin Mulder zijn standpunt had verdedigd, werd het neo-contagionisme in de jaren 1849-1851 nog enkele malen verdedigd. ${ }^{42}$ Artsen die bij de hulpverlening aan choleraslachtoffers betrokken waren geweest, benadrukten weliswaar dat de epidemie door bodem- en luchtverontreiniging was ontstaan, maar sloten evenals Mulder niet uit dat de cholera op een moment besmettelijk was geworden. Zo erkende Ali Cohen in 1850 dat hij de cholera in het verleden voor een zuiver miasmatische ziekte had gehouden. Hij noemde de cholera voortaan 'miasmatisch-contagieus', daar deze benaming het best weergaf dat de cholera in oorsprong miasmatisch was, maar dat de ziekte na verloop van tijd op plaatsen 'waar de ziekte alle kans kreeg' een contagieus karakter kon aannemen. De verspreiding van de cholera van huis tot huis was het gevolg. Henle had volgens Ali Cohen terecht opgemerkt, dat het enige onderscheid tussen miasma en contagium lag in het feit dat het eerste niet en het laatste wel 'zelfstandig gereproduceerd' kon worden. Dat was voor geneeskundigen het enig merkbare verschil. De wetenschap wist voor het overige nog vrijwel niets over de aard van 
de cholera. ${ }^{43}$ Ali Cohen toonde zich overigens geen voorstander van quarantainemaatregelen, omdat de ervaringen in binnen- en buitenland immers hadden uitgewezen dat ze geen effect hadden. ${ }^{44}$

Ook Penn constateerde dat de besmettelijkheid van de cholera duidelijk was aangetoond door het werk van De Man en Van den Broecke. Hij geloofde echter niet in een specifiek contagium als een op zichzelf staande oorzaak. Er moesten meer factoren in het spel zijn, zoals slechte huisvesting, dichtbevolkte buurten, onvoldoende voeding en de gesteldheid van de bodem. Volgens Penn konden quarantainebepalingen, gezien deze aetiologie, weinig uitrichten. Beter was het om maatregelen te treffen die de 'algemene belangen' niet zouden schaden. ${ }^{45}$

De medici die de quarantaine afwezen, meenden een duidelijk alternatief ter voorkoming van cholera te kunnen bieden. Hun miasmatisch-contagieuze opvatting ging hand in hand met een pleidooi voor een nieuw gezondheidsbeleid in de steden. De 'maatschappelijke toestand' als bron van epidemieën kreeg door de cholera juist zijn concrete betekenis: verontreiniging van bodem, water en lucht alsmede slechte behuizing en armoede. 'Letten' wij op deze voorbeschiktheid van personen en plaatsen voor de ziekte, dan moet reeds de alom bevestigde daadzaak, dat de cholera verreweg de meeste harer offers kiest onder de schamelijke bevolkingen, vooral van de grootere steden, tot nadenken wekken', schreef Ali Cohen. 'Er is geen twijfel mogelijk dat het hier om 'sociale epidemieën' gaat', zo vervolgde hij, verwijzend naar Virchow. ${ }^{46}$ Schick rapporteerde in 1852 over Den Haag: 'Zeer ongelijk deed zich de cholera hier gevallen. Terwij1 de straten door rijken en welgestelden bewoond bijna geheel verschoond bleven, werden eenige der wijken waar arbeiders en minvermogenden de meerderheid uitmaken, hevig geteisterd'. "7 Hij bracht de sanitaire voorzieningen in de stad direct in verband met de cholera door te stellen dat 'nergens, in geene der mij bekende inlandsche of buitenlandsche steden, mij zulke afschuwlijke riolen [zijn] voorgekomen dan in de hofstad van het zindelijke Nederland'. $O$ Ook voor Penn was het duidelijk dat het vervuilde milieu in de steden, de armoede en de slechte huisvesting verband hielden met het feit dat de lagere volksklassen zo zwaar waren getroffen. De geografische verschillen in sterfte toonden onmiskenbaar aan hoezeer plaatselijke omstandigheden en de levenswijze van de bevolking de gezondheid konden beinvloeden. Evenals Ali Cohen refereerde Penn aan het eerste rapport van de Engelse 'General Board of Health' uit 1849, door te stellen dat 'niet daar waar de medewerkende oorzaken bestaan, cholera [moet] zijn, maar [dat] waar cholera is, hare uitbreiding voornamelijk van de meeste dier oorzaken afhankelijk [zal] zijn. (..) Het menschelijk organisme is wel in staat tot op zekere hoogte nadeelige invloeden te weerstaan, maar bezwijkt, wanneer die mate wordt overschreden. ${ }^{49}$ Met andere woorden, als de verontreiniging en de sociale misstanden in de steden niet uit de weg worden geruimd, zal de eenmaal gearriveerde cholera grote hoeveelheden slachtoffers eisen.

Soortgelijke geluiden van geneeskundigen konden ook in andere plaatsen (Utrecht, Gouda, Dordrecht, Delft, Rotterdam, Schiedam, Haarlem) worden gehoord. In plaatsen waar de belangstelling voor atmosferische invloeden overheerste, hielden artsen nauwkeuriger dan ooit de ontwikkeling bij in de epidemische constitutie in de vorm van luchtdruk- en temperatuurmetingen. Waar men meer oog had voor de verspreidingsmechanismen, belangrijk voor een beter inzicht in de aard van de cholera, leverden medici zeer gedetailleerde 
informatie over de route die de cholera door de stad had afgelegd. Soms vonden beide vormen van onderzoek tegelijkertijd plaats.

Maar hoe het onderzoek ook plaatsvond, het contrast was groot tussen de werkeloos toeziende overheid en de bemoeienissen van de medici met de cholera. In tegenstelling tot de jaren 1831-1832 functioneerde het hiërarchisch systeem van medische politie in 1849 in het geheel niet als gevolg van het politieke vacuüm in 1848-1849. Anderzijds maakte het ontbreken van politieke leiding ook nieuwe ontwikkelingen mogelijk: het falende systeem van de medische politie werd als het ware korte tijd vervangen door een groot aantal 'activistisch' ingestelde geneeskundige genootschappen en choleracommissies. Geneeskundigen, aangezet door de politieke gebeurtenissen in de jaren veertig, konden ongehinderd door directieven van bovenaf eigen initiatieven ontplooien. Meer dan in 1832 konden discussies zich vrijelijk ontwikkelen. En duidelijker dan in 1832 kon na 1849 worden gesteld dat de hoge sterfte het gevolg was van het falend beleid van plaatselijke bestuurders. De epidemie van 1848-1849 droeg ontegenzeglijk bij tot het besef dat sociale sterfteverschillen niet op toeval berustten, maar juist een essentieel kenmerk vormden van de mortaliteit.

Zo betekenden de cholerajaren 1848-1849 de breuk met de wetenschappelijke denkschema's, waarin nu eens veranderingen in het natuurlijk milieu, dan weer de verspreiding van een contagium het ontstaan van een epidemie moesten verklaren. In de plaats van deze opvattingen kwam een miasmatisch-contagieuze theorie, waarin het voortbestaan van schadelijke milieu-invloeden werd toegeschresen aan maatschappelijke en politieke nalatigheid.

\section{Een nieuwe infectietheorie}

\section{De smetstof in het darmkanaal}

De argumenten ten gunste van de miasmatisch-contagieuze theorie waren omstreeks 1850 ontleend aan nauwkeurige observaties van de verspreidingswijze van de cholera. Men kon empirisch vaststellen, dat direct contact tussen patienten en gezonde personen niet absoluut noodzakelijk was voor de verspreiding van de cholera, maar ó́k dat de ziekte, eenmaal uitgebroken, volgens het patroon van een contagieuze aandoening van de ene op de andere persoon kon worden overgedragen. De hypothese was dat de cholera van miasmatische oorsprong was en op plaatsen waar de ziekte zich in volle hevigheid had ontwikkeld, een smetstof voortbracht die op een nog onbekende wijze op gezonde personen werd overgedragen. In Nederland hadden de meeste artsen deze hypothese aanvaard. Men stond afwijzend tegenover de observatieve quarantaine, die het uitbreken van een miasmatische ziekte immers niet kon voorkomen, maar men was het eens met de stelling van Mulder dat cholerapatiënten een bron van infectiegevaar vormden.

Toch was de miasmatisch-contagieuze hypothese in het begin van de jaren vijftig nauwelijks met natuurwetenschappelijke onderzoeksresultaten onderbouwd. Hierin kwam pas geleidelijk verandering, toen de juistheid van deze hypothese langs chemische en botanische getoetst werd. In Engeland werd na 1849 door sommige artsen de idee van een contagium vivum nieuw leven 
ingeblazen. De Londense medicus John Snow wees in 1849 op de betekenis van met faecaliën verontreinigd drinkwater voor de verbreiding van de cholera. ${ }^{50} \mathrm{Hij}$ opperde de aanwezigheid in de faecaliën van een specifiek choleragif, dat de darmmucosa rechtstreeks beschadigde, maar niet in het bloed werd opgenomen. Het gif kwam, naar hij aannam, via besmet drinkwater in de darmen terecht. Snow veronderstelde dat het infectueuze materiaal een cellulaire structuur bezat en zich in de darmen van een besmet individu vermeerderde. Ook de Britten W. Budd uit Bristol en W.P. Alison uit Edinburgh stelden na 1849 een contagium in de excreta van choleralijders verantwoordelijk voor de verspreiding van de cholera. ${ }^{51} \mathrm{Na}$ een bijzonder ontbindingsproces in de excreta, vergelijkbaar met gisting, kon het specifieke contagium gevaar voor de gezondheid opleveren. Dit contagium was naar hun mening hoogstwaarschijnlijk een fungus of een zwam. Budd en Alison concludeerden, dat de smetstof vernietigd kon worden door privaten en riolen te ontsmetten met chloorkalk of chloorzink.

Budd zag geen reden de conclusies van Snow in twijfel te trekken. Wanneer riolen in slechte staat verkeerden, kon de specifieke fungus gemakkelijk in het drinkwater terecht komen. Snow zag echter weinig in de fungustheorie van Budd. Hij hield vast aan een specifieke, mogelijk organische smetstof in het darmkanaal en, hij stelde zich ten doel te bewijzen dat deze smetstof via de ontlasting van cholerapatiënten in het drinkwater terecht kwam. In 1855 publiceerde hij de tweede editie van zijn in 1849 verschenen werk over cholera, waarin het beroemd geworden onderzoek naar de oorzaken van de zogenaamde 'Broad Street epidemic' in Londen in 1854 staat beschreven. Snow liet zien dat het aantal choleragevallen in het district Soho het hoogst was in het gebied waar de watervoorziening verzorgd werd door de Broad Street pomp en de riolering defect was. Personen die de ziekte opgelopen hadden, bleken allen van deze pomp gedronken te hebben, terwijl anderen die eveneens in het district woonden maar hun water elders hadden betrokken gezond bleven. ${ }^{52}$ Zowel het London College of Physicians als de Lancet hadden weinig waardering voor de 'speculaties' van Snow en Budd. ${ }^{s 3}$

\section{De bodemtheorie van Max von Pettenkofer}

Meer waardering oogstte de theorie van de Duitse medicus Von Pettenkofer. Deze leerling van de organisch-chemicus $\mathrm{K}$. von Liebig hield zich aanvankelijk bezig met scheikundig en fysiologisch onderzoek naar metabolische processen. Na 1851 richtte hij zijn aandacht op het vraagstuk van de cholera en de openbare hygiëne.

Toen in 1854 in Zuid-Duitsland een cholera-epidemie uitbrak, analyseerde Von Pettenkofer als lid van de choleracommissie in München het verloop van de epidemie in de Beierse hoofdstad en in negen andere steden. Zijn bevindingen publiceerde hij in $1855 .{ }^{54}$ In zijn verslag gaf Von Pettenkofer, geheel volgens de regelen der kunst, een nauwkeurige plaatsbeschrijving van München, Neurenberg en Augsburg, en vulde deze aan met sterfte- en ziektecijfers. Zijn conclusie luidde, dat de cholera zich door menselijk verkeer verspreidde, en dat de ziektekiemen vanuit één punt in korte tijd over een hele stad door een gering aantal mensen konden worden verspreid. Tot zover kwam de conclusie van Von Pettenkofer overeen met die van andere geneeskundigen.

Nieuw was echter Von Pettenkofers stelling, dat het tijdstip waarop en de kracht waarmee de epidemie zich ontwikkelde, afhankelijk was van de toestand 
van de bodem. Naar zijn mening moesten cholerakiemen eerst in een losse bodem verdeeld raken, voordat zich een onbekend 'cholera-miasma' kon vormen dat zich vooral 's nachts in de huizen verbreidde. Belangrijk was het grondwaterpeil. In een zeer vochtige bodem kon de cholerakiem zich niet ontwikkelen, maar daalde de vochtigheid tot een kritisch gehalte, dan ontstond de mogelijkheid van een epidemie. Op een rotsachtige bodem was de vorming van het 'cholera-miasma' nagenoeg uitgesloten.

Von Pettenkofer stelde zich voor dat de cholerakiem afkomstig was uit de faecaliën van choleralijders, maar anders dan Budd maakte hij onderscheid tussen de cholerakiem en de werkelijk infectueuze materie. De laatste was geen produkt van de darmen, maar een produkt van de bodem. De cholerakiem stond in een overeenkomstige relatie tot de infectueuze materie als zaad tot een volwassen plant. Wanneer zich eenmaal een infectueuze substantie in de bodem had gevormd, kon menselijk verkeer de ziekte van aangetaste plaatsen naar gezonde plaatsen overbrengen. Volgens Von Pettenkofer was het mogelijk dat daarbij gezonde personen ('dragers') het infectueuze materiaal van de ene naar de andere plaats brachten. Lucht en water als transportmedium alsmede besmetting door direct contact hield hij vrijwel voor onmogelijk. Hij verzette zich tegen de opvattingen van Snow, wiens onderzoeksresultaten hij zonder resultaat had getracht te verifiëren. Tot aan zijn dood hield Von Pettenkofer vol, dat met faecaliën verontreinigd drinkwater op zichzelf geen hoofdrol kon spelen in de verspreiding van de cholera.

De 'bodemtheorie' bracht Von Pettenkofer op slag nationale en internationale roem. Zijn internationale prestige was zo groot, dat hij de belangrijkste choleratheoreticus van het derde kwart van de negentiende eeuw kan worden genoemd. ${ }^{s 5}$ In München werd Von Pettenkofer als gevolg van zijn onderzoek na Von Liebig de meest gerespecteerde wetenschapsbeoefenaar. In de 'Gesellschaft Deutscher Naturförscher und Aerzte", de belangrijkste ontmoetingsplaats van Duitssprekende artsen en natuuronderzoekers, werd hij een veel gevraagd spreker. In de jaren zeventig werd hij ereburger van München en adviseur van Bismarck, dankzij zijn reputatie dat hij München tot één van de gezondste steden van Duitsland had gemaakt.

Von Pettenkofers succes was mede te danken aan het sociaal-conservatieve karakter van zijn theorie. Hij had laten zien dat verbetering van de volksgezondheid mogelijk was zonder ingrijpende sociale en politieke veranderingen. Hadden Virchow c.s. in 1849 hadden nog gepleit voor radicaal-democratische hervormingen, Pettenkofers bodemtheorie vergde slechts deskundigen op vooraanstaande posities in het overheidsapparaat. Deze moesten leiding geven aan de sanering van de bodem en van de volkswoningen en tevens plannen ontwikkelen ter beheersing van het grondwaterpeil. Pettenkofers technocratische aanpak van de volksgezondheid kwam dus niet alleen tegemoet aan de maatschappelijke behoefte het gevaar voor epidemieën in de steden te verkleinen, maar ook aan de wens van de maatschappelijke bovenlaag dat haar hegemonie niet werd aangetast. De bodemtheorie sloot goed aan bij het politieke klimaat van het post-revolutionaire Europa in de jaren vijftig en zestig.

Een andere reden voor Von Pettenkofers succes lag op wetenschappelijk terrein. Zijn bodemtheorie postuleerde een specifieke samenhang tussen chemische en biologische processen in bodem, lucht en menselijk lichaam. Von Pettenkofer had aangegeven welke factoren deze processen op gang brachten, maar had de processen zelf niet kunnen identificeren. Zijn theorie was met 
andere woorden vooral een model dat aangaf waar de gepostuleerde chemische en biologische processen plaatsvonden en onder welke omstandigheden deze het best konden worden onderzocht. De theorie inspireerde tal van onderzoekers ertoe de samenstelling van bodem en grondwater nauwgezet in kaart te brengen, en in het laboratorium te experimenteren, bijvoorbeeld met de zogenaamde 'gistingsproeven'. Deze leken Von Pettenkofer (en tot op zekere hoogte ook Budd) gelijk te geven. De Duitse hoogleraar in de chirurgie $\mathbf{K}$. Thiersch uit Erlangen bewees in 1856 dat het filtraat (de 'niet-vluchtige stoffen') van de darminhoud van choleralijders in een twee tot zes dagen oude oplossing cholera kon veroorzaken bij muizen. Thiersch concludeerde dat faecaliën niet in verse maar in door gisting veranderde toestand de oorzaak van de choleraverschijnselen waren. 56

In 1857 leek ook de Duitse arts Griesinger - die in het begin van de jaren vijftig de cholera in Egypte had onderzocht - de bevindingen van Von Pettenkofer, Thiersch en Budd experimenteel te bevestigen. De cholera werd volgens Griesinger veroorzaakt door een zich reproducerend specifiek gif, dat op zijn beurt door 'Hilfsursachen' werd gestimuleerd zich te reproduceren. ${ }^{57}$ Het standpunt van de contagionisten en dat van de anticontagionisten of lokalisten werden verzoend, doordat Griesinger zowel de lokale, miasmatische oorsprong van de cholera als het bestaan van een specifiek contagium in een aetiologisch schema had opgenomen. Von Pettenkofer zou dit schema in de jaren zestig nader uitwerken, zoals we nog zullen zien.

\section{Nederlandse artsen en de bodemtheorie}

De bodemtheorie werd in Nederland gunstig ontvangen. Vooral in het Nederlandsch Weekblad voor Geneeskundigen kwamen de opvattingen van Von Pettenkofer regelmatig ter sprake. De Amsterdamse geneesheer $\mathrm{C}$. de Bordes erkende als eerste de positieve heuristische waarde van Pettenkofers theorie. Hij meende dat de Münchener geleerde nu eindelijk 'een model voor onderzoek' had geleverd, dat tot opheldering van de cholerakwestie kon leiden. ${ }^{58} \mathrm{Hij}$ en ook J. Zeeman, lid van de redactie van het Weekblad, maakten in 1855 en 1856 melding van de 'gistingsproeven' van Thiersch. De Bordes concludeerde dat hiermee de theorie van Von Pettenkofer bevestigd werd: een (specifieke) smetstof was bij het verlaten van het lichaam niet werkzaam, maar kon bij voortgaande ontbinding onder gunstige omstandigheden 'rijpen'. 59 Opvallend is dat De Bordes de opvatting van de 'drinkwatertheoretici' uit Engeland, niet noodzakelijkerwijs in strijd achtte met de bodemtheorie. Hoe ook de smetstof zich zal blijken te ontwikkelen, zo stelde hij, voortaan zou het onverantwoord zijn geen rekening te houden met de faecaliën van choleralijders en met de bodemvervuiling.

Ook Ali Cohen beoordeelde de bodemtheorie positief. Aan de hand van de cholera-epidemie in Denemarken in de jaren 1853-1855, besprak hij in 1858 de betekenis van de bodemgesteldheid, de lage ligging van het land en de grondwaterverontreiniging. Tot 1853 was Denemarken gevrijwaard gebleven van de cholera, maar na de afschaffing van de quarantainemaatregelen bereikte de derde pandemie ook Kopenhagen. Voor de contagionisten was dit natuurlijk een duidelijk bewijs van hun gelijk. Niet echter voor Ali Cohen. De zeer lage ligging, de alluviale bodem en de slechte toestand van de kanalen van de stad vormden in zijn ogen de factoren die de cholera 'begunstigden'. Omdat de bodemgesteld- 
heid in hygiënisch opzicht zeer slecht was, concludeerde hij dat 'lokale omstandigheden den grootsten invloed hebben, niet om de cholera te doen ontstaan, maar om haar meer algemeen te verbreiden en in hevigheid te doen toenemen'. 6

Overigens maakte Ali Cohen melding van het onderzoek van Snow naar het drinkwater. 'Men heeft veel te weinig op dit aetiologische moment gelet', stelde hij, zonder hieraan verder aandacht te besteden. ${ }^{6 I}$ Een jaar later deed Zeeman dit wel in een artikel, waarin hij de verspreiding van de cholera in Nederland in 1859 met behulp van Pettenkofers theorie trachtte te verklaren. Hij stelde echter tevens dat de cholerasterfte in Amsterdam aanzienlijk lager was geweest dan in andere steden als gevolg van de aanwezigheid van een drinkwaterleiding in de hoofdstad. ${ }^{62}$ Blijkbaar waren beide hygiënisten er niet geheel van overtuigd, dat de cholerakiem nooit via drinkwater kon worden verspreid, zoals Von Pettenkofer beweerde.

\section{Cholera als collectief probleem}

Zo had de miasmatisch-contagieuze hypothese zich tegen het eind van de jaren vijftig ontwikkeld tot een door velen aanvaarde bodemtheorie: bepaalde lokale milieufactoren, in het bijzonder de bodemverontreiniging met organische stoffen, waren volgens de meeste medici noodzakelijk voor het epidemisch worden van de cholera. Maar ook de betekenis van het menselijk verkeer en van de besmetting was aanvaard, zonder dat men het oude contagiumbegrip behoefde te gebruiken. Von Pettenkofer zei hierover: 'Es wurde mir immer klarer, daß die Cholera wohl eine durch den Verkehr verschleppbare, aber deshalb durchaus noch nicht eine contagiöse Krankheit sei, daß die Ursache der Vermehrung des Cholera-infectionsstoffes in der Umgebung des Menschen zu suchen sei und nicht im Menschen selbst'.63

Van fundamenteel belang was de vaststelling, dat een organisch gif in de ontlasting van choleralijders een essentieel aetiologisch element moest zijn. Hierdoor werd niet alleen het nemen van 'antiseptische' maatregelen zinvol, maar onstond tevens het besef dat de vraagstukken van drinkwater en riolering onverbrekelijk met elkaar samenhangen. De controverse tussen contagionisten en miasmatici, in de betekenis van aanhangers van de bodemtheorie, was mede door deze inzichten tegen het eind van de jaren vijftig opgeheven. De discussie richtte zich nu op de vraag of lucht dan wel water het belangrijkste medium was voor wat men na 1860 het 'ontwikkelingsbeginsel der cholera' ging noemen.

De bestrijding van de cholera was dus in een geheel nieuw perspectief komen te staan. Het was duidelijk geworden dat de ontwikkeling van de cholera 'ondergronds' plaatsvond. Beschermende maatregelen in het dagelijks leven konden deze ontwikkeling niet vertragen. Zij konden hoogstens de verspreiding van de ziekte enigszins voorkomen. In de jaren dertig en veertig, toen de cholera als een ziekte van de armen werd beschouwd, kon de burgerij in de veronderstelling blijven dat zij het choleragevaar kon ontlopen door zich af te schermen van de arme en onhygiënische delen van de stad. In de jaren vijftig echter kon verontreiniging van de bodem door stadsvuil en faecaliën het gehele stedelijk milieu (bodem, water en lucht) aantasten. Ook al wist men elk contact met cholera-haarden - plaatsen of patiënten - te vermijden, het was niet meer zeker of men van de ziekte verschoond bleef.

De verschillende bevolkingsgroepen in de stad bleken op een specifieke wijze 
van elkaar afhankelijk: gebrek aan openbare hygiëne in een deel van de stad kon cholera in een ander deel doen ontstaan. De cholera was met andere woorden een probleem van de gehele bevolking. En, zoals de hygiënisten telkens betoogden, dit probleem kon alleen door collectieve voorzieningen worden opgelost, gericht op de preventie van bodemverontreiniging en op een deugdelijke scheiding van de drinkwatervoorziening en de afvoerstelsels van afval en faecaliën. Dit betekende op de eerste plaats de aanleg van riolering en de oprichting van diensten voor stadsvuilverwijdering.

\section{Een zaak van nationaal belang, 1865-1875}

\section{De rapporten van het Geneeskundig Staatstoezicht}

Uit de publikaties naar aanleiding van de vierde cholera-epidemie in de jaren 1866 en 1867 blijkt hoezeer het denken in Nederland over de cholera door de opvattingen van Von Pettenkofer is beïnvloed. Voor het eerst sinds 1832 konden de medici rekenen op ministeriële steun van enige betekenis. Bovendien was per 1 januari 1866 het Geneeskundig Staatsbestuur vervangen door een nieuw Geneeskundig Staatstoezicht met inspecteurs en provinciale geneeskundige raden.

Toen tegen het eind van 1865 berichten bleek dat de cholera opnieuw in aantocht was, vroeg minister Thorbecke de geneeskundige inspecteurs Penn en Ali Cohen, nog vóór hun officiële ambtsaanvaarding, advies over de te nemen maatregelen. Enige tijd later verzocht de minister de hoogleraar J. van Geuns om met de ambassadeur in Turkije de Nederlandse regering te vertegenwoordigen bij de derde internationale sanitaire conferentie in Constantinopel, die op initiatief van Frankrijk werd gehouden. ${ }^{64}$

Op 31 maart 1866 hadden Penn en Ali Cohen hun rapport gereed 'betreffende maatregelen tot wering van de cholera', dat zij echter niet aan Thorbecke konden aanbieden wegens de val van diens kabinet in januari. ${ }^{65}$ In het rapport staan de inzichten die in de jaren vijftig waren ontwikkeld helder verwoord: 'Het tijdelijk verkeer van gezonden in geinfecteerde plaatsen of het invoeren van zieken uit die plaatsen moet voor de hoofdoorzaak van het ontstaan in nog niet geïnfecteerde plaatsen erkend worden. De excrementen van lijders aan cholera en diarrhoea zijn de hoofdbronnen der verdere verspreiding. Zelfstandige ontwikkeling van cholera kan voor Europeesche Staten niet wel worden aangenomen. De plaatselijke gesteldheid, de bodem vooral, de toestand der bewoners, de aard der woningen, de levensmiddelen, en hieronder voomamelijk het drinkwater, zijn voor een groot deel als de dragers of bewaarders der infectie te erkennen, of spelen als medewerkende nadeelige invloeden een groote rol'.66

Quarantainemaatregelen hadden naar de mening van de inspecteurs geen zin, ook al niet omdat de cholera volgens Von Pettenkofer en Griesinger een incubatietijd van drie weken kon hebben. Het belangrijkste middel ter bestrijding van de cholera was 'de verwijdering van de excrementen der lijders, de desinfectie van woningen, linnen en beddegoed en eindelijk de spoedige verwijdering en desinfectie van choleralijken'. ${ }^{67}$ Opmerkelijk is overigens de geringe aandacht die in het rapport aan drinkwater was besteed. Penn en Ali Cohen stelden de oprichting van een breed samengesteld nationaal comité voor dat de 
aanbevelingen uit hun rapport moest uitwerken, en als permanent adviesorgaan de minister en de gemeentebesturen moest bijstaan.

Nadat in de eerste helft van april 1866 de eerste choleragevallen in Rotterdam en Delfshaven waren gesignaleerd, stelde minister Geertsema, die Thorbecke in februari 1866 was opgevolgd, een landelijke choleracommissie in. De commissie moest de eerder gedane voorstellen uitwerken, en werd tevens belast met een onderzoek naar de aetiologie van de ziekte. ${ }^{68}$ Leden van de commissie waren de inspecteurs Penn en Egeling, de Leidse hoogleraar Evers en namens het ministerie het hoofd van afdeling Medische Politie $H$. van Cappelle en het hoofd van de afdeling Binnenlands Bestuur mr. A.C. van Heusde. Voorts drong de minister bij de Commissarissen van de Koning aan op 'openbaarheid in volle omvang'. Door Penn en Ali Cohen was daarom gevraagd, aangezien de autoriteiten zich in het verleden nog al eens in geheimzinnigheid hulden om onrust onder de bevolking te voorkomen.

Vanaf haar oprichting organiseerde de choleracommissie in samenwerking met de inspecteurs de verspreiding van voorlichtingsmateriaal onder de overal in het land opgerichte plaatselijke choleracommissies. Geneeskundige raden kwamen in speciale zittingen bijeen, en de registratie van het aantal choleragevallen werd landelijk bijgehouden. De aanpak van de cholera-epidemie was een zaak van nationaal belang geworden.

De praktijk van de cholerabestrijding was, op enkele uitzonderingen na, echter nauwelijks veranderd. De plaatselijke choleracommissies en gemeentebesturen gingen grotendeels hetzelfde te werk als bij eerdere epidemieën. Ter preventie werden straten extra gereinigd en kermissen verboden. Er werden 'vliegende blaadjes' verspreid met aanbevelingen voor voeding, zindelijkheid en chloorberokingen, en men richtte in de meeste steden noodhospitalen in. Intensiever dan voorheen waren de bezoeken van medici aan 'besmette huizen', met het doel de bewoners over te halen hun zieke huisgenoten elders te laten verplegen. Nieuw was wel de doelgerichte verwijdering van faecaliën van choleralijders en van de kadavers van hen die aan de ziekte waren overleden. Men verschafte zelfs zuiver drinkwater: in veel gemeenten werd gratis of goedkoop drinkwater aan de armen verstrekt.

Maar talrijk zijn ook de gevallen waarbij de plaatselijke choleracommissies hun voorstellen door de gemeentebesturen zagen afgewezen. Vooral de structurele maatregelen, zoals aanleg van riolering en vaste voorzieningen voor kwalitatief goed drinkwater, vonden nauwelijks gehoor bij de bestuurscolleges. Onder de voorstanders van dergelijke voorzieningen was het bovendien nog geen uitgemaakte zaak of de overheid op dit terrein een taak had, en wie de kosten moest dragen. De cholera mocht dan een zaak van nationaal belang zin, minister Geertsema en zijn opvolger Heemskerk weigerden de gemeenten financieel te steunen of dwingende maatregelen op te leggen. ${ }^{69}$

\section{Het neocontagionisme}

Kenmerkend voor de benadering van de cholera in 1866 was de hernieuwde aandacht voor de besmettelijkheid van de ziekte. Dit had natuurlijk te maken met het idee dat choleralijders via de ontlasting of de vitgeademde lucht de ziekte konden verspreiden. De landelijke choleracommissie ging er van uit dat de 'stoffen der darmontlasting' de belangrijkste bron van besmetting vormden. In het zogenaamde desinfectierapport dat de commissie in de zomer van 1866 had 
opgesteld, schreef zij: 'In die excreta is aanwezig of vormt zich bij verwijl aan de lucht eene of meer stoffen, die of zelve het vergif uitmaken, of zijne verspreiding door de omgeving mogelijk maken'. Deze hypothese kon alle feiten logisch ordenen en "behoort dus te worden aangenomen", aldus de commissie. ${ }^{78}$ Als desinfectantia beval de commissie chloorkalk en ijzervitriool (sulphas ferrosus) aan, waarvan in de jaren 1866-1867 inderdaad op ruime schaal gebruik is gemaakt. Trots concludeerde de commissie dat dit de eerste epidemie was waarbij door het hele land ontsmetting van faecaliën, lijken, beddegoed en aangetaste huizen had plaatsgevonden. ${ }^{71}$ Omdat deze maatregelen bij de verantwoordelijke politici en geneeskundigen zoveel tevredenheid hadden veroorzaakt, bleven ze met enige wijzigingen in de aard der desinfectantia tot in de jaren negentig bij dreigende cholera en tyfus gebruikelijk. ${ }^{72}$

Vrees voor besmetting via faecaliën of uitgeademde lucht was ook de belangrijkste reden om choleralijders te isoleren. Men trachtte, overigens lang niet altijd met succes, patiënten over te halen zich in een hospitaal te laten opnemen. Quarantaine aan de kust, in de zin van de bepalingen van 1805, achtte men niet langer doelmatig, aangezien men immers kon volstaan met de isolering van zieken (bijvoorbeeld iedereen met diarrhee) na aankomst van het schip. Zoals op land de patiënten desnoods met dwang geïsoleerd moesten kunnen worden, zo moesten ook de zieke schepelingen in 'quarantaine' gehouden worden, schreef de toenmalige officier van gezondheid bij de Marine en latere inspecteur van het Geneeskundig Staatstoezicht G. van Overbeek de Meijer. Volgens hem konden de gezondheidscertificaten en de oude quarantaine-inrichtingen gerust worden afgeschaft. ${ }^{73}$

Thorbecke en de minister van Marine hadden al in 1863 geprobeerd, op advies van Penn en Ali Cohen, deze bepalingen door middel van een uit één artikel bestaand wetje af te schaffen. ${ }^{74}$ Thorbecke, die de verdediging van het wetsvoorstel op zich had genomen, wilde eventuele maatregelen aan de kust of de grenzen voortaan bij maatregel van bestuur nemen. Quarantainemaatregelen zouden dus niet langer onder de verantwoordelijkheid van de minister van Marine vallen. Thorbecke wilde dat de minister van Binnenlandse Zaken aan de kust of de grenzen dezelfde maatregelen kon nemen als in het binnenland. De uitvoering zou in handen van de gemeentebesturen komen te liggen. Het wetsvoorstel werd echter door de Tweede Kamer verworpen, omdat een Kamermeerderheid van mening was dat het volledig ontbreken van wettelijke, contagionistische bepalingen voor de gele koorts en de pest onverantwoord was. ${ }^{75}$

Desondanks ging minister Heemskerk in 1866 van dezelfde gedachte uit als Thorbecke. Hij richtte zich tot de gemeentebesturen met het verzoek streng toe te zien op eventuele gevallen van cholera op de binnenvaartschepen, omdat deze voor een belangrijk deel verantwoordelijk zouden zijn voor de verspreiding der ziekte. Formeel had de minister geen zeggenschap over het weren van zeeschepen. Maar het was duidelijk dat hij langs een omweg de zeeschepen eveneens onder toezicht plaatste. Burgemeester en wethouders mochten nu immers, buiten het ministerie van Marine om, zelf bepalen of en in welke vorm 'besmette schepen' de toegang tot de gemeente moest worden ontzegd. Inderdaad stelden diverse gemeentebesturen verordeningen op, die het mogelijk maakten om schepen met cholerazieken aan boord aan de gemeentegrenzen te weren. $^{76}$

De merkwaardige situatie was nu ontstaan, dat de bepalingen van 1805 formeel nog altijd van kracht waren, maar nauwelijks serieus werden genomen 
omdat ze door gemeentelijke verordeningen waren vervangen. ${ }^{77}$ Het duurde tot 1877 voordat de nieuwe inzichten in een wet waren vastgelegd. ${ }^{78}$ Vanaf dat jaar was de burgemeester verantwoordelijk voor de uitvoering van een bij de wet vastgelegde procedure met betrekking tot gevallen van pest, cholera of gele koorts aan boord van een schip. Een geneeskundige van het Staatstoezicht diende het schip te inspecteren en zorg te dragen voor ontsmetting en het afvoeren van zieken.

\section{Oppositie van Mulder}

De hoogleraar Mulder had al in het begin van 1866 duidelijk laten merken dat hij het nieuwe Geneeskundig Staatstoezicht - de creatie van Thorbecke volkomen nutteloos vond. $\mathrm{Hij}$ had ook weinig waardering voor het cholerabeleid van minister Geertsema. Aanvankelijk probeerde hij de bewindsman met een briefwisseling ervan te overtuigen om de aanbevelingen van Penn en Ali Cohen als ondeugdelijk af te wijzen. Maar de minister ging hier niet op in, en willigde tot Mulders grote ontstemming het verzoek van de choleracommissie in om de Amsterdamse hoogleraar in de chemie J.W. Gunning in de commissie op te nemen. Hoewel Gunning een leerling was van Mulder, werd hij door zijn leermeester als een persoonlijke concurrent gezien en uiterst vijandig bejegend. ${ }^{79}$

Kort na de benoeming van Gunning in de landelijke choleracommissie maakte Mulder in scherpe bewoordingen zijn ongenoegen openbaar. In een brochure sprak hij van gebrekkige voorlichting aan de minister door zogenaamde deskundigen en van 'misleiding van het volk' 80 Ali Cohen en Penn, 'steunend op de armoedige bodem van sommige Duitsche eenzijdigen met Von Pettenkofer aan het hoofd', werden door Mulder incompetent genoemd. ${ }^{81}$ De kern van Mulders kritiek was, dat men te weinig wist van de cholera-oorzaken om de in zijn ogen beperkte maatregelen te rechtvaardigen. Men moest naar zijn mening meer aandacht besteden aan de slechte openbare hygiëne in de steden en aan de onvoldoende voedingstoestand van de bevolking. Von Pettenkofers idecën bestempelde hij als speculatief en onwetenschappelijk, en het door hem aanbevolen ferrosulfaat ter ontsmetting van riolen en faecaliën als volkomen onwerkzaam. Hij uitte bovendien kritiek op het achterwege blijven van dwingende maatregelen en op de adviezen met betrekking tot het drinkwater die hij te vaag en onwetenschappelijk vond.

De kritiek van Mulder trok nogal de aandacht en de zojuist aangetreden minister Heemskerk zag zich genoodzaakt opnieuw advies bij de landelijke choleracommissie in te winnen. De commissie, waarvan nu ook Gunning lid was, bevestigde in het Desinfectierapport de denkbeelden van Penn en Ali Cohen. Om de kritiek van Mulder nog meer te ontkrachten, haalde de commissie het verslag van Van Geuns aan over de internationale sanitaire conferentie te Constantinopel. ${ }^{82}$ Op deze conferentie, die zes maanden had geduurd, hadden wetenschapsbeoefenaars uit heel Europa zich in grote lijnen achter de opvattingen van Von Pettenkofer geschaard. Op twee onderdelen waren zij ervan afgeweken. Ten eerste was onder druk van de Engelsen, behalve lucht ook drinkwater als verspreidingsroute voor de cholera aangemerkt. Ten tweede had men in het midden gelaten of 'het cholerabeginsel" een rechtstreeks produkt van de darmontlasting was (Budd), of pas na fermentatie onder invloed van bodemfactoren tot ontwikkeling kwam (Von Pettenkofer). De Nederlandse choleracommissie wees erop, dat alle maatregelen van de overheid in overeenstemming waren met 
de uitspraken van Constantinopel. De minister nam vervolgens alle aanbevelingen van de commissie over, en benoemde bovendien een tweede commissie, die een onderzoek naar de rol van het drinkwater moest instellen. ${ }^{83}$

De gang van zaken was voor Mulder aanleiding om in een tweede brochure zijn kritiek opnieuw naar voren te brengen. Hij herhaalde zijn standpunt uit 1848 , dat de cholera zich slechts via besmetting van de lucht over een beperkte afstand kon 'voortplanten'. Het contagium was vluchtig, aldus Mulder, en kon onmogelijk door de bodem 'marcheeren'. Evenmin was het verspreidingspatroon van de cholera toe te schrijven aan het gebruik van besmet drinkwater. Want 'de loop der rivieren [is] in strijd met de loop der epidemie", ondanks het feit dat de bevolking langs de rivieren hetzelfde rivierwater voor consumptie had gebruikt. ${ }^{84}$ Nogmaals benadrukte Mulder dat juist door de armoede van de volksklasse (de insufficiënte voedingstoestand, de slechte huisvesting) de ziekte epidemische vormen kon aannemen.

Een belangrijk verwijt dat telkens terugkeerde in Mulders kritiek, was dat de adviseurs van de minister zich eenzijdig op bepaalde factoren richtten, zich met hypothesen inlieten en weinig radicaal te werk gingen. In feite verzette hij zich tegen het pragmatisme van de adviseurs, die inderdaad bereid waren allerlei wetenschappelijke tegenstrijdigheden ter zijde te schuiven om een cholerabeleid te bepalen dat politiek haalbaar was. Mulder had gelijk met zijn bewering dat men eigenlijk te weinig wist van de oorzaken van cholera. Indien echter de maatregelen die hijzelf voorstond ter bestrijding van de 'algemeene choleratoestand' kracht van wet hadden gekregen, dan had de Nederlandse samenleving een reeks van saneringsmaatregelen te verwerken gekregen, die absoluut in strijd zouden zijn geweest met de liberale regeringspolitiek van die dagen.

\section{De drinkwatercommissie}

De drinkwatercommissie, waarin onder anderen Van Cappelle, Egeling en Gunning zitting hadden, pakte het onderzoek grondig aan. Correspondenten uit het hele land verschaften haar gegevens over het aantal choleragevallen in de omgeving van drinkwaterputten, rivieren en grachten. In 1868 beschikte de commissie over een grote hoeveelheid statistisch bewijsmateriaal, waarmee de betekenis van drinkwater aangetoond werd. $\mathrm{Zij}$ had een zeventigtal gemeenten gegroepeerd naar de aard van het drinkwater en de sterfte aan cholera. In gemeenten met polderwater bleek de sterfte het hoogst te zijn $(17,7 \%)$. In gemeenten waar pomp-, wel- of putwater werd gebruikt, was de sterfte iets lager $(16,8 \%)$. Gemeenten met rivierwater gaven een sterfte te zien van $11,9 \%$, die met regenwater van slechts 5,3\%. Opvallend laag was de sterfte in Amsterdam, waar sinds 1853 een drinkwaterleiding in gebruik was $(4,2 \%)$.

Niettemin luidde de conclusie van de commissie dat er géén rechtstreeks verband bestond tussen het gebruik van drinkwater en de verspreiding van cholera. Tenminste, 'wanneer men daarmede bedoelt dat het drinkwater uit zijnen aard en krachtens zijne scheikundige samenstelling de oorzaak kan zijn van het ontstaan van cholera bij personen die het drinken'. ${ }^{85}$ Wel was er naar het gevoelen van de commissie een indirect verband. Indien het drinkwater besmet was met faecaliën van choleralijders, kon verspreiding wèl via drinkwater plaatsvinden. Besmetting had zich juist bij polder-, pomp- en rivierwater voorgedaan. Met een verwijzing naar de onderzoekingen van de Engelsen Snow en Simon stelde de commissie voorzichtig vast: 'Bij de meer en meer veld winnende 
overtuiging dat de cholerakiem, in den poreuzen bodem gedrongen, zich onder begunstigende omstandigheden daarin snel voortplant en verbreidt, doordringt in de wellen en waterputten en op die wijze, in het drinkwater opgepompt (welligt ook nog op andere wijze bij de uitdamping van den bodem) in het ligchaam komt en ziek maakt, is de aandacht meer en meer op het pompwater gevestigd'. ${ }^{86}$

De commissie hield, zo blijkt hieruit, in hoofdzaak vast aan de opvattingen van Von Pettenkofer. Verwonderlijk is dit niet, want de commissie wenste zich tot de 'onomstotelijke' - statistische - feiten te beperken. En deze toonden volgens de commissie aan dat de meeste gevallen van cholera voorkwamen op plaatsen waar men zijn drinkwater uit de bodem haalde. Andere conclusies met betrekking tot het drinkwater liet de commissie - geheel volgens de inzichten van het positivisme - liever buiten beschouwing, er empirisch geen bewijs was geleverd.

De vraag is echter of de feiten wel zo onomstotelijk waren als de commissie dacht. Ten eerste waren de opgegeven sterftepercentages per watersoort weinig betrouwbaar. Het percentage in de polderwatergemeenten bijvoorbeeld was een gemiddelde gebaseerd op sterftecijfers die liepen van 9 tot $56 \%$. Bovendien was niet nagegaan wèlke personen polder- of put- water hadden gedronken en hoeveel van hen ziek waren geworden. Ten tweede had de commissie niet onderzocht of cholera via contactinfectie kon worden overgebracht. De lage sterfte in de regenwatergebieden (Zeeland, Friesland) kon immers evengoed verklaard worden door de geringe verkeersintensiteit. Het was de commissie overigens bekend dat de sterfte onder kanaalwerkers in Zeeland en onder binnenschippers opmerkelijk hoog was, hetgeen als een argument voor contactinfectie had kunnen gelden. Anders gezegd: de statistische overzichten gaven onder invloed van de bodemtheorie een vertekend beeld van de factoren die de verspreiding van de cholera hadden bevorderd.

Dat de commissie vastbesloten was om de nieuwe feiten in overeenstemming te brengen met de leer van Von Pettenkofer, blijkt ook uit de aanbevelingen die men op wat onlogische wijze op grond van chemisch en microscopisch onderzoek van pompwater deed. Gunning onderzocht in zijn chemisch laboratorium monsters van pomp- en putwater. In het bijzonder rcihtte hij zijn aandacht op de organische stoffen. De resultaten waren echter teleurstellend: 'de hoogst geringe kennis, die wij op dit gebied hebben, maakt dat ook het scheikundig onderzoek hier nagenoeg volslagen magteloos staat' en 'de grens tussen goed en slecht drinkwater [is] scheikundig niet te bepalen'. ${ }^{87}$ Op grond van statistische argumenten hield de commissie echter vast aan haar stelling dat de verspreiding van de cholera vooral door het drinken van bodemwater werd veroorzaakt. Polderwater en grondwater uit alluviale bodem moesten om die reden als drinkwater worden afgekeurd. Het gebruik van rivierwater was dubieus en het filtreren van dit water achtte de commissie onvoldoende : een meerderheid was voorstander van een 'scheikundig chloormiddel' (chloorijzer) zoals in sommige gemeenten reeds was voorgeschreven. De commissie besloot haar rapport met een ontwerp van wet, dat naar Engels voorbeeld het keuren van drinkwater regelde en strafbepalingen tegen de verontreiniging van drinkwater bevatte. $\mathrm{Ze}$ was van mening dat 'tusschenkomst van het staatsgezag' onmisbaar was om 'uitstelgedrag' van gemeentebesturen tegen te gaan. Ook vanuit de overweging dat 'de eene burger bewust of onbewust den ander benadeelt', was wetgeving noodzake$\mathrm{lijk}^{88}$ 
Al bleven vele vragen in het rapport onopgelost, voor de medici was de betekenis van het drinkwater bij de verspreiding van cholera aangetoond. Een scheiding van drinkwatervoorziening en faecaliënafvoer moest daarom zo spoedig mogelijk tot stand worden gebracht. Met het oog hierop onderschreef de Nederlandsche Maatschappij tot bevordering der Geneeskunst de conclusies van de drinkwatercommissie, en pleitte voor de invoering van een drinkwaterwet. ${ }^{89}$ Dok individuele geneeskundigen trachtten met hernieuwde energie hun stadgenoten te doordringen van het nut van een drinkwaterleiding. ${ }^{90} \mathrm{Er}$ moest echter nog een lange weg worden afgelegd, omdat de minister van Binnenlandse Zaken C. Fock al in 1869 het denkbeeld van een landelijke drinkwaterwet van de hand had gewezen.

\section{$5 \quad$ Bodemtheorie versus drinkwatertheorie}

\section{Von Pettenkofers afwijzing van een monocausale verklaring}

Men was het er over eens dat het gebruik van drinkwater afkomstig uit alluviale bodem de verspreiding van cholera kon bevorderen, maar wetenschappelijk was het nog lang niet uitgemaakt wat de exacte betekenis van drinkwater was bij het ontstaan van een epidemie. Internationaal trok Von Pettenkofer, sinds 1865 hoogleraar in de experimentele hygiëne in München, de aandacht door zijn felle polemieken in Engelse tijdschriften. ${ }^{91}$ In Engeland was door toedoen van Farr en Simon de betekenis van drinkwater voor de verspreiding van cholera inmiddels door een deel van de medische wereld aanvaard. Ook groeide het aantal voorstanders van het denkbeeld dat een 'contagium unicum', als produkt van de darmontlastingen van choleralijders, gezonde personen rechtstreeks kon aantasten. ${ }^{\$ 2}$ De standpunten van zowel de medici als de overheid in Engeland waren tegengesteld aan die van 1848: thans liet de regering blijken weinig heil te zien in nieuwe quarantainebepalingen, terwijl de geneeskundigen voorstander waren van quarantainebepalingen om choleralijders te isoleren.

Von Pettenkofer verzette zich tegen de gedachte dat drinkwater op zich zelf cholera kon veroorzaken. Naar zijn mening kon statistisch op overtuigende wijze worden aangetoond, dat met faecaliën verontreinigd drinkwater niet overal cholera veroorzaakte, en dat op plaatsen waar men uitsluitend 'onbesmet" drinkwater gebruikte, ook cholera kon uitbreken. In Nederland had Mulder ook op deze ongerijmdheid gewezen. Bovendien was niemand er sinds de publicaties in 1840 van Henle, in 1849 van Budd en in 1855 van Thiersch in geslaagd een contagium vivum aan te tonen dat rechtstreeks cholera veroorzaakte.

Von Pettenkofer verfijnde in de jaren 1865-1870 zijn bodemtheorie, waardoor deze een bruikbaarder basis voor experimenteel onderzoek werd. Vanaf 1869 betoogde hij dat cholera en tyfoide koorts veroorzaakt werden door specifieke micro-organismen die, tot ontwikkeling gekomen in de patiënt, via de ontlasting in het milieu terecht komen. Hij noemde vier omstandigheden die het ontstaan van een epidemie kunnen verklaren: I een specifieke, door het verkeer overdraagbare kiem; 2 bepaalde lokale gesteltenissen; 3 bepaalde seizoensveranderingen; 4 bepaalde individuele condities. De eerste genoemde omstandigheid kan op zichzelf geen ziekte veroorzaken: er moet ook een zekere ontvankelijkheid van bepaalde plaatsen in bepaalde perioden bestaan. Von Pettenkofer 
stelde zich voor dat een factor in de bodem (de factor y) bijdroeg tot de veranderingen van de specifieke kiem (de factor $\mathbf{x}$ ). Dit door hem als scheikundig-botanisch opgevatte veranderingsproces vond plaats onder specifieke condities van de bodem. Juist in alluviale, vochtige grond met organische stoffen in staat van ontbinding was de factor $y$ aanwezig. Bovendien moest de bodem het midden houden tussen droog en vochtig. Het niveau van het grondwater bepaalde daarom mede de hoeveelheid $y$. Pas het uiteindelijke produkt, de factor $z$, was het choleragif dat leidde tot de ziekte cholera. Hoe meer de factor $y$ aanwezig was, des te groter de hoeveelheid factor $z$. De werkzaamheid van factor $\mathrm{z}$ was afhankelijk van de lichamelijke gesteldheid van de besmette persoon. Met andere woorden, het agens $\mathbf{x}$ kon geen ziekte veroorzaken, tenzij het op de beschreven wijze een zekere virulentie had verworven.

\section{Het onderzoek naar de kwaliteit van drinkwater}

In Nederland kwamen de nabeschouwingen over de cholera-epidemie van 1866 inhoudelijk grotendeels overeen met die van Von Pettenkofer. In een uitvoerig verslag van de epidemie in Noord-Holland in het Nederlandsch Tijdschrift voor Geneeskunde concludeerde Jacobi, advocaat en hoofd van de afdeling statistiek van de provincie Noord-Holland, dat de 'vatbaarheid voor het ontvangen der ziekte' van de geologische gesteldheid van de bodem afhankelijk was, maar dat de intensiteit van de cholera vooral van de 'toestand der bevolking afhing (bedrijf, voeding, huisvesting, leefwijze)'. Op de zandgronden in het oosten en zuiden van Nederland kwam de cholera immers nauwelijks voor, terwijl de cholera het hevigst had gewoed waar het 'beschavingspeil' laag was, aldus Jacobi. ${ }^{94}$ Zeeman en Ali Cohen erkenden de betekenis van drinkwater, maar legden de nadruk op tal van andere predisponerende factoren. Zo berichtte Ali Cohen over de nieuwe, 'gezonde', arbeiderswoningen: 'De cholera drong er niet binnen, niettegenstaande die ziekte in de onmiddellijke nabijheid heerschte en daar vele slagtoffers maakte'. ${ }^{95}$ Zeeman wees op de gunstige resultaten van profylactische desinfectie van 624 huizen in Amsterdam: in slechts dertien huizen was cholera uitgebroken.

B.J. Stokvis, praktizerend arts in Amsterdam en werkzaam aan het fysiologisch laboratorium van de hoogleraar in de fysiologie A. Heynsius, constateerde dat anders dan werd gedacht - de joden in Amsterdam niet minder, maar juist meer dan de niet-joden door de cholera waren getroffen. Vooral de arme joden waren het slachtoffer. Toch kon volgens Stokvis de armoede niet de oorzaak zijn van de relatief hoge sterfte onder arme joden. De sterfte onder de arme niet-joden was namelijk veel lager dan die onder de arme joden, ondanks het feit dat de levenswijze van beide bevolkingsgroepen nagenoeg gelijk was. Ook de eigenschappen van de buurten die arme joden en arme niet-joden bewoonden waren gelijk. Zijn conclusie was dat een 'tertium quid - welligt in verband met de eigenaardigheid der cholerasmetstof' een rol moest spelen. ${ }^{97}$

Ook de in 1866 ingestelde landelijke choleracommissie bracht tussen 1872 en 1875 een aantal rapporten uit, waarin de bodemtheorie grotendeels werd bevestigd. De commissie had gegevens over de cholera-epidemie in statistische overzichten samengebracht. Eén van de eindrapporten was voorzien van twee kaarten van Nederland waarop de verspreiding van de cholera in verband met de bodemgesteldheid was aangegeven. De statistische overzichten van de epidemieën sinds 1832 toonden aan dat telkens dezelfde gebieden door de 
cholera werden bezocht. 'Ieder die maar eenigszins bekend is met de samenstelling van den bodem van Nederland, zal reeds (...) de opmerking hebben gemaakt, dat de choleralijnen vrij nauwkeurig overeenkomen met de lijnen, die de scheiding vormen tusschen alluvium en diluvium', aldus het rapport. ${ }^{98} \mathrm{De}$ commissie opperde de mogelijkheid dat het alluvium gevoeliger voor grondwaterfluctuaties was dan de diluviale zandgronden. Als aanvullende correctie op het drinkwaterrapport van 1868, waarin de hoge sterfte in de vissersplaatsen Egmond, Zandvoort en Katwijk aan het gebruik van putwater werd toegeschreven, wijtten de samenstellers van het cholerarapport de sterfte aan de alluviale bodemgesteldheid van die plaatsen. Men zag geen enkele aanwijzing voor de juistheid van een door Engelse contagionisten aangetoond verband tussen bevolkingsdichtheid en sterfte. De conclusie dat de relatief hoge sterfte in het westen en noorden van het land het gevolg was van de grotere bevolkingsdichtheid wees de commissie dan ook van de hand..$^{99}$

Samenvattend kan men stellen dat het dominante aetiologische model met betrekking tot de cholera er in de jaren zeventig als volgt uitzag: via verkeerswegen over land en over zee kan de cholerakiem vanuit India in Nederland worden geïmporteerd en via de ontlasting van choleralijders in de bodem terechtkomen. Al dan niet na een omzettingsproces in de 'vruchtbare' alluviale grond, kan het ziekmakende 'cholerabeginsel' zich verspreiden, hetzij via drinkwater, met name pomp-, put- en welwater, hetzij via de lucht in bedompte woningen in de armenbuurten. Het gevolg is het 'epidemisch worden' van de cholera onder de mensen wier lichamelijke gesteldheid door een lage levensstandaard en een onhygiënische levenswijze was verzwakt. Met behulp van deze theorie, die voor een groot deel op statistische bevindingen berustte, wisten de Nederlandse hygiënisten de bodemverontreiniging, de riolering, de huisvesting en het drinkwater onder de aandacht van het publiek en de regering te brengen.

De verbeterde registratie van het aantal choleragevallen had echter vragen opgeworpen, die met de statistische methode van onderzoek - in feite niet meer dan een getalsmatige bewerking van de sinds 1832 opgestelde beschrijvingen van de verspreiding der cholera - niet konden worden opgelost. In het rapport erkende de choleracommissie dat zij op vele gegevens was gestuit die niet strookten met de vigerende aetiologische denkbeelden. De afwezigheid van de erkende 'schadelijke momenten' was geen garantie voor het wegblijven van de cholera, en er bestond geen 'vast verband tusschen de cholera en de onreinheid der woningen, hare vochtigheid en overbevolking'. ${ }^{100}$ Slechts verder onderzoek naar het 'tertium quid' of de factor $z$, kon deze vragen ophelderen.

\section{Het zoeken naar de materies morbi}

\section{Drie microbiologische theorieën}

In het begin van de jaren zeventig was de aandacht van de medici gericht op de herkomst van het tertium quid, waarvan inmiddels vrij algemeen werd aangenomen dat het van 'georganiseerde' of 'parasitologische' aard was. De talrijke verklaringen van volksziekten die in deze tijd opgeld deden, kunnen op grond van hun uitgangspunten in drie theorieën worden verdeeld.

De eerste theorie vormde een bijzondere uitwerking van de 'kiemtheorie' van 
Schwann en Henle. Hierin wordt de aanwezigheid van ziekmakende, organische deeltjes in de lucht aangenomen. Volgens deze theorie worden infectieziekten zoals pokken, cholera, tyfus en mazelen, veroorzaakt door micro-organismen die zich onder invloed van veranderingen in het natuurlijk milieu - temperatuursveranderingen of verontreiniging - uit meer gecompliceerde zwammen ontwikkelen. Een zwam kende volgens deze zogenaamde pleomorfistische opvatting verschillende ontwikkelingsstadia. In elk van deze stadia kon de zwam een andere specifieke ziekteverwekker voortbrengen. ${ }^{101}$ De belangrijkste vertegenwoordiger van deze theorie was de hoogleraar in de botanie te Jena, E. Hallier. Vooraanstaande geneeskundigen zoals de hoogleraar in de chirurgie in Edinburgh Lister en de Weense hoogleraar in de chirurgie Billroth hebben lange tijd Halliers theorie ondersteund. Ook Virchow was in 1869 van mening dat een 'fungus' de oorzaak van cholera was. ${ }^{102}$

Deze theorie werd bevestigd door de experimenten van de Straatsburgse hoogleraar in de chemie Louis Pasteur. Pasteur had in de jaren 1860-1865 de juistheid aangetoond van Schwanns opvatting dat de atmosfeer rijk was aan schimmels en infusoriën. Volgens Pasteur waren deze 'fermenten', die hij 'bacteria' noemde, verantwoordelijk voor bepaalde gistings- en rottingsprocessen. Wanneer men namelijk verhitte lucht naar organische vloeistoffen voerde, vond geen gisting of rotting plaats. Dit gebeurde evenmin wanneer de vloeistoffen lange tijd afgesloten van de buitenwereld werden bewaard, hetgeen erop wees dat de lucht boven de vloeistoffen vrij van microscopisch leven was. Volgens Pasteur, en vele geneeskundigen, werd door deze proefnemingen afgerekend met het eeuwenoude denkbeeld dat leven spontaan uit organische of anorganische vloeistoffen kon ontstaan (generatio spontanea).

De theorie van Hallier was veelbelovend, omdat de door hem beschreven ontstaanswijze van pathogene micro-organismen goed paste in de denkbeelden van Von Pettenkofer over het ontstaan van volksziekten: het ontstaan en verdwijnen van een epidemie was te wijten aan versterking respectievelijk verzwakking van de ziekteverwekker door condities in het milieu. Hallier had bovendien Pasteurs experimenten op succesvolle wijze met de kiemtheorie over het ontstaan van infectieziekten in verband gebracht. Anders gezegd: Hallier had met zijn pleomorfistische kiemtheorie een verbinding gelegd tussen de vigerende bodemtheorie en de opkomende microbiologie. Het wekt geen verwondering dat Halliers publikaties een koortsachtig onderzoek teweeg brachten naar het pathogene karakter van micro-organismen die in de botanie al sinds jaar en dag bekend waren.

De tweede infectietheorie was opgesteld door de hoogleraar in de botanie te Breslau, F. Cohn. Hij erkende evenals Hallier de rol van 'contagia animata' in de atmosfeer bij het ontstaan van ziekten, maar verwierp het pleomorfisme. Cohn stelde in de jaren 1872-1875 een classificatie op, waarin hij alle op dat moment bekende micro-organismen naar morfologische en fysiologische eigenschappen rangschikte. Zo onderscheidde hij zes genera: micrococcus, bacterium, bacillus, vibrio, spirillium en spirochaet. Hij benadrukte bovendien dat elk micro-organisme een bestendige vorm had die, anders dan Hallier beweerde, niet kon overgaan in een andere.

Cohns theorie had aanvankelijk weinig weerklank. De medische wereld zag meer in het pleomorfisme van Hallier. Wèl legde Cohn de theoretische basis voor het onderzoek van de Duitse plattelandsarts Robert Koch. Deze ontrafelde in 1876 de levenscyclus van de miltvuurbacterie die inmiddels onder de naam 
bacillus anthracis bekend stond. Uit het onderzoek bleek dat miltvuur door een specifiek, geheel zelfstandig en zichzelf reproducerend agens werd veroorzaakt. Op grond hiervan trok Koch de algemene conclusie dat de bacterie als ziekteverwekker is te beschouwen, indien deze in het zieke organisme aantoonbaar is, zich vervolgens buiten het lichaam laat cultiveren en ten slotte bij overenting op gezonde individuen dezelfde ziekte opwekt. ${ }^{104}$

Volgens de derde theorie wordt een besmettelijke ziekte noch door pleomorfe noch door monomorfe bacteriën veroorzaakt, maar door een (anorganisch) gif. Ziektekiemen, verantwoordelijk voor besmetting van gezonde personen, ontstaan als gevolg van dissociatie van 'stervend' organisch materiaal in het lichaam van ernstig zieke patiënten. De vorming van ziekteverwekkers uit de aangetaste weefsels van de patiënt werd heterogenese genoemd.

De hoogleraar in de botanie te München, C.W. von Nägeli was een vurig pleitbezorger van de heterogenese, die in feite uitging van de generatio spontanea. ${ }^{105}$ Von Nägeli ontkende niet alleen de juistheid van de kiemtheorie, hij wilde ook de bacteriën - hij sprak van 'Spaltpilze', splijtzwammen - niet in verschillende soorten indelen, zoals Cohn had gedaan. Naar zijn mening bestond in de wereld van de micro-organismen een darwiniaanse strijd om het bestaan, waarin de organismen zich voortdurend aan de omgeving aanpasten. Veranderingen in het millieu deden ook de morfologie en de fysiologie van microorganismen veranderen. Dit gebeurde onder invloed van een 'Anpassungsstof' die door de best geacclimatiseerde micro-organismen werd geproduceerd. Op deze wijze werd het ene type organisme geleidelijk door het andere vervangen.

In zijn in 1877 gepubliceerde boek Die Niederen Pilze, in ihren Beziehungen zu den Infectionskrankheiten und der Gesundheitspflege verkondigde Von Nägeli de opvatting dat de ziekten malaria, tyfus, cholera en pokken door pathogene, pleomorfistische splijtzwammen werden veroorzaakt. Deze pathogene zwammen waren onder te verdelen in twee typen: contagium- en miasmazwammen. Deze kwamen samen met ongevaarlijke rottingszwammen vrij in de natuur voor. $\mathrm{Bij}$ een bepaalde bodemgesteldheid ontstonden grote hoeveelheden contagium- of miasmazwammen die afzonderlijk of gecombineerd bij de mens ziekten voortbrachten. Wanneer echter de toestand van de bodem gunstig was voor het ontstaan van rottingszwammen, veranderden de contagium- en miasmazwammen onder invloed van een aanpassingsstof in ongevaarlijke rottingszwammen. Op grond daarvan achtte Von Nägeli bepaalde hygiënische maatregelen ter voorkoming van cholera en tyfus, zoals de bodem vrijhouden van faecaliën en ander organisch materiaal door de aanleg van riolering, overbodig. Het vochtig houden van de bodem was volgens Von Nägeli voldoende. Miasmazwammen die uit het organisch materiaal in de bodem konden ontstaan, zouden zich aanpassen en in onschadelijke rottingszwammen overgaan.

\section{De specificiteit van micro-organismen in twijfel getrokken}

De discussie tussen voor- en tegenstanders van de kiemtheorie en het pleomorfisme leidde in de jaren zeventig tot een stroom van publikaties over het verband tussen micro-organismen en ziekten. Een groeiend, en tamelijk onkritisch enthousiasme voor de 'microbe' als ziekteverwekker maakte zich meester van een deel van de medische wereld, waardoor bijvoorbeeld ook de stofwisseling voorwerp van bacteriologisch onderzoek werd. Een voor iedereen bevredigende verklaring was echter omstreeks 1880 nog ver te zoeken. 
In Nederland volgden verschillende artsen nauwlettend de 'parasitologische onderzoekingen' in Frankrijk en Duitsland. De inspecteur van het Geneeskundig Staatstoezicht voor Overijssel en Drenthe, Lubach steunde de kiemtheorie, zoals trouwens de meeste inspecteurs, en aanvaardde Pasteurs conclusie met betrekking tot de generatio spontanea. In de jaren zeventig besteedde hij in het tijdschrift Album der Natuur, dat geheel aan de natuurwetenschappen was gewijd, tevens veel aandacht aan de opvattingen van Cohn, Koch en Von Nägeli. Een duidelijke voorkeur voor een bepaalde theorie had hij niet. ${ }^{106}$ Van Overbeek de Meijer, adjunct-inspecteur van het Geneeskundig Staatstoezicht voor Utrecht en Gelderland, stelde zich eveneens neutraal op. In een bespreking van de opvattingen van Hallier schreef hij dat 'de geheele zaak van het contagium animatum op het oogenblik nog niet veel meer [is] dan een kaartenhuis, dat wel een goed gebouw kan worden, maar thans nog in én oogwenk kan instorten'. ${ }^{107}$ De overige inspecteurs van het Geneeskundig Staatstoezicht lieten zich zelden uit over de kwestie van het contagium animatum. Met betrekking tot de aetiologie van cholera en tyfus stelden zij zich pragmatisch op: zij hielden vast aan Von Pettenkofers bodemtheorie, waarmee Pasteurs bevindingen niet in strijd waren. Op grond van deze houding konden de inspecteurs het nut van allerlei desinfectiemaatregelen voldoende beargumenteren. Pas in 1878 brachten de inspecteurs Penn en Egeling een rapport uit, waarin zij zich tegen de hygiënische opvattingen van Von Nägeli keerden. Over de theorie van het pleomorfisme lieten zij zich evenwel niet uit.

Andere vooraanstaande medici behielden hun twijfels over de infectietheorieen, met name die van Cohn en Koch. Zo bracht een commissie uit de natuurkundige afdeling van de Koninklijke Nederlandse Akademie van Wetenschappen op verzoek van de minister van Binnenlandse Zaken Heemskerk een rapport uit over de 'bacterienkwestie', waarin zij de opvatting dat bacteriën de kiemdragers van vele besmettelijke ziekten zijn, lichtvaardig en voorbarig noemde. ${ }^{\text {jos }} \mathrm{De}$ hoogleraar in de pathologie te Utrecht W. Koster, lid van genoemde commissie, besprak met instemming in het Nederlandsch Tijdschrift voor Geneeskunde de opvattingen van Von Nägeli. In hetzelfde tijdschrift uitte Koster zijn twijfels over de betrouwbaarheid van de proefnemingen van Pasteur en Koch met miltvuurbacteriën. ${ }^{109}$ Hij wees erop dat beide onderzoekers niet hadden aangetoond hoe de bacterie haar schadelijke werking uitoefende. Ook andere hoogleraren twijfelden aan de juistheid van de opvattingen van Pasteur en Koch. De Groningse hoogleraar in de fysiologie Dirk Huizinga spande zich in om het bestaan van de generatio spontanea experimenteel aan te tonen. ${ }^{I 10} \mathrm{De}$ Groningse hoogleraar in de hygiëne A.P. Fokker werd aan het eind van de jaren zeventig een vurig pleitbezorger van de theorie van de heterogenese. 111

In 1881 vatte de Amsterdamse hoogleraar in de pathologische anatomie C.H. Kuhn in een rede voor de NMG alle twijfels bij de Nederlandse medici nog eens samen. ${ }^{1 / 2}$ Allereerst was Cohns classificatie van de micro-organismen weinig overtuigend: het was niet bewezen dat pleomorfistische bacteriën niet bestonden. De meeste Nederlandse geneeskundigen kozen daarom volgens Kuhn noch de zijde van Cohn, noch die van Von Nägeli. Ten tweede bestond geen duidelijkheid over de fysiologie van de bacterie en was het onzeker of infectieziekten door bacteriën konden worden veroorzaakt. Slechts in het geval van miltvuur zou dit laatste zijn aangetoond. 
In de jaren tachtig belandde de discussie in een nieuwe fase. Cohn en Koch hadden verbeteringen in de kleuringsmethoden van bacteriën aangebracht, waardoor het identificeren van bacteriën gemakkelijker was. Ook hadden zij voedingsbodems ontwikkeld die geschikt waren voor het kweken van reinculturen. Pasteur beschreef in 1880 de streptococcus en de stafylococcus als verwekkers van kraamvrouwenkoorts en furunkels. Verder maakte Koch in 1882 en 1883 bekend respectievelijk de verwekkers van tuberculose en die van cholera te hebben geïsoleerd. Nog tal van andere ziekteverwekkers werden geïsoleerd (difterie, tetanus, tyfus, meningitis epidemica, influenza), terwijl Pasteur en zijn medewerkers de eerste successen boekten met de immunisering tegen rabiës (1885). Ten slotte werd experimenteel aangetoond dat sommige bacteriën met behulp van stoom konden worden gedood, hetgeen een effectievere sterilisering mogelijk maakte.

Vooral toen Koch berichtte de 'komma-bacillus' als de verwekker van cholera te hebben geïsoleerd, was de publieke opwinding groot. Koch werd in Duitsland als een nationale held geëerd. In medische kring waren de reacties echter verdeeld. Von Pettenkofer beschouwde de 'vibrio cholerae' als niets anders dan de door hem beschreven factor $x$ en betoogde dat hij Kochs bevindingen had voorzien. Naar zijn mening bestond er geen reden zijn bodemtheorie te herzien. Het drinkwater, waarin volgens Koch de specifieke ziekteverwekker voorkwam, noemde hij de laatste schuilplaats ('Schlupfwinkel') der contagionisten. ${ }^{1 i^{\prime} 3}$ Virchow daarentegen verdedigde Koch, en gaf de cholerabacterie zelfs de titel 'ens morbi'. Hij ontkende echter het bestaan van specifieke verwekkers van tuberculose en difterie en betwijfelde de besmettelijkheid van deze ziekten. Hij had in het algemeen niet veel op met de euforie der 'microbenjagers', en benadrukte dat het voor een beter begrip van ziekten meer ging om de wijze waarop het lichaam op besmetting reageerde dan om de bacteriën als zodanig. ${ }^{114}$

In Engeland waren de reacties evenmin onverdeeld positief. Enkele vooraanstaande artsen noemden Kochs proefnemingen zelfs een 'unfortunate fiasco'. Twee medische missies, één naar India (1884) en één naar Spanje (1885), moesten Kochs conclusies op hun waarheidsgehalte onderzoeken. Beide missies kwamen tot de slotsom dat de vibrio cholerae beslist niet de oorzaak van cholera kon zijn. Naar de mening van de delegatie naar India bleef Von Pettenkofer 'the greatest living authority on the etiology of cholera'.15 $\mathrm{Om}$ streeks 1890 kwam de wetenschappelijke erkenning van Koch in Duitsland en ook internationaal, maar het zou tot na 1900 duren, voordat het bestaan van een bestendige, specifieke ziekteverwekker van cholera algemeen werd aanvaard. ${ }^{116}$

In Nederland groeide tegen het eind van de jaren tachtig het aantal 'bacteriologisch gezinden' onder artsen, zoals H.M. Duparc, de auteur van het eerste Nederlandstalige boek over bacteriën en besmettelijke ziekten, R.H. Saltet, sinds 1893 hoofd van de geneeskundige dienst van Amsterdam en sinds 1896 hoogleraar in de gezondheidsleer in Amsterdam, de oogarts en hoogleraar $M$. Straub, die lessen bacteriologie gaf aan het militair hospitaal in Utrecht waar een klein laboratorium was ingericht, en C.C. Delprat, redacteur-gérant van het Nederlandsch Tijdschrift voor Geneeskunde. Sommige medici behielden hun twijfels. De eerder genoemde hoogleraar Fokker en de Bossche geneesheer Godefroi, hygiënist van het eerste uur, keerden zich zelfs fel tegen de 'dogmatiek van de specifieke bacil'. Tot na 1900 hield Fokker staande dat ziektekiemen door 
heterogenese ontstonden, en hij stelde zich onvoorwaardelijk achter Von Pettenkofer. Fokker legde evenals Von Pettenkofer de vinger op de zwakke stee in de bacteriologische theorie: niet iedereen die was besmet, werd ook ziek. Er bestond een individueel verschil in gevoeligheid. ${ }^{117}$ Zijn opstelling inzake de bacteriologie bracht hem in de jaren negentig in ernstig conflict met de reeds genoemde Straub, die als redacteur-gérant van het Nederlandsch Tijdschrift voor Geneeskunde vanaf 1895 elke kritiek op de bacteriologische leer fel bestreed. ${ }^{118}$

\section{Het Geneeskundig Staatstoezicht en de bacteriologie}

Het is opmerkelijk dat de bacteriologische richting een negatieve invloed heeft gehad op het denken en handelen van de functionarissen van het Geneeskundig Staatstoezicht. Bepaalde bacteriologische inzichten veroorzaakten binnen de vigerende hygiënische praktijk problemen die niet met de aanwezige bacteriologische technieken konden worden opgelost. De bacteriologische bevinding dat zich in drinkwater een groot aantal, mogelijk ziekteverwekkende bacteriën bevond, leidde tot verwarring over de vraag wat dan kwalitatief goed drinkwater was. Men kon weliswaar het totale aantal bacteriën in water bij benadering vaststellen, maar men beschikte niet over de middelen om de aard en de hoeveelheid van pathogene bacteriën in drinkwater aan te tonen. Ook de sinds 1872 bestaande ontsmettingsmaatregelen verloren onder invloed van de bacteriologie hun doelmatigheid, omdat de bacteriologie had uitgewezen dat allerlei micro-organismen ondanks de toepassing van chemische middelen in leven bleven.

De door de inspecteurs van het Staatstoezicht uitgevaardigde richtlijnen voor de preventie van infectiezieken dreigden door de bacteriologie dus veeleer te worden ondergraven dan te worden bevestigd. ${ }^{119}$ De inspecteurs beschikten niet over de middelen om zelf een oplossing voor dit probleem te vinden. Van experimenteel of routinematig bacteriologisch onderzoek door inspecteurs of leden van de geneeskundige raden was geen sprake, ook al niet omdat de regering hiervoor geen geld beschikbaar stelde. ${ }^{120} \mathrm{Zij}$ waren voor de beantwoording van nieuwe hygiënische vragen dus aangewezen op experimenteel onderzoek van bacteriologen.

Het is overigens de vraag of de inspecteurs zich voldoende bewust waren van deze structurele verandering in de wetenschappelijke verhoudingen op het gebied van de hygiëne. De lezer van de verslagen van het Staatstoezicht krijgt in elk geval niet de indruk dat men de betekenis van de bevindingen van Koch volledig overzag. Alleen Van Overbeek de Meijer concludeerde in 1888 met betrekking tot het bestaan van specifieke ziekteverwekkers dat 'de grondslag, waarop de hypothese is gebouwd, zodanig is, dat bij de thans ontbrekende mogelijkheden om tot een bewijs te geraken, het voorlopig aannemen van die hypothese gerechtvaardigd is'. ${ }^{121}$ Pas in de loop van de jaren negentig werd een begin gemaakt met bacteriologisch onderzoek van enige betekenis. Toen werden daarvoor in Amsterdam, Rotterdam en Den Haag kleine laboratoria opgericht. Ten slotte beschikte in 1898 ook het Geneeskundig Staatstoezicht over de mogelijkheid om bacteriologisch onderzoek te doen.

Samenvattend kunnen we stellen dat na 1870 het onderzoek naar microorganismen meer in de belangstelling kwam, maar dat er tot 1890 geen sluitende verklaring was voor het ontstaan van ziekten zoals cholera en tyfus, die voor het merendeel van de artsen bevredigend was. De medici van het Geneeskundig 
Staatstoezicht namen tot die tijd geen standpunt in over de infectietheorie van Hallier, Pasteur, Koch of Von Nägeli. De afwezigheid van laboratoria waar men bacteriologische onderzoekstechnieken kon beproeven, veroorzaakte bij de inspecteurs een zo grote kennisachterstand ten opzichte van bacteriologen, dat zij nimmer met kracht van argumenten partij konden kiezen in de controversen over de bestendigheid en specificiteit van ziekteverwekkers. Daardoor speelden de belangrijkste discussies over de infectieziekten zich vanuit het gezichtspunt van de inspecteurs als het ware in een andere wereld - in de wereld van het laboratorium - af.

Het is dan ook begrijpelijk dat het handelen van de hygiënisten ten aanzien van de cholera na 1870 niet veranderde: het lokaliseren van plaatsen waar het gevaar voor de ziekte het grootst was. Men voerde desalniettemin op grote schaal ontsmettingen uit, omdat men toch van oordeel was dat de cholera zich door een ziektekiem verspreidde. Dit oordeel was echter niet op de bevindingen van Pasteur en Koch gebaseerd, maar op die van Von Pettenkofer. De conclusie moet luiden, dat tot het eind van de negentiende eeuw het beleid van het Geneeskundig Staatstoezicht ten aanzien van de volksgezondheid en de activiteiten van de hygiënisten niet of nawwelijks door de bacteriologische wetenschap zijn beïnvloed.

Tussen 1830 en 1880 is de Nederlandse bevolking vier maal door een choleraepidemie getroffen. Verreweg de meeste slachtoffers waren afkomstig uit de armere volksklasse. Regering, burgerij en geneeskundigen hebben deze epidemieën altijd als een ernstige bedreiging voor de samenleving beschouwd. De verklaring voor deze bedreiging, is in de jaren 1830-1880 sterk veranderd.

In de jaren dertig beschouwde men de cholera als een contagieuze, uitheemse ziekte. De dreiging van de 'cholera asiatica' was extra groot, omdat het om een ongewoon agressieve ziekte ging die zich anders dan de bekende besmettelijke volksziekten vanuit de getroffen volksklassen over de gehele samenleving leek te kunnen verspreiden.

Overheidsmaatregelen hadden tot doel de smetstof uit het land te weren door besmette zeeschepen de toegang tot de Nederlandse wateren te ontzeggen. Toen men er niet in slaagde de cholera buiten de landsgrenzen te houden, trachtte men verdere verspreiding te voorkomen door de volksklasse te controleren, woningen te ontsmetten en zieken te isoleren. De bestrijding werd gecoördineerd door het ministerie van Binnenlandse Zaken. Een toenemend aantal geneeskundigen betwijfelde reeds tijdens de eerste epidemie de zin van deze maatregelen, maar dit leidde niet tot een politiek debat over het gevoerde gezondheidsbeleid.

Bij de epidemie van 1848 verschilden de reacties in de samenleving weinig van die in 1832. De maatregelen van overheidswege waren echter minder intensief dan zestien jaar tevoren. Niet alleen waren de quarantainemaatregelen afgeschaft, ook maakte de regering - ten dele wegens de onduidelijke politieke situatie, ten dele omdat het besmettelijke karakter van de cholera in twijfel werd getrokken - veel minder dan in 1832 gebruik van haar bevoegdheden om de plaatselijke besturen de nodige maatregelen op te leggen.

Na deze epidemie hebben de hygiënisten de discussie over de cholera gedomineerd en de cholerakwestie in een ander perspectief geplaatst. Zij ontwikkelden een wetenschappelijke theorie die het ontstaan van de cholera in verband bracht 
met de verontreiniging van bodem en grondwater door organisch afval. Chemische of microbiologische processen in de bodem produceerden een ziekmakende stof voortbrengen die via de atmosfeer en het voor consumptie gebruikte grondwater bij de bevolking cholera kon veroorzaken. Ernstig zieke patiënten ontwikkelden een smetstof die voor de verdere verspreiding van de ziekte zorgde.

Het belangrijkste probleem was volgens de hygiënisten het ontbreken van een deugdelijk stelsel van afvoer en verwerking van afval en faecaliën. Hierdoor betsond er met name in de steden in het westen en noorden van het land een permanent gevaar voor de ontwikkeling van het 'cholera-beginsel' in de bodem. Politiële maatregelen, zoals het controleren van de handel met het buitenland, verbod op het houden van kermissen, de isolering van zieken en dergelijke, waren onvoldoende om het gevaar van de cholera voor de samenleving te keren. Alleen de preventie van bodem- en grondwaterverontreiniging door middel van sanitaire voorzieningen en de aanleg van betere drinkwatervoorzieningen kon de gevreesde volksziekte afdoend bestrijden.

De hygiënisten hebben de ontwikkelingen op het terrein van de micro-biologie in de jaren zestig en zeventig nauwlettend gevolgd. In de door hen voorgestelde maatregelen ter bestrijding van de cholera hebben microbiologische theorieën echter geen rol van betekenis gespeeld. Ondanks de toenemende belangstelling voor deze theorieën hielden de hygiënisten vast aan de statistiek als belangrijkste methode om de empirische feiten te ordenen.

Vanaf 1850 hebben de hygiënisten onophoudelijk geprobeerd hun tijdgenoten ervan te doordringen dat de vervuiling van de armere delen van de stad doorwerkte in het bestaan van de overige bewoners: zover verontreiniging van de bodem doordrong en het grondwater aantastte. Anders gesteld: bewoners in de betere buurten waren voor hun gezondheid afhankelijk van de openbare hygiëne in de armere delen van de stad.

Volgens de hygiënisten was cholera een collectief probleem. Dit probleem moest door de overheid worden opgelost, omdat alleen zij in staat was de sanitaire hervormingen door te voeren die noodzakelijk waren om het circuit van faecaliën-afvoer en van het circuit van de drinkwatervoorziening te scheiden. $\mathrm{De}$ overheid was bovendien de enige onpartijdige instantie die de gehele bevolking de gewenste sanitaire hervorming kon garanderen.

Concluderend kunnen we stellen dat de contagionistische opvatting ten aanzien van de cholera weliswaar vanaf 1832 werd bekritiseerd, maar pas omstreeks 1850 definitief door medici werd verworpen. In de plaats van het contagionisme stelde de medische wetenschap een aetiologisch model waarin de sanitaire omstandigheden een verklaring bieden voor het ontstaan van de cholera-epidemieën. Dit model vestigde zich op het moment dat de geneeskundigen het positivisme ontdekten en de hygiënisten hun eerste ideeën voor de professionalisering van de openbare hygiëne formuleerden. In de volgende hoofdstukken zullen we zien dat de gelijktijdige verandering in het wetenschappelijk denken over de cholera en in de maatschappelijk oriëntatie van geneeskundigen katalyserend heeft gewerkt op het denken over volksziekten en op het politieke optreden van de hygiënisten. 



\section{Statistiek en openbare gezondheidsleer}

De middelen om tot onomstotelijke ervaringen te geraken worden uitsluitend en alleen aangeboden door de statistische methode van onderzoek.

L. Ali Cohen, 1850.

In de voorgaande hoofdstukken hebben we gezien dat de hygiënisten zich van andere geneeskundigen onderscheidden door een specifieke benadering van twee druk besproken problemen in de geneeskunde: de relatie tussen geneeskunde en maatschappij en de bestrijding van de cholera. Met betrekking tot het eerste meenden de hygiënisten dat de geneeskunde alleen een wezenlijke bijdrage aan de nationale vooruitgang kon leveren wanneer men vanuit het vakgebied het vraagstuk van de openbare hygiëne zou oplossen. In het kort is erop gewezen dat zij daarbij vooral van de statistiek gebruik wilden maken. De oplossing van het tweede probleem, de doeltreffende bestrijding van de cholera, was slechts mogelijk door lokale, pathogene milieufactoren uit de weg te ruimen. De kwestie van de cholera werd door de hygiënisten toegespitst op de sanitaire toestand in de steden.

In dit hoofdstuk wordt beschreven hoe de hygiënisten de bestaande leer van de volksziekten hebben omgevormd tot een openbare gezondheidsleer. Daarbij wordt ingegaan op de organisatie en de methode van het statistisch onderzoek, en wordt de betekenis van de choleratheorie voor het ontstaan van de openbare gezondheidsleer behandeld. Het beginpunt van dit hoofdstuk is 1849 , het jaar waarin in de NMG een discussie op gang kwam over de volksgezondheid in het algemeen en de cholera-epidemie van 1848 in het bijzonder.

\section{Van historische pathologie naar kwantitatief onderzoek}

\section{De NMG-commissie voor volksziekten}

De Nederlandsche Maatschappij tot bevordering der Geneeskunst was door de geneeskundigen opgericht om een zelfstandige bijdrage te leveren aan de verbetering van de volksgezondheid in het kader van de nationale herleving, en tevens om de belangrijke rol die de artsen speelden duidelijk te maken. Deze taak werd direct ter hand genomen: op de eerste algemene vergadering van de NMG in 1849 werd een drietal commissies in het leven geroepen die het onderzoek naar de gezondheidstoestand van de Nederlandse bevolking moesten stimuleren, de commissie voor geneeskundige statistiek, de commissie voor geneeskundige politie en openbare gezondheidsregeling en de commissie voor geneeskundige plaatsbeschrijving en volksziekten. De resultaten van het werk van deze commissies werden met regelmaat in het tijdschrift van de Maatschap- 
pij en in het Nederlandsch Weekblad voor Geneeskundigen gepubliceerd. Na 1857 werden de onderzoeksresultaten voornamelijk in het Nederlandsch Tijdschrift voor Geneeskunde bekend gemaakt; bovendien verschenen vanaf dat moment steeds meer monografieën. Door de gerichte activiteiten van de NMG werden de gegevens over de volksgezondheid voor het eerst op landelijke schaal verzameld en geordend. Hierdoor belandde de discussie over de richting van het onderzoek in een nieuwe fase.

Aanvankelijk overheersten in de NMG de traditionele concepties. Dit toont de geschiedenis van de commissie voor volksziekten die in de beginjaren de meest produktieve van de drie commissies was. De commissie bestond voornamelijk uit ervaren geneeskundigen uit Amsterdam, waar men al vroeg in de jaren veertig was begonnen met onderzoek naar de oorzaken van volksziekten. Dergelijk onderzoek werd verricht aan de hand van historisch-pathologische beschrijvingen, en sinds 1842 uitgevoerd door de Commissie voor de waarneming van de heerschende ziektegesteldheid van het Genootschap ter Bevordering van de Genees- en Heelkunde. In 1849 werd besloten om de waarnemingen voortaan onder auspiciën van de commissie voor de epidemiologie van de NMG-afdeling te laten plaatsvinden. 'Secretaris van deze commissie was C. de Bordes, die tevens secretaris van het Genootschap was. Sindsdieny verscheen ieder jaar een overzicht - gedeeltelijk kwalitatief, gedeeltelijk numeriek - van de ziekten die in Amsterdam hadden geheerst. Het werk van De Bordes vormde het begin van een onderzoekstraditie op het terrein van volksziekten in Amsterdam. ${ }^{2}$

N.D. Sybrandi nam in 1850 het eerste verslag over de jaren 1847 en 1848 voor zijn rekening. Hij gebruikte in hoofdzaak de gegevens die door het Amsterdamse Genootschap waren verzameld. ${ }^{3}$ De jaren daarop maakten Sybrandi en De Bordes tevens gebruik van gegevens die afkomstig waren van NMG-correspondenten of uit geneeskundige tijdschriften. Zij kregen bovendien toestemming van het ministerie van Binnenlandse Zaken om de verslagen van de provinciale commissies van geneeskundig toevoorzicht in te zien. ${ }^{4}$

Sybrandi en De Bordes analyseerden het verband tussen de jaarlijkse ontwikkeling van ziektekarakters en klimatologische gegevens om het ontstaan en het verdwijnen van bepaalde aandoeningen te kunnen verklaren. Alle beschikbare gegevens vatten zij samen onder het begrip 'constitutio epidemica'. 'Vragen wij', schreef Sybrandi in 1850, 'welke was de algemeene ziektegesteldheid gedurende de eerste drie maanden van 1847? Dan vinden wij het eenstemmig luidend antwoord in onze rapporten dat zij catarrhaal was. Hiermee wilde Sybrandi aangeven dat het ziektekarakter in het eerste kwartaal van 1847 werd gekenmerkt door een groot aantal luchtweginfecties. Het ziektekarakter in andere perioden van het jaar omschreef hij als 'catarrhaal-rheumatisch tot stenisch' of 'gastrisch-bilieus', doelend op het overwegen van rheumatische respectievelijk koortsende maag-darm aandoeningen.

Zoals in de historische pathologie gebruikelijk was, werd ook de pathogenese van de aandoeningen geanalyseerd. Uit de analyses van Sybrandi en De Bordes moest blijken hoe veranderingen in de natuurlijke gesteldheid het ziektekarakter konden wijzigen. Zo noteerden zij voor elke periode de stand van de thermometer en de barometer en stelden zij een overzicht van de windgesteldheden gedurende een bepaald jaar op. De constitutio epidemica of ziektegesteldheid van Nederland maakte, zo meenden deze onderzoekers, onder invloed van uitwendige fysische veranderingen een eigen geschiedenis door: zij kon in januari beginnen met febris catarrhallis, in de loop van het jaar overgaan in 
febris rheumatica, om zich in november vooral voor te doen als diarrhee en koliekpijnen. Een jaar later kon de volgorde van de karakters geheel anders zijn. Jaren achtereen heeft de commissie voor volksziekten op deze wijze de in Nederland heersende ziekten beschreven. Maar hoe plichtsgetrouw de commissie haar jaarverslagen ook presenteerde, erg veel bijval kreeg zij niet. Integendeel, veel geneeskundigen vonden de verslagen onbruikbaar en achterhaald. Met name de hygiënisten zagen weinig in de aanpak van de commissie. Volgens hen werd de kwestie van de sociale sterfteverschillen ten onrechte onbesproken gelaten en - wat ernstiger was - het ontbrak in de verslagen aan numerieke gegevens. Bovendien gingen de hygiënisten inmiddels uit van kentheoretische opvattingen die fundamenteel verschilden van die in de historische pathologie. Op deze kritiek zal thans nader worden ingegaan.

\section{Sociale sterfteverschillen}

Tijdens de eerste algemene vergadering van de Maatschappij in 1849 - het woord cholera lag op ieders lippen - ontstond in de algemene wetenschappelijke sectie een discussie over de aetiologie en de verspreiding van de cholera. Aanleiding was een rapport van Evers over de cholera-epidemie in Den Haag. Hierin toonde hij aan dat 'slecht voedsel, kleine woningen, in eén woord armoede, het meest tot de ontwikkeling der cholera in 's Hage hebben bijgedragen'. Evers presenteerde een aantal plattegronden van de stad waarop de geografische verdeling van de cholera stond aangegeven. Uit de cijfers bleek een groot verschil in sterfte tussen de 'arme' en de 'meestgegoede' wijken te bestaan. Daarenboven sprong de hoge sterfte in de omgeving van de grachten in het oog.

Evers oogstte van verschillende zijden bijval, bijvoorbeeld van A. Maas uit Schiedam, J.B. Molewater uit Rotterdam en J.J. Homoet uit Arnhem. Anderen, zoals H.J. Broers uit Utrecht, vonden het rapport echter te eenzijdig: Evers zou te weinig rekening hebben gehouden met de geologische toestand van de grond en met 'schadelijke uitwasemingen en mephytische dampen'. Broers c.s. konden zich niet verenigen 'met het gevoelen, dat opeenhoping van menschen, slechte ventilatie en gebrek aan goede voeding de voornaamste oorzaken der cholera zouden zijn'.6 De discussie leidde niet tot een duidelijke consensus, de voorzitter van de wetenschappelijke sectie kon slechts concluderen dat meer onderzoek naar de betekenis van de voeding en van de geologische gesteldheid van de bodem noodzakelijk was.

Evers stelde als secretaris van de vaste commissie voor geneeskundige politie daarom in 1850 voor om de 'voeding des volks' in Nederland aan een onderzoek te onderwerpen. Hij riep de afdelingen van de Maatschappij op gegevens over de volksvoeding te verzamelen en deze aan hem kenbaar te maken. Een dergelijk onderzoek moest volgens hem tot een beter inzicht leiden in het verband tussen de voedingsgewoonten van de 'onderscheidene klassen' in de samenleving en de gemiddelde leeftijd per klasse.

Evers voelde zich in zijn opvatting gesterkt door een recent onderzoeksverslag van Israëls, die aan de hand van gegevens die hij had ontleend aan de Amsterdamsche Courant uit de periode 1830-1850 een overzicht had gemaakt van de sterfte onder kinderen beneden de drie jaar. Israëls stelde vast, dat in deze periode $32 \%$ van alle kinderen beneden de drie jaar waren overleden, terwijl de sterfte onder kinderen uit die leeftijdsgroep eveneens $32 \%$ van de totale sterfte in Amsterdam uitmaakte. Sterfteoorzaken kon Israëls niet vermelden, daar deze 
niet waren opgegeven. Zijn conclusie luidde desalniettemin, dat de oorzaak van de hoge kindersterfte in de 'gebrekkige voeding' was gelegen. Die mortaliteit zou zijn terug te dringen door verbetering van de volkshuisvesting en verlaging van de belastingen, zodat 'het den armen man ook eens gegund ware, zijn stukje vleesch te nuttigen'. ${ }^{\prime}$

Evers' voorstel ondervond weinig steun. In 1854 waren uit het hele land nog maar vier reacties op zijn oproep binnengekomen, waarvan alleen die van de NMG-afdeling Groningen de moeite van het afdrukken waard was. ${ }^{9}$ Dit gebrek aan respons was voor Evers reden om maar verder van het plan af te zien.

De mislukking van het onderzoek was niet louter het gevolg van gebrek aan belangstelling bij de leden van de NMG. Velen vonden dat Evers en Israëls in hun conlcusies nogal voorbarig waren en dat zij eenzijdig de nadruk op de armoede legden. De verschillen in wetenschappelijke positiebepaling traden vooral aan de dag in Amsterdam. In $1852 \mathrm{kwam}$ E.C. Büchner, een vooraanstaand lid van het Genootschap ter bevordering van Genees- en Heelkunde, in zijn Statistiek der sterfte in Amsterdam tot de conclusie dat de sterfte van kinderen beneden de vijftien jaar sterk uiteenliep in de vier 'kantons' waarin Amsterdam was verdeeld. ${ }^{10}$ Hij stelde hiervoor primair de verschillen in het fysischgeografisch milieu (kwaliteit van water, lucht, bodem en huisvesting) van de vier stadsdelen verantwoordelijk.

De studie van Büchner werd niet met onverdeelde instemming ontvangen. In een bespreking in het Nederlandsch Weekblad voor Geneeskundigen van 1853 noemde Penn het een slecht boek, met onvolledige en onjuiste conclusies. ${ }^{I I} \mathrm{De}$ sterftecijfers van de vier kantons waren volgens Penn volstrekt onvergelijkbaar, omdat in elk kanton zowel gegoede als arme buurten voorkwamen. Hoewel de recensent het belang van de factoren water, lucht, bodem en voeding niet ontkende, verweet hij Büchner aan de interne kantonale verschillen in welvaartspeil volkomen te zijn voorbijgegaan.

Penn wilde, evenals Evers en Israëls, de sociale verschillen van de Amsterdamse bevolking als uitgangspunt voor statistisch onderzoek nemen, en pas later onderzoeken in hoeverre de fysisch-geografische gesteldheden hierin een rol spelen. Meer waardering had Penn voor een onderzoek van Zeeman. Laatstgenoemde had als secretaris van de commissie voor geneeskundige statistiek en topografie van de NMG-afdeling Amsterdam twee onderzoekingen naar de sociale sterfteverschillen in Amsterdam gepubliceerd. ${ }^{12}$ Eén over de sterfte als gevolg van de cholera in de jaren 1848-1849, ingedeeld naar wijken met elk een verschillend percentage bedeelden. De wijk met het laagste aantal bedeelden kende de minste, de wijken met de hoogste aantallen de meeste choleraslachtoffers. De tweede studie van Zeeman had betrekking op de sterfte in het jaar 1851, waaruit opnieuw bleek dat die in de 'arme buurten' veel hoger lag dan in de 'gegoede buurten'. ${ }^{13}$ Deze feiten, die volgens Penn door talrijke Engelse onderzoekingen werden ondersteund, bewezen weliswaar niet dat de armen met zekerheid het slachtoffer van de cholera zouden worden of op vroege leeftijd zouden sterven, maar wel dat zij veel meer risico liepen. Statistisch onderzoek had, mits goed uitgevoerd, een voorspellende waarde. Juist hierin lag volgens Penn het belang van dergelijk onderzoek.

De uitspraken van Penn leidden in 1853 tot een pennestrijd met Büchner in de Geneeskundige Courant en het Nederlandsch Weekblad voor Geneeskundigen. In 1854 pleitte Büchner nogmaals voor voortzetting van het statistisch onderzoek naar het verband tussen sterfte enerzijds en temperatuur, barometerstand en 
vochtigheidsgraad anderzijds. Zo'n onderzoek was naar zijn mening volkomen gerechtvaardigd, aangezien de Duitse econoom en theoloog Süssmilch honderd jaar eerder in Die göttliche Ordnung in den Veränderungen des menschlichen Geschlechts had aangetoond, dat het sterftepatroon een bepaalde 'orde' kende die in nauw verband stond met de seizoenskenmerken.

De controverse Büchner-Penn heeft niet tot ernstige onenigheid onder de Amsterdamse geneeskundigen geleid. Men heeft elkaar in een gezamenlijk onderzoeksprogramma kunnen vinden, gebaseerd op de gedachte dat statistische bewerking van sterftecijfers de verbanden tussen sterfte en omgeving (atmosferische invloeden dan wel welvaartsverschillen) definitief zou kunnen ophelderen. Vanaf 1854 verzamelden de leden van het Genootschap en van de NMGafdeling in gemeenschappelijk overleg statistische gegevens bij de Burgerlijke Stand om de sterftecijfers over een groot aantal jaren te berekenen, ingedeeld naar vijftig verschillende wijken en met opgave van leeftijd en geslacht van de overledenen en van de doodsoorzaak. De resultaten van dit onderzoek verschenen vanaf 1857 in de Verhandelingen van het Genootschap.

Op basis van deze resultaten publiceerden Büchner, Zeeman en Teixeira de Mattos in 1862 nog een rapport over het verband tussen sterfte en weersverandering. ${ }^{16}$ Maar het onderzoek naar sterfteverschillen van Zeeman, Israëls en andere later te bespreken hygiënisten had toen al duidelijk gemaakt dat de methode van onderzoek die in de jaren veertig in Amsterdam was ontwikkeld achterhaald was. Het onderzoek van Büchner, Zeeman en Teixeira de Mattos was de laatste in zijn soort van enige betekenis.

\section{Fysiologische geneeskunde, pathologische anatomie en empiricisme}

Tegelijk met de kwestie van de sociale sterfteverschillen vormde de nieuwe positivistische methodologie een bron van kritiek op de commissie voor volksziekten. In Duitsland, waar de historische pathologie was ontstaan, stond het vakgebied vanaf 1840 aan hevige kritiek bloot. In het bijzonder in de invloedrijke Gesellschaft für Naturförscher und Aerzte kwamen steeds meer artsen tot de overtuiging dat de historische pathologie te zeer op speculaties was gebaseerd. Men verweet de historisch-pathologen impliciet een ontologisch standpunt in te nemen: het standpunt namelijk dat ziekte een op zichzelf staande werkelijkheid met een eigen geschiedenis is. De aanhangers van de zogenaamde fysiologische geneeskunde waren van mening dat ziekte niet een historisch bepaald wezen is dat het menselijk lichaam van buitenaf bedreigt, maar evenals gezondheid het resultaat is van fysiologische, volgens vaste wetten verlopende verschijnselen. 'Die Natur wiederholt sich ewig', zo luidde hun adagium. ${ }^{17}$ Anderen benadrukten dat alle ziekteverschijnselen konden worden teruggevoerd op anatomische afwijkingen bij de patiënt; een zienswijze die aan invloed won, nadat de Weense hoogleraar C. Rokitansky zijn Lehrbuch der pathologische Anatomie (1842-1846) had gepubliceerd.

Een derde stroming die omstreeks 1850 weerklank kreeg, was het empiricisme. Virchow, de meest invloedrijke patholoog-anatoom in de tweede helft van de negentiende eeuw, was een belangrijke vertegenwoordiger van deze stroming. Hij verwierp niet alleen de oude theoretische systemen van de historische pathologie en de natuurfilosofie, maar keerde zich ook tegen de fysiologisch geneeskundigen en de school van Rokitansky, die naar zijn mening nog altijd op speculatieve theorieën vertrouwden. $\mathrm{Zij}$ redeneerden bovendien te 'zuiver 
wetenschappelijk': hun wetenschappelijke arbeid was onvoldoende gericht op verbetering van therapeutische kennis en was 'nicht hilfreich oder auch nur sorgenvoll für das Wohl des Volkes'. ${ }^{18}$ Volgens Virchow kunnen de geneeskundige kennis en praktijk pas éen worden, wanneer men zich tot de feiten beperkt; wanneer met andere woorden observatie en ervaring de grondslag voor de geneeskunde zijn. 'Wir erklärten den Formeln den Krieg und verlangten positive Erfahrung, die auf empirischen Wege, mit Hilfe und unter Kenntnis der vorhandenen Mittel, in möglichst großem Maßstabe gewonnen werden müssen. Wir verlangten die Emanzipation der Pathologie und Therapie von dem Drucke der Hilfswissenschaften und erkannten als den einzigen Weg dazu die Fernhaltung alles Systematischen, die Vernichtung der Schulen, die Bekämpfung des Dogmatischen in der Medizin. Wir verlangten die Autorität der Tatsachen, der Berechtigung des einzelnen, die Herrschaft des Gezetzes', aldus Virchow in $1855^{19}$

Elk van de genoemde nieuwe geneeskundige richtingen heeft invloed uitgeoefend op vooraanstaande NMG-leden, zoals Van Deen, Voorhelm Schneevoogt, Ramaer, Heije, Ali Cohen en Zeeman. ${ }^{20}$ De hygiënisten deelden na 1850 vooral de opvattingen van Virchow. Zij verwierpen evenals Virchow de ontologische elementen in de oude geneeskunde (contagionisme, historisch-pathologische ziekteleer) als aprioristische vormen van kennis. Dergelijke vormen van kennis in de geneeskunde hadden het ontstaan van diverse, onderling strijdige, theoretische systemen en een scheiding van theorie en praktijk in de hand gewerkt. In de plaats van apriorisme en ontologie stelden zij nog slechts het de 'directe waarneming' als primaire bron van kennis. De directe waarneming was de enige methode om 'natuurwetenschappelijke' kennis te verkrijgen - een kennis die door haar objectiviteit iedere reden tot verdeeldheid in de geneeskunde zou wegnemen.

De hygiënisten gaven dus geen nieuwe verklaringen voor bestaande ziekten. Evenmin formuleerden zij een nieuwe ziekteleer. In hun ogen was de tijd niet rijp voor verklaringen. Hun 'natuurwetenschappelijke' alternatief was veeleer programmatisch: het was een methodologie die voorschreef dat de geneeskunde zich zowel op diagnostisch als op fundamenteel-wetenschappelijk terrein diende te ontwikkelen aan de hand van waarnemingen met behulp van alle beschikbare middelen. Zij waren voorstander van de algemene toepassing van auscultatie en percussie, van meting van lichaamsmaten, van de thermometer, van microscopisch en chemisch onderzoek van lichaamsvochten, ontlasting en urine en van pathologisch-anatomisch onderzoek. Ali Cohen schreef in dit verband dat de opkomst van de 'anatomisch-pathologische school' had gezorgd voor de vervanging van de 'symptomatologische, uitwendige geneeskunde door een radicale geneeskunde: een wetenschap en kunst die de werkelijke inwendige processen op natuurwetenschappelijke wijze navorscht' ${ }^{21}$

Men was van mening dat een geneeskunde op empirische grondslag een schat aan objectieve, fysiologische en pathologische gegevens zou opleveren. Wanneer dat gebeurd was, kon men deze gegevens rationeel ordenen door logisch redeneren en vooral door het herkennen van regelmaat in de verschijnselen. Op den duur zouden de verbanden tussen uitwendige ziekteverschijnselen, pathologisch-anatomische afwijkingen en chemische bevindingen vanzelf duidelijk worden en was uiteindelijk een rationele therapie mogelijk. 
Het spreekt vanzelf dat de hygiënisten de classificatie van ziekten en doodsoorzaken ingrijpend wilden wijzigen. Tot het midden van de jaren vijftig was de classificatie gebaseerd op uitwendig vast te stellen verschijnselen (bloedspuwing, koorts, koliek, ontsteking, uittering), of op het verloop van de ziekte (acuut of chronisch). Een nadere aanduiding van de onderliggende ziekte was zinloos. Het 'wezen der ziekte' kon naar de heersende opvatting immers pas worden aangegeven, wanneer voldoende bekend was geworden over de historische ontwikkeling van de ziektekarakters. De in de sterftelijst opgenomen doodsoorzaken vormden slechts de mogelijke fatale lichamelijke gevolgen van die historische ontwikkeling.

De aandoeningen werden door plaatselijke commissies van geneeskundig toevoorzicht, geneeskundige gezelschappen en in enkele gemeenten door de Burgerlijke Stand (Amsterdam bijvoorbeeld), op een alfabetische lijst gerangschikt. Volgens een dergelijke lijst werd de doodsoorzaak genoteerd. ${ }^{22} \mathrm{De}$ waarde van deze lijsten was beperkt. De omschrijving van de doodsoorzaak was vaag, en kon door de individuele geneeskundige gemakkelijk anders worden begrepen. Bovendien werd de doodsoorzaak meestal door leken bij de Burgerlijke Stand opgegeven, en per gemeente kon de classificatielijst sterk verschillen. Een zinvolle uitwisseling van gegevens over de heersende ziektegesteldheid tussen geneeskundigen uit verschillende gemeenten of zelfs binnen één en dezelfde stad was daardoor moeilijk.

$\mathrm{Na}$ de oprichting van de NMG-afdeling Amsterdam in 1848 ontstond een discussie onder de hoofdstedelijke geneeskundigen over de sinds 1811 in gebruik zijnde 'gebrekkige ziektelijsten'. Zeeman en Israëls - beiden lid van de commissie voor geneeskundige statistiek van de afdeling - wilden dat zowel de Burgerlijke Stand als de geneeskundigen gebruik zouden maken van een lijst, waarop de doodsoorzaken naar hun lokalisatie waren ingedeeld. De betrouwbaarheid van de opgegeven sterfteoorzaken zou hierdoor aanzienlijk worden verhoogd, en de middelen om de sterfte terug te dringen zouden zich als vanzelf aandienen. Hun pogingen bleven aanvankelijk echter zonder resultaat. ${ }^{23}$ Bij de Burgerlijke Stand was men niet bereid mee te werken, en de commissie voor epidemiologie van de afdeling Amsterdam alsook de landelijke NMG-commissie voor volksziekten hielden vast aan de traditionele omschrijving van aandoeningen.

Het plan van Zeeman en Israëls kwam opnieuw in de belangstelling, toen in Nederland de resultaten bekend werden van het internationale statistisch congres dat onder leiding van Quetelet in 1853 in Brussel was gehouden. Op dit congres kwam de registratie van doodsoorzaken ter sprake. Om vergelijking van statistisch materiaal in internationaal verband mogelijk te maken, besloot het congres een lijst met doodsoorzaken op te stellen die voor alle vertegenwoordigde landen aanvaardbaar was. Twee geneeskundigen, de Britse hygiënist Farr en M. d'Espine uit Genève die vele medisch-statistische publikaties op zijn naam had staan, werden hiermee belast.

Beiden kwamen op het tweede internationale statistisch congres in 1855 met een eigen ontwerp. De uitgangspunten van de twee ontwerpen waren tegengesteld. D'Espine had een echte determineerlijst van ziekten opgesteld en had vooral de symptomen als indelingscriterium genomen. Op zijn lijst stonden als hoofdgroepen onder andere de congenitale, de acute en de chronische aandoeningen. De acute ziekten waren onderverdeeld in eenvoudige en miasmatische 
ontstekingen, de chronische in bijvoorbeeld de diathesis theumatica, nervosa en tuberculosa. Voor Farr daarentegen was het hoofddoel van een sterftestatistiek het bepallen van ongezonde levensomstandigheden. Een belangrijke hoofdgroep in zijn indeling vormde de 'zymotic diseases' of de 'maladies épidémiques, endémiques et contagieuses', waartoe Farr de koortsen, de pokken, de cholera en enkele ziekten als gevolg van voedingsdeficiënties rekende. 'They are more than other diseases under public control, and may be diminished to a large extend by sanitary measures', aldus Farr in zijn toelichting. De minder frequent voorkomende ziekten had Farr in andere hoofdgroepen ondergebracht: constitutionele ziekten (tuberculose bijvoorbeeld), ontwikkelingsstoornissen, en ziekten die de functie van een bepaald orgaan of orgaanstelsel verstoren. De ziekten waren door Farr dus voor een groot deel naar aetiologie en anatomische lokalisatie ingedeeld. Het statistisch congres van 1855 besloot tot een compromis tussen deze ongelijksoortige indelingen, maar dat werd nergens in Europa volledig geaccepteerd. Elk land ging ten slotte zijn eigen weg met de vernieuwing van de classificatie. ${ }^{25}$

Toch misten met name de voorstellen van Farr hun uitwerking in Nederland niet. Zowel in het Genootschap als in de NMG-afdeling te Amsterdam kwam een door Zeeman opgestelde ziekte-indeling in gebruik die met haar nadruk op de anatomische indeling van de ziekten grote overeenkomst met die van Farr vertoonde. Van belang was ook dat de eerste secretaris van de in 1855 gereorganiseerde geneeskundige dienst in Amsterdam, I. Teixeira de Mattos, zijn jaarlijkse verslagen over de heersende ziekten grotendeels op deze Engelse ziekte-indeling baseerde. ${ }^{26}$ Het belangrijkste verschil met de indeling van Farr was gelegen in het feit dat Zeeman en Teixeira de Mattos geen Nederlands equivalent voor 'zymotic diseases' en 'constitutional diseases' hadden ingevoerd, Koortsende aandoeningen en cholera, die in de indeling van Farr tot de zymotic diseases gerekend werden, werden door hen tot de hoofdgroepen 'koortsen' respectievelijk 'ziekten van de tractus digestivus' gerekend. ${ }^{27}$

In Amsterdam behoorde de ziekte-indeling die de basis had gevormd voor het onderzoek van de commissie voor volksziekten in 1856 dus definitief tot het verleden. Deze veranderingen stonden niet op zichzelf. In de loop van de jaren vijftig groeide de kritiek op de verslagen van Sybrandi en De Bordes. Met name de jaarlijkse analyse van ziektekarakters riep steeds meer weerstanden op. Het door de NMG-commissie voor volksziekten gebruikte begrippenapparaat uit de historische pathologie stond een ondubbelzinnige ziekte-indeling in de weg. En als gevolg daarvan, zo betoogden de tegenstanders, waren de sterftestatistieken weinig betrouwbaar. ${ }^{28}$ Het systeem van ziektekarakters moest geheel worden vervangen door een ziekte-indeling die op de directe waarneming, dat wi] zeggen de pathologische anatomie was gebaseerd. Alleen ziekten met een 'nietkosmische' oorzaak moesten statistisch worden onderzocht. ${ }^{29}$ Tegen het einde van de jaren vijftig gingen in de NMG steeds meer stemmen op om het voorbeeld van Amsterdam te volgen.

De kritiek en de ontwikkelingen in Amsterdam hadden tot gevolg dat de NMG-commissie voor volksziekten vanaf 1855 de beschouwingen over maandelijkse ziektegesteldheden achterwege liet, 'omdat de lezer er toch inderdaad weinig belang in [stelt], of men de ziektegesteldheid in januari catarrhaalrheumatisch met neiging tot het inflammatoire heeft genoend'. 30 De jaren daarop kostte het de commissie voor volksziekten steeds meer moeite haar jaarlijkse verslag uit te brengen, omdat de bereidheid tot medewerking in de 
NMG snel afnam. In 1860 verdwenen de verslagen in hun oorspronkelijke vorm geheel en al. ${ }^{31}$ Kortom, in de tweede helft van de jaren vijftig was het oude, op de historische pathologie en de constitutioleer gebaseerde classificatiesysteem gaandeweg in diskrediet geraakt. Het was nu mogelijk om ook op landelijk niveau de ziekteclassificatie aan de nieuwe kentheoretische inzichten aan te passen.

In 1861 verlangde de algemene vergadering een onderzoek naar de 'beste middelen tot het verkrijgen van een meer nauwkeurige geneeskundige statistiek' ${ }^{32}$ Egeling en J.A. Boogaard, prosector te Leiden en leerling van Virchow, stelden in 1862 namens de commissie voor de geneeskundige statistiek een model voor dat door de NMG-leden werd goedgekeurd. Boogaard deelde mee dat gestreefd was naar 'juistheid in de diagnose', hetgeen betekende dat was gekozen voor een indeling naar lokalisatie van de ziekte. De door Farr voorgestelde 'aetiologische indeeling' van een groot aantal infectieziekten wezen Egeling en Boogaard daarentegen van de hand.

Het model bestond uit twaalf hoofdgroepen, ingedeeld naar 'physiologische stelsels der organen' (borstziekten bijyoorbeeld) en de 'natuurlijke verwantschap der ziekten' (koortsen bijvoorbeeld). ${ }^{33}$ De indeling kwam dus in opzet overeen met degene die in Amsterdam werd gehanteerd. Deze lijst met indeling van ziekten, respectievelijk doodsoorzaken werden na 1867 door de inspecteurs van het Geneeskundig Staatstoezicht en de afdeling statistiek van het ministerie van Binnenlandse Zaken overgenomen. Sindsdien werden op basis van de verslagen van het Staatstoezicht de belangrijkste gegevens over de sterfte en de ziekten in het Nederlandsch Tijdschrift voor Geneeskunde door de Amsterdamse geneeskundige J. Hanlo gepubliceerd. ${ }^{34}$ Men beperkte zich daarbij tot de vermelding van numerieke en geografische gegevens van de afzonderlijke ziekten.

De hygiënisten in de commissie voor geneeskundige statistiek hadden in 1861 in feite het landelijk onderzoek naar volksziekten van de commissie voor volksziekten overgenomen. Hun methode van onderzoek gold in de NMG als de enig juiste methode voor het verzamelen van gegevens over morbiditeit en mortaliteit. Voortaan definieerde men ziekte als een pathologisch-anatomische afwijking of als een stoornis in het fysiologisch systeem, en niet meer als een entiteit die volgens bepaalde wetmatigheden in het natuurlijk milieu een eigen geschiedenis doormaakte. Het resultaat van deze verandering was een voor het gehele land geldende gestandaardiseerde lijst van ziekten en doodsoorzaken.

Het was dus niet langer de bedoeling om na te gaan hoe ziektekarakters onder invloed van bijvoorbeeld klimatologische factoren van kwaliteit veranderden, maar om sterfteverschillen te onderzoeken en zo het verspreidingspatroon van ziekten beter te begrijpen. In plaats van het begrip 'constitutio epidemica' gebruikten de hygiënisten het begrip 'algemeene gezondheidstoestand'. Deze toestand werd aan de hand van topografische en vooral kwantitatieve gegevens onderzocht. ${ }^{35}$

Het onderzoek naar de pathogenetische processen van de ziekte zelf werd geheel aan de patholoog-anatomen en de fysiologen overgelaten, terwijl de medische klimatologie en het historisch onderzoek naar ziekten als zelfstandige vakgebieden bleven voortbestaan, zonder nog van bijzondere betekenis voor de leer van de volksziekten te zijn. ${ }^{36}$ 


\section{De ontwikkeling van de bevolkingsstatistiek}

De hygiënisten wilden historisch-pathologische beschrijvingen door gestandaardiseerde en gekwantificeerde gegevens vervangen om statistisch onderzoek naar volksziekten te kunnen doen. Met behulp van een optimale bevolkingsstatistiek en een rekenkundige bewerking van gegevens kon de medische statistiek zich tot het betrouwbaarste analytisch instrument ontwikkelen op het terrein van de volksgezondheid.

Vóór 1850 was de waarde van medisch-statistische gegevens beperkt. De Provinciale Verslagen van Gedeputeerde Staten bevatten weliswaar kwantitatieve informatie over de sterfte, maar door het ontbreken van een goede bevolkingsstatistiek kon men daar weinig mee beginnen. ${ }^{37}$ De numerieke opgaven van sterfte en ziekte die individuele geneeskundigen in de jaren dertig en veertig publiceerden, bestonden uit eenvoudige tabellen met absolute en relatieve cijfers, bedoeld om de omvang van een epidemie in maat en getal weer te geven. ${ }^{38}$ Ali Cohen gaf vanaf 1847 een Statistisch geneeskundig Jaarboek uit, dat behalve uitvoerige informatie over het 'geheele geneeskundig leven' in Nederland, een grote hoeveelheid aan Lobatto ontleende demografische gegevens bevatte. ${ }^{39}$ Een systematisch overzicht van de demografische ontwikkelingen in de voorgaande jaren kon hij echter niet leveren.

Verschillende ministeries hadden reeds hun (numerieke) gegevens over politieen gevangeniswezen, handel en scheepvaart en krankzinnigenwezen vastgelegd, toen eindelijk in 1848 ook de ontwikkeling van de bevolkingsstatistiek in gang werd gezet. In dat jaar besloot de minister van Binnenlandse Zaken De Kempenaer de afdeling Binnenlands Bestuur van zijn ministerie met een Bureau voor de Statistiek uit te breiden: aan het hoofd ervan werd mr. M.M. von Baumhauer gesteld. ${ }^{40}$ In 1856 verschenen de eerste bevolkingstafels over de periode 18401851, waarin ook staten van geboorten en sterfgevallen waren opgenomen. In 1859 publiceerde Von Baumhauer een demografisch overzicht van de periode 1850-1859. In hetzelfde jaar werden de statistische werkzaamheden van de overheid uitgebreid met de instelling van de Rijkscommissie voor Statistiek en van de Provinciale Bureaus voor Statistiek. Hun belangrijkste taak was het tot ontwikkeling brengen van de bevolkingsstatistiek. ${ }^{42}$

De toenemende statistische werkzaamheden en de openbaarheid van gegevens werden in kringen van 'staathuishoudkundigen' enthousiast ontvangen. J. de Bosch Kemper, advocaat-generaal van het provinciaal gerechtshof in NoordHolland en na 1852 hoogleraar in de economie te Amsterdam, zag in de nieuwe grondwettelijke constitutie aanleiding om in 1849 met de uitgave van het Staatkundig en Staathuishoudkundig Jaarboekje te beginnen. Dit moest de kiesgerechtigden in staat stellen op verantwoorde wijze hun stem uit te brengen. De medewerkers van dit Jaarboekje richtten in 1857 de Vereeniging voor de Statistiek op, die de belangstelling voor de statistiek opwekte en de oprichting van overheidsinstellingen voor de statistiek bepleitte. ${ }^{43}$

Maar ook de hygiënisten waren zeer ingenomen met de toename van de statistische kennis. Met name de ontwikkeling van de bevolkingsstatistiek beschouwden zij als een belangrijke stap voorwaarts. Men kon nu sterftecijfers systematisch vergelijken met de bevolkingsomvang en van jaar tot jaar de de 
sterfteverhouding bepalen. Direct na de oprichting van de Vereeniging voor de Statistiek traden de geneeskundigen Zeeman, Israëls, De Man en Ali Cohen als lid toe - vooral om op de hoogte te blijven van de vorderingen in de statistische wetenschap. Enige jaren later volgden Vn Cappelle, Egeling, Coronel en Blom Coster. ${ }^{44}$ Geneeskundigen als Zeeman en Ali Cohen hebben tevens intensief deel genomen aan de werkzaamheden van de eerder genoemde overheidsinstellingen voor de statistiek, en er in een enkel geval ook leiding aan gegeven. ${ }^{45}$

\section{De betekenis van Quetelet}

Het is met name de Brusselse mathematicus en hoogleraar in de astronomie en geofysica Quetelet geweest, die de hygiënisten heeft overtuigd van het nut van de kwantitatieve benadering van de statistiek. Quetelet, die te boek staat als de grondlegger van de sociale statistiek, had zich in de jaren dertig en veertig ingespannen om de statistiek tot een kwantitatieve en analytische wetenschap te vormen. Hij deed dit onder meer door de sinds 1800 ontwikkelde inzichten uit de rekenkunde toe te passen op maatschappelijke processen. Naar zijn mening verliepen deze processen volgens bepaalde wetmatigheden die met behulp van de rekenkundige statistiek konden worden ontdekt. De kans- of waarschijnlijkheidsberekening, die door mathematici was ontwikkeld om regelmaat in biologische verschijnselen te kunnen ontdekken, diende volgens Quetelet de basis van de statistische wetenschap te zijn. Quetelet was van mening, dat in een toestand van maatschappelijke rust ('état equilibre') een groot aantal biologische en sociale gegevenheden (sterfte, lichaamslengte, criminaliteit, zelfmoord, intellectuele capaciteit) volgens de normale verdeling over de bevolking was verspreid. Deze verdeling werd bepaald door het gemiddelde en door de standaarddeviatie. Alle gemiddelden te zamen vertegenwoordigden de modale mens, ofwel 'l'homme moyen', die als maatstaf voor de uitkomsten van elk volgend onderzoek kon dienen. Bleken er bij voortgezet onderzoek afwijkingen in positieve of negatieve zin van deze fictieve natuurtoestand te bestaan, dan moest de oorzaak hiervan in bepaalde gunstige, respectievelijk ongunstige maatschappelijke omstandigheden liggen. Naarmate het aantal observaties groter was, zou de invloed van het toeval kleiner worden, en de werkelijke oorzaak van de afwijkingen van het gemiddelde duidelijk aan de dag treden. In dit opzicht, meende Quetelet, week de statistiek niet af van bijvoorbeeld de fysica, waarin men eveneens pas na een groot aantal metingen causale verbanden kan leggen. Aldus zou een rekenkundige statistiek moeten leiden tot een nieuwe wetenschap, een 'physique sociale', volgens welke de verbetering van de mensheid op waarlijk wetenschappelijke wijze ter hand kon worden genomen. ${ }^{46}$

De denkbeelden van Quetelet kregen grote bekendheid in Europa, niet in de laatste plaats als gevolg van de internationale statistische congressen die vanaf 1853 onder zijn leiding plaatsvonden. De verwachtingen omtrent de sociale statistiek waren in het derde kwartaal van de negentiende eeuw hooggespannen. ${ }^{47}$ Ook in de Nederlandse Vereeniging voor de Statistiek werden optimistische geluiden over de toekomst van de statistiek gehoord: 'Om de wetten, die aan het maatschappelijk leven ten grondslag liggen op te sporen, moet men door waarneming trachten te verkrijgen, wat men in Natuur- en Scheikunde door ervaring opgedaan heeft. Daartoe is geen beter middel dan de statistiek, die ons de maatschappij in al haar doen en laten leert kennen. Wat proeven voor de laatstgenoemde wetenschappen zijn, zijn voor ons de cijfers, de tabellen, die ons 
den afdruk van het leven der maatschappij geven'. 48

Deze verwachtingen maakten natuurlijk grote indruk op de hygiënisten. ${ }^{49} \mathrm{Zij}$ hielden zich immers sinds jaren met biologische verschijnselen op populatieniveau bezig, en waren aan het eind van de jaren veertig tot de slotsom gekomen dat deze verschijnselen slechts in het kader van de 'maatschappelijke toestand' te begrijpen waren. Hadden Virchow en Pruys van der Hoeven de toekomstige plaats van de geneeskunde in de samenleving aangegeven, Quetelet had het wetenschappelijk instrumentarium geleverd om deze plaats concreet gestalte te geven.

Een veel gehoorde bewering in kringen van de NMG was, dat de aan zekerheid grenzende waarschijnlijkheid van de statistische uitkomsten de speculaties over de verbanden tussen ziekte en omgeving kon vervangen door een wetenschappelijke bewijsvoering. Met behulp van de statistiek kon de complexe 'causaliteitsstructuur' van de constitutio epidemica tot enkele eenvoudige relaties tussen menselijk lichaam en milieu worden teruggebracht. ${ }^{50}$ Met behulp van deze 'ontleedkunde der sociologie, zonder welke men tot geen sociale physiologie kan geraken', konden sterfte-aantallen, demografische ontwikkelingen en de maatschappelijke toestand op een relatief eenvoudige en overtuigende wijze in slechts enkele tabellen worden samengevat. ${ }^{51}$

\section{De nauwkeurigheid van de sterftecijfers}

\section{Ongestandaardiseerde sterftecijfers}

De plannen van de NMG-commissie voor geneeskundige statistiek waren aanvankelijk nauwelijks uitvoerbaar, doordat veel geneeskundigen inzicht in de techniek van statistisch onderzoek misten. In de eerste plaats bestonden er rekenkundige problemen, die wel in de Veereniging voor de Statistiek werden onderkend, maar waarvan de meeste geneeskundigen in het begin van de jaren vijftig nog weet hadden. Een probleem was de verdiscontering van de veranderingen in de omvang van de populatie als gevolg van geboorte, sterfte en migratie. Geneeskundigen berekenden brutosterftecijfers per 100 inwoners over een groot aantal jaren zonder rekening te houden met dergelijke veranderingen. Sterftecijfers in bijvoorbeeld 1847 of 1852 werden zonder meer gerelateerd aan de demografische gegevens volgens de laatst gehouden volkstelling van 1849 . Ook werd voorbijgegaan aan het feit dat zowel het inwonertal als de sterfte van een gemeente werden beïnvloed door de aanwezigheid van tijdelijke, bijvoorbeeld de talrijke uit Duitsland afkomstige seizoenarbeiders.

Ten tweede werd geen rekening gehouden met veranderingen in de leeftijdsopbouw van een populatie. Brutosterftecijfers per 100 inwoners per jaar werden direct met elkaar vergeleken, zonder dat verschillen in leeftijdsopbouw van de bevolking in de berekeningen waren betrokken. Ook het verband met het geboortecijfer werd veelal over het hoofd gezien. Men realiseerde zich bijvoorbeeld niet, dat een stijging in het aantal geboorten een hogere zuigelingensterfte kon veroorzaken en dus een stijging van de totale sterfte tot gevolg had. In plaats daarvan werd een stijging van de zuigelingensterfte volledig aan een ongunstige constitutio epidemica toegeschreven, of werd een geografisch verschil in de sterfte beneden de leeftijd van één jaar uit een verschil in topografische 
omstandigheden verklaard. ${ }^{52}$

In de loop van de jaren vijftig begon de NMG-commissie voor de statistiek zulke tekortkomingen langzaam maar zeker te onderkennen. Penn kwalificeerde de studie van Büchner naar de sterfte in Amsterdam als volkomen onwetenschappelijk, juist vanwege het feit dat er geen rekening was gehouden met veranderingen in de leeftijdsopbouw en met de migratie. ${ }^{53}$ In 1854 trachtte Zeeman aan de hand van de resultaten van de volkstelling in 1849 aan de leden van de NMG duidelijk te maken, dat de brutosterftecijfers van jaar tot jaar konden verschillen als gevolg van veranderingen in de leeftijdsverdeling van een populatie. Het was daarom zaak te streven naar opgaven met leeftijdsspecifieke sterftecijfers, en moest tevens de sterfte per leeftijdsgroep met die uit voorgaande jaren worden vergeleken. ${ }^{54}$ Deze methode werd inderdaad tegen het eind van de jaren vijftig in de grotere steden toegepast.

Het besef dat leeftijdsopbouw en migratie de sterftecijfers konden beïnvloeden, betekende nog niet dat men de brutosterftecijfers standaardiseerde alvorens de mortaliteit per jaar, per gemeente of per stadsdeel te vergelijken. Tot ver in de jaren tachtig, toen een internationale methode van standaardisering in Nederland werd ingevoerd, was het gebruikelijk de brutosterfte per 100 of 1000 inwoners, of de brutosterfte uitgedrukt in het aantal inwoners per sterfgeval van elke gemeente, direct met elkaar te vergelijken. ${ }^{55}$ Nergens blijkt dat geneeskundigen als Ali Cohen, De Man of Egeling, zich bekommerden om de geringe exactheid van de voor de leeftijd ongecorrigeerde sterftecijfers. Naar hun mening waren de brutocijfers per 1000 inwoners voldoende betrouwbaar om aan te tonen, dat het sterfteverschil tussen gemeenten moest worden toegeschreven aan geografische factoren of aan het beleid van de gemeentelijke overheid. Met andere woorden: men vond de brutocijfers exact genoeg om te kunnen fungeren als 'gezondheidsthermometer' van de gemeentelijke populaties.

Geleidelijk werd uit het groeiend aantal opgaven met leeftijdsspecifieke sterftecijfers wèl duidelijk, dat de zuigelingensterfte een groot deel van de totale sterfte vormde, zoals ook Israëls in 1850 al had aangetoond. Ook zag men in, dat de sterfteverschillen per jaar en per gemeente of provincie voor een aanzienlijk deel door de schommelingen in de zuigelingensterfte werden teweeggebracht. Het gevolg was dat de zuigelingensterfte, uitgedrukt in het aantal geboorten per sterfgeval of de sterfte per 1000 inwoners, steeds vaker afzonderlijk werd vermeld. ${ }^{36}$ Vooral de laatstgenoemde uitdrukkingswijze maakte het aandeel van de zuigelingensterfte in de totale sterfte goed zichtbaar.

\section{De gebrekkige registratie}

Het waren niet alleen rekenkundige voetangels en klemmen, die het opstellen van deugdelijke mortaliteits- en morbiditeitsstatistieken lange tijd in de weg stonden. Een moeilijkheid was ook dat de registratie van de benodigde gegevens vóór 1850 gebrekkig, of in het geheel niet was geregeld. Er was bijvoorbeeld niets bekend over de veranderingen in de leeftijdsopbouw van de bevolking of over de migratie. De demografische kennis was in het begin van de jaren vijftig ontoereikend voor een verantwoord vergelijkend onderzoek naar de voorafgaande tien jaar.

Pas met de benoeming van Von Baumhauer tot hoofd van het Bureau voor de Statistiek bij het departement van Binnenlandse Zaken kwam hierin verandering. Von Baumhauers uitgave van het Statistisch Jaarboekje vanaf 1851, zijn 
publikaties over de volkstellingen van 1849 en 1859 en zijn in 1856 en 1859 uitgegeven sterftetafels over de periode 1840-1859 brachten de kennis over de loop der bevolking op een aanzienlijk hoger peil. ${ }^{57}$ Een andere belangrijke verbetering was de invoering van de gemeentelijke bevolkingsregisters op 1 januari $18500^{58}$ Hierdoor kwamen maandelijks de noodzakelijke gegevens over de veranderingen in de bevolkingsopbouw beschikbaar.

Voor de artsen in de NMG vormde dit laatste een aanleiding om ook de registratie van doodsoorzaken bij de bevolkingsregisters te bepleiten. Noch in de geneeskundige wetgeving van 1804 of 1818 , noch in de bepalingen met betrekking tot de Burgerlijke Stand en de bevolkingsregisters was daarover iets geregeld, zodat de vermelding van doodsoorzaken naar goeddunken van de plaatselijke overheid geschiedde. ${ }^{59}$

$\mathrm{Nu}$ was zelfs na 1850 een uniforme registratie van doodsoorzaken niet gemakkelijk tot stand te brengen, aangezien het grootste deel van de bevolking zonder geneeskundige bijstand overleed. In Amsterdam bijvoorbeeld, waar doodsoorzaken wel geregistreerd werden, waren de gegevens afkomstig van de aangiftebiljetten van de zogenaamde buurtmeesters, gewoonlijk winkeliers bij wie aansprekers of familie aangifte van overlijden deden. De NMG was echter van mening, dat de aangifte van een sterfgeval vergezeld diende te gaan van een doodsoorzakenverklaring, die was afgegeven door een geneeskundige, opdat een betrouwbare registratie gewaarborgd was.

Dit gebeurde voor het eerst in Amsterdam, toen het gemeentebestuur het afgeven van een overlijdensverklaring door een erkend geneeskundige verplicht stelde, en de artsen vervolgens besloten zelf de doodsoorzaken te registreren. Om het levend begraven van schijndoden te voorkomen, besloot de gemeenteraad in 1852 dat ambtenaren van de Burgerlijke Stand geen toestemming tot begraven mochten verlenen, voordat het overlijden door een geneesheer, een stadsgeneeskundige of stadsheel- of vroedmeester was geconstateerd. Deze bepaling, die op 1 juli 1853 van kracht werd, regelde echter niets omtrent de registratie van doodsoorzaken. Om dit gemis te compenseren besloot de NMGafdeling alle geneeskundigen in de stad op de roepen erop toe te zien 'dat de aard van de ziekte door de buurtmeesters behoorlijk en naar waarheid vermeld is'. Vanaf dat moment werd het mogelijk om een plaatselijke statistiek van doodsoorzaken op te stellen volgens het eerder beschreven - door Zeeman opgestelde - 'kader van ziektevormen'. ${ }^{60}$

Een landelijke regeling voor het opgeven van doodsoorzaken stuitte telkens op problemen. Minister Thorbecke had in 1852 een ontwerp-begrafeniswet opgesteld. Deze moest het Koninklijk Decreet van 1804 betreffende het begraven en de lijkbezorging vervangen. De bewindsman had met de wet vooral de handhaving van de openbare orde en de bescherming van de openbare hygiëne op het oog. Onderdeel was dat de kerkgenootschappen het recht verloren op een zelfstandig (financieel) beheer van begraafplaatsen. Het ontwerp bevatte tevens de bepaling dat een ambtenaar van de Burgerlijke Stand pas verlof tot begraven mocht geven, zodra een erkend geneeskundige schriftelijk te kennen had gegeven dat hij de dood had geconstateerd. Over aangifte van de doodsoorzaak werd niets geregeld.

De NMG was tevreden over het voorstel, al had zij graag gezien dat ook de opgave van de doodsoorzaak door een geneeskundige verplicht werd gesteld. Kerkgenootschappen waren daarentegen fel tegen het wetsvoorstel gekant, wegens het feit dat zij niet schadeloos werden gesteld voor het verlies van de 
begrafenisrechten. Zij keerden zich ook tegen het voorgestelde wetsartikel dat het inrichten van bijzondere begraafplaatsen verbood.

De val van het ministerie Thorbecke in 1853 verhinderde de indiening van het wetsontwerp. Nadien onderging het ontwerp, vooral onder confessionele druk, nog tal van wijzigingen. Maar ook de geneeskundigen gebruikten hun invloed met succes: in 1858 werd opgave van de doodsoorzaak door een geneeskundige verplicht gesteld. ${ }^{61}$ Door aanhoudend verzet van de kerkgenootschappen kon de Kamer echter pas in 1869 een wetsontwerp van minister C. Fock in de plenaire vergadering bespreken. ${ }^{62}$

Ondanks het uitblijven van een landelijke regeling volgden aan het eind van de jaren vijftig de gemeenten Leiden, Haarlem, Schiedam en Den Haag het voorbeeld van Amsterdam. Naar aanleiding daarvan wilden sommigen vanuit de NMG de overige gemeentebesturen in het land overtuigen van het nut van deze regelingen. Maar een meerderheid in de NMG gaf er de voorkeur aan een wettelijke regeling af te wachten.

De eerste stap tot algemene invoering werd gezet met het van kracht worden van de Wet op de uitoefening der geneeskunst in 1865 (Stb. 60). In deze wet werd de geneeskundige onder meer verplicht bij het overlijden van patiënten een getekende overlijdensverklaring af te geven, waarin tevens de oorzaak van de dood was vermeld, met inachtneming van de door hem afgelegde eed of belofte van geheimhouding (artikel 5). Een lijkschouwing was niet verplicht.

De volgende stap werd gezet met de Begrafeniswet uit 1869. Verlof tot begraven mocht pas worden verleend na de ondertekening van een overlijdensverklaring door de behandelend geneesheer of een gemeentelijk lijkschouwer. Bovendien moest getracht worden de doodsoorzaak vast te stellen. ${ }^{63}$ In principe was daarmee de registratie van doodsoorzaken geregeld, maar het zou lang duren voordat alle geneeskundigen - soms onder dwang van de inspectie volgens deze bepalingen handelden. Want zelfs in 1886 werd van sommige geneeskundigen nog vermeld dat zij tijdens de teraardebestelling van de overledenen een overlijdensverklaring ondertekenden. Men mag dus aannemen dat de registratie van doodsoorzaken niet volledig sluitend is geweest.

\section{Het onderzoeksprogramma van de hygiënisten}

\section{Het lotelingenonderzoek}

Het waren vooral Zeeman, Ali Cohen, Egeling en De Man die aan de nieuwe geneeskundige statistiek gestalte gaven. Als secretaris van de NMG-commissie voor de geneeskundige statistiek stelde Zeeman in 1850 voor om met behulp van de 'probabiliteitsrekening' van Quetelet de kennis over de aetiologie der ziekten te vergroten. Met steun van de overheid moest het werk van Lobatto voortgezet worden door een sterftestatistiek over de periode 1840-1849 uit te geven. Wanneer deze was gerealiseerd, moest er vervolgens elke twee jaar een overzicht van de sterfte en van enige ziekte-oorzaken worden gepubliceerd. ${ }^{64}$

Het plan van Zeeman stuitte echter op de praktische moeilijkheid, dat er onvoldoende leeftijdspecifieke cijfers waren de de registratie gebrekkig was. In 1852 moest Ali Cohen, op dat moment secretaris van de NMG-commissie voor de geneeskundige statistiek, laten weten dat het verzamelen van de benodigde 
gegevens was mislukt. Hij had gehoopt op de medewerking van de Provinciale Bureaus voor Statistiek, die volgens de Provinciewet opgericht hadden moeten zijn, maar enkel op papier bestonden. Hij was nu maar begonnen met een onderzoek naar de redenen van de afkeuring van militaire lotelingen in de provincie Groningen over de periode $1840-1851{ }^{65}$ Hiertoe was hij waarschijnlijk geinspireerd door vrijwel identieke onderzoekingen die in 1829 door Villermé en in de jaren dertig door Quetelet waren verricht. ${ }^{6}$

Ali Cohens verwachting was dat op grond van deze relatief eenvoudig te verkrijgen gegevens, in het bijzonder met betrekking tot de lichaamslengte van de lotelingen, een goede indruk van de gezondheidstoestand van de bevolking kon worden verkregen. Dit bleek een vruchtbare gedachte, want in 1854 kon Zeeman, wederom secretaris van de commissie voor de geneeskundige statistiek en met Egeling verantwoordelijk voor de onderzoeksverslagen, op zijn beurt een rapport uitbrengen over de gezondheidstoestand van de mannelijke bevolkingsgroep van rond de achttien jaar in de provincie Noord-Holland. Rapporten van Ali Cohen en De Man betreffende de provincies Groningen respectievelijk Zeeland werden enige jaren later gepubliceerd.

Zeemans conclusie voor Noord-Holland was dat het aantal lotelingen 'onder de maat' (minder dan $1.57 \mathrm{~m}$ ) tussen 1821-1850 flink was toegenomen. In 1852 was het aantal ondermaatsen opgelopen tot meer dan $20 \%$ van alle lotelingen. Nog eens $10 \%$ van alle lotelingen werd om andere redenen (lichaamsgebreken, ziekte) ongeschikt voor de dienst bevonden. 'Gebrek aan voedsel en malaria' was volgens Zeeman de oorzaak van de achteruitgang in de gezondheidstoestand van deze jonge mannen. ${ }^{67}$

Het onderzoek op het terrein van de militaire statistiek breidde zich gestaag uit. Talrijke geneeskundigen, verspreid over het land, werden bij het onderzoek betrokken, hetgeen resulteerde in een omvangrijk landelijk lotelingenonderzoek over de jaren 1861-1865. Het ministerie van Oorlog en diverse provinciale instanties werkten eveneens aan het onderzoek mee. ${ }^{68}$ Het belang van het onderzoek lag in het feit, dat een vergelijking van de gegevens over de lichaamslengte en de gezondheid van de potentièle recruten over een aantal jaren en in verschillende gemeenten iets zou leren over de relaties tussen de lichamelijke ontwikkeling van de bevolking enerzijds en de gezondheidstoestand en het welvaartspeil anderzijds. Ook was het leerzaam het aantal lotelingen uit een bepaalde gemeente te vergelijken met het aantal mannelijke geboorten in die plaats in het geboortejaar van deze dienstplichtigen. 'Wij mogen dan aannemen', zo stelde Zeeman in 1861 , 'dat de verhouding der ingeschrevenen tot de geborenen in hun geboortejaar den maatstaf aangeeft van de som der lethale invloeden, waaraan vooral de kinderleeftijd [..] heeft blootgestaan'. ${ }^{69}$ Met andere woorden, de plaatselijke gesteldheid van een gemeente was gunstiger, naarmate de gemiddelde lichaamslengte van de daar geboren lotelingen groter was, of naarmate het aantal voor de militaire dienst ingeschrevenen het aantal geboorten in het lichtingsjaar dichter benaderde.

Er was nog een andere factor die Zeeman bij zijn onderzoek betrok, en dat was de voedingstoestand van de bevolking. Reeds in 1850 had Evers de slechte kwaliteit van de volksvoeding aangewezen als een van de belangrijkste oorzaken van de achteruitgang van de volksgezondheid. Het bestaan van dit verband kon Zeeman op overtuigende wijze bevestigen. Aan de hand van een grafiek liet hij zien, dat telkens één tot twee jaren nadat de prijs van de rogge omhoog was gegaan het aantal wegens ontoereikende lichaamslengte afgekeurde lotelingen 
toenam. De geconstateerde groeiachterstand schreef hij toe aan een verminderd het gebruik van graanprodukten, dat weer het gevolg was van de stijging van hun marktprijs. ${ }^{70}$ Naar zijn mening bestond er dus behalve een structureel oorzakelijk verband tussen de plaatselijke gesteldheid van het milieu en de gemiddelde lichaamslengte, ook een relatie tussen voeding en lichaamslengte: deze kon het effect van de topografische gegevenheden versterken of juist verzwakken.

Zeemans bevindingen werden in de jaren zestig enkele malen door ander onderzoek bevestigd. "In het begin van de jaren zeventig vormden ze de aanleiding voor een hernieuwde poging vanuit de NMG tot het instellen van een onderzoek naar de volksvoeding in Nederland. Het lotelingenonderzoek heeft ook meer algemene betekenis gehad, het heeft op een groot aantal punten model gestaan voor het onderzoek in de jaren zestig naar de gevolgen van de kinderarbeid. Want, zo luidde de wetenschappelijke opinie, als de conclusies van het onderzoek voor jonge mannen geldt, waarom zouden ze dan niet voor jonge vrouwen, ja zelfs voor de gehele bevolking opgaan?

\section{De ontwikkeling van het lokalisme}

Het lotelingenonderzoek had een verband tussen bepaalde maatschappelijke omstandigheden en ontwikkelingen in de volksgezondheid aangetoond. Maar het had toch vooral de waarde van de statistiek zelf aangetoond. Dergelijk onderzoek bewees volgens de hygiënisten dat men met behulp van statistiek beter in staat ${ }^{~ w a s}$ ontwikkelingen in de volksgezondheid te verklaren dan door middel van historisch-pathologische analyse.

Het is niet alleen de commissie voor de geneeskundige statistiek geweest die de stoot tot wetenschappelijke vernieuwing heeft gegeven. Het onderzoek van individuele geneeskundigen naar de algemene sterfte in hun woonplaats is minstens zo belangrijk geweest. In één opzicht heeft dit onderzoek zelfs meer gewicht in de schaal gelegd, want het heeft een nieuwe wetenschappelijke theorie over de spreiding van ziekten en sterfte voortgebracht.

De eerste statistische studie naar de algemene sterfte werd verricht door de Haagse arts J.W. Schick. Schick was als geneesheer verbonden aan de 'Badinrigting' in Scheveningen. Hij berekende in 1851 op basis van gegevens van het provinciaal archief, dat de provincie Zuid-Holland over de periode 1837-1848 een hogere gemiddelde sterfte had dan de rest van Nederland. Bovendien was de sterfte in de steden veel hoger dan op het platteland. Op een landkaart maakte hij de sterftecijfers en de geologische gesteldheid van de provincie aanschouwelijk. Schick stelde vast dat de sterfte op de kleigronden het hoogst was en trok de volgende conclusie: 'De waarneming, dat de sterfteverhouding in verschillende plaatsen, die over een zekere uitgestrektheid verspreid zijn, eene zeer in het oogvallende overeenkomst vertoont, leidt tot het besluit, dat er omstandigheden zijn, welke hunnen invloed over eene bepaalde ruimte doen gevoelen'. ${ }^{72} \mathrm{Hij}$ besloot zijn onderzoeksverslag met een oproep aan alle Nederlandse geneeskundigen om zijn onderzoek in de rest van Nederland voort te zetten. Hij voegde er een schema aan toe, dat naar zijn mening als leidraad voor het onderzoek naar de volksgezondheid moest dienen. Dit schema behelsde een opsomming van alle 'natuurlijke en maatschappelijke oorzaken' van sterfte- en ziekteverschillen. ${ }^{73}$ 
De door Schick voorgestelde aanpak vond bij velen instemming. Een onderzoeksprogramma, gericht op het verzamelen van zoveel mogelijk gegevens, moest op den duur uitmaken welke variabelen in het milieu de belangrijkste zijn, lijkt men algemeen te hebben gedacht. De eerste die aan Schicks oproep gevolg gaf, was De Man. Hij publiceerde in 1852 een studie over de sterfte per gemeente in Zeeland, en bracht evenals Schick de gegevens op een kaart in beeld. Hij deelde de conclusie van Schick, dat de geologische gesteldheid van de bodem een belangrijke rol speelde in de sterfteverschillen. ${ }^{74}$

Het was opnieuw Schick die grote indruk maakte met zijn onderzoek naar de gezondheidstoestand van Den Haag. In 1852 constateerde hij dat deze sinds de achttiende eeuw eeuw aanmerkelijk was verslechterd. Aan de hand van de door hemzelf aanbevolen schematische indeling was Schick in staat een aantal factoren te bepalen dat voor de achteruitgang verantwoordelijk was: gebrekkige riolering, giftige uitwasemingen van grachten met rottende stoffen en stilstaand water, grote opeenhoping van woningen, overbewoning, onvoldoende reiniging van de straten, bedorven drinkwater en vervuiling van de bodem met organische stoffen. ${ }^{75}$ Schicks studie was na die van Büchner uit 1842 dus de eerste die de verslechtering van de gezondheidstoestand, zoals deze was op te maken uit de gemiddelde sterfte, direct in verband bracht met de toenemende vervuiling van de stad.

Hiermee had Schick de noodzaak van een nieuwe sanitaire gemeentepolitiek overduidelijk aangetoond. Voorhelm Schneevoogt riep in De Gids de Nederlandse geneeskundigen op om in navolging van Schick 'den engen kring van hunne dagelijksche praktijk te verlaten en hunne studieën en bemoeijingen uit te breiden tot alles wat meer tot het algemeen welzijn, tot de openbare gezondheidsregeling van de plaatsen hunner inwoning betrekking heeft' ${ }^{76}$ Buiten de kring van geneeskundigen trok de studie eveneens de aandacht. Zoals we in het volgende hoofdstuk zullen zien, ontleende het Tweede-Kamerlid Wintgens er argumenten aan ter ondersteuning van zijn initiatief-wetsvoorstel tot instelling van gemeentelijke gezondheidscommissies.

Het belang van het werk van Schick is veel groter dan onmiddelijk uit het voorgaande is op te maken. Om te beginnen heeft hij als eerste de reeds lang bestaande inzichten van buitenlandse hygiënisten op de Nederlandse situatie toegepast, en met succes bovendien. Daarmee heeft hij het wetenschappelijk onderzoek van de Nederlandse hygiënisten een totaal nieuw perspectief gegeven. Zoals de Franse hygiënisten het sterftepatroon definieerden als 'l'expression pathologique des localités', en de Engelse sanitaire hervormers de gezondheidsthermometer gebruikten om de gezondheid van woonplaatsen te meten, zo bracht Schick de sterfteverschillen in een provincie in verband met het verschil in plaatselijke levensomstandigheden. Hiervoor had hij net als de buitenlandse hygiënisten gegevens uit de bevolkingsstatistiek omgewerkt tot een 'statistiek van de openbare hygiëne' (de Engelsen gebruikten de term 'sanitary statistics'). Zodoende was hij in staat aan te tonen dat de verslechtering van de volksgezondheid in Den Haag direct samenhing met sanitaire misstanden.

Een mogelijk verband tussen weersgesteldheid en gezondheidstoestand noemde hij enkel terloops. Om duidelijk te laten uitkomen, dat niet de meteorologische waarnemingen of de historisch-pathologische analyse, maar de vergelijking van plaatselijke sociale en natuurlijke kenmerken en sterftecijfers de basis van het onderzoek naar de aetiologie van ziekten was, legde Schick zijn bevindingen vast in een cartogram. Hij heeft voor Nederland deze uitdrukkingswijze - wederom 
naar buitenlands voorbeeld - tot een basistechniek van het wetenschappelijk onderzoek naar volksziekten verheven. ${ }^{n}$

In de tweede plaats verschilde Schicks lokalisme van de vroegere benadering in de NMG. In de jaren 1849-1851 hadden Evers, Zeeman en Israëls de sterfteverschillen in verband gebracht met het voedingspatroon van de bevolking en de onderliggende verschillen in inkomen. Evers sprak zelfs van een verband tussen de voedingsgewoonten van 'klassen' en hun gemiddelde leeftijd. Hun 'sociologisch' onderzoek naar de sterfteverschillen raakte aan de inkomensverdeling en stelde de sociale verheffing van de volksklasse als zodanig aan de orde. Zij zijn hierin wellicht geinspireerd door de sociale pathologie van Virchow uit 1849.

In het onderzoek van Schick daarentegen lag de nadruk op het beheer van de geografische ruimte, in het bijzonder van die in de steden. Waar riolering, reiniging van straten en volkshuisvesting werden verwaarloosd, vertoonde het sterftepercentage een stijgende lijn. Schick stelde voor de verklaring van sterfteverschillen in dit perspectief te plaatsen. Hij bepleitte een technocratische aanpak van de volksgezondheid, waarbinnen de hygiënisten het 'bestuur' over de openbare hygiëne hadden.

Het door Schick voor de algemene gezondheidstoestand geformuleerde verklaringsmodel kan men in navolging van Ackerknecht het beste vatten onder de uitdrukking lokalisme: de opvatting dat de gezondheid van een bevolkingsgroep een resultante is van bepaalde plaatselijke omstandigheden. ${ }^{78}$ Anders gezegd: de weergave van statistische gegevens in een cartogram had een met de pathologisch-anatomische afbeelding vergelijkbare functie. Zoals deze afbeelding het lokalisme in het pathofysiologisch denken tot uitdrukking bracht, zo deed de sterftekaart dat in de leer van de volksziekten: het afbeelden van 'zieke' plaatsen in het leefmilieu. Deze benadering - korte tijd later door Von Pettenkofer gepropageerd - verdrong de meer sociologische interpretatie van sterfteverschillen en domineerde thans de discussie onder de hygiënisten.

\section{Het NMG-plan voor de geneeskundige plaatsbeschrijving}

Na Schick hadden alle statistische publikaties tot doel een 'natuurwetenschappelijk' antwoord te vinden op de vraag, welke factoren in het natuurlijk milieu en welke kanten van de stedelijke samenlevingsvorm bijdroegen aan de slechte gezondheidstoestand van met name het armste deel van de bevolking. Om bekend te raken met deze ziekmakende factoren, moesten er volgens de hygiënisten twee dingen gebeuren. Allereerst moest een nauwkeurige beschrijving van het natuurlijk milieu en van de 'fysieke conditie' van de steden plaatsvinden. Ten tweede moest een regelmatig herhaald onderzoek naar de geografische spreiding van sterfte- en ziektecijfers over stad en land de zogenaamde 'constante oorzaken' (ofwel verklarende variabelen) van de verschillen in het optreden van ziekten en sterfte aan het licht brengen. Om beide redenen was de medische statistiek onverbrekelijk met de geneeskundige plaatsbeschrijving en de medische geografie verbonden.

De algemene vergadering van de NMG koos in 1852 Ali Cohen en de eveneens uit Groningen afkomstige medicus Acker Stratingh in een commissie, die een plan voor een statistisch-geografisch onderzoek op landelijke schaal ("algemeene plaatsbeschrijving') moest opstellen. ${ }^{79}$ Het plan dat de commissie een jaar later aan de NMG-vergadering voorlegde, vertoonde grote gelijkenis met dat van Schick. Het bevatte ook enkele nieuwe elementen, die waren ontleend aan 
een in 1849 uitgekomen rapport van de door de Belgische regering ingestelde commissie voor de geneeskundige plaatsbeschrijving: de 'statistiek der bewoners', de 'gezondheidstoestand' en een overzicht van de plaatselijke 'geneeskundige wetgeving. ${ }^{80}$ Dit rapport gaf richtlijnen voor het bewerken van de geneeskundige plaatsbeschrijvingen die de provinciale commissies van toevoorzicht in België sinds 1847 opstelden. Acker Stratingh en Ali Cohen wensten dat ook in Nederland een rijkscommissie hun plan zou uitvoeren. Ali Cohen was sinds het begin van 1853 samen met Penn persoonlijk adviseur in medische aangelegenheden van minister Thorbecke, zodat het plan een redelijke kans leek te maken om door de minister ondershands te worden aanvaard, en in de nieuwe staatsregeling te worden verwerkt.

In de Maatschappij werd het voorstel van Acker Stratingh en Ali Cohen met instemming ontvangen. In de zomer van 1853 werd het zelfs als officieel beleidsstuk aanvaard. Het ministerie-Thorbecke was echter in april van dat jaar gevallen en Thorbecke had plaats gemaakt voor mr. G.C.J. van Reenen, die de NMG aanmerkelijk minder welgezind was. Bovendien bestond op de afdeling Medische Politie van het ministerie, belichaamd in de persoon van de referendaris Loncq, geen enkele bereidheid om aan de verlangens van de Maatschappij tegemoet te komen. Toen een poging tot de instelling van een rijkscommissie voor een geneeskundige plaatsbeschrijving faalde, trachtte Heije, als secretaris van de NMG, minister Van Reenen over te halen om in ieder geval het Topografisch Bureau van Binnenlandse Zaken, het Meteorologisch Instituut en de in 1851 ingestelde Rijkscommissie voor de geologische kaart van Nederland, bij het NMG-onderzoek te betrekken. ${ }^{81}$ Dit verzoek is door de minister nooit beantwoord. $^{82}$

Toch was het plan van Acker Stratingh en Ali Cohen hierdoor allerminst van de baan. Toen bleek dat het ministerie van Binnenlandse Zaken niet wilde meewerken, besloot de Maatschappij de plaatsbeschrijving zelf ter hand te nemen. Terwijl Ali Cohen een begin makkte met een inventarisatie van de gezondheidspolitiek per gemeente en daarover diverse publikaties het licht deed zien, namen anderen de eigenlijke topografie voor hun rekening. ${ }^{83}$ In 1856 publiceerden de Middelburgse geneeskundigen De Man en Fokker een plaatsbeschrijving van hun woonplaats. Evenals Schick wilden zij laten zien, dat de gezondheidstoestand een resultante van de plaatselijke levensomstandigheden in de stad is. ${ }^{84}$

Twee jaar later, in 1858, promoveerde de medicus Stratingh op een plaatsbeschrijving van de stad Groningen. Zijn dissertatie laat zien hoezeer het lokalisme onder de invloed was gekomen van de bodemtheorie van Von Pettenkofer. Meer dan De Man en Fokker ging Stratingh in op de bodemgesteldheid en de waterhuishouding van stad en provincie, 'wegens het belangrijke verband, dat ongetwijfeld tusschen den bodem eener plaats en de ziekte van hare inwoners bestaat'. ${ }^{85}$ Stratingh had met Ali Cohen tijdens de aanleg van de riolering vastgesteld, dat de bodem in delen van de stad rijk was aan organisch materiaal, dat in het grondwater terecht kon komen. Het was hen duidelijk geworden 'waarom in zekere, bepaalde gedeelten van onze stad herhaaldelijk epidemische ziekten zich in veel sterkere mate hadden voorgedaan dan in andere gedeelten'. ${ }^{86}$ Het bodemonderzoek verklaarde volgens Stratingh waarom de koortsepidemie van 1826 en de cholera in de jaren $1854-1855$ juist in de lager gelegen gedeelten van de stad de meeste slachtoffers hadden geëist. 
Op het eerste gezicht speelt 'armoede' in het begin van de jaren vijftig nauwelijks een rol in de plaatsbeschrijvingen. Maar de belangstelling van de hygiënisten voor sociale sterfteverschillen was niet afgenomen, integendeel, deze waren de gehele jaren vijftig een belangrijk onderwerp van studie. De Man en Fokker wezen herhaaldelijk op het ontbreken van een rationeel gezondheidsbeleid gericht op de armen, met als gevolg dat de 'besmettelijke en andere epidemische ziekten meestal ontstaan in de armhuizen en hutten der behoeftigen'. ${ }^{87}$ Coronel, sinds 1853 werkzaam bij de stadsgeneeskundige dienst van Middelburg, was dezelfde mening toegedaan. Hij was evenals De Man en Fokker lid van de in politiek en sociaal opzicht zeer actieve Middelburgse NMG-afdeling. In 1859 publiceerde hij een vervolgstudie op de plaatsbeschrijving van De Man en Fokker, waarin hij zijn aandacht richtte op de levnesomstandigheden van de armen. Coronel stelde vast, dat de kinderen van bedeelden en werklozen de grootste groep op de sterftelijsten vormden, en hij was ervan overtuigd dat de bestaande armenzorg, gebaseerd op de Armenwet van 1854, geen uitzicht op verbetering bood. ${ }^{88}$ Ook Zeeman wees op het belang van de bestrijding van de armoede. Voor hem was er op grond van studies in Engeland en Frankrijk maar één conclusie mogelijk, namelijk 'dat steeds en overal welvaart en gegoedheid de sterfte doen afnemen en het leven verlengen, terwijl armoede de sterfte vermeerdert en het leven verkort'. ${ }^{89}$

Wat de hygiënisten onder 'gegoedheid', 'sociale welstand' en 'armoede' verstonden, was sinds 1850 onder invloed van de lokalistische opvatting veranderd. Stratingh liet met zijn studie naar de gezondheidstoestand in Groningen niet alleen zien, dat de sterfte in de lager gelegen gedeelten van de stad het hoogst was, maar ook dat die gedeelten door armen werden bewoond. Hetzelfde beeld gaf een studie van Zeeman naar de cholera in 1859: de hoge sterfte onder de armen was te wijten aan het feit dat juist zij op geografisch ongezonde plaatsen woonden. In het bijzonder de kwaliteit van de bodem en het (drink)water waren verantwoordelijk voor de oversterfte aan de cholera onder de armen. ${ }^{90}$ Ook Ali Cohen werd niet moe erop te wijzen dat de 'lagere klassen' het grootste aandeel in de sterfte hadden, omdat zij op de ongezondste plaatsen woonden. 91

Nemen we in aanmerking wat volgens de hygiënisten ongezonde plaatsen waren, en hoe zij meenden dat die plaatsen de gezondheid beïnvloedden, dan wordt duidelijk welke definitie van sociale sterfteverschillen zij gebruikten. Sociale sterfteverschillen waren verschillen in sterftecijfers tussen groepen in de samenleving die onderscheiden waren naar woon- en levensomstandigheden, zoals bodemgesteldheid, kwaliteit van drinkwater, huisvesting en sanitaire voorzieningen. Ook het voedingspatroon rekenden de hygiënisten tot de levensomstandigdheden, omdat dit de lichamelijke weerstand tegen schadelijke milieuinvloeden bepaalde. Een deel van de sterfteverschillen was een gevolg van het feit, dat de welgestelden kwalitatief goede levensmiddelen konden betalen en de armen niet. Met uitzondering van de voeding, ging het dus om geografische criteria of, wat volgens de hygiënisten hetzelfde was, om hygiënische criteria. ${ }^{92}$ Anders gesteld: armoede was een toestand waarin mensen verkeerden die onder ongezonde omstandigheden leefden, wegens het ontbreken van een openbare hygiëne. In het perspectief van de hygiënisten was armoede dus vrijwel hetzelfde als gebrek aan openbare hygiëne. 
De zienswijze dat armoede hetzelfde was als gebrek aan openbare hygiëne, werd aan het einde van de jaren vijftig uitgewerkt. Toen werd eerst in Amsterdam, later ook in Rotterdam en Den Haag, de invloed van de 'sociale welstand' op de hoogte van de sterfte onderwerp van nader onderzoek. Nadat Teixeira de Mattos herhaaldelijk in zijn verslagen van de geneeskundige armendienst had gewezen op de grote verschillen in sterfte per wijk, publiceerde Israëls in 1862 de resultaten van het eerste grote onderzoek naar de sterfteverschillen tussen de sociale klassen in Amsterdam.

Het onderzoek had betrekking op de qua kindersterfte buitengewoon ongunstige jaren 1850-1859. Uitgaande van het gegeven dat 'de bevolking zich in groepen aaneen [voegt] naar gelang de levensomstandigheden waarin zij verkeert', deelde Israëls vijftig Amsterdamse wijken in vier groepen in: $I$ arme buurten; 2 buurten met meer armen dan gegoeden; 3 buurten met meer gegoeden dan armen; 4 gegoede buurten. ${ }^{94}$ Hij constateerde in het bijzonder ten aanzien van de zuigelingensterfte grote verschillen: 'Inderdaad hoogst belangrijk is het overzigt, wanneer wij [..] de sterfte der kinderen in het eerste levensjaar naar de buurten der stad, of wat bijna hetzelfde is, in hare sociale beteekenis beschouwen. [..] Armoede, gepaard met physieke en morele ellende, schijnt in gewone tijden de hoofdfactor der sterfte te zijn'. Zijn onderzoek bevestigde 'met welk een verschil een en dezelfde schadelijke invloed op verschillende bewoners in eene en dezelfde stad inwerkt'. ${ }^{95}$ Geldgebrek, ontoereikende voeding, lichamelijke verwaarlozing en zedeloosheid maakten de mensen eerder slachtoffer van schadelijke milieufactoren. Daarom kwamen, zo meende hij, meningitis, cachexie, stuipen, maag- en darmstoornissen en ziekten van de ademhalingsorganen zo veel vaker voor bij kinderen in de overwegend arme buurten.

Er was eén bijzonder statistisch verschijnsel dat om een nadere verklaring vroeg, namelijk de relatief gunstige sterfte onder de joodse inwoners van Amsterdam. In 1817 had Nieuwenhuys gewezen op de lagere sterfte onder de joden in de buurten rond het IJ, wat hij toeschreef aan de 'onbelemmerende stroom van versch water, alsook van lucht aldaar'. ${ }^{96}$ In de jaren vijftig vestigde Teixeira de Mattos opnieuw de aandacht op de relatief gunstige gezondheidstoestand van de arme joden, naar hij dacht als gevolg van de 'gunstige' bodemgesteldheid en de aanwezigheid van frisse lucht aan het IJ. Het bleek hem bovendien dat de sterfte van joodse kinderen beneden het jaar relatief laag was. Hij schreef de relatief lage sterfte onder de joden dan ook voor een deel toe aan een relatief lage zuigelingensterfte. Dit laatste was naar zijn mening te danken aan het feit, dat de zuigelingen bijna zonder uitzondering borstvoeding kregen. ${ }^{97}$

Deze verklaring was volgens Israëls in 1862 inderdaad de enig mogelijke. Hoewel hij erkende dat de joodse buurten rond het IJ 'niet geplaagd [worden] door stilstaand water in de grachten en geen gebrek [hebben] aan versche lucht', was de lage zuigelingensterfte in die buurten ook naar zijn mening een gevolg van het feit dat de 'moeders zeer veel zorg voor hare jonge kinderen dragen, ten minste zoo lang zij aan de borst zijn'. Israëls luidde dan ook, dat borstvoeding tot een daling van de zuigelingensterfte
kon leiden.

De tweede grote studie naar sterfteverschillen in Amsterdam werd in 1863 door Egeling gepubliceerd. Egeling baseerde zich op de sterftetabellen van 
Amsterdam over de jaren 1854-1860, uitgegeven door het Genootschap ter bevordering der Genees- en Heelkunde. In deze tabellen stonden tevens de sterfteoorzaken. Hij had gebruik gemaakt van de sterfte- en ziektegegevens van de geneeskundige armendienst, verzameld door Teixeira de Mattos. Egeling was daardoor als eerste in staat de sterfte over een langere periode te berekenen, en dat voor alle leeftijden onder vermelding van de doodsoorzaak naar afzonderlijke buurten.

Een aantal afzonderlijke ziektebeelden heeft hij geografisch in kaart gebracht. Uit zijn onderzoek bleek bijvoorbeeld dat 'fluxus alvinus' (waaronder Egeling diverse vormen van diarrhee verstond) veel voorkwam in buurten langs het IJ, waar 'de bevolking eene niet onbelangrijke hoeveelheid in rotting verkerende dierlijke stoffen eet of drinkt'. ${ }^{100}$ De 'intermitterende koorts' daarentegen bleek het meest aan de buitenrand van de stad en het minst in de buurten aan het IJ voor te komen. Ten slotte stelde hij vast dat het zuidwesten van de stad voor alle ziekten en sterfte-oorzaken het ongunstigst was van heel Amsterdam.

Ook Egeling was het opgevallen dat de buurten waar overwegend joden woonden 'een gunstiger sterfteverhouding leverden, dan wegens de omstandigheden zou worden verwacht'. ${ }^{101}$ Anders dan Teixeira de Mattos en Israëls dacht Egeling dat deze niet kon worden verklaard door het feit dat zuigelingen vaker borstvoeding kregen. Evenals Nieuwenhuys was hij geneigd 'de oorzaken dier mindere sterfte vooral toe te schrijven aan lokale omstandigheden in die buurten, aan frisschere lucht en betere doorstrooming in de grachten, meer aan de plaatselijke gesteldheid der buurten zelve, dan aan de gewoonten en levenswijze der bewoners'. ${ }^{102}$ Het ziektepatroon werd dus in hoofdzaak door fysischgeografische factoren gedetermineerd. Factoren die Egeling in dit verband noemde, waren ongunstige gesteldheid van de bodem, onvoldoende frisse lucht, aanwezigheid van vuilnisbelten, de vele stinkende grachten en de 'modderpoelen met hare miasmen'.

In het tweede deel van zijn onderzoek heeft Egeling willen aantonen, dat de factor sociale welstand bepalend is voor de vraag op welke wijze het bestaande ziektepatroon van invloed is op de mortaliteit. Egeling deelde de sterftecijfers in volgens de methode van Israëls: de groepering van de buurten in vier graden van sociale welstand (dus in graden van levensomstandigheden ter plekke). Zodoende kwam vast te staan dat over de periode 1856-1860 de arme buurten de hoogste gemiddelde sterfte vertoonden $(3,2 \%)$, terwijl in de gegoede buurten de gemiddelde sterfte het laagst was $(2,06 \%)$. De sterfteverhouding daalde parallel aan de trapsgewijze vermindering van het aantal armen in de vier groepen. ${ }^{103}$ Het verband tussen sterfte en sociale welstand was onweerlegbaar aangetoond, aldus Egeling.

Teixeira de Mattos, Israëls en Egeling bevestigden aan de hand van cijfers wat reeds algemeen werd vermoed: het grootste aantal slachtoffers van epidemische ziekten viel in de verontreinigde steden onder de armen, omdat zij in de meest ongezonde delen van de stad woonden; een begrijpelijke verklaring van sociale ziekte- en sterfteverschillen, wanneer men bedenkt dat de sociale lagen van de Amsterdamse bevolking in deze tijd inderdaad relatief gescheiden leefden in arme en rijke buurten, die in hun 'fysieke conditie' (kwaliteit van bodem, water en lucht, bevolkingsdichtheid en woningbouw) sterk van elkaar verschilden. 
Vanaf 1860 waren de leden en de correspondenten van de NMG-commissie voor de statistiek in staat een aanzienlijke hoeveelheid medisch-statistische boeken en artikelen te publiceren. ${ }^{104}$ Gedeeltelijk was dit te danken aan de verbeteringen van de berekeningsmethode en de registratie. Maar ook hebben vanaf 1859 de medewerking van afdeling Medische Politie van het ministerie van Binnenlandse Zaken en de verhoogde werkzaamheid van enkele commissies van geneeskundig toevoorzicht het statistisch onderzoek bevorderd. Het gevolg was een aantal publikaties over enkele afzonderlijke ziekten, zoals de cholera en de difterie.

In 1861 achtte de Maatschappij de tijd gekomen voor de samenstelling van een geneeskundige topografie van Nederland. Deze moest dienen 'als krachtige hefboom, om de behartiging der Hygiène bij Regeering, Autoriteiten en Gemeentebesturen te bevorderen en in de hand te werken'. ${ }^{\circ}$ ' De leiding van het onderzoek werd in handen van De Man gelegd. Hij kon niet alleen rekenen op de medewerking van het ministerie van Binnenlandse Zaken, maar ook op die van de geoloog en landhuishoudkundige W.C.H. Staring, die sinds 1857 in opdracht van de regering de bewerking van de geologische kaart van Nederland van de opgeheven Rijkscommissie voor de geologische kaart had overgenomen. Bovendien was een groot aantal geneeskundigen verspreid over het land De Man bij het onderzoek behulpzaam.

Ruim vier jaar heeft De Man aan de topografie gewerkt. Ze werd in 1866 onder de titel Sterfte-atlas van Nederland door de NMG uitgegeven. De Man heeft zich bij het opstellen ervan duidelijk door de bodemtheorie van Von Pettenkofer laten leiden. De atlas vermeldde voor de periode 1841-1860 per gemeente (in totaal 1139) de sterfte naar leeftijd, het aantal geboorten en levenloos aangegeven kinderen. Deze gegevens waren aangevuld met informatie over de bevolkingsdichtheid en het welvaartspeil van de gemeente. ${ }^{107}$ Op het cartogram werd de geologische gesteldheid aangegeven, terwijl in een tabel de gemeenten naar hun geologische kenmerken waren gegroepeerd: voor NoordBrabant bijvoorbeeld de Zeeuwse kleirand, het land van Heusden, de Limburgse Maasrand, de Peel enzovoorts.

Er bleek in Nederland een duidelijk statistisch onderscheid te bestaan tussen laag- en hooggelegen gebieden. De laaggelegen gebieden, gevormd door de kleien veengronden in het westen en het noorden, hadden een hoog sterftecijfer, soms wel oplopend tot 50 per duidend inwoners, terwijl op de hoger gelegen zandgronden bepaalde streken een sterfte van nog geen 20 per duizend inwoners kenden. Een soortgelijk geografisch bepaald onderscheid bleek te bestaan ten aanzien van de zuigelingensterfte. Door de wijze van presenteren van de gegevens liet De Man dus uitkomen, dat de sterfte over Nederland was verdeeld volgens een door de bodemgesteldheid bepaald patroon. Minder duidelijk daarentegen was het verband tussen sterfte enerzijds en bevolkingsdichtheid of gemiddeld welvaartspeil anderzijds, en het belang van verder statistisch onderzoek naar dit verband werd daarom betwijfeld. ${ }^{\text {los }}$

De sterfte-atlas bevestigde de theorie van Von Pettenkofer: het deel van de bevolking dat het meest te lijden had van dodelijke volksziekten, leefde op een vochtige bodem met een wisselend grondwaterpeil; een bodem die door voortdurende verontreiniging met organische stoffen deze volksziekten voortbracht. 'Men ontwaart dus, dat bijna de helft van den Nederlandschen bodem voor eene 
gezonde bewoning eigenlijk (d.i. van nature) ongeschikt is', luidde het commentaar van Coronel. De bevolking besefte dit echter volgens hem onvoldoende: 'De poreuze en veenachtige grond, die de overblijfselen van eene afgestorvene plantenwereld bevat, werd toch veelal vermengd met de uitwerpselen van menschen en dieren, ja zelfs met het stoffelijk overschot van menschen en dieren, waarbij zich voegden de producten van den organischen afval uit de menschelijke bedrijvigheid voortgesproten, en al deze stoffen in staat van ontbinding verkeerende, onder den invloed van lucht en water, maken dien bodem wel tot eene veilige rustplaats der dooden, maar tevens tot eene gevaarlijke verblijfplaats voor de levenden'. ${ }^{109}$ De hoge sterfte werd toegeschreven aan een verkeerd gebruik van de bodem die voor bewoning toch al weinig geschikt was.

Dat een groot deel van de bevolking op een 'ziektegevoelige' bodem woonde, was een historisch gegeven waaraan weinig viel te veranderen. Maar men kon de schadelijke eigenschappen van de bodem beheersbaar maken. 'Wij behoeven niet te zeggen van hoeveel gewigt het is, dat men de regels der gezondheidsleer naauwgezet in acht neme, wanneer men op zulk een bodem zich eene geschikte woonplaats kiezen wil', aldus Coronel in een verhandeling over het bouwen van woningen en het aanleggen van sanitaire voorzieningen. ${ }^{110}$ Ook Ali Cohen stipuleerde telkens dat 'meer nog dan de invloed der natuur [..] de gezondheidsen sterftetoestand wordt beheerscht door de verschillende toestanden der beschaving'. ${ }^{11}$ Om die reden legde hij zich na 1855 toe op de beschrijving van de 'maatschappelijke toestand der bewoners' en op de preventieve maatregelen die op gemeentelijk niveau mogelijk waren. Allereerst in een lang artikel in het Nederlandsch Tijdschrift voor Geneeskunde, en vervolgens in lezingen die hij in het hele land hield, wees hij op de grote sterfteverschillen tussen gemeenten met alluviale bodem. 'De statistiek der sterfte, en met name die van de kleine, tedere kinderen, die de beste thermometer voor de kennis van de welvaart van eenig volk of gedeelte van een volk is' toonde aan dat de sterfte het hoogst was op die plaatsen waar de schadelijke milieufactoren het minst krachtdadig werden bestreden. Hij was stelling van mening dat een groot deel van de sterfte niet 'fysiologisch', maar 'kunstmatig' was. ${ }^{112}$ Dit betekende volgens Ali Cohen niets anders dan dat de mensen zelf - in het bijzonder de verantwoordelijke politici de sterfte kunnen terugdringen door de mogelijkheden van wetenschap en techniek te benutten. Het politiek programma waarin de hygiënisten deze conclusie uitwerkten, vormt het onderwerp van de volgende drie hoofdstukken.

Samenvattend kunnen we stellen dat statistisch onderzoek naar de sterfte en een zorgvuldige beschrijving van de omstandigheden waaronder de bevolking leefde in de periode $1850-1865$ de basis vormden voor een analyse van de volksgezondheid. Aan de hand van brutosterftecijfers spoorde men gezondheidsverschillen per regio, gemeente of stadsdeel op. Wanneer de sterftepercentages van een omschreven plaats in ongunstige zin afweken van die in de directe of ruimere omgeving, wees dat erop dat zich daar ziekmakende invloeden lieten gelden.

Voorzien van deze kennis ging men aan de hand van beschrijvingen van woongemeenschappen na, welke oorzaken de gevonden verschillen in de sterfte konden hebben. Vooral omstandigheden die naar men veronderstelde 'schadelijke uitwasemingen' veroorzaakten of de uitwerking daarvan versterkten, stonden in de belangstelling: stedelijke vervuiling, de geologische gesteldheid van de 
bodem, de voedingstoestand van de bevolking. In een cartogram legde men de ruimtelijke verdeling van ziekten en sterfte vast. De aldus van plaats tot plaats verkregen gegevens interpreteerde men in het licht van de theorie dat de plaatselijke omstandigheden bepalend waren voor het voorkomen van ziekten en voor de relatieve hoogte van de sterftecijfers.

Dit lokalisme beleefde halverwege de jaren zestig een hoogtepunt. De hygienisten konden toen de gezondheidstoestand en de zorg voor de openbare hygiëne in een groot aantal gemeenten in een oogopslag met elkaar vergelijken. Een vergelijking van de sterftecijfers per gemeente maakte duidelijk dat de hoogte van de sterfte en de aanwezigheid van epidemische ziekten werden bepaald door overheidsmaatregelen ter eliminering van de schadelijke invloeden, die de samenleving zelf had opgeroepen. De scheidslijn tussen een gezond en een ongezond gebied was in feite een demarcatie tussen plaatsen met een actief en een passief gezondheidsbeleid. Ten slotte hadden de hygiënisten statistisch onderzoek naar de sociale sterfteverschillen ontwikkeld. Aangezien rijk en arm verschillende buurten bewoonden, herleidde men ook deze sterfteverschillen tot fysisch-geografische kenmerken van het milieu. De scheidslijn tussen de sociale klassen viel samen met die tussen het leven in een gezond en een ongezond milieu. Deze lokalistische opvattingen bepaalden het politieke optreden van de hygiënisten in de jaren tachtig. 


\title{
Politieke impasse
}

\begin{abstract}
Zij het langzaam (en wàt gaat er bij ons snel?), toch begint zich eene openbare meening te vormen omtrent [..] de openbare gezondheid. Voor den Staatsman begint de ligchamelijke welvaart der Natie een politiek moment te zijn.
\end{abstract}

\section{J.P. Heije, 1858.}

De hygiënisten wilden met hun statistisch onderzoek aantonen dat een groot deel van de sterfte door hygiënische maatregelen was te voorkomen. Zij wilden ook laten zien, dat de overheid alleen door nauw met hen samen te werken een doeltreffende openbare gezondheidsregeling tot stand kon brengen. Het onderzoek ging daarom van het begin af aan gepaard met het uitoefenen van politieke druk, zowel op landelijk als op plaatselijk niveau.

Tegelijkertijd moesten de hygiënisten rekening houden met de in 1849 voorgestelde hervormingen van het Geneeskundig Staatsbestuur. Hun positie in het toekomstig Geneeskundig Staatsbestuur was in het geding, omdat deze hervormingen ook betrekking hadden op de zorg voor de openbare hygiëne. Het is niet verwonderlijk dat enkele hygiënisten een vooraanstaande rol hebben gespeeld bij de herziening van de geneeskundige wetgeving.

In dit hoofdstuk worden de politieke activiteiten van de hygiënisten in de jaren 1850-1860 beschreven. Daarbij wordt tevens ingegaan op de landelijke politieke ontwikkelingen die voor de geneeskundige wetgeving van belang zijn geweest.

\section{Tussen liberaal en conservatief}

\section{Moeilijkheden bij de afdeling Medische Politie}

De discussies over de geneeskundige wetgeving werden in de jaren vijftig beheerst door de volgende drie problemen. Allereerst stond men voor de vraag war er moest gebeuren met de wetsontwerpen van de staatscommissie van 1848 . $\mathrm{Ze}$ werden de inzet van een tien jaar durende touwtrekkerij tussen politici en medici, en tussen medici onderling. Het tweede vraagstuk betrof de openbare hygiëne: welke praktische consequenties dienden de landelijke en plaatselijke overheden te trekken uit de door medici vastgestelde verbanden tussen volksgezondheid en sanitaire omstandigheden? Een derde, in geneeskundige kring druk besproken probleem was het gebrek aan daadkracht in bij de centrale overheid. Geen enkele minister was bij machte een duidelijke positie in te nemen ten opzichte van de talrijke politieke meningsverschillen en belangentegenstellingen.

Thorbecke wilde, zoals we gezien hebben, de aanbevelingen van de staatscommissie van 1848 niet overnemen, omdat deze niet in overeenstemming waren 
met zijn liberale staatsopvatting. Omdat de commissie geweigerd had de voorstellen in liberale zin bij te werken, moest Thorbecke omzien naar nieuwe adviseurs. Hierbij stuitte hij op problemen. Na zijn aantreden in 1849 had Thorbecke besloten de organisatie van zijn departement ingrijpend te herzien. In maart 1850 had hij de arts-jurist C.J. Loncq jr., plaatsvervangend kantonrechter te Apeldoorn, tot referendaris voor 'geneeskundige zaken' benoemd (het ministerie had sinds het ontslag van de raadadviseur Van Maanen in 1848 geen medisch adviseur meer). 'Geneeskundige zaken', dat sinds 1848 onder de afdeling Onderwijs, Kunsten en Wetenschappen viel, werd vervolgens aan een afzonderlijke afdeling onder zijn leiding opgedragen. Als de negende afdeling 'Medische Politie' keerde zo in 1850 de afdeling 'Geneeskundige Staatsregeling' terug, die het ministerie van Binnenlandse Zaken tot 1832 had gekend. ${ }^{I}$

Thorbecke had Loncq gekozen, omdat deze zowel medicinae doctor als meester in de rechten was en dus bij uitstek in staat moest worden geacht de nagestreefde wetsherzieningen tot een goed einde te brengen. Bovendien had Thorbecke het voornemen om in aansluiting op de nieuwe Gemeentewet, richtlijnen voor de burgemeesters te vervaardigen ter verbetering van de plaatselijke gezondheidsvoorzieningen. De minister bleek met Loncq echter een politieke tegenstander in huis gehaald te hebben. In november 1851 moest de minister de Tweede Kamer meedelen, dat van zijn voornemens vooralsnog niets was verwezenlijkt. Hij toonde zich bijzonder teleurgesteld en legde de schuld bij Loncq: 'de mindere werkzaamheid van het personeel der afdeeling medische politie was ook, hier eene reden van vertraging'. "Een jaar later kon de minister nog steeds geen wetsontwerpen aanbieden. Omdat hij niet de ondersteuning kreeg die hij verlangde, kon hij zelfs geen datum noemen waarop de ontwerpen ingediend zouden worden. Thorbecke beloofde de Kamer ditmaal dat 'binnen korten tijd gezorgd [zal] worden voor eene versterking van personeel" "De minister vroeg de Kamer verschoning voor het feit dat hij niet nader op deze zaak, 'die met persoonlijke omstandigheden zamenhangt', inging. ${ }^{3}$

Thorbeckes ongebruikelijke inculpatie van een ambtenaar was het gevolg van het feit dat Loncq na de ontbinding van de staatscommissie alle pogingen van Thorbecke om iets te bewerkstelligen op het gebied van de geneeskundige wetgeving had gedwarsboomd. Wat er precies aan de hand is geweest tussen Thorbecke en Loncq is onduidelijk, maar zeker is dat de verhouding tussen beiden emstig verstoord was. De houding van Loncq had Thorbecke al in de zomer van 1852 doen uitkijken naar een nieuwe adviseur. Sindsdien zouden Loncq en Thorbecke nog slechts schriftelijk met elkaar hebben gecommuniceerd. 4

\section{Thorbeckes persoonlijke adviseurs}

Het viel Thorbecke niet gemakkelijk zich te verzekeren van de steun van loyale adviseurs. Van de medici die in deze tijd schriftelijk hun diensten aanboden, zoals Ali Cohen, Verwey uit Den Haag, en Th.A. van Schermbeek uit Utrecht, had de laatste Thorbeckes voorkeur. Van Schermbeek was een bekende persoonlijkheid in Utrecht. Hij was in de jaren 1834-1840 stadsgeneesheer geweest en had daarna in de kring van welgestelden een grote praktijk opgebouwd. Thorbecke deed veel moeite om hem aan zijn ministerie te binden, maar op het laatste moment zag Van Schermbeek toch van de betrekking af. Hij vreesde ongewild betrokken te raken bij de discussies in de NMG, waarvan hij 
zelf geen lid was. Bovendien had men hem in zijn directe omgeving afgeraden zich met de zaak van de geneeskundige wetgeving in te laten zolang de politieke twisten tussen Thorbecke en Mulder voortduurden en de referendaris Loncq aan bleef. $^{6}$

Met het oog op een regeling van de openbare hygiëne trachtte Thorbecke ook de Haagse medicus Schick tot medewerking te bewegen. Schick had naam gemaakt door zijn onderzoekingen naar de gezondheidstoestand in Zuid-Holland en Den Haag, en had in 1852 de NMG vertegenwoordigd op het internationale hygiënische congres in Brussel. ${ }^{7}$ Ook Schick moet voor het adviseurschap hebben bedankt, want in december 1852 wendde Thorbecke zich tot Verwey met het verzoek om onafhankelijk van de referendaris Loncq, 'ontwerpen van voorschriften of verordeningen in het belang der openbare gezondheidsregeling samen te stellen'. ${ }^{8}$ Verweys loopbaan was tot dusverre weinig succesvol geweest. Na zijn studie in Groningen - hij was een jaargenoot van Ali Cohen - had hij zich in Den Haag gevestigd, maar hij was er niet in geslaagd een financieel gezonde praktijk op te bouwen. In 1848, na het ontslag van de referendaris Van Maanen, had hij zich tevergeefs als medisch adviseur bij minister De Kempenaer aangeboden. Vanaf 1850 kon hij maar ternauwernood in zijn levensonderhoud voorzien. Sindsdien schreef hij talrijke brieven aan Thorbecke, waarin hij de bewindsman zijn diensten aanbood. Dit leidde uiteindelijk tot Thorbeckes verzoek. ${ }^{9}$ De minister gaf te kennen van Verwey uitsluitend advies met betrekking tot openbare gezondheidsmaatregelen van gemeentebesturen te verwachten. Hem stonden aanvullende maatregelen op de Gemeentewet van 1851 voor ogen, naar het voorbeeld van België. ${ }^{10}$

De eerste - en enige - maatregel die Thorbecke in januari 1853 nam op grond van een advies van Verwey, betrof de hondsdolheid. De ziekte had de voorgaande jaren een toenemend aantal slachtoffers geëist. In een circulaire maande de minister de gemeentebesturen scherper toe te zien op het loslopen van honden. Thorbecke ging niet zover als Verwey, die een algemene hondenbelasting en muilkorving voor 'karrehonden' verplicht had willen stellen. ${ }^{\text {" }}$

Hoewel Verwey geen vergoeding voor zijn arbeid ontving, diende hij in de eerste twee maanden van 1853 tal van voorstellen bij de minister in: bouwvoorschriften voor scholen, een ontwerp begrafeniswet, een voorstel voor een landelijk onderzoek naar de kindersterfte en reglementen voor bad- en washuizen. Alle hadden ze de bedoeling de gemeentebesturen aan te zetten hun verplichtingen met betrekking tot de volksgezondheid na te komen. Verwey hield zich echter niet aan Thorbeckes verzoek om zich te beperken tot voorschriften voor gemeentebesturen. Hij stelde tevens drie wetsontwerpen met betrekking tot het geneeskundig staatsbestuur op, die in grote lijnen een uitwerking waren van de voorstellen van de staatscommissie van $1848 .{ }^{12}$ Thorbecke legde alle genoemde ontwerpen van Verwey naast zich neer, omdat ze hem politiek gezien niet gelegen kwamen. Bovendien had hij om deze voorstellen niet uitdrukkelijk gevraagd. De minister verzocht Verwey in februari om hem voorlopig geen nieuwe voorstellen meer te doen toekomen.

Ondertussen was het Thorbecke nog altijd niet gelukt zich te verzekeren van deskundige geneeskundige adviseurs op het gebied van de herziening der geneeskundige wetten. De tijd begon te dringen. In de Tweede Kamer werd herhaaldelijk gevraagd, wanneer de nieuwe geneeskundige wetten konden worden verwacht. Door het uitblijven van wetsontwerpen dreigde de minister tevens de sympathie van de NMG te verliezen. Daar kwam bij dat Mulder - die 
zich inmiddels als een persoonlijke vijand van Thorbecke had doen kennen - in de Geneeskundige Courant een venijnige aanval op Thorbecke had geopend. ${ }^{13}$

Mogelijk op advies van Van Schermbeek, die in deze tijd in persoonlijk en politiek op zeer goede voet met Thorbecke stond, trok de minister in februari Penn - op dat moment voorzitter van de NMG - en Ali Cohen als onbezoldigde, persoonlijke adviseurs aan. ${ }^{14}$ Ali Cohen werd bovendien - net als Verwey buiten de referendaris Loncq om - gevraagd naar Den Haag te komen, om de minister met raad en daad bij te staan, zodra de behandeling van de wetsontwerpen in de Kamer een aanvang zou nemen. Toen deze om financiële redenen weigerde, werd hem gevraagd of hij de voorstellen van de staatscommissie en van Verwey dan in zijn eigen studeerkamer wilde bewerken. Thorbecke was enigszins bekend met de persoon van Ali Cohen. Sinds 1850 verleende de minister zijn medewerking aan de totstandkoming van het door Ali Cohen uitgegeven Nieuw statistisch geneeskundig Jaarboekje. ${ }^{15}$ En bovendien had Ali Cohen zich, nadat hij in 1851 zonder succes had gesolliciteerd naar het hoogleraarschap voor fysiologie in Groningen (Thorbecke benoemde Izaak van Deen), tot de minister gewend met het verzoek hem aan te stellen in een betrekking 'waar geneeskunde en staathuishoudkunde hand in hand gaan'. ${ }^{16}$ Ali Cohen stond bekend als een toegewijd aanhanger van Thorbecke: hij was bestuurslid van de liberale kiesvereniging 'Vrijheid en Orde' in Groningen, waartoe onder meer de bekende Groningse politici Willem de Sitter en S. Blaupot ten Cate hoorden.

Penn en Ali Cohen behoorden tot de weinigen die openlijk afstand hadden genomen van het rapport van de staatscommissie, en uitvoerig waren ingegaan op de toekomst van de zorg voor de openbare gezondheid. In 1851 had Penn de aanval op het rapport van de staatscommissie geopend met een serie artikelen in het Nederlandsch Weekblad voor Geneeskundigen. ${ }^{17}$ Hij verwierp het idee van een vertegenwoordiging van kunstbeoefenaren in het staatsbestuur, omdat dit in strijd was met het beginsel van de staatsinrichting. Niet elke afzonderlijke stand, maar alle burgers gezamenlijk diende vertegenwoordigd te zijn. De politieke en zedelijke invloed van de beroepsgroep was door het bestaan van de NMG al groot genoeg. Voor advisering van de regering was een 'Academie van Geneeskunde' voldoende. Penn meende dat het toezicht op de uitoefening van de geneeskunst door bevoegde geneeskundigen (het later zo genoemde medisch tuchtrecht) in handen van de medische beroepsgroep zelf moest liggen en niet langer in een wet moest worden geregeld. In tegenstelling tot de commissie van 1848 pleitte Penn voor één soort van geneeskundigen. De vrees dat het platteland dan verstoken zou raken van medische hulp, achtte hij ongegrond.

De gerechtelijke geneeskunde, waarvoor de staatscommissie van 1848 een apart wetsvoorstel had opgesteld, kon beter in het kader van de bestaande strafrechtbepalingen geregeld worden. Wat betreft de 'verpligtingen en rechten der personen, belast met toezicht op de zorg van den gezondheidstoestand en uitoefening der geneeskunst' leek het Penn onverstandig zich te richten op landen als Oostenrijk en Pruisen, omdat de staatsinrichting er al te zeer afweek van die in Nederland. In de ontwerpen van de staatscommissie waren de rechten van de geneeskundige ambtenaren bovendien te vaag omschreven. Het al dan niet mogen betreden door zulke ambtenaren van fabrieken en werkplaatsen in 'het algemeen belang' moest volgens Penn per geval door de rechter worden beslist, en niet eens voor altijd door een wet op het geneeskundig bestuur.

Al met al probeerde Penn dus af te rekenen met het staatsgeneeskundige model uit de jaren veertig, door de verantwoordelijkheden van de staat en van 
de medische stand te scheiden, en de nieuwe wetten toe te snijden op de liberale staatsinrichting. Daarbij schilderde hij het model van de medische politie uit de Duitstalige landen als on-Nederlands af.

In vrijwel dezelfde tijd dat Penn zijn programmatische artikelen over een liberaal alternatief publiceerde, wierp Ali Cohen zich op als verdediger van wat hij een 'openbare gezondheidsregeling' noemde. Dit laatste begrip werd bewust door hem gebezigd in plaats van de oude uitdrukking medische politie, omdat er naar zijn mening een nieuwe fase in de zorg van de overheid voor de volksgezondheid was aangebroken. Zijn ervaringen met de cholera in de jaren 18481849 hadden Ali Cohen tot de overtuiging gebracht, dat er een landelijke regeling moest komen die de lagere overheden verplichtte sanitaire maatregelen te nemen. ${ }^{18}$ 'Wij weten zeer wel', schreef hij in 1850 , 'dat het niet geeischt kan worden van den Staat, dat hij de maatregelen neme, [..] maar wij meenen, dat het zijn pligt is te zorgen, dat die maatregelen genomen worden. Uit den aard der zaak zijn 't alleen plaatselijke handelingen, die hier in aanmerking komen. Daarom kan de Staat, als zoodanig, en onmiddellijk hier weinig doen'. Ali Cohen pleitte voor de instelling van permanente in plaats van incidentele gemeentelijke commissies. Geheel werkeloos kon de centrale overheid natuurlijk niet toezien, want 'zonder tusschenkomst der Hooge Regering zal 't toch wel niet aan te nemen zijn, dat algemeen de gewenschte maatregelen worden genomen. Bemoeit de Regeering zich er niet mede, dan zall bij 't onverhoopt wederverschijnen van de Cholera [..] het er mede gaan, zoo als 't nu gegaan is. Dan zal de eene stad [..] vele maatregelen nemen, [..j] terwijl de andere het laissez aller op treurige wijze zal in toepassing brengen'.

In 1852 publiceerde Ali Cohen een zeer lang artikel in zijn eigen Nieuw Practisch Tijdschrift voor de Geneeskunde, waarin hij de zorg van de staat voor de volksgezondheid theoretisch trachtte te onderbouwen. In het bijzonder steunend op Quetelet en herhaaldelijk verwijzend naar successen van de Franse en Engelse sanitaire hervormers, zette Ali Cohen uitvoerig uiteen, welke de maatschappelijke (lees: economische) voordelen van een goede openbare gezondheidszorg zijn. In Engeland, Frankrijk en België was de bevolking aanmerkelijk gezonder en dus produktiever geworden als gevolg van de gezondheidspolitiek in die landen, terwijl in Nederland de gemiddelde leeftijd sinds de achttiende eeuw was teruggelopen. ${ }^{20}$ Opnieuw verdedigde hij het denkbeeld van de plaatselijke commissies, die naar Belgisch voorbeeld en passend in het kader van de nieuwe 'uitmuntende' Gemeentewet de besturen moesten aanzetten tot het zorgdragen voor 'gezonde woningen en zuiverheid van spijzen en dranken'. 21 In dit artikel constateerde Ali Cohen bovendien dat de gemeentebesturen voor het merendeel geen uitvoering hadden gegeven aan de gezondheidsbepalingen in de Gemeentewet. Dit gaf hem eens te meer reden om voor aanvullende wettelijke bepalingen te pleiten.

De opvattingen van Ali Cohen weken aanzienlijk af van die van de staatscommissie van 1848, die immers een streng en centralistisch stelsel van medische politie in het leven had willen roepen. Hij streefde naar een openbare gezondheidsregeling die bij de nieuwe thorbeckiaanse staatsinrichting aansloot: de verantwoordelijkheid voor sanitaire maatregelen moest niet bij de landelijke, maar bij de gemeentelijke overheid liggen. Er diende een permanent gemeentelijk toezichthoudend apparaat gevormd te worden, dat uitsluitend gericht was op de bevordering van een gezondheidspolitiek en niet langer belast was met disciplinaire taken. 
Het is duidelijk dat Thorbecke, toen hij Penn en Ali Cohen vroeg de nieuwe geneeskundige wetten voor te bereiden, kon rekenen op twee medici, die bereid waren de voorstellen van de staatscommissie van 1848 te wijzigen, en die bovendien de kritiek van Mulder en zijn medestanders durfden te trotseren.

De bewerking van de wetsontwerpen door Thorbecke, Penn en Ali Cohen werd in april 1853 abrupt afgebroken door de val van het misschien ook enigszins uitgeregeerde kabinet-Thorbecke in april 1853 naar aanleiding van het herstel van de katholieke hièrarchie in Nederland. Daarmee kwam een voorlopig einde aan de pogingen de gezondheidszorg langs liberale lijnen vorm te geven. Thorbecke had al te veel tijd verloren met het zoeken naar goede adviseurs - mede door de interne verdeeldheid van de medische. Nu waren de conservatieven - met het rapport van de staatscommissie van 1848 in de hand aan zet.

\section{Het tegenspel van de conservatieven}

Het verzet tegen het herstel van de katholieke hiërarchie had zijn wortels in de onvrede over de grondwetswijziging van 1848. De kring rond de Koning, de meerderheid van het parlement en talrijke ambtenaren op hoge posten hadden de grondwetsherziening met verbijstering en afschuw aangezien. De patriciërs, de grote handelshuizen, de oude regentenfamilies en de aristocratie hoopten dat Nederland zich, zoals Frankrijk, Pruisen en Oostenrijk, in conservatieve richting zou ontwikkelen. Na een mislukte poging in $1852 \mathrm{om}$ via een petitie aan de koning het kiesrecht in conservatieve zin te herzien, greep behoudend Nederland het herstel van de katholieke hiërarchie en de liberale plannen voor een nieuw stelsel van armenzorg aan om Thorbecke het regeren onmogelijk te maken. De oppositie culmineerde in de bekende April-beweging, die de publieke opinie overspoelde met protestantse, anti-papistische en conservatieve sentimenten. Het was alsof iedereen zoch toen pas realiseerde waartoe de grondwetswijziging had geleid.

Het wekt geen verwondering dat juist Mulder zich tot een belangrijk woordvoerder van deze beweging ontpopte. Hem was er alles aan gelegen de verderfelijke politiek van 'de vuile Roomschen en liberalisten' te torpederen. ${ }^{22}$ Mulder, inmiddels een vertrouweling van de koning, behoorde ongetwijfeld tot degenen die de vorst ertoe hebben bewogen, zich van Thorbecke te ontdoen. Willem III keerde zich openlijk tegen Thorbecke en de Grondwet, en verleende prompt het vervolgens door het kabinet-Thorbecke aangeboden ontslag. Vrijwel direct presenteerde de Koning, die al enkele dagen met een regeling voor de opvolging van Thorbecke bezig was geweest, een nieuw kabinet: het kabinet-Van Hall. Tegen de zin van de Koning had F.A. van Hall 'een eerlijke en loyale uitvoering der bestaande Grondwet' bedongen. Desalniettemin had hij zich bereid verklaard tot 'wijziging, in eenen meer behoudenden zin, van kies- en gemeentewetten'.23 Tot minister van Binnenlandse Zaken werd benoemd mr. G.C.J. van Reenen, de jonge burgemeester van Amsterdam. Evenals Van Hall behoorde hij tot de Hollandse 'moderaten', gematigde liberalen met connecties in de Amsterdamse bankierswereld. Naar zou blijken, voegden Van Hall en Van Reenen zich gemakkelijk naar de door Thorbecke geschapen staatsinrichting. Deze bleef dan ook onveranderd in stand.

Voor de geneeskundige wetgeving zag het er minder rooskleurig uit. Zoals gezegd heeft Thorbecke tijdens zijn ministerschap op dit terrein geen noemens- 
waardige vooruitgang geboekt en zijn officieuze adviseurs moesten al snel hun plaats weer inruimen voor referendaris Loncq. ${ }^{24}$ Deze toonde weinig bereidheid om op enigerlei wijze met Penn, Ali Cohen of andere leden van de NMG samen te werken. Ali Cohen bood nog in augustus 1853 tijdens een persoonlijk onderhoud met Van Reenen zijn ontwerpen van wet aan, maar deze verdwenen geruisloos in de la. ${ }^{25}$ In november 1853 verklaarde de minister tegenover de Tweede Kamer geen kans te zien de gehele medische wetgeving op korte termijn te herzien. Hij was daarom desnoods bereid een partiële regeling in te voeren. Mogelijk stonden Van Reenen hiervoor twee door Ali Cohen opgestelde wetsontwerpen voor ogen. Die uitspraak van de minister ontmoette echter nogal wat kritiek, onder anderen van het kamerlid Thorbecke. ${ }^{26}$ Het jaar daarop verklaarde Van Reenen dat hij zich toch zou baseren op het rapport van de staatscommissie van $1848 .{ }^{27}$ Maar de minister wist blijkbaar niet goed wat hij met de hele kwestie aan moest - stagneerde referendaris Loncq het verloop? - , want tot aan het einde van zijn ambtsperiode in juni 1856 onthield hij zich van ieder initiatief om een wetsvoorstel in te dienen.

Ondertussen had Mulder niet stil gezeten. Tot groot ongenoegen van hem en zijn medestanders, die met de door de Aprilbeweging losgewoelde conservatieve sentimenten hun voordeel hadden willen doen, zette het kabinet-Van Hall in grote lijnen het beleid van Thorbecke voort. Mulder hervatte daarom de strijd, en zette zich aan de spits van de kiesvereniging 'Koning en Vaderland', die ijverde voor een terugkeer naar de situatie van vòor $1848 .^{28}$ Eind 1853 ondernam Mulder een poging om de minister via de Koninklijke Nederlandse Akademie van Wetenschappen onder druk te zetten met nieuwe voorstellen op geneeskundig gebied. ${ }^{29}$ Mulders streefde er waarschijnlijk naar de minister over te halen op het terrein van de medische politie voortaan advies in te winnen bij de Akademie. Die pogingen liepen op niets uit, omdat Van Reenen niet inging op de voorstellen van de Akademie.

Mulders kansen namen echter weer toe, toen in 1856 het kabinet-Van der Brugghen was aangetreden, dat vooral was bedoeld om de conservatieve wensen uit 1853 concreet ten uitvoer te brengen. De aanleiding voor de val van het kabinet-Van Hall vormde het onder minister Van Reenen gereedgekomen wetsontwerp op het lager onderwijs. Het ontwerp was naar de mening van de protestants-conservatieven te weinig op versterking van het christelijk onderwijs gericht. De Koning en zijn adviseurs, onder wie Mulder, meenden dat de tijd gekomen was om een werkelijk conservatief kabinet te vormen, dat niet alleen meer aandacht voor de belangen van het bijzonder onderwijs zou hebben, maar ook de grondwet van 1848 zou herzien. Na een zeer moeizame formatie kwam het door de koning gewenste kabinet inderdaad tot stand. De post van minister van Binnenlandse Zaken kreeg G. Simons toebedeeld, directeur van de Koninklijke Academie ter opleiding van burgerlijke ingenieurs en van de Opleidingsschool voor Indische ambtenaren te Delft. Simons was een vriend en een politiek geestverwant van Mulder, en tevens een vertrouweling van de koning. ${ }^{30}$ Behalve dat aan de doctrinair-liberale politiek een belangrijke slag was toegebracht, leek ook de realisering van de plannen van de staatscommissie van 1848 binnen bereik te liggen.

Simons, bijgestaan door referendaris Loncq, moet de zaak voortvarend hebben aangepakt, want tegen het einde van 1856 kon hij de Tweede Kamer melden, dat de wetsontwerpen in opzet gereed waren. Voor een belangrijk deel kwam de inhoud overeen met die van de wetsontwerpen van de staatscommissie van 1848: 
alleen het wetsontwerp op de gerechtelijke geneeskunde had de minister niet overgenomen. De aanhangers van de staatscommissie beschouwden deze weglating weliswaar als een ernstige vergissing, maar voor het overige leken de nieuwe geneeskundige wetten in de geest van de staatscommissie tot stand te zullen komen.

Alvorens de politieke verwikkelingen na 1856 te bespreken, moeten we eerst een de rol van de gemeentepolitiek en de gemeentelijke gezondheidscommissies bij de totstandkoming van de 'openbare gezondheidsregeling' in beschouwing nemen.

\section{De eerste pogingen tot sanitaire hervormingen}

\section{De gemeentelijke gezondheidscommissies}

De regering boekte dan wel geen vooruitgang bij de herziening van de geneeskundige wetten, in de samenleving zelf namen de bemoeienissen van medici met de volksgezondheid toe. De hygiënistische ideologie zoals onder andere verwoord door Pruys van der Hoeven vatte verbetering van de maatschappelijke toestand als een der belangrijkste wetenschappelijke en zedelijke plichten van de arts op. Vele artsen zetten zich nu op lokaal niveau in deze geest in. Hun activiteiten leidden ertoe dat de Tweede Kamer zich na 1856 niet alleen moest buigen over de bevindingen van de staatscommissie van 1848, maar ook over de taak van de lokale overheid op het terrein van de volksgezondheid.

Een belangrijke stimulans voor de lokale activiteiten van de hygiënisten waren de contacten met het buitenland. Op de internationale hygiënische congressen die in het van de jaren vijftig in Brussel plaatsvonden, bleek volgens de hygiënisten de grote achterstand, die Nederland op het punt van de openbare gezondheidszorg had. De Nederlanders hadden maar weinig positieve ontwikkelingen uit eigen land te melden. ${ }^{31}$ Egeling schreef naar aanleiding van de Brusselse congressen in De Gids, dat er 'geen land is, waar meer voor de openbare gezondheidsregeling gedaan, waar het physiek welzijn der burgers beter behartigd wordt dan in België'; verontwaardigd voegde hij er aan toe: 'weinig beschaafde landen zijn er, waar de hygiëne in alle opzichten meer verwaarloosd wordt dan in Nederland!' 32

Het idee dat Nederland een achterstand had ten opzichte van de omringende landen leidde tot een aantal initiatieven, die Nederland weer in de pas moesten doen lopen met de rest van Europa. Men bepleitte naar het voorbeeld van de Belgische 'comités d'hygiène et de salubrité' de instelling van gezondheidscommissies per gemeente. Juist nu het verband tussen volksgezondheid en plaatselijke levensomstandigheden steeds duidelijker werd, moesten zulke lokale commissies leiding geven aan de reorganisatie van het leefmilieu.

Bijna vier jaar nadat Ali Cohen als eerste had gepleit voor gemeentelijke gezondheidscommissies, nam de gemeenteraad van Rotterdam in april 1854 het initiatief tot de oprichting van een dergelijke commissie. Deze bestond - evenals in België - uit genees- en heelkundigen, rechtsgeleerden en natuur- en scheikundigen, die het gemeentebestuur adviseerde in alles wat de openbare hygiëne betrof en wat dit betreft de taken van de Plaatselijke Commissie van geneeskundig Toevoorzicht overnam. De initiatiefnemers in de Rotterdamse gemeenteraad 
koesterden de hoop dat de maatregel een stap in de richting van een landelijke regeling was, zoals ook in Frankrijk, Engeland en België was gebeurd. ${ }^{33}$ In september 1854 ging de Rotterdamse commissie voortvarend aan de slag. Zij onderzocht de toestand van de schoollokalen, nam de medische statistiek ter hand en diende enkele voorstellen in bij burgemeester en wethouders, zoals een ontwerp-bouwverordening, een plan voor de verbetering van de drinkwatervoorziening en een plan ter bestrijding van de bodemverontreiniging.

Op Rotterdam volgden meer steden. Mulder stelde in september 1854 als lid was van de Utrechtse gemeenteraad voor het voorbeeld van Rotterdam te volgen. ${ }^{35}$ Een jaar later werd een gezondheidscommissie ingesteld, waarvan hij voorzitter was en onder anderen ook Donders deel uitmaakte. In 1855 volgden ook de gemeenten Schiedam en Delft. ${ }^{36}$ In andere steden ging het minder voorspoedig. In Haarlem had de plaatselijke afdeling van de NMG onder aanvoering van Egeling scherpe kritiek op de nieuwe gemeentelijke ontwerpverordeningen op de openbare hygiëne. De afdeling deed het voorstel een gemeentelijke gezondheidscommissie in het leven te roepen, die deze ontwerpverordeningen aan een kritisch onderzoek moest onderwerpen. De gemeenteraad wees dit verzoek resoluut van de hand. ${ }^{37}$ In Groningen probeerde het Gezelschap van Groningsche Geneeskundigen op initiatief van Ali Cohen de gemeenteraad van het nut van een gezondheidscommissie te overtuigen. Ondanks de krachtige steun van de raadsleden De Sitter en Baart de la Faille, alsmede van de Plaatselijke Commissie van geneeskundig Toevoorzicht mislukte deze poging tot tweemaal toe. De meeste raadsleden voelden er niets voor 'geneeskundigen op het fluweel te helpen' en waren beducht voor een 'imperium in imperio". ${ }^{38}$

Terwijl verscheidene gemeenteraden zich nog bogen over de vraag of zij een gezondheidscommissie moesten instellen, nam de Delftse afgevaardigde in de Tweede Kamer mr. W. Wintgens een opmerkelijk, landelijk initiatief. Wintgens was de conservatieve richting toegedaan, al betoogde hij vrij van alle partijverband te zijn. Hij wilde veeleer de Grondwet van 1848 in conservatieve richting corrigeren, in tegenstelling juist tot de conservatieven van het type Mulder, die haar volledig afwezen.

Op 2 oktober 1854 diende Wintgens een initiatief-wetsontwerp in tot instelling van plaatselijke raden van gezondheid ter advisering van gemeentebesturen. Het wetsvoorstel hield in dat het aan de gemeentebesturen zelf werd overgelaten of zij een gezondheidsraad wilden instellen. Besloot men echter tot de oprichting van zo'n raad, dan zou in de betreffende gemeente de wet op de gezondheidsraden in werking treden. Daarin stonden de taken en bevoegdheden van de raad omschreven. De gezondheidsraad zou naast de bestaande commissie van geneeskundig toevoorzicht werkzaam moeten zijn. De bedoeling van het ontwerp was dat de gezondheidsraden, waarvan de leden door het gemeentebestuur werden benoemd, zich om te beginnen zouden toeleggen op een vorm van bouw- en woningtoezicht. Deze taak zou na verloop van tijd met verscheidene andere op het gebied van de openbare hygiëne kunnen worden uitgebreid. ${ }^{39}$

Het wetsvoorstel vertoonde grote gelijkenis met de Public Health Act die in Engeland in 1848 van kracht was geworden. Het belangrijkste verschil met de Engelse wet was dat er geen criteria werden genoemd op grond waarvan het gemeentebestuur een gezondheidsraad moest instellen, en dat een raad over beperktere bevoegdheden beschikte dan die in Engeland. De gemeentelijke autonomie bleef dus op het eerste gezicht intact. Niettemin opende het wets- 
voorstel de weg naar rijksbemoeienis met de gemeentepolitiek door de impliciete erkenning dat gemeentelijke instanties bij wet mochten worden gereglementeerd. De wet zou bovendien gemakkelijk kunnen worden aangevuld met bepalingen, die de gemeenten nog directer onder rijkstoezicht plaatsten.

In geneeskundige kringen hechtte men groot belang aan het initiatief van Wintgens. Het Nederlandsch Weekblad voor Geneeskundigen wijdde in 1856 drie hele nummers plus een bijlage aan de kamerbehandeling. De reeds genoemde Verwey liet het wetsontwerp in het door hemzelf en Pruys van der Hoeven geredigeerde Tijdschrift voor algemene Gezondheids-regeling in zijn geheel afdrukken met een uitvoerig commentaar. Veel hygiënisten hadden liever gezien dat de instelling van de gezondheidsraden verplicht was gesteld, maar de meesten oordeelden toch positief over het voorstel. Met name Ali Cohen gaf zijn onvoorwaardelijke steun aan de gematigd-conservatieve stroming in de persoon van Wintgens, onder meer in enkele artikelen in zijn tijdschrift Het Repertorium. ${ }^{4 O} \mathrm{Nu}$ de liberalen niet meer regeerden, was het kennelijk tijd voor Realpolitik.

In de Tweede Kamer, die de plenaire discussie over het wetsvoorstel in 1856 aangreep om voor het eerst sinds jaren uitvoerig over de volksgezondheid te debatteren, rezen talloze bezwaren tegen het ontwerp. Zo vond menigeen dat het ontwerp al te veel reglementeerde. Sommigen meenden dat het juist te vrijblijvend was, en volgens anderen liep het ontwerp ten onrechte vooruit op de herziening van de geneeskundige wetten. Ook voorzagen enkele kamerleden moeilijkheden tussen de voorgestelde gezondheidsraden en de bestaande plaatselijke commissies van toevoorzicht, die de gemeentebesturen immers ook adviseerden op het terrein van de openbare hygiëne. Vooral de medicus Westerhoff en de Amsterdamse jurist Godefroi, een gematigd liberaal en lid van de staatscommissie van 1848 , verzetten zich tegen het wetsontwerp. Westerhoff steunde gewoonlijk de liberale politiek van Thorbecke, maar op het terrein van de medische politiek was hij een stijle conservatief. Hij wenste de plannen van de staatscommissie van 1848 uitgevoerd te zien, en was dan ook voorstander van een medisch politie-apparaat, dat was samengesteld uit rijksambtenaren met ruime bevōegdheden die onafhankelijk van het plaatselijk bestuur moesten kunnen handelen (binnentreden van woningen, onteigening van goederen, verbaliseren). Godefroi wees bemoeienis van het rijk met de lokale openbare hygiëne juist af. ${ }^{4 l}$

Wintgens verdedigde zijn ontwerp in bewogen woorden, en voerde aan dat hij en 'de geleerde Ali Cohen' in de praktijk nauwelijks voorbeelden hadden gevonden van gemeentebesturen die de gezondheidsbepalingen in de Gemeentewet serieus hadden genomen. ${ }^{42}$ Wintgens had zijn pleidooi uitvoerig gedocumenteerd. Zo bracht hij de resultaten van het medisch-statistisch onderzoek van Schick naar de gezondheidstoestand van 's Gravenhage en andere steden onder de aandacht van de Tweede Kamer, en wees hij op de grote onderlinge sterfteverschillen per gemeente. Dat de sterfte onder pasgeborenen in Rotterdam bijvoorbeeld zo veel hoger was (35 per duizend inwoners) dan in Leeuwarden (17,5 per duizend inwoners), toonde volgens Wintgens ontegenzeglijk de invloed van plaatselijke omstandigheden aan en dus de noodzaak van een gemeentelijke gezondheidspolitiek. Toch werd het wetsontwerp in april 1856 met 29 tegen 22 stemmen verworpen, met name doordat degenen die een totale herziening van de geneeskundige staatsregeling wilden, hun steun aan het wetsvoorstel onthielden. 
Het denkbeeld van Wintgens en Ali Cohen om van hogerhand de gezondheidsbepalingen in de Gemeentewet nadere invulling te geven, was daarmee niet van de baan. De opeenvolgende ministers Simons, Van Rappard en Van Tets van Goudriaan zouden het idee van de gemeentelijke gezondheidscommissies opnemen in hun wetsontwerpen op de geneeskundige staatsregeling, zoals we nog zullen zien. De voorstanders van gezondheidscommissies boekten overigens nog een klein succes, toen de in juni aangetreden minister Simons een circulaire naar de Commissarissen van de Koning deed uitgaan, waarin hij hen verzocht er bij de gemeentebesturen op aan te dringen om naar het voorbeeld van Rotterdam en Utrecht gezondheidscommissies in te stellen. ${ }^{43}$ Het resultaat van deze circulaire viel echter tegen. In slechts acht gemeenten werd positief op de circulaire gereageerd. In veertien gemeenten werd het verzoek uitdrukkelijk van de hand gewezen. In alle overige gemeenten werd het waarschijnlijk niet eens in behandeling genomen. ${ }^{44}$

Egeling moest in 1857 in De Economist vaststellen dat de strategie die had moeten leiden tot het algemeen instellen van gezondheidscommissies was mislukt als gevolg van 'de geringschatting van het onderwerp, de miskenning van het doel, de onverschillige, ja minachtende wijze waarop de zaak op sommige plaatsen werd behandeld'. Er was op dat moment volgens Egeling 'volstrekt niets anders te doen dan het verspreiden van meerdere kennis omtrent openbare gezondheidsmaatregelen'. ${ }^{45}$ Egeling voegde zelf de daad bij het woord en richtte in 1858 met Lubach het tijdschrift Schat der Gezondheid op. Het moest datgene doen op het gebied van de medische politie en de hygiëne, wat De Economist deed voor de staathuishoudkunde, namelijk het geven van voorlichting aan 'lezers van alle beschaafde standen'. ${ }^{46}$ Aan het tijdschrift werkten de bekende artsen mee, met name Israëls, Van Cappelle, Ali Cohen, Coronel en Allebé. Men richtte zich op het kiesgerechtigde deel van de bevolking dat men van de noodzaak van een gemeentelijke gezondheidspolitiek trachtte te overtuigen. Of het tijdschrift daarin is geslaagd, valt moeilijk te zeggen. Zeker is wel, dat na 1857 de belangstelling van gemeentebesturen en gemeenteraden voor sanitaire vraagstukken langzaam toenam, en dat in steeds meer gemeenten gezondheidscommissies werden opgericht. ${ }^{47}$ Bovendien speelde de zorg voor de lokale volksgezondheid sindsdien een belangrijke rol in het debat over de medische wetgeving. Het lokalisme van de hygiënisten ging in andere woorden het denken over de volksgezondheid geleidelijk meer bepalen.

\section{Enkele lokale verbeteringen}

De jaren vijftig mogen dan geen landelijke bepalingen hebben opgeleverd, de discussie over de gezondheidscommissies heeft bij sommige gemeentebesturen in ieder geval bijgedragen tot een een beter begrip van de volksgezondheidsproblemen. Steeds vaker ook werden de sterftecijfers en de gegevens over sterfteverschillen per gemeente of stadswijk onder de aandacht van het publiek gebracht. Met name de hoge kindersterfte in arme buurten kon moeilijk worden genegeerd. ${ }^{48}$ Hoewel men in de meeste gemeenten weinig voelde voor een actieve gezondheidspolitiek, konden gemeentebesturen het zich niet langer veroorloven om geen standpunt in te nemen. De gang van zaken in enkele gemeenten tot omstreeks 1865 laat zien, hoe moeizaam en gebrekkig de plaatselijke gezondheidspolitiek vorm kreeg. 
In 1857 bepaalde minister Van Rappard naar aanleiding van het in 1855 verschenen rapport van het Koninklijk Instituut voor Ingenieurs over de arbeiderswoningen - en geînspireerd door het wetsvoorstel-Wintgens - dat de gemeenten verordeningen mochten uitvaardigen op het bouwen van huizen en op het ontruimen van woningen die voor de gezondheid schadelijk waren. In de grotere steden van het land werden ook daadwerkelijk gemeentelijke bouwverordeningen van kracht (Dordrecht, Delft, Utrecht, Schiedam, Leiden, Rotterdam, Gouda, Den Haag en Groningen). ${ }^{49}$ In Amsterdam en Rotterdam werd zelfs een bescheiden bouwpolitie in het leven geroepen.

In verband met de bouwvoorschriften kwamen in de gemeenten ook allerlei sanitaire vraagstukken ter sprake. Een veel besproken kwestie bijvoorbeeld was de verontreiniging van de bodem, die bepaalde plaatsen ongeschikt maakte voor het neerzetten van woningen. Ook het maximum aantal woningen per privaat, het maximum aantal inwoners per drinkwaterpomp en het dempen van grachten waren onderwerpen, waarover in gemeenteraden steeds vaker werd beraadslaagd. Rotterdam ging aanvankelijk het verst met wijzigingen van de stedelijke infrastructuur. Daar bestonden al sinds de jaren veertig plannen om een groot deel van de binnengrachten door riolering te vervangen en het drinkwater te verbeteren (het plan-Rose). ${ }^{50} \mathrm{Na}$ de cholera-epidemie van 1853-1854 was de tijd rijp voor het plan-Rose, dat de stad een 'bloedsomloop' van Maaswater moest geven, als ook plantsoenen, riolen en enkele nieuwe brede straten in het centrum. In verband hiermee kon de plaatselijke gezondheidscommissie niet geheel zonder succes diverse voorstellen betreffende bouwverordeningen, voedselvervalsing en de 'afvoer van fecale stoffen' bij de gemeenteraad indienen. 51

In een groot aantal andere gemeenten, zoals Amsterdam, Utrecht, Haarlem, Zwolle, Deventer, Groningen en Arnhem, bracht men in de tweede helft van de jaren vijftig kleinere verbeteringen aan 'betreffende de openbare reinheid': uitbreiding van urinoirs en publieke privaten, verbetering van de afwatering door de aanleg van straatgoten, dempen van stukjes gracht of regelmatiger verversing van het grachtwater. Ook werden in meerdere plaatsen politieverordeningen op de broodbereiding en de melkverkoop van kracht, en werden concessies verleend aan particuliere vuilnisophaaldiensten. De gemeenten Maastricht, Deventer en Groningen stelden zelfs een eigen reinigingsdienst in. Ten slotte nam het aantal koepokinentingen toe, nadat in verscheidene gemeenten de inenting van schoolgaande kinderen verplicht was gesteld, en er ook bureaus voor gratis vaccinatie van kinderen van minvermogenden waren opgericht. De actievere 'vaccinatiepolitiek' van sommige gemeenten betekende niet alleen meer druk op de ouders om hun kinderen te laten vaccineren, maar ook de berisping wegens nalatigheid van een flink aantal geneeskundigen, die hun inentingstaken hadden verwaarloosd.

Voor een groot deel was deze aarzelend op gang gekomen plaatselijke bemoeienis met de volksgezondheid het resultaat van de nieuwe gemeentelijke politieverordeningen, die als uitvloeisel van de Gemeentewet van 1851 van kracht werden. Plaatselijke gezondheidscommissies, commissies van geneeskundig toevoorzicht of NMG-afdelingen wisten slechts een enkele keer invloed uit te oefenen op het totstandkomen van zulke verordeningen. Dikwijls gingen er forse ruzies tussen geneeskundigen en gemeentelijk bestuur aan vooraf. In Amsterdam diende de Plaatselijke Commissie van geneeskundig Toevoorzicht zelfs haar ontslag in uit ontevredenheid met het gemeentelijke beleid. ${ }^{52}$ 
Het is frappant dat de geneeskundigen ondanks de tegenwerking in de periode 1855-1865 hardnekkig bleven ijveren voor gemeentelijke gezondheidsbemoeienis. Ook in plaatsen waar het gemeentebestuur van goede wil was, hadden zij daartoe redenen te over. Wanneer bijvoorbeeld na jaren eindelijk bouwverordeningen tot stand waren gekomen, functioneerden deze in de praktijk dikwijls zeer gebrekkig. Verder dan het vaststellen van een rooilijn, waarmee de bouwer rekening diende te houden, kwam men veelal niet. Bovendien ontbrak het aan een doeltreffend bouwtoezicht. Over het algemeen bleef het met de volkshuisvesting slecht gesteld. De verenigingen 'tot verbeteringen der woningen van de arbeidersklasse', die in de medische pers veel lof kregen, konden daar weinig aan veranderen. ${ }^{53}$ Voorts vervulden de vuilnisophaaldiensten hun taak vaak zeer gebrekkig, ontbrak een goed toezicht op de naleving van de brood- en melkverordeningen, en dreigde ook de aandacht voor de vaccinatie telkens te verslappen.

Samenvattend kan worden gesteld, dat in de jaren vijftig een discussie over een gemeentelijke gezondheidspolitiek op gang kwam. Niet alleen als gevolg van de bepalingen in de Gemeentewet of van de opkomst van gezondheidscommissies, maar ook omdat door publikaties van NMG-afdelingen, van gezondheidscommissies en individuele medici (krante-artikelen, brochures), bij een deel van de burgerij meer belangstelling was gekweekt voor de gezondheidstoestand van de bevolking als geheel. Toch was men nog ver verwijderd van het inzicht dat de stedelijke volksgezondheid een zaak van aanhoudende zorg van burgerij èn bestuurders moest zijn. Het bleef in de periode 1851-1865 in het algemeen bij kleine verbeteringen, die geen belangrijke aanslag op de gemeentelijke financiën waren. In de praktijk veranderde er dus weinig. Het belangrijkste verschil met voorgaande jaren was dat een kleine groep liberalen in de burgerij openlijk, en soms beschuldigend de besturen op hun verantwoordelijkheid voor de volksgezondheid wezen.

\section{De politieke onhaalbaarheid van de ontwerpen van 1848}

In de jaren dat de belangstelling voor de gemeentepolitiek groeide, vonden er zowel in de landelijke politiek als in de NMG veranderingen plaats die een doorbraak zouden bewerkstelligen in de impasse waarin de discussie over de gezondheidswetgeving was geraakt. We zagen dat minister Simons op het laatst van 1856 had meegedeeld dat er vier ontwerpen van wet gereedgekomen waren. De indiening ervan bij de Tweede Kamer werd enigszins vertraagd, doordat Simons, naar het heette om gezondheidsredenen, begin 1857 aftrad. In werkelijkheid had hij zich politiek onmogelijk gemaakt. Zijn optreden in de Tweede Kamer was als provocerend ervaren en zijn fanatieke anti-liberalisme, dat zelfs enige collega-ministers te ver ging, had zijn vertrek onvermijdelijk gemaakt. Hij werd opgevolgd door jhr. mr. A.G.A. Ridder van Rappard. Van Rappard had reeds een lange ambtelijke carrière achter de rug en was beslist minder conservatief dan Simons. In het najaar van 1857 bood hij de vier wetsontwerpen aan de Tweede Kamer aan. ${ }^{54}$

Voor een groot deel kwamen de ontwerpen overeen met die van de staatscommissie van 1848 . Ze hielden in dat de provinciale en plaatselijke commissies van geneeskundig toevoorzicht moesten worden vervangen door artsen in dienst van het rijk of de provincie, die waren belast met het houden van en streng 
politioneel toezicht op de geneeskunstbeoefenaren. Bovendien wilde de minister, evenals de staatscommissie, naast de doctores een aparte stand van geneesmeesters in het leven roepen. Deze geneesmeesters dienden te zorgen voor de geneeskundige hulp op het platteland.

Het ontwerp op het geneeskundig bestuur week op enkele punten af van dat van 1848. De minister had het denkbeeld van Wintgens over de gemeentelijke gezondheidscommissies overgenomen. Hij stelde zelfs twee commissies voor in gemeenten met meer dan 10.000 inwoners. Een geneeskundige commissie in engere zin, enkel bestaande uit geneeskundigen en bedoeld voor het toezicht op de gemeentelijke armenverzorging, de koepokinenting, de prostitutie en de maatregelen tegen epidemieën, en een breder samengestelde gezondheidscommissie, bestaande uit een scheikundige, een bouwkundige, een lid van de gemeenteraad en een geneeskundige, die de algemene gezondheidstoestand diende te bevorderen. De leden van beide commissies moesten door de gemeenteraad worden benoemd. De kosten zouden voor rekening van de gemeente komen.

Het wetsontwerp op de gerechtelijke geneeskunde had de minister niet overgenomen. Ook een (gekozen) vertegenwoordiging van geneeskundigen en apothekers in het geneeskundig bestuur - bijvoorbeeld in de in 1848 voorgestelde landelijke raad van geneeskundigen die de minister moest adviseren - vond hij overbodig. De bescherming van de rechten en de behartiging van de belangen van de medische en farmaceutische beroepsbeoefenaars konden beter aan de Maatschappij, tot bevordering der Geneeskunst en de Maatschappij tot bevordering der Pharmacie worden overgelaten, meende Van Rappard.

Het eerste commentaar van de Tweede Kamer was tamelijk afwijzend. Zowel ter linker als ter rechter zijde had men allerlei bezwaren. Liberale kamerleden wezen 'de macht om alles te regelen' in het ontwerp op het geneeskundig bestuur af. Anderen wilden de bestaande provinciale commissies van toevoorzicht handhaven of keurden het ontbreken van vertegenwoordiging van geneeskundigen in het bestuur af. Met name het voorstel om twee gemeentelijke commissies in te stellen viel bij geen enkele 'fractie' in goede aarde. De taken van de commissies waren wederzijds niet goed afgebakend, en er zouden onvoldoende ambtenaren zijn voor de uitvoering ervan. ${ }^{s}$

Ook buiten de Kamer was kritiek te horen. De voorstanders van de eenheid van stand keerden zich tegen een nieuw te vormen stand van geneesmeesters. Anderen hekelden het ontbreken van een regeling voor de gerechtelijke geneeskunde. Penn en Ali Cohen konden wel enige waardering opbrengen voor de plannen van de minister. Zij zagen echter niets in het voorstel om twee gemeentelijke commissies in het leven te roepen. Ali Cohen pleitte natuurlijk opnieuw voor één gemeentelijke commissie in de zin van het voorstel van Wintgens. ${ }^{56}$ Penn was helemaal gekant tegen de invoering van gemeentelijke commissies. Hij bepleitte slechts medisch-hygiënische commissies, die als staatsorganen te zamen met een aantal rijksartsen vrijblijvend ter beschikking van de gemeenten moesten staan. Ze moesten niet bij wet worden opgedrongen, maar als adviesorganen worden aangeboden. 'Mogt dan later onwil van gemeentebesturen blijken, om rationeele maatregelen tot verbetering der gezondheidstoestand, die door het geneeskundig bestuur zouden zijn aan de hand gedaan, in werking te brengen; dan eerst zou het een punt van overweging moeten worden, waarin en tot hoe ver men de gemeentebesturen bij de wet zou moeten dwingen om de belangen hunner ingezetenen niet te verzuimen', aldus Penn. ${ }^{57}$ Een formulering 
die vrijwel woordelijk door Thorbecke zal worden herhaald, als hij zeven jaar later zijn eigen ontwerp van geneeskundige wetgeving in de Tweede Kamer verdedigt! Penn herhaalde overigens zijn kritiek op de voorstellen van de staatscommissie van 1848, die grotendeels door de minister waren overgenomen.

De wetsontwerpen van Van Rappard kwamen niet aan verdere behandeling in de Tweede Kamer toe; het kabinet-Van der Brugghen moest in maart 1858 aftreden. De doelstellingen van dit kabinet die erop waren gericht de hervormingen van 1848 ongedaan te maken, mislukten jammerlijk als gevolg van onhandig politiek gemanoeuvreer - en het heeft slechts geleid tot grote poltieke verwarring. ${ }^{58}$ Mulder beschouwde dit falen als de beslissende nederlaag van zijn beginselen. De vereniging 'Koning en Vaderland' ging geruisloos ten onder en Mulder trok zich terug uit de landspolitiek. Daarmee was zijn rol en die van zijn politieke vrienden bij de totstandkoming van de geneeskundige wetgeving uitgespeeld. Een algemene zwakte van de conservatieve 'partij', maar ook de verdeeldheid onder de voorstanders van een conservatieve medische wetgeving had Mulder niet kunnen wegnemen. Het ontbreken van één heldere conservatieve visie op de geneeskundige staatsregeling zou de komende jaren duidelijk aan het licht treden. In feite was het na 1858 definitief afgelopen met de plannen van de staatscommissie van 1848 , al wilden sommigen dit zelfs toen nog niet inzien.

$\mathrm{Na}$ de val van het kabinet-Van der Brugghen volgde een herstel van het liberale regime. Van Rappard werd opgevolgd door jhr. mr. J.G.H. van Tets van Goudriaan. Van Tets van Goudriaan was in 1836 bij Thorbecke gepromoveerd en in 1850 door hem aan het hoofd van de afdeling Binnenlands Bestuur van het departement van Binnenlandse Zaken gesteld. In 1853 was hij Commissaris van de Koning in Zeeland geworden. Hij was een bekwaam ambtenaar, maar in politicis was hij minder gelukkig. Zijn belangstelling ging voornamelijk uit naar de interne gang van zaken op zijn departement.

Op 20 februari 1859 diende hij vier ontwerpen van wet inzake de geneeskunde in: deze waren omgewerkt op basis van het voorlopig verslag van de Kamerbehandeling van de vorige ontwerpen van Van Rappard. De minister had in zijn voorstel de beide gemeentelijke commissies samengevoegd tot zogenaamde gezondheidsraden. Voor het toezicht op de uitoefening van de geneeskunst wilde de minister rijksartsen per provincie en geneeskundige raden per arrondissement. Nog altijd hadden de wetsontwerpen tot doel een krachtig medischpolitioneel apparaat in het leven te roepen. Bij deze ontwerpen werd voor het eerst uitgegaan van gelijke bevoegdheden voor elke geneeskundige in het hele land. Om tot de praktijk toegelaten

te worden was slechts een minimum aan kennis vereist. De wet bepaalde echter niet waar die kennis verkregen moest worden. Wèl moest het artsexamen voortaan door een staatscommissie worden afgenomen.

De eerste reacties vanuit de Tweede Kamer waren afwijzend. Alleen het voorstel aangaande de provinciale rijksartsen en de gemeentelijke gezondheidsraden kreeg instemming. Voor het overige spraken sommige afgevaardigden van een 'volslagen gemis aan vastheid van beginselen', en van 'gebrek aan doorzigt'. De minister werd verweten de vorige wetsontwerpen op een halfslachtige wijze te hebben aangepast aan zowel de kritiek ter linker-als ter rechterzijde en bovendien de ontwerpen onzorgvuldig te hebben gemotiveerd. ${ }^{59}$ Buiten de Tweede Kamer richtte de kritiek zich op het feit dat de minister, in afwachting 
van een regeling van het hoger onderwijs, slechts een minimum aan kennis voor de kunstbeoefenaren wilde voorschrijven. Heije noemde de ontwerpen om deze reden in 1860 'de onaannemelijkste van al de reeds onaannemelijk gebodene'. 60

Het verwijt van gebrek aan visie en onzorgvuldigheid, bracht Van Tets van Goudriaan ertoe de ontwerpen in te trekken om ze opnieuw te bezien. Maar het verwijt gold zeker ook de enige ambtenaar voor de medische politie waarover de minister beschikte, de referendaris Loncq. Deze trok uit de gebeurtenissen van de afgelopen jaren zijn conclusies en bood zijn ontslag aan. De minister verving Loncq vrijwel onmiddellijk door een nieuwe referendaris, namelijk C.C. Roëll, als geneesheer verbonden aan het gesticht voor krankzinnigen te Dordrecht. $^{6 I}$ Roëll zou niet alleen een aanmerkelijk slagvaardiger beleid op de afdeling Medische Politie voeren, maar bovendien de betrekkingen met de NMG-top volledig herstellen.

\section{De koerswijziging van de Maatschappij}

Tegen het einde van de jaren vijftig had een gedrukte stemming zich van de NMG meester gemaakt. Het ledental liep terug, wetenschappelijke initiatieven werden door gebrek aan enthousiasme nauwelijks ontplooid en de onderlinge meningsverschillen verscherpten. De oorzaak van de verflauwing van het verenigingsleven is niet moeilijk te geven. De Maatschappij stond na 1853 politiek buiten spel. Voor een niet onbelangrijk deel was dat een gevolg van de beëindiging van het adviseurschap van Penn en Ali Cohen. Mulders streven om de herziening van de wetten buiten de Maatschappij om te regelen had het politieke isolement van de NMG bovendien nog vergroot.

Tot overmaat van ramp was tussen de secretaris van de NMG Heije en referendaris Loncq een persoonlijke vijandschap ontstaan, wat de verhouding tussen de Maatschappij en het departement van Binnenlandse Zaken grondig had verstoord. Reeds tijdens het ministerschap van Van Reenen had de Maatschappij zich het ongenoegen van Loncq op de hals gehaald. Heije had eind 1853 namens de artsenorganisatie bij de minister aangedrongen op een spoedige indiening van de verwachte wetsontwerpen, daar Nederland anders 'uit de rij der beschaafde landen [kon] worden uitgewischt'. De minister reageerde afhoudend: pas een half jaar later liet hij weten dat het onderwerp zijn aandacht had. ${ }^{62}$ Omdat Van Reenen geen aanstalten maakte de zaak te bespoedigen, stelde Heije in opdracht van de algemene vergadering der NMG

in 1855 een nieuw adres op, dat thans niet aan de minister gericht was, maar aan de leden van de Tweede Kamer. Hierin verzocht hij de leden van de Kamer om de minister te dwingen zijn ambtenaar tot grotere werkzaamheid aan te sporen. ${ }^{63}$

Heije trachtte aan iedereen die het maar horen wilde duidelijk te maken dat referendaris Loncq voor de trage gang van zaken verantwoordelijk was. Een mening die overigens ook enkele malen in het parlement werd gehoord. ${ }^{4}$ In 1856 legde Heije in een toespraak tot de Algemene Vergadering van de Maatschappij alle schuld van de vertraging bij de referendaris: 'Hoe onaangenaam het ons ook zij, telken male over dat Departement te moeten klagen, wij achten ons toch verpligt [..] den steen uit te hollen en te verbreken, die in dat Departement, zoo al niet de verbetering onzer Geneeskundige Staatsregeling in 't algemeen, dan toch elke bijzondere, en reeds afzonderlijke mogelijke verbete- 
ring - en alle administratieve orde en promptheid, in den weg schijnt te staan'. 65 Het gevolg van Heijes aanvallen op Loncq was evenwel, dat iedere poging van de NMG om met de afdeling Medische Politie samen te werken door Loncq werd afgewezen of zelfs volkomen werd genegeerd. Zoals we in hoofdstuk 5 hebben gezien, "heeft door deze houding van de referendaris ook het onderzoek naar de gezondheidstoestand emstig bemoeilijkt.

Het uitblijven van politiek succes deed de twijfel over de haalbaarheid van de oorspronkelijke doelstellingen uit 1849 (volledige eenheid van stand, het concentreren van het geneeskundig onderwijs aan twee universiteiten, hervormingen in de openbare gezondheidszorg en krachtig centraal geleid geneeskundig bestuur) binnen de NMG toenemen. In 1857, na de indiening van de wetsvoorstellen van Van Rappard, bleken slechts 15 van de 26 afdelingen voor een volledige eenheid van stand te zijn.

Ook Penn, die altijd voor 'éen klasse van geneeskundigen' had gepleit, liet in zijn reactie op de wetsvoorstellen van Van Rappard weten, dat hij bij nader inzien toch voor verschillende soorten van geneeskundigen koos: doctores in de genees-, heel- en verloskunde, doctores in de geneeskunde en geneesmeesters, opgeleid aan een klinische school. Laatstgenoemden moesten zich met een vergunning van het geneeskundig staatsbestuur op het platteland vestigen. Overheidssubsidies moesten de medicinae doctores ertoe verleiden op het platteland te gaan praktizeren, zodat de geneesmeesters geleidelijk overbodig werden. ${ }^{66}$ Ook Ali Cohen legde zich in 1857 neer bij de regeringsvoorstellen om overeenkomstig de plannen van de staatscommissie van 1848 verschillende bevoegdheden te handhaven. De volledige eenheid van stand was blijkbaar voor velen geen halszaak meer.

In hetzelfde jaar liet de NMG in nog een ander opzicht haar maximalistische houding varen. Donders, die op dat moment voorzitter van Maatschappij was, trok tot groot ongenoegen van Mulder de sinds 1849 op tafel liggende eis in, dat eerst het geneeskundig onderwijs werd geregeld voordat de bevoegdheden van de geneeskundigen in een nieuwe wet werden vastgelegd. Donders ging zelfs zover, dat hij alle studenten van iedere opleiding hetzelfde examen bij een staatscommissie wilde laten afleggen. Hij deed daarmee dus afstand van de eis dat alleen een universitaire opleiding volledig bevoegde geneeskundigen zou mogen afleveren. ${ }^{67}$

\section{Toenemende invloed van liberale geneeskundigen}

Voor een medicus die omstreeks 1860 de balans van vijftien jaar discussie over de medische wetgeving had willen opmaken, zou het niet eenvoudig geweest zijn de gebeurtenissen op hun juiste waarde te schatten. De jaren vijftig hadden bovenal legislatieve onmacht, een improduktief ministerie en verdeeldheid onder de geneeskundigen laten zien. $\mathrm{Na}$ de staatscommissie van 1848, de adviezen van Penn en Ali Cohen, het afgewezen wetsontwerp-Wintgens, de bemoeienis van Mulder, en twee zonder succes ingediende wetsontwerpen, was de discussie in een impasse geraakt.

Aan de andere kant hadden zich enkele gebeurtenissen voltrokken, waaruit vooral de liberale medicus hoop geput moet hebben. Dankzij de voorbereidingen van Penn fuseerden in 1857 het Nederlandsch Weekblad voor Geneeskundigen, Het Repertorium onder redactie van Ali Cohen, het tijdschrift van de NMG, 
en het Nederlandsch Tijdschrift voor gerechtelijke psychiatrie en geneeskunde onder redactie van Ramaer tot het Nederlandsch Tijdschrift voor Geneeskunde. Tevens hield het door Donders uitgegeven Nederlandsch Lancet op te bestaan. ${ }^{68}$ Het Nederlandsch Tijdschrift voor Geneeskunde kon rekenen op brede steun vanuit de medische beroepsgroep. De voormalige redactieleden van het Nederlandsch Weekblad voor Geneeskundigen - zij waren allen op de hand van Thorbecke! zouden de komende jaren de redactionele koers van het nieuwe tijdschrift bepalen. ${ }^{69}$ De Geneeskundige Courant, de spreekbuis van Mulder, hield zich buiten deze fusie. De redactie kon het moeilijk verkroppen, dat de NMG haar orgaan volledig in het nieuwe tijdschrift had laten opgaan en en ze stelden zich op het punt om de monopolisering van de medische berichtgeving die de oprichters van het nieuwe tijdschrift klaarblijkelijk nastreefden te bestrijden. ${ }^{70}$

De veranderingen in het politieke vlak waren evenzeer hoopgevend. De antiliberale agitatie was uitgelopen op een mislukking als gevolg van de zwakke en weinig creatieve kabinetten. Mulder had zich teruggetrokken uit de politiek en zou de eerstkomende jaren weinig van zich laten horen. Referendaris Loncq, mede verantwoordelijk voor de stagnatie en het gebrek aan samenwerking tussen ministerie en NMG, had ontslag genomen. Tegelijkertijd waren de opvattingen van regering en parlement ten aanzien van de medische wetgeving in liberale richting opgeschoven. Het door Heije in de jaren veertig opgeworpen, en door Mulder nog altijd verdedigde denkbeeld dat de medische stand in het staatsbestuur vertegenwoordigd diende te zijn, was sinds 1857 uit de wetsontwerpen verdwenen. Pleitredes van conservatieve kamerleden en van enkele geneeskundigen konden dit niet voorkomen. Dit betekende een stap op weg naar de scheiding van staats- en standsbelang, zoals Penn die verdedigde. Al in 1856 had minister Simons het wetsvoorstel betreffende de gerechtelijke geneeskunde geschrapt, wat een aanmerkelijke vereenvoudiging van de juridische aspecten van de voorgestelde wetgeving met zich bracht. De meeste kamerleden waren inmiddels van mening dat binnen de openbare gezondheidsregeling de gemeentelijke activiteiten een centrale plaats dienden te krijgen. Verschil van mening bestond alleen over de vraag, of de instelling van gemeentelijke gezondheidscommissies bij wet moest worden voorgeschreven, of dat voorlopig eerst een overheidsapparaat de gemeentebesturen slechts tot advies zou moeten dienen.

De kansen voor de liberale hervormers waren dus aanmerkelijk vergroot. Het enige wat volgens mensen als Penn, Ali Cohen, Zeeman, Egeling, Heije en Evers ontbrak, was een krachtige minister op Binnenlandse Zaken. En voor hen kon dit alleen Thorbecke zijn. Zij moesten echter tot 1862 wachten voordat de liberale politicus opnieuw minister werd.

Vatten we het voorgaande samen, alvorens we de liberale eindstrijd bespreken, dan krijgen we het volgende beeld. Het politieke programma van de hygiënisten bestond in de jaren vijftig uit twee doelstellingen. Ten eerste moest de nieuwe geneeskundige wetgeving aansluiten bij de staatsinrichting van 1848. Ten tweede moesten gemeentebesturen in samenwerking met gezondheidscommissies een openbare gezondheidsregeling tot stand brengen. Beide doelstellingen hielden een afwijzing in van het rapport van de staatscommissie van 1848 .

Politieke moeilijkheden hebben de uitvoering van deze programmapunten verhinderd. Allereerst bleek geen enkele minister in staat om de wetsontwerpen van de staatscommissie van 1848 aan de gewijzigde staatkundige omstandighe- 
den aan te passen. Omgekeerd lukte het evenmin de plannen van de staatscommissie ongewijzigd uit te voeren, hoofdzakelijk omdat de aanhangers van de conservatieve richting het onderling niet eens konden worden. Het resultaat was een patstelling die tot 1860 duurde. In dat jaar had het conservatieve verzet tegen de Grondwet van 1848 aan kracht ingeboet, en was de uitvoering van het rapport van de staatscommissie onwaarschijnlijk geworden.

In de tweede plaats bleek telkens hoe sterk de kwesties van de bevoegdheden en de medische opleiding de discussie over het gehele gezondheidsbeleid beheersten. Een behoorlijk gezondheidsbeleid was onmogelijk, zolang men over deze kwesties geen overeenstemming had bereikt. Pas tegen het einde van de jaren vijftig was de NMG bereid water in de wijn te doen en ontstond op hoofdpunten consensus over de medische wetgeving.

In derde plaats waren de liberalen tegen het voorstel van conservatieve zijde om gemeentelijke gezondheidscommissies wettelijk voor te schrijven. Hierdoor werd de hygiënisten de mogelijkheid ontnomen om op korte termijn hun invloed op plaatselijk niveau te vergroten.

Toch hebben de hygiënisten wel iets bereikt. De resultaten van hun onderzoek zijn al spoedig een rol in de politieke discussies gaan spelen, zowel in het parlement als op gemeentelijk niveau. In diverse gemeenten werden gezondheidscommissies opgericht. Door toedoen van deze commissies zijn verschillende gemeentebesturen meer aandacht aan gezondheidsvraagstukken gaan besteden. In enkele steden zorgde dit voor een bescheiden verbetering van de openbare hygiëne. 



\title{
De overwinning van de liberalen
}

De despotieke bepalingen van de Engelsche wetgevingen [..]zouden bij ons niet worden geduld.

\author{
J.R. Thorbecke, 1865
}

\section{Herstel van de betrekkingen tussen de Maatschappij en het ministerie van Binnenlandse Zaken}

\section{De afdeling Medische Politie}

We hebben gezien, dat zich rond 1860 zowel in de Tweede Kamer als onder de geneeskundigen een zekere consensus ten aanzien van de geneeskundige wetgeving begon af te tekenen. Het feit met name dat de Nederlandsche Maatschappij tot bevordering der Geneeskunst haar eis tot herziening van het medisch onderwijs had laten vallen, maakte de discussie eenvoudiger; de top van de NMG had hierdoor meer bewegingsvrijheid gekregen in de onderhandelingen met de minister. Het probleem van de nieuwe inrichting van het medisch onderwijs - gezien de belangen van de drie medische faculteiten en de zes klinische scholen (Middelburg, Haarlem, Hoorn, Alkmaar, Amsterdam en Rotterdam) een uiterst gevoelige zaak - kon men voorlopig laten rusten.

Een tweede zeer belangrijke gebeurtenis was de vervanging in 1859 van Loncq door Roëll als referendaris op Binnenlandse Zaken. Onder leiding van Roëll als hoofd van de afdeling Medische Politie van het ministerie van Binnenlandse Zaken deed zich een voor de NMG gunstige wending in de activiteiten van het departement voor. Roëll werkte mee aan een onderzoek naar het voorkomen van difterie in ons land. ${ }^{I}$ De eerste sterftekaart van Nederland kwam met steun van Roëll tot stand, als ook het NMG-onderzoek naar de armenverpleging, dat onder leiding van Coronel plaatsvond. En vanaf 1861 beschikte men over volledige jaaroverzichten van het aantal geneeskundigen.

Overigens bleek ook minister Van Tets van Goudriaan meer oog te hebben voor de problematiek van de volksgezondheid dan zijn voorganger. Hij verzond in december 1859 een circulaire aan Gedeputeerde Staten, waarin een een aantal door Ali Cohen voorgestelde maatregelen ter bestrijding van de milieuvervuiling door fabrieken, als richtlijn voor het beleid werd aanbevolen. ${ }^{2}$ Ali Cohen had deze richtlijn eerder dat jaar op verzoek van Gedeputeerde Staten van Groningen inzake een aardappelmeelfabriek opgesteld. ${ }^{3}$ Ook besteedde Van Tets van Goudriaan als eerste serieuze aandacht schonk aan het probleem van de kinderarbeid. Wat betreft de openbare gezondheidszorg kon de NMG omstreeks 1860 de toekomst met enig vertrouwen tegemoet zien.

Wat de geneeskundigen het meest bezighield, was evenwel de herziening van de geneeskundige wetten. Roëlls aanstelling als referendaris betekende een 
ommekeer, want anders dan Loncq was hij wel bereid met vertegenwoordigers van de Maatschappij samen te werken. Ook de nieuwe referendaris ging ervan uit, dat een regeling van het medisch onderwijs voorlopig moest wachten. Degenen, die het medisch onderwijs wilden hervormen voordat een nieuwe geneeskundige staatsregeling tot stand gekomen was (Mulder bijvoorbeeld), vonden in Roëll dus geen medestander.

Vrijwel direct na zijn benoeming trad Roëll in overleg met Heije, secretaris van de NMG, en met Voorhelm Schneevoogt, lid van het hoofdbestuur. Waarschijnlijk zal Heije zijn advies uit 1857 aan Thorbecke hebben herhaald, namelijk om Penn als adviseur in de arm te nemen. Roëll betrok Penn tenminste vrij spoedig bij het opstellen van een serie nieuwe wetsvoorstellen. Blijkbaar lag een adviseurschap van Penn nog steeds gevoelig, want in de briefwisseling tussen Roëll en Penn wees Roëll er meerdere malen op dat de adviezen officieus waren en vertrouwelijk moesten blijven. ${ }^{4}$ Terwijl af en toe Heije en soms ook Donders door Roëll werden geconsulteerd, werkten de referendaris en Penn hecht samen en in hoog tempo aan de nieuwe wetsontwerpen. ${ }^{5}$ In maart 1860 had Roëll de ontwerpen gereed, die dankzij de intensieve betrokkenheid van Penn feitelijk als een gezamenlijk werkstuk beschouwd moeten worden.

In het wetsontwerp op het geneeskundig bestuur was nu geen sprake meer ${ }^{\text {L }}$ van enige bestuurlijke invloed van de medische beroepsgroep op het geneeskundig bestuur. Het toezicht op de openbare hygiëne en op de uitoefening van de geneeskunst kwam in handen van een overheidslichaam, waarvan de functionarissen alleen aan de minister verantwoording schuldig waren. Omgekeerd was in het ontwerp de overheidsbemoeienis met praktiserende geneeskundigen tot slechts enkele praktijkvoorschriften teruggebracht. Het idee om in de grote gemeenten gezondheidscommissies in te stellen was uit het ontwerp verdwenen. De leiding van het geneeskundig bestuur werd toebedeeld aan een hoofdinspecteur, die tevens hoofd van de afdeling Medische Politie was. Het uitvoerende 'bestuur' lag bij de provinciale en arrondissementsartsen. Penn en Roëll wilden het mogelijk maken om in voorkomende gevallen een statisticus of een ingenieur als bijzonder inspecteur aan te stellen. Het Wetsontwerp ter regeling van de bevoegdheid der geneeskundigen beoogde elke geneeskundige gelijke bevoegdheden te verlenen ofwel 'één stand van genees-, heel- en vroedmeesters' in het leven te roepen. Dezelfde wet hield echter ook in dat de leden van deze stand op twee verschillende manieren hun bevoegdheid konden verkrijgen: door een opleiding aan een klinische school, gevolgd door een aantal staatsexamens, of door een studie aan een hogeschool, afgesloten met een promotie. De gepromoveerden kregen het voorrecht om tot tot inspecteur of tot arts aan een krankzinnigengesticht te worden benoemd. ${ }^{6}$

De wetsontwerpen haalden de Tweede Kamer niet, omdat het ministerie-Rochussen in februari 1860 wegens de spoorwegkwestie moest aftreden. De nieuwe minister van Binnenlandse Zaken, S. baron van Heemstra heeft tijdens zijn ambtsperiode (23 februari 1860-31 januari 1862) de ontwerpen waarschijnlijk zelfs niet willen bestuderen. De werkzaamheden van Roëll en Penn zouden desondanks van groot belang blijken te zijn, toen Thorbecke twee jaar later hun ontwerpen voor een aanzienlijk deel tot de zijne zou maken.

Tijdens het bewind van minister Van Heemstra heerste er op het ministerie volgens Roëll in een brief aan Penn weer een 'vreeselijke vis inertiae'. 7 In de NMG groeide hierover de ongerustheid. Na zelfs een boycot van de provinciale en plaatselijke commissies van geneeskundig toevoorzicht te hebben overwogen, 
stuurde de Maatschappij in december 1860 een adres aan de Tweede Kamer. Heije voegde er een stuk bij, waarin hij de twintig jaar lange lijdensweg naar de herziening van de geneeskundige wetten in scherpe bewoordingen uiteenzette. Heije was desillusioneerd en bitter. Nergens maakte hij echter melding van het feit dat het voor hem duidelijk was dat veel van de oude NMG-idealen - die voor een belangrijk deel ook de zijne waren - geen schijn van kans meer hadden. ${ }^{8}$ Een door de medische beroepsgroep gekozen geneeskundig bestuur, een streng politioneel toezicht op de uitoefening van de geneeskunst en de openbare hygiëne, alsmede eenheid van onderwijs en stand waren immers in de voorgaande jaren uit de ontwerpen van wet verdwenen, niet in de laatste plaats door toedoen van Penn. Heije was een teleurgesteld man toen hij in november 1861 als secretaris aftrad. Sindsdien heeft hij zich van de gebeurtenissen in en om de Maatschappij volledig afzijdig gehouden.

Eind 1861 werd Heije als secretaris opgevolgd door Zeeman. Zeeman was voor de volle honderd procent een thorbeckiaan. Dit was van groot belang voor de verhouding tussen de NMG en Thorbecke. ${ }^{9}$ Op het ministerie lag een reeks sterk liberaal getinte wetsontwerpen te wachten op aanbieding aan de Tweede Kamer. Ze waren opgesteld door Roëll en Penn en kwamen vergaand tegemoet aan de bezwaren van Thorbecke tegen het rapport van de staatscommissie van 1848. Ten slotte moest een compromis over de regeling van de bevoegdheden opgesteld worden. Vertrouwelijk hadden Roëll, Penn, Heije, Donders en Voorhelm Schneevoogt een wetsontwerp geformuleerd, waarin de eenheid van bevoegdheid werd gerealiseerd, maar de situatie aan de universiteiten en een aantal klinische scholen ongewijzigd bleef. ${ }^{10}$ Het opstellen van deze wetsontwerpen had zich in alle rust afgespeeld. Niemand kon vermoeden dat ze bij openbaarmaking in 1862 een geweldig tumult zouden veroorzaken dat drie jaar aanhield.

\section{Thorbecke voor de tweede maal minister}

$\mathrm{Na}$ het echec van het conservatieve kabinet-Van der Brugghen in de jaren 18561858 , was de landelijke politiek in rustiger vaarwater gekomen. Verscheidene gematigd-liberale kabinetten volgden elkaar op van welke de doelstelling voornamelijk was om, uitgaande van de constitutie van 1848 , politieke tegenstellingen te vermijden en een modus vivendi te zoeken tussen conservatieven en liberalen. In het begin van de jaren zestig had een aantal politieke controverses aan scherpte verloren. Sinds de Armenwet van 1854 en de Schoolwet van 1857 waren enkele netelige kwesties - die voor flink wat agitatie in protestants Nederland hebben gezorgd - uit het centrum van de politieke belangstelling verdwenen. De invloed van het confessionalisme op de politieke verhoudingen was sterk teruggelopen. De pacificatiepolitiek van de gematigd-liberale kabinetten leidde er evenwel toe, dat ook een aantal kwesties onopgelost bleef. De koloniale politiek, beheerst door conservatieve en anti-liberale beginselen, was volkomen verouderd, maar geen van de opeenvolgende ministers wist een bevredigend alternatief te formuleren. Hetzelfde kan worden gezegd van de gezondheidspolitiek, die geen enkele wezenlijke verandering had ondergaan. Zelfs de oplossing van minder ingewikkelde problemen, zoals aanvullende wetgeving op de Provincie- en de Gemeentewet (begrafeniswet, quarantainewet) en wetgeving op het gebied van de veeartsenijkunst bracht men niet tot een bevredigend eind. 
Maar het zou de koloniale kwestie zijn, die in de jaren zestig de politiek ging beheersen, en de aanleiding zou vormen voor een definitieve uitschakeling van de conservatieve 'partij'. Belangrijk was bovendien, dat de Amsterdamse maatschappelijke elite na 1860 steeds sterker door een liberale handelsgeest werd beheerst, waardoor een belangrijk obstakel voor een verdere liberalisering van de economie was weggevallen. De terugval van de conservatief-protestantse invloed, de versterking van het economisch liberalisme en de onmacht van de kabinetten sinds 1858 , die geen duidelijke keus makten tussen conservatief en liberaal, gaven Thorbecke de kans zijn tweede kabinet te formeren. Op 1 februari 1862 werd hij voor de tweede maal minister van Binnenlandse Zaken.

Met opmerkelijke voortvarendheid pakte Thorbecke de zaak van de geneeskundige wetgeving aan. Al op 18 februari herstelde hij de door hem in 1853 geschapen situatie door Penn en Ali Cohen tot zijn adviseurs te benoemen. De Haagse geneesheer Blom Coster - bevriend met Ali Cohen - werd door de minister aan het tweetal toegevoegd. Zij kregen de opdracht om een herziening van de geneeskundige wetgeving voor te bereiden, en wel met zoveel spoed, dat deze voor 1 januari 1863 kracht van wet kon krijgen. ${ }^{11}$ Thorbecke verwachtte blijkbaar dat de aanvaarding ervan op niet al te grote moeilijkheden in de Tweede Kamer zou stuiten.

Penn, Ali Cohen en Blom Coster kwamen op 22 februari bijeen om de werkzaamheden te verdelen. Het ging daarbij om een nadere bewerking van de eerder door Penn en Roëll opgestelde ontwerpen. De medici moesten rekening houden met Thorbeckes wens, dat de nieuwe wetgeving zo weinig mogelijk extra onkosten voor de staat zou geven. Binnen drie maanden stonden de bijgewerkte ontwerpen op papier, en op 18 juni kon Thorbecke de wetsontwerpen tot herziening van de geneeskundige wetten van 1818, aan de Staten-Generaal aanbieden. Het zou bijna drie jaar duren eer de Kamer zich definitief uitsprak over de wetsontwerpen die na indiening nog drie maal werden gewijzigd. ${ }^{12}$

\section{De wetsontwerpen van Thorbecke}

\section{Van staatsbestuur naar staatstoezicht}

Er waren, net als in de jaren vijftig, vier wetsontwerpen: de Wet regelende het geneeskundig staatstoezicht, de Wet regelende de voorwaarden tot verkrijging der bevoegdheid van geneeskundige, apotheker, hulpapotheker, leerling-apotheker en vroedvrouw, de Wet regelende de uitoefening der geneeskunst en de Wet regelende de uitoefening der artsenijbereidkunst. Ook ditmaal werd de gerechtelijke geneeskunde niet geregeld. De hervorming van het medisch onderwijs werd slechts in het vooruitzicht gesteld. Met het oog op dit laatste werd het tweede wetsontwerp een tijdelijke regeling genoemd.

Het eerste ontwerp schreef de benoeming van geneeskundige inspecteurs en adjunct-inspecteurs voor en de instelling van geneeskundige raden, gelijkelijk over het land verdeeld. De inspecteurs moesten in vol-ambtelijke dienst zijn, hetgeen inhield dat zij geen praktijk mochten uitoefenen. De leiding was niet in handen van een hoofdinspecteur, zoals Penn had gewild, maar lag direct bij de minister. De taak van de inspecterende ambtenaren was drieledig. Ten eerste moesten zij onderzoek naar de gezondheidstoestand verrichten. Ten tweede 
dienden zij te adviseren over middelen tot verbetering van de gezondheidstoestand. En ten derde moesten zij toezien op de uitvoering van wetten en verordeningen in het belang van de volksgezondheid. Blijkens de memorie van toelichting behoorden daartoe ook de provinciale en gemeentelijke verordeningen.

Ali Cohens voorstel om gemeentelijke gezondheidscommissies plaatselijke verordeningen te laten opstellen en te bewaken volgens een bij wet vastgelegde procedure vond bij Thorbecke geen gehoor. De minister ontzegde de inspecteurs echter niet het recht zulke commissies naar eigen goeddunken in te stellen. Eventueel daaruit voortvloeiende kosten waren voor rekening van de gemeente, zoals trouwens alle plaatselijke verbeteringen op het gebied van de openbare hygiëne uit de gemeentekas moesten worden gefinancierd.

Ook was Thorbecke tegen een regeling die de inspecteurs van het Staatstoezicht verplichtte om gerechtelijk-geneeskundig onderzoek te doen. Anders dan de staatscommissie van 1848 meende hij dat de gerechtelijke geneeskunde en geneeskundige politie twee zo zeer verschillende takken van wetenschap waren en zo zeer verschillende studies vereisten, dat deze niet door één en dezelfde persoon konden worden uitgeoefend. Het uitoefenen van forensische geneeskunde door ambtenaren van het Geneeskundig Staatstoezicht zou naar zijn mening het primaire doel van de wet - bevordering van de volksgezondheid - in de weg staan. Bovendien mocht de rechter niet de mogelijkheid worden ontnomen om zelf een adviserend geneeskundige te kiezen. ${ }^{13}$

Uit de vier wetsontwerpen en de bijbehorende memories van toelichting en antwoord blijkt hoe consequent Thorbecke zijn staatkundige beginselen op de gezondheidszorg heeft toegepast. Hij deed natuurlijk in veel gevallen een beroep op de Gemeente- en Provinciewet, die hij zelf in 1850-1851 tot stand had gebracht.

Thorbecke wilde dat de gemeenten het initiatief zouden nemen voor verbetering van de gezondheidszorg. Hij wilde gemeentelijke zelfstandigheid, omdat de lokale gemeenschap haar belangen beter kon bepalen dan de provincie of de staat. 'Het geheel ziet in de regel af van de beoordeling van de lokale belangen', luidde één van zijn stelregels. Bovendien, hoe meer men de gemeente voor zichzelf liet zorgen, des te krachtiger de steun voor de staat. Het kwam de nationale kracht ten goede, indien de lagere organen niet voor al hun daden afhanelijk waren van het centrale gezag en indien de besturen zich, gedifferentieerd naar plaatselijke omstandigheden, met alles wat zij voor de lokale gemeenschap goed dachten, bezighielden en daarvoor verantwoordelijkheid droegen.

De gemeenten hadden natuurlijk niet volstrekte zelfstandigheid of vrijheid. De plaatselijke besturen mochten hun bevoegdheden niet uitstrekken over zaken die niet tot de huishouding van de gemeenten behoorden. Maar ook binnen de plaatselijke gemeenschap was de vrijheid begrensd. Waar het gemeentelijk initiatief, of juist het gebrek daaraan, schade toebracht aan de belangen buiten de gemeente, moest de provincie het initiatief overnemen. In laatste instantie, als het 'belang van het geheel' in het geding was, diende de staat regelend op te treden. De vrijheid van de plaatselijke gemeenschap werd dus bepaald door het belang van het grotere geheel. De gemeente was in de eerste plaats onderdeel van de staat, en pas daarna een zelfstandig geheel in de staat. ${ }^{14}$

Om te voorkomen dat de plaatselijke besturen de gestelde grenzen zouden overschrijden - Thorbecke zou zeggen: om de organische verbondenheid tussen het geheel en de delen te waarborgen - was toezicht op het handelen van de 
gemeenten noodzakelijk. Dit toezicht werd uitgeoefend door het provinciale orgaan, dat op zijn beurt gecontroleerd werd door de centrale overheid. Dit toezicht mocht de lagere overheden niet van hun verantwoordelijkheid ontheffen, nooit mocht het eigen initiatief overbodig worden gemaakt.

Het toezicht waarborgde dus een dubbele verantwoordelijkheid: de verantwoordelijkheid van het lagere orgaan, geprikkeld door de kans op toezicht; de verantwoordelijkheid van het hogere orgaan, dat onafhankelijk van de motieven, die tot het aan controle onderworpen besluit hebben geleid, toetst aan een aantal vaste criteria. Deze criteria wisselden slechts met het karakter van wat het aan het toezicht is onderworpen: voor het beheer van de waterhuishouding (de waterschappen) of van de financiën (de gemeentelijke begroting) golden andere maatstaven dan voor de zorg voor de volksgezondheid. ${ }^{15}$

Thorbeckes conclusie was dat de Wet van 1818 in zijn geheel moest worden afgeschaft, omdat deze niet aansloot bij het beginsel van zelfstandig bestuur van plaatselijke gemeenschappen. De regeling van 1818 bepaalde immers dat het Geneeskundig Staatsbestuur op last van de minister, dan wel op grond van medische politiewetten overal in het land moest kunnen handelen. Hoezeer ook de wetgever sinds 1818 had nagelaten de commissies van toevoorzicht bevoegdheden te verschaffen om tegen misstanden in de gezondheidszorg op te treden, dit principe had men altijd gehandhaafd. Hierdoor was het in de lokale gemeenschappen gewoonte geworden te wachten op een teken van hogerhand, voordat men - al dan niet onder leiding van het Geneeskundig Staatsbestuur - iets ondernam tegen, een bedreiging van de volksgezondheid.

Waar het Geneeskundig Staatsbestuur ieder plaatselijk initiatief op het gebied van de volksgezondheid had onderdrukt, had de regering nu de plicht de lokale gemeenschap weer tot leven te wekken, meende Thorbecke. De toekomstige inspecteurs en de leden van de geneeskundige raden mochten daarom nooit in de plaats treden van gemeentelijke of provinciale bestuurders. De plaatselijke autoriteiten, en niet de geneeskundige ambtenaren, moesten maatregelen ter bevordering van de openbare hygiëne nemen hetgeen overigens duidelijk in de Gemeentewet was vastgelegd. ${ }^{16}$

De contouren van de zorg voor de volksgezondheid waren dus gegeven met de organieke wetten, maar het bijzondere karakter van dit vraagstuk was daarmee nog niet erkend. De zorg voor de volksgezondheid omvatte zo veel verschillende vaak technisch ingewikkelde problemen, en was bovendien zo sterk in ontwikkeling, dat de overheidsorganen het niet zonder deskundig advies konden stellen. Er moesten geneeskundige ambteren en geneeskundige raden komen, die de gemeentebesturen zouden helpen om de gezondheidsbepalingen in de Gemeentewet naar behoren uit te voeren, en de rijksoverheid een deugdelijk toezicht op de lagere organen zouden bieden. Dit was reden om niet langer van geneeskundig staatsbestuur, maar van geneeskundig staatstoezicht te spreken.

\section{De medische wetenschap}

Een andere kwestie die Thorbecke geregeld wilde zien, was de bevordering van de medische wetenschap en de geneeskunst. Thorbecke was voorstander van staatsonthouding op het gebied van wetenschapsbeoefening. In plaats van 'materialistische protectie' van de wetenschap diende de regering zich te beperken tot het toegankelijk maken van bronnen en het beschikbaar stellen van informatie. Het wetenschappelijk onderzoek behoorde aan de onderzoeker, en 
delegering van wetenschapsbeoefening aan publieke lichamen, zoals de door de staatscommissie van 1848 en Mulder voorgestelde 'Academie voor geneeskunde', wees Thorbecke af. Door in te grijpen in de wetenschap zou de staat het 'levenselement van de wetenschap' miskennen, 'welker beoefening een gebied is, waar de staatsmagt niets heeft te scheppen, waar zij geen initiatief te nemen noch iets te regelen heeft; waar zij de particuliere krachten kan onderdrukken, maar waar zij in de regel geen leven te voorschijn zal roepen'. ${ }^{17}$

Op deze regel bestonden uitzonderingen. 'Wanneer het Goevernement in zulk een naauw - ik zou haast zeggen dagelijksch - verband staat met de beoefening van sommige wetenschappen, dat het bij de verrigtingen de hulp van die wetenschappen, het advies van hen, welke zich aan die wetenschappen wijden, telkens behoeft', dan kon overheidssteun geoorloofd zijn, had Thorbecke in de jaren vijftig gesteld. ${ }^{18}$ Dergelijke wetenschappelijke hulp was naar de mening van Thorbecke onontbeerlijk voor de volksgezondheid. De overheid moest daarom het onderzoek naar de volksgezondheid rechtstreeks steunen. Ten eerste door ambtenaren van het Geneeskundig Staatstoezicht met dit onderzoek te belasten. Ten tweede door deze ambtenaren ruime mogelijkheden te bieden om de resultaten van hun onderzoek te publiceren. Ten derde door geneeskundigen en lagere overheden te verplichten om aan het onderzoek mee te werken. Bij dit laatste doelde Thorbecke in het bijzonder op de ontwikkeling van de medische statistiek.

Anders lag het met de rest van de medische wetenschap en de geneeskunst. De belangen van de medische beroepsgroep zoals de organisatie van geneeskundigen en de kwaliteitsbewaking van degenen die officieel bevoegd waren ('de belangen der wetenschap') behoorden uitdrukkelijk niet tot de verantwoordelijkheid van de overheid. Thorbecke zei daarover tijdens de slotbehandeling van de wetsontwerpen in de Tweede Kamer: 'Waarop komt het aan bij het Staatstoezigt? Op het onderzoek van den toestand van de algemeene gezondheid, en het letten op de middelen, welke tot verbetering van dien toestand kunnen vereischt worden. Dat is geen taak van de medici, individueel of collegialiter. Dat is een gansch ander belang, waarvan de behartiging aan de Regeering behoort. [..] De zoogenaamde kunstoefenaren [..] kunnen zich vereenigen, zich organiseeren tot een comité, niemand zal hun iets daartegen in de weg leggen. [..] Is het noodig dat toezigt gehouden worde over de uitoefening van de praktijk, welnu, dat de medici zelven zoodanig toezigt organiseeren." $B$ Het lijdt geen twijfel dat de minister hierbij de NMG in gedachte had.

Door zo een scheiding aan te brengen tussen het openbare belang en het privé-belang was een belangrijke pijler onder het oude Geneeskundig Staatsbestuur weggevallen. Er was immers, anders dan in de Wet van 1818, met betrekking tot de medische beroepsgroep niets meer te 'besturen'. Dit was een tweede reden om niet langer van geneeskundig staatsbestuur, maar van geneeskundig staatstoezicht te spreken.

\section{De medische beroepsgroep}

De kracht van Thorbeckes voorstellen lag in het feit dat er voor het eerst sinds 1848 een visie op de gezondheidszorg werd geformuleerd. De vier ontwerpen vertoonden een duidelijke samenhang. Zodanig zelfs, dat een belangrijke wijziging in één van de ontwerpen automatisch gevolgen moest hebben voor de 
andere. Het was daarom noodzakelijk dat de vier ontwerpen te zamen door de Kamer werden aangenomen.

Een belangrijk uitgangspunt voor het tweede en het derde wetsontwerp ('regelende de voorwaarden tot verkrijging der bevoegdheden' respectievelijk 'de uitoefening der geneeskunst') was het staatstoezicht op de uitoefening van de geneeskunst zo eenvoudig mogelijk te houden. Thorbecke wilden tevens bereiken dat alle burgers een beroep zouden kunnen doen op geneeskundige hulp van gelijke kwaliteit; het onderscheid tussen stad en platteland, en tussen de hulpverlening van gegradueerde en van ongegradueerde geneeskundigen diende te verdwijnen. Daarom wille Thorbecke alle geneeskundigen dezelfde bevoegdheden geven. Dit stemde overeen met het compromis dat Roëll en Penn in de jaren 1859-1861 hadden bereikt. In zijn memorie van toelichting stelde Thorbecke voor om naast de drie medische faculteiten slechts twee klinische scholen respectievelijk in Amsterdam en Rotterdam te laten voortbestaan, in afwachting van een definitieve regeling van het medisch onderwijs. In een apart wetsartikel zouden alle op dat ogenblik praktizerende heel- en vroedmeesters dezelfde bevoegdheden worden verleend als de academisch gevormde geneeskundigen.

De bedoelingen van Thorbecke en zijn adviseurs waren duidelijk. Ten eerste moest het onderscheid tussen de geneeskunde en de heel- en verloskunde verdwijnen: de medische wetenschap was eén en ondeelbaar. Ten tweede bleef de situatie aan de drie faculteiten ongewijzigd. Aan het denkbeeld dat de opleiding aan de medische faculteiten werkelijk academisch en universitair (promotie!) moest blijven, werd tegemoet gekomen. Ten derde moest de handhaving van twee klinische scholen niet alleen een kostbare uitbreiding van de medische faculteiten voorkomen, maar ook de geneeskundige hulp op het platteland garanderen. ${ }^{20}$ Samengevat beoogde Thorbecke wel de eenheid van bevoegdheid, maar niet de eenheid van stand.

\section{De reacties van de artsen}

Vrijwel direct na de aanbieding van de wetsvoorstellen aan de Staten-Generaal in juni 1862, kwam het hoofdbestuur van de NMG dat volledig op hand was van Thorbecke, in actie. Het bestuur ging er van uit dat de ontwerpen nog voor het zomerreces van de Kamer in behandeling zouden worden genomen, en willde daarom zo snel mogelijk een uitspraak van de leden. Op 24 juni besloot het bestuur de wetsvoorstellen voo een urgente behandeling op de agenda van de algemene vergadering van 25 en 26 juni in Tilburg te plaatsen. ${ }^{21}$ Op deze vergadering werd een door secretaris Zeeman opgesteld adres van adhesie voorgelegd. Nadat de afgevaardigden enkele wijzigingen hadden aangebracht zonder te hebben overlegd met hun afdelingen - werd het adres onder druk van voorzitter Evers en bestuurslid Penn goedgekeurd. ${ }^{22}$ Tot twee weken na dato mochten de afdelingen hun mening over het adres te kennen geven, echter zonder dat de adhesiebetuiging inhoudelijk kon worden gewijzigd. Zeeman heeft uit de schriftelijke reacties willen opmaken, dat een meerderheid van de afdelingen accoord ging met de strekking van het adres. ${ }^{23}$

Het lijdt geen twijfel dat de leden van de Maatschappij zich door de handelwijze van het bestuur overrompeld hebben gevoeld. Dit gevoel werd nog versterkt toen bleek dat de Tweede Kamer de behandeling van de wetsvoorstellen tot na de zomer had uitgesteld. Al in juli werd duidelijk hoe vzeer het bestuur de stemming onder de geneeskundigen verkeerd had beoordeeld. Zowel 
over de in Tilburg gevolgde procedure als over de wetsvoorstellen brak een storm van verontwaardiging los. Er werd opgeroepen om zich van de NMG af te scheiden en de scheldwoorden ('valsch, aartsdom, jezuïetenstreek') waren niet van de lucht. Tegen het einde van 1862, toen het zich liet aanzien dat de Kamerdebâtten lang zouden duren, hadden individuele hoogleraren en groepen geneeskundigen tientallen adressen aan de Tweede Kamer verzonden, waarvan de inhoud veelal lijnrecht stond tegenover die van de adhesiebetuiging van de Maatschappij. ${ }^{24}$ Van de medische tijdschriften voerde vooral de Geneeskundige Courant oppositie tegen de wetsvoorstellen en tegen de 'Amsterdamsche Heeren' in het hoofdbestuur. ${ }^{25}$ In de Maatschappij voelde een groep hoogleraren zich verraden door het hoofdbestuur, dat de belangen van Amsterdam zou hebben bevoordeeld (uitbreiding van de Klinische School). Onder leiding van Baart de la Faille hief de afdeling Groningen zich zelfs uit protest op. Ali Cohen, behalve adviseur van Thorbecke ook secretaris van de afdeling Groningen, raakte hierdoor in een pijnlijke situatie; de afdeling had het besluit buiten hem om genomen. Ook hij had de emotionele reacties op de handelwijze van het bestuur en de wetsontwerpen niet verwacht. De onderlinge verhoudingen in stad en ommelanden zijn door deze 'Groninger kwestie' jarenlang verstoord gebleven. ${ }^{26}$

Van wie kwamen de protesten en waarom raakten de gemoederen zo verhit? Thorbecke had het vooral te stellen met de bezwaren die tegen het 'Wetsontwerp regelende de voorwaarden tot verkrijging der bevoegdheden' werden opgeworpen door sommige hoogleraren en medicinae doctores op het platteland. De hoogleraren, voornamelijk uit Utrecht en Groningen, vreesden dat de twee klinische scholen de medische faculteiten in aantallen studenten en wetenschappelijke invloed zouden overtreffen. Volgens sommige Utrechtse hoogleraren ontstond hierdoor het gevaar, dat de geneeskunde tot een zuiver praktisch beroep werd gedegradeerd, en als academisch vakgebied met bepaalde geestelijke tradities zou ophouden te bestaan. Ook Baart de la Faille, die al in de jaren veertig had gefulmineerd tegen het oprukkend utilitaristisch denken in het medisch onderwijs, was woedend over het wetsontwerp dat volgens hem de toekomst van het academisch medisch onderwijs op het spel zette.

Onder de gegradueerden richtte de verontwaardiging zich op de overgangsbepalingen van het wetsontwerp. Daarin was vastgelegd dat de reeds praktizerende plattelandsheelmeesters de bevoegdheid kregen de genees-, heel- en verloskunst in haar gehele omvang uit te oefenen, terwijl anderzijds de al gevestigde medicinae doctores zich ook in de toekomst tot de geneeskunst moesten beperken. Vooral de medicinae doctores op het Groningse en Friese platteland zagen zich in hun bestaan bedreigd. Zij eisten uitbreiding van hun bevoegdheden, en beperking van die van de plattelandsheelmeesters.

De niet-gegradueerden waren over het algemeen tevreden. Men sprak in deze kringen zelfs van een 'waar meesterwerk'. De kritiek van de medicinae doctores en hoogleraren werd beschouwd als een uiting van 'gekrenkte hoogmoed en eigen belang'.27

Doordat elk van de drie partijen op steun in de Tweede Kamer kon rekenen, was Thorbecke gedwongen rekening te houden met deze intra-professionele tegenstellingen. Tweemaal moest hij zijn wetsontwerp bijstellen (eenmaal door de bevoegdheden van reeds practizerende medicinae doctores uit te breiden), en 
tot op het laatste moment bleef het onzeker of er een kamermeerderheid zou zijn. Na een schorsing tijdens de slotbehandeling en opnieuw wijzigingen (een voor alle medische studenten verplicht staatsexamen in de praktische genees-, heel- en verloskunde, af te nemen door een rijkscommissie), gaf de Kamer in maart 1865 eindelijk haar steun aan Thorbecke. ${ }^{28}$

Hier blijkt hoezeer de totstandkoming van het Geneeskundig Staatstoezicht afhankelijk was van een bevredigende oplossing van de tegenstellingen binnen de medische beroepsgroep. Terwijl Thorbecke echter zijn wetsvoorstellen door de Kamer loodste, raakte de NMG als gevolg van de drie jaar durende, soms pijnlijk verlopende discussies volkomen stuurloos, en dreigde op een gegeven moment zelfs aan scheuringen ten onder te gaan. In het hoofdbestuur liepen de meningsverschillen soms hoog op. ${ }^{29}$ Zeeman, als secretaris direct betrokken bij de interne conflicten, had het zwaar te verduren. Ook voor Ali Cohen, Penn en Egeling, die na het overlijden van Roëll in 1863 door Thorbecke tot hoofd van de afdeling Medische Politie van het ministerie van Binnenlandse Zaken was benoemd, moeten het geen gemakkelijke jaren zijn geweest. Zij werden herhaaldelijk rechtstreeks verantwoordelijk gesteld voor de inhoud van de wetsontwerpen.

\section{De Kamerbehandeling van de Wet op het geneeskundig staats- toezicht}

De discussie over het Wetsontwerp op het geneeskundig staatstoezicht raakte als gevolg van het rumoer rond de kwesties van de bevoegdheden en het medisch onderwijs op de achtergrond. Toch werd hiertegen krachtig oppositie gevoerd. Tijdens de voorbehandeling en in het kamerdebat van 1865 vormden zich in de Kamer vier verschillende facties.

Ter linkerzijde bevonden zich M.H. Godefroi, het voormalig lid van de staatscommissie van 1848 en afgevaardigde uit Amsterdam, en W.H. Idzerda, medicinae doctor in Friesland en afgevaardigde van Leeuwarden. Godefroi was in godsdienstige kwesties conservatief, maar in staatkundige zaken was hij liberaal. Hij was één van de bekwaamste en meest gezaghebbende leden van de Tweede Kamer. Idzerda maakte sinds 1858 deel uit van de Tweede Kamer en was trouw aanhanger van de liberale partij. Beide kamerleden stonden welwillend tegenover het wetsontwerp, en zij schoten de minister tijdens het debat dan ook herhaaldelijk te hulp.

Ter rechterzijde waren de belangrijkste woordvoerders $\mathbf{R}$. Westerhoff, medicinae doctor in Groningen en afgevaardigde van Appingedam en $\mathrm{mr}$. W. Wintgens, afgevaardigde van Delft. De conservatief Wintgens was in 1854 de indiener van de initiatief-wet op de gezondheidscommissies. Westerhoff was sinds 1849 kamerlid en doorgaans een aanhanger van Thorbecke. In medische aangelegenheden waren hij en Thorbecke het echter zelden eens. Genoemde kamerleden vertegenwoordigden ieder een variant van de conservatieve oppositie.

Ten slotte was een groot aantal kamerleden bevreesd voor de gevolgen voor de schatkist. Zij twijfelden ernstig of het door Thorbecke voor het staatstoezicht uitgetrokken bedrag van $f 75.000,--$ verantwoord was, en of het niet zou kunnen overschreden. Zowel de liberale als de conservatieve woordvoerders probeerden deze twijfelaars aan hun kant te krijgen. 
De oppositie pakte de zaak principieel aan. Ten eerste richtte zij haar kritiek op het feit dat er weinig of niets met betrekking tot de openbare hygiëne zelf was geregeld. Ten tweede verweet zij de minister de uitoefening van de geneeskunst te veel te reguleren. Westerhoff wilde eerst 'politiewetten' net als in Duitsland dan pas ambtenaren. Naar zijn mening bevatte het wetsontwerp niets dat de bestaande bedreigingen van de volksgezondheid kon wegnemen. Hij had geen enkel vertrouwen in een liberaal staatstoezicht, en stelde dat verbetering van de volksgezondheid een grote staatsbemoeienis vereiste.

Thorbeckes uitvoerige repliek geeft een duidelijk beeld van zijn bedoelingen. Hem stond juist het omgekeerde van wat Westerhoff bepleitte voor ogen. Hij wilde vooralsnog geen landelijke wetgeving, waarmee van hogerhand de verbetering van de openbare hygiëne afgedwongen kon worden. Het doel van het Geneeskundig Staatstoezicht was enkel 'licht te doen vallen op hetgeen licht behoeft'. En '(men) mag aannemen dat dat licht, telkens aangebragt, telkens opnieuw verspreid, leiden zal tot die maatregelen, tot het nemen waarvan in de eerste plaats de gemeentebesturen verpligt zijn. Gebeurt het niet, dan zall welligt later de wet aan de gemeentebesturen eene douce violence moeten aandoen." 30 Als Thorbecke dus sprak over voorlichting aan 'hen die te besturen hebben', had hij met name de gemeentebesturen op het oog. Met andere woorden, Thorbecke wilde met de wet vooral de plaatselijke verantwoordelijkheid voor de volksgezondheid garanderen - een verantwoordelijkheid die in de Gemeentewet was vastgelegd.

Dit sloot niet uit dat het Geneeskundig Staatstoezicht zekerheid moest geven voor de verantwoordelijkheid van de provincies en de staat. In het bijzonder als de gemeenten niet volkomen vrij waren in hun gezondheidspolitiek, en de staat regelend behoorde op te treden, moest het Staatstoezicht de lagere organen controleren. Maar, stelde Thorbecke bij herhaling, de kennis over de gezondheidstoestand van de bevolking was nog te gering om deze taak volledig te kunnen omschrijven.

Over de handel in geneesmiddelen, de onbevoegde uitoefening van de geneeskunst en de toelatingseisen voor geneeskundigen tot de praktijk kon de minister duidelijk zijn. De ervaring had geleerd dat alle burgers, ongeacht hun woonplaats en maatschappelijke positie, belang hadden bij hulp van een geneeskundige, wiens kwaliteiten wettelijk waren gegarandeerd. Lokaal gedifferentieerde regelingen zouden hier vrijwel zeker schade toebrengen aan de volksgezondheid. Dit belang was daarom geen zaak voor de lagere overheden, maar voor de staat. 'Voor bereikbaarheid van geneeskundige hulp zoveel mogelijk en noodig te zorgen, schijnt mij plicht', verklaarde Thorbecke vast. Het Staatstoezicht had de taak de bereikbaarheid en de kwaliteit van de geneeskundige hulp te garanderen. Met betrekking tot het laatste werden de taken van het Staatstoezicht in het derde Wetsontwerp, 'regelende de uitoefening der geneeskunst', nader omschreven.

Over de openbare hygiëne kon Thorbecke minder stellige uitspraken doen. Landelijke regelingen (bouwvoorschriften, rioleringsplicht, regeling voor besmettelijke ziekten) waren in beginsel ongewenst, gezien de eigen verantwoordelijkheid van de gemeentelijke en provinciale bestuursorganen. Maar ze leken Thorbecke ook onmogelijk om de eenvoudige reden, dat de regering nog niet kon aangeven waar het plaatselijk belang ophield en het staatsbelang begon. De wetenschappelijke kennis over de 'algemene gezondheid" en de ervaring met de 
zorg voor de openbare hygiëne waren volgens hem zo gering, dat er geen objectieve maatstaven voor de wetgever bestonden.

Bij dit punt ging Thorbecke uitvoerig in op de gang van zaken in Engeland. Hij wees erop dat de Public Health Act van 1848 tot stand was gekomen als het resultaat van jarenlang wetenschappelijk onderzoek. Om die reden moesten er ook in Nederland eerst inspecteurs en geneeskundige raden 'als blijvende commissiën van enquête' komen. ${ }^{3 i}$ Anderzijds meende de bewindsman dat de Engelse wet niet tot voorbeeld kon dienen, omdat het Verenigd Koninkrijk, anders dan Nederland geen Gemeentewet kende. De Public Health Act bepaalde dat de rijksoverheid in het gemeentelijk gezondheidsbeleid kon ingrijpen ofwel op verzoek van $10 \%$ van de belasting betalende inwoners ofwell als de sterfte hoger was dan 23 per duizend inwoners. Thorbecke wees de invoering van een dergelijke bepaling in Nederland nadrukkelijk van de hand: 'de despotieke bepalingen van de Engelsche wetgeving zouden bij ons niet worden geduld. In Engeland kon men niet anders handelen, omdat daar dat verband tussen gemeentebestuur en algemeen bestuur niet bestaat. Men had geen ander orgaan dan de algemeene wet en de uitvoering der algemeene wet, doordringende, zoo het noodig ware, tot in de gemeenten en in de woningen van particulieren'. ${ }^{32} \mathrm{De}$ minister redeneerde dat een wet naar het voorbeeld van de Public Health Act de staat meer macht gaf dan goed was voor Nederland. Zijn ontwerp was voortgekomen uit 'vrijheidszucht'. Daarom leek hem de situatie in de Duitse staten, waar medische politiewetten veelvuldig voorkwamen en waarnaar de oppositie graag verwees, ongewenst voor Nederland met zijn in de Gemeentewet vastgelegde autonomie van het lokale bestuur.

Thorbecke liet zich niet alleen leiden door een principieel streven naar vrijheid. Hij keerde zich ook om praktische redenen tegen de Public Health Act. Bovengenoemd artikel zou in Nederland geheel anders uitwerken dan in het Verenigd Koninkrijk, omdat de sterfte per gemeente in ons land gemiddeld 26 per duizend inwoners bedroeg. Dit percentage was aanzienlijk hoger dan in Engeland. Op grond van het Engelse wetsartikel zouden daarom veel gemeenten onder curatele van de overheid worden gesteld. Meer nog dan in Engeland zou een dergelijke bepaling het gezondheidsbeleid centraliseren, wat precies in strijd was met Thorbeckes bedoelingen. Het verschil tussen de gezondheidstoestand in het Verenigd Koninkrijk en in Nederland is dus een van de belangrijkste redenen, waarom de door Farr ontwikkelde 'biometer' in Nederland geen wettelijke toepassing $\mathrm{kreeg}$. ${ }^{33}$

Thorbecke wees de in Engeland ontwikkelde maatstaven af, omdat ze niet in het Nederlandse staatsbestel pasten. Het was juist de taak van het Staatstoezicht om maatstaven te ontwikkelen, die in overeenstemming waren met de traditie van het Nederlands staatsrecht. ${ }^{34}$ Wanneer zou blijken dat de plaatselijke besturen niet naar deze maatstaven handelden, kon de rijksoverheid alsnog een meer specifieke wetgeving overwegen. De medische ambtenaren van het Staatstoezicht hadden wellicht dan de noodzakelijke kennis vergaard. Voorlopig echter moesten zij slechts toezien op de naleving van provinciale en gemeentelijke verordeningen.

Uit de toelichting op de taken van de geneeskundige ambtenaren blijkt het vooruitgangsdenken dat zo typerend is voor Thorbeckes rechts- en staatsopvatting. Volgens Thorbecke kon maatschappelijke verbetering niet door wetgeving worden afgedwongen, zeker niet als een wet in strijd was met het nationale karakter. Wetgeving kon de politieke wil tot maatschappelijke verbetering 
onderdrukken of bevorderen, en goede wetgeving beoogde het laatste. Een wet moest altijd een 'bron van ontwikkeling' zijn: nieuwe inzichten en rechtsbeginselen vloeiden hieruit voort. De regering moest volgens Thorbecke voortdurend trachten de wetgeving aan deze inzichten en rechtsbeginselen aan te passen. Zulke aanpassing was in wezen niets anders dan maatschappelijke vooruitgang. ${ }^{35}$

Het was Thorbeckes vaste overtuiging dat de eerste opdracht van het Geneeskundig Staatstoezicht, het onderzoek naar de volkgezondheid, tot vooruitgang in kennis zou leiden. Daarmee konden de plaatselijke gemeenschappen hun voordeel doen. Maar het was ook mogelijk dat de verhouding tussen de staat en de lagere organen in een nieuw perspectief kwam te staan. Dit kon betekenen dat de staat scherper moest toezien op de lagere organen, of dat de staat verantwoordelijkheden van de lagere organen overnam. Zo moest uit de geneeskundige wetten 'eene algemeene, wèl ingerigte gezondheidszorg, voor land, woning, en menschen, voortvloeijen'.

Thorbecke werd in zijn opvattingen gesteund door de kamerleden Godefroi en Idzerda, hoofdrolspelers in de drie jaar durende kamerbehandeling. Ook zij meenden dat men eerst de kwaal moest kennen alvorens het geneesmiddel aan te wenden. $\mathrm{Zij}$ gingen er blijkbaar van uit dat de oorzaken van bijvoorbeeld volksziekten nog onvoldoende duidelijk waren. Strenge politiewetten, waar Westerhoff herhaaldelijk voor pleitte, wezen zij als 'irrationeel' van de hand. De beide kamerleden vonden hoogstens afzonderlijke wetten voor speciale onderwerpen wenselijk. Opvallend is overigens dat vrijwel geen van de woordvoerders op de gezondheidscommissies is ingegaan. Alleen Godefroi wees Thorbecke erop, dat diens verwachting dat het Staatstoezicht en de gemeentelijke gezondheidscommissies harmonisch zouden samenwerken, een illusie zou blijken te zijn. ${ }^{37}$

Ook al had Thorbecke zijn ontwerp gegrond op het beginsel van zo weinig mogelijk staatsbemoeienis, een aantal bepalingen ging de kamermeerderheid nochtans te ver. Het betrof met name de artikelen vijf en zes. Artikel vijf regelde het betreden van openbare en niet-openbare gebouwen (scholen, kazernes, fabrieken, privé-woningen) door leden van het Staatstoezicht. Artikel zes verschafte de inspecteurs de mogelijkheid 'werktuigen of bezittingen' waarmee een overtreding was begaan, in beslag te nemen. De Kamer deelde veeleer de vrees van de liberalen dat de inspecteurs een te grote macht zouden krijgen dan de mening van de conservatieven die juist een krachtig staatsapparaat in het leven wilden roepen. Nadat het kamerlid Van der Bosse naar voren had gebracht 'dat deze wet in handen van geneeskundigen, die gewoon zijn hunne voorschriften zoo blindelings gehoorzaamd te zien, een gevaarlijk wapen kon worden voor de vrijheid der ingezetenen', en ook Godefroi waarborgen tegen machtsmisbruik had geëist, werden beide artikelen - overigens zonder grote bezwaren van Thorbecke - geamendeerd. Het betreden van 'niet-openbare gebouwen' werd aan banden gelegd en de mogelijkheid tot inbeslagneming van het corpus delicti werd geschrapt. ${ }^{3}$

Aan conservatieve zijde bestonden bezwaren tegen een geheel ander aspect van de staatsbemoeienis: het 'toezicht op de uitoefening der geneeskunst'. Wintgens sprak van een wet 'ontsproten aan staatsvoogdij'. Hij had er geen goed woord voor over dat de medische stand geen enkele invloed op het staatstoezicht kon uitoefenen. Het geneeskundig beroep, een 'profession libérale', zou naar hij vreesde in het keurslijf van een bureaucratische organisatie worden 
geperst. Het kamerlid vertolkte hiermee de mening van onder anderen de Utrechtse hoogleraren G.J. Loncq en M. Imans, die het vrije ondernemerschap door de instelling van een 'ondemocratische inspectie' zagen aangetast. Wintgens pleitte ervoor de geneeskundigen onder een bestuur te plaatsen, dat was gekozen volgens' geheel en al het zelfde beginsel, waarvan ons constitutioneel leven uitgaat'. Een democratisch gekozen 'collegiaal bestuur', en niet een aantal overheidsfunctionarissen, moest toezien op de uitoefening van de geneeskunst. ${ }^{39}$

Ook Westerhoff was tegen het voorgestelde toezicht op de uitoefening der geneeskunst gekant, zij het dat zijn beweegredenen anders waren dan die van Wintgens. Westerhoff was met Wintgens van mening dat geneeskundigen aan een 'staatsleiband' zouden lopen. Hij noemde de voorstellen 'illiberaal en patriarchaal', en vreesde dat met name de inspecteurs op grond van de wetgeving een te grote macht over de geneeskundigen konden uitoefenen. Westerhoff zag niets in het door Wintgens voorgestelde democratisch gekozen geneeskundig staatsbestuur. Hij wilde juist voorkomen dat geneeskundigen zonder academische titel aan een of andere vorm van geneeskundig toezicht zouden deelnemen, daar het 'vernederend en kwetsend voor de gegradueerden' was om aan het toezicht van een heelmeester onderworpen te zijn. 40

Thorbecke wees de kritiek van beide afgevaardigden af en gaf ze te verstaan dat een bestuur van geneeskundigen in het geheel niet aan de orde was. Hij stelde vast dat het ambt van inspecteur en de geneeskundige raden in geen enkel opzicht te vergelijken waren met tuchtrechtelijke organen of "raden van discipline'. Verkiezingen waren daarom niet op hun plaats en van een staatsleiband was al hellemaal geen sprake, aldus de Thorbecke. ${ }^{41}$ Godefroi en Idzerda waren het hiermee volledig eens, omdat immers 'alle toezigt op de kunstuitoefening is weggenomen'.

Wintgens en Westerhoff waren niet onder de indruk van de argumenten. In de belangen van de medische stand werd volgens hen wel degelijk ingegrepen. De voorgestelde plicht om bij vestiging het diploma door een inspecteur te laten viseren en de mogelijke disciplinaire maatregelen tegen geneeskundigen die hun bevoegdheden overschreden (Wet regelende de uitoefening, de artikelen 5, 6 en 18) waren daar voorbeelden van. Ook de meldingsplicht met betrekking tot besmettelijke ziekten en de verplichting een overlijdensverklaring af te geven (met vermelding van de doodsoorzaak) zagen zij als een inbreuk op de autonomie van de medische stand. Voor Westerhoff waren deze bepalingen onaanvaardbaar, omdat de belangen van de medici principieel geen voorwerp van staatszorg behoorden te zijn. Wintgens handhaafde zijn bezwaar, dat de geneeskundigen niet zelf degenen konden aanwijzen die moesten toezien op uitvoering van de bepalingen. Hij diende een amendement in, dat een democratische verkiezing van de leden van het Staatstoezicht beoogde.

De situatie deed zich dus voor dat zowel de minister als de oppositie het staatsgezag wilden versterken, maar op geheel verschillende terreinen. Thorbecke wilde met de aanstelling van inspecteurs het toezicht op de onbevoegde uitoefening der geneeskunde centraliseren om zo een goede geneeskundige hulpverlening garanderen. Hij wilde tevens dat gegevens over de nationale volksgezondheid werden verzameld. Een centrale regeling van het beleid inzake de openbare gezondheid wees hij af. De oppositie verdedigde juist het omgekeerde: namelijk de invoering van algemene politiewetten ter bevordering van de openbare gezondheid, terwijl de medische beroepsgroep vrij en autonoom moest blijven. Echter tot het laatst bleek de oppositie te zeer verdeeld om aan 
dit alternatief een constructieve vorm te geven. Tijdens de eindstemming werd het amendement-Wintgens met ruime meerderheid verworpen, omdat Westerhoff en een groot aantal andere tegenstanders van de minister tegenstemden. ${ }^{43}$ Alleen in hun verzet tegen artikel 2, dat het toezicht aan inspecteurs opdroeg, vonden Wintgens en Westerhoff elkaar. Samen trachten zij in te spelen op de beduchtheid van een deel van de kamerleden voor een te zware belasting van de staatskas. Bij stemming bleek de Kamer echter met de aanstelling van inspecteurs accoord te gaan, zij het met een meerderheid van slechts zes stemmen. Bij de volgende stemmingen over de afzonderlijke artikelen was de oppositie machteloos en zag Thorbecke zijn Ontwerpwet op het geneeskundig staatstoezicht op 10 maart 1865 met 35 tegen 27 stemmen aangenomen worden. ${ }^{44}$ Op 30 mei werd het ontwerp door de Eerste Kamer aangenomen en op 1 juni werd de Wet op het geneeskundig staatstoezicht in het Staatsblad (nr. 58) gepubliceerd.

De Wet op het geneeskundig staatstoezicht trad op 1 november 1865 in werking. Kort daarop werden zeven inspecteurs beëdigd, onder wie zich de belangrijkste voorstanders van een openbare gezondheidsregeling bevonden. Penn werd behalve inspecteur voor de provincie Noord-Holland plaatsvervangend voorzitter van de inspecteursvergadering. Ali Cohen werd tegen de verwachting in inspecteur voor de provincies Drenthe en Overijssel. Mogelijk had deze benoeming met de eerder vermelde 'Groninger affaire' te maken. Hij werd tevens secretaris van de inspecteursvergadering, en dus de eerst verantwoordelijke voor de wettelijk verplichte jaarlijkse verslaglegging van de werkzaamheden van het Staatstoezicht. Idzerda gaf zijn kamerlidmaatschap op om tot inspecteur voor Groningen en Friesland benoemd te kunnen worden. Eind 1868 werd hij echter opnieuw in de Kamer gekozen, waarop Ali Cohen alsnog het ambt van inspecteur in de twee noordelijke provincies kon bekleden. Lubach werd vervolgens tot inspecteur voor Overijssel en Drenthe benoemd. Egeling verruilde zijn functie van hoofd van de afdeling Medische Politie voor die van inspecteur voor ZuidHolland. Van Cappelle, voormalig lid van de Provinciale Commissie van geneeskundig Toevoorzicht van Noord-Holland, volgde hem als hoofd van deze afdeling op. De oud-docent aan de Klinische School te Middelburg Fokker, de oud-voorzitter van de Provinciale Commissie van geneeskundig Toevoorzicht in Zuid-Holland W.F.P. Kiehl, en de betrekkelijk onbekende A.F.J. Ingenhousz, werden tot inspecteur van respectievelijk Zeeland, Utrecht/Gelderland en Noord-Brabant/Limburg benoemd. De meeste inspecteurs waren reeds lange tijd werkzaam op het terrein van de openbare hygiëne. Op 16 januari 1866 kwamen de zeven inspecteurs onder voorzitterschap van Thorbecke voor het eerst bijeen en namen de werkzaamheden van het Staatstoezicht een aanvang.

\section{$5 \quad$ De medische stand na 1865}

Met de invoering van de geneeskundige wetten in 1865 ontstond een nieuwe structuur in de medische beroepsgroep. De Wet 'regelende de voorwaarden tot verkrijging der bevoegdheid van geneeskundige', erkende slechts één soort van bevoegdheid, te verkrijgen door het afleggen van een aantal staatsexamens. Een ieder die deze examens na 1865 met succes had afgelegd, kreeg het recht op de 
nieuwe titel 'arts'. Alle tot op dat ogenblik praktizerende heel- en vroedmeesters kregen dezelfde bevoegdheden als hun academisch gevormde collega's. De opleiding was aan een der drie medische faculteiten of aan de Klinische School in Amsterdam plaatsvinden. In afwachting van een definitieve regeling van het medisch onderwijs was hierin reeds een belangrijke wijziging ingevoerd: het werd noodzakelijk om tijdens de studie ervaring aan het ziekbed op te doen. Daarom had men bepaald dat elke student een staatsexamen in de praktische genees-, heel- en verloskunde moest afleggen. Was vóór 1865 een promotie goed genoeg voor een praktijk als doctor medicinae, na 1865 was een promotie alléen niet voldoende om de bevoegdheid van arts te krijgen. Omgekeerd was een met goed gevolg afgelegd theoretisch en praktisch examen wèl voldoende om deze bevoegdheid te krijgen. ${ }^{45}$

Niet alleen de structuur, maar ook de maatschappelijke positie van de beroepsgroep was door de invoering van de geneeskundige wetten veranderd. De wetten zorgden voor een nieuwe taakverdeling tussen de rijksoverheid en de medische beroepsgroep. Het systeem van de medische politie - het uit provinciale en plaatselijke commissies bestaande staatsapparaat, dat in 1804 was opgezet om vanuit Den Haag de medische stand te besturen en de volksgezondheid te bevorderen - werd opgeheven. Een groot deel van de taken van de medische politie werd overgelaten aan het particulier initiatief. Voortaan gold de Nederlandsche Maatschappij tot bevordering der Geneeskunst als de instantie die de belangen van de geneeskundigen en de medische wetenschap moest behartigen. Dit had tot gevolg dat de praktijkuitoefening door bevoegde geneesheren, behoudens bij zeer grove misslagen, niet langer onderheving was aan overheidsbemoeienis.

Of de Maatschappij inderdaad de bestuurlijke rol heeft vervuld, die haar door Thorbecke was toegedacht, is zeer de vraag. Tijdens de kamerdebatten in de jaren 1862-1865 bleek, dat de NMG haar invloed onder een deel van de geneeskundigen had verloren. Doordat haar ledenbestand voor de helft uit gegradueerden en voor de andere helft uit niet-gegradueerden bestond - twee groepen met tegengestelde belangen - was zij niet in staat een krachtige stem te laten horen. Het ledental was teruggelopen tot 869 , nog niet de helft van het totaal aantal geneeskundigen. Een aantal afdelingen werd zelfs opgeheven.

Ook na 1865 verminderde het aantal leden gestaag; pas in de tweede helft van de jaren zeventig gegon het weer langzaam te groeien. ${ }^{45}$ Wetenschappelijke sectie-vergaderingen werden sinds 1861 niet meer gehouden en bleven ook in de rest van de negentiende eeuw achterwege. De redevoeringen van de NMGvoorzitters waren in de jaren zeventig en tachtig veelal somber van toon. Ondanks pogingen om de NMG nieuw elan te geven, duurde het tot in de jaren negentig voor er een einde kwam aan de aangeslagen toestand van de Maatschappij.

Als gevolg van deze verwikkelingen beschikte de NMG over onvoldoende aanhang om een effectief gezag uit te oefenen over alle geneeskundigen. De Maatschappij was bovendien een federatief verband van betrekkelijk autonome afdelingen, die hun leden geen dwingende maatregelen konden opleggen. De invoering van een medisch-tuchtrechtelijk systeem voor alle bevoegde geneeskundigen onder verantwoordelijkheid van de Maatschappij was daardoor niet goed mogelijk. Pas omstreeks 1900 was haar machtsbasis onder artsen sterk genoeg om te kunnen denken aan gewestelijke raden van disciplinair toezicht, 
bindende besluiten voor alle leden en sancties als geldboetes en uitsluiting van lidmaatschap. ${ }^{47}$

Vóór 1900 jaar kon alleen het Geneeskundig Staatstoezicht de geneeskundige (en farmaceutische) praktijk aan landelijke regels onderwerpen, en individuele geneeskundigen dwingen deze na te leven. Het is dan ook niet de Nederlandsche Maatschappij tot bevordering der Geneeskunst, maar het Geneeskundig Staatstoezicht dat gedurende de laatste decennia van de negentiende eeuw de basis heeft gelegd voor een goed georganiseerde medische beroepsgroep. ${ }^{4}$

Samenvattend kunnen we stellen dat de samenwerking in de jaren 1862-1865 tussen minister Thorbecke en de hygiënisten heeft geresulteerd in een organisatie van de gezondheidszorg op liberale grondslag. Men werd het eens over het verlenen van dezelfde bevoegdheden aan alle geneeskundigen, een scheiding van verantwoordelijkheden tussen staat en stand en de handhaving van de gemeentelijke autonomie.

De vier geneeskundige wetten van 1865 vertonen een grote onderlinge samenhang door de consequente toepassing van de volgende uitgangspunten:

1 De kennis van de gezondheidstoestand van de burgers en het inzicht in de middelen ter verbetering daarvan zijn onvoldoende. De staat moet de ontwikkeling van die kennis stimuleren. Gezien de beperkte kennis kan de regering voorlopig niet aangeven welke terreinen van de openbare hygiëne onder verantwoordelijkheid van de staat vallen.

2 De ervaring heeft geleerd dat plaatselijke regelingen op het gebied van de handel in geneesmiddelen, de uitoefening van de geneeskunst en de toelating tot de praktijk schadelijk zijn voor de volksgezondheid. Deze onderdelen van de gezondheidszorg behoren daarom tot de verantwoordelijkheid van de staat.

3 Voor het overige is het algemeen belang er het meest mee gediend, als de plaatselijke gemeenschappen het initiatief voor de verbetering van de volksgezondheid nemen. Dit initiatief staat onder toezicht van de staat. Mocht na verloop van tijd uit onderzoek blijken dat het algemeen belang door staatsonthouding schade is berokkend, dan diente de regering zich dit belang aan te trekken.

4 Alle burgers moeten een beroep kunnen doen op geneeskundige hulp van gelijke kwaliteit.

5 De voorgaande vier uitgangspunten bepalen de grenzen, waarbinnen de geneeskundigen vrij zijn zich te organiseren en naar eigen inzicht de geneeskunst te bevorderen.

Met deze uitgangspunten heeft Thorbecke de staatkundige duidelijkheid gebracht, waaraan het sinds 1818 had ontbroken. De wet van 1818 was in opzet bedoeld voor een centralistische gezondheidspolitiek, maar in de praktijk was daarvan niets terecht gekomen. Doordat tevens gezondheidsvoorschriften voor de lagere overheidsorganen ontbraken, ontstond een rechtsvacuüm waardoor bedreigingen van de volksgezondheid op hun beloop werden gelaten en ook gemakkelijk tegenstrijdige praktijken konden ontstaan.

Met de Provincie- en Gemeentewet van 1850-1851 heeft Thorbecke de verantwoordelijkheid voor de volksgezondheid expliciet bij de lagere organen gelegd. De wet van 1818 raakte daardoor in één klap verouderd. In 1865 verving Thorbecke de wet van 1818 door vier wetten, die aan de hand van duidelijke 
criteria bepaalden waar de plaatselijke verantwoordelijkheid ophield en die van de staat begon.

De grens tussen de plaatselijke verantwoordelijkheid en die van de staat lag niet voor altijd vast. Thorbecke geloofde te zeer in historische ontwikkeling en vooruitgang. Nieuwe inzichten en ervaringen konden het noodzakelijk maken dat provincie of staat verantwoordelijkheden van de plaatselijke gemeenschap overnam. Om deze ontwikkeling in de verhouding tussen staat en lagere organen te stimuleren, en om de regering over de gewenste verhouding bij specifieke gezondheidsproblemen te adviseren, stelde Thorbecke het Geneeskundig Staatstoezicht in.

Het vierde uitgangspunt - alle burgers moeten toegang hebben tot geneeskundige hulp - noodzaakte Thorbecke om belangen van de medische stand of delen daarvan ondergeschikt te maken aan die van de bevolking c.q. de volksgezondheid. Tegen alle protesten in schafte hij daarom het onderscheid tussen gegradueerden en ongegradueerden af, voerde hij wel praktische ervaring in maar geen promotie als toelatingseis, en stelde hij Amsterdam als opleidingsplaats op één lijn met de drie universiteitssteden. In het belang van de volksgezondheid legde hij de praktiserende geneeskundigen allerlei verplichtingen op, zoals de verplichting overlijdensverklaringen te ondertekenen en besmettelijke ziekten bij de autoriteiten aan te melden.

Zo bracht Thorbecke niet alleen staatkundige helderheid voor het moment, maar ook duidelijkheid over de wijze waarop veranderingen in de staatkundige verhoudingen op het gebied van de volksgezondheid moesten plaatsvinden.

De hygiënisten hebben een grote rol gespeeld bij de totstandkoming van de wetten. Zij hebben niet alleen Thorbecke in het drie jaar durende kamerdebat met raad en daad bijgestaan, maar ze hebben er ook voor gezorgd dat de NMG, ondanks felle protesten, bestuurlijke twisten en een dalend ledenaantal Thorbecke bleef steunen.

$\mathrm{Zij}$ hadden goede redenen om de nieuwe wetgeving als een verbetering te beschouwen. Want ook al hadden zij vele concessies gedaan, op het hoogste politiek niveau was erkend dat een goede volksgezondheid een nationaal belang was, waarvoor de landelijke overheid verantwoordelijkheid droeg. Voortaan behoorde de gezondheidstoestand van de bevolking een terugkerend onderwerp van bespreking in de landelijke politiek te zijn.

Voor de hygiënisten was de toekomst hoopvol: zij gaven leiding aan het Geneeskundig Staatstoezicht. Van de provinciale en gemeentelijke besturen werd verwacht dat zij de volksgezondheid bevorderden, de hygiënisten konden gevraagd en ongevraagd advies uitbrengen. Tegelijk moesten zij de gezondheidszorg en de gezondheidstoestand van de bevolking van jaar tot jaar in kaart brengen. De hygiënisten kregen dus daadwerkelijk de kans het gezondheidsdebat naar hun hand te zetten. 


\section{Het Geneeskundig Staatstoezicht in de jaren 1865-1890}

Door de allengs voortgeschreden kennis der natuur [..] is de maatschappij al meer en meer tot de overtuiging gekomen, dat men niet slechts door redenering of vertoog over godsdienst en zedekunde, maar vooral door de zorg voor doelmatige voeding, voor gezonde woning, voor licht en lucht, voor zuiver water en eene reukloze omgeving moet streven naar de tegenwoordige alom krachtig aangeprezene hervorming der maatschappelijke toestanden.

L. Ali Cohen, 1866

\section{De politieke achtergronden, $1865-1870$}

\section{De laatste poging van Mulder}

$\rightarrow$

De inspecteurs en de overige functionarissen van het Geneeskundig Staatstoezicht vingen hun arbeid in 1865 onder een niet al te gunstig politiek gesternte aan. Drie weken na de eerste vergadering van de inspecteurs, kwam Thorbecke in conflict met de minister van Koloniën en werd genoodzaakt af te treden. Het liberale kabinet regeerde nog enkele maanden, maar bood uiteindelijk in verwarring en onenigheid zijn ontslag aan. De Koning, altijd verheugd wanneer hij de liberalen kon laten gaan, benoemde een conservatief- ministerie Van Zuylen van Nijevelt-Heemskerk met de opdracht de binnenlandse problemen voorlopig onaangeroerd te laten. Het nieuwe kabinet kwam al in september 1866 in conflict met de Tweede Kamer, waar de liberalen de meerderheid hadden. Deze keer ontbond de Koning het parlement en schreef verkiezingen uit. De conservatieven deden het voorkomen alsof het ging om de keuze tussen monarchie en republiek, maar zij kregen van de kiezers weinig steun. Ondanks de voor de conservatieven teleurstellende verkiezingsuitslag bleef het door de Koning gesteunde conservatieve kabinet met mr. J. Heemskerk Azn. als minister van Binnenlandse Zaken, nog tot het midden van 1868 in functie. Heemskerk heeft zich in deze periode ontwikkeld tot de aanvoerder van de in aantal sterk teruglopende conservatieven.

De politieke verwikkelingen in 1866 werden door de tegenstanders van de liberale, geneeskundige wetgeving aangegrepen om nog éénmaal front te maken. De Geneeskundige Courant herhaalde de bezwaren tegen het ontbreken van medische politiereglementen. Mulder wendde zich in een open brief tot Heemskerk, waarin hij constateerde dat de Wet op het geneeskundig staatstoezicht 'niets inhield, dat voor de algemeene gezondheidstoestand van eenige waarde was'. Mulder trok de zaak in het constitutionele vlak door te wijzen op wat er in het Franse politieke bestel was bereikt. Wetende dat de Koning grote bewondering voor Napoleon III koesterde, prees Mulder de vernieuwingen die onder 
diens leiding tot stand waren gekomen. In Parijs waren de krottenwijken opgeruimd en had men riolering, waterleiding en brede straten aangelegd. Op deze zelfde wijze zou men ook een deel van Mulders woonplaats Utrecht met behulp van 'imperatief' gegeven voorschriften moeten afbreken en volgens de modernste hygiënische inzichten weer opbouwen. ${ }^{\text {I }}$

Mulders radicale alternatief voor het liberale gezondheidsbeleid kreeg zelfs in conservatieve kring geen bijval. Wel reageerde Ali Cohen op de open brief. Hij verweet Mulder een onjuiste voorstelling van zaken te geven ten aanzien van het staatsbestel en de rol van geneeskundigen. Zijn voorstellen waren bijzonder onpraktisch en zouden bovendien tot een bankroet van Utrecht en iedere andere gemeente leiden. Ali Cohen herhaalde het liberale standpunt, dat eerst onderzoek gedaan moest worden, alvorens men een beleid kon gaan uitstippelen. In plaats van Mulders dirigistische model moesten er gemeentelijke gezondheidscommissies komen, die met behulp van het Staatstoezicht politieke druk op de plaatselijke besturen konden uitoefenen. ${ }^{2}$

De discussie in de zomer van 1866 vormde de laatste schermutseling tussen de invloedrijk geworden liberale medici en de verzwakte conservatieve partij. De Koning en de conservatieven moesten in de jaren 1866-1868 trouwens over de gehele linie hun anti-liberale ambities laten varen. In 1868 kon er weer een liberaal kabinet door Thorbecke gevormd worden zonder dat hij er zelf aan deelnam (het zakenkabinet-Van der Bosse-Fock). Minister van Binnenlandse Zaken werd mr. C. Fock. Hij reorganiseerde het departement op bekwame wijze en was tevens verantwoordelijk voor de 'professionalisering' van het ambtenarenapparaat.

\section{Toenemende invloed van de hygiënisten}

Halverwege de jaren zestig had de hygiënische beweging vaste grond onder de voet gekregen. De beweging had zich aanzienlijk uitgebreid en aan sociale en politieke invloed gewonnen. Talloze hygiënisten bekleedden officiële functies bijvoorbeeld als lid van een geneeskundige raad, zoals Coronel, Teixeira de Mattos, Pous Koolhaas, De Man, Israëls, Allebé, J.F. van Hengel, A.M. Ballot en M.F. Onnen. " Bovendien raakten door het betrekkelijk democratische roulatiesysteem bij de benoeming van de leden van de geneeskundige raden ook plattelandsheelmeesters en apothekers bij de zorg voor de openbare hygiëne betrokken.

Ook de invloed van de hygiënisten op politiek terrein groeide. Vanaf het begin van de jaren zestig werd een toenemend aantal hygiënisten lid van een gemeenteraad. ${ }^{5}$ Op advies van de hygiënisten nam Thorbecke tegen het eind van 1865 op landelijk niveau maatregelen ter bestrijding van een dreigende choleraepidemie. Een ander succes was de invoering van enkele veewetten. Deze waren niet alleen voor de economisch belangrijke veeteelt, maar ook voor de volksgezondheid van betekenis. Onder andere in 1865 , toen een runderpestepidemie uitbrak die grote verwoestingen onder de veestapel aanrichtte. Thorbecke vaardigde direct op advies van Ali Cohen een tijdelijke Wet ter beteugeling van de runderpest uit (Stb. 121).

De landelijke choleracommissie, de rapporten, de ministeriële circulaires en de maatregelen ter bestrijding van de runderpest vestigden alom de indruk dat de volksgezondheid een zaak van nationaal belang was. Op de rijksbegroting van 1867 was al een half miljoen gulden voor medische politie uitgetrokken. En in 
1868 was er zelfs meer dan $f 1.134 .000$,-beschikbaar, waarvan één miljoen voor de bestrijding van veeziekten. De geneeskundige inspecteurs maakten van de gelegenheid gebruik een ontwerp-wet op het drinkwater en een ontwerp-wet op de besmettelijke ziekten in te dienen. De inspecteurs drongen er met kracht op aan om het al in 1852 onder Thorbecke gereedgekomen en sindsdien vele malen gewijzigde wetsontwerp op de begraafplaatsen tot wet te verheffen en een Staatstoezicht op de veeartsenijkunde in het leven te roepen.

Minister Fock bleek in 1868 bereid op een deel van deze wensen in te gaan. Een drinkwaterwet wees hij echter van de hand, omdat deze de gemeenten op hoge kosten zou jagen. Een wet op de besmettelijke ziekten hield hij aan. Wel kwam er door zijn toedoen in 1869 een Begrafeniswet. Met deze wet kwam de minister tegemoet aan de verlangens van de NMG inzake het begraven en het lijkbezorgingsrecht: de inrichting en lokalisatie van begraafplaatsen en de wijze van begraven werden gereglementeerd. Tevens werd bepaald dat een ambtenaar van de Burgerlijke Stand pas verlof tot begraven mocht geven, wanneer een erkend geneeskundige via een schriftelijke verklaring te kennen had gegeven, dat hij de dood had geconstateerd. ${ }^{6}$ Dit was de eerste wet sinds 1865 die de gemeentebesturen dwong ministeriële bepalingen met betrekking tot de openbare hygiëne op eigen kosten uit te voeren. Volgens de Wet van 1865 was het toezicht op de uitvoering van deze bepalingen aan de inspecteurs opgedragen, hetgeen hen blijkens de verslagen van het Staatstoezicht handen vol werk moet hebben bezorgd. Ten slotte kwam er op initiatief van minister Fock in 1870 een Wet tot regeling van het veeartsenijkundig staatstoezicht. ${ }^{7}$ Deze wet maakte het, anders dan bij de maatregelen van Thorbecke, mogelijk gemeentebesturen tijdens een epidemie tot werkzaamheid te dwingen.

\section{Het wetenschappelijk onderzoek}

Tegen het eind van de jaren zestig had de Tweede Kamer de liberale beginselen van de wetten van 1865 in meerderheid aanvaard. De meeste politici en functionarissen van het Staatstoezicht, meenden dat er een stevig fundament gelegd was, waarop het moderne gebouw van de openbare gezondheidszorg kon worden opgetrokken. Dit kon pas plaatsvinden na een grondig onderzoek naar de gezondheidstoestand van Nederland en naar de beste middelen ter verbetering daarvan. Met voortvarendheid werd dit onderzoek ter hand genomen. In de volgende paragraaf zullen wij op de belangrijkste onderdelen ingaan.

\section{De geneeskundige plaatsbeschrijving van Nederland}

De geneeskundige plaatsbeschrijving werd door de NMG vanaf het begin van de jaren vijftig gezien als een onmisbaar onderdeel van het onderzoek naar de gezondheidstoestand van de Nederlandse bevolking. Bij de installatie van de inspecteurs in 1866 zei Thorbecke, die dezelfde mening was toegedaan, dat 'deze zaak zeer belangrijk was, èn wat de zaak betreft, èn om aan te duiden dat voor de hygiëne hier te lande een nieuwe epoque is aangebroken, een epoque die schone gevolgen belooft." $\mathrm{De}$ inspecteurs ontwierpen een plan dat behelsde dat de leden van de geneeskundige raden de gegevens voor een 'medische topographie' moesten verzamelden. Het plan week niet veel af van wat Schick, en vervolgens Ali Cohen en Acker Stratingh in de jaren vijftig hadden bepleit. 
De fysische geografie, de geologie, de hydrografie, de meteorologie, de statistiek van de inwoners, de beschrijving van het welvaartsniveau, de lichaamslengte in verband met voeding en gemeentelijke gezondheidsverordeningen: dit alles behoorde volgens de inspecteurs tot de geneeskundige plaatsbeschrijving."

In elke provincie werden in de jaren 1867-1869 commissies benoemd die de beschrijvingen ter hand moesten nemen. ${ }^{10}$ Onder redactie van Ali Cohen, Lubach en Teixeira de Mattos, verschenen tussen 1870 en 1881 vijf plaatsbeschrijvingen, te weten van de provincies Zeeland, Friesland, Overijssel en Limburg en van het Gooiland. ${ }^{I I}$ Behalve de plaatsbeschrijving van het Gooiland uit 1875 door J. van Hengel, hadden alle studies uitsluitend betrekking op de natuurlijke gesteldheid van de provincies. De overige onderdelen van de plaatsbeschrijving zijn nooit in afzonderlijke publikaties verschenen. ${ }^{12}$ Dit laatste werd gedeeltelijk gecompenseerd door de jaarlijkse verslagen van het Geneeskundig Staatstoezicht, waarin een statistische rubriek en een overzicht van de gemeentelijke verordeningen waren opgenomen. ${ }^{13}$

De inspanningen van de inspecteurs en van de geneeskundige raden hebben in de jaren zeventig en tachtig diverse statistische bewerkingen van de sterfte in samenhang met plaatsbeschrijvingen van gemeenten als Kampen, Leeuwarden, Arnhem en Den Haag opgeleverd. ${ }^{14}$ Ook het door de NMG geïnitieerde en door de geneeskundige raden uitgevoerde onderzoek naar de volksvoeding in de jaren zeventig was een uitvloeisel van de plaatsbeschrijvingen. Deze onderzoekingen betekenden in veel gevallen het begin van een medisch-geografische en statistische traditie.

\section{De medische statistiek}

Uit het voorgaande moge duidelijk zijn geworden, dat men na 1865 de lokalistische leer van de volksziekten verder tot ontwikkeling wilde brengen met behulp van de medische topografie. Omdat het Staatstoezicht tot taak had de gemeentebesturen ervan te overtuigen dat de gezondheid van de bevolking afhankelijk was van de plaatselijke sanitaire omstandigheden, was daarvoor meer reden dan ooit.

De medici hadden duidelijk baat bij de in 1865 en 1869 verbeterde registratie van de sterfte. ${ }^{15}$ In de verslagen van het Geneeskundig Staatstoezicht werd jaarlijks een uitvoerig overzicht opgenomen van de sterfte ingedeeld naar doodsoorzaak per provincie, gemeente en voor het hele land. Enkele belangrijke infectieziekten, zoals pokken, roodvonk, mazelen, tyfus en difterie werden nog eens apart geregistreerd. Over de epidemieën van cholera (1832-1869) en pokken (1870-1873 en 1876) zijn afzonderlijke rapporten uitgegeven. ${ }^{16}$ Vanaf 1875 wordt de sterfte tevens ingedeeld naar leeftijd, terwijl het aantal doodsoorzaken in de overzichten aanzienlijk wordt uitgebreid (tot 34 categorieën). Vanaf hetzelfde jaar wordt de sterfte in gemeenten met meer dan 20.000 inwoners afzonderlijk opgegeven. Na 1880 geeft het departement van Binnenlandse Zaken vijfjaarlijkse overzichten uit van de sterfte naar doodsoorzaak, geslacht, leeftijd en gemeente. Voorts verschijnen er vijfjaarlijkse overzichten met grafische voorstellingen betreffende de sterfteverhouding voor het gehele land, de provincies en de vier grootste gemeenten. In deze overzichten zijn tevens opgaven van de zuigelingensterfte in elke gemeente en van de relatieve sterfte aan enkele infectieziekten in iedere buurt van Amsterdam opgenomen. ${ }^{17}$ Ten slotte verdient de publikatie van de door de NMG in 1879 uitgegeven sterfte-atlas over de 
jaren 1860-1874 vermelding. Deze tweede atlas is, anders dan die uit 1866 , in samenwerking met het departement van Binnenlandse Zaken tot stand gekomen. ${ }^{18}$

De samenvattingen van al dit statistisch materiaal verschenen jaarlijks in het Nederlandsch Tijdschrift voor Geneeskunde, bezorgd door J.G.M. Hanlo, Egeling en een enkele maal Ali Cohen. ${ }^{19}$ De artsen informeerden het publiek regelmatig over hun statistische bevindingen, bijvoorbeeld in het Tijdschrift voor Gezondheidsleer en het tijdschrift De Gezondheid. De arts L. Scheltema Beduin, die in 1874 Teixeira de Mattos als secretaris van de geneeskundige dienst van Amsterdam was opgevolgd, zette de in 1848 gevestigde traditie van de verslaglegging over sterfte en ziekten voort. Vanaf 1881 deed hij zelfs wekelijks opgave van de sterfte en ziekten te Amsterdam. ${ }^{20}$

$\mathrm{Na} 1870$ verschenen ook studies over de sterfte in afzonderlijke gemeenten, zoals die in de jaren zestig voor Amsterdam waren verricht. Soms betrof het analyses op kleine schaal (Dordrecht, Numansdorp, Middelburg), soms ging het om groot statistisch onderzoek. ${ }^{2 I}$ Tot de laatste moeten de plaatsbeschrijvingen van Leeuwarden, Arnhem en Den Haag worden gerekend. Aan de hand van gegevens over meerdere jaren onderzochten de auteurs de verdeling van de sterftegevallen naar leeftijd en over de verschillende wijken en straten. De grotere sterfte die zij in de armenbuurten constateerden, schreven zij toe aan de slechte sanitaire omstandigheden. Een enkele keer werd de sterfte gerelateerd aan andere criteria voor sociale stratificatie, zoals de maatschappelijke positie van de inwoners of de bevolkingsdichtheid van een wijk. Omdat in deze onderzoekingen de verklaring voor de sociale sterfteverschillen nogal afweek van die uit de lokalistische leer der volksziekten, zullen zij later apart worden besproken.

Evenmin als dat vóór 1865 geschiedde, werden brutosterftecijfers niet gestandaardiseerd als men de gezondheidstoestand van gemeenten of stadswijken met elkaar wilde vergelijken. Pas vanaf omstreeks $1880 \mathrm{kwam}$ hierin geleidelijk verandering. Ten eerste werd sindsdien de leeftijdsverdeling van de bevolking steeds vaker opgegeven. Hierdoor was men in staat de verhouding van de sterfte in een bepaalde leeftijdscategorie tot het totale aantal mensen uit die leeftijdsgroep te berekenen. Deze nieuwe benadering treffen we aan in de tweede sterfte-atlas van de NMG, waarin opgaven staan van het gemiddelde aantal overledenen op 1000 levenden van dezelfde leeftijd per jaar. Op deze wijze kreeg men een beter inzicht in de betekenis van de leeftijd als sterfte- en ziektefactor. Ten tweede werd omstreeks 1880 het gebruik van een standaardpopulatie gangbaar, zij het aanvankelijk vooral in de kring van statistici. $\mathrm{Zij}$ bewerkten en vergeleken de sterftecijfers volgens de methode van de Hongaar $J$. Korösy, die directeur was van het statistisch bureau in Budapest. Hierbij werden de leeftijdsspecifieke sterftecijfers van de te vergelijken populaties toegepast op de leeftijdsverdeling van een standaardpopulatie (tegenwoordig 'direct standaardiseren' genoemd). ${ }^{22}$ In Nederland zouden de geneeskundigen pas rond 1900 al hun gegevens standaardiseren. Tot dat jaar bleef het vergelijken van de sterfte per wijk of straat een moeilijke zaak, omdat de wijksgewijze leeftijdsopbouw van de bevolking onvoldoende was vastgelegd.

Het is opmerkelijk dat de inspecteurs en andere functionarissen van het Staatstoezicht tot 1890 vasthielden aan de gewoonte de brutosterfte per gemeente niet-gestandaardiseerd te vergelijken. De onverschilligheid ten aanzien van de betrouwbaarheid van de statistische uitkomsten kwam wellicht voort uit het feit 
dat het Staatstoezicht niet zozeer de perfectionering van de statistische methoden nastreefde, als wel het vaste verband tussen plaatselijke omstandigheden en sterfte wilde aantonen. Dit kan aan de hand van een reeks artikelen en overzichten uit de periode tussen 1875 en 1890 worden geillustreerd. In 1876 vergeleek M.F. Onnen, lid van de Geneeskundige Raad van Zuid-Holland en actief sanitair hervormer de sterfte in Dordrecht voor de perioden 1840-1860 en 18661875 met die in Den Haag. Het was zijn bedoeling na te gaan, in hoeverre de bemoeiingen der Regeering ten gunste van de volksgezondheid in Dordrecht reeds vruchten gedragen hebben, erkenbaar in de verbetering van het gemiddelde jaarlijksche sterfte-cijfer. ${ }^{, 23}$ Het bleek dat de gezondheidstoestand in Dordrecht de laatste tien jaren ten opzichte van de eerste periode sterk was verbeterd, terwijl die in Den Haag achteruit was gegaan. De verschillen waren volgens Onnen volledig te verklaren, als men het actieve sanitaire beleid in Dordrecht en de onachtzaamheid van het Haagse gemeentebestuur ten aanzien van de drinkwatervoorziening, het schoonhouden van de grachten en de riolering in de beoordeling betrok.

Na 1876 treffen we deze wijze van analyseren ook bij andere medici aan. Egeling publiceerde jaarlijks de brutosterftecijfers van veertien grotere gemeenten in het Nederlandsch Tijdschrift voor Geneeskunde, en een enkele keer in het hygiënisch tijdschrift De Gezondheid, met de bedoeling dat de opgaven als een 'gezondheidsthermometer' voor de desbetreffende gemeente zouden fungeren. Ali Cohen rangschikte in 1880 de belangrijkste steden volgens de stand van hun gezondheidsthermometer. Hij kon zodoende de gevolgtrekking maken dat in de laagst geplaatste gemeenten met de gemiddeld hoogste sterfte de ziekmakende factoren onvoldoende werden bestreden. ${ }^{24}$ De adjunct-inspecteur voor ZuidHolland, Carsten, trachtte in 1882 en 1884 eveneens met behulp van brutosterfte-opgaven de zegeningen van sanitaire maatregelen in twee kleinere gemeenten aan te tonen. Hij liet zien dat dankzij de vervanging van zout water in kanalen en sloten door zoet water, en door de verbetering van het grondwater de volksgezondheid met sprongen was vooruit gegaan. ${ }^{25}$ Nog in 1890 presenteerde Van Overbeek de Meijer - in een terugblik op de resultaten van het Staatstoezicht - de brutosterfte van een groot aantal gemeenten om aan te tonen, dat sterfte in nauw verband stond met gemeentelijke gezondheidspolitiek. ${ }^{26}$

De conclusie moet luiden dat de lokalistische leer van de volksziekten, ondanks haar statistische onvolkomenheden, tot aan de jaren negentig onaantastbaar is gebleven. De reden om aan de 'gezondheidsthermometer' per gemeente vast te houden was niet alleen om het belang van een gemeentelijk sanitair beleid aan te tonen, maar ook om het nut van het Staatstoezicht te bevestigen. Immers, waar de gemeentebesturen de adviezen van de inspecteurs hadden opgevolgd, bleek de sterfte gedaald te zijn. Bij het onderzoek naar sociale sterfteverschillen binnen een gemeente werd de methode gevolgd die voor Amsterdam is beschreven: men vergeleek geaggregeerde gegevens per wijk of straat om verschillen in de fysisch-geografische kenmerken op te sporen. 


\section{Het Handboek der openbare gezondheidsregeling}

Het door de inspecteurs verrichte onderzoek naar de technische en wettelijke mogelijkheden tot verbetering van de volksgezondheid was evenals het topografisch en statistisch onderzoek gericht op het lokale en regionale fysisch-geografische milieu. Het doel was in de eerste plaats om de provincie- en gemeentebesturen concrete maatregelen aan de hand te doen om de 'assaineering der maatschappij' te bevorderen. Maar de inspecteurs wilden met hun onderzoek tevens aantonen, dat de rijksoverheid in veel gevallen het voortouw in de gezondheidspolitiek moest nemen, en dat de uitbreiding van het werkterrein van het Geneeskundig Staatstoezicht beslist noodzakelijk was.

Ali Cohen vatte in 1866 het plan op om een encyclopedisch werk over de openbare hygiëne in Nederland uit te geven. In dit werk moesten alle bedreigingen van de gezondheid aan bod komen die door de overheid behoorden te worden aangepakt. Het project resulteerde in 1872 in de uitgave van het Handboek der openbare gezondheidsregeling en der geneeskundige politie, het eerste oorspronkelijke Nederlandstalige boek over de openbare gezondheidszorg. ${ }^{27}$ Het Handboek bevatte bijdragen van talrijke vooraanstaande hygiënisten over uiteenlopende onderwerpen als voedingsmiddelen, woningen, arbeidsgeneeskunde, openbare hygiëne in steden, hygiëne in hospitalen, gevangenissen en schoolgebouwen, volksziekten en zorg voor een gezond nageslacht. De bespreking van een indrukwekkende hoeveelheid binnen- en buitenlandse literatuur maakte van de verschijning van het Handboek een mijlpaal in de ontwikkeling van de openbare gezondheidsleer. Het boek, dat in zijn omvang en rijkdom aan details in de negentiende eeuw niet meer is geëvenaard, heeft jarenlang dienst gedaan als naslagwerk voor de geneeskundigen die op plaatselijk niveau de openbare hygiëne wilden bevorderen.

In het Handboek waren alle problemen op het terrein van de volksgezondheid beschreven die de inspecteurs en de geneeskundige raden door middel van overheidsmaatregelen opgelost wilden zien. Er werd in het bijzonder de nadruk gelegd op milieuverontreiniging, riolering en drinkwatervoorziening, de hygiëne van openbare gebouwen, huisvesting en de strijd tegen de besmettelijke en epidemische ziekten. De bespreking van de betekenis van het Geneeskundig Staatstoezicht voor het provinciaal en gemeentebeleid zal tot deze onderwerpen beperkt blijven, ook al omdat indertijd de doelmatigheid van het Geneeskundig Staatstoezicht hieraan getoetst werd.

\section{Drinkwater}

In hoofdstuk 4 is beschreven, dat de geneeskundigen van het Staatstoezicht omstreeks 1870 ervan uitgingen dat het drinkwater een rol speelde bij de verspreiding van de cholera. Het drinkwaterrapport van 1869 en ook andere rapporten van de inspecteurs bevatten de conclusie dat het ziekmakende 'cholerabeginsel' al dan niet na fermentering in de bodem, via met name pomp-, put- of oppervlaktewater tot epidemieën kon leiden. Men stelde zich op het standpunt dat een dergelijke verspreidingsroute ook voor tyfus en andere gastrointestinale aandoeningen gold. 
Men was in beginsel in staat om op twee manieren het drinkwater van de burgers te verbeteren. Ten eerste kon het aantal drinkwatervoorzieningen worden uitgebreid, zoals pompen, putten, waterwagens en drinkwaterleidingen. In de tweede plaats kon men de vervuiling van bodem- en oppervlaktewater bestrijden, om het weer enigszins geschikt te maken voor consumptie.

De inspecteurs en de geneeskundige raden hebben aan de tweede methode de voorkeur gegeven. Daar hadden zij goede redenen voor. Verbetering van de drinkwatervoorziening kwam maar moeizaam op gang. De halfslachtige pogingen die na de cholera-epidemie van 1866 waren ondernomen, hadden weinig uitgehaald. De verkoop van vers drinkwater via waterwagens en het slaan van diepere putten op kosten van de gemeente konden niet voorkomen dat een groot deel van de stadsbevolking grachtwater bleef consumeren, omdat het verstrekte water veelal te duur was of slecht van smaak. ${ }^{28} \mathrm{Er}$ bestonden geen mogelijkheden om de plaatselijke besturen te dwingen de drinkwatersituatie te verbeteren. Een wet op het drinkwater, waar de inspecteurs om hadden gevraagd, was in 1869 politiek onhaalbaar gebleken. De aanleg van drinkwaterleidingen gaf te grote financiële en technische problemen om tot de directe mogelijkheden te behoren. De bouw van een watertoren of een stoominstallatie (voor het opbouwen van drukverschil) ging de financiële draagkracht van de meeste gemeenten te boven, en ook het bepalen van een geschikt drinkwaterreservoir stuitte in sommige streken op onoverkomelijke bezwaren. Een groot bijkomend nadeel van een drinkwaterleiding was volgens de inspecteurs dat de gemeenten vanwege de hoge kosten een beroep op particuliere investeerders moesten doen. Deze konden het water uiteraard tegen een bepaalde prijs verkopen, waardoor alleen degenen die het konden betalen van de drinkwaterleiding zouden profiteren. ${ }^{29}$

De sanering van bodem- en oppervlaktewater bood daarentegen meer perspectief. De inspecteurs beschikten namelijk over ruime bevoegdheden om de bestuurders op hun verantwoordelijkheid ten aanzien van vervuiling te wijzen. Zij gingen er terecht van uit dat een stadsreinigingsdienst, een tonnenstelsel of riolering - in tegenstelling tot een waterleiding - de gehele stadsbevolking ten goede kwamen. Dergelijke maatregelen boden daarom een betere bescherming tegen het uitbreken van epidemieën. Bovendien betoogden de inspecteurs bij voorduring, dat een goede stadsreiniging kon worden bekostigd uit de opbrengsten van de verkoop van mest (zie hierna), terwijl een drinkwaterleiding de burgerij alleen maar geld zou kosten. Het laatste was politiek een zwaarwegend argument. Juist vanwege die kosten voelden de beter gesitueerden die vaak op hoger gelegen plaatsen in de gemeenten woonden en over relatief goed putwater beschikten (zoals in Utrecht en Groningen), weinig behoefte aan een waterleiding. 30

Omstreeks 1880 wijzigde de publieke opinie zich definitief ten gunste van de waterleiding. In een groot aantal gemeenten werden concessies aan particuliere drinkwaterbedrijven verleend. In 51 gemeenten werden waterleidingen aangelegd, die te zamen aan het eind van de eeuw ongeveer veertig procent van de Nederlandse bevolking van leidingwater voorzagen. Het oorspronkelijke bezwaar van de inspecteurs was echter nog steeds geldig, omdat vooral de beter gesitueerden van de nieuwe voorziening profiteerden. 
Op grond van Von Pettenkofers bodemtheorie had het Staatstoezicht een belangrijke taak in de zorg voor het milieu. Met name werd de verontreiniging van bodem en grondwater door afvalprodukten van agrarische bedrijven als een potentiële bron gezien van cholera, tyfus of malaria. Verontreinigde gebieden werden herhaaldelijk gecontroleerd om te zien of de gemiddelde sterfte hoger was dan elders.

Artikel 14 van de Wet op het geneeskundig staatstoezicht gaf de inspecteurs de mogelijkheid gevraagd en ongevraagd adviezen te geven inzake de vervuiling van het milieu. Van deze mogelijkheid is zeer veel gebruik gemaakt. Na 1865 vroegen bijvoorbeeld de Gedeputeerde Staten veelvuldig de inspecteurs om hun mening, alvorens een vergunning tot vestiging van een fabriek te verlenen. Het kwam nogal eens voor dat de inspecteurs een negatief advies uitbrachten, bijvoorbeeld in het geval van een leerlooierij, een slachterij of een bergplaats van lompen in de bebouwde kom. Uit de verslagen van het Staatstoezicht komt echter ook naar voren, dat de inspecteurs niet altijd één lijn trokken. Zo kon de ene inspecteur adviseren een bepaald milieubedervend fabrieksprocédé te verbieden, terwijl een andere het toestond, omdat niet was bewezen dat de volksgezondheid erdoor werd geschaad.

Een onderzoek van Ali Cohen naar de gevolgen voor het milieu van de aardappelmeelindustrie in Groningen en Friesland verwierf landelijke bekendheid. Op verzoek van Gedeputeerde Staten bracht hij tussen 1871 en 1881 een viertal rapporten uit, waaruit bleek dat het oppervlaktewater ernstig was verontreinigd met rottende eiwitprodukten, die met het afvalwater van de fabrieken in grote hoeveelheden op sloten en kanalen werden geloosd. ${ }^{32}$ Ondanks de massale vissterfte en de stank die dit tot gevolg had, achtte Ali Cohen het niet bewezen dat er gevaar voor de volksgezondheid te duchten was. Wel leek het hem om 'esthetische' overwegingen wenselijk een methode te ontwikkelen, die het afvaleiwit uit het door vele inwoners als drinkwater gebruikte oppervlaktewater kon weren. Gedeputeerde Staten moesten de fabrikanten dwingen mee te helpen aan de oplossing van dit probleem, luidde het advies in zijn rapporten. De inspanningen van Ali Cohen konden evenwel niet verhelpen dat de milieuverontreiniging door de economisch belangrijke aardappelmeelindustrie de rest van de negentiende eeuw aanhield.

Ali Cohens onderzoek was, getuige de verslagen van het Staatstoezicht, slechts één van de vele onderzoekingen naar de invloed van de nijverheid op het milieu. Een permanent probleem was de afwezigheid van een wettelijke sanctie om de fabrikanten te dwingen eventuele schade aan milieu en volksgezondheid te beperken. Het vergunningenstelsel dat sinds 1824 de vestiging van fabrieken regelde, was verouderd. Dit was gebaseerd op de gedachte, dat de mate van 'gevaar' voor omwonenden, bepaalde of het plaatselijk bestuur, de Gedeputeerde Staten of de Kroon vergunning tot vestiging van een fabriek verleende. Er bestonden geen algemene bepalingen met betrekking tot dat gevaar, zodat een aanvraag tot vestiging van geval tot geval door de betrokken autoriteiten werd behandeld. De willekeur was daardoor bijzonder groot. De deskundigheid van de autoriteiten schoot bovendien steeds vaker tekort bij de technische veranderingen die zich in de industriële nijverheid na 1850 voltrokken. De door Gedeputeerde Staten, gemeentebesturen en inspecteurs te hooi en te gras opgestelde aanvullingen op het bestaande concessiestelsel hadden geen verbetering ge- 
bracht: ze waren dikwijls tegenstrijdig en gemakkelijk te ontduiken. ${ }^{33}$ Thorbecke had in 1865 geprobeerd in deze situatie verandering te brengen door een ontwerp-hinderwet, maar deze haalde niet eens een openbare behandeling. Ook de liberale minister Fock diende in 1870 een ontwerp-hinderwet zonder succes in.

De inspecteurs waren vanzelfsprekend voorstander van de vervanging van het vergunningenstelsel door een wet 'op de hygiëne van bodem, water en lucht'. Zij verlangden bovendien dat een dergelijke wet ook betrekking zou hebben op de veiligheid en gezondheid van arbeiders. Dit laatste stuitte echter op verzet van zowel Thorbecke als Fock. Beide ministers wilden met hun wetsontwerpen alleen het milieubederf door fabrieken aan banden leggen - zoals de milieuverontreiniging als gevolg van de fabricage van kleurstoffen. De publieke opinie was al evenmin rijp voor een algemene reglementering van de arbeidsomstandigheden en de voorstellen van de inspecteurs maakten dan ook geen schijn van kans. In 1875 werd eindelijk een Hinderwet van kracht, die bepaalde dat de gemeentebesturen een vergunningenstelsel in het leven moesten roepen voor fabrieken en werkplaatsen, dat bij algemene maatregel van bestuur nader zou worden omschreven. ${ }^{34}$

Afgaande op de verslagen van het Staatstoezicht hebben de meeste gemeentebesturen na de invoering van de verplichte plaatselijke verordeningen de inspecteurs veelvuldig om advies gevraagd, alvorens een vergunning tot vestiging van een fabriek of werkplaats te verlenen. De door de inspecteurs gestelde voorwaarden zijn volgens die verslagen althans voor het merendeel door burgemeester en wethouders overgenomen. De werkelijkheid is waarschijnlijk minder rooskleurig geweest. Aan het toezicht op de uitvoering van de toch al niet strenge voorwaarden schortte het nogal eens, en de behandeling van de klachten van inspecteurs kon soms jaren op zich wachten. De gemeentebesturen beperkten zich zo veel mogelijk tot een administratieve afhandeling van de verplichte procedure en vermeden angstvallig ieder eigen initiatief, vooral als dit de gemeente geld kon kosten. ${ }^{35}$ De Hinderwet was afgezien van enkele kleine wijzigingen en aanvullingen de laatste landelijke maatregel, die in de negentiende eeuw op het gebied van de 'industriële' milieuvervuiling in ons land is uitgevaardigd. ${ }^{36}$

\section{Niet-industriële verontreiniging}

De tijdgenoten maakten zich veel meer zorgen over de niet-industriële verontreiniging: de gebrekkige stadsreiniging, de vervuiling in woonkernen als gevolg van particuliere mestverzamelingen en veehouderij, de afwezigheid van riolen voor de afvoer van regenwater, de stinkende grachten en sloten. De geneeskundigen van het Staatstoezicht hadden uiteraard de meeste belangstelling voor de vervuiling van bodem en oppervlaktewater met organische stoffen. Zij zagen hierin immers één van de belangrijkste oorzaken van epidemische volksziekten als cholera en tyfus. De inspecteurs wilden het probleem daarom zo snel mogelijk opgelost zien. ${ }^{37}$

De hygiënisten stonden voor zeer grote problemen. Om te beginnen waren er geen deugdelijke oplossingen voor het verwijderen en verwerken van afvalstoffen. Slechts drie gemeenten - Deventer, Groningen en Maastricht - deden de vuilverwijdering in eigen beheer. In de overige gemeenten was deze taak verpacht aan particulieren of instellingen als armbesturen en werkfondsen. ${ }^{38}$ In 
sommige steden waren centrale vuilnisbakken geïnstalleerd, waarvan de inhoud door de exploitanten naar as- en vuilnisbelten werd overgebracht. Het vuil in de vuilnisbakken bleef meestal te lang liggen, zodat het rotte voordat de bakken werden geleegd. In talloze steden waren bovendien 'spontane' vuilstortplaatsen ontstaan op braakliggende terreinen, in doodlopende stegen of onder bruggen. Er moeten naar schatting duizenden vuilstortplaatsen in het land zijn geweest. De vuilnisbakken en vuilstortplaatsen die meestal binnen de bebouwde kom lagen, gaven veel stof- en stankhinder. Voorts kwam allerlei vuil in de grachten terecht: afval van groente, vis, huisvuil, as en stalvuil, slagersafval, faecale stoffen, lozingen van branderijen, azijnmakerijen en suikerfabrieken. Van een goede doorstroming in de grachten was zelden sprake, zodat uit de grachten soms een ondraaglijke stank opsteeg.

Een tweede probleem was het ontbreken van deugdelijke methoden voor het bewaren en afvoeren van 'drekstoffen'. Wie in een huis zonder privaat woonde en zijn behoefte niet op straat wilde doen, kon gebruik maken van openbare privaten, maar de hygiënische toestand daarvan was doorgaans schrikbarend. De particuliere privaten waren op het platteland, maar ook in de steden boven stilstaande sloten gebouwd. In vele steden hadden de huizen uitlopen, waardoor het afvalwater naar de grachten stroomde. Bepalingen die afvoer van privaatvuil verboden, werden over hetr algemeen niet nageleefd. Als men zijn toevlucht had genomen tot berging van faecaliën, dan werd gebruik gemaakt van beerkuilen of beerputten, waarvan de inhoud in de bodem werd opgenomen. Amsterdam had enkele honderden van dergelijke putten. Slechts een deel werd van gemeentewege leeggemaakt.

Ten slotte waren er zowel op het platteland als in de dichtbevolkte stedelijke buurten talrijke mestvaalten en mestmakerijen. Niet alleen veehouders hielden een mestvaalt, ook vele armen deden dat. $\mathrm{Zij}$ verzamelden allerlei stoffen op een kleine mestbult dicht bij huis (soms zelfs in huis), voor hun eigen tuin of akkertje, of voor de verkoop. Ook trof men in de steden kleine mestmakers aan, die in combinatie met het houden van varkens, koeien of geiten, mest produceerden voor de verkoop. ${ }^{39}$

De gedrevenheid van de inspecteurs en geneeskundige raden in de jaren zeventig en tachtig in deze kwestie had veel te maken met de vorderingen die in de omringende 'beschaafde landen' werden gemaakt. In Engeland was men in de jaren veertig al begonnen met het aanleggen van drainagesystemen in de steden. Soms waren dat zogenaamde spoelstelsels, waarbij regenwater en faecale stoffen gezamenlijk via een riool op het oppervlaktewater werden geloosd. En soms maakte men gebruik van een buizensysteem waarmee de faecaliën uit de stad gevoerd en over de omliggende landerijen verspreid werden.

Hoewel de laatste methode sinds het hygiënisch congres te Brussel in 1853 internationaal als de meest geavanceerde gold, werd deze op het Europese vasteland vrijwel nergens toegepast. In Parijs, Lyon en Marseille werd het spoelstelsel toegepast. Desondanks geschiedde de afvoer van faecale stoffen er hoofdzakelijk volgens het zogenaamde tonnenstelsel. In dit stelsel werden met faecaliën gevulde tonnen (fosses mobiles) door wagens opgehaald en vervolgens op een bepaalde plaats aan de rand van de stad geleegd. Daar werden de stoffen tot mest verwerkt ten behoeve van de landbouw. In Duitsland woedde in de jaren zestig de discussie over de 'Kanalisationsfrage' nog in alle hevigheid. 
Talloze geneeskundigen, onder wie Virchow in Berlijn, Von Pettenkofer in München en Varrentrap in Frankfurt, waren in deze jaren actief betrokken bij de keuze en aanleg van rioleringssystemen. Veelal werd aan het spoelstelsel de voorkeur gegeven. De artsen wezen op de daling van het aantal tyfusgevallen en van de kindersterfte dankzij de aanleg van riolering in Engeland, en ze betoogden dat de economische bloei van de Engelse steden mede te danken was aan het geringere verlies van mensenlevens.

De Nederlandse inspecteurs Ali Cohen, Van Overbeek de Meijer en Lubach bevonden zich dus in goed internationaal gezelschap, toen zij in 1868 een onderzoek begonnen naar de vigerende methoden van faecaliënafvoer in binnenen buitenland. In 1870 brachten zij een rapport uit, dat een oplossing bood voor de technische en financiële problemen waarmee men te maken zou krijgen. ${ }^{4 I} \mathrm{De}$ opstellers lieten zich leiden door drie overwegingen. De eerste was dat de oplossing hygiënisch verantwoord moest zijn. De tweede was dat de gemeenten zo min mogelijk op kosten moesten worden gejaagd. En de derde was dat het afvoersysteem de economie ten goede moest komen door de afvalstoffen tot mest voor de landbouw te verwerken.

Op dit laatste punt bestond grote eenstemmigheid onder geneeskundigen, economen en landbouwdeskundigen. Een afvoersysteem dat de landbouw van mest voorzag, zou een aantal problemen in één keer oplossen: de import van relatief dure mest werd overbodig, de gemeenten konden met de verkoop van de mest de onkosten bestrijden, en vervuiling van de bodem en het oppervlaktewater werd voorkomen. De verwachting was dat op deze manier de natuurlijke kringloop van stad en platteland zou worden hersteld. Dit was van belang - zo schreef Ali Cohen al in 1861 in de Economist - omdat het verbreken van de 'natuurlijke ruiling' van 'in een bepaalden omloop bestaand evenwigt [..] tusschen den mensch en de agrarische wezens waarvan hij zich voedt, tusschen de stad en het land' in het verleden vaak genoeg tot 'groote rampen voor het menschelijk geslacht' had geleid. ${ }^{42}$

Op grond van de bovenstaande overwegingen kwamen naar de mening van de inspecteurs twee methoden in aanmerking. De eerste was het transport van faecaliën via vacuüm gezogen buizen naar onder de straat gelegen reservoirs. Deze reservoirs werden vervolgens door tankwagens geleegd. Regen- en afvalwater moesten via een apart rioleringssysteem worden afgevoerd. Dit door de ingenieur Ch.T. Liernur ontworpen, en na 1867 vurig bepleite stelsel had een aantal voordelen, maar het was tevens ingewikkeld en vrij kostbaar. ${ }^{43}$ De tweede mogelijkheid was het tonnenstelsel, dat in Frankrijk en Duitsland op vele plaatsen en in Nederland sinds 1822 in Groningen in gebruik was. it stelsel had het voordeel, dat het aanmerkelijk goedkoper was dan het Liernurstelsel. Andere mogelijkheden, zoals beerputten of het spoelstelsel, kwamen bij de inspecteurs niet in aanmerking. Beerputten veroorzaakten een onaanvaardbare vervuiling van bodem en grondwater, en het spoelstelsel had behalve lekkages en vorming van gassen als nadeel dat het oppervlaktewater werd verontreinigd. In beide gevallen kwamen de afvalstoffen bovendien niet ten goede aan de landbouw.

De kwestie van de afvalverwijdering genoot in de jaren zeventig zeer grote belangstelling van inspecteurs en geneeskundige raden. De verslagen van het Staatstoezicht wekken de indruk dat de oplossing ervan zelf als een prestigezaak werd beschouwd. Vooral Ali Cohen spande zich in om de publieke opinie te winnen voor het in Groningen toegepaste tonnenstelsel. Gezien de beperkte 
financiële armslag van de meeste Nederlandse gemeenten, was dit volgens hem het best denkbare alternatief. ${ }^{4}$ De inspecteurs maakten in de tweede helft van de jaren zeventig de balans op van de resultaten van hun inspanningen. Deze waren bepaald niet overweldigend, maar ook niet totaal ontmoedigend. ${ }^{45} \mathrm{De}$ in de jaren vijftig en zestig op gang gekomen discussie handelde na 1870 niet meer over de vraag of er een regeling voor de vuilnis- en faecaliënkwestie moest komen, maar over de vraag voor welke vorm van stadsreiniging men moest kiezen. De problematiek was toen ook geen exclusief medisch terrein meer. De hygiënische beweging was op dit punt inmiddels tot een beweging uitgegroeid van medici, ingenieurs, reinigingsdirecteuren en hoofden van gemeentelijke publieke werken. ${ }^{46}$ Gezamenlijk zorgden zij ervoor dat vanaf 1870 in alle grote steden een gemeentelijke reinigingsdienst werd opgericht. ${ }^{47}$

Tezelfdertijd werd, soms na jarenlange debatten in de gemeenteraad, een begin gemaakt met een regeling van de faecaliënkwestie. In de meeste gevallen werd aan het tonnenstelsel de voorkeur gegeven. Alleen in Amsterdam, Leiden en Dordrecht werd op beperkte schaal het Liernurstelsel ingevoerd. In enkele gemeenten bestond het tonnenstelsel naast het spoelstelsel, en werden de afvalstoffen in de rivier geloosd. ${ }^{48}$ Met nog grotere stelligheid dan in 1870 keerden de inspecteurs zich in 1876 tegen deze laatste methode, omdat zowel in Engeland als in Duitsland was gebleken, dat de sterfte in gemeenten met een spoelstelsel gestegen was. In deze landen had men daarom van regeringswege beperkingen aan aanleg en gebruik van dit stelsel verbonden.

Naarmate het tonnenstelsel in meer plaatsen in Nederland was ingevoerd, werd het duidelijk dat ook deze methode vele nadelen had. Rechtstreekse hygiënische bezwaren waren er niet tegen aan te voeren, mits de inhoud van de tonnen op zindelijke wijze verwerkt werd. Maar hieraan schortte het nogal. Er was dikwijls stankoverlast door het gebruik van niet-afgesloten ophaalwagens en tonnen van slechte kwaliteit. In de jaren tachtig gaf daarom een toenemend aantal hygiënisten en gemeentebesturen de voorkeur aan riolering als alternatief voor het tonnenstelsel.

De eenstemmigheid die ten aanzien van de bodemsanering heerste, werd in 1877 ruw verstoord door een publikatie van Von Nägeli. Von Nägeli bestreed de juistheid van alles wat de sanitaire hervormers in de voorgaande vijf-en-twintig jaar hadden beweerd. ${ }^{49}$ Hij bracht naar voren dat een groot aantal pathogene micro-organismen slechts uitingsvormen of stadia waren van één type splijtzwam. Uitgaande van de gedachte dat deze splijtzwam zich door telkens andere vormen aan te nemen kon aanpassen aan uiteenlopende uitwendige omstandigheden, betoogde hij dat rottingsprocessen in de bodem enkel het ontstaan van rottingszwammen tot gevolg hebben, en dat zij de groei van pathogene miasmazwammen juist verhinderen. Als men de bodem nat houdt, is het volstrekt zinloos om de faecaliën daaruit te weren. Uit hygiënisch oogpunt was er dus geen enkel gevaar van vervuild water te duchten.

De opvattingen van Von Nägeli veroorzaakten in Duitsland en snel daarna ook in Nederland grote opschudding onder de sanitaire hervormers. De tegenstanders van de kostbare sanitaire voorzieningen kregen natuurlijk een krachtig argument in handen. Het onhoudbare van de bodemtheorie kon aangetoond worden, en met een gerust hart kon men zich verlaten op een goedkoop stelsel van beerputten, waarbij de faecaliën geleidelijk in de bodem wegzakten. ${ }^{50}$ In 1878 waren de inspecteurs Penn en Egeling genoodzaakt het beleid van het Staatstoezicht te verdedigen. In een rapport bestreden zij Von Nägeli's conclu- 
sies, en lieten zelfs een brief afdrukken van F. Cohn, de destijds zeer bekende hoogleraar in de botanie te Breslau, waarin de opvattingen van Von Nägeli bekritiseerd werden. ${ }^{s I}$

De opwinding over Von Nägeli's publikatie was slechts van korte duur. Het was achteraf bezien niet meer dan een incident. De zwammentheorie verdween na 1880 vrij snel uit de publiciteit, toen Cohn, Koch, Pasteur en anderen de wetenschappelijke wereld confronteerden met hun ontdekkingen. De theoretische onderbouwing van de sanitaire hervormingen belandde in een overgangsfase. Enerzijds namen vele geneeskundigen niet voetstoots het gelijk aan van de 'microbenjagers'. Anderzijds was de lokalistische leer der volksziekten aan het wankelen gebracht. De geneeskundigen in het Staatstoezicht, bacteriologisch ongeschoold en verstoken van de ondersteuning van een laboratorium, konden weinig anders doen dan op de ingeslagen weg voortgaan. De sterftedaling in de steden werd dan ook zonder enige terughoudendheid toegeschreven aan de gerealiseerde sanitaire hervormingen. Volgens het Staatstoezicht was er weinig reden om dit verband te ontkennen, wat de bacteriologische onderzoekingen ook mochten opleveren.

Ondanks alle pleitredes en inspanningen van de geneeskundigen in het Staatstoezicht, waren de meeste tijdgenoten niet onverdeeld enthousiast over de praktische resultaten van ruim vijftien jaar Staatstoezicht. De aanbevolen voorzieningen (tonnenstelsel, gemeentelijke reiniging) functioneerden gebrekkig, en hadden het vervuilingsprobleem slechts ten dele opgelost. Het door de inspecteurs verdedigde Liernurstelsel was landelijk gezien een mislukking. Daar kwam bij hun adviezen op het gebied van de riolering werden genegeerd. In de loop van de jaren tachtig was in enkele grote steden toch een begin gemaakt met de aanleg van het spoelstelsel, het rioleringssysteem dat in 1870 en 1876 door de inspecteurs nog met zoveel kracht als ondoelmatig was afgekeurd. ${ }^{52}$ Het was de mening van velen dat de bedenkingen, die de inspecteurs tegen het spoelstelsel hadden, inmiddels uit de weg waren geruimd. Een groot verschil met de situatie in de jaren zeventig was namelijk, dat steeds meer gemeentebesturen een drinkwaterleiding hadden laten aanleggen. De lozing van afvalstoffen op het oppervlaktewater leek nu zonder gevaar te kunnen geschieden.

De conclusie dat de inspecteurs en de geneeskundige raden weinig invloed hebben gehad op concrete saneringsmaatregelen, lijkt gerechtvaardigd. Hun inspanningen zijn evenwel van groot politiek belang geweest. Zij hebben ervoor gezorgd dat - in samenwerking met ingenieurs en gemeentelijke ambtenaren - de faecaliënkwestie onderdeel is geworden van het gemeentebeleid, en dat er gemeentelijke reinigingsdiensten zijn opgezet. Beide resultaten vormden de aanvang van een afdeling publieke werken binnen het gemeentelijk apparaat, en een vele taken omvattende gemeentereiniging, die omstreeks 1900 in de grotere steden tot stand zijn gekomen. ${ }^{53}$

\section{Volkshuisvesting}

De mogelijkheden voor inspecteurs en geneeskundige raden om de ontwikkelingen in de volkshuisvesting te beïnvloeden, waren uiterst gering. In hoofdstuk 6 is aangegeven, dat tussen 1855 en 1865 in een aantal grote en middelgrote steden weliswaar gemeentelijke bouw- en sloopverordeningen van kracht werden, maar dat deze weinig effect hadden omdat op de uitvoering nauwelijks toezicht was. Pogingen om een gemeentelijk bouw- en woningtoezicht bij wet te regelen 
mislukten, zoals we zagen. In de Wet op het geneeskundig staatstoezicht kwam 'volkshuisvesting' niet voor.

In gemeenten met verordeningen stelde de gemeenteraad van geval tot geval vast welke bepalingen van toepassing waren op de aanvragen voor een bouwvergunning. De verordeningen gaven om die reden nogal eens aanleiding tot politiek geharrewar, terwijl de naleving van de besluiten doorgaans niet gecontroleerd werd. De omslachtige procedures en het ontbreken van direct toezicht hadden tot gevolg dat de bouwverordeningen met de op zichzelf zinvolle technische voorschriften ontoereikend waren om de huisvestingsproblemen in de steden het hoofd te bieden. En dat terwijl die problemen ongekende vormen begonnen aan te nemen. De economische groei van steden als Amsterdam, Rotterdam, Utrecht, Haarlem en Arnhem veroorzaakten een geweldige uitbreiding van het inwoneraantal. Deze migratiestroom werd aanvankelijk opgevangen door de bebouwingsdichtheid binnen de bestaande verdedigingswerken op te voeren. Op leegstaande plekken werden woningblokken voor werklieden neergezet, onder verre van ideale omstandigheden in hofjes, poorten en stegen. Deze nieuwbouw zorgde er voor dat de binnensteden nog dichter bevolkt werden, hetgeen de toestand des te erbarmelijker maakte. Nadat herziening van de Vestingwet in 1874 het slopen van de wallen mogelijk maakte, verrezen ook rond de oude stad wijken met dicht opeengepakte huizen. De behuizing van de volksklasse werd er na 1865 weinig beter op.

De gemeentelijke autoriteiten namen veelal een passieve houding aan. In tegenstelling tot de riolerings- en drinkwaterkwestie was de volkshuisvesting niet bepaald een onderwerp, waarover men zich in de landelijke of plaatselijke politiek druk wenste te maken. De reden hiervoor was eenvoudig: men beschouwde de oplossing van de woningnood niet als een taak van de politici, maar als een zaak voor particuliere ondernemingen. De bouw van arbeiderswoningen bijvoorbeeld werd tot in de jaren tachtig nog aan de fabrikanten overgelaten. De industriëlen lieten weliswaar arbeiderswoningen neerzetten, maar in aantallen en van een kwaliteit die niet in verhouding stonden tot de werkelijke behoefte aan betere huisvesting. ${ }^{55}$

Een kleine groep schrijvers en sociaal bewogen liberalen begon zich bij het weinig regulerend ingrijpen van de gemeentebesturen zorgen te maken over de wantoestanden bij de volkshuisvesting. Zij probeerden de burgerij te interesseren de woningbouwverenigingen die zich ten doel hadden gesteld goedkope en gezonde woningen voor de werkende stand te bouwen. De Amsterdamse arts $\mathrm{S}$. Sarphati, nauw betrokken bij de Amsterdamse woningbouwvereniging Salerno, constateerde 'dat een derde der geheele bevolking gedwongen is te verblijven in holen en hokken, welke wij voor onze huisdieren zouden afkeuren'. ${ }^{56}$ In bladen als De Economist, het Staatkundig en Staathuishoudkundig Jaarboekje en het Tijdschrift voor Gezondheidsleer verschenen in de jaren zestig en zeventig analyses en sfeertekeningen, die de publieke opinie wakker moesten schudden en de sympathie van de burgerij voor de woningbouwverenigingen moesten vergroten.

Het ligt voor de hand dat de inspecteurs en de leden van de geneeskundige raden zich betrokken voelden bij de kwestie van de volkshuisvesting. Het was immers hun zorg dat in de overbevolkte krottenwijken geen epidemieën zouden uitbreken. De steeds aanwezige vervuiling van bodem en grondwater verontreinigde gemakkelijk ook de lucht in de vochtige en bedompte vertrekken met ziekmakende 'substanties'. Eigenlijk, zo schreef Coronel in 1872, was de helft 
van de Nederlandse bodem voor bebouwing ongeschikt, omdat deze alluviaal van oorsprong was, en aan alle voorwaarden voldeed voor de ontwikkeling van een epidemie (klei, grondwaterfluctuaties, verontreiniging met organische stoffen). Slechts als woningen en gebouwen volgens strikte hygiënische regels werden neergezet, kon de schadelijke invloed van de bodem te niet worden gedaan. ${ }^{58}$

Het verband tussen huisvesting en gezondheid werd in de jaren zeventig herhaaldelijk bevestigd. Veel bekendheid kreeg het onderzoek naar de zogenaamde kelderwoningen, dat in 1873 op verzoek van het gemeentebestuur van Amsterdam door de plaatselijke gezondheidscommissie werd ingesteld. Er waren bijna 5000 van deze vochtige en donkere behuizingen, waarin in totaal ruim 20.000 mensen $(7,48 \%$ van de Amsterdammers) leefden. Van deze kelderwoningen lag de vloer in ruim 2000 gevallen één meter onder de begane grond, bij 1270 kelders was deze afstand anderhalve meter en bij meer dan 130 lag de vloer twee meter onder het straatoppervlak. Bij één-vijfde van de woningen lag de zoldering gelijk of beneden het straatoppervlak. De met het onderzoek belaste commissie, bestaande uit de medici Israëls, Allebé en Outshoorn, stelde in haar rapport vast dat de sterfte aan cholera onder de kelderbewoners in de jaren 1866-1867 aanzienlijk hoger was geweest dan elders. Voorts was haar gebleken, dat de sterfte van personen onder de tien jaar in de kelders verreweg het hoogste was van heel Amsterdam. De commissie concludeerde, dat de bewoners op onverantwoorde wijze aan de schadelijke invloeden van de bodem werden blootgesteld, en dat bewoning van kelders eigenlijk verboden moest worden. ${ }^{59}$

Had de Amsterdamse commissie aangetoond dat slechte huisvesting schadelijk was voor de gezondheid, andere artsen lieten het effect zien van goede huisvesting namelijk bescherming tegen schadelijke invloeden van de bodem. Huizen van woningbouwverenigingen gaven naar verhouding een lage sterfte te zien. In de jaarverslagen van de verenigingen en van de plaatselijke gezondheidscommissies vindt men herhaaldelijk de uitspraak, dat de cholera, 'eene bodemziekte bij uitnemendheid', met behulp van 'gezonde woningen' kon worden geweerd. ${ }^{60}$

De meeste hygiënisten waren actief lid van dergelijke woningbouwverenigingen, omdat ze de verenigingen als pioniers beschouwden van het bouwen van gezonde woningen. Volgens de arts Stratingh Tresling hadden de verenigingen de stoot tot de woningbouwhervorming gegeven en gebroken met de traditie der filantropie, 'welke altijd maar aalmoezen geeft [..] en niet genoeg denkt [..] om de natuurlijke wijze waarop het logge kapitaal in een goede richting kan worden voortbewogen'. ${ }^{61}$ Velen beseften echter dat de volkshuisvesting onmogelijk alleen door de verenigingen op peil kon worden gebracht. De geneeskundigen wilden dat ook de gemeenten maatregelen namen, ze wilden, om een moderne uitdrukking te gebruiken, een gemeentelijk planologisch beleid dat zowel de structuur van de nieuw te bouwen wijken, als de bouw en inrichting van de woningen kon bepalen. ${ }^{62}$ Tegelijk moesten de gemeentebesturen strenger toezien op de naleving van de bestaande verordeningen om de bouw van minderwaardige woningen en huisjesmelkerij te voorkomen.

Hoezeer en hoevaak de hygiënisten hun standpunten ook over het voetlicht brachten, voor de meeste stadsbewoners veranderde weinig aan hun woonsituatie. De gemeentelijke politieke verhoudingen in de jaren zeventig en tachtig stonden het verder aan banden leggen van de 'vrijheid der ingezetenen' in de weg. Bovendien kon aan de wens van hygiënisten om de krotten te slopen en 
het aantal inwoners per pand te verkleinen vrijwel nooit gevolg worden gegeven, omdat er eenvoudig geen alternatieve woonruimte voor de bewoners beschikbaar was. De veel geprezen woningbouwverenigingen konden, zoals Brugmans het uitdrukt, in de krottenzee slechts enige eilandjes scheppen waar betere woontoestanden heersten. ${ }^{63}$ De hele kwestie van de krotbewoning en de overbevolking was daardoor betrekkelijk uitzichtloos. Zelfs Coronel die gewoon was de sociale misstanden scherp te veroordelen, zag wel in dat er voor de kelderwoningen in Amsterdam voorlopig geen oplossing was. ${ }^{64}$

Toch hebben de hygiënisten met hun publikcaties over de nadelige effecten van de slechte volkshuisvesting voor de volksgezondheid wel iets bereikt, ze hebben namelijk de belangstelling onder de burgerij voor het onderwerp levend gehouden. Het ism onder meer aan hun aanhoudende kritiek te danken dat eindelijk omstreeks 1890 landelijk en plaatselijk de noodzaak werd ingezien om de bouw van gezonde volkswoningen via wetgeving en subsidies actief te stimuleren. ${ }^{65}$

\section{Openbare gebouwen}

Beter was het gesteld met het toezicht op gebouwen met een openbare bestemming, zoals scholen, logementen voor de mindere stand ('slaapsteden'), krankzinnigengestichten, gevangenissen, kazernes, ziekenhuizen en gestichten van liefdadigheid - deze vielen krachtens artikel 14 van de Wet op het geneeskundig staatstoezicht onder het opzicht van de inspecteurs. Inspecteurs en leden van de geneeskundige raden voerden een vrijwel permanente correspondentie met de gemeente- en provinciebesturen over de hygiënische misstanden. Hun adviezen kwamen altijd op hetzelfde neer: verbeter de ventilatie, maak een einde aan de overbevolking en zorg voor betere sanitaire voorzieningen. Soms werd ook de sluiting van de instelling aanbevolen. ${ }^{66} \mathrm{De}$ resultaten van deze inspanningen waren mager. Verbeteringen van enige omvang kwamen pas in de jaren tachtig, toen in het hele land met de nieuwbouw van gestichten, ziekenhuizen en gevangenissen werd begonnen. De hygiënische toestanden in de logementen bleven de gehele negentiende eeuw slecht.

Het meeste succes werd nog geboekt met de schoollokalen. De geneeskundige inspectie besteedde daaraan in de loop van de jaren zeventig bijzondere aandacht, omdat de onderwijskwestie weer in de politieke belangstelling kwam en er een goede kans op een nieuwe onderwijswet bestond. Het eerste kabinetHeemskerk (1874-1877) was in conflict gekomen met de volksvertegenwoordiging over de inrichting van het lager onderwijs. Toen de liberalen na de verkiezingen van 1877 de meerderheid in de Tweede Kamer hadden, dwongen zij de regering tot aftreden. Het nieuwe ministerie- Kappeyne van de Coppello (18771879) stelde zich vervolgens ten doel het onderwijs eens en voor al naar liberaal inzicht in te richten.

De hygiënische bepalingen in de Wet op het lager onderwijs van 1857 waren sterk verouderd. Een uitvoerig onderzoek door de inspecteurs naar de toestand van de schoollokalen gaf de minister van Binnenlandse Zaken, Kappeyne van de Coppello, de overtuiging dat de op handen zijnde onderwijswet aan de modernste hygiënische inzichten omtrent bouwterrein, privaten, verwarming, luchtverversing, kunstlicht en schoolbanken moest voldoen. ${ }^{67}$ In de Lager Onderwijswet van 1878 werd het hygiënisch toezicht op de schoollokalen expliciet aan de 
inspecteurs der volksgezondheid opgedragen. Het jaar daarop werd dit toezicht uitgebreid tot het middelbaar onderwijs.

De bepalingen hielden echter niet lang stand. In confessionele kring was men van meet af aan tegen het opnemen van hygiënische bepalingen in de onderwijswet, omdat daarmee het ongesubsidieerde bijzonder onderwijs voor te hoge kosten werd gezet. De liberale minister had dit bezwaar in 1878 niet erkend. Hij had meer oog voor de belangen van het neutrale onderwijs. Maar al in 1879 konden de confessionelen hun zaak opnieuw bepleitten. In dat jaar kwam het liberale kabinet ten val door onenigheid binnen de liberale partij over de hervorming van de kieswet. De opvolger van Kappeyne, jhr. W. Six, was bereid de bezwaren van de confessionelen te verhelpen. Hij versoepelde de bepalingen ten gunste van het bijzonder onderwijs aanzienlijk. In 1880 werden aangepaste voorschriften omtrent bouw en inrichting van de schoollokalen bij algemene maatregel van bestuur uitgevaardigd. ${ }^{6}$

Een ontwerpwet van de inspecteurs, die de bewaarscholen aan het hygiënisch toezicht moest onderwerpen, stuitte eveneens op bezwaren van confessionele kant. Het voorstel werd in de jaren 1882-1884 door de toenmalige confessionele ministers afgewezen.

\section{Besmettelijke ziekten}

\section{Terugkeer naar het contagionisme}

In het voorgaande hebben we gezien hoe de geneeskundige inspecteurs telkens probeerden het lokale gezondheidsbeleid bij wet te laten vastleggen, terwijl de centrale overheid een dergelijke aantasting van de gemeentelijke autonomie even zo vaak onaanvaardbaar vond. Op deze politiek van non-interventie was één belangrijke uitzondering: regering en parlement waren met de inspecteurs van mening dat het gezondheidsbeleid bij onmiddellijke dreiging van epidemieën niet volledig aan de welwillendheid van de lagere overheden kon worden overgelaten. Deze eensgezindheid was een direct gevolg van een drietal epidemieën die de Nederlandse bevolking hadden getroffen, namelijk een choleraepidemie in 1866-1867, een tyfusepidemie in 1869-1871, en een pokkenepidemie in $1870-1872$.

De eerste aanvullende maatregelen op de Wet op het geneeskundig staatstoezicht hadden betrekking op de pokkeninenting. Over de wijze van vaccinatie waren de inspecteurs allerminst tevreden. De strijd tegen de pokken dreigde in het slop te raken, omdat de sinds de jaren vijftig bestaande vaccinatiebureaus met een chronisch gebrek aan geld en vaccine kampten. Gemeenten en provincies gaven niet of nauwelijks financiële steun. Bovendien werden de bestaande vaccinatiebepalingen (gemeentelijk toezicht, meldingsplicht van artsen, overzicht van de verrichte vaccinaties) halfslachtig of zelfs in het geheel niet uitgevoerd. Op advies van de inspectie besloot minister Heemskerk in 1867 het vaccineren onder direct toezicht van de inspecteurs te plaatsen, en subsidiemogelijkheden voor de vaccinatiebureaus te scheppen. ${ }^{69}$

Aan het einde van de cholera-epidemie werd de uitbreiding van bevoegdheden van de inspectie en de geneeskundige raden in meer algemene zin onderwerp van uitvoerige beraadslagingen binnen het Staatstoezicht. De inspecteurs stelden in hun nabeschouwingen vast, dat zij onvoldoende macht hadden om de onwillige gemeentebesturen te dwingen maatregelen te nemen, die 'wetenschap en 
ervaring met het oog op de cholera aanbevelen". Naar hun mening was het grote aantal slachtoffers mede het gevolg van onverschilligheid en vrees 'voor onaangenaamheden bij het nemen van eenigszins doortastende maatregelen'. ${ }^{70}$ Dit sloeg op het feit, dat de gemeentebesturen ten tijde van de epidemie de voortgang van het dagelijks leven (handel, markten, verkeer) zo weinig mogelijk wilden belemmeren.

Om dit in het vervolg te voorkomen, deden de inspecteurs in 1868 de minister het voorstel voor een wet 'tot beteugeling van epidemische ziekten'. ${ }^{11}$ Deze wet zou elke gemeente tot een vijfjaarlijkse 'algemeene schouwing' van straten, grachten, riolen, openbare gebouwen en al het overige wat de openbare gezondheid betrof verplichten. Tevens bevatte het wetsontwerp een uitvoerig overzicht van de maatregelen die de gemeentebesturen bij een dreigende epidemie moesten nemen. De ziekten waarop dit overzicht betrekking had, waren cholera, tyfus, pokken, mazelen, roodvonk, difterie, kinkhoest en 'besmettelijke oogziekte'? 72

De indieners hadden in de tijd dat zij nog geen inspecteur waren het besmettelijke karakter van enkele van deze ziekten als een factor van ondergeschikt belang beschouwd. Sommigen hadden de besmettelijkheid zelfs in twijfel getrokken. Maar nu stelden zij zich volledig op een contagionistisch standpunt: de verspreiding van de ziekten moest tegengegaan worden door de isolering van patiënten, ontsmetting van kleding en beddegoed, het onmiddellijk begraven van lijken, en de ontsmetting van 'brandpunten' zoals logementen. Op de deuren van 'besmette huizen' dienden waarschuwingsborden te worden aangebracht. Voor de scheepvaart op de binnenwateren wilden de inspecteurs een 'selectieve quarantaine' invoeren. Dit hield in dat een binnenvaartschip waarop één van de genoemde ziekten voorkwam, zijn lading pas mocht lossen, nadat de zieke opvarenden van boord gehaald en in een isoleerinrichting geplaatst waren. Voor zeeschepen stelden de inspecteurs een afzonderlijke wet op, die de verouderde bepalingen van 1805 moest vervangen. ${ }^{73}$

\section{De Wet besmettelijke ziekten}

De in 1868 in functie getreden liberale minister Fock was het met de geneeskundige inspectie eens, dat de bestrijding van de cholera-epidemie onbevredigend was verlopen. Ook de Kamercommissie, die de jaarverslagen van de inspecteurs controleerde, was tot de conclusie gekomen, dat 'grootendeels niet is voldaan aan de verwachting van den Minister van Binnenlandsche Zaken, die de geneeskundige wetten verdedigd heeft, dat de provinciale en de gemeentebesturen in het nemen van maatregelen tot verbetering van den algemeenen gezondheidstoestand, zouden voorgaan'. ${ }^{74}$ Fock ondernam geen poging een wetsontwerp in te dienen, en beperkte zich tot het verzenden van circulaires aan gemeentebesturen met het verzoek de adviezen van de inspectie voortaan op te volgen.

Vanaf 1870 werd meer gehoor gegeven aan de adviezen van de inspecteurs. Een tyfusepidemie die vele duizenden slachtoffers eiste, en een pokkenepidemie met alleen al in 187116.000 sterfgevallen waren de aanleiding voor deze koersverandering. In de Kamer gingen stemmen op om de gemeentebesturen door middel van een epidemiewet tot werkzaamheid te dwingen. Vooral het in 1869 gekozen liberale Kamerlid K.A. Rombach, een geneeskundige, was een actief pleitbezorger van uitbreiding van de gezondheidswetgeving. Ook het invloedrijke Kamerlid Godefroi oefende druk uit op de minister. In het voorjaar 
van 1871 publiceerde hij een artikel in het Handelsblad, waarin hij ervoor pleitte om de ministeriële circulaires door een wet te vervangen. ${ }^{75}$ Thorbecke, die Fock in 1871 als minister was opgevolgd, zette aanvankelijk het beleid van zijn voorganger voort. ${ }^{76}$ Maar hij zag in dat dit onvoldoende resultaten opleverde en diende in augustus 1871 een ontwerp-wet in 'tot voorziening tegen besmettelijke ziekten'.77

De voorgestelde wet had tot doel de bevoegdheden van de burgemeester om de door de inspectie besmettelijk verklaarde ziekten te voorkomen aanzienlijk uit te breiden. De burgemeester kreeg de bevoegdheid lijders aan cén van de ziekten die in logementen verbleven tegen hun wil te isoleren. Desinfectie van huizen, goederen en elke andere besmettingsbron kon zo nodig onder dwang plaatsvinden, volgens een door de minister nader vast te stellen ontsmettingsreglement. Indien noodzakelijk was zelfs onteigening toegestaan. Besmette binnenvaartschepen konden verplicht worden om bij een door de burgemeester aangewezen ligplaats aan te leggen, in afwachting van isolering van de zieke opvarenden en ontsmetting van het vaartuig. Wanneer inspecteurs van het Geneeskundig Staatstoezicht de 'epidemische verschijning' van één der ziekten signaleerden, diende de burgemeester dit te afficheren. Vervolgens moest hij in samenwerking met de inspecteur maatregelen treffen om verspreiding te voorkomen, bijvoorbeeld door beperking van schoolbezoek en fabrieksarbeid, het opschorten van kermissen en markten, en verwijdering van mestvaalten. Bovendien werden de burgemeester, de inspecteurs en de leden van de geneeskundige raden bevoegd om particuliere woningen te betreden, desnoods zonder toestemming, indien de verdenking bestond dat eén of meer bewoners aan een besmettelijke ziekte leden. Alle gemeenten werden verplicht tot de vestiging van een 'isoleerinrigting', waarin lijders aan besmettelijke ziekten konden worden opgenomen.

Thorbecke wilde tegelijk met deze wet de oude vaccinatiebepalingen vervangen. Hij bepaalde dat het onderwijzend personeel en alle leerlingen moest de toegang tot de school ontzegd kon worden, indien zij geen verklaring konden overleggen, waarin stond dat zij de inenting met koepokken met goed gevolg hadden doorstaan. ${ }^{78}$ Ook militairen, gevangenen en patiënten in krankzinnigengestichten werden verplicht gevaccineerd. De gemeenten moesten vaccinatieinrichtingen voor kosteloze inenting opzetten. De kosten hiervan kwamen voor rekening van de centrale overheid.

Het voorstel van de inspecteurs om eens in de vijf jaar gemeentelijke schouwingscommissies in het leven te roepen, nam Thorbecke niet over. Wel wilde hij de gemeenten verplichten om, wanneer er een cholera-epidemie dreigde, choleracommissies in te stellen die in samenwerking met de geneeskundige inspectie preventieve maatregelen moesten treffen.

Het was van meet af aan duidelijk dat een meerderheid in de Tweede Kamer het wetsontwerp op hoofdpunten steunde. De in Engeland veel gehoorde stelling 'public health is public wealth' werd nu ook door de Nederlandse politieke partijen van links tot rechts als uitgangspunt aanvaard. ${ }^{79}$ Toch had het nog heel wat voeten in de aarde voor het ontwerp tot wet werd.

In de eerste plaats kwam het niet meteen tot een plenaire behandeling door de val van het kabinet in de zomer van 1872. De nieuwe minister Geertsema nam het wetsvoorstel weliswaar over, maar niet zonder er een aantal wijzigingen 
in te hebben aangebracht: de verplichte pokkeninenting kwam te vervallen, en de gemeenten kregen minder dwingende voorschriften opgelegd. ${ }^{80}$

In de tweede plaats vond de volksvertegenwoordiging, meer dan bij eerdere wetsontwerpen inzake de volksgezondheid het geval was, het nodig om de rol van de staat principieel aan de orde te stellen. Een belangrijk punt was uiteraard de gemeentelijke autonomie. Hoewel Thorbecke en Geertsema beiden ontkenden dat deze wezenlijk werd aangetast, was de Kamer van mening dat dit wel degelijk het geval was. Een meerderheid vond dit trouwens terecht. Algemeen was men mening dat voorkomen moest worden dat laksheid van de ene gemeente een andere schade kon berokkenen. Toch heeft Thorbecke in de voorbesprekingen onder druk van de Kamer het aantal ziekten, waarop het wetsontwerp betrekking had moeten beperken, en wilde Geertsema in zijn gewijzigde ontwerp de gemeenten niet bij wet verplichten een isoleerinrichting te vestigen. De Kamer schrapte later nog alle bepalingen betreffende de cholera-commissies.

Een ander niet onbelangrijk punt van discussie was de inbreuk op de persoonlijke vrijheid, waartoe de wet zou kunnen leiden. Een gedwongen isolering van lijders in logementen bijvoorbeeld zou naar velen vreesden gevolgd kunnen worden door bepalingen, waarbij iiedereen met een besmettelijke ziekte onder dwang kon worden geïsoleerd. Burgers zouden gevallen van besmettelijke ziekte verzwijgen om isolatie, huisbezoek en gedwongen ontsmetting te voorkomen. De liberale meerderheid deelde deze bezwaren niet en stemde voor het betreffende wetsartikel. Wel werd het verbod op fabrieksarbeid door bewoners van huizen waar een besmettelijke ziekte was geconstateerd door de Kamer geschrapt. Een dergelijk verbod zou tot een onaanvaardbare inkomstenderving van de betrokken arbeiders leiden, meende de Kamer.

De kwestie van de koepokinenting bezat eveneens genoeg stof tot discussie. Geertsema had een verplichte vaccinatie op scholen, in het leger, in gevangenissen en krankzinnigengestichten laten vallen, omdat deze onverenigbaar was met het beginsel dat de vaccinatie om godsdienstige redenen mocht worden geweigerd. De liberale kamerleden Godefroi, Idzerda en Jonckbloet, eertijds hoogleraar vaderlandse geschiedenis in Groningen en sinds 1864 afgevaardigde van het district Winschoten, namen in soms felle bewoordingen stelling tegen deze weglating, die onder druk van de 'christelijk-historische richting' tot stand was gekomen. De overheid moest ten aanzien van de bevolking in haar geheel dezelfde gedragslijn kiezen als die, welke de geneesheer bij de individuele zieke placht te volgen: opereren, desnoods zonder toestemming. ${ }^{81}$ De minister had weinig in te brengen tegen de op veel statistisch cijfermateriaal gefundeerde pleidooien voor verplichte vaccinatie. In zijn verdediging van het recht om op grond van godsdienstige bezwaren vaccinatie te weigeren toonde hij zich bovendien tamelijk ongeïnspireerd.

Na een debat van ruim een dag aanvaardde de Kamer het amendement van de drie liberale Kamerleden om de verplichte vaccinatie op scholen, in het leger, in gevangenissen en krankzinnigengestichten weer in de wet op te nemen. ${ }^{82}$ Nadat over deze principiële kwestie uitspraak was gedaan, kon de parlementaire behandeling van het wetsontwerp zonder grote moeite worden afgerond. Op 4 december 1872 trad de Wet in werking. ${ }^{83}$

De Wet was beperkter van opzet dan de inspecteurs hadden gewild. Het doel van de Wet was niet de gemeentebesturen te dwingen om permanent preventief op te treden tegen haarden van besmettelijke ziekten, maar die besturen voor te 
schrijven hoe bij een dreigende epidemie moest worden gehandeld. Eigenlijk was de Wet dus niet meer dan een 'rampenplan'.

De politieke betekenis van de Wet moet echter niet worden onderschat. De realiteit had menig liberaal duidelijk gemaakt, dat interventie van de staat niet altijd op principiële gronden kon worden verworpen. Als direct gevolg van het contagionistische standpunt was een aanzienlijke inbreuk op de persoonlijke vrijheid geoorloofd geworden indien een besmettelijke ziekte geconstateerd was. De vrees voor verspreiding was sindsdien telkens aanleiding om de werkingssfeer van de Wet uit te breiden. Ook het vergroten van de mogelijkheden om in het algemeen belang de persoonlijke vrijheid aan banden te leggen werd na 1872 herhaaldelijk onderwerp van discussie. ${ }^{84}$ Ten slotte kunnen we stellen dat het pleit was beslecht ten gunste van een wet die de oude quarantainebepalingen van 1805 verving. In 1877 trad een wet in werking, die voorschreef, dat zeeschepen met aan cholera, gele koorts of pest lijdende opvarenden niet mochten binnenvaren, voordat de zieken van boord waren gehaald en in een isoleerinrichting waren geplaatst. De selectieve quarantaine voor zeeschepen was, net als die voor de binnenvaart en de inwoners van een gemeente, de verantwoordelijkheid van de burgemeester en de geneeskundig inspecteur. ${ }^{\text {s }}$

\section{Plaatselijke voorzieningen, commissies en verenigingen}

Het is niet eenvoudig een oordeel te vormen over de wijze waarop aan de Wet ter wering van de besmettelijke ziekten uitvoering is gegeven. Uit de verslagen van het Staatstoezicht valt op te maken dat de 'vrees voor besmetting' het handelen van geneeskundige en gemeentelijke autoriteiten nadrukkelijker ging bepalen. ${ }^{86}$ Het aantal aan ziekenhuizen verbonden isoleerafdelingen nam na 1872 gestaag toe, ondanks het feit dat Gedeputeerde Staten vele gemeenten en in sommige provincies bijna alle gemeenten van de verplichting tot het vestigen van een isoleerinrichting hadden vrijgesteld. ${ }^{87}$

De verslagen van het Staatstoezicht laten evenwel ook zien, dat de verplichting om een uiterlijk kenteken aan te brengen op een woning waar een besmettelijke ziekte heerste herhaaldelijk werd ontdoken. De ontsmetting van goederen of woningen bleef vaak achterwege in gevallen waarin dit volgens de wet was voorgeschreven en niet zelden verzuimden geneeskundigen om een besmettelijke ziekte aan te geven. Uit de verslagen blijkt bovendien dat gemeentebesturen nauwelijks gebruik maakten van de wettelijke bevoegdheden inzake de verwijdering van mestvaalten of de onteigening of sluiting van logementen. ${ }^{88}$

Alleen op het punt van de pokkenbestrijding was de Wet betrekkelijk succesvol. Dit was voor een belangrijk deel te danken aan een nieuwe techniek, waarbij de pokstof rechtstreeks van speciaal gefokte kalveren op de mens werd overgeënt. Het gebruik van 'animale lymfe' was sinds de jaren veertig in Europa bekend, maar deed in Nederland pas in 1865 zijn intrede met de oprichting van een 'parc vaccinogène' in Rotterdam, een stal waarin men kalveren hield die kunstmatig met koepokken waren besmet. In Amsterdam en Den Haag verschenen in 1868 respectievelijk 1871 inrichtingen voor het verkrijgen van koepokstof. $\mathrm{Na}$ de invoering van de Wet op besmettelijke ziekten werden met overheidssteun behalve talrijke vaccinatiebureaus ook een aantal parcs vaccinogènes elders in het land opgericht. Sindsdien beschikte men over voldoende entstof van goede kwaliteit. ${ }^{8}$ De inspecteurs steunden dit actieve overheidsbeleid onder meer door mee te werken aan de in 1872 opgerichte landelijke Vereniging tot 
Bevordering van de Koepokinenting. De verbeteringen maakten een succesvolle vaccinatiecampagne mogelijk. Bedroeg het aantal vaccinaties in de jaren zestig niet meer dan 50.000 per jaar, in het volgend decennium steeg dit aantall tot 100.000 per jaar. ${ }^{90}$ In 1880 was de helft van de Nederlandse bevolking gevaccineerd. Het resultaat van deze toename van het aantal vaccinaties was spoedig merkbaar: na 1872 daalde het aantal gevallen van pokken sterk. $^{9 I}$

Eén van de meest in het oog lopende moeilijkheden bij de uitvoering van de Wet van 1872 was het traag verlopende, sterk bureaucratische contact tussen het provinciaal georganiseerde Staatstoezicht en de gemeentebesturen. In de grote steden waren voor de in 1865 opgeheven plaatselijke commissies van toevoorzicht waren geen nieuwe gemeentelijke organen gevormd. Om toch te beschikken over plaatselijke uitvoeringsorganen (en om de burgerij te betrekken bij de doorvoering van een sanitaire politiek), hadden de inspecteurs en de geneeskundige raden na 1865 het initiatief genomen tot de oprichting van gezondheidscommissies, zoals die sinds de jaren vijftig in een aantal gemeenten functioneerden. In een enkele stad, zoals Amsterdam, besloot de gemeenteraad zelf om de opheffing van de Plaatselijke Commissie van Toevoorzicht te compenseren met de oprichting van een gezondheidscommissie.

$\mathrm{Na} 1866$ verschenen er naar het voorbeeld van de Duitse 'Vereine für öffentliche Gesundheitspflege' talrijke 'Verenigingen ter bevordering van de volksgezondheid' (in Utrecht, Den Haag en Groningen). Deze hadden een bredere samenstelling dan de gezondheidscommissies. Ali Cohen, van meet af aan een groot voorstander van zulke plaatselijke verenigingen, had er grote verwachtingen van: 'De strekking der Vereenigingen is, om langs den weg van grondig onderzoek en gemeenschappelijk overleg eene overtuiging te vestigen, die krachtiger is en meer zal uitwerken dan de strafverordeningen, die een gemeentebestuur maakt, al werden of worden ze nog zoo streng gehandhaafd [..]. De magt en kring van het openbaar gezag worden diensvolgens door de bemoeijingen der vereenigingen krachtig gesteund, vruchtbaar gemaakt en op den weg der praktijk gebragt. ${ }^{.92}$ Ali Cohen zelf gaf leiding aan de Groningse vereniging en ook de inspecteurs Egeling, Penn en Van Overbeek de Meijer traden tot zulke plaatselijke organisaties in hun provincie toe.

Zo ontstonden er na 1865 soms met geldelijke steun van de gemeente, soms met die van de burgerij, in een groot aantal gemeenten plaatselijke organisaties, waarvan althans een deel in nauwe relatie stond tot het Staatstoezicht. Ten tijde van de cholera-epidemie in 1866-1867 hebben zij hun nut bewezen. De circulaires van de minister en de adviezen van de inspecteurs werden ter uitvoering doorgaans in handen van gemeentelijke organisaties gelegd. Zij waren onmisbaar bij de controle op 'reinheid der woningen', de aanwezigheid van mestvaalten, of bij de oprichting van lazaretten en de distributie van goedkope soep of kwalitatief goed drinkwater.

De betekenis van dergelijke organisaties voor het plaatselijke gezondheidsbeleid werd evenwel snel kleiner, wanneer de epidernie eenmaal was geweken. Pogingen om ook bij afwezigheid van besmettelijke ziekten de verstrekking van goed drinkwater of de verwijdering van mestvaalten bij gemeentelijke verordening te regelen, liepen meestal op niets uit. De invloed van commissies en verenigingen was uitsluitend tastbaar bij de directe bestrijding van epidemieën. Vergelijkt men de situatie in enkele steden in de periode $1865-1880$, dan hadden 
de commissies en verenigingen vrijwel overal te maken met conflicten tussen gemeentebesturen en geneeskundigen. Leden van commissies die ontslag nemen of commissies die zichzelf opheffen uit protest tegen het uitblijven van sanitaire maatregelen zijn eerder regel dan uitzondering. Bovendien bleken de verhoudingen tussen Staatstoezicht, commissies en gemeentebesturen onduidelijk geregeld te zijn. Gemeentebesturen betrokken hun adviezen nu eens van de inspecteurs en dan weer van de gezondheidscommissies, en speelden zo de inspecteurs en de plaatselijk werkzame geneeskundigen tegen elkaar uit. Een poging van de inspecteurs om in deze situatie verbetering aan te brengen door gemeentelijke schouwingscommissies met duidelijke en afgeperkte taken bij wet te laten regelen, mislukte.

Omstreeks 1875 bestonden er in totaal 36 gezondheidscommissies en 12 verenigingen. $\mathrm{Zij}$ hadden lang niet allemaal goede verbindingen met het Staatstoezicht. Penn trachtte daarom in 1874 in Noord-Holland alle bestaande lokale commissies in de provinciale vereniging 'Het Witte Kruis' te bundelen. De inspecteurs spraken een jaar later in een gezamenlijk rapport de hoop uit, dat Het Witte Kruis in de toekomst alle plaatselijke commissies en verenigingen uit het gehele land zou bundelen. Tevens weigerden $\mathrm{zij}$ de oprichting van plaatselijke commissies nog lariger te bevorderen, zolang niet hun verhouding tot het Staatstoezicht bij wet was geregeld. Zo'n wet is er evenwell voor 1900 niet gekomen. Tot dat jaar heeft de geneeskundige inspectie moeten werken met 'officieuze' lokale adviesorganen, die in betekenis toenamen naarmate de problemen in de steden groeiden. ${ }^{93}$

\section{Reacties van de bevolking}

Een derde moeilijkheid, waarmee zowel de gemeentelijke autoriteiten als het Staatstoezicht bij de uitvoering van de Wet op de besmettelijke ziekten te kampen hadden, was het gebrek aan medewerking van de bevolking. Meermalen kwam het voor, dat inwoners van armenbuurten controlerende medici de toegang tot hun woning weigerden of anderszins niet wilden meewerken aan sanitaire hulpprogramma's, omdat zij het optreden van de medici als 'vernederend' of als 'ongewenste inmenging van buitenaf' beschouwden. Om die reden mislukte in 1867 de ontsmetting van zo'n 1300 woningen in Rotterdam volkomen. Ook slaagden de leden van gezondheidscommissies er vaak niet in lijders aan besmettelijke ziekten in een hospitaal te laten opnemen. ${ }^{94}$

Verordeningen zoals die op het schoonhouden van de straten konden eveneens op verzet van de bevolking stuiten. Economische motieven speelden hierbij een belangrijke röl. Het verwijderen van mestvaalten bij de huizen was nadelig voor de armen, voor wie het beakkeren van kleine stukjes land buiten de stad een onmisbare aanvulling op het levensonderhoud vormde. Ook de beperkingen op het houden van (pluim)vee en de controle op karrehonden in verband met hondsdolheid betekenden een aanslag op het inkomen van de lagere klassen. Tot welke conflicten dit aanleiding kon geven, toont een verslag in de stukken van het Staatstoezicht over het zogenaamde mestvaaltoproer in Hilversum: 'Toen de ingezetenen bemerkten, dat het $\mathrm{B}$. en $\mathrm{W}$. ernst was [met de opruiming van mesthopen], werden de hoofden bijeengestoken, er werd gedreigd, er werd gescholden, 't kwam zelfs tot daadelijkheden; maar de meer bedaarden organiseerden een petitie, die spoedig met een groot aantal handteekeningen prijkte, en het gevolg was, dat op 20 september [1873] door B. en W. een besluit 
genomen werd, waarbij dat van 27 augustus [1873] werd ingetrokken en de mesthoopen vooreerst weer vrijheid van bestaan kregen'. ${ }^{95}$ Ook elders in het land wilden de burgemeesters liever moeilijkheden met de bevolking voorkomen, zodat ze geneigd waren om de hygiënische voorstellen van de hygiënisten niet te honoreren. Resultaten konden beter worden bereikt, zo heette het, 'door redelijken invloed dan door geweld'.

Ten slotte werden ook de vaccinatiebepalingen, vooral in het zuiden van het land, veelvuldig ontdoken. Vervalste vaccinatiebewijzen en toelating van ongevaccineerde leerkrachten en leerlingen op scholen waren - soms met medeweten van burgemeesters of geneeskundigen - tot in de jaren tachtig bepaald geen uitzondering. Daarbij vinden we meldingen van 'het onverstand van het publiek, dat resultaten van de pokkeninenting bleek te niet te doen, door het uitwassen van de scarificaties met water en zeep of het bestrijken met een tabakspruim'. ${ }^{97}$

Een uitvoeriger studie naar de houding van de bevolking tegenover de maatregelen van de hygiënisten dan hier mogelijk is, zal pas volledige duidelijkheid kunnen verschaffen over dit aspect van de geschiedenis van de openbare hygiëne.

\section{De hygiënisten en de sociale kwestie}

Met de opkomst van moderne economische theorieën omstreeks 1850 groeide de belangstelling voor de arbeiders als een afzonderlijke klasse. De arbeidende klasse kon niet simpelweg tot de sociale laag van armen worden gerekend, maar vormde een bevolkingsgroep met eigen problemen. Deze problemen hingen samen met de ontwikkeling van handel en nijverheid. Niet de ontoereikende filantropische hulp of de overbevolking waren de oorzaak van de armoede van de arbeiders, maar het lage loonpeil en het gebrek aan technische scholing. Ook de arbeidsduur en de arbeidsomstandigheden konden de gezondheid en de fysieke prestaties van de arbeider beïnvloeden, en waren dus medebepalend voor de mate waarin de arbeider een redelijk bestaan kon opbouwen.

In geneeskundige kring werd over de positie van de arbeiders als bijzondere sociale categorie aanvankelijk niet of nauwelijks nagedacht. De hygiënisten met hun aandacht voor het fysisch-geografisch milieu zagen de 'nijvere handwerksman' in de eerste plaats als 'consument' van de hem omringende lucht en van het beschikbare voedsel en drinkwater. Pas na 1860 ontwikkelden zij enige belangstelling voor de arbeider als zodanig. Naarmate het industriële grootbedrijf (textiel, strokarton, levensmiddelen) aan maatschappelijke betekenis won, moesten ook de hygiënisten erkennen dat langdurig verblijf in stoffige, donkere werkplaatsen een ernstige bedreiging vormde voor de gezondheid van de arbeidende klasse.

Toch krijgt men uit de medische literatuur van de jaren 1860-1880 - op enkele hieronder te bespreken uitzonderingen na - niet de indruk dat het volgens de hygiënisten om een nieuw probleem ging. Het groeiend aantal mensen dat werkzaam was in fabrieken en werkplaatsen betekende voor hen slechts, dat een deell van de bevolking intensiever dan voorheen aan reeds bekende schadelijke milieufactoren werd blootgesteld. De geneeskundigen hebben in de jaren zestig en zeventig weliswaar talrijke aspecten van de fabrieksarbeid onderzocht, maar slechts vanuit een algemeen 'milieu' perspectief. 
In de volgende paragraaf zullen wij hierop nader ingaan. Bovendien zullen de opvattingen worden besproken van enkele artsen, die de toestand van de arbeidende klasse aan de hand van sociaal-economische determinanten hebben getracht te analyseren.

\section{Kinderarbeid}

De publieke discussie over de gevolgen van fabrieksarbeid voor de gezondheid van de arbeidende klasse spitste zich in de jaren zestig toe op de kinderarbeid. Eén van de meest gehoorde bezwaren was, dat de tewerkstelling van kinderen in fabrieken een goede opvoeding in de weg stond. En dit zou op den duur een ernstige bedreiging vormen voor het 'zedelijk peil' van de arbeidende klasse als geheel. Elders is de kwestie van de kinderarbeid reeds uitvoerig beschreven. ${ }^{98}$

In 1861 ontstond in de NMG een discussie over de vraag, in hoeverre geneeskundigen zich met deze kwestie moesten inlaten. Aanleiding was een rede van Coronel op de jaarlijkse algemene vergadering van de Maatschappij. Daarin oefende Coronel kritiek uit op de enquête naar de omvang van kinderarbeid, die minister Van Heemstra het jaar tevoren had ingesteld bij de Commissarissen van de Koning. ${ }^{99}$ Coronel had met name kritiek op het feit dat het medisch element in de door de minister aan de Commissarissen toegezonden vragenlijst volledig had ontbroken. Hij pleitte ervoor om bij de regering aan te dringen op een nieuwe volledige enquête als voorbereiding op een wettelijke regeling van de kinderarbeid. Dit nieuwe onderzoek zou niet door bestuursorganen maar door geneeskundigen en industriëlen moeten worden verricht. Coronels voorstel werd gunstig ontvangen. De vergadering besloot zich tot de minister te richten met het door Coronel reeds opgestelde adres waarin de instelling van een commissie, bestaande uit artsen en fabrikanten, werd bepleit. De zinsnede waarmee Coronel het doel van de enquête had willen omschrijven - 'als noodwendig middel en voorbereiding tot eene afdoende wet' - werd echter door de vergadering geschrapt. ${ }^{100}$

Het adres bleef aanvankelijk zonder gevolgen; van minister Van Heemstra werd zelfs geen antwoord ontvangen. Toen Thorbecke begin 1862 Van Heemstra opvolgde, kwam de kwestie opnieuw aan de orde, in het parlement zowel als daarbuiten. Van medische zijde liet met name Coronel weer van zich horen. Hij schreef in 1862 in de Schat der Gezondheid, dat uit een onderzoek dat hij zelf had ingesteld was gebleken, dat de lengtegroei van kinderen van fabrieksarbeiders verre achter bleef bij die van andere kinderen. ${ }^{10 t}$ Op al te jeugdige leeftijd begonnen arbeid zou meer dan armoedige levensomstandigheden de fysieke ontwikkeling van de mens in de weg staan. Coronels conclusie week nogal af van die van Zeeman, die ten aanzien van dienstplichtigen behalve de algemene voedingstoestand ook de lokale milieu-omstandigheden voor de geretardeerde lengtegroei aansprakelijk had gesteld.

In 1863 bracht Coronel de kinderarbeid ter sprake in een vergadering van de Maatschappij ter bevordering van Nijverheid, waarbij hij wederom de lichamelijke achterstand van de fabriekskinderen schetste. Kort daarop verzond ook deze Maatschappij een adres aan de Koning, waarin werd gesteld dat wettelijke maatregelen een einde moesten maken aan de kinderarbeid. Coronel richtte bovendien een persoonlijk schrijven aan minister Thorbecke, waarin hij hem nogmaals verzocht een enquêtecommissie in te stellen, alvorens een wettelijke regeling in te voeren. ${ }^{102}$ 
In hetzelfde jaar, in 1863, ontving de minister een tweede adres van de NMG, dit keer opgesteld door secretaris Zeeman. Het ging minder ver dan dat van Coronel uit 1861 en dat van de Maatschappij ter bevordering van Nijverheid uit 1863. Aan zijn verzoek om een enquête door een staatscommissie van geneeskundigen en fabrikanten voegde Zeeman namelijk de opmerking toe, dat de enquête niet noodzakelijkerwijs tot een wet op de kinderarbeid behoefde te leiden. ${ }^{103}$ Daarmee was de politieke angel uit het NMG-voorstel gehaald. Onmiddelijk stelde Thorbecke een staatscommissie in die overeenkomstig de wensen van de NMG de opdracht kreeg een onderzoek in te stellen naar de lichamelijke, geestelijke en zedelijke toestand van de in fabrieken arbeidende kinderen. ${ }^{104}$ Deze commissie bestond uit de voorzitter A.A.C. de Vries Robbé, ingenieur bij het Stoomwezen en sinds 1859 eén van de belangrijkste voorvechters van een beperking van de kinderarbeid, W.C.D. Olivier, secretaris van de Leidse Kamer van Koophandel en lid van de Provinciale Staten van ZuidHolland, J. van Heukelom, fabrikant te Leiden, en de geneeskundigen Zeeman en Evers. De naam van Coronel ontbrak. ${ }^{\text {IOS }}$

Tot grote ergernis van velen bood de commissie pas zes jaar later in 1869 haar rapport aan. De commissie had zo lang over haar werk gedaan, omdat Zeeman en Evers het onderzoek een veel grotere omvang hadden gegeven dan oorspronkelijk de bedoeling was. Zij wilden niet alleen de toestand van de fabriekskinderen als zodanig vastleggen, maar ook eens en voor al uitgemaakt zien of fabrieksarbeid werkelijk zo nadelig was als Coronel niet ophield te beweren.

De wijze van onderzoek was onmiskenbaar van Zeeman afkomstig. ${ }^{106}$ De lichamelijke gesteldheid van fabriekskinderen werd vergeleken met die van andere kinderen van dezelfde leeftijd zoals weeskinderen of leerlingen van armenscholen. Zulke vergelijkingen werden gennaakt in gebieden met gelijke brutosterfte en geologische gesteldheid, zodat de 'alles overheerschende invloed van den bodem' geen rol van betekenis kon spelen. Ook vergeleek de commissie de volwassen fabrieksarbeiders met werklieden die niet in fabrieken werkten, om uit te maken of de gevolgen van vroegtijdige en langdurige kinderarbeid zich wellicht op latere leeftijd openbaarden. Tevens werden gegevens verzameld over huisvesting, voedsel, drinkwater, kleding en lucht. De commissie bestudeerde ook de militie-statistieken, omdat zij hiermee de verhouding tussen fabrieksarbeiders en andere 'werklieden' die beneden de maat waren gebleven kon nagaan.

De gegevens die de commissie bijeen bracht, waren weinig verhelderend. ${ }^{107}$ Men meende te kunnen concluderen, dat kinderarbeid niet bijzonder schadelijk voor de gezondheid was, mits deze niet te vroegtijdig werd begonnen, te langdurig of te zwaar was. Het had geen zin kinderen uit de fabrieken te weren, omdat de algemene ongunstige omstandigheden waaronder elk arbeiderskind opgroeide bleven bestaan. ${ }^{908}$ De voeding en de huisvesting werden als oorzaak van de fysieke onderontwikkeling van een deel van de arbeidende klasse aangemerkt. Verbetering was derhalve alleen mogelijk door verhoging het arbeidsloon van de ouders te verhogen. Het enige positieve dat de commissie deed, was het voorstel om een schoolplicht in te stellen voor kinderen gedurende een bepaalde leeftijd. Overigens ging het rapport vergezeld van een minderheidsnota, opgesteld door de voorzitter, waarin hij verklaarde een wettelijke regeling van de kinderarbeid volstrekt noodzakelijk te achten, 'opdat ook in ons vaderland de fabrieksarbeider 
zoowel physiek als intellectueel en moreel worde opgeheven uit den droevigen staat, waarin hij thans verkeert.'

Het rapport van de staatscommissie heeft nauwelijks invloed gehad op de openbare meningsvorming. Het was met 1500 pagina's vol tabellen en cijferreeksen volkomen onleesbaar. Daar kwam nog bij dat de in het rapport doorklinkende leerstellingen van de klassieke economie reeds bij het verschijnen achterhaald waren. Belangrijker voor de openbare meningsvorming over de kinderarbeid waren de politieke veranderingen. Een groep jonge liberale Kamerleden gaf blijk van de overtuiging, dat interventie van de staat in het economisch leven niet langer op principièle gronden kon worden afgewezen. Nauw verbonden met deze links-liberalen was een sociale beweging die zich de zedelijke, materiële en politieke verheffing van de arbeiders ten doel stelde. In 1870 werd het 'Comité ter bespreking van de sociale quaestie' opgericht, waarin behalve politici als $\mathrm{H}$. Goeman Borgesius, ook leidende figuren uit de in opkomst zijnde arbeidersorganisaties zitting hadden. Het ontstaan van dit comité vormde een eerste aanwijzing dat het arbeidersvraagstuk in zijn volle omvang werd onderkend. De nieuwe politiek-economische richting die een verbod op kinderarbeid, opheffing van het stakingsverbod voor arbeiders en uitbreiding van het kiesrecht nastreefde, verspreidde haar ideeën via het in 1874 opgerichte tijdschrift Vragen des Tijds.

$\mathrm{Na}$ de verschijning van het rapport over de kinderarbeid gebeurde er aanvankelijk weinig. Noch de minister, noch de Tweede Kamer bleken van zins een oplossing voor de kwestie van de kinderarbeid te zoeken. In de NMG werd het werkstuk van de staatscommissie voor kennisgeving aangenomen. De enige medicus die zich openlijk aan de zijde van de links-liberalen schaarde was Coronel. In 1861 had hij de fabrikanten nog opgeroepen om door 'eene regeling van den arbeid, een waarborg voor het welzijn der massa' zelf een einde te maken aan de 'volstrekte anarchie in de fabrieken', maar tien jaar later vertrouwde hij niet langer op de goede wil van de fabrikanten: 'Het nood breekt wet! geldt hier helaas maar al te vaak en verklaart meer dan voldoende den treurigen toestand, waarin duizenden van blanke werkslaven verkeeren en gedwongen zijn te verkeeren!' Hij stond nu een doeltreffend stelsel van controle op de werkomstandigheden voor, uitgeoefend door geneeskundige ambtenaren, omdat het 'een eerste pligt voor den Staat [is] [...]door een naauwlettend toezigt te voorkomen, dat onkunde of eigenbelang van enkelen schade aan lijf en have van het algemeen toebrengen'. 110 In 1869 pleitte hij bovendien voor meer politieke rechten van de arbeiders. Volgens hem was in Engeland gebleken dat dit ook nog eens gunstig uitwerkte op de gezondheidstoestand van de arbeidende klasse. ${ }^{17 \mathrm{~J}}$

In 1871 hield Coronel op een vergadering van de Vereeniging voor de Statistiek een lezing over de wenselijkheid van een verbod op kinderarbeid, die ook door het Kamerlid Samuel van Houten werd bijgewoond. Deze redevoering moet indruk hebben gemaakt op Van Houten, want niet veel later bracht deze de kinderarbeid onder de aandacht van de Kamer. Hij besteedde daarbij nadrukkelijk aandacht aan de rede van Coronel, en hij vroeg minister Thorbecke een voorstel voor een wet op de kinderarbeid voor te bereiden. Thorbecke kaatste de bal terug en zei dat Van Houten zelf maar een wetsvoorstel moest indienen. 
Toen in 1872 Thorbeckes opvolger Geertsema onomwonden weigerde in te grijpen, en de Kamer als geheel verstek liet gaan in dadeloosheid, diende Van Houten in 1873 zelf een voorstel in. Het voorstel behelsde een verbod van arbeid door kinderen beneden de 12 jaar en de toekenning van de bevoegdheid van gemeentebesturen om een leerplicht in te voeren voor alle kinderen van 8 tot 12 jaar. Tijdens de Kamerbehandeling durfden de liberalen niet langer de leer van de absolute staatsonthouding te prediken. Dit nam niet weg, dat de wet die uiteindelijk in 1874 in het Staatsblad verscheen, als gevolg van diverse amendementen feitelijk weinig regelde. De Wet kwam erop neer dat kinderen beneden de 12 jaar alleen voor huishoudelijke werkzaamheden en veldarbeid in loondienst mochten worden genomen. ${ }^{1 / 2}$ Tot een directe verbetering van de positie van het arbeiderskind heeft deze Wet dan ook niet geleid. Bovendien duurde het bij gebrek aan doeltreffende controle nog vele jaren, voordat het toch al bescheiden verbod volledig werd nageleefd.

\section{Fabriekshygiëne}

De tien jaar durende discussie over de kinderarbeid heeft de geesten van de hygiënisten rijp gemaakt voor het aanvaarden van een wettelijke bescherming van de fabrieksarbeiders. Een meerderheid van de geneeskundigen in het Staatstoezicht had het beginsel van de verbetering van de arbeidsomstandigheden door interventie overgenomen. Het denkbeeld van Coronel om een 'nijverheidspolitie' te ontwikkelen, vond bij de inspecteurs een gewillig oor.

In 1867 verzochten de inspecteurs minister Heemskerk om overheidsprojecten (bijvoorbeeld het aanleggen van een spoorlijn) enkel aan bedrijven te gunnen die zorgden voor aanvaardbare werkomstandigheden, waarbij inbegrepen bijvoorbeeld goed drinkwater, behoorlijke privaten en een goede huisvesting. ${ }^{113}$ De minister wees het voorstel echter af. Twee jaar later stelden de inspecteurs minister Fock voor het wetsontwerp tot regeling van het toezicht op fabrieken zodanig te wijzigen, dat niet alleen de vervuiling van de omgeving, maar ook de gevaren voor de gezondheid van de arbeiders onder controle van de geneeskundige inspectie werd gebracht. Tot tweemaal toe wees de minister dit verzoek af. $^{1 / 4}$ De inspecteurs en de geneeskundige raden besloten daarom in 1870 tot zogenaamde 'enquêtes van fabrieken', iets waartoe zij op grond van artikel 5 van de Wet op het geneeskundig staatstoezicht gemachtigd waren. ${ }^{I 15}$ De inspecteurs en de leden van de geneeskundige raden bezochten talloze fabrieken en werkplaatsen in Gelderland en Overijssel (Arnhem, Zutphen, Nijmegen, Almelo, Enschede), en later ook in andere delen van het land om ter plaatse de arbeidsomstandigheden in ogenschouw te nemen. De onderzoeksverslagen tussen 1870 en 1875 bevatten veel kritiek, omtrent te kleine werkruimten, ongeschiktheid van de bodem waarop de fabriek was gebouwd, geringe ventilatie, onvoldoende verwarming, afwezigheid van sanitaire voorzieningen, aanwezigheid van schadelijke stoffen en lozing van het fabrieksafval op het oppervlaktewater.

Het onderzoek naar de fabrieksarbeid onderscheidde zich dus niet wezenlijk van de plaatsschouwing van schoolgebouwen en woningen. ${ }^{116}$ In de rapporten werden slechts spaarzaam opmerkingen over de fysieke toestand van de arbeiders gemaakt. Hierdoor wordt de indruk gewekt dat het daarmee niet bijzonder slecht was gesteld. Van de metaaldampen, waaraan de gieters in een ijzergieterij waren blootgesteld, wordt gemeld dat deze 'hen weinig schijnen te schaden', en over arbeiders in een bierbrouwerij vernemen we dat hun verblijf in ruimten 
met 'excessieve temperaturen' onschadelijk moet worden geacht, gezien 'hun robuust, forsch gespierd voorkomen, hun kleurig uiterlijk, dat door vrij genot van uitstekend bier gesteund en onderhouden wordt'. Van een gasfabriek stelde de inspecterende arts vast dat deze 'geheel naar de eischen der wetenschap' was ingericht en dat het schraal en bleek voorkomen [van de arbeiders] dus aan niets anders geweten schijnt te mogen worden dan aan de onvermijdelijke gevolgen van hun beroep'. "I'

De medici stelden zich dus wat betreft de lichamelijke toestand van de arbeiders tevreden met een tamelijk oppervlakkige observatie, die vervolgens koel, zakelijk en zonder enig inlevingsvermogen in een rapport werd vastgelegd. Veel informatie over de arbeiders was bovendien van de fabrikant verkregen. De enquête gaf daardoor een betrekkelijk gunstig beeld van de lichamelijk toestand van de industrie-arbeiders. Die toestand zou, aldus de hygiënisten, op den duur verslechteren, als er geen verbeteringen in de fabrieksgebouwen en in het fysisch-chemisch "klimaat' op de werkvloer werd aangebracht. Er waren dus genoeg redenen om een wet op het fabriekswezen op te stellen, met voorschriften omtrent het maximaal aantal arbeiders per werkruimte, verwarming, privaten en gevaarlijke stoffen. Maar geen van de ministers van na 1870 was bereid een dergelijke wet te entameren. Zoals eerder vermeld legde de Hinderwet van 1875 slechts de overlast van fabrieken voor de directe omgeving aan bandlen.

$\mathrm{Na}$ de invoering van deze Wet verflauwde de belangstelling van de leden van het Staatstoezicht voor de hygiënische aspecten van de fabrieksarbeid. Alleen Coronel - secretaris van de Geneeskundige Raad van Friesland - zette de strijd voor uitbreiding van de arbeidswetgeving voort. Zowel binnen als buiten het Staatstoezicht bleef hij pleiten voor een verbod op gevaarlijke arbeid door vrouwen en jeugdige personen, voor beperking van het aantal werkuren en de aanstelling van onafhankelijke rijksambtenaren voor het toezicht op de arbeidsomstandigheden. Het was in belangrijke mate aan het doorzettingsvermogen van Coronel te danken, dat de geneeskundige inspectie omstreeks 1880 deze standpunten overnam.

Alvorens de ontwikkelingen rond de sociale kwestie na 1880 te bespreken, moet eerst iets worden gezegd over de pogingen van Coronel en zijn medestanders om een alternatief te bieden voor de traditionele, lokalistische leer van de volksziekten.

\section{De sociologische benadering van sterfteverschillen}

Veel meer dan de zakelijke en afstandelijke verslagen van het Staatstoezicht heeft Coronel met zijn artikelen in De Economist, het Algemeen Handelsblad en de Leewwarder Courant de belangstelling van de gezeten burgerij voor de sociale kwestie - de toestand van de arbeidende klasse - weten te wekken. Coronels gewoonte om aan zijn wetenschappelijke conclusies een politieke stellingname te verbinden ten gunste van de arbeidende klasse heeft daaraan zeker bijgedragen. Telkens liet hij blijken, hoe geschokt hij was wanneer hij de lichamelijke toestand van de arbeiders onderzocht. ${ }^{118}$ Dit maakte hem, in een tijd van afgewogen delibereren en geduldig streven naar beschaving, tot een controversiële persoonlijkheid. Zijn helder geformuleerde standpunten en beeldende beschrijvingen trokken in tegenstelling tot de publikaties van zijn collegahygiënisten, vaak de aandacht en lokten regelmatig reacties uit. 
Er is een tweede reden waarom Coronel in verband met de sociale kwestie speciale vermelding verdient. Hij begreep als éen van de weinige geneeskundigen van zijn tijd, dat de opkomst van de fabrieksarbeid om een nieuwe vorm van medische statistiek vroeg, waarbij de gezondheidstoestand van de 'industriele stand" (fabrieksarbeiders èn fabrikanten) met die van de andere standen werd vergeleken. Coronel maakte zich dus los van de topografische onderzoeksmethode om ze te vervangen door een sociologie van ziekte- en sterfteverschillen. ${ }^{119}$

Coronels eerste studie naar fabrieksarbeid in 1860 was een kwalitatief onderzoek naar de gezondheidstoestand van de calicotwevers op Walcheren. ${ }^{120}$ Dit leverde een zeer ongunstig beeld op van de gezondheid van de arbeiders. Velen leden aan misvormingen van het skelet, longziekten, oogkwalen, cardiologische en theumatische aandoeningen. Coronel gaf evenwel geen statistisch vergelijkingsmateriaal.

Een jaar later was zijn inzicht in de sociologie van sterfte- en ziekteverschillen aanzienlijk verdiept. In zijn boek Gezondheidsleer toegepast op de fabrieksnijverheid stelde hij dat de gezondheidstoestand van de arbeidende klasse een sociaalmedisch probleem met een geheel eigen karakter was. Het betrof volgens Coronel een specifieke reeks van factoren, zoals vervuiling van de werkplaats, arbeidsduur, fysieke inspanning, huisvesting, lonen en volksvoeding. Deze factoren konden in gecombineerde werking de bijzondere gezondheidstoestand van de arbeidende klasse verklaren. Uitvoerig behandelde hij de beroepsziekten. Hij beschreef tevens de wettelijke bepalingen betreffende de fabrieksarbeid die in het buitenland bestonden.

Uit een diepgaande, 1862 gepubliceerde studie naar de gevolgen van de tapijtindustrie voor de volksgezondheid in Hilversum blijkt de snelle ontwikkeling van Coronel. ${ }^{122}$ Bij dit onderzoek liet hij de beschrijving van de directe invloed van de industrie-arbeid op de lichamelijke gesteldheid van de arbeiders vergezeld gaan van allerlei statistische analyses. Hij vergeleek de sterfte bij de diverse standen van de Hilversumse gemeenschap, en concludeerde dat die onder de fabrieksarbeiders het hoogst was. ${ }^{123}$ Ten aanzien van de zuigelingensterfte stelde hij grote verschillen vast eveneens ten nadele van de arbeidersstand. Een vergelijking van de lengte van de kinderen en de lotelingen uit arbeidersgezinnen met die van kinderen en lotelingen uit andere beroepsgroepen met een vergelijkbaar inkomen, liet een duidelijke achterstand zien in de lichamelijke ontwikkeling van de arbeidersstand. Coronel kon zonder veel moeite concluderen dat de industrie in Hilversum een 'neerwaartse werking' op de volksgezondheid uitoefende.

In twee in 1864 gepubliceerde studies van het personeel van de Leidsche Wolfabrieken en van de diamantwerkers in Amsterdam toonde hij opnieuw aan dat de gezondheidstoestand van de arbeidende klasse ernstige schade ondervond van de slechte arbeids- en levensomstandigheden. ${ }^{124}$ Nadien verrichtte hij geen oorspronkelijk onderzoek meer naar de fabrieksarbeid. Wel schreef hij nog een hoofdstuk over fabrieksarbeid en beroepsziekten in het door Ali Cohen uitgegeven Handboek der openbare gezondheidsregeling (1872), en bleef hij in tijdschriften kranteartikelen pleiten voor een wettelijke regeling van de fabrieksarbeid.

Coronel stond in zijn pogingen om een sociologie van sterfte- en ziekteverschillen te ontwikkelen vrijwel alleen. Niet geheel ten onrechte weet hij dat aan de politieke omstandigheden van zijn tijd. ${ }^{\text {T2 }}$ Maar behalve politieke redenen waren er ook wetenschappelijke redenen voor Coronels isolement. De wijze 
waarop hij de sterfteverschillen aan sociale klassen relateerde was in zijn tijd absoluut niet in overeenstemming met het lokalisme dat de grondslag vormde van de leer van de volksziekten. Een indeling van de bevolking in sociale klassen aan de hand van sociaal-economische criteria was trouwens technisch moeilijk te realiseren, zoals Coronel ook zelf heeft moeten ondervinden: gegevens over inkomens bijvoorbeeld ontbraken geheel.

Slechts een enkele geneeskundige heeft het aangedurfd om in de voetsporen van Coronel te treden. De Hilversumse arts Van Hengel heeft met gebruikmaking van door Coronel verzameld materiaal de sterfte berekend in vier sociale categorieën in het Gooi voor de periode $1860-1869.126$ Hieruit bleek onder meer dat de sterfte onder de kinderen uit de stand van de 'fabrieksarbeiders' beneden de vijf jaar aanzienlijk hoger lag dan die van hun leeftijdgenootjes uit de stand van de 'burgers'. Voor Van Hengel was er geen twijfel aan dat de hoge kindersterfte in de arbeidende klasse het gevolg was van de geringe zorg die men aan de kinderen kon geven. ${ }^{127}$ Ook voor de overige leeftijdscategorieën presenteerde Van Hengel tabellen, waaruit het verband tussen het sterftepercentage en de sociaal-economische situatie van elke klasse moest blijken.

In Rotterdam toonde de arts A.M. Ballot, lid van de gemeenteraad en de gezondheidscommissie, grote belangstelling voor de invloed van sociaal-economische factoren op ziekte- en sterftecijfers. In 1873 publiceerde hij een studie naar de mortaliteit in zijn woonplaats over de jaren 1866-1870, die hij combineerde met kritisch onderzoek naar de juistheid van de bodemtheorie van Von Pettenkofer. ${ }^{128} \mathrm{Om}$ de sterfte in twee verschillende sociale klassen bij gelijke fysischgeografische omstandigheden te kunnen vergelijken, verdeelde Ballot de stad in twaalf districten, die qua bodemgesteldheid homogeen waren. In elk district onderscheidde hij een welgesteld en een arm gedeelte. Bij gebrek aan een 'ideale inkomstenbelasting' moest hij afgaan op het 'uiterlijk aanzien der groepen'. De grotere sterfte die Ballot onder de armen vaststelde, kon niet aan de verschillen in geologische gesteldheid worden toegeschreven, een reden waarom hij de grondwater- en bodemtheorie van Von Pettenkofer kon afwijzen. De kwaliteit van het drinkwater kon evenmin als verklaring worden aangevoerd, daar arm en rijk in de meeste van de twaalf gebieden hetzelfde water gebruikten. Ballot meende daarom dat de sterfte hoofdzakelijk werd bepaald door sociale factoren, namelijk de bevolkingsdichtheid en de 'meerdere of mindere graad van welvarendheid'.

Coronel, Van Hengel en Ballot waren hun tijd te ver vooruit. Om verscheidene redenen, waarvan enkele in het voorgaande zijn vermeld, kreeg het door hen op gang gebrachte onderzoek naar het verband tussen mortaliteit en sociaaleconomische factoren geen navolging. Zowel in de verslagen van het Staatstoezicht als in het Nederlandsch Tijdschrift voor Geneeskunde bleef men de medische statistiek uitsluitend beschouwen als een methode om de doelmatigheid van het gemeentelijk sanitair beleid te toetsen. Niet eerder dan na 1890 werden, dankzij een grotere belangstelling van de rijksoverheid en een verbeterde statistiek van de inkomenspositie van de bevolking sterfte-statistieken gepubliceerd, waarbij nadrukkelijk de sociaal-economische positie (inkomen, beroep) in de analyse werd betrokken. Toen waren het echter niet meer geneeskundigen, maar statistici (Centrale Commissie voor de Statistiek) die het onderzoek deden. ${ }^{129}$ 


\section{Ontwikkelingen in Duitsland}

Het was in de jaren zeventig niet gelukt om de essentie van de sociale kwestie het bestaan van klasse-gebonden verschillen - in de leer van de volksziekten tot uitdrukking te brengen. Toch was wel duidelijk dat de lokalistische leer vanwege de eenzijdige nadruk op de sanitaire omstandigheden correctie behoefde.

Dit inzicht groeide onder invloed van de ontwikkelingen in de hygiënische wetenschap in Duitsland. In de jaren zestig had men het beperkte bereik van de stadssanering bekritiseerd, omdat slechts een klein deel van de bevolking er profijt van had. De hygiënist Fr. Oesterlen, die bij links georiënteerde artsen in hoog aanzien stond, meende dat de arbeidende klasse meer gebaat was bij een verhoging van de levensstandaard dan bij de aanleg van rioleringen. Hij kwalificeerde de statistiek van de lokalistisch georiënteerde hygiënisten als weinig wetenschappelijk, omdat er geen rekening werd gehouden met de inkomenspositie van de populaties. Daardoor kon nooit met enige zekerheid uitsluitsel gegeven worden omtrent de pathogene betekenis van allerlei milieufactoren. Ook de in deze jaren weer politiek actief geworden Virchow vroeg zich af, of verbetering van de voedingstoestand van de arbeidende klasse niet meer zou bijdragen aan het terugdringen van de sterfte dan stadssanering. Hij toonde zich een voorstander van het verhogen van de levensstandaard langs politieke weg.

Von Pettenkofer en diens medewerker $\mathrm{K}$. von Voit betoogden dat de volksgezondheid een resultante was van de omgevingsfactoren en de lichamelijke weerstand van een bevolking. De sanering van de stad bewerkstelligde een gezonde omgeving, en door de kwaliteit van de volksvoeding te verbeteren werd het weerstandsvermogen verhoogd. Von Pettenkofer en Voit waren in München daarom druk in de weer om een voedingsfysiologie te ontwikkelen die op een verantwoorde wijze het individu tegen ziekmakende milieu-invloeden kon beschermen. De resultaten van het wetenschappelijk onderzoek werden via voorlichtende literatuur aan het grote publiek kenbaar gemaakt.

Zowel de opvattingen van Virchow en Oesterlen als die van Von Pettenkofer en Voit hebben in Nederland invloed gehad. Ballot heeft zijn methode van onderzoek naar de sterfte in Rotterdam aan Oesterlen ontleend en zijn conclusies waren met die van Oesterlen in overeenstemming. ${ }^{131}$ Zeeman bevestigde daarentegen, op grond van zijn bekende onderzoek van dienstplichtigen, voor een deel de opvattingen van Von Pettenkofer. Hij concludeerde dat de gezondheid en de lengte van de lotelingen behalve door voeding ook rechtstreeks door fysisch-geografische omstandigheden (bodem) werd beïnvloed. De door Von Pettenkofer gevestigde traditie van het experimenteel voedingsonderzoek vond in 1878 zijn weg naar Nederland door de benoeming van zijn leerling J. Forster tot hoogleraar in de hygiëne aan de universiteit van Amsterdam, en al eerder in 1877 door de benoeming van A.P. Fokker, een fervent aanhanger van Von Pettenkofer, tot hoogleraar in de hygiëne aan de Groningse universiteit. Door hun werk heeft de voedingshygiëne in de medische wetenschap aan betekenis gewonnen. ${ }^{132}$ 
Coronel, Van Hengel en Ballot benadrukten meer dan andere artsen uit die tijd de sociaal-economische achtergrond van de slechte voedingstoestand van de lagere klassen. Hun opvattingen vonden bevestiging in een in 1873 door de NMG opgezet onderzoek naar de kwaliteit van de volksvoeding, ter beantwoording van de vraag 'van hoeveel invloed verschillende spijs en drank is voor de physionomie van [ons] volk'. ${ }^{133}$

Dit onderzoek, onder leiding van de arts Th. Haakma Tresling uit Winschoten, leverde tussen 1873 en 1888 zo'n tien rapporten op. Het bracht met name verschrikkelijke toestanden onder de landarbeiders aan het licht. ${ }^{134}$ Op het menu van de gemiddelde arbeider stonden soms weken achtereen alleen aardappelen. Vetten ontbraken nagenoeg, en erwten en bonen gingen de koopkracht van de meesten te boven en dat gold tevens voor melk en karnemelk. In sommige streken van het land, zoals in Noord-Holland, was het iets beter gesteld, aangezien daar soms kaas en vis op tafel kwamen. Groente en fruit waren vrijwell nergens in het voedingspakket opgenomen. Een heel ander kwaas was de 'voedselvervalsing': meel vermengd met gips en melk met water. Bovendien waren melk en vlees dikwijls afkomstig van tuberculeuze koeien. Overigens hadden ook de betere standen van deze voedselvervalsingen te lijden.

Sommige geneeskundigen die aan het onderzoek meewerkten, hebben scherpe kritiek gegeven op de economische onderdrukking van de arbeidende bevolking. Zo berichtte een anonieme auteur dat in Wissenkerke jaarlijks tientallen kinderen stierven als gevolg van de 'winzucht' van de werkgevers. ${ }^{135}$ Ook Coronel, verantwoordelijk voor het onderzoek in Friesland, toonde zich zeer verontwaardigd over de scherpe klassetegenstellingen op het platteland. Het menu van de boerenarbeider noemde hij een flauwe afspiegeling van dat van de boer. Het was, zo schreef hij, een ware strijd om het bestaan, waarbij men zich er over verbaasde, dat nog zovelen die harde strijd te boven kwamen, 'om op hun beurt een even zwak kroost het leven te schenken, om ... het proletariaat in stand te houden'. ${ }^{136}$

Van directe betekenis voor het opwekken van de publieke belangstelling voor de sociale kwestie, respectievelijk de volksvoeding zijn de rapporten niet geweest. Daarvoor waren ze te breedvoerig en te medisch van aard. Maar indirect, via samenvattingen en commentaren in het Tijdschrift voor Gezondheidsleer, De Gezondheid en in verscheidene kranten, kwamen de conclusies wel onder de aandacht van een groter publiek. Ook dankzij de 'volksvoorlezingen' die door NMG-afdelingen of gezondheidscommissies werden georganiseerd, raakte een deel van de burgerij met de feiten bekend.

\section{Bestrijding van de voedselvervalsing}

Op grond van de bestaande wetgeving was het voor de geneeskundigen van het Staatstoezicht niet goed mogelijk om handelend op te treden tegen de veelvuldig voorkomende voedselvervalsingen. Het in 1810 ingevoerde Franse wetboek van strafrecht, de Code pénal', verbood alleen de verkoop van 'vervalschte en voor de gezondheid schadelijke bestanddeelen bevattende dranken'. In 1829 was bovendien 'vermenging van eet- en drinkwaren met vergiftigde of schadelijke zelfstandigheden' strafbaar gesteld. ${ }^{137}$ Met deze bepalingen kon men evenwel weinig beginnen tegen 'vervalschingen' van eet- en drinkwaren met stoffen die 
niet giftig of schadelijk waren, maar wel de voedingswaarde verminderden of de koper benadeelden (brood- en melkvervalsing, het gebruik van kleurstoffen). Net zo min kon tegen de verkoop van verrotte fruitprodukten of van vlees dat afkomstig was van ziek vee worden opgetreden, tenzij er een plaatselijke verordening op de verkoop van deze levensmiddelen bestond. De wettelijke bepalingen waren bovendien gericht tegen het opzettelijk plegen van een misdrijf; zij waren repressief en niet preventief bedoeld. Maar ondanks het herhaaldelijk aandringen van de inspecteurs durfden de achtereenvolgende ministers het niet aan om deze bepalingen door een levensmiddelenwet te vervangen. ${ }^{138}$ Het zou tot 1919 duren, voordat de eerste Warenwet (Stb. 581) verscheen.

De strategie van de geneeskundige inspectie, de gezondheidscommissies en de particuliere verenigingen was er daarom op gericht de gemeentebesturen op grond van de Gemeentewet te bewegen tot het uitvaardigen van plaatselijke verordeningen. Inderdaad zijn in de loop van de jaren zeventig en tachtig in vele gemeenten plaatselijke verordeningen op de verkoop van vlees, vis en melk van kracht geworden. Maar het toezicht op de naleving bleef overal gebrekkig. ${ }^{139}$ Daarom werden op medisch initiatief bijzondere commissies of verenigingen in het leven geroepen, waarvan ook schei-, natuur- en veeartsenijkundigen deel uitmaakten, en die levensmiddelen moesten keuren. Met name de consumptie van vlees van tuberculeuze runderen beschouwden de medici als een bedreiging voor de gezondheid, nadat de Franse arts Villemin in 1866 had aangetoond dat tuberculose van dier op mens kon overgaan. ${ }^{140}$ Een ander initiatief van de gezondheidsverenigingen en -commissies waren de volksgaarkeukens die goedkoop en relatief goede warme maaltijden verstrekten. Er werden coöperatieve bakkerijen opgericht waar brood van goede kwaliteit werd gebakken alsook melkinrichtingen, waar melk van gegarandeerd gezonde koeien verkrijgbaar was. $^{141}$

Men mag veronderstellen dat als gevolg van deze activiteiten niet alleen de burgerij, maar ook een deel van de arbeidende bevolking in de steden kon beschikken over betere voedingsmiddelen. Zoals in de jaren tachtig echter duidelijk bleek, hebben de meeste arbeiders zelfs van deze bescheiden verbeteringen niet kunnen profiteren. De belangrijkste oorzaak was gelegen in de economische uitbuiting van arbeiders in fabrieken en in de landbouw. Daaraan konden de liberale geneeskundigen weinig veranderen.

\section{De sociale kwestie na 1880}

Omstreeks 1880 begon de kritiek op de sociale misstanden scherpere vormen aan te nemen. Dit was natuurlijk mede te danken aan de vakverenigingen en de propagandisten van het socialisme die hun stem verhieven. $\mathrm{Zij}$ kregen met het door Domela Nieuwenhuis in 1879 opgerichte blad Recht voor Allen een forum en ze organiseerden zich in 1881 in de Sociaal-Democratische Bond organiseerden. Van werkelijk politiek belang echter was de groeiende invloed van de antirevolutionairen en van de linkervleugel van de liberalen. Beide politieke groeperingen waren, ieder uit verschillende motieven, tot de conclusie gekomen dat het economisch laissez-faire van de liberalen zijn langste tijd had gehad. In de loop van de jaren tachtig groeide onder invloed ook van het toenemend aantal opstootjes en het palingoproer in 1886, een zekere overeenstemming bij 
de partijen over de noodzaak van sociale wetten, die het leven van de arbeider draaglijker moesten maken.

Aanvankelijk spitste de discussie zich wederom toe op de kinderarbeid. De Wet op de kinderarbeid had bij gebrek aan toezicht nauwelijks enige verbetering gebracht in de levensomstandigheden van het arbeiderskind. De liberale minister van Justitie Modderman nam in 1882 het initiatief tot een wetsontwerp dat overmatige arbeid en verwaarlozing van kinderen moest tegengaan door aanstelling van speciale 'inspecteurs van den kinderarbeid". 142 In de kring van geneeskundigen vond hij uiteraard steun bij Coronel, die in een reeks artikelen in het Algemeen Handelsblad het voorstel met vreugde begroette, en de tegenstanders ervan hekelde. Volgens Coronel zou het een zegen voor de arbeidende klasse zijn als dit wetsontwerp tot wet werd verheven. ${ }^{143}$ Maar de Tweede Kamer verwierp het voorstel uit vrees voor hoge kosten en voor het ontstaan van een leger van ambtenaren.

De nieuwe minister van Justitie in het tweede ministerie Heemskerk (18831888) Du Tour van Bellinchave legde zich echter niet neer bij de bezwaren van de Kamer. Om over nieuwe argumenten te kunnen beschikken, vroeg hij de Commissarissen van de Koning naar hun mening over de wenselijkheid van een herziening van de Wet op de kinderarbeid. Zij informeerden bij de inspecteurs van het Staatstoezicht, en hoewel de antwoorden van de afzonderlijke inspecteurs in 1884 nogal uiteen liepen, bleek hieruit hoe zeer de algemene opvattingen binnen het Staatstoezicht waren gewijzigd. Hun adviezen behelsden onder meer een geneeskundige keuring van jeugdige werknemers, een verbod op fabrieksarbeid door personen jonger dan zestien jaar en een maximale arbeidstijd. ${ }^{145}$ In mei 1885 diende de minister een tweede wetsontwerp op de arbeid in, dat wederom op bezwaren van de Kamer stuitte.

Nadat de Kamer in 1886 op voorstel van de links-liberaal Goeman Borgesius had besloten een staats-enquête naar de arbeidsomstandigheden in te stellen, kwam de zaak in een stroomversnelling. Dit onderzoek, waarbij voor het eerst ook de arbeiders zelf waren geënquêteerd, bracht schrijnende arbeidsomstandigheden aan het licht. Hierdoor raakten zeer velen overtuigd van de noodzaak om enigerlei wettelijke regeling te maken.

Heemskerk stelde zich als minister van Binnenlandse Zaken op als een man van het midden: hij kwam zowel de links-liberalen als de kerkelijke partijen enigszins tegemoet. Tegelijk was hij een verklaard tegenstander van de sociaaldemocraten. Uitgerekend deze voormalige woordvoerder van de conservatieve partij schiep in 1887 de mogelijkheden tot een ruimere toekenning van het kiesrecht. In hezelfde jaar diende hij samen met zijn collega van Justitie een ontwerp-arbeidswet in, waarin vele elementen uit de rapporten van de inspecteurs en uit de staatsenquête zijn terug te vinden. Dit ontwerp bepaalde dat de politie en de geneeskundige inspectie de naleving van het verbod op arbeid door kinderen jonger dan 12 jaar moesten controleren. Ook konden de inspecteurs bepaalde arbeid voor kinderen onder de 16 jaar verbieden, indien zij deze schadelijk achtten voor de gezondheid. ${ }^{146}$ Een gewijzigd vierde ontwerp in 1888, ingediend door de katholieke minister van Justitie Ruys van Beerenbroek, bevatte bovendien bepalingen die overmatige arbeid van vrouwen moesten tegengaan. ${ }^{147}$

Tot teleurstelling van de hygiënisten verwierp de Kamer het voorstel van de minister om het toezicht op de fabrieksarbeid aan de geneeskundige inspectie over te laten. Een meerderheid vreesde een al te grote bemoeizucht van de 
medici met de gang van zaken in de fabrieken. In plaats daarvan werden drie aparte, niet-medische fabrieksinspecteurs aangesteld. ${ }^{148}$ In 1889 werd aldus in Nederland de eerste Arbeidswet van betekenis van kracht, maar bij de uitvoering waren geen geneeskundigen betrokken. ${ }^{149}$ Hierin zou althans tot 1900 geen verandering komen.

\section{Het verval van het liberaal hygiënisme}

\section{Dalende sterftecijfers}

In de jaren tachtig kwam de systematische verbetering van de openbare hygiëne en van de preventieve gezondheidszorg op gang. In de grotere steden werd begonnen met de planmatige aanpak van de riolering, de drinkwatervoorziening en de stadsvuilverwijdering. Er ontstond een netwerk van vaccinatiebureaus en stedelijke melkinrichtingen. Ook in de curatieve gezondheidszorg veranderde veel: er werden volgens de modernste inzichten nieuwe ziekenhuizen gebouwd, het ziekenvervoer werd beter geregeld en de poliklinieken ontstonden. Op het gebied van de volkshuisvesting was de situatie minder gunstig, maar de plannen voor het bouwen van hygiënisch verantwoorde volkswijken waren in voorbereiding.

Deze veranderingen waren in veel gevallen mogelijk, omdat gemeentebesturen hun laissez-faire politiek lieten varen. De besturen toonden zich meer en meer bereid om zelf de verantwoordelijkheid voor de openbare hygiëne te nemen, preventief-geneeskundige instellingen te subsidiëren of verordeningen uit te vaardigen. Bovendien had de nationale regering zich tot een voorstander ontwikkeld van wetgeving ter bescherming van de arbeidende klasse.

Niet alleen de zorg voor de volksgezondheid veranderde in gunstige zin, ook de volksgezondheid zelf verbeterde. Van 1850 tot 1875 schommelde het sterfteniveau van het gehele land rond de 25 sterfgevallen per 1000 inwoners. Vanaf 1875 zette een daling in van de sterftecijfers, die vanaf dan vrijwel onafgebroken doorgaat. In 1890 was het sterftepercentage beneden het niveau van de 20 per duizend inwoners gedaald. Spectaculair was de daling van de sterfte in de provincies Noord-Holland, Zuid-Holland en Zeeland. In deze provincies lag het sterfteniveau vó́r 1860 gewoonlijk tussen de 30 en 35 per duizend inwoners met soms uitschieters naar boven. In de periode 1861-1865 zakte het sterfteniveau in de drie provincies voor het eerst onder de 30 pro mille en kwam daar nooit meer boven. In 1890 was het sterftepercentage gedaald tot ongeveer 19 per duizend inwoners. De daling van de zuigelingensterfte verliep trager. Tussen 1850 en 1875 steeg de zuigelingensterfte zelfs enigszins, tot ruim 20 per duizend inwoners. Maar daarna daalde ook het sterfteniveau voor zuigelingen onafgébroken. ${ }^{150}$

De jaren tachtig kunnen we dus beschouwen als een succesvolle periode voor het Geneeskundig Staatstoezicht. Maar voelden de tijdgenoten dat ook zo? En kunnen de genoemde maatregelen werkelijk aan de activiteiten van het Geneeskundig Staatstoezicht worden toegeschreven? Het eerste is zeker niet het geval, het laatste is zeer de vraag. 
Een oppervlakkig onderzoek naar het Geneeskundig Staatstoezicht in de jaren tachtig leert, dat het Staatstoezicht nauwelijks leiding heeft gegeven aan de veranderingen. Integendeel, in de jaren tachtig lijkt er juist een sfeer van berusting over de inspecteurs en de leden van de geneeskundige raden te zijn gekomen. De geneeskundige raden waren verworden tot weinig actieve, administratieve organen die nauwelijks meer directe betekenis hadden voor de openbare hygiëne. De aanleg van riolering en waterleiding werd meestal buiten de geneeskundige inspectie om verricht en de bedrijfshygiëne kwam tot ontwikkeling zonder enige bemoeienis van de inspectie. En wat kwalijker was, het toezicht op genees- en levensmiddelen en op de kwaliteit van het drinkwater een taak die altijd door leden van het Geneeskundig Staatstoezicht was uitgevoerd - werd meer en meer overgenomen door chemici en bacteriologen van universitaire of particuliere instellingen. Of om met de woorden van Van Overbeek de Meijer te spreken: het Staatstoezicht had zichzelf overleefd omdat 'de aetiologie en de epidemiologie zich ver buiten de grenzen, die de wetgever in het jaar 1865 zich heeft kunnen denken, ontwikkeld hebben.'

Hoe was het mogelijk dat geneeskundigen, die ooit vervuld waren van wetenschappelijke en politieke hervormingsdrang, onderdeel waren geworden van een overheidsapparaat, dat eerder achter de ontwikkelingen aanholde dan er leiding aan gaf? Het antwoord op deze vraag is samengesteld.

Allereerst de zwakke organisatorische structuur van het Staatstoezicht. Voor het toezicht op de naleving van wetten en verordeningen - de tweede taak van het Staatstoezicht - was de inspectie absoluut onvoldoende toegerust. Was het Staatstoezicht in 1865 uitsluitend belast met het toezicht op de geneeskundige beroepsuitoefening en de verkoop van geneesmiddelen, door de invoering van de Begrafeniswet in 1869 werd de toezichthoudende arbeid aanzienlijk uitgebreid. In de jaren zeventig groeide het aantal politionele taken gestaag door de invoering van de Epidemiewet, de Wet op de kinderarbeid en de Lager Onderwijswet, zonder dat het ambtelijk apparaat evenredig werd versterkt. De herhaalde klacht van de inspecteurs dat 'het wetenschappelijke karakter, dat het Geneeskundig Staatstoezigt moet hebben, geheel op [ging] in het administratieve', deed de minister weliswaar de afdeling Medische Politie op het departement uitbreiden, maar dat kon niet voorkomen dat het werk van de inspecteurs na 1880 volledig door administratieve bezigheden in beslag werd genomen. ${ }^{152} \mathrm{Het}$ werk werd bovendien ernstig bemoeilijkt door het ontbreken van een solide topstructuur. Penn had in 1863 voorgesteld om de inspecteurs onder leiding van één hoofdinspecteur te plaatsen, maar Thorbecke vond het voldoende dat een inspecteursvergadering eens per jaar door de minister werd voorgezeten. Dit is evenwel vrijwel nooit gebeurd. De contacten met de druk bezette Van Cappelle, die behalve hoofd van de afdeling Medische Politie ook inspecteur van de krankzinnigengestichten was, waren spaarzaam, en overleg met het ministerie was eerder vitzondering dan regel. Pogingen van de inspecteurs in 1873 en 1876 om alsnog het ambt van hoofdinspecteur in te stellen, liepen door de weigering van de minister beide keren op niets uit.

Een andere factor van betekenis vormde het gebrek aan tastbare resultaten. Het aantal afwijzingen dat de inspectie ten aanzien van wetgeving en andere voorstellen vooral na 1875 moest incasseren, was te groot om de organisatie nog goed te kunnen laten functioneren. Het kon niet anders dan dat de geringe 
politieke invloed een demotiverend en demoraliserend effect had. Zo liet Egeling zich tegen het eind van zijn leven ontvallen dat 'hij had leeren beseffen, dat hij zich vruchteloos had opgeofferd en ingespannen in het ambtelijk leven'. Veelzeggend was de geringe toevloed van nieuwe, jonge geneeskundigen. Het wegvallen in de jaren tachtig van de stuwende krachten achter het Staatstoezicht, mensen als Penn, Ali Cohen, Egeling en Coronel, werd onvoldoende opgevangen. Er waren nauwelijks gemotiveerde geneeskundigen die de fakkel wilden overnemen. De onvermoeibare Van Overbeek de Meijer noch de zeer actieve Ruysch, die in 1884 hoofd van de afdeling Medische Politie was geworden, konden deze situatie ten goede keren. ${ }^{153}$

Er is ook een meer fundamentele oorzaak voor de crisis in het Staatstoezicht aan te wijzen, namelijk de diepgaande sociale en ideologische veranderingen in de Nederlandse samenleving tijdens de jaren tachtig. De migratie naar de steden nam als gevolg van de landbouwcrisis en de industrialisatie massale vormen aan. In de jaren 1882-1886 heerste hoge werkloosheid, doordat de economische depressie zich ook in de industriële sector deed voelen. De ongekend omvangrijke sociale en hygiënische misstanden als gevolg van de bevolkingsconcentratie en armoede konden onmogelijk door een handvol inspecteurs worden overzien, laat staan bestreden. De geneeskundige raden, die door hun provinciale karakter ver van de problemen in de steden stonden, speelden evenmin nog een rol van betekenis. De openbare hygiëne werd meer en meer de taak van gemeentelijke organisaties.

Wat de ideologische veranderingen betreft: het ging voor de meesten niet meer om de behartiging van het algemeen belang, noch om een geduldig streven naar geleidelijke vooruitgang, waarvan elk individu op den duur zou kunnen profiteren. De nieuwe politieke bewegingen streden juist voor omwenteling en groepsbelang. Voor de socialisten was de staat geen neutraal orgaan. Integendeel, deze vertegenwoordigde slechts de belangen van de heersende klasse. Om de sociale misstanden op te lossen wilden zij het kiesrecht uitbreiden. Het waren echter niet de socialisten, maar de kerkelijke partijen die in staat bleken om aan de overmacht van de liberalen een einde te maken. Al vanaf omstreeks 1870 hadden de christelijk geïnspireerde partijen zich tegen de liberale staat verzet, en tegen de zorgeloze overheidspolitiek van onthouding en ontkenning van de sociale kwestie en de 'vloek van het moderne leven'. In betrekkelijk korte tijd wisten ze een netwerk van eigen sociale verenigingen op te bouwen.

Hierdoor werden de liberale geneeskundigen die werkzaam waren in de neutrale verenigingen, door de kerkelijke groeperingen zo al niet voorbijgestreefd, dan toch ter zijde gestreefd in hun pogingen de samenleving te hervormen. Naast de liberale beschavingsmissie ontwikkelde zich de protestantse inwendige zending en het snel groeiende apparaat van de katholieke kerk: instellingen voor wezen en 'gevallen vrouwen', verenigingen tegen drankmisbruik, vrouwenbonden, bestrijding van prostitutie, intensievere controle op de kerkelijk bedeelden, de 'vereedeling van het volksvermaak' enzovoorts.

Juist in de tijd dat de grote steden een begin maakten met de aanleg van riolering en waterleiding en de discussie over de sociale kwestie eindelijk vorm kreeg, verloor de inspectie haar greep op de gang van zaken. Daar kwam nog bij dat het Geneeskundig Staatstoezicht het doelwit werd van bezuinigingen, ingegeven door de economische depressie en de geld verslindende Atjeh-oorlog. Het aantal inspecteurs werd verminderd, terwijl de salarissen zo laag mogelijk werden gehouden. In 1885 gingen zelfs stemmen op om het Staatstoezicht maar 
af te schaffen. ${ }^{154}$ Een jaar later kwam minister Heemskerk met een wetsvoorstel dat een reorganisatie van het Staatstoezicht inhield. Het Staatstoezicht moest in het vervolg uit slechts acht inspecteurs bestaan. Adjunct-inspecteurs en geneeskundige raden zouden verdwijnen en worden vervangen door onbezoldigde adviseurs. Gemeenten met meer dan 15.000 inwoners moesten op eigen kosten een gezondheidscommissie instellen. 15s Het wetsontwerp van Heemskerk kwam dus neer op een forse inkrimping van het Geneeskundig Staatstoezicht. Door de val van het kabinet kwam het niet in behandeling, maar het was duidelijk dat alleen een forse koerswijziging het voortbestaan van het Geneeskundig Staatstoezicht kon veilig stellen.

\section{Opkomst van de radicaal-liberale hygiënisten en de bacteriologische hygiëne}

Omstreeks 1890 keerden de kansen voor het Staatstoezicht, toen in het parlement de links-liberalen voorstelden om de sociale en gezondheids-wetgeving uit te breiden en daarin het Geneeskundig Staatstoezicht een cruciale plaats te geven. Ook op het ministerie van Binnenlandse Zaken bezon men zich op de vraag hoe de rijkszorg voor de volksgezondheid, i.c. het Staatstoezicht, een betere aansluiting kreeg bij de snelle ontwikkelingen in de steden. Men was gaan beseffen dat het Staatstoezicht in wetenschappelijk opzicht achter was geraakt door het ontbreken van overheidsinstellingen op het gebied van chemisch, farmaceutisch, bacteriologisch en statistisch onderzoek.

Van even groot belang voor het Geneeskundig Staatstoezicht was een nieuwe generatie hygiënisten die ten tonele verscheen en het initiatief weer naar zich toe trok. Belangrijke vertegenwoordigers van deze generatie waren R.H. Saltet en H.G. Ringeling die in Amsterdam de in 1893 opgerichte gemeentelijke gezondheidsdienst hebben opgebouwd; $\mathrm{Ch}$. Ali Cohen (een zoon van L. Ali Cohen) en H.P. Kapteyn die veel hebben gedaan voor de verbetering van de drinkwatersituatie op het platteland, B.P.B. Plantenga, oprichter van het eerste consultatiebureau in Den Haag en G. Oosterbaan, die actief was op het gebied van de zuigelingen- en kinderzorg. Ook M.W. Pijnappel, J. Menno Huizinga en A.P. Fokker behoren tot deze nieuwe generatie.

Deze geneeskundigen streefden naar een uitbreiding van het Geneeskundig Staatstoezicht en vooral naar een versterking van de medisch-hygiënische voorzieningen die aan brede lagen van de bevolking ten goede zouden komen. Allen (op Fokker na) waren voorstander van een nieuwe gezondheidsleer op bacteriologische grondslag. Hun politieke inspiratie hadden ze gekregen van de nieuwe vitale denkstroming die halverwege de jaren tachtig in de liberale partij was opgekomen. De aanhangers daarvan toonden zich afkerig van starre politieke doctrines, en wilden zich juist flexibel opstellen ten aanzien van de nieuwe eisen des tijds (openbaar onderwijs, algemeen kiesrecht, gemeentelijke exploitatie van plaatselijke monopolies, progressieve inkomstenbelasting). Deze zogenaamde radicaal-liberalen legden de basis voor een nieuwe gemeentepolitiek - vooral in Amsterdam - waarbij de plaatselijke overheid een actieve rol speelde ten behoeve van het algemeen welzijn. Naasting van Nutsbedrijven, actieve bevordering van de volkshuisvesting en de oprichting van gemeentelijke gezondheidsdiensten waren het directe gevolg.

De vertegenwoordigers van de nieuwe, bacteriologische hygiëne en andere hygiënisten 'van de tweede generatie' organiseerden zich in 1895 op initiatief van Ruysch in het Congres voor Openbare Gezondheidsregeling. Op dit jaarlijk- 
se congres debatteerden medici samen met chemici, ingenieurs, politici, ambtenaren en enkele vooraanstaande SDAP-leden over school- en bedrijfshygiëne, tuberculosebestrijding, volkshuisvesting en gratis drinkwater voor iedereen, maar vooral over de versterking van het Geneeskundig Staatstoezicht. Het Congres heeft menige sociale en gezondheidswet die na 1900 van kracht werd voorbereid: de Gezondheidswet in 1901, de Woningwet in 1901, de Drankwet in 1904, de Armenwet in 1912 en de Warenwet in 1919. Het heeft tevens de basis gelegd voor de bloei van de sociale geneeskunde en de preventieve gezondheidszorg in de eerste decennia van de twintigste eeuw.

Samenvattend, kunnen we het volgende concluderen. Vanaf 1865 was het uitgangspunt van de regering dat de verantwoordelijkheid voor de volksgezondheid bij de provinciale en gemeentelijke overheden lag. Voor de landelijke overheid waren in beginsel slechts drie taken weggelegd: zij diende te zorgen voor een wettelijke regeling op het gebied van de opleiding tot geneeskundige en apotheker en op het gebied van de uitoefening van de genees- en artsenijbereidkunst; zij diende de lagere overheden van advies te dienen; en zij moest zorg dragen voor het verzamelen van wetenschappelijke informatie over de volksgezondheid.

De gedachte achter de laatste twee taken was, dat lokale overheden meer initiatieven zouden nemen in het belang van de volksgezondheid, als de kennis van de volksgezondheid toenam. Vooruitgang in de wetenschap zou tevens leiden tot vooruitgang in de politieke praktijk van alledag. Alleen wanneer zou blijken dat gebrek aan initiatief bij het bestuur van de ene gemeente of provincie schadelijke gevolgen had voor de volksgezondheid in een andere gemeente of provincie, of zelfs de volksgezondheid in het gehele land aantastte, mocht de rijksoverheid maatregelen nemen.

Deze politieke doctrine heeft in de periode 1865-1880 de grenzen bepaald, waarbinnen de hygiënisten hun doelstellingen moesten verwezenlijken. Bij het vele dat de hygiënisten als functionarissen van het Geneeskundig Staatstoezicht hebben gedaan, vallen twee zaken in het oog. Zij zijn erin geslaagd de criteria voor de beoordeling van de volksgezondheid, die zij in de jaren vijftig hadden ontwikkeld, in het gehele land te doen gelden. Maar vervolgens is het hen niet gelukt om in het hele land hetzelfde stelsel van gezondheidsmaatregelen in te voeren.

Wat de algemene criteria zijn de hygiënisten erin geslaagd het onderzoek naar de gezondheidstoestand met behulp van de statistiek te standaardiseren. Door sterftecijfers per gemeente (per duizend inwoners) te presenteren, hebben de hygiënisten de gezondheid van de inwoners van een gemeente getransformeerd tot een collectieve gezondheid: de 'algemene gezondheidstoestand' of de 'volksgezondheid'. Een gemeente werd een gemeenschap met kenmerkende sterftecijfers en gezondheidsbepalende omstandigheden.

Van elke gemeente werden jaarlijks het sterfteniveau en de levensomstandigheden vastgesteld. Uitgaande van de stelling - men zou kunnen zeggen: de empirische wet - dat een relatief hoge sterfte in een gemeente (of stadswijk) door plaatselijke 'kunstmatige' omstandigheden werd veroorzaakt, onderzocht het Geneeskundig Staatstoezicht alle mogelijke pathogene factoren in de gemeente. Op landelijk niveau (op het niveau van de geneeskundige inspecteurs, het ministerie van Binnenlandse Zaken, de regering en het parlement) kon 
vervolgens de gezondheid van gemeenten onderling rechtstreeks worden vergeleken. Maar ook de doeltreffendheid van gezondheidsbevorderende maatregelen (bijvoorbeeld de vaccinatie) kon per regio worden vastgesteld en vergeleken. Op gemeentelijk niveau (op het niveau van de plaatselijke gezondheidscommissie, van de gemeenteraad en bestuur) kon de gezondheid van de verschillende stadswijken onderling worden vergeleken.

Wat zijn de effecten van de verslagen en rapporten van het Geneeskundig Staatstoezicht geweest? Enerzijds is door deze rapporten de zorg voor de openbare hygiêne een permanent terugkerend onderwerp van discussie in de gemeentepolitiek geworden, zowel in de steden als op het platteland. Een relatief hoge sterfte, een dreigende epidemie of hygiënische misstanden konden niet langer door plaatselijke overheden worden genegeerd. Bovendien zijn door de rapporten van de inspecteurs landelijk dezelfde hygiënische problemen en oplossingen in de discussie gebracht. Anders gesteld, de taal van de hygiënisten de sterftecijfers, de statistische correlaties tussen sterfte en hygiënische misstanden, het begrip volksgezondheid - werd bepalend voor de plaatselijke debatten. Anderzijds zijn talloze voorstellen van de hygiënisten door gemeentebesturen afgewezen, die bij voorkeur lippendienst bewezen aan de zorg voor de volksgezondheid. Zelden traden ze doortastend op.

De inspectie gebruikte haar onderzoek tevens om aan te tonen, dat het gebrek aan initiatief van de lagere overheden schadelijk voor het 'algemeen belang' was - in de liberale staatsopvatting hèt argument om de staat regulerend te laten optreden. Concreet wilde de inspectie een wetgeving die de gemeenten tot een actief gezondheidsbeleid aanzette, en tegelijk een uitbreiding van de bevoegdheden van het Geneeskundig Staatstoezicht.

De pogingen van de inspectie om de greep van de rijksoverheid op de gemeentepolitiek te versterken, hebben weinig uitgehaald. Voorstellen voor wetgeving met betrekking tot drinkwater, fabriekshygiëne, levensmiddelen en volkswoningbouw werden afgewezen. Het belangrijkste succes van de inspectie was de totstandkoming van de Wet op de besmettelijke ziekten in 1872. Deze Wet gaf de minister de mogelijkheid om, op voorspraak van de inspectie, een gemeentebestuur te dwingen maatregelen te nemen ter bestrijding van besmettelijke ziekten. Op het terrein van besmettelijke ziekten moest de staat over het 'algemeen belang' waken, meende de minister en met hem de meerderheid van de Tweede Kamer. Overigens betekende de wet voor een deel niet meer dan het herstel van vroeg-negentiende-eeuwse regelingen, zoals de verplichte vaccinatie van schoolkinderen en het recht van de rijksoverheid een rampenplan in werking te zetten.

$\mathrm{Na} 1880$ werd in de grote steden een begin gemaakt met de systematische verbetering van de openbare hygiëne. Het is enigszins tragisch dat juist op dat moment het Geneeskundig Staatstoezicht door een zwakke organisatorische structuur, door gebrek aan mankracht, geld en deskundigheid haar greep op de ontwikkelingen in de steden heeft verloren. Pas omstreeks 1890 trad een nieuwe generatie hygiënisten aan, die bij machte was het initiatief naar zich toe te trekken. 


\section{De wereld van de hygiënisten}

\section{Een beweging van hygiënisten}

De voorgaande hoofdstukken beschrijven een groep van bijzondere geneeskundigen in Nederland in de jaren 1840-1890. Deze geneeskundigen waren van mening dat de volksgezondheid wordt bepaald door de toestand van de openbare hygiëne. Hun wetenschappelijke publikaties waren gericht op het aantonen van dit verband. $\mathrm{Zij}$ maakten enerzijds deel uit van een netwerk van organisaties die onderzoek verrichtten naar de volksgezondheid, en ze spanden zich voortdurend in voor de verbetering van de openbare hygiëne en voor de invoering van preventief-geneeskundige wetgeving. Anderzijds ontplooiden zij activiteiten in politieke en sociale organisaties of participeerden in overheidsorganen. De geneeskundigen die deze activiteiten uitoefenden, zijn in deze studie hygiënisten genoemd.

De geschiedenis van de hygiënisten kan in drie perioden worden verdeeld. De eerste begint in 1840 en eindigt omstreeks 1850 . In dit tijdvak voltrokken zich ingrijpende veranderingen in de medische beroepsgroep. Ontevredenheid over de ondoelmatige organisatie van de gezondheidszorg, het lage peil van de geneeskunde en het geringe maatschappelijke aanzien van de geneeskundige stand, bracht in de plaatselijke medische gezelschappen een discussie op gang over de medische wetgeving.

Deze discussie heeft geleid tot een politieke bewustwording van de geneeskundigen. Een deel van de medici wierp zich op als de voornaamste woordvoerders in een openbaar en nationaal gezondheidsdebat. Tegelijkertijd zochten de plaatselijke medische gezelschappen toenadering tot elkaar. Dit resulteerde in 1849 in de oprichting van de Nederlandsche Maatschappij tot bevordering der Geneeskunst (NMG).

Het politieke engagement treffen we voornamelijk aan bij de jonge geneeskundigen. De meesten hadden zich na hun promotie aan de hogeschool als (stads)geneesheer in de steden in het westen, midden en noorden van het land gevestigd. De politieke gebeurtenissen aan het einde van de jaren veertig in Frankrijk en Duitsland, sterkten deze hervormingsgezinde geneeskundigen in het geloof dat in Nederland een algehele reorganisatie van de gezondheidszorg, de geneeskunde en de medische beroepsgroep noodzakelijk en mogelijk was. Uit deze groep geneeskundigen zijn na 1850 de hygiënisten voortgekomen.

De tweede periode begint in 1850 en eindigt in 1865. In deze periode heeft zich in de NMG een netwerk van hygiënisten gevormd. Deze hebben zich toegelegd op de verbetering van de openbare hygiëne. Tegelijkertijd hebben zij de bestaande leer van de volksziekten veranderd door gebruik te maken van de statistische methode van onderzoek en door de systematisering van het topografisch onderzoek. $\mathrm{Zij}$ traden toe tot plaatselijke gezondheidscommissies en liberale kiesverenigingen. Enkelen zoals Penn, Ali Cohen en Zeeman speelden ook een rol in de landelijke politiek.

Hoewel de hygiënisten hun maatschappelijke rol vooral op lokaal niveau speelden, kan men toch van een beweging met een duidelijk nationaal karakter 
spreken. De hygiënisten beschikten over een reeks landelijke ontmoetingspunten en wetenschappelijke fora, zoals de NMG-commissie voor geneeskundige statistiek en de NMG-commissie voor volksziekten en geneeskundige plaatsbeschrijving. Deze commissies fungeerden als de knooppunten in het netwerk van hygiënisten. De hygiënisten hadden tevens toegang tot een aantal landelijke tijdschriften, zoals het tijdschrift van de Maatschappij, het Nederlandsch Weekblad voor Geneeskundigen en het Nederlandsch Tijdschrift voor Geneeskunde. De resultaten van hun onderzoek vonden daardoor altijd een weg naar het medisch publiek. De hygiënisten publiceerden de resultaten van hun wetenschappelijk onderzoek en hun analyses bovendien in tijdschriften die voor een breder publiek waren bestemd, zoals De Gids, de Economist en de Schat der Gezondheid. Ten slotte was er binnen de beweging een groep landelijke woordvoerders die zowel in wetenschappelijk als in politiek opzicht leiding gaven aan de beweging. Dit waren meestal Penn, Ali Cohen en Zeeman alsmede Egeling, Israëls en De Man. Omstreeks 1860 waren zij de enige medici die op het totale terrein van de gezondheidswetgeving deskundig waren.

De derde periode begint in 1865 met de invoering van de Wet op het geneeskundig staatstoezicht. Deze wet bleef te zamen met drie andere wetten, die de toetreding tot de medische beroepsgroep en de uitoefening van de geneeskunde regelden, tot 1901 de basis vormen voor het gezondheidsbeleid van de overheid. De periode eindigt omstreeks 1890 , wanneer het debat over de volksgezondheid in een nieuwe fase belandt. De meeste hygiënisten van het eerste uur zijn dan overleden.

Vrijwel alle hygiënisten werden na 1865 medewerker van het Geneeskundig Staatstoezicht. Sommigen vervulden het ambt van inspecteur en werden volledig ambtenaar. Anderen traden als onbezoldigd ambtenaar toe tot de geneeskundige raden van het Staatstoezicht. De medische statistiek en de geneeskundige plaatsbeschrijving zijn daarmee het terrein van de overheid geworden.

Inspecteurs en leden van de geneeskundige raden hebben onafgebroken bij gemeente- en provinciebesturen aangedrongen op verbetering van de openbare hygiëne. De aanleg van riolering en de verstrekking van kwalitatief goed drinkwater waren de belangrijkste 'actiepunten'. De leden van het Staatstoezicht bemoeiden zich echter ook herhaaldelijk met de vestiging van nieuwe fabrieken en werkplaatsen, de arbeidsomstandigheden in de fabrieken, de volkshuisvesting en de kwaliteit van voedingsmiddelen. $\mathrm{Z}_{\mathrm{ij}}$ besteedden bovendien veel aandacht aan de bestrijding van besmettelijke ziekten, zoals pokken, cholera en tyfus.

Evenals vòòr 1865 ontplooiden de hygiënisten een indrukwekkende hoeveelheid politieke en sociale activiteiten op plaatselijk niveau. Elke hygiënist was wel lid van een gezondheidscommissie of een vereniging ter bevordering van de volksgezondheid, die veelal door hemzelf was opgericht. $\mathrm{Zij}$ vervulden bestuursfuncties in de verenigingen ter bevordering van de koepokinenting, in instellingen voor verbetering van de melkvoorziening, in woningbouwcorporaties en vele andere organisaties, die de bevordering van de hygiena publica en privata in hun vaandel voerden. In de strijd voor verbetering van de openbare hygiëne werd een aantal hygiënisten bovendien lid van de gemeenteraad of zelfs wethouder van hun woonplaats. 
De hygiënisten hebben het gezondheidsdebat, dat in de eerste helft van de negentiende eeuw vorm had gekregen, aan fundamentele kritiek onderworpen. Bestaande discussies richtten zich naar de mening van de hygiënisten op de verkeerde politieke en wetenschappelijke doelstellingen en waren gebaseerd op onjuiste redeneringen. Daardoor was het niet mogelijk om doeltreffende oplossingen te geven voor de gezondheidsproblemen, waarmee de samenleving te kampen had. Het alternatief van de hygiënisten was een geheel nieuw debat en een geheel nieuwe praktijk met betrekking tot de gezondheid van burgers. In dit nieuwe debat stond het begrip volksgezondheid, of ook wel algemene gezondheidstoestand centraal.

Als doelstellingen en praktijken veranderen, dienen er ook nieuwe normen en waarden te worden ontwikkeld. Gebeurt dat laatste niet, dan worden de doelstellingen al snel zinloos en kan een nieuwe praktijk zich niet handhaven tegenover de druk van bestaande praktijken. De hygiënisten hebben zich zeer beijverd om nieuwe beoordelingscriteria te ontwerpen voor de gezondheid van de burgers. Hun belangrijkste instrument daarbij was de statistiek. De statistiek moest de noodzaak en de betrouwbaarheid aantonen van de manier waarop de hygiënisten de gezondheidsproblemen wilden aanpakken.

In de volgende twee paragrafen zal worden nagegaan welke betekenis de hygiënisten aan de termen statistiek en volksgezondheid hebben toegekend. In de paragraaf over de statistiek zal worden besproken, waarom de hygiënisten juist de statistiek hebben gekozen om nieuwe normen en waarden te ontwikkelen, en hoe zij vervolgens het onderzoek naar de volksgezondheid konden domineren. In de paragraaf over de volksgezondheid komt aan de orde, hoe het begrip volksgezondheid zich tot de liberale denkbeelden verhield, en welke inhoud de hygiënisten aan het begrip hebben gegeven. In dit verband wordt opnieuw de statistiek bekeken, maar dan vanuit de vraag hoe de hygiënisten de statistiek op politiek niveau hebben gebruikt. In de laatste paragraaf van dit hoofdstuk wordt besproken, waarom de hervormingsplannen van de hygiënisten maar zeer ten dele zijn uitgevoerd.

\section{Statistiek}

De hygiënisten maakten bij hun onderzoek naar de gezondheidstoestand van de bevolking gebruik van statistische gegevens. Dit hield in dat zij het aantal sterfte- en ziektegevallen bijvoorbeeld in hun woonplaats per maand of per jaar vaststelden, en dit vervolgens uitdrukten in een percentage van de bevolkingsomvang. Jaren achtereen stelden de geneeskundigen op deze wijze het brutosterftecijfer van hun gemeente vast. Het resultaat was verbluffend. Waren omstreeks 1850 kwantitatieve sterftegegevens nog zeer onvolledig, reeds vijftien jaar later hadden de hygiënisten gezondheidsstatistieken ontwikkeld, waarin van elke gemeente en provincie de jaarlijkse mortaliteit gedifferentieerd naar doodsoorzaken stond opgetekend.

Om te kunnen begrijpen wat de hygiënisten bij deze gegevens voor ogen stond, moet eerst worden uiteengezet wat zij precies onder 'statistiek' verstonden. De ontdekking van de numerieke, rekenkundige statistiek als wetenschappelijk instrument was zonder twijfel voor een belangrijk deel te danken aan het werk van Quetelet. Quetelet had in de jaren dertig en veertig een grootse poging ondernomen om biologische en sociale verschijnselen in de samenleving met 
behulp van statistisch onderzoek te verklaren. Hij verdedigde de stelling, dat in elk land vaste verdelingen bestaan van sociale en biologische verschijnselen, zoals criminaliteit, zelfmoord, lichaamslengte en ook sterfte. Deze verdelingen beschouwde hij als de wetten van een sociaal systeem. Hij liet zien, dat de spreiding van bepaalde biologische en andere, niet-biologische kenmerken van een populatie volgens een 'normale verdeling' in een grafiek konden worden weergegeven. Het moest volgens hem mogelijk zijn een 'sociale fysica' te ontwikkelen, die veranderingen in de samenleving kon verklaren, en zelfs voorspellen. In 1848 stelde Quetelet een aantal 'wetten' op, die een verklaring moesten geven voor de normale verdeling van biologische en sociale verschijnselen per land en per tijdseenheid.

\section{De biometer}

Quetelet is vanwege zijn determinisme sterk bekritiseerd, desondanks heeft hij grote invloed op de sociale wetenschappen gehad. ${ }^{l}$ Niemand kon na hem nog ontkennen dat 'maatschappij-onderzoek' alleen volgens strenge wetenschappelijke normen moest plaatsvinden. Quetelet heeft menige geneeskundige in Europa, zoals Farr en Simon, persoonlijk aangezet tot het verder ontwikkelen van de bevolkingsstatistiek. In Nederland zijn de hygiënisten Penn, Ali Cohen en Zeeman duidelijk door Quetelets opvattingen beïnvloed. Quetelet heeft de hygiënisten 'gevoel' voor kwantitatieve normen bijgebracht door te laten zien dat de wereld van de biologische en sociale verschijnselen regelmaat vertoont en in maat en getal kan worden beschreven.

Veel verder dan dit ging zijn invloed niet. De Nederlandse hygiënisten hebben nauwelijks aandacht besteed aan Quetelets ideeën over de 'sociale fysica'? $\mathrm{Zij}$ hebben ook nooit gebruik gemaakt van zijn wiskundige methoden. In hun ogen was het streven naar statistisch inzicht in de gezondheidstoestand vooral een kwestie van accumulatie en rangschikking van gegevens. Deze accumulatie en rangschikking moesten op den duur speculaties, meningen en zelfs theorieën overbodig maken.

De basis van hun statistiek was eenvoudig. Deze werd gevormd door de berekening van de verhouding tussen sterftegevallen en het aantal levenden, of tussen ziektegevallen en het aantal gezonden. Het belangrijkste gegeven was het sterftecijfer per duizend levenden. Dit was volgens de hygiënisten vergelijkbaar met de waarde op een thermometer. Het cijfer vormde de 'objectieve weergave' van de gezondheidstoestand in een bepaalde gemeente of streek. Had men eenmaal de sterftepercentages van een reeks gemeenten vastgesteld, dan kon men ze vergelijken. Dit schiep weer de mogelijkheid een norm te ontwikkelen en afwijkingen van de norm vast te stellen.

De werkwijze was overgenomen van William Farr. In 1843 introduceerde hij de 'biometer', aan de hand waarvan men ieder jaar gezonde en ongezonde districten kon onderscheiden. De 'normaalwaarde' die Farr deze biometer gaf, was een sterftepercentage van 17 pro mille. De statistiek van de Nederlandse hygiënisten was dus naar het voorbeeld van hun Engelse collega's opgezet. De hygiënisten leerden door Quetelet de waarde van de statistiek kennen, maar van de Engelsen hebben zij geleerd hoe ze zonder ingewikkelde wiskundige berekeningen de 'wetenschap van het sociale leven' in de praktijk van alledag konden toepassen. 
De hygiënisten hebben met de statistiek meer tot stand gebracht dan uit het voorgaande zou kunnen blijken. De tabellen met de sterftepercentages waren niet zomaar een beschrijving van de werkelijkheid, ze schiepen op een specifieke manier orde in de werkelijkheid. ${ }^{4} \mathrm{Om}$ te beginnen stelde de statistiek alle burgers aan elkaar gelijk. Voor de hygiënist-statisticus had elk sterfgeval hetzelfde gewicht. Of nu een gegoede burger of een arme aan de cholera stierf, in beide gevallen moest het sterftecijfer met één worden vermeerderd. Bovendien maakte het voor de biometer niet uit hoe groot het aandeel van de verschillende standen in de sterfte was.

In de tweede plaats beschouwden de hygiënisten een sterftecijfer als de uitdrukking van lokale, pathogene milieu- en levensomstandigheden. Sterfte- en ziektecijfers werden te zamen met gegevens over de geografische gesteldheid of de sanitaire toestand op landkaarten en plattegronden afgebeeld, zodat in een oogopslag de zieke plaatsen van het land of de stad konden worden herkend. Een vergelijking met sterftecijfers van andere plaatsen maakte duidelijk in welke mate de omstandigheden gezond of ongezond waren.

De hygiënisten schiepen met de statistięk nog een derde, een politieke orde. Was een plaats ongezond, dan waren er in de voorgaande jaren onvoldoende maatregelen genomen om de kwaliteit van het drinkwater en de hygiëne van bodem en lucht te garanderen. Met andere woorden, een plaats met een relatief hoog sterftecijfer was tevens een plaats waar onvoldoende gebruik was gemaakt van moderne hygiënische technieken. Het deed er in dit verband niet veel toe of de 'plaats' een provincie, een gemeente of een (arme) stadswijk was. In plaatsen met een relatief hoog sterftecijfer was de 'beschaving' nog niet doorgedrongen.

Door de statistiek in de leer der volksziekten toe te passen, brachten de hygiënisten tussen ziekte, ziekte-oorzaak, individu, politiek en maatschappij een verband aan dat voorheen niet had bestaan. Ziekten werden de uitdrukking van een verkeerde organisatie van het leefmilieu, een gevolg van onvoldoende beschaving en een verkeerd politiek beleid. Ziekten werden daarmee tekens van een falend politiek leiderschap. Het statistisch aangetoonde verband tussen ziekte en politiek plaatste ziekte en individu in een nieuwe verhouding tot elkaar. Het verband impliceerde immers dat burgers in veel gevallen buiten hun schuld ziek werden of stierven. Burgers die aan de gevolgen van een epidemische ziekte waren gestorven, moesten voortaan worden beschouwd als slachtoffers van degenen die de 'vooruitgang' in de weg stonden. Precies deze, door de statistiek in het leven geroepen werkelijkheid moest volgens de hygiënisten centraal staan in het debat over de volksgezondheid.

\section{De macht van de statistiek}

De statistiek werd de belangrijkste onderzoeksmethode van de hygiënisten, omdat de statistiek, anders dan de bestaande methoden, een duidelijk perspectief bood op een praktijk voor de verbetering van de gezondheidstoestand. De statistiek maakte van de leer der volksziekten een praktische wetenschap met een groot maatschappelijk nut.

In de ogen van de hygiënisten was de slepende discussie over de vraag of cholera en andere volksziekten wel of niet contagieus waren, niet relevant. Deze 
discussie had in de voorgaande periode weinig tastbare resultaten opgeleverd. Noch scheikundige proefnemingen met lichaamsvloeistoffen, besmet materiaal, lucht en water, noch botanisch-microbiologisch onderzoek hadden overtuigende bewijzen geleverd voor het bestaan van contagia. Denkbeelden over de aard van de smetstof, over de levenscyclus en over de pathofysiologische werking in het menselijk lichaam waren louter theoretische constructies gebleven. Het onderzoek naar de belangrijkste volksziekten was omstreeks 1850 in een impasse gekomen.

Tegenover deze discussie stelden de hygiënisten 'objectieve' metingen en empirisch onderzoek. De statistiek kwam tegemoet aan hun behoefte een inductieve wetenschap van de volksziekten te formeren, op dezelfde wijze als de natuurwetenschappen de wens vervulden om de pathologie en de therapie een inductieve grondslag te geven. Zoals de microscoop en de pathologisch-anatomische atlas de belangrijkste hulpmiddelen in de klinische geneeskunde waren, zo waren de statistiek en de geneeskundige plaatsbeschrijving dat in de leer van de volksziekten.

Deze analogie is geen toeval: de nieuwe leer van de volksziekten was juist opgezet naar het model van bestaand biomedisch onderzoek teneinde haar te kunnen bestempelen als natuurwetenschap. De statistiek schiep zodoende de mogelijkheid om 'wetenschappelijk' te argumenteren, op een moment dat de uiteindelijke oorzaken van de volksziekten duister waren. Zonder zich druk te hoeven maken over de verborgen oorzaken (bijvoorbeeld het contagium), kon men direct de correlaties bestuderen tussen talloze aspecten van de hygiena publica en de verschijning van volksziekten. Daarmee was de leer van de volksziekten een wetenschap geworden, die richting kon geven aan het maatschappelijk en politiek handelen van geneeskundigen èn politici.

De statistiek is in minder dan tien jaar de leer van de volksziekten gaan domineren. Drie van haar eigenschappen waren daarbij van doorslaggevend belang: de schaalvergroting van het aantal gegevens, de standaardisering, en het vergemakkelijken van verspreiding van gegevens in verschillende richting.

Het statistisch onderzoek was anders georganiseerd dan het bestaande onderzoek. Het statistisch onderzoek was opgezet door de leden van plaatselijke NMG-afdelingen. Deze leden stelden iedere maand of soms zelfs iedere week het aantal sterfte- en ziektegevallen in hun woonplaats vast. De gegevens werden bewerkt en doorgegeven aan de landelijke NMG-commissie voor geneeskundige statistiek. Vanaf 1850 herhaalden deze activiteiten zich ieder jaar. Het resultaat van deze onderzoekscyclus was dat de NMG-commissie voor geneeskundige statistiek reeds na enkele jaren overzichten van de sterfte en een aantal ziekten voor het gehele land en voor afzonderlijkse provincies en gemeenten kon publiceren. Deze overzichten brachten geografische gezondheidsverschillen aan het licht. Ook maakten ze het mogelijk veranderingen in de gezondheidstoestand over meerdere jaren waar te nemen.

Het verschil met de bestaande organisatie van onderzoek was groot. Vò̀r 1850 was de organisatie van het onderzoek gebaseerd op losse, informele contacten tussen geneeskundigen verspreid over het land. De provinciale commissies van geneeskundig toevoorzicht waren sinds 1818 weliswaar verplicht om ieder jaar een verslag van de heersende ziekten op te stellen, en dit bij de minister van Binnenlandse Zaken in te dienen, maar de rapporten werden nooit bewerkt of openbaar gemaakt. Daardoor was het onderzoek vrijwel geheel het resultaat van 
inspanningen van individuele geneeskundigen, die naar eigen inzicht gegevens over de lokale of regionale gezondheidstoestand verzamelden. Het debat over de volksgezondheid werd daardoor telkens gevoerd aan de hand van 'lokale' onderzoekingen. De vermeerdering van kennis was afhankelijk van incidentele gebeurtenissen, bijvoorbeeld het uitschrijven van een prijsvraag door een geleerd genootschap. Het onderzoek naar de volksziekten werd kortom gekenmerkt door een trage accumulatie van kennis.

$\mathrm{Na} 1850$ ontstond een netwerk van geneeskundigen die statistische informatie uitwisselden en kwantitatieve gegevens samenvoegden tot reeksen tabellen. Enkele hygiënisten in dit netwerk waren al snel in staat om over het ontstaan van volksziekten een aantal algemene conclusies te trekken. Afzonderlijke plaatsen waar tevoren de lokale onderzoeker 'heer en meester' was, werden nu als het ware meegenomen naar de burelen van Binnenlandse Zaken, waar ze overzichtelijk werden gemaakt en met elkaar werden vergeleken. Het ministerie ging vervolgens functioneren als centrum dat verder onderzoek deed en nieuwe feiten aan het licht bracht.

De hygiënisten brachten dus alleen al op grond van de organisatie van het statistisch onderzoek een cyclus van kennisaccumulatie op gang, die gepaard ging met een schaalvergroting van het onderzoek. Zij-beschikten over kennis van de gezondheidstoestand in elk deel van het land en hadden zo een sterkere wetenschappelijke positie dan de geneeskundigen die de traditionele weg bewandelden. De hygiënisten zijn daardoor de belangrijkste 'leveranciers van gezondheidkundige kennis' aan de landelijke overheid geworden. De politieke problemen in de jaren vijftig tussen de NMG en het ministerie van Binnenlandse Zaken hebben deze ontwikkeling weliswaar vertraagd, maar niet verhinderd.

Tegelijk met de schaalvergroting bracht het statistisch onderzoek een standaardisering van de onderzoeksprocedures met zich mee. Demografische veranderingen werden volgens een vast stramien in het sterftecijfer verdisconteerd. De NMG stelde tevens een protocol vast voor het verrichten van topografisch onderzoek. De Duitse hoogleraar in de hygiëne Von Pettenkofer heeft met zijn theorie over het ontstaan van cholera en tyfus het wetenschappelijk kader voor dergelijk onderzoek geleverd. Tot 1880 hanteerden de hygiënisten de vaste regels van kwantitatief, chemisch onderzoek van bodem, lucht en grondwater, die door Von Pettenkofer waren opgesteld.

Ook de ziektedefinities werden gestandaardiseerd. In de eerste helft van de negentiende eeuw bestond het onderzoek naar de volksgezondheid in hoofdzaak uit het beschrijven en classificeren van ziekten op grond van uiterlijk waarneembare kenmerken. Aandoeningen met gemeenschappelijke kenmerken werden in een bepaald ziektekarakter ondergebracht. Zo'n ziektekarakter was naar vorm gelijk aan de species die in de botanie voor het classificeren van de flora werden gebruikt. Een door koortsen gekenmerkt ziektekarakter kwam voornamelijk in de kustprovincies voor, omdat daar de geografische en klimatologische omstandigheden het gunstigst waren voor 'het tot bloei komen' van een koortsende ziekte. Ook het jaargetijde bepaalde welk ziektekarakter dominant was.

De hygiënisten verwierpen deze wijze van classificeren, omdat ten onrechte werd uitgegaan van een ontologisch ziektebegrip. Ziekten waren geen zelfstandige entiteiten, die door veranderingen in het natuurlijk milieu konden opbloeien en afsterven, maar niets meer of minder dan de verstoorde anatomische en fysiologische verhoudingen in het menselijk lichaam zelf. Vanaf de jaren vijftig 
deelden de onderzoekers in de NMG daarom de meeste ziekten in naar hun anatomische lokalisatie, of naar de fysiologische stoornis die als oorzaak van de ziekte werd aangemerkt. Dit leidde tot een aanzienlijke reductie van het aantal mogelijke doodsoorzaken.

Door deze standaardisering konden de statistische verslagen van de NMGonderzoekers gemodelleerd worden volgens een vast classificatieschema van ziekten en doodsoorzaken. Nadat de verantwoordelijkheid voor de verslaglegging van onderzoek bij de inspecteurs van het Geneeskundig Staatstoezicht was komen te liggen, werd dit classificatieschema vrijwel ongewijzigd voor geheel Nederland ingevoerd. De statistiek veranderde de medische kennis dus niet alleen door de hoeveelheid gegevens te vergroten, maar ook door het produceren van andere en stabielere gegevens: sterfte- en ziektetabellen waren gebaseerd op een algemeen geldende classificatie van ziekten.

Door de ziektegegevens te standaardiseren hebben de hygiënisten de gebruikswaarde van de leer der volksziekten voor de overheid vergroot. Vòor 1850 waren de aantallen ziekte- en sterftegevallen - als die al werden opgegeven niet meer dan ruwe schattingen. De uitgangspunten bij de berekeningen verschilden per geneeskundige. De beschrijvingen van één en dezelfde ziekte liepen soms sterk uiteen, zowel wat betreft de klinische symptomen als de uiteindelijke doodsoorzaak. Het was daardoor vaak niet mogelijk de gezondheidstoestand van twee plaatsen te vergelijken. De invoering van én onderzoeksprocedure en van een vast stramien voor de presentatie van gegevens maakte het mogelijk om grote aantallen ,gegevens in vergelijkbare getallen, formules, eenduidige begrippen en beknopte teksten vast te leggen. De gezondheidstoestand van een plaats kon zo in een oogopslag worden vergeleken met die van een andere plaats; de gezondheidstoestand van het land was overzichtelijker geworden dan ooit.

Ten slotte produceerden de hygiënisten met de statistiek kennis, die zich gemakkelijker verspreidde dan die van hun voorgangers en ook in bredere kring controleerbaar was. Vò̀r 1850 was de onderzoekspraktijk gericht op het verzamelen van informatie over ziektegeschiedenissen van patiënten. Op basis van dergelijk nosografisch materiaal werd de gezondheidstoestand van de bevolking of het ontstaan van een epidemie geanalyseerd. De discussie over de volksgezondheid werd dus gevoerd aan de hand van 'persoonlijke verslagen' over betrekkelijk lokale medische ervaringen. Zo plaatste de ene geneesheer zijn analyse van een epidemie tegenover die van een andere, en de derde becommentarieerde de verschillen tussen beide analyses en zette daar zijn eigen zienswijze tegenover, enzovoorts. De uitwisseling van gegevens beperkte zich doorgaans tot geneesheren met voldoende kennis van de geschiedenis der geneeskunde; alleen zij waren in staat hun eigen ervaringen met die van hun voorgangers uit andere delen van het land (of uit het buitenland) te verbinden, en zo de strekking van hun betoog een meer globale waarde te geven.

$\mathrm{Na} 1850$ speelde een medicus die het feitenmateriaal verzamelde alleen nog maar een ondergeschikte rol. Naarmate het statistisch onderzoek vorderde, was het niet meer van belang wie de tabellen en percentages had opgesteld. De onderzoeker in het ene deel van het land hoefde niet meer te weten wie de gezondheidsgegevens van elders in het land had verzameld. Voor de politicus was het evenmin noodzakelijk om de opsteller van een sterftekaart en zijn werkwijze te kennen. De statistische verslagen maakten de discussie over de volksgezondheid los van de onderzoeker die de gegevens voor die verslagen had 
verzameld. $\mathrm{Na} 1850$ observeerde men veranderingen in de volksgezondheid zonder dat de observator bekend hoefde te zijn. In het netwerk van hygiënisten, maar ook in politieke kringen konden de getallen voor zichzelf gaan spreken.

Deze mobilisering van gegevens vond niet alleen plaats op het terrein van de sterfte- en ziektegegevens. Ook factoren die correleerden met het ontstaan en de verbreiding van volksziekten werden losgemaakt van de waarnemers. De bodemgesteldheid en de kwaliteit van het grond- en oppervlaktewater werden in tabellen met de resultaten van chemisch onderzoek opgetekend, evenals de kwaliteit van de huisvesting.

Met behulp van deze resultaten - stabieler en mobieler dan die van het onderzoek van vò̀r 1850 - konden de volksziekten en de sociale misstanden worden opgetekend, en 'meegenomen' naar de burelen van de NMG-commissie voor geneeskundige statistiek en het Geneeskundig Staatstoezicht. De analyses en argumenten van de hygiënisten plaatsten de gezondheid van de burgers vanaf dat moment in een nieuw politiek perspectief.

\section{Volksgezondheid}

We hebben gezien hoe de hygiënisten met behulp van de statistiek nieuwe normen ontwikkelden ter beoordeling van de gezondheid van burgers en van de doeltreffendheid van de gezondheidspolitiek. Tegelijkertijd brachten zij ziekte, ziektę-oorzaak, individu, maatschappij en politiek met elkaar in verband: ziekte was een teken van een verkeerde organisatie van de samenleving, zieken waren slachtoffers van degenen die de vooruitgang belemmerden. De statistiek stelde de hygiënisten in staat om op elk willekeurig moment plaatsen en ziekten te vergelijken op een schaal, die de commissies van geneeskundig toevoorzicht en de lokaal werkzame geneeskundigen vòò 1850 nooit hadden kunnen bereiken. De hygiënisten zagen verschijnselen die hun voorgangers nooit eerder hadden gezien, omdat zij door het omslaan van een paar bladzijden met tabellen of door het bestuderen van een nationale sterftekaart een 'wereld' konden overzien die niemand eerder had gezien. De statistiek bleek bovendien zeer geschikt om de kennis over volksziekten om te vormen tot politiek bruikbare kennis; kennis met een grotere zeggingskracht dan de kennis uit de voorgaande periode. De hygiënisten hadden een krachtig wapen ontwikkeld om hun eigenlijke doel te bereiken, namelijk het entameren van een politieke discussie over de 'volksgezondheid'.

De hygiënisten hebben hun leer van de volksziekten verbonden met nieuwe politieke begrippen, die het gezondheidsdebat zijn gaan domineren. Sprak men in 1850 nog over de 'constitutio epidemica', in 1880 discussieerde men over de 'algemeene gezondheidstoestand' of over de 'volksgezondheid'. In de jaren veertig streefde men naar een betere 'medische politie', in de jaren zestig ging het om een goede 'openbare gezondheidsregeling'. En terwijl er bij de aanvang van de hygiënische beweging nog een 'natuurlijk' verband tussen armoede en volksziekten bestond, waren de epidemieën tien jaar later 'kunstmatige' verschijnselen. Men kan stellen dat de discussie over de gezondheidstoestand van de bevolking in ieder geval in terminologisch opzicht een verandering heeft ondergaan. In deze paragraaf zal duidelijk gemaakt worden dat achter deze terminologische verandering een ware transformatie van het gezondheidsdebat schuil is gegaan. 
In de eerste helft van de negentiende eeuw stond de discussie over de volksziekten vrijwel geheel in het teken van én thema, namelijk de toestand van de zogenaamde volksklasse. De regering en de hogere standen beschouwden de volksklasse wegens haar armoedig bestaan en haar onbeschaafde levensstijl als bijzonder ziektegevoelig. Armoede, gebrek aan morele orde of rationeel inzicht hadden de volksklasse volgens vele tijdgenoten bij uitstek tot de natuurlijke voedingsbodem van gevaarlijke ziekten gemaakt. Dit betekende dat de samenleving permanent door ziekten werd bedreigd om de eenvoudige reden, dat er een volksklasse bestond. Gezondheidkundige interventies hadden daarom tot doel het gevaarlijke mengsel van armoede, onbeschaafde levenswijze en ziekte beheersbaar te maken. De interventies moesten voorkomen dat dit mengsel de gehele samenleving te gronde zou richten.

Opmerkelijk is de relatief ruime aandacht voor de geneeskundige hulpverlening aan de volksklasse. Ten behoeve van de plattelandsbewoners was in 1804 bij wet een gehele nieuwe stand van heel- en vroedmeesters in het leven geroepen. In 1823 werd het besluit genomen de examens en de scholing van deze heelmeesters te verbeteren door de oprichting van klinische scholen:*Voor de armen in de stad was er een regeling in het kader van de armenzorg: zieke armen mochten gebruik maken van de gratis geneeskundige voorzieningen, die door de kerkgenootschappen en de stedelijke overheid werden onderhouden.

Er bestond bovendien een medisch-politioneel stelsel, dat moest voorkomen dat de endemisch heersende, contagieuze ziekten van de volksklasse - bijvoorbeeld pokken - zich over de gehele bevolking verspreidde. Bij besmettelijke ziekten die niet endemisch waren, zoals de pest, de gele koorts en de cholera lag het enigszins anders. De natuurlijke grenzen van deze ziekten werden geacht buiten Europa te liggen. Quarantainemaatregelen en sluiting van de landsgrenzen moesten verhinderen dat deze ziekten het land 'binnenvielen'. Gebeurde dit laatste toch, dan concentreerden de autoriteiten en de burgerij zich evenals bij endemisch heersende ziekten op de 'voedingsbodem' van de ziekte, namelijk de volksklasse. De armenbuurten werden permanent gecontroleerd, kermissen en markten werden verboden, zieken werden geïsoleerd, pamfletten met goede wenken werden uitgedeeld en de begrafenissen vonden versneld en onder toezicht plaats. De hogere burgerij ontvluchtte desnoods de stad om op een 'gezond' buiten het einde van de epidemie af te wachten.

\section{Tekenen van verandering}

In de jaren dertig en veertig raakte het politionele stelsel ter beheersing van het maatschappelijk complex van volkscultuur, armoede en gevaarlijke ziekten slechter op zijn taak berekend. De beperkingen ervan werden duidelijk, toen in 1830 de cholera op het Europese continent verscheen. De cholera was in verscheidene opzichten een nieuwe en onbekende ziekte. Voor het eerst sinds 1720 - het jaar van de laatste pestepidemie - werd Europa weer door een pandemie getroffen. Het was een ziekte waarvan de verbreiding niet met behulp van traditionele middelen kon worden beperkt tot een controleerbaar geografisch gebied of een controleerbare groep van de bevolking. De cholera was een ziekte, waarvan moest worden gevreesd dat deze zich vanuit de armenbuurten over de gehele samenleving kon verspreiden. Dit besef versterkte de angst van 
de burgerij voor de armen en hun leefwijze. Het zette een preventie- en bestrijdingscampagne in gang zoals niet eerder in Nederland was vertoond.

De maatregelen van openbare orde en de hulpverleningsacties bereikten ditmaal een groter deel van de volksklasse dan alleen de geregistreerde armen. Ze richtten zich tevens op een nieuw leger van hulpbehoevenden, dat als gevolg van de cholera brodeloos was geworden: arbeiders, knechten en kleine zelfstandigen, die altijd op de rand van armoede hadden geleefd en door de choleraepidemie niet meer in staat waren voor zichzelf te zorgen. De bemoeienis van overheid en burgerij met de volksklasse was niet alleen ingrijpender dan ooit, zij ging ten dele ook buiten de institutionele kaders van het geneeskundig bestuur en de armenzorg om. ${ }^{6}$

In de loop van de jaren dertig en veertig groeide de twijfel over de doelmatigheid van het gezondheidkundige verdedigingssysteem. In geneeskundige kringen raakte men er van overtuigd dat de cholera geen contagieuze, maar een miasmatische ziekte was: een ziekte die op plaatsen waar de bodem en het oppervlaktewater sterk waren verontreinigd telkens de kop op kon steken. In beginsel kon iedereen het slachtoffer worden, omdat de oorsprong van de ziekte niet in de leefwijze van de volksklasse, maar in de openbare hygiëne lag. Cholera was slechts een volksziekte, omdat het volk door armoede het ontvankelijkst voor de ziekte was en dus het zwaarst werd getroffen. Maar de oorzaken raakten aan een fundamenteel probleem, namelijk de organisatie van de samenleving, met name de stedelijke samenleving.

Een tweede structureel probleem vormde de armenzorg. Door de gestage groei van het aantal bedeelden na 1834 - het jaar waarin dit aantal een laagtepunt had bereikt - stuitte het systeem van armenzorg op de grenzen van zijn mogelijkheden. De kwaliteit van de geneeskundige hulpverlening verminderde en de financiële positie van de armenartsen verslechterde met het jaar. Daartegenover stond een toenemende werkdruk door de groei van het aantal bedeelden. Omdat de armenartsen bovendien geen enkele invloed hadden op de kerkelijke en burgerlijke armbesturen, hebben ze uit ontevredenheid met hun arbeidsomstandigheden de algemene organisatie van de geneeskundige armenzorg ter discussie gesteld.

In deze situatie nam een deel van de jongere generatie geneeskundigen het initiatief tot de oprichting van de Nederlandsche Maatschappij tot bevordering der Geneeskunst. De Maatschappij hield zich na 1849 nadrukkelijk met het vraagstuk van de armenzorg en de ziekenfondsen bezig. Men verlangde een beter inkomen, een wettelijke regeling van de arbeidsvoorwaarden van busdokters en een doelmatiger organisatie van de geneeskundige armenzorg. Ook wilde de Maatschappij meer zeggenschap over de financiering van de geneeskundige hulpverlening, en leden van de NMG namen het intiatief tot het oprichten van eigen ziekenfondsen.

Sommige geneeskundigen, zoals Penn, Israëls, Egeling en Ali Cohen, wilden meer dan betere arbeidsvoorwaarden alleen. Naar hun mening zou zelfs een verbeterde armenzorg nooit een oplossing kunnen bieden voor de gezondheidsproblemen, waarmee de samenleving te kampen had. De reorganisatie van individueel gerichte geneeskundige hulp aan armen moest worden geplaatst in het kader van een alomvattend plan voor de hervorming van de gezondheidszorg. Alleen 'algemeene maatregelen' die gericht waren op de hygiëne van het openbare leven konden de vicieuze cirkel van armoede en ziekte doorbreken, en tevens de samenleving verlossen van gevaarlijke ziekten als de cholera. Deze 
hygiënisten voelden zich in ideologisch en politiek opzicht verwant met de liberale stroming die in de jaren veertig het politieke stelsel en de maatschappij wilde hervormen.

\section{De hygiënisten als liberalen}

De hygiënisten steunden de politiek van de doctrinair-liberalen. Dit blijkt natuurlijk uit het feit dat zij hebben bijgedragen aan de totstandkoming van Thorbeckes gezondheidspolitiek. Maar ook met de constitutie van 1848 Thorbeckes belangrijkste creatie - stemden zij van harte in. Zij maakten gebruik van de mogelijkheden van de vrije directe verkiezingen en de openbaarheid van bestuur om hun wensen over het voetlicht te brengen. Zonder veel terughoudendheid rekenden zij zichzelf tot het 'denkend deel der natie' dat Thorbecke vrij baan wilde geven.

De hygiënisten hebben veel voordeel gehad bij de politieke hervormingen die na 1848 zijn doorgevoerd. Het is daarom ook niet verwonderlijk dat zij de liberale 'partij' altijd hebben gesteund. De verwantschap tussen liberalen en hygiënisten ging echter verder dan enkel dit 'politieke verbond'. De beweging van hygiënisten was in ideologische opzicht verbonden met de liberale burgerij, wier maatschappelijke invloed na 1848 langzaam maar onweerstaanbaar toenam. Deze verbondenheid blijkt bijvoorbeeld uit een vergelijking van het normen- en waardenpatroon van liberalen en hygiënisten. De liberalen gebruikten termen als 'algemeen belang', 'nationale economie' en 'vooruitgang van de menschheid' om zich te onderscheiden in een samenleving waarin de leidende aristocratie zelfgenoegzaam was, en waarin afkomst en zedelijke normen boven economische prestatie gesteld werden. De hygiënisten spraken over 'algemeene gezondheidstoestand' en 'volksgezondheid' om zich te zetten onderscheiden in een samenleving die vooral de gezondheid van de hogere burgerij beschermde. De bestaande gezondheidsmoraal berustte volgens de hygiënisten op onverschilligheid, omdat men niet veel anders deed dan de volksklasse en haar ziekten weghouden van plaatsen waar de burgerij vertoefde. Niet het behoud van de standensamenleving, maar de vooruitgang van de totale gemeenschap behoorde het perspectief van de gezondheidsmoraal te zijn.

In het liberale mensbeeld waren alle mensen gelijkwaardig, omdat elk individu in beginsel een rationeel denkend wezen is. Zijn positie in de samenleving behoorde niet afhankelijk te zijn van de stand waarin hij was geboren, noch van overgeërfde rechten en plichten. Iedereen moest in gelijke mate de kans krijgen zijn eigen belangen na te streven. De maatschappij diende zodanig te worden ingericht, dat het nastreven van individuele belangen werd bevorderd, maar wèl in overeenstemming met het 'algemeen belang'.

De hygiënisten hebben dit mens- en maatschappijbeeld vertaald in termen van gezondheid. Gezondheid behoorde geen privilege van de hogere standen te zijn. Zij wilden een samenleving waarin een ieder bij zijn geboorte dezelfde kansen op gezondheid had. Vervolgens moest iedereen in gelijke mate zijn gezondheid kunnen nastreven. De openbare gezondheidszorg schiep daarvoor de juiste voorwaarden. Tegelijk mocht de gezondheid van de één niet ten koste gaan van de gezondheid van de ander. Daarom moest in het belang van de 'algemeene gezondheidstoestand' een nieuwe, rationele gezondheidsmoraal de gezondheidsrechten en -plichten gelijkelijk over alle burgers verdelen. 
Volgens de liberalen werd het land bewoond door één enkel en ondeelbaar volk, waarvan elk afzonderlijk individu gelijk was. Dit land en zijn volk vormden de Nederlandse natie, waarvoor een ieder zich naar vermogen en uit overtuiging behoorde in te zetten. Was 'volk' vò̀r 1850 synoniem met mindere stand, voor de liberalen betekende het na 1850 alle burgers te zamen, de natie.

Dit idee van de Nederlandse natie hebben de hygiënisten willen vertalen in de term volksgezondheid. De volksgezondheid maakte deel uit van de nationale identiteit en gaf bovendien aan op welke trede van de beschaving een land zich bevond. Voor de volksgezondheid behoorde een ieder zich in te zetten. Het streven naar verbetering van de volksgezondheid was een streven naar versterking van de Nederlandse natie, een middel om het land uit zijn geestelijke apathie en materieel verval te halen. In dit verband benadrukten de hygiënisten het belang van nationale beginselen in de gezondheidszorg op dezelfde wijze als de intellectuelen elders in de samenleving dat deden voor de kunsten en de wetenschappen, de economie en het staatkundig bestel. ${ }^{7} \mathrm{Zij}$ verdedigden in de jaren vijftig en zestig de stelling dat een openbare gezondheidsregeling op de Nederlandse situatie moest zijn toegesneden.

De gezondheidsmoraal van de hygiënisten was ten dele een bijzondere vorm van het liberale streven om ieder individu behalve politieke vrijheid ook burgerlijke vrijheid te verlenen. Burgerlijke vrijheid kwam tot stand doordat de staat iedereen gelijk sociale rechten op het gebied van godsdienst, economie en de wetenschap verleende. Hierdoor konden alle burgers hun 'hogere eigenschappen' door eigen kracht en inspanning ontwikkelen en een bijdrage leveren aan het gezamenlijk levensdoel, namelijk de 'vooruitgang der mensheid'. 8 Met de liberalen waren de hygiënisten van mening dat de staat in de eerste plaats moest zorgen voor een politieke en juridische orde, waarin de burgerlijke samenleving zich vrij kon ontplooien en een ieder op grond van deskundigheid en prestatie beloond werd. Zij stelden dat die orde ook op het terrein van de volksgezondheid moest heersen, omdat anders nooit een biologisch-medische gelijkwaardigheid zou ontstaan. Slechts een deel van de samenleving zou dan zijn maatschappelijke positie door (economische) prestaties en scholing kunnen verbeteren en een bijdrage leveren aan de gemeenschappelijke levenstaak. De gezondheidsverhoudingen behoorden daarom volgens de hygiënisten tot de sfeer van het sociale recht. Omdat de gezondheidszorg op zich geen rechtsorde was, dienden er rechtsregels te komen die de (openbare) gezondheidszorg tot een sociaal recht zouden maken. De gezondheidszorg als sociaal recht zou gezonde, en daardoor vrije en produktieve leden van de gemeenschap kweken. Zo'n gezondheidszorg zou bijdragen aan de vestiging van het staatsburgerschap, zoals Thorbecke het in 1844 had geformuleerd, en dat het beginsel vormde van de constitutie van $1848^{\circ}$

\section{Volksgezondheid in wording}

Het wereldbeeld van de hygiënisten was gevormd uit het liberale gedachtengoed gecombineerd met de claim dat de gezondheid van de burgers tot de sfeer van de sociale rechtsorde behoorde. In dit wereldbeeld school een tegenstrijdigheid. De vereenzelviging met de liberale ideologie hield in dat de hygiënisten een verbintenis aangingen met de liberale politieke economie, waarin het idee van staatsonthouding domineerde. Door de liberale kiesverenigingen te steunen, stelden zij zich achter het liberale streven de overheidsuitgaven te beperken. De liberale burgerij was bovendien afkerig van belastingverhoging, die de investerin- 
gen in plaatselijke gezondheidsvoorzieningen mogelijk moesten maken. Anderzijds impliceerde het wereldbeeld van de hygiënisten een oproep om ziekte en armoede op gemeenschapsniveau te bestrijden. Dit laatste kon niet anders betekenen dan dat de staat intervenieerde in de maatschappelijke verhoudingen, en dat de burgerij betaalde voor investeringen in preventief-geneeskundige voorzieningen. In de ruim dertig jaar dat de hygiënische beweging actief is geweest, is deze strijdigheid blijven bestaan.

De hygiënisten hebben in dit spanningsveld tussen liberale ideologie en sociaal gezondheidsrecht ruimte weten te scheppen voor een nationale discussie over de 'algemeene gezondheidstoestand'. Daarbij benadrukten zij telkens twee zaken: de betekenis van hun hervormingsprogramma voor het sociale vraagstuk, en de betekenis voor de economische ontwikkeling van het land. Tegelijk gebruikten de hygiënisten de statistiek om hun positie in het debat te verstevigen. De hygiënisten concentreerden zich in de eerste plaats op het verband tussen armoede en epidemieën. Een verpauperde volksklasse bracht epidemieën voort, maar omgekeerd hielden de terugkerende epidemieën de armoede in stand, zo luidt kort samengevat de opvatting van de hygiënisten. Deze vicieuze cirkel kon verbroken worden door het verband tussen armoede en volksziekten niet meer te beschouwen als iets dat nu eenmaal bestaat, maar als een maatschappelijk probleem dat door verbetering van de openbare hygiëne kan worden opgelost.

De hygiënisten hebben deze visie dertig jaar lang uitgedragen. En niet zonder succes: het aantal voorstanders van een systematische aanpak van volksziekten beperkte zich in $1850 \mathrm{nog}$ tot een kleine groep geneeskundigen en intellectuelen, maar in 1890 deelden de geneeskundigen en een meerderheid van de burgerij althans in beginsel de visie van de hygiënisten. ${ }^{10}$ Hoe deze verandering in de samenleving tot stand is gekomen, is te traceren door de ontwikkeling van het denken in ogenschouw te nemen, die zich tussen 1830 en 1870 heeft voltrokken ten aanzien van de cholera - de volksziekte die de hygiënisten tot het centrale probleem van hun programma hadden gemaakt.

In 1832 was de cholera in de eerste plaats een 'uitheemsche' ziekte die zich als een plaag vanuit India over Europa verspreidde. Cholera was een on-europese ziekte, niet alleen in geografisch, maar ook in cultureel-antropologisch opzicht. De ziekte hoorde thuis in verre landen waar onbeschaafde en onchristelijke volkeren met vreemde, irrationele gebruiken woonden; landen waar de Europese beschaving (nog) niet was doorgedrongen. De wereld van de cholera vormde met andere woorden de tegenpool van de wereld van de beschaafde burgerij in Europa. Dezelfde schematische tweedeling paste men toe op de eigen samenleving. Enerzijds leefde het beschaafde deel van de bevolking, dat in de ogen van de tijdgenoten gelijk stond met de maatschappelijke bovenlaag. Deze bovenlaag werd geacht vrij te zijn van besmettelijke ziekten. Anderzijds was er de onbeschaafde volksklasse, die in de voorstellingswereld van de burgerij zeker zo uitheems was als de vreemde volkeren in het Verre Oosten. Door een samenspel van schuld en noodlot was de volksklasse gedoemd te leven in de wereld van de cholera.

In de jaren vijftig en zestig had de cholera een geheel andere betekenis gekregen. De aandacht ging niet meer in de eerste plaats uit naar een bepaald volk of volksdeel als natuurlijke voedingsbodem van de cholera, maar naar plaatsen waar de faecaliën van de stadsbewoners en ander organisch afval de bodem ernstig hadden verontreinigd - daar kwam de cholera tot ontwikkeling; plaatsen ook waar het afval zich vermengde met het grond- en oppervlaktewater 
dat als drinkwater werd gebruikt. De cholerasterfte was niet langer een 'fysiologisch' verschijnsel, dat nu eenmaal aanwezig was in een samenleving met een volksklasse, maar een 'kunstmatig' verschijnsel, dat paste bij de fase waarin de maatschappelijke ontwikkeling verkeerde. Cholera stond voor een gebrek aan economische, sociale en wetenschappelijke vooruitgang. De statistiek wees in de eigen samenleving de plaatsen met deze gebreken aan. Het waren tevens de plaatsen waar de kans op het opnieuw uitbreken van de cholera het grootst was. Men kon het gedrag van de volksklasse proberen te beïnvloeden, maar dit veranderde niets aan de werkelijke oorzaken van de cholera. In werkelijkheid lag de situatie volgens de hygiënisten precies omgekeerd: het onhygiënisch gedrag van de volksklasse kwam voort uit de onhygiënische levensomstandigheden. Gebrek aan zedelijkheid was veranderd van het eigenlijke probleem in een symptoom van maatschappelijke misstanden.

Zo was de cholera geëvolueerd van een on-europese armenziekte in een ziekte die haar wortels had in de maatschappelijke structuren zelf. De ziekte was voor een belangrijk deel van haar morele connotaties ontdaan, en als het ware van haar klasse-achtergrond losgemaakt. In plaats daarvan was de cholera een collectief probleem geworden. Alleen door een collectieve inspanning, gericht op de scheiding van de afvoer van stadsvuil en de aanvoer van drinkwater, kon de cholera worden overwonnen. Niet de armen, maar de tegenstanders van deze collectieve inspanning, van een schone, rationeel ingerichte omgeving waren verantwoordelijk voor de verspreiding van de cholera. De strijd tegen de cholera moest daarom niet meer gevoerd worden als moraliserende hulpverlening aan de volksklasse, maar als een strijd van rationeel denkende gezondheidsdeskundigen en politici tegen onwetende, onwillige burgers.

De cholera heeft een zeer prominente rol in het gezondheidsdebat gespeeld. Zozeer zelfs, dat de veranderende houding ten opzichte van de cholera een ommekeer in het denken over andere volksziekten heeft teweeggebracht. Al vroeg in de jaren vijftig gold voor tyfus, intermitterende koortsen, pokken, mazelen, meningitis en tal van andere ziekten hetzelfde wat voor cholera gold: een algemene, nationale aanpak van de levensomstandigheden van alle burgers was noodzakelijk. De genoemde ziekten konden en moesten worden voorkomen door alle burgers, ongeacht hun afkomst, aan dezelfde gezondheidsmaatregelen te onderwerpen.

Het sociale vraagstuk kwam daarmee in een geheel ander perspectief te staan. Het natuurlijk verband tussen volksziekten en volksklasse werd doorgesneden en maakte plaats voor een politiek verband tussen volksziekten en openbare hygiëne. Een filantropisch zorgsysteem was niet langer vanzelfsprekend. De volksklasse was meer gebaat bij verbetering van de levensomstandigheden en de openbare hygiëne. Riolering, goedkope en kwalitatief goede voedingsmiddelen, goedkoop en kwalitatief goed drinkwater en betere huisvesting zouden het armoedevraagstuk misschien niet in én klap oplossen, maar vormden wel noodzakelijke voorwaarden. Dergelijke maatregelen zouden de vicieuze cirkel van ziekte en armoede doorbreken en ieder lid van de volksklasse in staat stellen als een volwaardig individu en producent deel te nemen aan de samenleving. Een goede openbare hygiëne - de kern van het nieuwe gezondheidsbeleid - zou derhalve bijdragen aan de vestiging van het staatsburgerschap dat Thorbecke en zijn medestanders in het vooruitzicht hadden gesteld.

In de tweede plaats stelden de hygiënisten dat hun hervormingsprogramma noodzakelijk was voor de economische ontwikkeling van het land. Economische 
vooruitgang en welvaart konden alleen worden bereikt, indien de volksklasse over voldoende werklust en lichaamskracht beschikte. Volgens de hygiënisten was dit niet het geval, integendeel, de fysieke conditie van een groot deel van de beroepsbevolking was bijzonder slecht. Dit werd veroorzaakt, aldus de hygiënisten, door de 'ongezonde' omstandigheden waarin de meesten gedwongen waren te leven. Volgens de hygiënisten was het hoog tijd dat de 'werkende stand' de kans kreeg een gezond bestaan te leiden, bijvoorbeeld door de kwaliteit van de volksvoeding te verhogen of door goede arbeiderswoningen te bouwen. Tegenover deze verbeteringen stonden wel nieuwe verplichtingen van de werkende stand. 'Gezonde woningen' waren bijvoorbeeld bedoeld voor de geschoolde arbeiders en hun gezinnen, die hun huur op tijd konden betalen en naar hygiënische maatstaven fatsoenlijk leefden. ${ }^{I I}$

Ten slotte hebben de hygiënisten de 'volksgezondheid' in het centrum van de politieke discussie over de gezondheidszorg geplaatst door de analyse van de gezondheidstoestand uit te drukken in tabellen en cijfers, en deze als weten schappelijk, objectief en waar te presenteren. De verantwoordelijke politici konden de gegevens aanvankelijk laten voor wat ze waren, maar ze tegenspreken kon niet meer. Hoe meer gegevens er beschikbaar kwamen, en hoe verfijnder de statistische overzichten werden, des te moeilijker was het voor lokale politici de 'harde feiten' te negeren, bijvoorbeeld dat hun gemeente tot de ongezondste van Nederland behoorde. Politici moesten ten langen leste erkennen dat de volksgezondheid hun belangstelling had, ook al was dit vaak maar een façade.

De statistiek kreeg dit politieke effect, doordat sterfte- en ziektecijfers aangaven welke plaatsen in Nederland de grootste kans hadden om door een nieuwe uitbarsting van een gevaarlijke ziekte te worden getroffen. Als op een plaats de sterfte jaren achtereen relatief hoog was geweest, dan zou dit in de komende tijd zo blijven, beweerden de hygiënisten. $\mathrm{Zij}$ voegden er echter direct aan toe, dat dit niet zo behoefde te zijn, wanneer de lokale overheid hun adviezen opvolgde. Door ziekten op deze manier in de toekomst te projecteren kon de statistiek een machtig middel worden om handelingen in het heden af te dwingen.

Statistische feiten gingen al spoedig, nadat zij door de hygiënisten waren geproduceerd, een eigen leven leiden in politieke discussies. Ministers en Kamerleden maakten in toenemende mate gebruik van 'harde' statistische feiten om tegenstanders te bestrijden (het voorstel-Wintgens in de jaren vijftig, de bestrijding van de besmettelijke ziekten in 1871). Steeds vaker kwamen feiten tegenover meningen te staan. Geleidelijk werd de discussie over de volksgezondheid gedomineerd door de 'positieve wetenschap' van de hygiënisten. Als gevolg daarvan kregen de partijen die sinds de achttiende eeuw aan het debat hadden deelgenomen steeds minder ruimte om zelf een oordeel over de gezondheidstoestand te formuleren. Vroeger bood een essayistische discussiebijdrage van een geneesheer nog de mogelijkheid van verschillende interpretaties van de werkelijkheid, nu sprak de statistiek onverbiddelijk het laatste woord: sterfteverschillen tussen landen, steden en stadswijken bestonden vele jaren achtereen, ze waren structureel en waren het gevolg van maatschappelijke condities, die overal op dezelfde wijze in kaart waren gebracht. Met hun statistische interventie in het gezondheidsdebat verminderden de hygiënisten dus de 'onderhandelbaarheid' van gezondheidkundige feiten. 
Wat hebben de hygiënisten bereikt met hun interventie in de wetenschappelijke en politieke discussie over gezondheid?

1 De gezondheid van de volksklasse en van de hogere standen zijn samengevoegd tot één domein, dat met de term volksgezondheid werd afgebakend. Het gezondheidsdebat ging vanaf dat moment over de gezondheid van het gehele volk. De politiek ter bevordering van de volksgezondheid was per definitie een politiek die uitsteeg boven de belangen van een afzonderlijke klasse.

2 Door het begrip volksgezondheid kreeg de individuele en collectieve gezondheid een plaats in het liberale wereldbeeld. Zoals gemeenschap en individu organisch met elkaar waren verbonden, zo waren ook de gezondheid van de gemeenschap en die van het individu organisch met elkaar verbonden. Verbetering van de volksgezondheid stond in dienst van de gezondheid van het individu. Omgekeerd droeg de gezondheid van iedere burger afzonderlijk bij aan de gezondheid van het volk. Dit schiep voor iedere burger de morele verplichting om zijn gezondheid na te streven volgens de weg die de hygiënisten hadden aangewezen.

3 Men kon de 'bevordering van de volksgezondheid' plaatsen in het kader van de nationale vooruitgang. De gezondheidspolitiek kon bijvoorbeeld worden besproken in het kader van de bevordering van handel en nijverheid. Met andere woorden, de gezondheid van de burgers kon net als de prestaties van de burgers op het terrein van de economie, de kunsten en de wetenschappen, gelden als iets dat bijdroeg aan de welvaart en de culturele identiteit van het Nederlandse volk.

4 Het debat over de 'volksgezondheid' riep een standaard in het leven, waaraan men de gezondheid van het land, lokaal en nationaal, kon afmeten. De volksgezondheid in Nederland kon worden uitgedrukt in maat en getal, en worden vergeleken met de volksgezondheid in omringende 'beschaafde' landen. Uit zo'n vergelijking kon Nederland te voorschijn komen als een relatief beschaafd of juist een relatief onbeschaafd land, afhankelijk van het land waarmee werd vergeleken. Maar ook de volksgezondheid in een gemeente kon worden vergeleken met die in andere gemeenten of met landelijke gemiddelden. Daardoor konden gemeenten als relatief 'onbeschaafd' worden bestempeld. Spreken over volksgezondheid impliceerde dus spreken over een culturele norm.

5 Het begrip volksgezondheid had ook een ethische inhoud. Het impliceerde dat iedere burger volgens dezelfde maatstaven moest worden beoordeeld. Of iemand arm of rijk was, tot de aristocratie of de werkende stand behoorde, iedereen had recht op dezelfde kans op gezondheid en op dezelfde gezondheidsvoorzieningen. Men kan stellen dat de hygiënisten met het gebruik van de termen 'algemeene gezondheidstoestand' en 'volksgezondheid' vooruitliepen op de realisering van dit ideaal. Men postuleerde als het ware de mogelijkheid van het bestaan van één ondeelbaar volk, zonder sociale sterfte- of ziekteverschillen. Ook in dit opzicht vertoont het streven van de hygiënisten grote gelijkenis met dat van de liberale 'partij'. Deze ging er immers van uit dat de nieuwe politieke en juridische orde uiteindelijk tot sociale harmonie zou leiden.

6 Zoals gezegd, hebben de hygiënisten met hun statistische interventie in het gezondheidsdebat de onderhandelbaarheid van gezondheidkundige feiten verminderd. Dit plaatste de partijen, die reeds decennia lang een rol in de discussie over de bestrijding van volksziekten hadden gespeeld, in een andere 
verhouding tot elkaar. In de eerste plaats hadden de hygiënisten deze verhouding in het voordeel van de medici gewijzigd. De medici wierpen zich op als de enigen die een gefundeerd oordeel over de volksgezondheid konden vellen. Alleen zij konden een rationeel gezondheidsbeleid formuleren, omdat alleen zij positieve feiten over de volksgezondheid verzamelden.

Dit heeft de positie van de medische stand ten opzichte van de overheid versterkt. Maar ook de verhouding tussen de medici en de bevolking veranderde. Deze verhouding kreeg de vorm van een arts-patiënt relatie. Zoals een patiënt geneest als hij zijn lot in handen van een deskundig en onbaatzuchtig geneesheer legt, zo wordt het volk verlost van gesels als de cholera als het zijn gezondheidsbelangen door de medische stand (lees: de NMG) laat verdedigen. En zoals de patiënt voor zijn eigen bestwil de adviezen van de dokter moet opvolgen, zo dienen het volk en de gekozen volksvertegenwoordigers de plichten na te komen, die de hygiënisten hebben geformuleerd. Doen zij dat niet, dan handelen ze niet alleen irrationeel, maar zullen ze ook nooit de gezondheid en welvaart kennen die nodig is voor een harmonieuze samenleving. Met andere woorden, het positivisme van de geneeskundigen moest er toe leiden dat het deel van de burgerij dat aanvankelijk een belangrijke rol had gespeeld in het gezondheidsdebat (de Maatschappij tot Nut van 't Algemeen, de kerken, de regenten) hierin na 1850 alleen nog maar een bijrol kreeg te vervullen. Hoewel dit in deze studie niet systematisch is onderzocht, lijkt het wel zeker dat de genoemde maatschappelijke groeperingen deze bijrol niet zonder meer hebben aanvaard.

De hygiënisten hebben met de introductie van gezondheidsstatistieken ook de verhouding tussen de centrale en de plaatselijke overheid veranderd. Nadat in 1865 het Geneeskundig Staatstoezicht tot stand was gekomen, kon de rijksoverheid tal van lokale variaties in gezondheid als onnodig en abnormaal afschilderen. Als de sterfte in een gegeven plaats jaren achtereen hoog bleef, dan kon dit worden toegeschreven aan het onverantwoordelijke gedrag van een lokale bevolking of een plaatselijk bestuurscollege. Sinds de oprichting van het Geneeskundig Staatstoezicht werden lokale besturen geconfronteerd met een landelijke gezondheidsnorm. Anderzijds zag de rijksoverheid zich vanaf dat ogenblik voor de taak geplaatst lokale variaties in gezondheid op te heffen.

De sterfte kon daarmee inzet worden van een discussie over de noodzaak van staatsinterventie. Dit is bijvoorbeeld het geval geweest tijdens het Kamerdebat in 1871 over de verplichting tot vaccinatie van alle schoolkinderen. De voorstanders van deze verplichting wonnen het pleit door statistische bewijzen voor de effectiviteit van vaccinatie in te zetten tegenover godsdienstige argumenten van hun kerkelijke tegenstanders. De statistiek verschafte de rijksoverheid, in het bijzonder het Geneeskundig Staatstoezicht, dus een structureel overwicht in het gezondheidsdebat door de lokale cultuur- en gezagsdragers te beperken in hun mogelijkheden van een eigen beleid. En dat laatste was precies wat de hygiënisten als een noodzakelijke voorwaarde zagen om een nationaal beleid ter bevordering van de volksgezondheid tot stand te brengen. 


\section{De hygiënisten en de politieke verhoudingen}

In de voorgaande paragraaf is gesteld, dat de hygiënisten erin zijn geslaagd hun maatschappelijke positie te versterken. Toch zijn zowel de rijksoverheid als de provinciale en gemeentelijke autoriteiten slechts in zeer beperkte mate tegemoet gekomen aan de politieke wensen van de hygiënisten, en dan vaak na zeer lang aarzelen. Deze trage voortgang in de uitvoering van het politieke programma van de hygiënisten is aan verschillende oorzaken te wijten.

Om te beginnen vond de discussie over de volksgezondheid in de jaren 18481865 plaats tegen de achtergrond van fundamentele politieke meningsverschillen over de staatsinrichting. De strijd tussen de voor- en tegenstanders van de constitutie van 1848 beheerste de politieke gebeurtenissen in de jaren vijftig. Daardoor was het landsbestuur niet in staat om nieuwe wetgeving tot stand te brengen (begrafeniswet, quarantainewet, aanvullende maatregelen op de Gemeentewet). Maar de strijd speelde zich ook af in het gezondheidsdebat zelf. De leidende hygiënisten Penn, Ali Cohen, Egeling, Israëls en Zeeman stelden zich constitutioneel op en streefden een gezondheidspolitiek na die aansloot bij de nieuwe staatsinrichting. Andere geneeskundigen, zoals Mulder en Donkersloot steunden de tegenstanders van de constitutie, onder wie de Koning. Weer andere geneeskundigen, zoals Westerhoff en Heije, stonden in hun opvatting over de Grondwet dicht bij Thorbecke, maar verdedigden op het terrein van de geneeskundige wetgeving bepaalde anti-liberale standpunten van Mulder.

De discussie tussen bovengenoemde medici spitste zich toe op het in 1849 verschenen rapport van de staatscommissie tot herziening van de geneeskundige wet van 1818. In dit rapport stonden plannen voor een vergaande integratie van de medische beroepsgroep in het staatsapparaat, alsmede voor een aanzienlijke uitbreiding van de macht van de staat in de gezondheidszorg. Thorbecke, die in 1849 minister van Binnenlandse Zaken was geworden, keerde zich tegen deze plannen. Hij heeft tijdens zijn ambtsperiode geprobeerd de inhoud van het rapport in liberale richting bij te stellen. Ook de hygiënisten verwierpen dit onderdeel van het rapport. Zij waren met Thorbecke van mening dat de medische beroepsgroep zichzelf, onafhankelijk van de staat, diende te besturen en dat een nieuw gezondheidsbeleid binnen het raamwerk van de organieke wetten gestalte moest krijgen. Mulder, lid van de staatscommissie, was voorstander van een onverkorte uitvoering van de voorgestelde plannen. Naar zijn mening moest de autocratische regeervorm, zoals die op papier sinds 1814 bestond, worden versterkt. Hij wilde een krachtige gezondheidspolitiek die naar achttiende-eeuws model onder leiding van de soevereine vorst en zijn dienaren stond. Bijgestaan door deskundige ambtenaren moesten de Koning en zijn minister het medisch onderwijs en de openbare hygiëne bevorderen, en strenge maatregelen uitvaardigen ter bestrijding van de kwakzalverij en de voedselvervalsing. Deze politieke meningsverschillen hebben bijna tien jaar lang de voortgang in het gezondheidsbeleid onmogelijk gemaakt.

Een tweede probleem was, dat de transformatie van het gezondheidsdebat alleen kon slagen wanneer tegelijkertijd de medische beroepsgroep en de geneeskunde werden hervormd. Dit was echter uiterst ingewikkeld, niet in de laatste plaats omdat facties binnen de medische beroepsgroep hun deelbelangen fel verdedigden. 
In de ogen van de hygiënisten ging het om een eenvoudig probleem. De gezondheidszorg, de medische beroepsgroep en de medische opleiding moesten in de eerste plaats ten dienste van het 'maatschappelijke nut' staan. De geneeskunde ontleende haar bestaansrecht immers vooral aan het verbeteren van de volksgezondheid. Een beperkt aantal onderwijsinstellingen mocht geneeskundigen met praktische ervaring afleveren. Deze geneeskundigen moesten wel volgens een natuurwetenschappelijk model worden opgeleid. De geneeskundigen moesten allen dezelfde rechten en plichten hebben. Dit zou een overzichtelijk stelsel van geneeskundige hulpverlening opleveren, hetgeen de doeltreffendheid van het staatstoezicht op de uitoefening van de geneeskunst aanzienlijk zou bevorderen. De medische stand zou dan bovendien optimaal inzetbaar zijn voor de verbetering van de volksgezondheid. Dit hield in dat de (rijks)overheid gezondheidsmaatregelen kon uitvaardigen die door alle artsen konden worden uitgevoerd (uniformering en registratie van doodsoorzaken, ontsmettingsreglement, farmaceutische voorschriften).

Om verschillende redenen waren tal van facties binnen de medische beroepsgroep tegen dit plan. Een groep gegradueerde geneeskundigen was tegen de volledige opheffing van het onderscheid tussen academisch gevormde geneesheren en heelmeesters. Medische hoogleraren vreesden dat het utilitarisme van het plan het wetenschappelijk karakter van de hogescholen zou aantasten. Anderen voorzagen dat door de opheffing van de klinische scholen het platteland en de mindere stand verstoken zouden raken van geneeskundige hulp. Een concentratie van alle medische studenten aan de hogescholen zou bovendien tot verschraling van het onderwijs leiden, indien er geen extra geld voor de hogescholen beschikbaar was. Ten slotte waren de hoogleraren gekant tegen de vestiging van een nieuw opleidingscentrum in Amsterdam.

De meningsverschillen waren in de jaren vijftig en in de eerste helft van de jaren zestig aanleiding voor talloze discussies, tactische manoeuvres en tussenvoorstellen. De medici bleken niet in staat de onderlinge verschillen van inzicht op eigen kracht te overbruggen. Een interventie van buitenaf bleek nodig om een beslissing te forceren. Deze interventie vond plaats in 1862 , toen Thorbecke vier wetsvoorstellen aan de Tweede Kamer aanbood. De minister koos voor het standpunt van de hygiënisten: hij stelde hetmaatschappelijk nut van een nieuwe geneeskundige wetgeving voorop. Thorbecke was bereid verschillende deelbelangen (tijdelijk) opzij te zetten, bijvoorbeeld door een regeling van het medisch onderwijs uit te stellen. Er kwam een overheidsapparaat dat tot taak had de volksgezondheid te onderzoeken en te bevorderen. De hygiënisten kregen nu de gelegenheid om het gezondheidsdebat definitief naar hun hand te zetten.

Het verzet van de liberale 'partij' tegen de uitvoering van delen van het hygienisch programma vormde het derde obstakel voor de hygiënisten. Al in de jaren vijftig manifesteerde dit verzet zich, bijvoorbeeld bij de Tweede- Kamerbehandeling van het wetsvoorstel ter oprichting van gezondheidscommissies. Maar de tegenstellingen tussen de liberalen en de hygiënisten werden toen nog volledig overschaduwd door hun gemeenschappelijke strijd tegen de 'inertie' van de kabinetten. Pas na de vestiging van de liberale hegemonie in het midden van de jaren zestig bleek dat de hygiënisten een andere koers wilden dan de liberale politici.

Zoals eerder is vastgesteld, rekenden de hygiënisten de volksgezondheid tot de sfeer van het sociaal recht. Zij verlangden liberale rechtsverhoudingen op het 
terrein van de gezondheidszorg, opdat iedereen biologisch-medisch gelijkwaardig was. Om dit te bereiken diende de overheid een wettelijk stelsel in het leven te roepen, dat de aanwezigheild van pathogene omgevingsfactoren moest terugdringen, en wel zodanig dat iedere burger zich in een 'gezonde omgeving' aan de gemeenschappelijke levenstaak kon wijden. De hygiënisten wensten vooral wetgeving die de gemeenten tot een actiever gezondheidsbeleid aanzette (begraafplaatsen, drinkwater, stadsvuilverwijdering, huisvesting, openbare gebouwen). Daarnaast verlangden zij een uitbreiding van het werkterrein van het Geneeskundig Staatstoezicht naar het fabrieks- en schoolwezen, de kinderbewaarplaatsen, de volkshuisvesting en de verkoop van levensmiddelen. Zij zagen het liefst dat de overheid het recht kreeg om alle burgers te dwingen zich te laten vaccineren en zich aan ontsmettingsreglementen te houden. Om vaccinatie en ontsmetting op grote schaal mogelijk te maken moest de rijksoverheid geld beschikbaar stellen voor de oprichting van vaccinatiebureaus en ontsmettingsinrichtingen.

De liberale 'partij' wees dergelijke voorstellen vrijwel altijd af als uitingen van ongewenst 'etatisme'. De voorstellen van de hygiënisten kwamen neer op het opnieuw invoeren van staatsbemoeienis met maatschappelijke sectoren die daarvan nog maar kort tevoren waren verlost. De meeste liberale woordvoerders waren er niet van overtuigd, dat het algemeen belang in gevaar kwam als niet snel een drinkwaterleiding werd aangelegd, of als de fabriekshygiëne niet werd verbeterd. Overheidsingrijpen was in de ogen van de liberalen pas geoorloofd, wanneer de volksgezondheid concreet werd bedreigd.

De Wet op de epidemische ziekten van 1872 illustreert deze opvatting duidelijk. De Wet moest de minister het recht geven om een bepaalde ziekte 'epidemisch' te verklaren, en de lokale overheden te dwingen om in samenwerking met leden van het Geneeskundig Staatstoezicht maatregelen ter bestrijding van de ziekte te nemen. Dergelijke maatregelen konden bestaan uit een verbod op het houden van kermissen of markten, op mestvaalten op de openbare weg, of uit het onder dwang isoleren van zieken, het ontsmetten van woningen of het dempen van een sloot. Deze wet was dus meer een rampenplan dan een middel om het leefmilieu 'gezond' te maken, zoals de hygiënisten hadden gewild. Met andere woorden, de liberale overheid viel in jaren zeventig terug op de oude traditie die voorschreef dat besmettelijke ziekten zo snel mogelijk moesten worden ingedamd.

De gezondheidspolitiek stond weliswaar na 1865 in het teken van het nieuwe begrip volksgezondheid, maar dat betekende niet dat liberalen en hygiënisten het eens waren over de concrete wijze, waarop die volksgezondheid moest worden verbeterd. Terwijl liberale bewindslieden, Kamerleden en politici op lokaal niveau vanaf 1865 in meerderheid tevreden waren met het politieke en maatschappelijke bestel van '1848', ontwikkelden de hygiënisten zich tot een interventionistische vleugel binnen de liberale 'partij'. Vanaf 1865 spitste de discussie zich toe op de vraag welke maatregel wel en welke niet in het algemeen belang was, welke voorziening wel en welke niet een sociaal recht was (gratis drinkwater bijvoorbeeld). De hygiënisten hebben hun liberale geestverwanten er niet van kunnen overtuigen, dat structurele hervormingen in de openbare hygiëne noodzakelijk waren om de volksgezondheid te verbeteren. Tot 1880 bleef het beeld bestaan, dat de gezondheidstoestand in de steden slechts incidenteel, door min of meer toevallige oorzaken werd bedreigd. 
Dit brengt ons op de vierde factor die heeft bijgedragen aan de politieke nederlagen van de hygiënisten. De leidende groeperingen in de burgerij zagen niet de noodzaak van structurele hervormingen in, omdat ze eigenlijk voor de beheersing van maatschappelijke problemen niet nodig waren. We kunnen deze stelling aannemelijk maken door een vergelijking met ontwikkelingen in het buitenland.

Historici hebben terecht opgemerkt, dat het succes van de hygiënische beweging in Engeland en Frankrijk voor een belangrijk deel te danken is geweest aan de groei van de steden en de vestiging van fabrieken in de steden. De Engelse Sanitary Movement had haar basis in de industriesteden. Het programma van deze beweging was een antwoord op de hygiënische en sociale problemen, die het industrieel kapitalisme had voortgebracht en die het voortbestaan van de steden bedreigden. ${ }^{12}$ De Franse hygiënisten vonden hun werkterrein eveneens in de grotere steden en met name in Parijs. Het Franse hygiënisch programma was evenwel niet zozeer een reactie op de industrialisering en de trek naar de steden. Die kwamen pas omstreeks 1850 goed op gang. Veeleer vormde het programma een onderdeel van een bredere intellectuele reactie op de permanent dreigende sociale onrust sinds $1830 .{ }^{13}$

In vergelijking met de omringende landen was Nederland een toonbeeld van stabiliteit. Van industrialisering en sociale onrust was geen sprake. Nederland kende in 1800 weliswaar de hoogste urbanisatiegraad van Europa (34\% van de bevolking woonde in steden met meer dan 5000 inwoners), maar er was sindsdien geen grote trek naar de steden met meer dan twintig duizend inwoners geweest. Het absolute inwonertal van steden met meer dan 20.000 inwoners groeide in de periode 1800-1880 slechts zeer langzaam. In deze periode daalde de urbanisatiegraad zelfs enigszins. Pas na 1870 groeide de bevolking in de steden sterker dan op het platteland. ${ }^{14}$ Deze stabiele verhouding tussen stads- en plattelandsbevolking komt onder meer tot uiting in de bijzonder lage woningproduktie in de steden en de geringe activiteiten van het stadsbestuur op het terrein van publieke werken vò̀r $1870 .^{15}$

Wat verder opvalt zijn de relatief geringe veranderingen in de economische en sociale structuur. Anders dan in Engeland, Frankrijk en Duitsland was de industrie in Nederland tot 1880 geen economische factor van betekenis. Nederland was vò̀r 1880 een 'vroeg-kapitalistisch' land, waar naar schatting de helft van de beroepsbevolking rechtstreeks afhankelijk was van de werkgelegenheid in de landbouw of daarbij nauw betrokken was. Activiteiten in de nijverheid vonden plaats in werkplaatsen, manufacturen en kleine fabrieken die niet in de steden, maar verspreid over het platteland waren gevestigd. Pas omstreeks 1870 nam het proces van concentratie en urbanisering van de industrie een aanvang. ${ }^{16}$

Klassenverhoudingen, zoals in de omringende landen, waren in Nederland dan ook een vrijwel onbekend verschijnsel. Omdat fabrieken in de eigenlijke zin van het woord vò̀r 1870 nauwelijks voorkwamen, ontbrak er een fabrieksproletariaat. De opkomst daarvan moet in de jaren 1880-1900 worden gedateerd. Voor die tijd bestond de arbeidende klasse grotendeels uit (vrouwelijke) thuiswerkers en arbeiders die een deel van het jaar in de landbouw werkten. Het werkvolk in de manufacturen was een vlottende verzameling handwerkers, terwij1 in de enkele fabrieken die er waren het aantal losse arbeiders groter was dan het
aantal vaste. ${ }^{17}$

In Nederland bestond evenmin een ondernemersklasse, een uitsluitend van de industrie levende stand. Voorzover er fabrikanten waren, vormden zij geen 
afzonderlijke economische klasse, maar behoorden zij tot de 'hogere stand' die op grond van leefwijze, opvoeding en afstamming een bepaald maatschappelijk aanzien genoot. ${ }^{18}$ In de kring van kapitaalbezitters waren de renteniers veel groter in aantal en invloedrijker dan de fabrikanten. De toonaangevende kringen in het bedrijfsleven achtten de economische rol van Nederland bovendien vooral bepaald door de handel (stapelmarkt in Amsterdam, transitohandel in Rotterdam). Industriële activiteit was niet onbelangrijk, maar ondergeschikt. ${ }^{19}$

Een sterke groei van de steden of de industrialisatie waren in Nederland dus geen factor die de opkomst van de hygiënische beweging hebben begunstigd. De basis van die beweging moet elders worden gezocht. Laten we daarom een blik werpen op wat de hygiënisten zelf daarover dachten en onderzoeken in hoeverre hun beoordeling juist was.

$\mathrm{Om}$ te beginnen ontleende de beweging haar bestaansrecht voor een belangrijk deel aan de constatering, dat de gezondheidstoestand in Nederland aanzienlijk slechter was dan in Engeland en Frankrijk. De hygiënisten wezen in dit verband met name op de relatief hoge sterfte in de steden. Naar hun mening werd het verschil in sterfte veroorzaakt door het relatief lage 'beschavingspeil' van Nederland. In hun poging de politici voor hun zaak te winnen, traden zij daarom dikwijls op als 'vertalers' van Engelse, Franse en Belgische gezondheidsmaatregelen. $\mathrm{Zij}$ gingen er veelal impliciet van uit, dat de volksgezondheid in Nederland zich op dezelfde wijze verhield tot de levensomstandigheden van de bevolking als in Engeland en Frankrijk.

Naar de maatstaven van de geneeskunde uit die tijd, was dit een volkomen juiste vergelijking. Cholera had in Engeland dezelfde oorzaak als in Nederland, namelijk een chronisch gebrek aan kwalitatief goed drinkwater en een voortwoekerende verontreiniging van de bodem en het oppervlaktewater met organisch afval. De hygiënisten hadden geen enkele reden om aan te nemen, dat in Nederland andere determinanten van de volksgezondheid werkzaam waren dan in de omringende landen. Net als in het buitenland werd de hoogte van de algemene sterfte sterk bepaald door de zuigelingen- en kindersterfte. En zoals elders was de zuigelingen- en kindersterfte hoog in vergelijking met de sterfte onder volwassenen, omdat juist kinderen werden getroffen door maag- en darmaandoeningen, pokken en andere infectieziekten. Ook moet er nogmaals op worden gewezen, dat de urbanisatiegraad in Nederland in het midden van de vorige eeuw vele malen hoger lag dan in Frankrijk en Duitsland. Alleen Engeland overtrof Nederland in het relatieve aantal stadsbewoners. ${ }^{20}$ De hygiënisten gingen er dus terecht van uit, dat de bodem- en waterverontreiniging in de steden, krotbewoning, een hoog gemiddeld aantal bewoners per woning en een hoge bevolkingsdichtheid in het westen van het land evenals in Engeland belangrijke determinanten van de volksgezondheid waren.

De hygiënisten zagen met hun vergelijking tussen Nederland en de omringende landen echter één belangrijk verschil over het hoofd. Zoals eerder is opgemerkt, ondergingen de samenlevingen in Engeland en Frankrijk ingrijpende economische en sociale veranderingen op het moment dat de hygiënisten er hun werk begonnen. De sociaal-economische veranderingen in Nederland daarentegen waren gedurende de eerste twintig jaar van de hygiënische beweging veel minder ingrijpend. In Engeland maakten de hygiënisten de sterfteverschillen en veranderingen zichtbaar op een moment, dat iedereen kon zien dat ook de 
maatschappij veranderde. In Nederland maakten de hygiënisten de sterfte zichtbaar onder de omstandigheid dat de samenleving onveranderd bleef.

Dit verschil in maatschappelijke dynamiek tussen Nederland en andere landen verklaart de relatief grote invloed van de Engelse hygiënisten en de relatief geringe invloed van Nederlandse hygiënisten. In de publieke opinie hield de stelling lange tijd stand, dat sterfteverschillen en -veranderingen geen relatie hadden met verschillen en veranderingen in de maatschappelijke organisatie, juist omdat die organisatie niet veranderde. Anders gesteld, het was juist de afwezigheid van ingrijpende veranderingen in de structuur van de Nederlandse samenleving, die in Nederland een klimaat schiep waarin politici en burgerij konden volstaan met kleine aanpassingen in de organisatie van de openbare hygiëne en noodmaatregelen.

Samenvattend kunnen we concluderen, dat de hygiënisten in de jaren 1850-1880 met succes het gezondheidsdebat hebben omgesmeed tot een nationale discussie over volksgezondheid, gezondheidsverschillen en de oorzaken van de verschillen. Een uniform gezondheidsbeleid voor alle burgers was sindsdien uitgangspunt van de discussie. Liberalen konden in een concreet geval een gezondheidsmaatregel afwijzen, kerkelijke partijen konden in een ander geval de 'soevereiniteit in eigen kring' opeisen, de norm was voortaan een algemeen geldig gezondheidsbeleid, een beleid dus voor het gehele land en alle burgers.

Gesteund door nieuwe wetten en plaatselijke verordeningen hebben de hygiënisten zich tot de belangrijkste gesprekspartners van de landelijke, provinciale en plaatselijke overheden gemaakt in kwesties van openbare hygiëne. Tegelijkertijd echter hebben ze de publieke opinie niet volledig kunnen overtuigen van de stelling, dat de gezondheidstoestand zijn wortels in de maatschappelijk organisatie had. Regering en parlement waren niet bereid de lagere bestuursorganen de wet voor te schrijven, en provincie- en gemeentebesturen wilden de organisatie en de financiering van de publieke werken niet op zich nemen. Alleen bij de signalering en de bestrijding van acute bedreigingen van de volksgezondheid kregen de hygiënisten alle medewerking, en werden op hun voorstel ook maatregelen uitgevoerd. De overgrote meerderheid van de burgerij steunde dit beleid. De gegoede stand zag de noodzaak niet in van bijzondere voorzieningen ten behoeve van de openbare hygiëne, noch van bijzondere maatregelen gericht op de verbetering van de levensomstandigheden van de arbeidende klasse.

In het nadeel van de hygiënisten was de betrekkelijke starheid van de economische en sociale structuren van de Nederlandse samenleving. Tot in de jaren zeventig was de groei van de steden niet zo groot dat de belasting van het stedelijk milieu het leven in de stad ondraaglijk maakte. Met uitzondering van Amsterdam was de aanleg van een drinkwaterleiding in de steden niet noodzakelijk, omdat de burgerij nog juist over voldoende kwalitatief goed drinkwater beschikte. Het bouwen van grote aantallen arbeiderswoningen was evenmin een dringend probleem, omdat er geen vast fabrieksproletariaat was dat voor zijn voortbestaan van enkele basisvoorzieningen afhankelijk was. Er waren bovendien nauwelijks kapitaalbezitters, die in de publieke voorzieningen wilden investeren.

Tegen deze achtergrond doet het hervormingsprogramma van de hygiënisten enigszins geforceerd aan, zeker wanneer we de periode vóór 1870 in ogenschouw 
nemen. Het programma was voor een belangrijk deel opgesteld naar buitenlands voorbeeld. De hygiënisten baseerden hun programma ook op buitenlandse ervaringen met de gevolgen van urbanisering en industrialisering: als een Engels stadsbestuur sanitaire hervormingen had doorgevoerd, verbeterde de gezondheidstoestand. De economische en sociale dynamiek, die de sanitaire hervormingen in het buitenland mogelijk maakten, waren in de Nederlandse samenleving echter afwezig. Pas na 1870 ondervonden de hygiënisten meer steun voor hun plannen. Aanvankelijk schoorvoetend, en in de jaren tachtig met meer overtuiging namen de besturen van de grotere steden de sanering ter hand. Het was tegen die tijd absoluut noodzakelijk geworden om de terugkerende grote bedreigingen van de volksgezondheid weg te nemen, wilde de stad als economisch en industrieel centrum blijven voortbestaan.

We kunnen stellen dat de hygiënische beweging niet de geschiedenis in gaat als een beweging die in de jaren 1850-1880 ingrijpende hervormingen in de openbare hygiëne tot stand heeft gebracht. Wèl kan zij gelden als een beweging, die het denken en spreken over gezondheid heeft veranderd. De beweging heeft het idee vorm gegeven en levend gehouden, dat de volksgezondheid tot de sfeer van de sociale rechtsorde behoort, ook al is dit beginsel in politiek opzicht niet altijd even effectief gebleken. 


\section{De belangrijkste hygiënisten in de periode 1840-1890}

\section{Levy Ali Cohen}

Ali Cohen is in 1817 in Meppel geboren. Na zijn promotie tot doctor medicinae in 1840 aan de Groningse Hogeschool vestigde hij zich als geneesheer in Groningen. Hij raakte er spoedig bevriend met de bekende geneeskundige Acker Stratingh die hem kennis liet maken met geologisch, botanisch en historisch onderzoek van de noordelijke provincies. Ali Cohen was tot 1845 assistent bij de hoogleraar in de obstetrie J. Baart de la Faille, bij wie hij zijn aandacht richtte op fysiologische en klinische onderwerpen (zoals diabetes mellitus). In de tweede helft van de jaren veertig solliciteerde hij enkele keren zonder succes naar een wetenschappelijke functie elders in het land. In 1848 nam hij de redactie van het Nieuw Practisch Tijdschrift voor de Geneeskunde op zich. Vanaf dat jaar legde hij zich geheel toe op de hervorming van de openbare gezondheidszorg.

Ali Cohen heeft vele bestuurlijke functies bekleed. Hij behoorde tot de oprichters van de Nederlandsche Maatschappij tot bevordering der Geneeskunst. Reeds in 1848 richtte hij samen met onder anderen Acker Stratingh en D. de Vries de Reilingh de Groningse afdeling van de NMG op, waarvan hij tot 1862 secretaris was. In de jaren zeventig en tachtig is hij enkele malen voorzitter van de afdeling geweest. Hij is verantwoordelijk geweest voor de reorganisatie van de (geneeskundige) armendienst van de Nederlandse Israëlitische Gemeente in Groningen. In 1864 werd hij lid van de Groningse gemeenteraad. In de jaren vijftig maakte hij samen met Zeeman en Egeling deel uit van de NMG-commissie voor geneeskundige statistiek. Zowel in de stad als in de provincie Groningen was hij zeer actief als sanitair hervormer. Ali Cohen was in 1857 nauw betrokken bij de oprichting van het Nederlandsch Tijdschrift voor Geneeskunde. Tot in jaren zeventig is hij medewerker van dit tijdschrift geweest voor de onderwerpen 'medicina politica', 'hygiena publica' en 'binnenlandse berichten'.

In 1853 verzocht Thorbecke Ali Cohen om samen met Penn de herziening van de wetgeving voor te bereiden, maar de val van het kabinet-Thorbecke in april 1853 maakte aan dit adviseurschap een voortijdig einde. In de jaren 1862-1865 waren Ali Cohen en Penn opnieuw adviseur van minister Thorbecke, en ditmaal met succes. In $1865 \mathrm{kwamen}$ vier nieuwe geneeskundige wetten tot stand. Ali Cohen werd tot inspecteur van de provincies Overijssel en Drenthe benoemd en tevens tot secretaris van de inspecteursvergadering van het Geneeskundig Staatstoezicht. De eerstgenoemde functie vervulde hij tot 1869 . In dat jaar werd hij inspecteur van de provincies Groningen en Friesland. Tot aan zijn overlijden in 1889 heeft Ali Cohen dit ambt bekleed. Ali Cohen heeft een zeer groot aantal (vertaalde) boeken, rapporten en artikelen op zijn naam staan, die in meerderheid de openbare hygiëne, de medische wetgeving en de medische statistiek tot onderwerp hebben. 


\section{Gerardus Arnoldus Nicolaas Allebé}

Allebé is in 1810 in Amsterdam geboren. Hij behaalde de graad van doctor medicinae in 1836 in Leiden. Hij vestigde zich in Amsterdam en bouwde er een grote praktijk op waarvoor hij tot 1874 is blijven werken. In 1845 publiceerde hij het populaire boek De antwikkeling van het kind naar lichaam en geest eene handleiding voor moeders bij de eerste opvoeding. Een tweede druk verscheen in 1848. Een zesde, herziene en laatste druk verscheen in 1887. In 1847 nam Allebé met enkele andere geneeskundigen het initiatief tot de oprichting van het Algemeen Ziekenfonds voor Amsterdam, het eerste door geneeskundigen geleide ziekenfonds in Nederland. In de jaren 1848-1849 nam hij actief deel aan de oprichting van de NMG. Van 1851 tot 1855 was hij lid van het hoofdbestuur van de Maatschappij. Sindsdien legde hij zich toe op de verbetering van de openbare hygiëne en op de gezondheidsvoorlichting en -opvoeding. Samen met H. van Cappelle publiceerde hij in 1861 een handboek voor de hygiëne van schoolgebouwen. Hij was na 1867 actief lid van de Amsterdamse gezondheidscommissie en verrichtte in deze functie in 1873 met A.H. Israëls het bekende onderzoek naar de kelderwoningen. In 1866 werd hij lid van de Geneeskundige Raad van Noord-Holland en van 1868 tot 1891 was hij secretaris van deze raad. Allebé was in de jaren 1867-1870 curator van het Athenaeum Illustre in Amsterdam. In 1875 richtte hij met Penn en Teixeira de Mattos het 'Witte Kruis' op.

Allebé heeft niet alleen boeken over de hygiena publica en privata geschreven, hij heeft ook een zeer groot aantal artikelen over de hygiëne gepubliceerd in het Nederlandsch Tijdschrifi voor Geneeskunde en in de hygiënistische tijdschriften Schat der Gezondheid, Tijdschrift voor Gezondheidsleer en De Gezondheid. Hij overleed in 1892.

\section{Adrianus Marinus Ballot}

Ballot is in 1823 in Rotterdam geboren. Hij behaalde in 1850 in Leiden de graad van doctor medicinae. In de jaren 1852-1853 promoveerde hij tevens tot doctor in de heel- en verloskunde. Hij vestigde zich in Rotterdam. Zijn belangstelling ging uit naar de openbare hygiëne in de stad en naar het medischstatistisch onderzoek. Ballot streed in zijn woonplaats voor hervormingen op het gebied van afvalverwijdering, riolering en drinkwatervoorziening. Hij stond kritisch ten opzichte van de bodemtheorie van Von Pettenkofer. In de jaren 1866-1873 maakte hij deel uit van de Geneeskundige Raad van Zuid-Holland. In 1872 werd hij lid van de gemeenteraad gekozen. Ballot heeft een aantal belangrijke hygiënische en medisch-statistische publicaties over de gezondheidstoestand in Rotterdam op zijn naam staan. Hij overleed in 1873.

\section{Johannes Adrianus Boogaard}

Boogaard is in 1823 in Rotterdam geboren. Hij promoveerde in 1847 in Leiden tot doctor medicinae. Na een studie in Berlijn (bij Virchow), Praag en Parijs behaalde hij in 1850 zijn graad in de heelkunde. Daarna werd hij prosector bij de afdeling pathologische anatomie in Leiden. Boogaard werkte als lid van de NMG-commissie voor geneeskundige statistiek samen met Zeeman, Egeling en de Man. Hij heeft een actief aandeel gehad in de hervorming van de classificatie van doodsoorzaken, in het medisch-statistisch onderzoek naar dienstplichtigen en 
in de totstandkoming van de sterftekaart van Nederland (1866). Boogaard werd in 1862 lid van de redactie van het Nederlandsch Tijdschrift voor Geneeskunde, en was tevens lid van het hoofdbestuur van de NMG. Van 1866 tot aan zijn dood was hij lid van de Geneeskundige Raad van Zuid-Holland. In 1870 werd hij benoemd tot hoogleraar in de pathologie in Leiden. Boogaard overleed in 1877.

\section{Constantijn de Bordes}

De Bordes is waarschijnlijk in 1817 geboren. Hij vestigde zich in 1842 als doctor medicinae in Amsterdam. De Bordes was aan het einde van de jaren veertig secretaris van het Genootschap ter Bevordering der Genees- en Heelkunde en tevens secretaris van de commissie voor de epidemiologie van de plaatselijke NMG-afdeling. In deze functies heeft hij het onderzoek naar volksziekten in Amsterdam vaste vorm gegeven. Bovendien is hij als medewerker van de landelijke NMG-commissie voor volksziekten van het begin af aan verantwoordelijk geweest voor jaarlijkse overzichten van de heersende ziekten in Nederland. In de jaren vijftig steunde hij met enthousiasme de bodemtheorie van Von Pettenkofer. De Bordes overleed in 1858.

\section{Jacobus Cornelis van den Broecke}

Van den Broecke is in 1799 in Aardenburg geboren. Hij behaalde in 1822 in Leiden de graad van doctor medicinae. In hetzelfde jaar vestigde hij zich in Middelburg waar hij een grote praktijk opbouwde. Hij was voorzitter van het Natuurkundig Genootschap in Middelburg en van de Provinciale Commissie van geneeskundig Toevoorzicht Zeeland. In 1848 benoemde minister De Kempenaer hem tot lid van de staatscommissie tot herziening van de geneeskundige staatsregeling. Van 1853 tot 1866 was hij met Fokker en De Man lid van het bestuur van de Klinische School te Middelburg.

Van den Broecke heeft verschillende belangrijke wetenschappelijke en hygiënische studies geschreven. In 1850 publiceerde hij met De Man een studie over de verbreiding van de cholera in Zeeland, waarin het contagieuze karakter van de ziekte werd verdedigd. Met De Man en Fokker schreef hij bovendien nog een geneeskundige plaatsbeschrijving van Middelburg, en enkele andere hygiënische studies over Zeeland. In de jaren 1866-1867 was hij lid van de Geneeskundige Raad van Zeeland. Van den Broecke overleed in 1870.

\section{Hermanus van Cappelle}

Van Cappelle is in 1825 in Amsterdam geboren. Na zijn promotie tot doctor medicinae in Leiden in 1848, vestigde hij zich als praktizerend geneeskundige in Amsterdam. Zijn belangstelling richtte zich op hygiënische vraagstukken. In 1857 schreef hij Leven en gezond zijn. Volksboek voor de school en het huisgezin. Dit voorlichtend boek over de hygiena privata is door de Maatschappij tot Nut van 't Algemeen uitgegeven. Om de werkzaamheden van de schoolopzieners (inspectie) een wetenschappelijke grondslag te geven, publiceerde hij in 1861 met Allebé een Handboek voor de schoolhygiëne, getiteld Gezondheidsvereischten van schoolgebouwen. Hij was lid van de Provinciale Commissie van geneeskundig Toevoorzicht van Noord-Holland. In 1865 benoemde Thorbecke hem tot hoofd van de afdeling Medische Politie van het ministerie van Binnen- 
landse Zaken, een functie die Van Cappelle tot 1884 heeft uitgeoefend. In de jaren vijftig, zestig en zeventig heeft hij verschillende hygiënische en medischstatistische studies (over pokken, cholera en tyfus) geschreven. Als belangrijkste adviseur van de minister heeft hij een groot aandeel gehad in de totstandkoming van enkele veterinaire wetten en de Wet ter bestrijding van epidemische ziekten. Van Cappelle werd in 1875 benoemd tot parttime inspecteur van het staatstoezicht op de krankzinnigen en de krankzinnigengestichten. Na de invoering van de tweede Krankzinnigenwet in 1884 vervulde hij deze functie in volledig dienstverband. In 1889 vroeg hij om gezondheidsredenen ontslag. Van Cappelle overleed in 1890.

\section{Berend Carsten}

Carsten is in 1829 in Assen geboren. Nadat hij in 1850 zijn opleiding aan 's Rijkskweekschool voor Militaire Geneeskundigen te Utrecht had afgerond, diende hij veertien jaar in het leger als officier van gezondheid. In 1862 promoveerde hij in Groningen tot doctor medicinae en doctor artis obstetriciae. In hetzelfde jaar vestigde hij zich in Amsterdam. Carsten werd in 1866 benoemd tot adjunct-inspecteur van de provincie Zuid-Holland, een functie die hij tot 1890 bekleedde. Van 1890 to 1892 was hij inspecteur. Carsten heeft zich ingezet voor de bestrijding van de pokken. Hij publiceerde in de jaren zeventig medischstatistische studies over de pokken en hij was mede-oprichter van de Vereeniging ter bevordering van de koepokinenting. Carsten was bestuurslid van het Rode Kruis. Hij overleed in 1892.

\section{Samuel Senior Coronel}

Coronel is in 1827 in Amsterdam geboren. Hij studeerde aan het Athenaeum Illustre te Amsterdam, maar promoveerde in Leiden in 1850 tot doctor medicinae. Nadat hij twee jaar had gepraktizeerd in Zevenhuizen (Zuid-Holland), vestigde hij zich in 1853 in Middelburg, waar hij korte tijd later tot stadsgeneesheer werd benoemd. In 1858 werd hij voorzitter van het Middelburgsch Ziekenfonds. In navolging van De Man, J.C. van den Broecke en Fokker publiceerde Coronel in 1859 een geneeskundige plaatsbeschrijving van Middelburg. In deze studie toonde hij zich zeer kritisch ten opzichte van de bestaande zorg voor de openbare hygiëne en de kerkelijke armenzorg. In 1860 vertrok hij naar Amsterdam, waar hij tot stadsgeneesheer werd benoemd. Vanaf dat jaar groeide zijn belangstelling voor de fabriekshygiëne en de leef- en werkomstandigheden van de arbeidende klasse. Over dit onderwerp heeft hij tal van studies geschreven, die door andere hygiënisten nogal eens werden bekritiseerd om de 'fabrikantvijandige' toon waarin zij waren gesteld. Coronel is altijd een groot voorstander geweest van een verbod op de kinderarbeid en heeft zijn leven lang gestreden voor wettelijke maatregelen ter verbetering van de arbeidsomstandigheden. Hij sloot zich omstreeks 1870 aan bij de 'links-liberalen'. Zijn pogingen om de leer der volksziekten een moderne sociologische grondslag te geven moeten als mislukt worden beschouwd.

In 1866 kreeg Coronel zijn ontslag als stadsgeneesheer op grond van klachten uit zijn wijk. Coronel verliet Amsterdam en vestigde zich in Leeuwarden, waar hij een particuliere praktijk opbouwde. Van 1868 tot 1890 was hij secretaris van de Geneeskundige Raad van Groningen en Friesland. In deze functie heeft hij 
zich ingezet voor de verbetering van de schoolhygiëne. Coronel heeft een zeer groot aantal artikelen op zijn naam staan in bladen als het Nederlandsch Tijdschrift voor Geneeskunde, Vragen des Tijds, de Economist, Schat der Gezondheid, Tijdschrift voor Gezondheidsleer en diverse landelijke en regionale dagbladen. Hij heeft ook een belangrijk aandeel gehad in het door Ali Cohen geredigeerde Handboek voor openbare gezondheidsregeling (1872). Coronel overleed in 1892.

\section{Lucas Jacob Egeling}

Egeling is in 1824 in Haarlem geboren 1824. Hij behaalde in 1849 te Leiden de graad van doctor medicinae. Nadat hij in 1850 tevens de graad van doctor artis obstetriciae had behaald, vestigde hij zich te Haarlem. In hetzelfde jaar nam hij met enkele collega's het initiatief tot de oprichting van een NMG-afdeling. In de jaren die volgden, bekleedde hij tal van functies in de Maatschappij. Zo is hij meerdere jaren secretaris van de NMG-commissie voor geneeskundige statistiek geweest. In deze functie heeft hij samen met Zeeman, Boogaard en Ali Cohen het statistisch onderzoek tot een van de belangrijkste activiteiten van de NMG weten te maken. In de jaren 1861-1865 was Egeling lid van het hoofdbestuur van de Maatschappij. Omdat hij van 1863 tot 1865 tevens hoofd was van de afdeling Medische Politie van het ministerie van Binnenlandse Zaken, vervulde hij een sleutelrol bij de totstandkoming van de nieuwe geneeskundige wetten in 1865 . In 1869 werd Egeling tot voorzitter van de NMG gekozen.

Naast zijn bestuurlijke werkzaamheden ontplooide Egeling tal van medische en hygiënische activiteiten. In 1855 werd hij geneesheer van het Elisabeth-gasthuis te Haarlem en lector in de pathologie en therapie aan de Klinische School te Haarlem. En in 1857 werd hij benoemd tot stadsgeneesheer. Deze functies heeft hij bekleed tot 1863 . Hij is evenals Ali Cohen altijd een groot voorstander van de instelling van gemeentelijke gezondheidscommissies geweest. Toen in de jaren vijftig bleek, dat veel gemeenten deze commissies niet wensten, richtte hij in 1858 met Lubach het tijdschrift Schat der Gezondheid op met de bedoeling zijn tijdgenoten ervan te overtuigen dat een gemeentelijke gezondheidspolitiek noodzakelijk was. Het tijdschrift heeft tot 1865 bestaan. In 1865 benoemde Thorbecke hem tot inspecteur van Zuid-Holland en verhuisde hij naar Den Haag. In zijn nieuwe woonplaats heeft hij zich ingezet voor sanitaire hervormingen, onder meer door middel van de oprichting in 1866 van de Vereeniging tot onderzoek naar de middelen tot verbetering van de gezondheidstoestand in de gemeente 's Gravenhage. Hij was mede-oprichter van de landelijke Vereeniging ter bevordering van de koepokinenting. Daarnaast heeft hij tal van medischstatistische publikaties over de gezondheidstoestand in Amsterdam en Den Haag op zijn naam staan. Als medewerker van het Nederlandsch Tijdschrift voor Geneeskunde verzorgde hij in de jaren zeventig en tachtig de statistische overzichten van de sterfte in Nederland. Egeling legde in 1891 het ambt van inspecteur neer en overleed in 1892.

\section{Adriaan Abraham Fokker}

Fokker is in 1810 geboren in Middelburg geboren. Na een opleiding aan de Klinische School in zijn geboorteplaats vertrok hij naar Leiden om er een academische opleiding te volgen. In 1833 behaalde Fokker de graad van doctor 
medicinae. Na een praktijk van enkele jaren in Rotterdam vestigde hij zich in 1837 in Middelburg. Fokker richtte in 1848 met De Man en J.C. van den Broecke de Vereeniging van Genees- en Heelkundigen op. Deze vereniging veranderde in 1850 na een fusie met de NMG-afdeling Goes in een reguliere afdeling van de NMG. Fokker was sindsdien jarenlang voorzitter van deze afdeling. Hij was van 1854 tot 1866 tevens lector in de vakken therapie, geologie en scheikunde aan de Klinische School te Middelburg en tot 1865 secretaris van de Provinciale Commissie van geneeskundig Toevoorzicht van Zeeland. Met De Man schreef hij in 1856 een geneeskundige plaatsbeschrijving van Middelburg en in 1870 een natuurkundige plaatsbeschrijving van Zeeland. In de jaren 1863-1867 was hij lid van het hoofdbestuur van de NMG en van 1866 tot 1875 was hij inspecteur van de provincie Zeeland. Fokker overleed in 1878. Fokker was de vader van A.P. Fokker, hoogleraar in de hygiëne te Groningen vanaf 1877.

\section{Michaël Jacobus Godefroi}

Godefroi is in 1819 in Londen geboren. Na zijn promotie tot doctor medicinae in 1842 in Leiden vestigde hij zich in 's Hertogenbosch. Godefroi heeft daar meer dan vijftig jaar gepraktizeerd. Hij was een actief sanitair hervormer en heeft meerdere medisch-statistische studies op zijn naam staan, onder andere over de kindersterfte in zijn woonplaats. Godefroi was een NMG-lid van het eerste uur en is twee maal (in 1873 en in 1890) voorzitter van de Maatschappij geweest. In 1866 werd hij lid van de Geneeskundig Raad van Noord-Brabant en Limburg. Vanaf 1880 was hij secretaris van deze raad. In zijn latere leven bestreed hij de bacteriologische verklaring van volksziekten. Van een mogelijke verwantschap met het bekende, joodse kamerlid M.H. Godefroi wordt nergens melding gemaakt. Godefroi overleed in 1895.

\section{Theunis Haakma Tresling}

Haakma Tresling is in 1834 in Scharmier geboren. Hij behaalde zijn graad van doctor medicinae in 1860 in Groningen en vestigde zich in Winschoten, waar hij de functie van armendoctor kreeg. Haakma Tresling was een zeer actief lid van de plaatselijke NMG-afdeling. Hij was mede-oprichter en lid van de gemeentelijke gezondheidscommissie in Winschoten. In de jaren zeventig werd hij gekozen tot lid van de gemeenteraad. Haakma Tresling was de leidende kracht achter het onderzoek naar volksvoeding, dat de Maatschappij in de jaren zeventig had opgezet. Hij is verschillende malen lid geweest van het hoofdbestuur van de NMG, en in 1895 werd hij voorzitter van de Maatschappij. Hij overleed in 1907.

\section{Jan Pieter Heije}

Heije is in 1890 in Amsterdam geboren. Na zijn promotie tot doctor medicinae in 1832 in Leiden, vertrok hij naar Amsterdam om huip te bieden aan de slachtoffers van de cholera-epidemie. Heije is 25 jaar in Amsterdam als praktizerend geneeskundige gevestigd gebleven. In 1838 richtte hij het tijdschrift Wenken en Meeningen omtrent de Geneeskundige Staatsregeling op, waarin werd gedebatteerd over de gezondheidspolitiek van de regering. Dit tijdschrift ging in 1840 wegens moeilijkheden met de uitgever ter ziele. In 1841 werd hij benoemd 
tot secretaris van de staatscommissie tot herziening van de geneeskundige wetgeving. In hetzelfde jaar richtte hij het tijdschrift Archief voor Geneeskunde op, waarin hij de conclusies van de staatscommissie besprak, het lage peil van de geneeskundige opleiding bekritiseerde en de natuurwetenschappelijke richting in de geneeskunde verdedigde. Nadat in 1845 was gebleken dat een herziening van de medische wetgeving niet haalbaar was, staakte hij het jaar daarop de uitgave van het Archief en riep alle geneeskundigen om zich landelijk aaneen te sluiten. Heije was een groot voorstander van de eenheid van stand en wilde het liefst slechts één of twee onderwijsinstellingen waaraan alle geneeskundigen konden worden opgeleid.

Heije behoorde tot de oprichters van de NMG. In de jaren 1850-1862 was Heije secretaris van de Maatschappij. In deze functie uitte hij in soms harde bewoordingen kritiek op de besluiteloosheid van regering en parlement. In 1853 werd hij gekozen tot lid van de Amsterdamse gemeenteraad. Op zijn initiatief besloot de gemeenteraad de geneeskundige armenzorg te reorganiseren. Door een conservatieve lobby verloor hij bij de verkiezingen van 1857 zijn lidmaatschap van de gemeenteraad. In hetzelfde jaar legde hij zijn praktijk neer.

Heije was een bekend volkszanger en kinderdichter en een gewaardeerd medewerker van onder meer De Gids. Hij was van 1841 tot 1861 lid van het hoofdbestuur van de Maatschappij tot Nut van 't Algemeen en secretaris van het hoofdbestuur van de Maatschappij ter bevordering der Toonkunst. Door zijn liederenbundels kreeg hij landelijke bekendheid. Hij overleed in 1876.

\section{Johannes Frederikus van Hengel}

Van Hengel is in 1811 in Grootebroek geboren. Na zijn promotie tot doctor medicinae, doctor chirurgiae en doctor artis obstetriciae in 1838 in Leiden vestigde hij zich in Hilversum. In de jaren vijftig werd hij in toenemende mate geconfronteerd met de slechte levensomstandigheden van de fabrieksarbeiders in zijn woonplaats. Daardoor groeide zijn belangstelling voor medisch-statistisch onderzoek naar de gezondheidstoestand van de bevolking. Van Hengel behoort met Coronel tot de eerste geneeskundigen die over de levens- en werkomstandigheden van de arbeidende klasse publiceerde. Hij was tot 1866 lid van de Provinciale Commissie van geneeskundig Toevoorzicht van Noord-Holland, en van 1866 tot 1887 lid van de Geneeskundige Raad van deze provincie. In laatstgenoemde functie schreef hij een geneeskundige plaatsbeschrijving van het Gooiland. Dankzij zijn inspanningen werd in 1875 in Hilversum het sanatorium 'Trompenberg' gesticht. Van Hengel overleed in 1892.

\section{Abraham Hartog Israëls}

Israëls is in 1822 in Groningen geboren. Gedurende zijn medische studie in Groningen ontstond een hechte vriendschapsband met Ali Cohen. Ali Cohen heeft hem onderwezen in de geschiedenis van de geneeskunde en in de joodse letterkunde. $\mathrm{Na}$ het behalen van de graad van doctor medicinae in 1845 vestigde hij zich in Amsterdam. Israëls was nauw betrokken bij de oprichting van de NMG in 1849. Tevens richtte hij in 1850 met Penn en Zeeman het Nederlandsch Weekblad voor Geneeskundigen op. Als lid van de NMG-afdeling Amsterdam publiceerde hij enkele belangrijke medisch-statistische studies. Hij schreef echter vooral over medisch-politieke en medisch-historische onderwerpen. In 1859 heeft 
hij $\mathrm{H}$. Haesers bekende leerboek van de geschiedenis der geneeskunde in het Nederlands vertaald en van vele aanvullingen voorzien. Als lid van het hoofdbestuur van de NMG van 1861 tot 1871 heeft hij een belangrijke rol gespeeld in de discussies in de Maatschappij over de door Thorbecke opgestelde geneeskundige wetten In 1867 werd hij benoemd tot lector in de hygiëne en de geschiedenis der geneeskunde aan het Athenaeum Illustre in Amsterdam. Toen het Athenaeum in 1877 de status van universiteit kreeg, werd hem de titel van buitengewoon hoogleraar verleend: Israëls was tot aan zijn overlijden lid van de in 1868 ingestelde gemeentelijke gezondheidscommissie, en van 1866 tot 1883 lid van de Geneeskundige Raad van de provincie Noord-Holland. Als lid van de gezondheidscommisse publiceerde hij met Allebé een rapport over kelderwoningen. Daarnaast heeft hij bestuursfuncties in de joodse kerkgemeenschap vervuld en is geneesheer geweest van enkele joodse instellingen. Israëls die in 1883 overleed, was een broer van de kunstschilder Jozef Israëls.

\section{Douwe Lubach}

Lubach is in 1815 in Dokkum geboren. Na een opleiding aan de Klinische School te Haarlem vertrok hij naar Groningen, waar hij in 1842 de graảd van doctor medicinae behaalde. Hij vestigde zich in Haarlem. In 1857 richtte hij met Egeling het hygiënistische tijdschrift Schat der Gezondheid op. In de jaren 18601865 was Lubach lector in de anatomie en de fysiologie aan de Klinische School in Haarlem. In die jaren ontwikkelde hij zich tot een actief hygiënist. In 1865 benoemde Thorbecke hem tot adjunct-inspecteur van de provincie NoordHolland. Drie jaar later volgde hij Ali Cohen op als inspecteur van de provincies Drenthe en Overijssel. Lubach verliet deze betrekking in $1897 \mathrm{om}$ gezondheidsredenen. In zijn nieuwe woonplaats Kampen spande hij zich in voor tal van verbeteringen van de openbare hygiëne.

Lubach publiceerde in 1875 een plaatsbeschrijving van Overijssel. Als redacteur van het tijdschrift Album der Natuur schreef hij in de jaren zestig en zeventig artikelen over de nieuwste micro-biologische theorieën. Lubach overleed in 1902.

\section{Jan Cornelis de Man}

De Man is in 1818 in Middelburg geboren. In de jaren 1841-1842 promoveerde De Man in Leiden tot doctor medicinae, doctor artis obstetriciae en doctor chirurgiae. De Man heeft altijd grote bewondering gehad voor Pruys van der Hoeven en diens opvattingen over de geneeskunde. Na een wetenschappelijke reis naar Parijs en Wenen vestigde hij zich in 1845 te Middelburg. Van 1849 tot 1859 was hij stadsgeneesheer. In 1854 werd hij bovendien benoemd tot lector in de anatomie, fysiologie en verloskunde aan de Klinische School in Middelburg. De Man richtte met Fokker in 1848 de 'Vereeniging van Genees- en Heelkundigen' op. Na een fusie met de afdeling Goes sloot de vereniging zich in 1850 bij de NMG aan. De Man was met J.C. van den Broecke en Fokker de stuwende kracht achter de activiteiten van de NMG in Middelburg en ook in de rest van de provincie Zeeland. Hij heeft tal van medisch-statistische en hygiënische publikaties op zijn naam staan. In 1846 schreef hij over het uitbreken van een koortsepidemie, in 1850 deed hij met Van den Broecke een onderzoek naar cholera in Zeeland en in 1856 schreef hij met Fokker een geneeskundige 
plaatsbeschrijving van Middelburg. De Man was verder een belangrijk lid van de NMG-commissie voor geneeskundige statistiek. De eerste sterftekaart van Nederland (1866) is voor het grootste deel door hem opgesteld. Hij is van 1866 af lid geweest van de Geneeskundige Raad van Zeeland. De Man overleed in 1909.

\section{Gerardus Johannes Mulder}

Mulder is in 1802 in Utrecht. In 1825 promoveerde hij daar tot doctor medicinae en doctor pharmaceuticae. In datzelfde jaar vestigde hij zich in Amsterdam maar vertrok reeds in 1826 naar Rotterdam. Daar kon hij de praktijk overnemen van J. van der Hoeven die in Leiden tot buitengewoon hoogleraar in de natuurlijke historie en vergelijkende anatomie was benoemd. Mulder nam bovendien het lectoraat aan het Bataafsch Genootschap voor proefondervindelijke wijsbegeerte over van Van der Hoeven. Bij de oprichting van de Klinische School te Rotterdam in 1828 werd hij benoemd tot lector in de botanie, de scheikunde, de farmacie en de mathematica. Na zijn medewerking aan de bestrijding van de cholera in de jaren 1831-1833 was Mulder volledig uitgeput en hij legde in 1835 zijn praktijk neer. Vanaf dat moment wijdde hij zich geheel aan het wetenschappelijk onderzoek. In 1840 werd hij benoemd tot hoogleraar in de chemie aan de Hogeschool van Utrecht. Mulder was gaandeweg een vooraanstaand man op het gebied van de scheikunde (fysiologische chemie) en de voedingsleer geworden. $\mathrm{Hij}$ correspondeerde met internationaal bekende scheikundigen zoals Berzelius in Zweden, en voerde polemieken met de Duitse chemicus J. Liebig. Hij schreef scheikundige handboeken. Onder zijn leerlingen bevond zich F.C. Donders, de latere hoogleraar in de fysiologie te Utrecht.

In de jaren veertig leverde Mulder felle kritiek op het peil van de medische opleiding en de gebrekkige handhaving van de geneeskundige wetgeving. Mulder raakte bij de landspolitiek betrokken na zijn benoeming in 1848 tot lid van de staatscommissie tot herziening van de geneeskundige staatsregeling. In hetzelfde jaar trachtte hij met Heije, Evers, Ramaer, Voorhelm Schneevoogt en Ali Cohen de geneeskundigen landelijk te organiseren. Zijn visie op de toekomstige gezondheidspolitiek en op de grondwetsherziening van 1848 vervreemdde hem echter spoedig van zijn collega's. In de jaren vijftig en zestig toonde hij zich een fel tegenstander van Thorbecke. Als voorzitter van de vereniging 'Koning en Vaderland', en als vertrouweling van de koning heeft hij na de val van het kabinet-Thorbecke geprobeerd de oude staatkundige verhoudingen te herstellen. Mulder verbond zijn politieke opvattingen met radicale voorstellen ter bevordering van de openbare hygiëne. Herhaaldelijk veroordeelde hij de gezondheidspolitiek van de regering als halfslachtig en tegenstrijdig.

In 1868 legde hij het ambt van hoogleraar neer. Na dat jaar leefde Mulder een teruggetrokken en eenzaam bestaan. Veel van zijn vroegere vrienden hadden hem de rug toegekeerd. Mulder overleed in 1880.

\section{Gilles van Overbeek de Meijer}

Van Overbeek de Meijer is in 1831 in Rotterdam geboren. Na een vierjarige studie aan 's Rijkskweekschool voor Militaire Geneeskundigen te Utrecht, werd hij in 1851 benoemd tot officier van gezondheid derde klasse bij de marine. In 
die betrekking heeft hij geruime tijd doorgebracht in het toenmalige NederlandsIndië. In 1856 publiceerde hij een geneeskundige topografie van de RiouwLinggas-Archipel. Drie jaar later keerde Van Overbeek de Meijer terug naar Nederland waar hij als officier van gezondheid tweede klasse werd toegevoegd aan de inspecteur van de geneeskundige dienst van de marine. In 1861 schreef hij een handboek van de scheepsgezondheidsleer, en van 1863 tot 1866 was hij redacteur van het Tijdschrift voor de Zeemacht. In 1865 promoveerde hij te Leiden tot doctor in de geneeskunde. Het jaar daarop benoemde Thorbecke hem tot adjunct-inspecteur van de provincies Gelderland en Utrecht. Tien jaar later werd hij inspecteur van beide provincies. Van Overbeek de Meijer werd in 1877 benoemd tot hoogleraar in de gezondheidsleer te Utrecht. Dit ambt heeft hij tot 1898 bekleed.

In zijn functie van adjunct-inspecteur heeft Van Overbeek de Meijer veel gedaan voor de aanleg van een riolering en een drinkwaterleiding in Utrecht. Over het rioleringsstelsel publiceerde hij met Ali Cohen enkele rapporten. Hij pleitte voor een verplichte koepokinenting en toonde zich tevens een groot voorstander van medische controle op de prostitutie. Als hoogleraar heeft hij geijverd voor de oprichting van een hygiënisch laboratorium. Hierin slaagde hij echter pas in 1893. Van Overbeek de Meijer overleed in 1918.

\section{Jacobus Penn}

Penn is in 1821 in Dordrecht geboren. Hij behaalde zijn graad van doctor medicinae in 1843 in Leiden. Penn raakte spoedig betrokken bij het medische verenigingsleven in Amsterdam. Met C.B. Tilanus, Heije, Israëls, Voorhelm Schneevoogt en Zeeman reorganiseerde hij de Amsterdamse vereniging van geneeskundigen. In de jaren veertig was hij betrokken bij de oprichting van het Algemeen Ziekenfonds voor Amsterdam. Penn ontwikkelde zich in de jaren vijftig tot één van de belangrijkste woordvoerders van de hygiënisten. Van meet af aan keerde hij zich tegen een aantal opvattingen van de staatscommissie voor herziening van de geneeskundige staatsregeling en verdedigde hij het standpunt dat een nieuwe medische wetgeving op liberale beginselen gegrondvest moest zijin.

Penn heeft vele bestuurlijke functies bekleed. Hij was secretaris van de Provinciale Commissie van geneeskundig Toevoorzicht van Noord-Holland. Van 1850 tot 1854 was hij lid van het hoofdbestuur van de NMG. In 1852 werd hij tot voorzitter van de Maatschappij gekozen. In deze functie heeft hij in het begin van 1853 op verzoek van Thorbecke met Ali Cohen de herziening van de geneeskundige wetgeving voorbereid. De val van het kabinet-Thorbecke maakte echter een einde aan dit adviseurschap. Hij was een vooraanstaand lid van de NMG-commissie voor de geneeskundige politie en vanaf 1853 bibliothecaris van de Maatschappij. In de jaren 1861-1864 was hij opnieuw lid van het hoofdbestuur van de Maatschappij, en speelde als adviseur van Thorbecke (opnieuw met Ali Cohen) een hoofdrol bij de totstandkoming van de nieuwe geneeskundige wetten. Bovendien was Penn curator van het Athenaeum Illustre (1871-1875), lid van de commissie van toezicht op 's rijkskweekschool voor vroedvrouwen te Amsterdam (vanaf 1866) en lid van de gemeenteraad. Penn behoorde in 1850 niet alleen tot de oprichters van het Nederlandsch Weekblad voor Geneeskundigen, hij was ook de drijvende kracht achter de fusie van enkele medische tijdschriften tot het Nederlandsch Tijdschrift voor Geneeskunde in 1857. Van 1857 
tot 1866 is hij 'gérant' van dit tijdschrift geweest. Thorbecke benoemde hem in 1865 tot inspecteur van de provincie Noord-Holland. Hij heeft deze betrekking tot 1884 vervuld. Penn overleed in 1890.

\section{Casper Pieter Pous Koolhaas}

Pous Koolhaas is in 1831 in Waardenburg geboren. Hij promoveerde in Leiden in de jaren 1856-1858 tot doctor medicinae, doctor artis obstetriciae en doctor chirurgiae. Na een tweejarig verblijf in Middelburg vestigde hij zich in Den Haag. Daar was hij een zeer actief sanitair hervormer. Bovendien spande hij zich in voor verbetering van de schoolhygiëne. Pous Koolhaas leverde tal van bijdragen aan het tijdschrift Schat der Gezondheid van Egeling en Lubach. Toen dit tijdschrift in 1865 werd opgeheven, richtte hij het jaar daarna het Tijdschrift voor Gezondheidsleer op. Vrijwel alle hygiënisten werkten aan dit tijdschrift mee. Het heeft tot 1872 bestaan. Pous Koolhaas heeft in het door Ali Cohen in 1872 uitgegeven Handboek der Openbare Gezondheidsregeling een hoofdstuk over epidemische ziekten en een hoofdstuk over schoolhygiëne geschreven. Van 1867 tot 1890 was Pous Koolhaas secretaris van de Geneeskundige Raad van ZuidHolland. Als secretaris van de Vereeniging ter verbetering van de gezondheidstoestand heeft hij gestreden voor de aanleg van riolering en een drinkwaterleiding in Den Haag. Pous Koolhaas overleed in 1893.

\section{Cornelis Pruys van der Hoeven}

Pruys van der Hoeven is in 1792 in Rotterdam geboren. Na zijn promotie tot doctor medicinae in 1816 in Leiden vestigde hij zich in Rotterdam. Hij werd in 1824 benoemd tot buitengewoon hoogleraar in de pathologie, de geschiedenis der geneeskunde en de antropologie te Leiden. Na de politieke gebeurtenissen van 1848 achtte hij de tijd gekomen om zijn colleges niet langer in het Latijn maar in het Nederlands te geven.

De opvattingen van Pruys van der Hoeven over de geneeskunst zijn voor een hele generatie geneeskundigen richtinggevend geweest. Hij was een tegenstander van wetenschappelijke systemen en legde de nadruk op de klinische ervaring. Herhaaldelijk keerde hij zich tegen het volgens hem overdreven vertrouwen dat de geneeskundigen in geneesmiddelen stelden. De naar zijn mening overmatige benadrukking van het fysieke in de geneeskunde was voor Pruys reden om een zogenaamde antropologische richting in de geneeskunde te ontwikkelen, waarbij de mens niet alleen als lichamelijk wezen, maar ook als maatschappelijk, zedelijk en godsdienstig wezen centraal staat.

Hoewel Pruys van der Hoeven niet betrokken is geweest bij de dagelijkse strijd voor sanitaire hervormingen en ook niet bij de statistische onderzoekingen van de hygiënisten, kan hij toch gelden als één van de woordvoerders van de beweging. In de jaren 1850-1854 publiceerde hij een boek in vier delen, Pathologische, Historische, Klinische en Christelijke Anthropologisch Onderzoek, waarin hij een theoretische verantwoording gaf van het hygiënisme in de geneeskunde. Naar zijn mening was de preventie van ziekten door de bevordering van de openbare hygiëne de belangrijkste opdracht van de geneeskunde. In 1854 trad Pruys van der Hoeven tot de redactie van het door Verwey opgerichte Tijdschrift voor algemeene Gezondheids-regeling en Geneeskundige Politie toe. Pruys van der 
Hoeven was in de jaren dertig en veertig de leermeester van tal van hygiënisten. In 1862 legde hij het ambt van hoogleraar neer. Hij overleed in 1871.

\section{Lourens Scheltema Beduin}

Scheltema Beduin is in 1833 in Amsterdam geboren. Na zijn studie aan het Athenaeum Illustre promoveerde hij in 1858 te Leiden tot doctor medicinae. Hij vestigde zich in Amsterdam, waar hij in 1860 tot stadsgeneesheer werd benoemd. Hij toonde grote belangstelling voor de geneeskundige statistiek. Als lid van de NMG-commissie voor geneeskundige plaatsbeschrijving ontstonden tal van medisch-statistische publikaties onder zijn verantwoordelijkheid. Hij trad in de voetsporen van Egeling door aan het eind van de jaren zestig een studie over de sterfte in Amsterdam te publiceren. Tevens schreef hij over de gezondheidstoestand in Middelburg en over de gezondheid van dienstplichtigen. Van 1881 tot 1892 verzorgde hij voor het Nederlandsch Tijdschrift voor Geneeskunde de wekelijkse overzichten van de sterfte te Amsterdam. In 1871 werd hij benoemd tot lid van de Geneeskundige Raad van Noord-Holland. Van 1874 tot 1884 was hij secretaris van de geneeskundige armendienst in de hoofdstad. Scheltema Beduin overleed in 1892 .

\section{Johannes Willem Schick}

Over Schick is weinig bekend. Schick is waarschijnlijk in 1818 geboren. Hij vestigde zich in 1845 als doctor medicinae in Den Haag. Hij was geneesheer van de 'Badinrigting Scheveningen'. Schick heeft in het begin van de jaren vijftig grote invloed uitgeoefend op het onderzoek naar volksziekten. In zijn publikaties over de gezondheidstoestand in Den Haag en Zuid-Holland liet hij zien dat met een combinatie van topografisch en statistisch onderzoek de gezondheid van de bevolking in kaart gebracht kon worden, en dat tevens de aetiologie van volksziekten kon worden aangegeven. Schick overleed in 1853 op jonge leeftijd aan de gevolgen van tyfus.

\section{Isaac Teixeira de Mattos}

Teixeira de Mattos is in 1821 in Amsterdam geboren. Na een studie aan het Athenaeum Illustre in Amsterdam promoveerde hij in Leiden in 1846 tot doctor medicinae. Hij vestigde zich in Amsterdam, waar hij als geneesheer ging werken bij de portugees-joodse gemeente. Hij moest zijn praktijk echter opgeven toen hij slachtoffer werd van tyfeuze koorts, en hij als gevolg van gangreen een van zijn benen moest missen. In 1856 werd hij benoemd tot eerste secretaris van de commissie van toezicht op de (gereorganiseerde) stedelijke geneeskundige dienst in Amsterdam. In deze functie bracht Teixeira de Mattos ieder jaar een verslag uit van de gezondheidstoestand van de armen in de hoofdstad. Hierin voerde hij een nieuwe classificatie van doodsoorzaken in. Teixeira de Mattos verliet deze betrekking in 1865. Na drie jaar werkzaam te zijn geweest als secretaris van de Geneeskundige Raad van Noord-Holland, werd hij in 1869 benoemd tot adjunctinspecteur van de provincie Noord-Holland. In 1884 volgde hij Penn op als inspecteur van provincie. Teixeira de Mattos was van 1867 tot 1874 lid van de gemeentelijke gezondheidscommissie van Amsterdam, van 1873 tot 1885 lid van 
de gemeenteraad en van 1877 tot 1985 lid van de Provinciale Staten van NoordHolland.

Behalve het opstellen van de verslagen van de geneeskundige armendienst, heeft Teixeira de Mattos veel bijgedragen aan de totstandkoming van de eerste en de tweede sterftekaart van Nederland (1866 en 1874). Ten slotte moet hij worden genoemd als mede-oprichter van het 'Witte Kruis'. Teixeira de Mattos overleed in 1904.

\section{Johannes Zeeman}

Zeeman is in 1824 in Numansdorp geboren. Hij was in Leiden een leerling van de hoogleraar Pruys van der Hoeven. Na zijn promotie tot doctor medicinae in 1847 ging hij als assistent werken in het Amsterdamse Buitengasthuis, waar Voorhelm Schneevoogt eerste geneesheer was. In 1849 startte hij een praktijk in Amsterdam die hij tot enkele jaren voor zijn dood in stand hield. In 1852 werd hij stadsgeneesheer, belast met de zorg voor huidziekten en syfilis.

Zeeman heeft op medisch-statistisch gebied een zeer belangrijke rol gespeeld. Van 1850 af was hij één van de stuwende krachten in de NMG-commissie voor geneeskundige statistiek. Als lid van deze commissie heeft hij de statistiek tot de belangrijkste methode van onderzoek naar de volksziekten gemaakt. Met onder anderen Ali Cohen heeft hij de 'gezondheidsthermometer' van William Farr ingevoerd. Bovendien heeft hij in de jaren vijftig een groot onderzoek naar de gezondheidstoestand van dienstplichtingen gedaan en belangrijke bijdragen aan de eerste en tweede sterftekaart van Nederland geleverd. Hij was lange tijd aanhanger van de bodemtheorie van Von Pettenkofer. Op verzoek van Thorbecke verrichtte hij in de jaren 1863-1869 onderzoek naar de gevolgen van kinderarbeid op de gezondheid. Op grond van zijn onderzoek concludeerde Zeeman dat een verbod op de kinderarbeid niet veel zin had.

Zeeman heeft talrijke bestuurlijke functies vervuld. Hij was lid van het bestuur van het Algemeen Ziekenfonds voor Amsterdam. Van 1852 tot 1857 was hij redacteur van het Nederlandsch Weekblad voor Geneeskundigen. In 1857 trad hij tot het comité van redactie van het Nederlandsch Tijdschrift voor Geneeskunde toe. In 1861 volgde hij Heije op als algemeen secretaris van de NMG. Die jaren waren voor Zeeman niet gemakkelijk. De Maatschappij werd verscheurd door interne twisten over de nieuwe medische wetgeving. In 1867 verwisselde Zeeman zijn betrekking van NMG-secretaris voor die van 'gérant' van het Nederlandsch Tijdschrifi voor Geneeskunde. Hij heeft deze functie tot 1884 vervuld. Ten slotte was Zeeman lid van de Geneeskundige Raad van Noord-Holland, lid van de Koninklijke Nederlandse Akademie van Wetenschappen (vanaf 1872) en curator van de Universiteit van Amsterdam vanaf 1883. Zeeman overleed in 1905. 


\section{Geneeskundigen die cen belangrijke bijdrage hebben geleverd aan de verbetering van de openbare hygiëne of aan het onderzoek naar de volksgezondheid}

G. Acker Stratingh (1804-1876), M.D. in Groningen vanaf 1828. Acker Stratingh was lid van Plaatselijke Commissie van geneeskundig Toevoorzicht. Hij werkte nauw samen met $D$. de Vries Reilingh en Ali Cohen bij de bestrijding van cholera en tyfus. Op verzoek van de NMG stelde hij in 1854 met Ali Cohen een plan op voor de geneeskundige plaatsbeschrijving van Nederland. Hij was van 1866 tot 1876 lid de Geneeskundige Raad voor Groningen en Friesland. Acker Stratingh was een groot kenner van de geschiedenis van de provincie Groningen.

A.H. van Andel (1836-1905), M.O.C.D. vanaf 1862. Van Andel was in de jaren 1863-1884 eerste geneesheer van het krankzinnigengesticht in Zutphen. Vanaf 1884 was hij geneesheer-directeur van het krankzinnigengesticht in Medemblik. In 1889 volgde hij Van Cappelle op als inspecteur van het staatstoezicht op de krankzinnigen en de krankzinnigengestichten. Als lid van de Geneeskundige Raad voor Utrecht en Gelderland (1868-1884) was hij betrokken bij de 'enquêtes van fabrieken', die na 1870 door leden van het Geneeskundig Staatstoezicht werden uitgevoerd.

G.C. van Balen Blanken (1827-1903), heel- en vroedmeester in Sijbecarspel (West-Friesland). Vanaf 1869 enkele jaren lid van het hoofdbestuur van de NMG. Van 1866 tot 1902 lid van de Geneeskundige Raad van Noord-Holland. Hij heeft zich in deze functie actief ingezet voor sanitaire verbeteringen en voor de totstandkoming van de geneeskundige plaatsbeschrijving van Nederland. Hij behoorde tot de oprichters van het 'Witte Kruis'.

J.P. Berdenis van Berlekom (1832-1903), M.O.C.D. en stadsgeneesheer in Middelburg vanaf 1859. Berdenis van Berlekom was van 1866 tot 1891 secretaris van de Geneeskundige Raad van Zeeland. Hij schreef met Fokker en De Man de natuurkundige plaatsbeschrijving van Zeeland (1870).

T.H. Blom Coster (1817-1904), M.O.D. vanaf 1843. Stadsgeneesheer in Den Haag tot 1857. In 1848 benoemd tot secretaris van de staatscommissie tot herziening van de geneeskundige staatsregeling. Oprichter van het 's Gravenhaagsche Geneeskundig Gezelschap en tot 1857 secretaris van de NMG-afdeling Den Haag. Lid van de NMG-commissie voor geneeskundige statistiek vanaf 1849. Evenals Penn en Ali Cohen adviseur van minister Thorbecke in 1862-1865. Lid van de Geneeskundige Raad van Zuid-Holland na 1866. Blom Coster was bevriend met Ali Cohen. 
E.A.G.van den Bogaert (1828-1880), M.C.D. in 's Hertogenbosch. Secretaris van de Geneeskundige Raad van Noord-Brabant en Limburg van 1866 tot 1880. In zijn woonplaats trad hij actief op als hygiënist. Hij heeft een begin gemaakt met een geneeskundige plaatsbeschrijving van Noord-Brabant, maar de topografie is nooit gepubliceerd.

A. van der Boon Cz. (1812-1886), M.O.C.D in Zaandam vanaf 1834. Lid van de Provinciale Commissie van geneeskundig Toevoorzicht van Noord-Holland. Verrichtte medisch-statistisch onderzoek in zijn woonplaats. Lid van de Geneeskundige Raad van Noord-Holland van 1866 tot 1886.

K. Broes van Dort (1816-1867), heelmeester, heelmeester ten plattelande en vroedmeester in Goes vanaf 1837. Broes van Dort verrichtte enkele malen onderzoek naar volksziekten en arbeidsomstandigheden en was een actief sanitair hervormer. Lid van de Geneeskundige Raad van Zeeland, 1866-1867.

E.C. Büchner (1812-1882), M.D. in Amsterdam vanaf 1835. Büchner werkte nauw samen met Sarphati bij de verbetering van de volkshuisvesting. Hij is lid van de gemeenteraad geweest en werd in 1873 tot lid van de Eerste Kamer gekozen. In de jaren vijftig publiceerde hij enkele studies over de sterfte in Amsterdam.

W.F. Büchner (1780-1855), M.C.D. te Gouda sinds 1801. Werkzaam als stadsgeneesheer en voorzitter van de Plaatselijke Commissie van geneeskundig Toevoorzicht in de jaren dertig en veertig. Büchner gebruikte in 1842 bij de plaatsbeschrijving van zijn woonplaats als eerste in Nederland de medischstatistische onderzoeksmethoden van de Engelse en Franse hygiënisten. Hij was een actief sanitair hervormer.

D. Cohen (1815-1896), M.C.O.D. in Assen vanaf 1839. Cohen was in de jaren vijftig lid van de Provinciale Commissie van geneeskundig Toevoorzicht van Drenthe. Hij heeft meegewerkt aan de onderzoekingen van de NMG-commissie voor geneeskundige statistiek (dienstplichtigen, sterftekaart) en heeft ook zelf medisch-statistisch onderzoek verricht. Cohen was lid van de Geneeskundige Raad van Drenthe en Overijssel in de jaren 1866-1890.

M.H. Damme (1819-1889), M.O.D. in Middelburg vanaf 1843. Damme was onder meer werkzaam bij de geneeskundige armendienst in Middelburg. Hij behoorde tot de oprichters van de NMG-afdeling Middelburg. Als lid van de Geneeskundige Raad van Zeeland heeft hij in de jaren 1866-1870 bijgedragen aan de natuurkundige plaatsbeschrijving van de provincie Zeeland.

J.H. Damman de Witt (1820-1900), M.O.D. in Gieten. Damman de Witt was in de jaren 1866-1890 een zeer actief lid van de Geneeskundige Raad van Drenthe en Overijssel. Hij heeft onder meer bijgedragen aan de geneeskundige plaatsbeschrijving van de provincie Overijssel.

P. van Delden Szn. (1819-1914), M.O.D. in Deventer vanaf 1843. Heeft als lid van de Geneeskundige Raad bijgedragen aan de geneeskundige plaatsbeschrijving van de provincie Overijssel. Verder heeft hij meegewerkt aan de 'enquêtes 
van fabrieken' die door het Geneeskundig Staatstoezicht in de jaren zeventig zijn opgezet. In 1873 werd hij voorzitter van de heropgerichte NMG-afdeling Deventer.

J.A. Delhez (1816 - 1885), M.D. in Dordrecht vanaf 1842. Delhez trad in zijn woonplaats in de jaren vijftig en zestig op als een gedreven sanitair hervormer. Hij werkte nauw samen met zijn collega M.F. Onnen. Delhez was lid van de gemeenteraad en tevens lid van de Geneeskundige Raad van Zuid-Holland van 1877 tot 1885 .

N.B. Donkersloot (1813-1890), M.D. en vroedmeester in Amerongen vanaf 1836. Donkersloot richtte in 1847 de Geneeskundige Courant op. Dit medisch tijdschrift besteedde ruim aandacht aan de geneeskundige wetgeving en de openbare gezondheidsregeling. Donkersloot keerde zich in 1857 tegen de fusie van enkele medische tijdschriften tot het Nederlandsch Tijdschrift voor Geneeskunde. Hij was tevens een tegenstander van Thorbeckes gezondheidspolitiek, die hij als te liberaal beschouwde. Donkersloot staat vooral bekend als grondlegger van de Nederlandse Vereniging voor Psychiatrie.

J.P. Dozij (1838-1906). Na zijn promotie in 1861 tot medicinae doctor is Dozij in Nederlands-Indië gaan werken. Aan het begin van de jaren zeventig keerde hij terug naar Nederland. In 1874 werd hij tot stadsgeneesheer in Geertruidenberg benoemd. Dozij was adjunct-inspecteur voor Noord-Brabant en Limburg van 1877-1879. In 1879 volgde hij Fokker op als inspecteur van de provincie Zeeland. Deze functie heeft hij tot 1902 uitgeoefend. Dozij heeft zich vooral ingespannen voor de bevordering van de koepokinenting.

J.C.G. Evers (1818-1886), M.O.C.D. in Den Haag vanaf 1841. Evers behoorde tot de oprichters van de NMG. Hij vormde samen met G.E. Voorhelm Schneevoogt en J.N. Ramaer in 1849 het eerste hoofdbestuur van de Maatschappij. Evers verrichtte medisch-statistisch onderzoek in zijn woonplaats tijdens de cholera-epidemie van 1848-1849. Hij werd in 1850 tot voorzitter van de NMGafdeling Den Haag benoemd. In 1862 was hij voorzitter van de Maatschappij. In 1864 werd hij benoemd tot hoogleraar in de pathologie in Leiden. Nadat hij zijn hoogleraarschap in 1872 had neergelegd, keerde hij terug naar Den Haag. In de jaren 1874-1884 was hij lid van de gemeenteraad van Den Haag. Hij was tevens lid van de Geneeskundige Raad van Zuid-Holland van 1866 tot 1885 .

H. Fabius (1827-1893), M.D. in Amsterdam vanaf 1853. Na studie aan het Athenaeum Illustre werkte Fabius enige tijd als assistent van Voorhelm Schneevoogt in het Buitengasthuis. Hij heeft zich onder meer ingezet voor het statistisch onderzoek naar de sterfte en de volksziekten in Amsterdam. Fabius werd in 1867 lid van de staatscommissie die de uitgave van een nieuwe nationale Farmacopee moest voorbereiden. Hij was nauw betrokken bij de bestrijding van drankmisbruik.

J.M. Fuchs (1819-1900), M.D. in Amsterdam vanaf 1845. Fuchs was onder meer werkzaam bij het Algemeen Ziekenfonds voor Amsterdam. Hij werkte samen met De Bordes en Teixeira de Mattos op het gebied van de medische statistiek. 
Fuchs is voorzitter geweest van de Amsterdamse vereniging ter bevordering van de koepokinenting. Vanaf 1892 bekleedde hij het ambt van secretaris van de Geneeskundige Dienst van Amsterdam.

G.Ph.F.Groshans (1814-1874), M.D. in Rotterdam vanaf 1837. In 1840 benoemd tot lector in de pathologie en therapie aan de Klinische School te Rotterdam. Lid van de plaatselijke gezondheidscommissie (de eerste in Nederland) en directeur van het Algemeen Ziekenfonds Rotterdam (opgericht in 1855). Van 1866 tot 1874 lid van de Geneeskundige Raad van Zuid-Holland.

C.D.L.Hanegraaf (1819-1880), M.C.O.D. in Rotterdam vanaf 1845. In de jaren vijftig of zestig heeft hij zich in Arnhem gevestigd. Als lid van de Geneeskundige Raad van Gelderland en Utrecht van 1870 tot 1880 heeft Hanegraaf medischstatistisch onderzoek in Arnhem verricht en bijgedragen aan de geneeskundige plaatsbeschrijving van Nederland. In de jaren zeventig zette hij in samenwerking met J.J. Homoet een onderzoek naar de woonomstandigheden in Arnhem en omgeving op.

J.G.M.Hanlo (1831-1897), M.C.O.D. in Amsterdam vanaf 1857. Als lid van de redactie van het Nederlandsch Tijdschrift voor Geneeskunde heeft Hanlo in de jaren 1863-1881 de sterftestatistiek van Amsterdam en in de jaren 1866-1887 de sterftestatistiek per provincie bijgehouden. Zijn overzichten betekenden het begin van een fystematische weergave van sterftecijfers voor het geneeskundig publiek. In de jaren zeventig nam Hanlo de binnenlandse berichtgeving van het tijdschrift over van Ali Cohen.

J. Hanou Jzn. (1811-1881), heel- en vroedmeester in Barsingerhorn (NoordHolland) vanaf 1850. Als lid van de Geneeskundige Raad van Noord-Holland tussen 1866 en 1881 heeft Hanou zich onder meer ingezet voor de geneeskundige plaatsbeschrijving van de provincie (o.a. Schagen en Winkel).

H.G. Hesselink (1836-1901), M.D. in Almelo vanaf 1861. Hesselink heeft in de jaren zestig op verzoek van de NMG getracht een plan op te stellen voor een onderzoek naar arbeidsomstandigheden. Zijn poging liep echter op niets uit. Als lid van de Geneeskundige Raad van Drenthe en Overijssel van 1866 tot 1878 verrichtte hij regelmatig onderzoek naar de werkomstandigheden in fabrieken in het kader van een landelijk onderzoek van het Geneeskundig Staatstoezicht. In 1879 werd hij benoemd tot directeur van het stadsziekenhuis te Rotterdam.

P. Hofstede Crull (1797-1870), M.O.D. in Meppel vanaf 1822. Hofstede Crull, eén van de eerste joodse doctores in Drenthe en een groot voorstander van de joodse emancipatie, is waarschijnlijk de eerste leermeester van Ali Cohen op geneeskundig gebied geweest. Hij was voorzitter van de Plaatselijke Commissie van geneeskundig Toevoorzicht in Meppel (de enige in Drenthe) in de jaren veertig en vijftig. Lid van het hoofdbestuur van de NMG in de jaren 1858-1861. Als lid van de Geneeskundige Raad van Overijssel en Drenthe was hij betrokken bij de geneeskundige plaatsbeschrijving van Drenthe en bij een breed opgezet onderzoek naar bewaarscholen. Hofstede Crull was tevens een actief sanitair hervormer in Meppel. 
J.J. Homoet (1818-1908), M.C.O.D. in Arnhem vanaf 1844. Homoet behoorde tot de mede-oprichters van de NMG. Hij was lid van de Geneeskundige Raad van Gelderland en Utrecht in de jaren 1866-1890. Homoet heeft veel gedaan voor de oprichting van sanatoria.

W.H. Idzerda (1816-1881), M.D. in Akkrum vanaf 1833. Lid van de Tweede Kamer voor het district Leeuwarden in de jaren 1858-1865 en een trouw aanhanger van Thorbecke. Idzerda was een groot voorstander van een liberale gezondheidswetgeving. Mede door zijn toedoen werden de door Penn en Ali Cohen opgestelde en door Thorbecke verdedigde geneeskundige wetten in 1865 door de Tweede Kamer aangenomen. Hij was inspecteur van Groningen en Friesland van 1865 tot 1869 . In 1869 is hij opnieuw tot lid van de Tweede Kamer gekozen. Vanaf dat jaar tot 1881 was hij tevens lid van de Geneeskundige Raad van Groningen en Friesland.

A.F.J.Ingenhousz (1812-1886), M.D. in Breda vanaf 1837. Ingenhousz is lid van de Provinciale Commissie van geneeskundig Toevoorzicht van Noord-Brabant en voorzitter van de Plaatselijke Commissie van geneeskundig Toevoorzicht in Breda geweest. Van 1865 tot 1886 was hij inspecteur van de provincies NoordBrabant en Limburg.

J.A. Ketwich Verschuur (1822 - 1882), M.D. in Baarn van 1848 tot 1856, daarna in Defventer. Ketwich Verschuur werkte bij de geneeskundige armendienst van Deventer tot 1870 . Hij was lid van de plaatselijke gezondheidscommissie en secretaris van de Geneeskundige Raad voor Overijssel en Drenthe van 1867 tot 1882. In deze functie was hij onder meer betrokken bij een groot onderzoek naar bewaarscholen.

W.F.P.Kiehl (1798-1876), M.D. in Den Haag vanaf 1822. Later heeft hij zich in Arnhem gevestigd. Kiehl was eerst lid, later voorzitter van de Provinciale Commissie van geneeskundig Toevoorzicht van Zuid-Holland (tot 1865). Hij heeft enkele publicaties over cholera en medische wetgeving op zijn naam staan. Van 1865 tot 1876 was hij inspecteur van de provincies Gelderland en Utrecht.

M.C. Klep (1818-1881), vroedmeester in Oosterhout (Noord-Brabant) vanaf 1844 en M.D. vanaf 1852 in dezelfde plaats. Klep was een zeer actief lid van de gezondheidscommissie in zijn woonplaats en tevens lid van de Geneeskundige Raad van Noord-Brabant en Limburg van 1866 tot 1870.

H.J. Lulofs (1806-1875), M.D. in Hardinxveld vanaf 1836. Als lid van de Geneeskundige Raad van Zuid-Holland vanaf 1866 verrichte hij onder meer onderzoekingen naar de hygiënische omstandigheden in scholen en 'slaapsteden' (logementen voor daklozen).

A. Luyten (1815-1899), M.C.O.D. in Gouda vanaf de jaren veertig. Na zijn vestiging werd hij tot stadsgeneesheer benoemd. Luyten pleitte in de jaren veertig en vijftig krachtig voor maatregelen in zijn woonplaats ter preventie van cholera en tyfus. Hij spande zich tevens in voor hervormingen op het gebied van de volkhuisvesting. Luyten was lid van de gemeenteraad en wethouder. 
A. Maas (1811-1869), M.D. in Schiedam vanaf 1834. Maas was lid van de Plaatselijke Commissie van geneeskundig Toevoorzicht sinds de jaren veertig. Hij was een zeer actieve hygiënist. Hij was lid van de plaatselijke gezondheidscommissie (opgericht in 1854) en lid van de gemeenteraad van Schiedam. Hij maakte tevens deel uit van het hoofdbestuur van de NMG in de jaren 18511854.

J.J.F.H.T.Merkus Doornik (1825-1906), M.C.O.D. in Amsterdam vanaf 1849. Hij was werkzaam bij de geneeskundige armendienst van Amsterdam van 1849 tot 1853. Merkus Doornik was tevens secretaris van de Plaatselijke Commissie van geneeskundig Toevoorzicht in de jaren 1860-1865. Hij heeft zich verdienstelijk gemaakt op het gebied van het onderzoek naar volksziekten.

A. Meursinge Hzn. (1819-1893), M.D. in Leeuwarden vanaf 1844. Hij behoorde tot de oprichters van de Vereeniging van Friesche Geneeskundigen die in 1849 in de NMG opging. Hij leverde belangrijke bijdragen voor het onderzoek van de NMG-commissie voor geneeskundige statistiek (dienstplichtigen, sterftekaart van Nederland). In zijn woonplaats trad hij op als een actief sanitair hervormer. Hij was tevens lid van de gemeenteraad. Meursinge was verder lid van het hoofdbestuur van de NMG in de jaren 1862-1865 en voorzitter van de Maatschappij in 1864. In de jaren 1866-1890 vervulde hij het ambt van adjunct-inspecteur van de provincies Groningen en Friesland.

W.J.F.Nuijens (1823-1894), M.O.D. in Westwoud (Noord-Holland) vanaf 1848. Als lid van de Geneeskundige Raad van Noord-Holland in de jaren 1866-1890 stelde hij een geneeskundige plaatsbeschrijving van West-Friesland op. Nuijens genoot overigens vooral bekendheid om zijn geschiedschrijving van de Nederlanden, in het bijzonder van het katholieke volksdeel.

M.F. Onnen (1809-1877), M.D. in Dordrecht vanaf 1840. Onnen was lid van de Provinciale Commissie van geneeskundig Toevoorzicht van Zuid-Holland en directeur van het stadsziekenhuis. Evenals zijn collega J.A. Delhez was hij lid van de gemeenteraad. Onnen heeft zich als lid van de plaatselijke gezondheidscommissie ingezet voor een actief gezondheidsbeleid. Hij was van 1866 tot aan zijn dood lid van de Geneeskundige Raad van Zuid-Holland.

H. Polijn Büchner (1814-1887), M.O.D. in Katwijk in de jaren 1838-1855. Hij was in deze jaren armendoctor en lid van de gemeenteraad. In 1856 vestigde hij zich in Kampen, waar hij tot 1874 armendoctor is geweest. Als actief hygiënist verrichtte hij onderzoek naar de gezondheidstoestand van Kampen. Polijn Büchner was een zoon van W.F. Büchner.

A.E. Post (1841-1917), tussen 1862 en 1871 officier van gezondheid, vanaf 1871 M.D. en officier van gezondheid eerste klasse in Arnhem. Post was in de jaren 1879-1893 adjunct-inspecteur en in de jaren 1895-1902 inspecteur van de provincies Utrecht en Gelderland.

C.H. Riehm (1822-1852), M.D. in Amsterdam vanaf 1848. Riehm richtte samen met onder anderen Israëls en Penn in 1851 het Nederlandsch Weekblad voor Geneeskundigen op, na een mislukte poging tot samenwerking met Donkersloot. 
Hij was een groot voorstander van vergaande wetgeving inzake de openbare hygiëne. Riehm was een veelbelovend medicus en schrijver (hij was onder meer redacteur van $D e$ Gids), wiens loopbaan door een vroegtijdig overlijden werd afgebroken.

C.C. Roëll (1814-1863), M.D. in Nijmegen vanaf 1838. In de jaren vijftig was Roëll geneesheer van het krankzinnigengesticht in Dordrecht. In 1859 werd hij benoemd tot hoofd van de afdeling Medische Politie van het ministerie van Binnenlandse Zaken. In deze functie heeft hij nauw samengewerkt met Penn, Van Cappelle, Ali Cohen en Coronel op het terrein van de medische wetgeving, de medische statistiek en het onderzoek naar de toestand van de geneeskundige armendiensten in het land.

J. Roosenburg (1823- ?), M.O.D. in 's Hertogenbosch vanaf 1849. Roosenburg behoorde met M.J. Godefroi tot de belangrijkste hygiënisten in Den Bosch. Hij was van 1866 tot 1892 lid van de Geneeskundige Raad van Noord-Brabant en Limburg.

W.P. Ruysch (1847-1920). Ruysch was officier van gezondheid tweede klasse, toen hij in 1879 tot adjunct-inspecteur van de provincies Noord-Brabant en Limburg werd benoemd. In 1884 werd hij hoofd van afdeling Medische Politie bij het ministerie van Binnenlandse Zaken, als opvolger van Van Cappelle. Ruysch heeft zich ingezet voor de instelling van een geneeskundige inspectie voor de fabrieksarbeid. Hij is te beschouwen als een vertegenwoordiger van de nieuwe generatie hygiënisten.

G.H. Saltet (1825-1858), M.D. in Amsterdam vanaf 1851. Saltet heeft zich vooral ingezet voor het onderzoek naar volksziekten en de ontwikkeling van de medische statistiek in Amsterdam. Saltet was de vader van de latere hoogleraar in de hygiëne R.H. Saltet (1853-1927).

S. Sarphati (1813-1866), M.D. in Amsterdam vanaf 1839. Sarphati nam in 1842 het initiatief tot de oprichting van de Nederlandsche Maatschappij tot bevordering der Pharmacie. Hij richtte in 1848 tevens de Maatschappij tot bevordering van landbouw en landontginning op, die in de hoofdstad tot 1875 een monopolie had op de afvoer en verwerking van het stadsvuil. Ter bevordering van de nijverheid richtte hij in 1852 met de Delftse hoogleraar S. Bleekrode en W.C. Staring de Maatschappij van Volksvlijt op. Hieruit is in 1855 de Maatschapij voor meel- en broodfabrieken voortgekomen. Sarphati deed verder voorstellen voor een planmatige aanpak van de stadsontwikkeling en de volkswoningbouw. Hij behoorde vreemd genoeg niet tot de woordvoerders van de groep hygiënisten. Ook heeft hij geen wetenschappelijke artikelen op zijn naam staan. Toch was Sarphati een exponent van het hygiënisme binnen de geneeskunde. Zijn activiteiten hebben hem tot een nationale figuur gemaakt.

Th.A. van Schermbeek (1810-1882), M.D. in Utrecht vanaf 1833. Schermbeek was aanvankelijk armendoctor, na 1840 bouwde hij een grote praktijk op onder de welgestelden van de stad. Hij was een zeer geziene figuur onder brede lagen van de bevolking. Vanaf de jaren vijftig (met name de aprilbeweging) stond hij op vriendschappelijke voet met Thorbecke. In de jaren zestig was hij lid van de 
gemeenteraad. Hij heeft zich ingezet voor een betere openbare hygiëne en de reorganisatie van de armenzorg. Schermbeek was lid van de Geneeskundige Raad van Utrecht en Gelderland van 1866 tot 1882.

H. Snellen (1834-1908), M.C.D. in 1857-1858. Snellen werkte als assistent van F.C. Donders in het Nederlandsch Gasthuis voor behoeftige en minvermogende ooglijders te Utrecht. In $1862 \mathrm{kreeg}$ hij de leiding over het Gasthuis. Snellen was bijzonder actief op het gebied van de openbare hygiëne. Hij was voorzitter van de in 1866 opgerichte Vereeniging ter bevordering van de volksgezondheid in Utrecht. Hij heeft zich in deze functie ingezet voor de verbetering van de drinkwatervoorziening.

J.P. Snoep (1815-1882), heelmeester en heelmeester ten plattelande eerst in Wolphaartsdijk (1833), later in Goes. Als lid van de NMG-afdeling Zeeland probeerde hij verbeteringen door te voeren in de organisatie en financiering van de geneeskundige hulpverlening aan armen. Als lid van de Geneeskundige Raad van Zeeland van 1872 tot 1882 was naauw betrokken bij de bestrijding van sanitaire en sociale misstanden.

H.W. Stork (1808-1877), M.O.D. in Almelo vanaf 1835. Stork verrichtte in de jaren zeventig als lid van de Geneeskundige Raad van Overijssel en Drenthe (vanaf 1866) onderzoek naar de arbeidsomstandigheden in fabrieken en de hygiënische omstandigheden in bewaarscholen.

S.E. Stratingh (1833- ?), M.O.D. in Zuidlaren in de jaren 1859-1862. Hij stelde in de jaren 1857-1858 in samenwerking met Ali Cohen een geneeskundige plaatsbeschrijving van de stad Groningen op. Stratingh promoveerde in 1858 in Groningen op deze plaatsbeschrijving.

S. Stratingh Tresling (1831-1897), M.O.D. in Havelte van 1861 tot 1875, later in Hilversum. Hij stelde in 1872 een handboek voor het bouwen van arbeiderswoningen op. Stratingh Tresling was lid van de Geneeskundige Raad van Overijssel en Drenthe van 1869 tot 1875 . Hij was eindredacteur van het tijdschrift De Gezondheid (1877-1881) en voorzitter van de NMG-afdeling Hilversum.

N.D. Sybrandi (1816-1886), M.D. in Amsterdam vanaf 1841. Sybrandi publiceerde vanaf 1847 als één van de eersten jaarverslagen over de heersende volksziekten in Amsterdam. Hij was secretaris van de NMG-afdeling Amsterdam en in de jaren 1849-1854 lid van het hoofdbestuur van de NMG. Hij was tevens de eerste bibliothecaris van de Maatschappij. Tot 1856 maakte hij deel uit van de NMG-commissie voor de geneeskundige plaatsbeschrijving en volksziekten. In deze functie was hij mede verantwoordelijk voor de jaaroverzichten van de heersende ziekten in Nederland, die in het tijdschrift van de Maatschappij werden afgedrukt. In 1874 vertrok Sybrandi naar Haarlem.

H.F. Thijssen (1830-1915), M.C.D. in Arnhem vanaf 1855. Als lid van de Geneeskundige Raad van Gelderland en Utrecht in de jaren 1866-1890 was Thijssen nauw betrokken bij onder meer de 'enquêtes van fabrieken' die omstreeks 1870 door het Geneeskundig Staatstoezicht waren opgezet. 
G.P. van Tienhoven (1836-1901), M.C.O.D. in Tiel vanaf 1861. In 1868 werd hij benoemd tot directeur van het stadsziekenhuis in Den Haag. In 1876 werd hij adjunct-inspecteur voor de provincies Gelderland en Utrecht. Deze functie gaf hij echter reeds in 1879 op, nadat hij opnieuw tot directeur van het stadsziekenhuis in Den Haag was benoemd.

H.L. Verspijck (1825-1902), Officier van gezondheid vanaf 1848. Verspijck verliet in 1865 als officier van gezondheid eerste klasse de militaire dienst. Hij was van 1869 tot 1877 adjunct-inspecteur van de provincies Noord-Brabant en Limburg en van 1877 tot 1895 inspecteur van de provincies Gelderland en Utrecht.

L.H. Verwey (1816-1875), M.D. in Den Haag vanaf 1839 . Verwey werkte vanaf december 1852 tot februari 1853 voor minister Thorbecke als adviseur 'openbare gezondheidsregeling'. In 1853 richtte hij het Tijdschrift voor algemeene Gezondheids-regeling en Geneeskundige Politie op. Pruys van der Hoeven trad eveneens tot de redactie toe. Het beleefde slechts twee jaargangen. Verwey was lid van de Geneeskundige Raad van Zuid-Holland.

D. de Vries Reilingh (1800-1879), M.O.D. in Groningen vanaf 1826. De Vries Reilingh genoot aanzien in Groningen. Hij werkte als armendoctor samen met Ali Cohen en Acker Stratingh. In de jaren vijftig en begin jaren zestig was hij voorzitter van de Plaatselijke Commissie van geneeskundig Toevoorzicht. Hij was tevens lid van de Provinciale Commissie van geneeskundig Toevoorzicht. De Vries Reilingh was van 1866 tot 1879 lid van de Geneeskundige Raad van Groningen en Friesland. Hij heeft enkele belangrijke (historische) verhandelingen over de cholera, de tyfus en de koortsen op zijn naam staan.

R. Westerhoff (1801-1874), M.D. in Warffum vanaf 1825. Westerhoff had grote belangstelling voor de geschiedenis en de geologische gesteldheid van de provincie Groningen. Met Acker Stratingh schreef hij Natuurlijke historie der provincie Groningen (1839). Hij was voorzitter van de Groningse Maatschappij ter bevordering van de Nijverheid. Westerhoff behoorde tot de liberale denkrichting en was lid van de Tweede Kamer voor het district Appingedam in de jaren 1849-1874. Hij was een voorstander van strenge geneeskundige wetten op de openbare hygiëne en een goed uitgerust medisch politie-apparaat. Hij keerde zich in 1862 tegen de geneeskundige wetsvoorstellen van Thorbecke omdat die naar zijn mening de overheid te weinig bevoegdheden gaven en bovendien de academisch gevormde geneeskundigen ten onrechte gelijk stelden aan de nietacademisch gevormde geneeskundigen.

J.J. Willems (1834-1869?), M.C.O.D. in Schimmert. Adjunct-inspecteur van de provincies Noord-Brabant en Limburg in de jaren 1866-1869. De in 1881 (posthuum?) gepubliceerde natuurkundige plaatsbeschrijving van Limburg is van zijn hand.

H.M. de Witt Hamer (1811-1895), M.D. in Delft vanaf 1835. Hij was in de jaren vijftig lid van de NMG-commissie voor geneeskundige politie en de NMGcommissie voor geneeskundige statistiek. Hij heeft zich met name ingezet voor de verbetering van de volkshuisvesting in zijn woonplaats. 
. 
1 Kossmann, De Lage Landen, 136-137

2 Aldus de voorzitter van de Nederlandsche Maatschappij tot bevordering der Geneeskunst, J.N. Ramaer in 1858. Ramaer, 'Openingsrede', 403

3 Tussen 1849 en 1868 kende de Amsterdamse afdeling van de NMG een commissie voor de epidemiologie. Elders in het land sprak men over de commissie voor volksziekten of de commissie voor geneeskundige statistiek. In het Handboek uit 1872 komt de term epidemiologie welgeteld cén keer voor (vol. II, 195)

4 Ali Cohen, 'Openbare gezondheidsregeling', 299

5 Voorhelm Schneevoogt, 'Hygieine', 515

6 Israëls, 'De Hygiëne', 132 e.v.

7 Stamhuis, 'Cijfers en Aequaties', 3-4, 154-159. De inhoud die de hygiënisten aan het begrip statistiek gaven, kwam overeen met de omschrijving die de bekende Leidse hoogleraar in de statistiek S. Vissering hiervan had gegeven. Stamhuis maakt overigens duidelijk dat ook het begrip statistiek in de tweede helft van de negentiende eeuw van inhoud veranderde.

8 Sturmans, Epidemiologie, 1-4, 13-15

9 De term epidemiologie is afgeleid van het Griekse bijvoeglijke naamwoord epidèmios dat "onder het volk verspreid' betekent. Epidemiologie duidt in de oorspronkelijke betekenis op de leer van de verspreiding van ziekte onder het volk.

10 Saltet, Voordrachten, 481-482

11 Zie daarvoor: Dawber, The Framingham study

12 Een mooi voorbeeld is te vinden in: Susser, Epidemiology

13 Van der Korst, Om liifen leven

14 Cannegieter, 150 jaar Gezondheidswet; Querido, Een eeuw Staatstoezicht

15 Juffermans, Staat en gezondheidszorg

16 Verdoorn, Het gezondheidswezen

17 Bosschaert, Utrechr; Romijn, Welvaart en gezondheid

18 Festen, 125 jaar Geneeskunst; Bergink, Coronel

19 Een deel hiervan zijn afstudeerscripties die op verschillende historische instituten tot stand zijn gekomen, maar niet zijn gepubliceerd. 
1 Van der Woude, 'Bevolking en Gezin', 19-38

2 Roodvonk-epidemieän deden zich voor in de jaren $1806,1811,1817-1819,1822-1823$ en 18341835; pokken-epidemië̈n in verschillende steden in de jaren 1817-1818, 1820-1821 en 1831-1832. Ali Cohen (red.), Handboek $I$, 279-280 en 319-321

3 Zie voor een bespreking van deze publikaties, Rosen 'Cameralism and the concept of medical police' en Rosen, 'The fate of the concept of medical police'. Enkele Bataafse geneeskundigen waren bovendien geinspireerd door de politieke hervormingen die in Frankrijk na de revolutie tot stand waren gekomen. Voor ontwikkelingen in Frankrijk, die de medische hervormers in Nederland tot voorbeeld hebben gediend: La Berge, 'The Paris health Council'; Weiner, 'Le Droit de l'homme à la Sante' en 'Public Health under Napoleon'

4 Het boekwerk dat in 1819 zes delen omvatte, werd vrijwel onmiddellijk na het verschijnen van het eerste deel in heel Europa door artsen als handboek in gebruik genomen. De eerste vier delen van Franks boek zijn door de Leidse arts H.A. Bake in het Nederlands vertaald: Samenstel eener Geneeskundige Staatsregeling of verhandeling van die middelen, welke tot aanwas der bevolking, en bevordering der algemeene gezondheid bij ons en andere volken zijin in het werk gesteld of nog aangewend zouden kunnen worden. Leiden: 1787-1794.Zie ook: Sypkens Smit, Matthias van Geuns, $446-452$

5 Heederik, Van kasboekregister tot burgerlijkestand, $196 \mathrm{e.v}$

6 Zie voor een beschrijving van de politieke strijd die aan de regeling vooraf is gegaan: Van der Korst, Om lijf en leven, 179-188; Cannegieter, 150 jaar Gezondheidswet, 14-15, 26-33; Querido, Een eeuw Staatstoezicht, 223-225; Sypkens Smit, Matthias van Geuns, 198-199,446, 449-452, 486

7 Bierman, Van artsenijmengkunde naar artsenijbereidkunde, 128-130

8 Het besluit regelde tevens wie tot inenting bevoegd waren: medicinae doctores en de chirurgijn die een schriftelijk bewijs van de departementale geneeskundige commissies konden overleggen, waarin werd verklaard dat hij voldeed aan de eisen van ervaring, deskundigheid en voorzichtigheid. Zie: Rutten, 'Interventie, revolutie en het civilisatieproces', 3 e.v.

9 Daniëls, 'De kinderpok-inenting in Nederland', 172-176

10 Rutten, 'Interventie, revolutie en het civilisatieproces', 3 e.v.

11 Heederik, Van kasboekregister tot burgerlijkestand, 196 e.v.

12 Heederik, Van kasboekregister tot burgerlijkestand, 205-206

13 Kossmann, De Lage Landen, 91

14 Wet ter regeling van hetgeen betrekkelijk is tot de uitoefening van de verschillende takken der geneeskunde van 12 maart 1818 (Stb. 16) en het Besluit, houdende een reglement, betrekkelijk het Geneeskundig Onderzoek en Toevoorzigt van 31 mei 1818 (Stb. 25)

15 Artikel 28 van het Besluit van 1818

16 Artikel 31 van het Besluit van 1818

17 Het navolgende is gebaseerd op: Van Lieburg, 'De tweede geneeskundige stand' en Van Lieburg, 'Geneeskunde en medische professie'.

$18 \mathrm{~KB} 6$ januari 1823, nr. 176 in: Verzameling van Wetten, 245-25

19 In 1830 werd het besluit van 1823 weer ingetrokken, omdat het in strijd met de vrijheid van onderwijs zou zijn. De klinische scholen bleven bestaan.

20 Practisch Tijdschrift woor de Geneeskunde in al haren omvang (1823-1846). Met supplementbanden, 1823-1841. Vanaf 1847 voortgezet onder de titel Nieuw Practisch Tijdschrift voor de Geneeskumde in al haren omvang. Zie voor een korte bespreking van dit tijdschrift: Van Lieburg, 'De Nederlandse medische tijdschriften en de wetenschappelijke geneeskunde', 7-8

21 Deze eis gold ook voor het Athenaeum Illustre te Amsterdam, waar men een studie in de geneeskunde kon volgen maar niet kon promoveren.

22 Beukers, 'Groei en ontwikkeling. De Leidse faculteit der geneeskunde', 77-79

23 Een uitzondering vormden de provincies Groningen en Friesland, waar ook in de kleinere steden en dorpen gegradueerden werkten.

24 De bevoegdheden van de diverse geneeskunstbeoefenaars waren gedeeltelijk bij wet geregeld, gedeeltelijk in een reglement met 'Instructies', vastgesteld bij KB van 31 mei 1818, nr. 63. Deze instructies zijn echter nooit in het Staatsblad verschenen. Bax, Wetgeving voor genees-, heel-, vroed-
en artsenijmengkunde, 66-112 25 Van der Korst, Om lijfen leven, 194 
26 Artikel 11 van de Wet van 1818

27 Artikel 7 van de Wet van 1818. Waren er twee of meer doctores in een dorp gevestigd, dan moest een heelmeester zich beperken tot eerste hulp

28 Van Lieburg, 'Geneeskunde en medische professie', 126-132

29 Wet van 27 maart 1838, houdende wijzigingen in die van den 12 mart 1818, nopens de gecombineerde uitoefening van enige takken der geneeskunde (Stb. 10)

$30 \mathrm{~KB} 7$ september 1814 (Stb. 98), houdende bepalingen ter bevordering van het meer algemeen gebruik der koepokinenting

$31 \mathrm{~KB} 18$ april 1818 (Stb. 20), ter bevordering van de koepok-inënting

32 Ministeriële circulaire 30 augustus 1823, vermeld in: Ali Cohen (red.), Handboek II, 311. Op 31 maart 1825 verzond de minister voor de tweede maal een circulaire over dit onderwerp. Bergink, Schoolhygiene, 12

33 Bergink, Schoolhygiëne, 15-17

34 Een derde methode die men soms toepaste, was de ontruiming van de bevolking van besmette plaatsen (stadswijk, garnizoen), met achterlating van de zieken.

35 Algemeen Reglement ter wering van besmettelijke ziekten, welke, door middel der scheepvaart, naar herwaarts zouden kunnen worden overgebragt, Publicatie van het Staatsbewind der Bataafsche Republiek 10 januari 1805 in: Verzameling van Wetten, 405-414

36 Ali Cohen (red.), Handboek II, 254

37 Bijvoorbeeld: Huisman, 'Itinerant medical practitioners in de Dutch Republic' en de daar aangehaalde literatuur; Van Lieburg, 'Sympathische genezers, galvanisten en magnetiseurs te Rotterdam

38 Verdoorn, Het gezondheidswezen, 157-163; Juffermans, Staat en gezondheidszorg, 113. Van Lieburg, 'Van gildebus tot ziekenfonds', 157-163

39 Het $\mathrm{KB}$ van 11 april 1818 (het zogenaamde 'Menschlievende Besluit') gelastte het onderzoek naar alle aanwezige gestichten voor krankzinnigen en verllangde dat ondoelmatige gestichten gesloten en voor verbetering vatbare inrichtingen hervormd zouden worden, terwijl het tevens aandrong op nieuwbouw. Vervolgens hebben ambtenaren van het ministerie van Binnenlandse Zaken radicale hervormingsplannen ontworpen

40 Melief, De strijd om de armenzorg, 91 e.v.

41 Van Holthoon, 'De Armenzorg in Nederland', 176; Melief, De strijd omde armenzorg, 120-142

42 Ook in het Reglement van het Bestuur der Stad, uitgevaardigd bij KB van 4 januari 1824, nr. 111 (Bijvoegsel Stb. 1824), stond niets vermeld over de volksgezondheid. In het Reglement op het Bestuur ten Platten Lande, uitgevaardigd bij KB van 23 juli 1825, nr. 132 (Bijvoegsel Stb. 1825), was alleen bepaald dat de burgemeester de uitvoerende instantie van de zorg voor de volksgezondheid is. Wel waren de gemeentebesturen volgens de Wet op de koepokinentingen van 1818 verplicht goed toe te zien op de wijze waarop de armbesturen zorg droegen voor de vaccinatie van armlastige kinderen.

43 Ook technisch-hygiënische voorschriften met betrekking tot de inrichting van schoolgebouwen, opgenomen in de Wet op het Lager Onderwijs van 1806, werden sllecht nageleefd ondanks het bestaan van plaatselijke commissies van toezicht op het onderwijs. Bergink, Schoolhygiène, 9-12

44 Daalder, 'Politieke Instellingen', 306-307

45 Zie noot 20

46 Instructie voor de Commissarissen tot de Zaken der Geneeskunde bij het Ministerie van Binnenlandsche Zaken, vastgesteld bij KB van 23 november 1816. Zie Bax, Wetgeving voor genees-, heel-, vroed-en artsenijmengkunde, 113-118

47 Van Maanen kreeg de tweede commies J.B.T. Ramaeckers als zijn adjunct toegewezen. Van Usselmuiden, Binnenlandse Zaken, 54

48 Van IJsselmuiden, Binnenlandse Zaken, 38, 54, 61, 79, 88

49 Cannegieter, 150 jaar Gezondheidswet, 45

50 Kerkhoff, 'Over de verhouding tussen gerechtelijke geneeskunde en openbare gezondheidsregeling', 12-13. Reeds in 1815 was bij KB bepaald dat de gerechtelijke geneeskunde voortaan aan de hogeschool moest worden gedoceerd, maar dit voorschrift had er slechts toe geleid dat het vak als nevenopdracht aan reeds zittende leerstoelhouders werd toevertrouwd.

51 Bijvoorbeeld: Verslag wan de in het jaar 1826 te Groningen waargenomene ziekten

52 Van Maanen had samen met enkele andere geneeskundigen in een 'Speciale Commissie omtrent de Epidemische ziekte te Groningen' al in 1826 een rapport voor de minister opgesteld. De inhoud van dit rapport heb ik niet kunnen achterhalen.

53 Van Usselmuiden, Binnenlandse Zaken, 62-63 
54 Cannegieter vermeldt dat er in 1831 sprake is geweest van een ontwerp van wet tot vervanging van de Wet van 1818 . Het is mij onbekend wat er van dit ontwerp, dat waarschijnlijk door Van Maanen is opgesteld, geworden is. Cannegieter, 150 jaar Gezondheidswet, 47

55 Delprat, 'Het ontstaan der Maatschappij', 30-32

56 Kossmann, De Lage Landen, $97-98$

57 Van Isselmuiden, Binmenlandse Zaken, 49-53,69-70

58 Van IJsselmuiden, Binnenlandse Zaken, 49-53, 70, 74-75 en 79-80

$59 \mathrm{~KB} 2$ augustus 1815 , nr. 14. Zie voor de artikelen die op het geneeskundig hoger onderwijs van toepassing zijn: Verzameling van Wetten, 222-229

60 Hienuit mag men niet concluderen dat de heelmeesters in het geheel geen bijdrage aan het geneeskundig kennisarsenal hebben geleverd. Het tegendeel is het geval. Verschillende heelmeesters hebben vernieuwingen in de heelkundige behandeling doorgevoerd en verbeterde instrumentaria geïntroduceerd.

61 Huizinga, Verzamelde Werken VIII, 119-120. Zie ook: De Moulin, 'Die Medizin zur Zeit der Regierung des Königs Wilhelm I' en Van Lieburg, 'Geneeskunde en medische professie', 124-125

62 Karakteristiek voor deze tijd zijn de argumenten waarmee de vooraanstaande Groningse doctor J. van Geuns in 1831 zijn zoon - de latere hoogleraar J. van Geuns - verbood om na het doctoraalexamen zijn praktische kennis te vergroten door als assistent in een cholera-hospitaal te gaan werken met de voor deze tijd karakteristieke argumenten: 'Niets doen, wat $U$ bindt en wat $U$, om eenen bijkomende reden van Uw hoofddoel: het voltooien Uwer dissertatie en het ondernemen van een reis naar buitenslands zou kunnen aftrekken ... Ik ben er volstrekt en woedend tegen, dat gij Uw welberedeneerd studieplan zoudt laten varen, om als halfbakken aide-médecin of chirurgijn in een Cholera-hospitaal te ageeren'. Geciteerd bij Verdoorn, Het gezondheidswezen, 96

$63 \mathrm{Zie}$ voor de geschiedenis van het klassieke gezondheidsmodel: Henkelmann \& Karpf, Gesundheitserziehung, 19-74; Burns, 'The nonnaturals'; Tutzke, 'Inhaltliche und methodische Entwicklungstrends der Gesundheitserziehung, 16-36

64 Pennink, Gezondheidsleer, 191-192

65 Elias, Het civilisatieproces, bijvoorbeeld $I, 23-75$ en de daarop volgende voorbeelden van gedragsveranderingen

66 Elias, Het civilisatieproces II, 326-327

67 Coleman, 'Health and Hygiene'; Frevert, Krankheit als politisches Problem, 28-36; zie ook: Lenders, De burgeren de volksschool, 100-104

68 Mijnhardt, Tot Heil van 't Menschdom, 259-272 en 289-293

69 Het volgende is ontleend aan: Lenders, De burger en de volksschool

70 Lenders, De burgeren de wolksschool, 76-78; Brugmans, De arbeidende klasse, 195

71 Schadewaldt, 'Diaita - Methoden der Gesundheitsbelehrung'. Gezondheids-blad ter onderrigting en waarschuwing, woor allen die prijs stellen op leven en gezondheid. Amsterdam, 1822-1825.

72 Een mooi voorbeeld daarvan in Nieuwenhuys, Proeve eener geneeskundige plaatsbeschrijving $I$, 222-234. Zie ook: Kruithof, 'De deugdzame natie', 370-372

73 Verslag van de in her jaar 1826 te Groningen waargenomene ziekten, 39-40

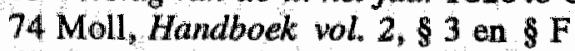

75 Dewhurst, Sydenham, 60-67; Stevenson, 'New diseases', 10 e.v.; Bleker, 'Die Idee einer historischen Entwicklung', 197; Riley, 'The medicine of the environment', 167-168

76 Het laatstgenoemde begrip, het Griekse substantief miasma, werd na Sydenham het meest gebruikt en stamt af van het werkwoord miaino, dat besmeuren, bevlekken, bezoedelen betekent. Het werd sinds de Griekse oudheid vooral onder invloed van Hippocratische geschriften in de medische teksten gebruikt om onreinheid, onzuiverheid van het milieu van de mens te kunnen aangeven. Het gebruik van de begrippen emanatie, effluvium en mephitische damp sinds de zeventiende eeuw was een gevolg van pogingen om met behulp van de natuurwetenschappelijke methode de aard van het miasma nader te bepalen. Ten Have, Geneeskunde en filosofie, 59

77 Contagium is afgeleid van het Latijnse werkwoord contingere, dat aanraken, aantasten, besmetten betekent.

78 Een theorie van het contagionisme werd voor het eerst opgesteld door Hieronymus Fracastorius in zijn De contagionibus et contagiosis et eorum curatione libritres uit 1546 . Zie voor een bespreking

van deze theorie: Ten Have, Geneeskunde en filosofie, 39-56; Bulloch, History of bacteriology, 3-37

80 Dergelijk onderzoek treffen we aan in bijvoorbeeld: Pruys van der Hoeven, Van Kaathoven en Salomon, Geschiedverhaal van de cholera-epidemie

81 Ackerknecht, 'Anticontagionism', 563-598 
82 Dat vooral het verspreidingspatroon van contagieuze ziekten centraal in de controverse tussen contagionisten en miasmatici stond, blijkt bijvoorbeeld uit: Coleman, Yellow fever, met name 134138 en 182-187

83 Mijnhardt, Tot Heil van het Menschdom, 106 e.v.

84 Van Lieburg, 'Geneeskunde en medische professie'

85 Jusatz, 'Die Bedeutung der medizinischen Ortsbeschreibungen', 185

86 Risse, 'Typhus fever', 179; Bynum, 'Cullen and the study of fevers', 141

87 Het begrip koorts was een zeer belangrijk klinisch begrip in de achttiende eeuw en kon naar ziekten met een verschillende aetiologie en symptomatologie verwijzen. Men kan alleen al op grond van Nederlandse publikaties dertien verschillende koortsen onderscheiden, zoals 'kwaadaardige rotkoortsen', 'gele koorts', 'tussenpoozende koorts', galkoorts', 'zinkingskoorts'. Van Kalmthout, 'Koortstypen', passim

88 Metz, 'Social thought', 255-257; Rosen, 'Statistical analysis, passim

89 Hannaway, 'The Société royale de médecine and epidemics", passim; Jusatz, "Die Bedeutung der medizinischen Ortsbeschreibungen', 186

$90 \mathrm{De}$ Vooys, 'Medische geografie', 6

91 Riley, 'The medicine of the environment', 170

92 CBS, Geschiedenis van de statistiek, 2-6, 81-84. De tussen 1815 en 1826 in de noordelijke Nederlanden gehouden provinciale volkstellingen waren gebrekkig georganiseerd. De resultaten ervan zijn pas na 1827 bewerkt en uitgegeven. CBS, Geschiedenis van de statistiek, 61-62

93 Neurdenburg, Doodsoorzaak en statistiek, 24

94 CBS, Geschiedenis van de statistiek, 3-4

95 R. Lobatto, Jaarboekje, uitgegeven op last van Zijne Majesteit den Koning. 's Gravenhage: 18261849. Zie voor een bespreking van de betekenis van Lobatto: Stamhuis, 'Cijfers en Aequaties', 67131

96 KB 29 september 1828 (Stb. 57)

97 CBS, Geschiedenis van de statistiek, 62

98 Buchner, Verhandeling over den invloed der droogmakerijen, 157

99 Banga, Verhandeling over de epidemische ziekte, 80

100 Banga, Verhandeling over de epidemische ziekte, 60 en 107

101 De Verhandeling van Banga werd in 1828 door de Provincialle Commissie van Geneeskundig Onderzoek en Toevoorzigt in Noord-Holland bekroond en uitgegeven. Het boek werd nog vele jaren daarna aangehaald in tal van wetenschappelijke studies. Andere hier niet besproken teksten met analyses als die van Banga: Sasse, Gedachten over de Natuur; Snabilié, Praktische waarnemingen; Keiser, Diss. annotationes quasdam in febrem intermittentem; Schleurholts, De effluviorium paludasorum; artikelen in het Practisch Tijdschrift voor de Geneeskunde 6 (1827); 7 (1828); Suppl.

$V ; 14(1835) ; 15(1836) ; 26(1846)$

102 Zie hoofdstuk 5

103 Bleker, 'Die historische Pathologie', 34 e.v.

104 Zie bijvoorbeeld: H.F. Thijssen, Geschiedkundige beschouwingen der ziekten uit 1824

$105 \mathrm{De}$ Friese geneeskundige J. Vitringa Coulon, geciteerd in: Banga, Verhandeling over de epidemische ziekte, 115-116

106 Deze matregelen vindt men besproken in de literatuur die in noot 101 staat vermeld.

107 De Vooys, 'Medische geografie', 3

108 Jusatz, 'Die Bedeutung der medizinischen Ortsbeschreibungen", 181-183; Smith, "Medical science in mid-eigthteenth-century Britain', 126-127; Bynum, 'Cullen and the study of fevers', 141; Léonard, La médecine entre les pouvoirs et les savoirs, 43

109 De Vooys, 'Medische geografie, 3-6; Sypkens Smit, Matthias van Geuns, 445-446; Kerkhoff, Over de geneeskundige verzorgingin het staatse leger, 211

110 Nieuwenhuys, Proeve eener geneeskundige plaatsbeschrijving

111 Volgens methoden die de Duitse econoom en theoloog J.P. Süssmilch 75 jaar eerder had ontwikkeld stelde Nieuwenhuys de rekenkundige relaties tussen het aantal huwelijken, geboorten en sterfgevallen vast, en berekende hij op grond van gegevens uit de volkstellingen van 1795, 1809, 1811 en 1812 de verwachte ouderdom van de verschillende leeftijdsgroepen. Nieuwenhuys, Proeve eener geneeskundige plaatsbeschrijvingI, 234-307

112 Mulder, Amsterdam, 204-205

113 Pennink, Gezondheidsleer, 95

114 Zie voor een uitvoeriger bespreking van geneeskundige opvattingen over de stad als leefmilieu: Bleker, 'Die Stad als Krankheitsfaktor'

115 Pennink, Gezondheidsleer, 3 
116 Pennink, Gezondheidsleer, 30-31, 175, 184

117 Van der Woud, Het lege land, 315-319

118 De Wit, Thorbecke, 51

119 Zie hoofdstuk 4

120 Giele, 'Arbeidersbestaan', 28 e.v. en 39 e.v.

121 Kossmann, De Lage Landen, 132; Brugmans, De arbeidende klasse, 193-200 
1 Ook bij de lagere standen heerste gebrek. Het aantal bedeelden was sinds 1830 fors gestegen, van $10 \%$ in 1830 naar $16 \%$ in 1848 . In de provincie Noord-Holland bedroeg het percentage in dat jaar $25 \%$, in sommige steden zelfs meer dan $30 \%$. De werkloosheid was hoog. In zijn economische structuur was Nederland ouderwetser en conservatiever dan andere landen, mede alls gevolg van tegenwerking van financiers en kooplieden, bij wie grote weerstanden tegen cen nieuwe industriële maatschappij bestonden. Moderne industrieën waren er nauwelijks, alleen een niet-gemachinaliseerd kleinbedrijf waarin slechts $11,7 \%$ van de bevolking werk vond. De Jonge, Industrialisatie in Nederland, 161-204, 276-277, 281-282

2 De Jonge, Industrialisatie in Nederland, 276-277

3 Van Usselmuiden, Binnenlandse Zaken, 72-84 en 95-106

4 Zie voor het verval van het uit de Bataafse Republiek stammende corps van civiele ingenieurs: Lintsen, Ingenieurs, 70 e.v.

5 Aerts, Calis, e.a., De Gids sinds 1837,12-22

6 Delprat, 'De geschiedenis der Ned.geneesk.tijds. II', 1795

7 Aerts, Calis, e.a., De Gids sinds 1837,9

$8 \mathrm{~J}$. van Geuns was lid van de redactie van 1838 tot 1849 , Voorhelm Schneevoogt van 1846 tot 1871 . Andere medici die in de jaren veertig bijdragen schreven, waren Ali Cohen, Ramaer en S.P. Scheltema. In de jaren vijftig en zestig publiceerden Coronel en Egeling enkele artikelen in $D e$ Gids

9 Arntzenius, 'Noodzakelijkheid eener hervorming', 89-100

10 Voorhelm Schneevoogt, 'Over de afzonderlijke uitoefening der Genees- en Heelkunde', 29

11 De gevolgen van de hervormingen voor apothekers, drogisten en de geneesmiddelenvoorziening laat ik buiten beschouwing. Volstaan kan worden met de vermelding dat de apothekers als beroepsgroep niet vertegenwoordigd zijn geweest in de staatscommissie van 1841 . Om deze reden werd in april 1842 de Nederlandsche Maatschappij tot bevordering der Pharmacie opgericht. In die Maatschappij heeft de Amsterdamse medicus Sarphati een belangrijke rol gespeeld.

12 Van Geuns, 'Blik op onze tegenwoordige geneeskundige staatsregeling', 1-17,57-73

13 Ramaer, 'Geneeskundige stand en controle', 91-119

14 Bijvoorbeeld: Anonymus, Ontwerp van verbeteringder geneeskundige wetgeving

$15 \mathrm{~KB} 20$ november 1841 , nr. 60

16 Stukken betreffende de herziening, 8,24 en 41

17 Stukken betreffende de herziening, 54-56

18 Stukken betreffende de herziening, 85-86

19 Stukken betreffende de herziening, 98

20 Stukken betreffende de herziening,98-104

21 Heije, 'Over geneeskundige staatsregeling', 270-271

22 Stukken betreffende de herziening, 111

23 Aangehaald in: Bijdragen tot Geneeskundige Staatsregeling III, 283 en 294

24 Aangehaald in: Bijdragen tot Geneeskundige StaatsregelingIII, 282

25 Van Lieburg, 'De tweede geneeskundige stand', $442-446$

26 'Ontwerp van wet, tot regeling van hetgeenbetrekkelijk is tot de uitoefening van de verschillende takken der Geneeskunst', Staatscourant 20 november 1844

27 Zie voor een uitvoerig overzicht van de geschiedenis van de gerechtelijke geneeskunde: Kerkhoff, 'Over de verhouding tussen gerechtelijke geneeskunde en openbare gezondheidsregeling"

28 Van IJsselmuiden, Binnenlandse Zaken, 92

29 KB 6 maart 1848, nr. 2. 'Geneeskundige zaken' viel nu onder de afdeling Onderwijs, Kunsten en Wetenschappen

30 Heije, 'Een woord aan alle geneeskundigen', 213-215

31 Van Lieburg, 'Geneeskunde en medische professie', 136

32 Het aantal niet-gegradueerden was in de jaren dertig sterk toegenomen. Vooral nadat het leger na de afwikkeling van de crisis met Belgiê weer tot normale proporties was teruggebracht, ontstond een grote toeloop van officieren van gezondheid die als heelmeester op het platteland gingen werken. In 1849 bedroeg het aantal inwoners per geneeskundige in Nederland 1256 (2432 geneeskundigen, 3054528 inwoners). Drooglever Fortuyn, 'Statistiek van de NMG', 184

33 Van Holthoon, 'De Armenzorg in Nederland', 180 
34 Een stadsgeneeskundige in de grotere steden verdiende tussen de 100 en 150 gulden per jaar. Op het platteland verdiende een armenarts, verantwoordelijk voor vijfhonderd armen, vaak niet meer dan 60 gulden per jaar. Heelmeesters verdienden gewoonlijk nog minder. De geneeskundigen vuilden hun inkomen aan door tevens als behandelend geneesheer van een oude mannen- en vrouwenhuis te gaan werken. Heelmeesters verdienden bij door bijvoorbeeld het aanleggen van breukbanden (tachtig cent per keer). De ziekenfondsen betaalden de geneeskundigen 0,75 tot 1,50 per patiënt. Om een inkomen van duizend tot tweeduizend gulden per jaar te halen, zou een geneeskundige 2000 fondspatiënten moeten hebben. Dit zou 50 visites per dag betekenen.

Tegelijkertijd drukten de belastingen op de jonge geneeskundigen. Geneeskundigen werden als kleine ondernemers beschouwd en moesten daarom patent-belasting betalen. Medici vielen in de zogenaamde groep 14, samen met kooplieden, makellaars en bakkers. De belasting bestond uit een vast bedrag met een minimum en een maximum. Bosschaert, Utrecht, 135-160; Festen, 125 jaar Geneeskunst, 49 en 317; De Jonge, Industrialisatie in Nederland, 11

35 Bosschaert, Utrecht, 150-159

36 Thorbecke, 'Over het hedendaagsche staatsburgerschap' in: J.R. Thorbecke, Historische schetsen (1872). Opgenomen in: De Wit, Thorbecke, 177-373. Citaat: De Wit, Thorbecke, 270

37 Een verslag van dit congres was door de Duitse geneeskundige Szokalski gepubliceerd in het Archiv fur physiologische Heilkunde. A.F.H de Lespinasse, gemeente-arts in Vaassen, vertaalde dit verslag in 1846 in het Nederlands. Delprat, 'Dr. A.F.H. de Lespinasse', 16-17

38 Van Lieburg, 'Geneeskunde en medische professie', 137; Querner \& Schipperges (Herausg.), Wege der Naturforschung, 171-185

39 Delprat, 'Het ontstaan der Nederlandsche Maatschappij', 42-45

40 Delprat, 'Het ontstaan der Nederlandsche Maatschappij', 46

41 ARA: NMG, inv. nr. 78

42 In 1849 mondden deze plannen uit in het door vijftien Berlijnse artsen bewerkte 'Entwurf der Grundsatze einer neuen Medizinal-ordnung'. Hierin werd aangedrongen op de oprichting van vrije artsenverenigingen. Een gekozen vertegenwoordiging van deze verenigingen moest een door de staat erkende Raad van Eer vormen die disciplinaire en wettelijke bevoegdheden zou moeten krijgen. Het ontwerp werd door Virchow in opdracht van de Algemene Vergadering van Berlijnse artsen aan de minister van Binnenlandse Zaken van Pruisen aangeboden. De minister riep daarop een vergadering van geneeskundigen bijeen, die van 1-29 juli beraadslaagde. Hieraan namen uit elke provincie een geneeskundige ambtenaar en een praktiserende arts deel. Kort daarop volgde de politieke reactie in heel Duitsland en werd niets meer van de plannen van de Berlijnse artsen

43 ARA: NMG, inv. nr. 78 ("wet op de uitoefening der Geneeskunst in haren gehelen omvang')

44 De overige leden van de commissie waren de medicinae doctores J.C. van den Broecke en Th. Blom Coster (amanuensis). KB 25 juli 1848, nr. 64 en KB 4 augustus 1848, nr. 50

45 De vijf wetsontwerpen hadden betrekking op het geneeskundig staatsbestuur, de gerechtelijke geneeskunde, de uitoefening der geneeskunst, de artsenijbereidkunst en de examens ter uitoefening der geneeskunst en artsenijbereidkunst. ARA: BiZa OKW, inv. nr. 39. Zie ook: Ontwerpen van Wet
op het geneeskundig Staatsbestuur

$46 \mathrm{Na} 1849$ waren alle ministers van Binnenlandse Zaken van mening dat een wetsontwerp inzake het geneeskundig onderwijs niet thuishoorde bij de geneeskundige wetten, maar behandeld moest worden in het kader van een nieuwe wet op het Hoger Onderwijs. Met het oog op een dergelijke wet was bij KB van 15 januari $1849(S t b$. 3) een staatscommissie belast met het ontwerpen van een wet op het hoger onderwijs, met inachtneming van hetgeen de geneeskundige staatscommissie wie Mulder, waren sindsdien van mening dat regeling van het geneeskundig onderwijeraren, onder gaan aan een regeling van de bevoegdheden. Een nieuwe 'Hooger Onderwijswet' kon echter maar
niet tot stand worden gebracht. Deze kwam er pas in 1876 . De prioriteitstelling van van het onderwijs ging daardoor een belangrijk pas in 1876 . De prioriteitstelling van een regeling die zo snel mogelijk een geneeskundige staatsregeling wilden.

47 Voorhelm Schneevoogt was in 1848-1849 voorlopig voorzitter, en werd in oktober 1849 tot voorzitter gekozen. Hij bleef dit in de jaren 1850 en 1851. Ramaer was in 1848-1849 voorlopig Schneevoogt, Ramaer en Evers stelden de statuten van de Matschappij bekleden. Voorhelm hoofdbestuur was in Amsterdam gevestigd. Het voltallige eerste hoofdbestum zetel van het Voorhelm Schneevoogt, Ramaer, Evers, Mulder en J.B. Molewater. uitstappen.

48 Delprat, 'Het ontstaan "der Nederlandsche Maatschappij', 58-59 
49 Godefroi, 'De ontbinding der commissie', passim. Godefroi onderhield in deze tijd nauwe contacten met de Amsterdamse medici C.B. Tilanus, C.E. Heynsius, de latere energieke wethouder van publieke werken en Penn, over wie we nog uitvoerig komen te spreken.

50 Mulder, 'Aanspraak bij de opening der Tweede Algemeene Vergadering', 127-128

51 Kossmann, De Lage Landen, 201-203; Labruyère, Mulder, 32-40

52 Van IJselmuiden, Binnenlandse Zaken, 87 en 95-101

53 De Wit, Thorbecke, 102-104

54 ARA: Thorbecke, inv. nr. 324. In dit verband dient het onder Thorbecke gereedgekomen ontwerp-politiewet te worden genoemd. Deze wet bepaalde onder meer dat het politieambtenaren was toegestaan de woningen in het belang der volksgezondheid, zonder toestemming van de bewoners te betreden. Een dergelijke bepaling was ook opgenomen in het door de staatscommissie van 1848 opgestelde ontwerp van wet op het geneeskundig staatsbestuur, omdat dit de opsporing van ziektehaarden zou vergemakkelijken. Thorbecke meende dat deze inbreuk op de persoonlijke vrijheid alleen van de gerechtelijke macht mocht uitgaan en derhalve niet in een wet op het geneeskundig staatsbestuur behoorde te worden geregeld. Thorbeckes opvolger, minister Van Reenen, nam het wetsontwerp inzake de politie over en zag het in 1853 door de Tweede Kamer aangenomen.

55 Tijds.NMG 1 (1850) I, 248-252

$56 \mathrm{~KB} 8$ april 1851, nr. 70; ARA: Medische Politie: inv. nrs. 1, 3 en 5

57 'Algemeen rapport omtrent het advies der Staatscommissie', 15-35

58 Delprat, 'Het ontstaan der Nederlandsche Maatschappij', 64-65

59 Delprat, 'Het ontstaan der Nederlandsche Maatschappij', 65

60 Geneesk. Cour. 4 (1851), 23 november. De oproep was ondertekend door Ramaer, die nog altijd secretaris was van de commissie tot inleiding van het geneeskundig congres.

61 Tijds.NMG. 3 (1852)I, 20-24

62 'Algemeen rapport omtrent de Ontwerpen van Wet', 117-136

63 Mulder beschouwde Thorbeckes voornemen in deze als een daad van barbarisme. Mulder, Open brief. De nieuwe Koninklijke Academie, die tot doel had de wis- en natuurkunde te bevorderen, werd opgericht bij K.B. 26 oktober 1851, nr.3. Van Geuns was voorzitter van 1852 tot 1856. Kühler, Van Geuns, 11

64 Ali Cohen verdedigde tevens Thorbeckes politiek ten aanzien van het Koninklijk Instituut, dat 'zeer impopulair in den lande' was, en waarop van alles viel aan te merken. [Ali Cohen], 'Professor G.J. Mulder en de Minister Thorbecke'

65 Ook de Amsterdamse geneeskundigen C.H. Riehm en J.M. Schrant traden tot de redactie toe. $66 \mathrm{De}$ andere redactieleden van het Weekblad waren Riehm, Schrant en J.W.R. Tilanus, zoon van C.B. Tilanus. Delprat, 'De geschiedenis der Ned.geneesk.tijds. III', 46-56 
1 Haines, 'Inter-relations between social, biological and medical thought', 21 e.v. Voor een bespreking van de invloed van Comte op de biologische en medische wetenschap: Canguilhem, Wissenschaftsgeschichte, 89-109 en Canguilhem, La connaissance de la vie, 129-154

2 Guérin was liberaal en republikein. Sinds 1830 gaf hij het veelgelezen Gazette médicale de Paris uit. Enige weken na de val van koning Louis Philippe (24 februari 1848) opende Guérin in de Gazette een rubriek met de titel 'Médecine Sociale'. Uit deze rubriek blijkt de invloed van het 'Saint-Simonnisme' op Guerin. Eind 1848 werd de rubriek al weer opgeheven. In het verleden is nogal wat invloed aan Guérin toegekend. Virchow bijvoorbeeld zou zijn definitie van de 'Soziale Medizin" van Guérin hebben overgenomen. Toch is de betekenis van Guérin enigszins overschat. Na 1848 vernemen we niet veel meer van hem, althans wat betreft de openbare gezondheidszorg. Ook de uitdrukking 'médecine sociale' heeft nergens in Europa ingang gevonden. Toonaangevende geneeskundigen gaven de voorkeur aan de termen ' 1 'hygiène publique', 'öffentliche Gesundheitspflege', 'public health' en 'openbare hygiëne'. Zie voor Guérin: Galdston, 'Social medicine', $10-$ 14; Timmer en Hansma, 'Social medicine', 4-7

$3 \mathrm{Zie}$ voor een uitvoerige bibliografische bespreking: Ackerknecht, 'Hygiene'. Voor de doelstellingen en werkwijze van de beweging: La Berge, 'The early nineteenth-century french public health movement', 363-379 en Coleman, Death is a social disease

4 Coleman, Death is a social disease, 8. Coleman beschrijft uitvoerig de nauwe samenhang tussen het programma van de hygiënische beweging en dat van de leidende liberale politieke economen.

Overigens wordt ook duidelijk hoezeer de wensen van Villermé op gespannen voet stonden met de liberale ideologie.

5 Ackerknecht, 'Hygiene', 141

6 Metz, 'Social thought', 264-265. Over de geschiedenis van de Engelse sanitaire beweging zijn vele boeken geschreven. Een goed overzicht bieden Eyler, Victorian social medicine; Eyler, 'The conceptual origins of William Farr's epidemiology"; Wohl, Endangered lives; Lewis, Edwin Chadwick and the public health movement; De invloed die de Engelse en Franse sanitaire beweging op elkaar hebben uitgeoefend, wordt beschreven in: La Berge, 'Edwin Chadwick and the French connection'. Voor de invloed van Bentham op Chadwick en Southwood Smith zie: Ten Have, Geneeskunde en filosofie

7 In de personen van bijvoorbeeld de 'Kreisphysicus' F. Schnurrer (Geographische Nosologie, 1833) en L.Th.E. Isensee (Elementa nova Geographica et Statistices medicinalis, 1833). Jusatz, 'Die Bedeutung der medizinischen Ortsbeschreibungen', 186; Querner \& Schipperges (Herausg.), Wege der Naturforschung, 172-174

$8 \mathrm{Bik}$, Vijf eeuwen medisch leven, 388-399

9 Büchner, Geneeskundige topographie van Gouda, 21

10 Büchner, Geneeskundige topographie van Gouda, 21

11 Ackerknecht, Virchow, 38-39

12 Bleker, 'Die Stadt als Krankheitsfaktor', 44. Voor een overzicht van de Duitse medische hervormingsbeweging en haar banden met de liberale en socialistische politiek van die dagen, zie: Ackerknecht, "Beiträge zur Geschichte der Medizinalreform"

13 Ackerknecht, Virchow, 35; Virchow \& Leubuscher (Herausg.), Die medicinische Reform

14 Ackerknecht, Virchow, 111

15 Virchow, Die Einheitsbestrebungen in der wissenschaftlichen Medicin. Berlijn: 1849, 46-47. Gecit.

bij Ackerknecht, Virchow, 108

16 Coleman, Death is a sociale disease, 286

17 Virchow, Mitteilungen aber die in Oberschlesien herrschende Typhus-Epidemie, 217 en 223

18 Ackerknecht, Virchow, 142-161

19 Rosen, 'Disease and social Criticism', passim

20 Ackerknecht, 'Beiträge zur Geschichte der Medizinalreform', 78

21 Coleman, Death is a social disease, 81-82 en 238

22 Weindling, 'Was social medicine revolutionary?', 16 e.v.

23 Ackerknecht, 'Beiträge zur Geschichte der Medizinalreform', 79 e.v.

24 Ali Cohen, 'Openbare gezondheidsregeling', 269-270

25 Alli Cohen, 'Openbare gezondheidsregeling', 299

26 Pruys van der Hoeven, Anthropologisch Onderzoek 1, 208 
27 Pruys van der Hoeven, Anthropologisch onderzoek II, 190-191

28 Pruys van der Hoeven, Anthropologsich onderzoek I, 162-170

29 Pruys van der Hoeven, Anthropologisch Onderzoek III, 234. Volgens Pruys van der Hoeven kwam daar og bij dat Virchow er terecht op had gewezen dat bij alle specialisatie in de geneeskunde (pathologische anatomie, fysiologie) nooit mocht worden vergeten dat het de medicus om de mens in zijn totaliteit moest gaan: de mens was niet alleen een lichamelijk, maar ook een mastschappelijk, zedelijk en godsdienstig wezen.

30 Pruys van der Hoeven week door zijn gehele werk tellkens af van het positivisme van Comte, door ook het christelijke ideaal als wezenlijk uitgangspunt voor kennisvernieuwing to nemen. Vooral uit het vierde deel, Christelijke Anthropologie, blijkt hoe dicht hij nog stond bij de Duitse Romantiek, die leerde dat christelijke deugd en naastenliefde onontbeerlijk waren voor de wetenschapsbeoefenaar. Het ging de hoogleraar om de vestiging van een praktisch christendom, ver verwijderd van de orthodoxe kerkelijke leer. De hygiëne en de door hem opgestelde antropologie beschouwde hij als een voorbeeld van zulk een praktisch christendom.

31 Pruys van der Hoeven, Anthropologisch Onderzoek I, 191

32 Scheltema, 'Over de waarde der geneeskunde voor de maatschappij', 49-53

33 Egeling, 'Gezondheid, ziekte en dood', 116

34 Daniëls, 'Levensschets van Dr. A.H. Israëls', 100

35 Pous Koolhaas, 'Een woord vooraf, 4

36 Voorhelm Schneevoogt, 'Hygieine', 554-555

37 Voorhelm Schneevoogt, 'Hygieine', 554-555

38 Kooij, 'Stad en Platteland', 94-98

39 Brugmans, De arbeidende klasse, 214-221; Kossmann, De Lage Landen, 190-192

40 Het nijpende drinkwatertekort in Amsterdam bijwoorbeeld, veroorzaakt door de bijzondere ligging van de stad, gaf in de jaren dertig aanleiding tot allerlei discussies over de vraag wat aan de onhoudbare toestand viel te doen. Totdat in 1849 gekozen werd voor de aanleg van een drinkwaterleiding. Niet de gezondheid van de bevolking, maar het tekort aan drinkwater alsmede de dikwijls onaangename smaak ervan speelden een rol bij deze beslissing. De waterleiding werd in 1853 in werking gesteld. Ook elders hielden dergelijke problemen de gemoederen vroeg bezig. In Rotterdam, waar het drinkwater bijzonder slecht was, was in de jaren veertig een plan voor sanitaire verbeteringen opgesteld, dat met een vertraging van tien jaar werd uitgevoerd. In overige delen van Holland, in Utrecht, Gelderland en het noorden zagen lokale overheden zich eveneens betrekkelijk vroeg gedwongen iets te doen aan de drinkwatervoorziening. Zo kwam het slaan van diepe putten (tot honderd meter) op rekening van de gemeente, omdat dit voor particulieren te kostbaar was. Vogelzang, Drinkwatervoorziening,79-80

41 Boogman, Rondom 1848, 101

42 Wet van 29 juni 1851, regelende de zamenstelling, inrigting en bevoegdheid der gemeentebesturen (Stb. 85)

43 Wat dit betreft is nog van belang te vermelden dat voor 1851 volgens het Reglement van het Bestuur der Stad plaatselijke ambtenaren, onder wie de armendoctores, geen lid mochten zijn van de gemeenteraad. In Thorbeckes wetsontwerp op de gemeenten werd dit verbod gehandhaafd (artikel 23). Het Tweede-kamerlid Westerhoff, medicinae doctor te Warffum, diende echter een amendement in dat dit verbod voor armendoctores ongedaan moest maken. Het amendement werd met 34 tegen 30 stemmen aangenomen. Handelingen der Staten-Generaal 1850-1851, 758-761, 766 ${ }^{2}$, $766^{3}$

44 Stokvis, 'Toespraak', 654

45 Verkade, Overzicht der staatkundige denkbeelden van Thorbecke, 138. In hoofdstuk 7 zullen Thorbeckes opvattingen over het verband tussen gezondheidszorg en Gemeentewet nader worden besproken.

46 Ali Cohen, 'Openbare gezondheidsregeling', 280

47 Boogman, Rondom 1848, 30

48 Brugmans, De arbeidende klasse, 204, 216-218. Kossmann, De Lage Landen, 190 
1 Sommige medici en historici in de negentiende en twintigste eeuw zijn van mening dat de cholera ook in de zeventiende en achttiende eeuw in Europa voorkwam. Het is wel zeker dat zij in hun beoordeling zijn afgegaan op verslagen, waarin met de term 'cholera morbus' andere ziekten werden aangeduid dan de 'negentiende-eeuwse cholera', die met braken, diarrhee, krampen in de buik en extremiteiten, wegvallen van de pols, bleekheid, verzonken oogholten gepaard ging en binnen een aantal uren tot de dood kon leiden. Howard-Jones, 'Cholera nomenclature', 320; Ackerknecht, Geschichte der Krankheiten, 21

2 Zoals het volgende overzicht van de verschillende sterftecijfers voor de periode 1832-1909 laat zien, zijn voor Nederland vooral 1848-1849 en 1866-1867 rampjaren geweest.

jaar

1832

1833

$1848 / 49$

1853

1854

1855

1859
Nederland zonder
Brabant en Limburg

jaat

Nederland totaal

$\begin{array}{lll}4.872 & 1866 & 19.691 \\ 4.671(4,4 \circ / \circ) & 1867 & 1.591(6 \mathrm{o} / 00) \\ 22.078(9 \circ / \circ) & 1873 & 277 \\ 2.891 & 1874 & 48 \\ 2.038 & 1892 & 293 \\ 2.980 & 1893 & 263 \\ 3.748 & 1894 & 228 \\ & 1901 / 04 & 2 \\ & 1909 & 18\end{array}$

Bron: Van Cappelle e.a., De choleraepidemie, 376-379; Saltet, Voordrachten, 504. Tussen 1820 en 1870 schommelde het percentage totale sterfte per jaar in Nederland tussen 30 o/oo en $25 \% / 00$. Van der Woude, 'Bevolking en Gezin', 30 e.v.

3 Al ten tijde van de epidemic in het Verre Oosten in 1817 verscheen een groot aantal medische publicaties, in het bijzonder vanuit Brits-Indië. Algemeen was men van oordeel dat de cholera als zeer alarmerend moest worden beschouwd. Maar over de aard van de ziekte waren de meningen verdeeld. Sonmigen zagen de cholera in India als een epidemische of zware vorm van een gastrointestinale aandoening die in Europa reeds in de zeventiende en achttiende eeuw onder de naam "cholera morbus" was beschreven. Anderen meenden dat het om een ziekte zonder precedent ging. In de jaren twintig werden vele nieuwe benamingen voor de ziekte voorgesteld, waardoor een grote spraakverwarring onder de medici ontstond. Toch was het na 1830 gebruikelijk te spreken van 'cholera asiatica' of 'cholera epidemica' in tegenstelling tot de van oudsher bekende 'cholera nostras' of 'cholera sporadica'. Howard-Jones, 'Cholera nomenclature', 318-322

4 Van Andel, 'Cholera-prophylaxis', 5765

5 Raymakers, "Ideeën over de besmettelijkheid" , 11-21; Verslag van de in het jaar 1826 te Groningen waargenomene ziekten, 39-40

6 Bijvoegsel Stb. (1831) nrs. 124, 131 en 137

7 Korte beschrijwing van den thans heerschenden Aziatischen braakloop of cholera en deszelfs genezing en Aanwijzing ter bewaring van de gezondheid en ter voorbehoeding van de aansteking van den Aziatischen braakloop of cholera. 's Gravenhage: Algemeene Landsdrukkerij 1831; zie ook de Staatscourant 9 en 14 juli 1831. De inhoud van het laatstgenoemde rapport schijnt grotendeels te zijn overgenomen van een eerder in Duitsland verschenen rapport. Van Andel, 'Cholera-prophylaxis", 5767-5768

$8 \mathrm{~KB} 6$ juli 1831 (Stb. 21)

9 Ackerknecht, 'Anticontagionism', 563-567

10 Ackerknecht, 'Anticontagionism', 570-575

11 Overigens erkenden zelfs de felste anti-contagionisten wel de besmettelijkheid van syfilis, pokken, gonorrhoe en scabiës.

12 Ackerknecht, 'Anticontagionism', 590

13 ARA: SvS, inv. nr. 3595

14 Bijwoegsel Stb.(1831) nr. 148

$15 \mathrm{~KB} 10$ augustus 1831 (Bijvoegsel Stb.(1831) nr. 170) 
16 Bijvoegsel Stb.(1832) nr. 109; zie ook Olvers, Dordrecht, 15

$17 \mathrm{~KB} 2$ oktober 1831 , nr. 84

18 Hendriksz e.a., Algemeen Rapport, 35 e.v.

19 Hendriksz e.a., Algemeen Rapport, 160 e.v.

20 Hendriksz e.a., Algemeen Rapport, 159-160

21 Hendriksz e.a., Algemeen Rapport, 163 e.v.

22 Bijuoegsel Stb. (1832) nr. 109

23 Niet alleen streken in Oost-Europa en Duitsland waren nu besmet verklaard, maar ook grote gebieden in Frankrijk en Engeland en delen van Ierland. Bijvoegsel Stb. (1832) nr. 109

24 Ali Cohen (red.), Handboek $I I, 255$

$25 \mathrm{De}$ gemeentelijke voorbereidingen waren soms zeer uitvoerig. In Gouda bijwoorbeeld, waar op initiatief van Büchner al vớr de ontvangst van het ministerieel schrijven van 5 mei een choleracommissie was ingesteld, rekende men op een morbiditeit van 2,5\%. Op een bevolking van 12.000 zielen zou dat een te verwachten getal van 300 choleralijders betekenen. De duur van de epidemie werd op drie maanden geschat en de gemiddelde duur van een ziektegeval op acht dagen, zodat gerekend moest worden op 23 patiënten per week. De mortaliteit zou, zo verwachtte men, $50 \%$ bedragen. Bik, Vijf eeuwen medisch leven, 402-403; zie ook: Van Andel, 'Gorinchem', passim

26 Metz, 'Social thought', 264-265

27 Bijvoorbeeld: Pruys van der Hoeven, Van Kaathoven en Salomon, Geschiedverhaal van de cholera-epidemie. De auteurs voerden talloze feiten ten gunste van het contagionistisch standpunt aan en besteedden nauwelijks aandacht aan de slechte openbare hygiëne. Ook in andere Nederlandse publikaties werd vrijwel uitsluitend de vraag besproken of de cholera wel of niet besmettelijk was: Raymakers, 'Ideeën over de besmettelijkheid', 17-25

28 Ackerknecht, 'Anticontagionism', 578-580; McDonald, 'History of quarantaine', 32-33

29 Bijwoegsel Stb.(1848) nrs. 189, 204, 239, 270 en 271

30 Bijvoegsel Stb.(1848) nr. 290

31 Mulder, 'Besmettelijkheid der cholera', 278

32 Mulder, 'Besmettelijkheid der cholera', 284

33 Henle, Von den Miasmen und Kontagien, 14, 17, 24-30 en 63 e.v.

34 Bulloch, History of bacteriology, 48-55, 83-86

35 Advies van de Eerste Klasse van het KNIW van 22 maart 1850, opgenomen in het 3e deel van het Tijdschrift der Klasse, gecit. in: Ali Cohen (red.), Handboek II, 254, en Bijlagen Handelingen der Staten-Generaal 1863-1864,II, 1170-1171

36 'Ontwerp van wet, houdende algemene bepalingen tot het weren van besmetting op aankomende schepen, 23 september 1858', Bijlagen Handelingen der Staten-Generaal 1858-1859, II, 139-140

37 Bijlagen Handelingen der Staten-Generaal 1858-1859, II, 423-429

38 Tot 1938 volgden nog dertien van zulke internationale conferenties, die alle op twee na in Europa plaatsvonden. De internationale afspraken die op deze conferenties werden gemaakt, vormden de basis voor de oprichting van de Wereldgezondheidsorganisatie in 1946. Howard-Jones, The scientific backgrounds

39 McDonald, 'History of quarantaine', 39

40 De Man \& Van den Broecke, De cholera asiatica, 159

41 De Man \& Van den Broecke, De cholera asiatica, 153-155 en 190

42 Nederlandsch Lancet 5 ( $2_{-}^{e}$ serie), (1849-1850) 60-63, 100-107,300-301

43 Ali Cohen, 'Studiën over de cholera', 15-18

44 Ali Cohen, 'Studiën over de cholera', 71

45 Penn, 'Over maatregelen ter wering der cholera', passim

46 Ali Cohen, 'Studiën over de chollera', 73-74

47 Schick, Over den gezondheidstoestand van 's-Gravenhage, 56

48 Schick, Over den gezondheidstoestand van 's-Gravenhage, 69

49 Penn, 'Over maatregelen ter wering der cholera', 391-392

$50 \mathrm{~J}$. Snow, On the mode of Communication of Cholera. Londen: 1849, besproken in: Brown, 'John Snow", 519 e.v.,en Barret, 'A tribute to John Snow', passim

$51 \mathrm{~W}$. Budd, Malignant cholera, its mode of propagation and its prevention. Londen: 1849 , besproken in: Brown, 'John Snow', 520-523.

52 Barret, 'A tribute to John Snow', 527-531; Brown, 'John Snow', 523-526

53 McDonald, 'History of quarantaine', 34; Raymakers, 'Ideeën over de besmettelijkheid', 42. Deze negatieve houding veranderde niet, nadat de Italiaan Pacini, hoogleraar in de anatomie en histologie in 1854 in zijn publikatie, getiteld Osservazioni microscopiche e deduzioni pathologiche sul colera asiatico (Florence, 1854), de pathofysiologische denkbeelden van Snow en Budd gedeeltelijk 
bevestigde. Hij wees de door hem beschreven 'vibrio cholera' als oorzaak van de cholera aan, maar kon het specifieke contagium niet isoleren en kweken. Aan de publicatie van Pacini werd nauwelijks aandacht besteed. Pacini kreeg pas enige bekendheid nadat Farr tegen het eind van de jaren zestig zijn vondst opnieuw onder de aandacht bracht. Hirsch (Herausg.), Bio.Lex.IV, 469-470 $54 \mathrm{M}$. von Pettenkofer, Untersuchungen und Beobachtungen uber die Verbreitungsart der Cholera, nebst Betrachtungen uber Maßregeln derselben Einhalt zu thun. München: 1855. Besproken in: Evans, 'Pettenkofer revisited', 172; De Bordes, Bespreking van Untersuchungen, 317-320

55 Uit een mededeling in het Nederlandsch Weekblad voor Geneeskundigen blijkt dat de levensverzekeringsmaatschappijen in Londen rekening hielden met de bodemgesteldheid: hoe hoger men in de stad woonde en hoe minder vervuild het grondwater was, des te lager was de premie die men moest betalen. Ned. Weekb. Geneesk 5 (1855) 44-45

$56 \mathrm{~K}$. Thiersch, Infectionsversuche an Thieren mit dem Inhalte des Choleradarmes. München: 1856. Besproken in: Raymakers, 'Ideeën over de besmettelijkheid', 39; zie ook Hirsch (Herausg.), Bio.Lex. V, 556

57 W. Griesinger, 'Infectionskrankheiten', in: Virchow (Herausg.), Handbuch der speziellen Pathologie und Therapie II (1857) $2^{e}$ Abt. Besproken in: Hirsch (Herausg.), Bio.Lex.II, 852

58 De Bordes, Bespreking van Untersuchungen, 317-320

59 De Bordes, 'Bijdragen tot de theorie van Professor Von Pettenkofer'; Zeeman, 'Pathologie der Cholera'

60 Ali Cohen, 'Gesteldheid van den bodem', 165

61 Ali Cohen, 'Gesteldheid van den bodem', 163

62 Zeeman, 'Geschiedenis van de cholera gedurende 1859', 704-705 en 714-715. Vrijwel nergens wordt door historici melding gemaakt van het feit dat medici een pragmatisch - zo men wil eclectisch - standpunt innamen in de 'Snow-Von Pettenkofer' controverse. Alleen Rosenberg vermeldt dit feit in een artikel over de cholera in de Verenigde Staten. Rosenberg, 'The cause of cholera', 349 e.v.

63 Degen, 'München als Tagungsort', 6

64 Van Geuns, 'Rapport Konstantinopel'; Kühler, Van Geuns, 11 en 119-120; Van Cappelle, 'Conferentie Konstantinopel'

65 Penn en Ali Cohen, 'Rapport betreffende de maatregelen tot wering der cholera'; tevens als bijlage IV opgenomen in: Van Cappelle e.a., De choleraepidemie

66 Penn en Ali Cohen, 'Rapport betreffende de maatregelen tot wering der cholera, 2

67 Penn en Ali Cohen, 'Rapport betreffende de maatregelen tot wering der cholera', 2. De adviezen van Penn en Ali Cohen waren grotendeels ontleend aan: W. Griesinger, M. von Pettenkofer, C.A. Wunderlich, Cholera-Regulativ. Den Sanitats-behörden, den Aerzten und den Publikum vorgelegt.München: 1866

68 Missive van de minister van Binnenlandsche Zaken, 23 april 1866, Staatscourant 25 april 1866

69 De bemoeienissen van minister Geertsema en zijn opvolger Heemskerk met de gemeentepolitiek beperkten zich tot verzending van voorlichtende circulaires. Verder verzocht de minister de katholieke gemeenschap de afgestorven choleraslachtoffers voorlopig niet in kerken op te baren. In 1867 werd de gemeentebesturen met het oog op de cholera verzocht, preventief sanitaire verbeteringen aan to brengen. Deze circulaires alsmede een overzicht van plaatselijke maatregelen in: Van Capelle e.a., De choleraepidemie, $399-420$ en bijlage XII; een overzicht van ministeriële en provinciale maatregelen in: Ali Cohen (red.), Handboek II, 413-415

70 Rapport over desinfectie met betrekking tot de cholera (1 jull 1866); tevens als bijlage VIII opgenomen in: Van Cappelle e.a., De choleraepidemie

71 Opmerkelijk is de aanbevolen gedragsregel met betrekking tot de stoffelijke overschotten. Zolang er geen doodskist was, moest men in de onmiddellijke omgeving van de overledene schoteltjes met chloorkalk en azijn plaatsen. Over het dode lichaam en op de bodem van de kist moest chloorkalk worden gestrooid. Van Cappelle e.a., De cholerdepidemie, LXXIII; Saltet, 'Ontsmettingen', 83

72 Bij KB van 17 april 1873 (Stb. 43) werd op grond van de epidemiewet van 1872 voorgeschreven dat privaten en riolen moesten worden ontsmet met behulp van carbolzuurmengsels, ijzervitriool, zwaveligzuurgas of plantaardige kool. Dit besluit bleef tot 1885 van kracht. Saltet, 'Ontsmettingen', 84

73 Ali Cohen (red.), Handboek $I I, 256$

74 'Ontwerp van wet tot intrekking der quarantainemaatregelen vervat in de publicatie van 10 januari 1805, 22 september 1863', Bijlagen Handelingen der Staten-Generaal 1863-1864,II, 104-105 75 Bijlagen Handelingen der Staten-Generaal 1863-1864, II, 472-474, 1168-1170; Handelingen der Staten-Generaal 1863-1864,II, 539-546 
76 Circulaire van 19 juni 1866 van den Minister van Binnenlandsche Zaken, in: Van Cappelle e.a., De choleraepidemie, bijlage $\mathrm{LX}$

77 De minister van Marine had nog wel in 1867 bepaald dat schepen, afkomstig uit de golf van Mexico en Noord-Afrika en schepen waarop zich pest, polkken, gele koorts of cholera had voorgedaan, in ieder geval gevisiteerd moesten worden. Bijwoegsel Stb. (1867) nr. 211

78 Wet van 28 maart 1877 , tot wering van besmetting door uit zee aankomende schepen (Stb.35). De Nederlandse bepalingen kwamen grotendeels overeen met die van de eerder in Engeland ingevoerde Sanitary Act (1866) en Local Government Act (1871). McDonald, "History of quarantaine', 36-38

79 Labruyère, Mulder, 26

80 Mulder, De Scheikundige middelen, 3-5

81 Mulder, De Scheikundige middelen, 14

82 Van Geuns, 'Rapport Konstantinopel'

$83 \mathrm{~KB} 16$ juli 1866, nr. 68 (Staatscourant 19 juli): Commissie tot onderzoek van drinkwater, in verband met de verspreiding van cholera en tot aanwijzing der middelen ter voorziening in zuiver drinkwater. Tot lid werden benoemd: de eertijds met de drooglegging van het Haarlemmermeer belaste ingenieur J.A. Beijerink (inspecteur waterstaat voor Utrecht, Noord- en Zuid-Holland en Zeeland), J.F. Boogaard (hoofd afdeling Waterstaat van Binnenlandse Zaken), H. van Cappelle (hoofd afdeling Medische Politie van Binnenlandse Zaken), L.J. Egeling (inspecteur Geneeskundig Staatstoezicht Zuid-Holland), A.W.M. van Hasselt (officier van gezondheid le klasse en docent Rijkskweekschool militair geneeskundigen), J.G. Jäger (lid van het bestuur van de duinwatermaatschappij te Amsterdam), L.Ch. Levoir (docent technische chemie an de Polytechnische School te Delft), de bekende geoloog en landbouwkundige W.C.H. Staring (inspecteur middelbaar onderwijs). Op 8 september werden daar nog aan toegevoegd: J.W. Gunning en P. Harting. Gunning was vanaf 1846 hoogleraar in de farmacologie en plantenfysiologie aan de faculteit Wisen Natuurkunde te Utrecht. Harting was oorspronkelijk geneeskundige. Hij had echter vooral naam gemaakt als geoloog en dier- en plantkundige. Hij genoot tevens grote bekendheid om zijn vernieuwingen op het terrein van het microscopisch onderzoek. Samenvattend kan men stellen dat de minister een bijzonder 'zware' commissie had ingesteld.

84 Mulder, De natuurkundige methode, 177

85 Rapport drinkwater, 99

86 Rapport drinkwater, 18, waar de commissie refereert aan: J. Simon, Ninth Report of the Medical Officer of the Privy Council. Londen: 1867

87 Rapport drinkwater, 30-33

88 Rapport drinkwater, 94-96 en bijlage XX

89 ARA: NMG, inv. nr. 12 (Notulen Hoofdbestuur NMG, juni 1869)

90 Pous Koolhaas, De waterleiding te 's-Gravenhage; De cholera, haar ontstaan; De waterleiding en de bodemverontreiniging; Ballot, 'Invloed van het drinkwater'; 'Het drinkwater in eenige onzer steden'; Voorstel tot den aanleg eener drinkwaterleiding; zie ook: Vogelzang, Drinkwatervoorziening,passim, voor de vele artikelen en brochures over drinkwater die in de jaren zestig en zeventig zijn verschenen.

91 Evans, 'Pettenkofer revisited', 170

92 Farr bracht bijvoorbeeld de eerder vermelde bevindingen van Pacini onder de aandacht van het medisch publiek, zij het vooralsnog zonder veel succes. Howard-Jones, 'Choleranomalies', 422-423

93 McDonald, 'History of quarantaine', 38

$94 \mathrm{Jacobi}$, 'Cholera in Noord-Holland', 129

95 Ali Cohen \& Zeeman, 'De invloed van woning, stand en algemeene maatregelen', 111

96 Ali Cohen \& Zeeman, 'De invloed van woning, stand en algemeene matregelen', 113

97 Stokvis, 'De cholera-sterfte bij de Israëlieten', 108

98 Van Cappelle e.a., De choleraepidemie, 383-384

99 Van Cappelle e.a., De choleraepidemie, 393

100 Van Cappelle e..., De choleraepidemie, 395

101 Bulloch, History of bacteriology, 188-192

102 Ackerknecht, Virchow, 90

103 Bulloch, History of bacteriology,96-105

104 Bulloch, History of bacteriology, 165

105 Bulloch, History of bacteriology, 79, 177-178, 184-185

106 De Knecht-van Eekelen, 'Berichten over bacteriologie', passim

107 Van Overbeek de Meijer, 'Algemeene beschouwing over den aard en de werking van smetstoffen', 210 
108 Van den Eerenbeemt, 'De "blauwe dood", 95

109 Koster, Bespreking van Die Niederen Pilze, 1-16; Koster, 'Het vraagstuk der specifieke bacteriën", 457-472

110 Bulloch, History of bacteriology, 297

111 De Knecht-van Eekelen, 'Abraham Pieter Folker', passim; Fokker, 'De beteekenis der organismen bij miltvuurinfectie', 709-716; Fokker, 'Een en ander over bacteriën', 453-460

$112 \mathrm{Kuhn}$, 'Morfologie der bacteriën', 705-706

113 Evans, 'Pettenkofer revisited', 174; Howard-Jones, 'Choleranomalies', 43

114 Ackerknecht, Virchow, 98-99

115 Howard-Jones, "Gelsenkirchen', 104

116 Howard-Jones, 'Gelsenkirchen', 105

117 Godefroi, 'Oud en nieuw uit de geschiedenis der geneeskunde', 1014-1017; De Knecht-van Eekelen, 'Abraham Pieter Fokker', 164-165

118 De Knecht-van Eekelen, 'Abraham Pieter Fokker', 168-170

119 Bijvoorbeeld: Van Overbeek de Meijer, 'Onderzoek en zaivering van drinkwater', 334-341 en 'Het vermogen der thans gebruikelijke gasvormige en vloeibare ontsmettingsmiddelen', 89

120 De nieuwe bacteriologische praktijk beperkte zich omstreeks 1890 tot het gebruik van ontsmettingsovens, waarin beddegoed en dergelijke kon worden gesteriliseerd. Saltet, 'Ontsmettingen', 8485

121 Van Overbeek de Meijer, 'Bacteriologisch onderzoek', 316

122 De Haan, 'Bacteriologische laboratoria', 110-115 


\section{Voorhelm Schneevoogt, De heerschende ziektegesteldheid te Amsterdam}

Het eerste verslag had betrekking op de jaren 1849-1851. De overzichten verschenen tot 1860 onder de titel Verslag over de ziekten, welke in her jaar ... binnen Amsterdam geheerscht hebben van de hand van achtereenvolgens De Bordes, Fuchs, Van der Voort, Van Cappelle, Merkus Doornik, G.H. Saltet, Fabius en Huet. In 1868 verscheen nog een verslag over de jaren 1860-1866, opgesteld door Wurfbain. Behalve deze artsen en de reeds genoemde Teixeira de Mattos, Zeeman, en Israèls, hebben tussen 1860 en 1900 L. Scheltema Beduin, J.G.M. Hanlo en Egeling de traditie van de jaarlijkse verslaglegging over de heersende ziekten levend gehouden. In 1894 riep de gemeente Amsterdam een statistisch bureau in het leven, dat een deel van hun werk overnam.

3 Sybrandi, 'Verslag omtrent de ziekten, welke in de jaren 1847 en 1848 in Nederland hebben geheerscht'. Onder dezelfde titel verschenen tot 1857 de verslagen over de jaren 1851-1854 in het tijdschrift van de NMG en de verslagen over de jaren $1855-1857$ in het Ned.Tijds. Geneesk. van 1858 en 1859 .

4 Tussen 1850 en 1859 hebben de Amsterdamse medici De Bordes, Sybrandi, Waardenburg en Merkus Doornik de verslagen van de landelijke NMG-commissie voor plaatsbeschrijvingen en volksziekten geschreven.

5 Sybrandi, 'Verslag omtrent de ziekten, welke in de jaren 1847 en 1848 in Nederland hebben geheerscht", 184

6 Anonymus, "Verslag wetenschappelijke sectie', passim

7 Evers, 'Programma commissie geneeskundige politie'

8 Israëls, 'Over de sterfte der kinderen in de drie eerste levensjaren'

9 Acker Stratingh, Keiser e.a., 'Bijdrage over de voedingsmiddelen'. De schrijvers hadden de consumptie van graanprodukten, vlees en drinkwater in de stad Groningen onderzocht en geconstateerd, dat de arbeidende stand minder vlees gebruikte dan vroeger, en over het algemeen verontreinigd grondwater moest drinken. $\mathrm{Zij}$ konden echter geen duidelijk verband tussen voeding en gemiddelde leeftijd aangeven.

10 E.C. Büchner was op dat moment voorzitter van de zojuist opgerichte historische en staatsgeneeskundige sectie van het Genootschap (5e sectie). Büchner koesterde grote sympathie voor Sarphati. Hij richtte in $\mathbf{1 8 5 2}$ de 'Vereeniging Salerno' voor verbetering van arbeiderswoningen op, waarvan hij tevens voorzitter werd. Büchner is vele jaren lid geweest van de Amsterdamse gemeenteraad en was sinds 1873 lid van de Eerste Kamer.

11 Penn, Bespreking van Bijdragen tot de statistiek, passim

12 De commissie voor geneeskundige statistiek van de Geneeskundige Kring bestond sinds november 1848. Behalve Zeeman, waren Israëls, B.J. Stokvis, en de aardrijkskundige I. Dorn Seiffen daarvan lid. Bibliotheek KNMG: Zeeman, Notulenboek commissie geneeskundige statistiek

13 Besproken in: Penn, Bespreking van Bijdragen tot de statistiek, 55 en Penn, 'Over maatregelen ter wering der cholera', 390-391

14 Büchner, 'Over den invloed der luchtgesteldheid'.

15 In 1857 verschenen de 'staten der sterfte' over de jaren 1854,1855 en 1856 in het tweede stuk van het tweede deel der Verhandelingen. De gegevens over 1857 verschenen in het derde stuk. Het vierde stuk uit 1862 bevatte cijfers voor de jaren 1858 en 1859 plus een vijfjarig overzicht over de jaren 1854-1859.

16 Israëls, 'De sterfte der kinderen in de eerste drie jaren cles levens'; Büchner, Zeeman en Teixeira de Mattos, 'Wekelijksche sterftestatistiek te Amsterdam, over de jaren 1853-1862, in verband met den stand van baro- en thermometer en den graad van vochtigheid'. Dit rapport werd besproken in de historische en staatsgeneeskundige sectie van het Genootschap terbevordering der Genees- en Heelkunde. Ik heb het rapport niet kunnen vinden en het is mij ook onbekend wat ervan geworden is. Coronel, 'Over het verhandelde in de 5de sectie', 377

17 Bleker, 'Die historische Pathologie', 44-46

18 Ackerknecht, Virchow, 39

19 Ackerknecht, Virchow, 38

20 Zo verdedigde Ramaer vooral de fysiologische geneeskunde. Ramaer keerde zich in zijn kritiek op het ontologisch ziektebegrip zelfs tegen het gebruik van het begrip 'ontsteking', omdat het teveel als een afzonderlijke ziekte werd gezien en geen enkele opheldering over de onderliggende patho- 
fysiologische processen gaf. Van Vondelen, 'Een heldere geest tussen krankzinnigenr', 56-66; zie verder: Ter Meulen en Widdershoven-Heerding, 'Het fysiologische ziektebegrip'; Hahneveld, 'Veranderingen in de pathologie" ; De Knecht-van Eekelen, 'Een fysiologische geneeskunde" 21 Ali Cohen (vert.), Choulant's Handboek, 2

22 Neurdenburg, Doodsoorzack en statistiek, 25-26; Van Dijk, 'Doodsoorzakenclassificaties' (1981), bijlagen $2.12-2.14$

23 Ned. Weekb. Geneesk I (1851) 18. Bibliotheek KNMG: Zeeman, Notulenboek commissie geneeskundige statistiek

24 Lewes, 'Marc d'Espines statistical nosology', passim

25 Neurdenburg, Doodsoorzaak en statistiek, 43-50; Van Dijk, 'Doodsoorzakenclassificaties'(1981), $17-19$

26 Op initiatief van Heije, die in $\mathbf{1 8 5 3}$ tot lid van de gemeenteraad van Amsterdam was gekozen, werd de geneeskundige armendienst in de hoofdstad in 1855 gereorganiseerd. Amsterdam werd verdeeld in twaalf, later achttien wijken. Voor de geneeskundige armenverzorging in elk van de wijken werden stadsdoctoren en verloskundigen aangesteld. Verder werden vier zogenaamde zittingslokalen (een soort poliklinieken) ingericht en contracten afgesloten met zes apothekers voor het verstrekken van geneesmiddelen en het zetten van lavementen. De dagelijkse leiding van de dienst berustte bij een gedelegeerde van de Plaatselijke Commissie van geneeskundig Toevoorzigt en de secretaris van de armendienst. De laatste was verplicht ieder jaar een rapport uit te brengen. Vanaf 1857 tot 1862 verscheen onder redactie van de toenmalige secretaris Teixeira de Mattos het Verslag omtrent den ziektetoestand der stad Amsterdam. Allema en Ringoir, Amsterdam zonder GG en $G D, 34-35$

27 De nieuwe indeling bleef tot 1867 van kracht. Neurdenburg, Doodsoorzaak en statistiek, 327-329; Van Dijk, 'Doodsoorzakenclassificaties' (1981), 20

28 Bibliotheek KNMG: Zeeman, Notulenboek commissie geneeskundige statistiek

29 Bijvoorbeeld: Schmidt, 'Beschouwingen over de waarneming van de constitutio epidemica'

30 Sybrandi, 'Verslag omtrent de ziekten, welke in 1853 in Nederland hebben geheerscht', 93

31 Het lukte na 1859 zelfs niet meer een jaarlijks verslag over de gezondheidstoestand van Amsterdam uit te brengen. Pas in 1868 verscheen weer een rapport van de commissie epidemiologie van de Geneeskundige Kring: C.L. Wurfbain, Verslag amtrent de ziekten, welke in de jaren 1860-1866 binnen Amsterdam geheerscht hebben. In hetzelfde jaar werd de commissie epidemiologie opgeheven. In 1871 verscheen nog één keer een verslag van de NMG-commissie voor volksziekten van de hand van Scheltema Beduin, secretaris van deze commissie. Daarin werd de gezondheidstoestand van Middelburg over de jaren 1848-1868 besproken en ook nog uitvoerig ingegaan op allerlei meteorologische waarnemingen. Scheltema Beduin, 'Middelburg', 357-386

32 'Handelingen dertiende Algemeene Vergadering', Ned.Tijds. Geneesk. 5 (1861) 533

33 Boogaard, 'Model en toelichting'

34 In de jaren 1863-1885 verzorgde Hanlo de berichtgeving over de sterfte in Amsterdam in het Ned.Tijds. Geneesk. Scheltema Beduin was in de jaren 1885-1892 daarvoor verantwoordelijk. Van 1869 af gaf Hanlo in dit tijdschrift regelmatig een overzicht van de sterfte in enkele grote gemeenten, ingedeeld naar leeftijd en de belangrijkste ziekten. Dit betekende nog niet dat er in Nederland van 1867 af een volledige uniformiteit in nomenclatuur bestond. Tot het eind van de negentiende eeuw kon deze per gemeente verschillen. Op international niveau werd een vergaande uniformering bereikt nadat $\mathrm{J}$. Bertillon, hoofd van de afdeling statistiek van de gemeente Parijs, in 1893 een ontwerp-lijst met doodsoorzaken bij het in Parijs in 1885 opgerichte 'Institut International de Statistique' had ingediend. Bertillon was van mening dat de doodsoorzaken moesten worden ingedeeld, 'd'apress leur siège et non pas d'apres leur nature'. Omstreeks de eeuwwisseling is de lijst van Bertillon, enigszins gereviseerd, in vrijwel geheel Europa en Noord- en Zuid-Amerika ingevoerd. Nadat in Nederland de registratie van de sterfte door het Centraal Bureau voor Statistiek was overgenomen (1900), werd ook hier de lijst van Bertillon ingevoerd. Neurdenburg, Doodsoorzaak en statistiek, 55-63; Van Dijk, 'Doodsoorzakenclassificaties' (1981), 21-22

35 De uitdrukking 'constitutio epidemica' bleef nog tot ver in de jaren zeventig in wetenschappelijke verhandelingen in gebruik. $\mathrm{Zij}$ hield toen niet meer in dan een eenvoudige weergave van het aantal ziekten per maand of per jaar.

36 Tot na 1900 bleef de belangstelling voor een klimatologisch gezonde omgeving (bossen, bergen, zee) groot, bijvoorbeeld in verband met de tuberculose. In de geschiedschrijving van ziekten stond na 1860 niet meer de historische veranderingen van de pathofysiologie der ziekten, maar de historie van ziekten in de belangstelling. Belangrijk in dit opzicht was de publikatie van A. Hirsch, Handbuch der historisch-geographischen Pathologie, uitgegeven in de jaren 1859-1864. Jusatz, 'Die Bedeutung der medizinischen Ortsbeschreibungen', 188. In Nederland legde vooral Israëls zich toe 
op de geschiedschrijving van ziekten. Een vorm van onderzoek dat met 'historische epidemiologie' kan worden angeduid. Israëls, 'Bijdragen tot de geschiedenis der lepra'; 'De geschiedenis der diphteritis'

37 CBS, Geschiedenis van de statistiek, 5-6

38 De Man, Over de statistiek der maandelijksche sterfte

39 Ali Cohen, Nieuw statistisch Geneeskundig Jaarboek(je), uitgegeven in de jaren 1847-1852

40 In 1857 gaf minister A.G.A. van Rappard de referendlaris Von Baumhauer de leiding over een nieuwe achtste afdeling Statistiek. Von Baumhauer was tot 1876 onder meer verantwoordelijk voor de bewerking en publicering van de uitkomsten van de tien-jaarlijkse volkstellingen.

41 CBS, Geschiedenis van de staristiek, 7-8

42 De Rijkscommissie en de Provinciale Bureaux voor Statistiek werden ingesteld bij KB van 5 november 1858 (Stb.76) Helaas besloot de Tweede Kamer in 1861 de Rijkscommissie uit bezuinigingsoverwegingen op te heffen, wama het tot het eind van de negentiende eeuw zou duren alvorens opnieuw een rijksinstelling voor de statistiek van enige omvang tot stand kwam. CBS, Geschiedenis van de statistiek, 17-20

43 Stamhuis, 'Cijfers en Aequaties', 187-188. Bijna veertig jaar moest de vereniging wachten op een goed uitgeruste overheidsinstelling voor de statistiek. In 1892 werd een Centrale Commissie voor de Statistiek opgericht. In $1899 \mathrm{kwam}$ het Centraal Bureau voor de Statistiek tot stand. Zoals gezegd, beschikte Binnenlandse Zaken sinds 1848 wel over een Bureau voor de Statistiek, in 1857 uitgebreid tot een afdeling, onder leiding van Von Baumhauer. Deze werd in 1876 opgevolgd door G. de Bosch Kemper. In 1878 werd de afdeling voor de statistiek weer opgeheven. Neurdenburg, Doodsoorzaak en statistiek, 338; CBS, Geschiedenis van de statistiek, 23-45

44 Staatkundig en staathuishoudkundig jaarboekje 18 (1866) V-X. Zie ook: Stamhuis, 'Ciffers en Aequaties', 198-201

$45 \mathrm{Lid}$ van de Rijkscommissie waren onder andere Zeeman en Van Cappelle. Ali Cohen was hoofd van het Provinciaal Bureau voor Statistiek in Groningen.

46 Gysel, 'Quetelet'; Stamhuis, 'Cîfers en Aequaties', 56-62; Taton (હ̊d.), Hist. générale des sciences III, vol. $I$, in het bijzonder 77-92

47 De congressen vonden plaats in Brussel (1853), Parijs (1855), Wenen (1857), Londen (1860), Berlijn (1863), Florence (1867), Den Haag (1869), Petersburg (1872) en Budapest (1876). Na 1878 werden de internationale contacten voortgezet in het kader van het 'Internationaal Demografisch Congres' (later 'Internationaal Demografisch en Hygiënisch Congres' geheten) en na 1885 op bijeenkomsten van het 'Institut International de Statistique'.

48 H.A. Wijnne, 'Statistische studiën over Nederland' (1856), geciteerd bij]: Stamhuis, 'The "Vereeniging voor de Statistiek", 74-75

$49 \mathrm{Zie}$ voor de betekenis van Quetelet voor de medische statistiek in internationaal verband: Rosen, 'Statistical analysis' en Ackerknecht, 'Quetelet and Villerme'

50 Metz meent dat het op de rekenkundige statistiek gebaseerde denken over causaliteit (waarschijnlijkheid) niet alleen het denken over volksziekten, maar de gehele geneeskunde diepgaand heeft beïnvloed. Hij ziet de geneeskundige statistiek als historische schakel tussen de traditionele, op de kunst en de ervaring gebaseerde medische kennis en het moderne, op de chemie en de microscopie gebaseerde concept van natuurwetenschappelijke geneeskunde. Metz, 'Social thought", 257

51 Penn, Bespreking van Bijdragen tot de statistiek, 53. Stamhuis concludeert dat de invloed van Quetelet in Nederland beperkt is gebleven en dat, anders dan Quetelet voorstond, in ons land geen integratie van de statistiek en de kanstheorie heeft plaatsgevonden. Zoals we zullen zien, geldt dit laatste ook voor de medische statistiek. Dit betekent dat de bewondering die Quetelet van de kant van geneeskundigen in Nederland ten deel viel, voor het onderzoek naar de volksgezondheid slechts in algemene zin consequenties heeft gehad; $1^{e}$ men erkende meer dan ooit de waarde van de statistiek voor het onderzoek naar de volksgezondheid; $2^{e}$ men ging er voortaan van uit dat met behulp van een uniforme, numerieke statistiek verbanden tussen ziekten en milieu-omstandigheden konden worden gelegd. Stamhuis, 'Ciifers en Alequaties', 231-232

52 Bijvoorbeeld in: Schick, 'Over de sterfteverhouding' en De Man, 'Bijdrage tot de kennis der sterfte in Zeeland'

53 Penn, Bespreking van Bijdragen tot de statistiek, 56-57

54 Zeeman, 'Verslag commissie statistiek' (1855)

55 Andere methoden om het probleem van ongelijk samengestelde populaties op te lossen, zoals de berekening van het relatieve risico of de levensverwachting en de indirecte standaardisering werden evenmin toegepast. 
56 Omdat men ook een direct verband vermoedde tussen het brutosterftecijfer en de geboortefrequentie, werd tevens de verhouding tussen beide berekend, uitgedrukt als 1 staat tot het aantal geboorten. De verhouding was in feite een maat voor het geboorte- of sterfte-overschot.

57 CBS, Gieschiedenis van de statistiek; 6-8, 64-70 en 94

$58 \mathrm{~KB} 19$ oktober 1849 (Stb. 55). In enkele provincies bestonden al sinds 1825 bevolkingsregisters. CBS, Geschiedenis van de statistiek, 81 en 84-85

59 Neurdenburg, Doodsoorzaak en statistiek, 25-26; Van Dijk, 'Doodsoorzakenclassificaties' (1981), 13-14

60 Neurdenburg, Doodsoorzaak en statistiek, 28

61 Artikel 4 van het Ontwerp van wet omtrent het begraven van lijken, de begraafplaatsen en de begrafeniskosten, 23 september 1858, Bijlagen Handelingen der Staten-Generaal 1858-1859, II, 134139. In dat jaar verzocht de Rijkscommissie voor de Statistiek, op initiatief van de lleden Zeeman en Van Cappelle, de Kamer met klem deze bepaling te aanvaarden. CBS, Geschiedenis van de statistiek, 14

62 Cappers, 'Op zoek naar zekerheid omtrent de dood', 105

63 Wet van 10 april 1869 , houdende bepalingen betrekkelijk het begraven van lijken, de begraafplaatsen en de begrafenisregten (Stb. 65). In geval van een gewelddadige dood of een besmettelijke ziekte werd een verklaring omtrent de doodsoorzaak geëist. Ook nu was een lijkschouwing niet verplicht.

64 Zeeman, 'Programma commissie geneeskundige statistiek'

65 Tijds.NMG 4 (1853) I, 52

66 Coleman, Death is a social disease, 182-187; Gysel, 'Quetelet', 650-652

67 Zeeman, Verslag commissie statistiek' (1854), 71

68 ARA: NMG, inv, $\mathrm{nr}$. 84. Resultaten van het onderzoek zijn te vinden in onder meer: 'Verslagen commissie statistiek', 1855-1859, opgesteld door achtereenvolgens Egeling, Zeeman, Egeling en Boogaard. Bijvoorbeeld: Egeling, 'Een vlugtige blik op de vrijstelling wegens Ligchaamsgebreken'; Zeeman, 'Rapport over lotelingen'

69 Zeeman, 'Rapport over lotelingen', 691

70 Zeernan, "Rapport over lotelingen', 712 e.v.

71 Boogaard, 'Bijdrage tot de militie-statistiek'; Zeeman, 'Verslag commissie van statistiek' (1868). Op 19 augustus 1861 werd een nieuwe Wet op de Nationale Militie van kracht (Stb.72), die onder meer de bekendmaking van de resultaten van de keuring der dienstplichtigen regelde. Tegen de uitdrukkelijke wens van Zeeman c.s. in werd ook de minimum-lengte der manschappen van $1.57 \mathrm{~m}$. naar $1.55 \mathrm{~m}$. verláagd. Vanaf 1863 werd voor iedere provincie de afloop van de keuring der nationale militie gepubliceerd in de Staatscourant en in de Statistische bescheiden van het Koninkrijk der Nederlanden, uitgegeven door het Departement van Binnenlandse Zaken (tot 1877). Tussen 1863-1878 verscheen in het Ned. Tijds. Geneesk. jaarlijks een overzicht van ziekten in het leger, opgesteld door de geneeskundig inspecteur van de landmacht. Vanaf 1879 werden deze overzichten afzonderlijk uitgegeven. CBS, Geschiedenis van de statistiek, 89 en 93. In 1891 publiceerde Scheltema Beduin als secretaris van de commissie voor de statistiek: 'De physieke en intellectueele
ontwikeling der militieplichtigen'

72 Schick, "Over de sterfteverhouding', 37

73 Dit schema zag er kort samengevat als volgt uit: A. Natuurlijke oorzaken. I Geografische ligging (hoog, laag, aan zee, meer of plas, overstromingen). II Atmosferische oorzaken (temperatuur, industrie). B. Maatschappelijke oorzaken. I Beschaving. II Wem (landbouw, veeteelt, veenderij, voeding, huisvesting)

74 De Man, 'Bijdrage tot de kennis der sterfte'

75 Schick, Over den gezondheidstoestand van 's-Gravenhage

76 Voorhellm Schneevoogt, Bespreking van Over den gezondheidstoestand van 's-Gravenhage,525

77 In 1849 werkten Evers en Zeeman met plattegronden van Den Haag, respectievelijk Amsterdam methode van het presenteren van bevindingen voor 1850 slechts op beperkte het overige werd deze 78 Ackerknecht, Virchow, 17 en 106-107

79 Tijds. NMG 3 (1852) I, 67

80 Acker Stratingh en Ali Cohen, 'Ontwerp van een plan voor eene geneeskundige plaatsbeschrij-
ving', Tijds. $N M G$. ving', Tijds. $N M G$ (1853) I, 236-243. Opmerkelijk is dat voor het eerst 'ziekten uit beroepen
ontstaande' bij het onderzoek werden betrokken.
81 De Rijkscommissie voor de

hoogleraar in de vergelijkende anatomie, geologie stond onder het voorzitterschap van de Leidse 
82 ARA: NMG, inv. nr. 89; NMG-tijds. 6 (1855) I, 27-30,46-48

83 Ali Cohen publiceerde na 1855 talrijke overzichten van verordeningen die in de provincies waren uitgevaardigd. Sinds 1854 was hij secretaris van de commissie voor de statistieke beschrijving der provincie Croningen, die hij in samenwerking met de Commissaris van de Koning voor de provincie Groningen, mr. I.A. van Royen, in het leven had geroepen. In deze functie nam hij de redactie van de Bijdragen tot de kennis der provincie Groningen voor zijn rekening. Voorts was Ali Cohen als medewerker voor de binnenlandse berichtgeving van het Ned. Tijds. Geneesk. verantwoordelijk voor de besprekingen van de gezondheidspolitiek in de Nederlandse gemeenten.

84 Fokker \& De Man, 'Proeve eener geneeskundige plaatsbeschrijving'

85 Stratingh, Groningen, Voorrede

86 Ali Cohen, 'Gesteldheid van den bodem', 164

87 De Man \& Fokker, 'De ziekenverpleging', 65

88 Coronel, Middelburg. Zie ook Bergink, Coronel, 78-82. De Wet op het armbestuur van 1854, tot stand gekomen onder minister Van Reenen, was gebaseerd op het beginsel dat de armenzorg tot de verantwoordelijkheid behoorde van particuliere, met name kerkelijke instellingen. Omdat de kerkelijke instanties in Middelburg en vaak ook elders de kosten van de armenzorg niet konden opbrengen, betekende de invoering van de Armenwet nogal eens een verlaging van het voorzieningenpeil. Coronel kreeg door zijn publikatie over Middelburg landelijke bekendheid. In 1860 besloot de NMG de leiding van een landelijk onderzoek naar de geneeskundige armenzorg in handen van Coronel te leggen. Het onderzoek mislukte echter wegens gebrek aan medewerking van de armbesturen.

89 Zeeman, 'De sterfte beschouwd in verband met rijkdom en armoede', 123. Zeeman baseerde zich hierbij op een statistisch onderzoek van M. d'Espine uit Genève, die op zijn beurt gebruik had gemaakt van studies van Villermé en Chadwick.

90 Zeeman, 'Geschiedenis van de cholera gedurende 1859'

91 Coll. Ali Cohen: Ali Cohen, Lezing over de geneeskunde (manuscript), 17

92 Tegenwoordig onderscheidt men sociale groepen aan de hand van criteria als de plaats in het produktieproces, de woonsituatie (huurbedrag, woningbezetting), het inkomen, en het opleidingsniveau.

93 Israëls, 'De sterfte der kinderen in de eerste drie jaren des levens'. De resultaten van een bescheiden onderzoek naar sterfteverschillen per sociale klasse waren een jaar tevoren door de arts K. Broes van Dort uit Goes bekend gemaakt. De sterfte onder armen in Goes bedroeg $4 \%$, die onder de 'min of meer gegoeden' 2,4\%. De gemiddelde leeftijd lag volgens Broes van Dort op 25,4 respectievelijk 31,7 jaar. Broes van Dort, Bijdrage tot de kennis van de sterfte, 36

94 Israëls, 'De sterfte der kinderen in de eerste drie jaren des levens', 289 . Deze indeling vond plaats op grond van 'locale kennis der verschillende buurten' en van gegevens van Teixeira de Mattos, secretaris van de geneeskundige armendienst.

95 Israëls, 'De sterfte der kinderen in de eerste drie jaren des levens', 294

96 Nieuwenhuys, Proeve eener geneeskundige plaatsbeschrijvingI, 5 en 288-305

97 Teixeira de Mattos, Verslag omtrent de ziektetoestand over 1860,182. Ook Coronel en Broes van Dort wezen in deze jaren op het gunstige effect van borstvoeding op de zuigelingensterfte.

98 Israëls, 'De sterfte der kinderen in de eerste drie jaren des levens', 294. Israëls en Teixeira de Mattos zagen dit gegeven overigens niet als een anomalie in de lokalistische theorie, aangezien pathogene invloeden vanuit de omgeving volgens hen pas effect op de mens sorteerden wanneer hij langere tijd op één en dezelfde plaats had gewoond. Zuigelingen waren nog te jong om de schadelijke gevolgen van die invloeden te ondergaan. Om dezelfde reden hield men altijd rekening met de migratie. De gezondheidstoestand van migranten beinvloedde immers de sterftecijfers van een buurt of stad, maar kon niet worden verklaard uit de plaatselijke gesteldheid van die buurt of stad, omdat de migranten daar nog maar een te korte tijd hadden gewoond.

99 In de jaren zestig en zeventig werden in populair-hygiënische tijdschriften, zoals de Schat der Gezondheid (1858-1864), Tijdschrift voor Gezondheidsleer (1867-1871) en De Gezondheid (18771881), de voordelen van borstvoeding in diverse toonaarden onder de aandacht van het publiek gebracht. In 1869 publiceerde M.J. Godefroi de resultaten van een onderzoek naar de kindersterfte in 's Hertogenbosch. Zijn conclusie was grotendeels gelijk aan die van Israēls, namelijk 'dat het contingent der overleden kinderen, voor bijna drie vierden geleverd wordt door de mindere klasse der maatschappij'. Oorzaken hiervan waren 'bedorven lucht, ongepast voedsel en lichamelijke verwaarlozing'. Godefroi, 'Kindersterfte te 's Hertogenbosch'. Zie ook: De Knecht-van Eekelen, Naar een rationele zuigelingenvoeding, in het bijzonder de hoofdstukken 8 en 9

100 Egeling, 'Gezondheidstoestand der stad Amsterdam', 582

101 Egeling, 'Gezondheidstoestand der stad Amsterdam', 585 
102 Egeling, 'Gezondheidstoestand der stad Amsterdam', 588

103 Egeling, 'Gezondheidstoestand der stad Amsterdam', 590. Egelings publikatie kreeg een vervolg in een artikel van Scheltema Beduin in 1868: 'Over de sterfte te Amsterdam, 1854-1865'

104 Naast de reeds genoemde publikaties over Amsterdam, verschenen na 1858 medische statistieken over Overijssel, Rotterdam, Drente, Zeeland, Goes, Hilversum, Middelburg, Groningen, Zaandam, Kampen, 's Hertogenbosch, Leeuwarden, Amhem en Den Haag.

105 'Handelingen dertiende Algemeene Vergadering', Ned.Tijs. Geneesk.5 (1861) 533

106 Geneeskundigen die nauw bij de totstandkoming van de topografie waren betrokken, waren Boogaard in Leiden, A. Meursinge in Leeuwarden, D. Cohen in Assen, M.J. Godefroi in 's Hertogenbosch en natuurlijk Zeeman en Ali Cohen.

107 Dit laatste werd aangegeven door het aantal kiezers van de gemeenteraad van 1860 en het bedrag in hoofdsom der persoonlijke belasting over 1859-1860.

108 In de eveneens door de Maatschappij in 1879 uitgegeven tweede sterfte-atlas over de jaren 1860-1871, waren gegevens over dichtheid en welvaartspeil van de bevolking weggelaten.

109 Coronel, 'De zorg voor gezonde woningen', 189

110 Coronel, 'De zorg voor gezonde woningen', 189

111 Coll. Ali Cohen: Ali Cohen, Lezing over de geneeskunde (manuscript), 17

112 Volgens Ali Cohen was de 'sterfteverhouding' in Amsterdam 1:28, in Zwolle 1:41, in Maastricht 1:41, enzovoorts. In Zeeland en Zuid-Holland stierf én op de drie kinderen beneden het jaar, terwijl de zuigelingensterfte in Friesland slechts één op de acht was. Coll. Ali Cohen: Ali Cohen, Lezing over de geneeskunde (manuscript), 16 
1 Van Isselmuiden, Binnenlandse Zaken, 118; ARA: KdK, inv. nr. 604. C.J. Loncq jr. was een bloedverwant van de Utrechtse hoogleraar in de geneeskunde G.J. Loncq.

2 Handelingen der Staten-Generaal 1851-1852, II, $320^{l}$

3 Handelingen der Staten-Generaal 1852-1853,11, 191-193 en $201^{5}$

4 Van de persoonlijke vijandschap tussen Thorbecke en Loncq wordt gewag gemaakt in een brief van de Haagse medicus Verwey aan Thorbecke, gedateerd op 16 februari 1859. ARA: Thorbecke, inv. nr. 70

5 ARA: Kabinet, inv. nrs. 82, 83, 86; ARA: Thorbecke, inv. nrs. 59, 61, 62, 63

6 ARA: Kabinet, inv. nr. 86; ARA: Thorbecke, inv. nr. 621

7 ARA: Kabinet, inv. nr. 86; ARA: Thorbecke, inv. nr. 63

8 Tijds. Gezondheidsregeling 1 (1853) 24

9 ARA: Kabinet, inv. nr. 82

10 ARA: Kabinet, inv. nr. 87: brief van Thorbecke aan Verwey, 13 januari 1853

11 Ministeriële circulaire, 14 januari $1853 \mathrm{in:}$ Bijvoegsel Stb.(1853) nr. 14. Tijds. Gezondheidsregeling 1 (1853) 24-26. Verscheidene gemeentebesturen hebben daarop verordeningen op het houdlen van honden uitgevaardigd.

12 Alle voorstellen van Verwey staan afgedrukt in het Tijds. Gezondheidsregeling

13 Geneesk. Courant 5 (1853) 9, 23 en 30 januari, 6, 13, 20 en 27 februari en 6 en 13 maart

14 ARA: Kabinet, inv. nr. 86 en Coll. Ali Cohen: brieven van Thorbecke aan Ali Cohen, 6 en 23 februari 1853. Van Schermbeek zou Thorbecke in de jaren vijftig nog enkele malen informeren over diens politieke tegenstanders in Utrecht, door Schermbeek de "aprilmannen" genoemd. ARA: Thorbecke, inv. nrs. 67 en 69

15 ARA: Thorbecke, inv. nr. 59; ARA: Medische Politie, inv. nrs. 3 en 10

16 ARA: Kabinet, inv. nr. 83; Coll. Ali Cohen: brief van 15 september 1852

17 Penn, 'Geneeskundige Staatsregeling I-VII'

18 Ali Cohen, 'Studiën over de cholera', 75-76

19 Ali Cohen, 'Studiën over de cholera', 76-77

20 Ali Cohen, 'Openbare gezondheidsregeling', 287 en 289

21. Ali Cohen, 'Openbare gezondheidsregeling', 275 en 297

22 Boogman, Rondom 1848, 129-130

23 Boogman, Rondom 1848, 135

24 Afgezien van de bepalingen in de Gemeentewet en de circullaire over de hondsdolheid, nam Thorbecke nog twee maatregelen met betrekking tot de volksgezondheid: het besluit van 2 april 1851, dat bepaalde dat het scheepsheelmeesterexamen gelijk moest zijn aan het examen voor stedelijk heelmeester; de instelling in 1852 van een staatscommissie die de invloed van de drooglegging van de Haarlemmermeer op de volksgezondheid moest bestuderen. Voorzilter van deze commissie was J. van Geuns. Kühler, Van Geuns, 11 en 34. Voorts kwam in juni 1852 een ontwerp-begrafeniswet tot stand, dat het koninklijk decreet van 1804 betreffende het begraven en de lijkbezorging moest vervangen.

25 ARA: Kabinet, inv. nr. 86: ontwerpen van wet, 29 augustus 1853. Het is overigens interessant om te zien dat zich in deze ontwerpen reeds de contouren wan het latere staatstoezicht aftekenen, terwijl nog geen afstand wordt genomen van de gedachte aan een streng politiëel overheidsapparaat voor de uitoefening der geneeskunst. Thorbecke zou, indien hij minister was gebleven, dit laatste zeker hebben afwezen.

26 Handelingen der Staten-Generaal 1853-1854,11, 235-236 en Bijlagen, 114.

27 Handelingen der Staten-Generaal 1854-1855,II, 238 en Bijlagen, 126

28. Labruyère, Mulder, 19

29 'Voorstel van de Heeren J. van Geuns, W. Vrolik, G.J. Mulder, en G. Simons betreffende de zorg voor den algemeenen gezondheidstoestand, als onderwerp van een opzettelijk onderzoek, aan 's Lands Regeering aan te bevelen'. In: Verslag Koninklijke Academie van Wetenschappen 1 (1853) 305 en 2 (1854) 4 e.v. Geciteerd bij Labruyère, Mulder, 126 en Ned.Weekb. Geneesk. 4 (1854) 17 en 77

30 Mulder kreeg in 1856 de kans om de ontwikkelingen in het onderwijs naar zijn hand te zetten, toen hem de leiding over de afdeling Onderwijs van Binnenlandse Zaken werd aangeboden. Hij zou dan verantwoordelijk worden voor een ontwerp lager onderwijswet, maar ook de door hem zo begeerde reorganisatie van het medisch onderwijs kunnen voorbereiden. Mulder weigerde echter in 
102 Egeling, 'Gezondheidstoestand der stad Amsterdam', 588

103 Egeling, 'Gezondheidstoestand der stad Amsterdam', 590. Egelings publikatie kreeg een vervolg in een artikel van Scheltema Beduin in 1868: 'Over de sterfte te Amsterdam, 1854-1865'

104 Naast de reeds genoemde publikaties over Amsterdam, verschenen na 1858 medische statistieken over Overijssel, Rotterdam, Drente, Zeeland, Goes, Hilversum, Middelburg, Groningen, Zaandam, Kampen, 's Hertogenbosch, Leeuwarden, Arnhem en Den Haag.

105 'Handelingen dertiende Algemeene Vergadering', Ned.Tijds. Geneesk. 5 (1861) 533

106 Geneeskundigen die naw bij de totstandkoming van de topografie waren betrokken, waren Boogaard in Leiden, A. Meursinge in Leeuwarden, D. Cohen in Assen, M.J. Godefroi in 's Hertogenbosch en natuurlijk Zeeman en Ali Cohen.

107 Dit laatste werd aangegeven door het aantal kiezers van de gemeenteraad van 1860 en het bedrag in hoofdsom der persoonlijke belasting over 1859-1860.

108 In de eveneens door de Maatschappij in 1879 uitgegeven tweede sterfte-atlas over de jaren 1860-1871, waren gegevens over dichtheid en welvaartspeil van de bevolking weggelaten.

109 Coronel, 'De zorg voor gezonde woningen', 189

110 Coronel, 'De zorg voor gezonde woningen", 189

111 Coll. Ali Cohen: Ali Cohen, Lezing over de geneeskunde (manuscript), 17

112 Volgens Ali Cohen was de 'sterfteverhouding' in Amsterdam 1:28, in Zwolle 1:41, in Maastricht $1: 41$, enzovoorts. In Zeeland en Zuid-Holland stierf én op de drie kinderen beneden het jaar, terwijl de zuigelingensterfte in Friesland slechts ến op de acht was. Coll. Ali Cohen: Ali Cohen, Lezing over de geneeskunde (manuscript), 16 
1 Van Isselmuiden, Binnenlandse Zaken, 118; ARA: KdK, inv. nr. 604. C.J. Loncq jr. was een bloedverwant van de Utrechtse hoogleraar in de geneeskunde G.J. Loncq.

2 Handelingen der Staten-Generaal 1851-1852, II, $320^{I}$

3 Handelingen der Staten-Generaal 1852-1853,II, 191-193 en $201^{5}$

4 Van de persoonlijke vijandschap tussen Thorbecke en Loncq wordt gewag gemaakt in een brief van de Haagse medicus Verwey aan Thorbecke, gedateerd op 16 februari 1859. ARA: Thorbecke, inv. nr. 70

5 ARA: Kabinet, inv. nrs. 82, 83, 86; ARA: Thorbecke, inv. nrs. 59, 61, 62, 63

6 ARA: Kabinet, inv. nr. 86; ARA: Thorbecke, inv. nr. 621

7 ARA: Kabinet, inv. nr. 86; ARA: Thorbecke, inv. nr. 63

8 Tijds. Gezondheidsregeling 1 (1853) 24

9 ARA: Kabinet, inv. nr. 82

10 ARA: Kabinet, inv. nr. 87: brief van Thorbecke aan Verwey, 13 januari 1853

11 Ministeriële circulaire, 14 januari 1853 in: Bijvoegsel Stb.(1853) nr. 14. Tijds. Gezondheidsregeling 1 (1853) 24-26. Verscheidene gemeentebesturen hebben daarop verordeningen op het houden van honden uitgevaardigd.

12 Alle voorstellen van Verwey staan afgedrukt in het Tijds. Gezondheidsregeling

13 Geneesk. Courant 5 (1853) 9, 23 en 30 januari, 6, 13, 20 en 27 februari en 6 en 13 maart

14 ARA: Kabinet, inv. nr. 86 en Coll. Ali Cohen: brieven van Thorbecke aan Ali Cohen, 6 en 23 februari 1853. Van Schermbeek zou Thorbecke in de jaren vijftig nog enkele malen informeren over diens politieke tegenstanders in Utrecht, door Schermbeek de 'aprilmannen' genoemd. ARA: Thorbecke, inv. nrs. 67 en 69

15 ARA: Thorbecke, inv. nr. 59; ARA: Medische Politie, inv. nrs. 3 en 10

16 ARA: Kabinet, inv. nr. 83; Coll. Ali Cohen: brief van 15 september 1852

17 Penn, 'Geneeskundige Staatsregeling I-VII'

18 Ali Cohen, 'Studiën over de cholera', 75-76

19 Ali Cohen, 'Studiën over de cholera', 76-77

20 Ali Cohen, 'Openbare gezondheidsregeling', 287 en 289

21 Ali Cohen, 'Openbare gezondheidsregeling', 275 en 297

22 Boogman, Rondom 1848, 129-130

23 Boogman, Rondom 1848, 135

24 Afgezien van de bepalingen in de Gemeentewet en de circulaire over de hondsdolheid, nam Thorbecke nog twee maatregelen met betrekking tot de volksgezondheid: het besluit van 2 april 1851, dat bepaalde dat het scheepsheelmeesterexamen gelijk moest zijn aan het examen vöor stedelijk heelmeester; de instelling in 1852 van een staatscommissie die de invloed van de drooglegging van de Haarlemmermeer op de volksgezondheid moest bestuderen. Voorzitter van deze commissie was J. van Geuns. Kühler, Van Geuns, 11 en 34. Voorts kwam in juni 1852 een ontwerp-begrafeniswet tot stand, dat het koninklijk decreet van 1804 betreffende het begraven en de lijkbezorging moest vervangen.

25 ARA: Kabinet, inv. nr. 86: ontwerpen van wet, 29 augustus 1853. Het is overigens interessant om te zien dat zich in deze ontwerpen reeds de contouren van het latere staatstoezicht aftekenen, terwijl nog geen afstand wordt genomen van de gedachte aan een streng politiëel overheidsapparaat voor de uitoefening der geneeskunst. Thorbecke zou, indien hij minister was gebleven, dit laatste zeker hebben afwezen.

26 Handelingen der Staten-Generaal 1853-1854,II, 235-236 en Bijlagen, 114.

27 Handelingen der Staten-Generaal 1854-1855,II, 238 en Bijlagen, 126

28 Labruyère, Mulder, 19

29 'Voorstel van de Heeren J. van Geuns, W. Vrolik, G.J. Mulder, en G. Simons betreffende de zorg voor den algemeenen gezondheidstoestand, als onderwerp van een opzettelijk onderzoek, aan 's Lands Regeering aan te bevelen'. In: Verslag Koninklijke Academie van Wetenschappen I (1853) 305 en 2 (1854) 4 e.v. Geciteerd bij Labruyère, Mulder, 126 en Ned. Weekb. Geneesk. 4 (1854) 17 en 77

30 Mulder kreeg in 1856 de kans om de ontwikkelingen in het onderwijs naar zijn hand te zetten, toen hem de leiding over de afdeling Onderwijs van Binnenlandse Zaken werd aangeboden. Hij zou dan verantwoordelijk worden voor een ontwerp lager onderwijswet, maar ook de door hem zo begeerde reorganisatie van het medisch onderwijs kunnen voorbereiden. Mulder weigerde echter in 
te gaan op het aanbod, omdat naar zijn mening voor deze functie juridische kennis vereist was. Boogman, Rondom 1848,162

31 In Brussel vond in 1851 op instigatie van het 'Conseil Superieur d'Hygiène' een hygiënisch congres met waarnemers uit andere landen plaats: het Congrès d'Hygiène publique. In aanwezigheid van de Belgische rechts-liberale minister van Binnenlandse Zaken Ch. Rogier werd daar besproken hoe men steden en plattelandsgemeenten 'gezonder kon maken' en welke wetgeving daarvoor was vereist. Het Brusselse congres kreeg in september 1852 een vervolg in een internationaal congres, waarbij vele vooraanstaande hygiënisten en medici uit Europa waren betrokken. Onder de aanwezigen bevonden zich bijvoorbeeld Chadwick, Quetelet, Magendie, Villermé, Varrentrapp en Boudin. Varrentrapp uit Frankfurt had al een lange staat van dienst op het gebied van gevangenishervormingen. Hij zou in 1873 met Von Pettenkofer de 'Deutsche Verein für öffentliche Gesundheitspflege' oprichten. Boudin was een invloedrijke Franse medisch-geograaf.

Nederland was ook vertegenwoordigd. Namens de NMG was Schick aanwezig en namens het Nederlandsch Weekblad woor Geneeskundigen Zeeman. Verder woonden mr. M.M. von Baumhauer van het Bureau voor Statistiek van het ministerie van Binnenlandse Zaken en mr. W. de Sitter, de latere burgemeester van Groningen, het congres bij. Schick en Zeeman waren diep onder de indruk van dit internationale treffen en deden na hun terugkomst in Nederland uitvoerig verslag. Ned. Weekb. Geneesk. 1 (1851) 357, 427, 437; Ned. Weekb.Geneesk. 2 (1852) 50. Schick, 'Rapport omtrent het Europeesch Congres'; Zeeman, 'Het Hygiènisch congres'

32 Egeling, Bespreking van Zeeman, De werkzaamheden van het hygiènisch congres te Brussel, 357

33 Ned. Weekb. Geneesk 4 (1854) 196 en 255

34 Ned. Weekb. Geneesk. 5 (1855) 189

35 Ned. Weekb. Geneesk 4 (1854) 371; Mulder, 'Voorstel tot oprigting eener gezondheidscommissie'; Bosschaert, Utrecht, 93-95

36 Ned. Weekb. Geneesk. 5 (1855) 40 en 130

37 Ned. Weekb. Geneesk. 4 (1854) 432-433

38 Ned. Weekb. Geneesk. 5 (1855) 510; Baart de la Faille, Advies Gezondheids-Commissie

39 'Ontwerp van wet tot instelling van Plaatselijke Raden van Gezondheid, 3 october 1854', Bijlagen Handelingen der Staten-Generaal 1854-1855, II, 69-72. Wintgens had een gunstig tijdstip voor zijn initiatief gekozen: het jaar tevoren had de koning het Koninklijk Instituut van Ingenieurs verzocht om 'de zaak der woningen van de arbeidende klasse tot onderwerp van gezette overweging te maken'. In 1855 - een jaar voor de plenaire behandeling van het ontwerp van Wintgens - bracht het K.I.V.I. haar rapport uit. Daarin werden erbarmelijke toestanden geconstateerd en werd gesteld dat wettelijke bepalingen nodig waren om de arbeiderswoningen en de gezondheidstoestand in het
algemeen te verbeteren. Lintsen, Ingenieurs, 318

40 Het Repertorium 8 (1855) 559-560 en 635-640

41 Handelingen der Staten-Generaal 1855-1856, II, 770-783

42 Handelingen der Staten-Generaal 1855-1856, II, 784-791.

in 1855 nog niet $7 \%$ van alle gemeenten in Nederland hebben getroffen. Ali Cohen tekende daarbij aan dat de verordeningen 'medisch-praktische' aard brood en op de hondsdolheid meer dan de helft van de verordeningen op de kwaliteit van het 'Staat van de verordeningen', 520-523

43 Ministeriële circulaire, 2 augustus 1856 in: Bijvoegsel Stb. (1856) nr. 167

44 Behalve in Rotterdam, Schiedam, Utrecht en Delft, bestonden er nu ook gezondheidscommissies

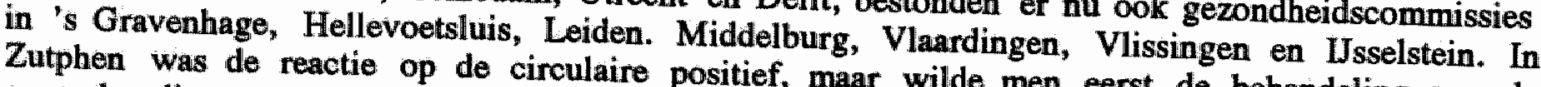
Zutphen was de reactie op de circulaire positief, maar wilde men eerst de behandeling van de
geneeskundige wetten in de Tweede Kamer afwachten. Toen uitbleven, stelde men in 1860 een gezondheidscommissie in. Terwachte geneeskundige wetten vertraging een commissie tot stand. In de gemeenten Amerongen, Amersfoort ook na enige Arnhem, Beerta, Deventer, Groningen, Haarlem, Leeuwarden, Nieuwe en Oude, Amsterdam, Winschoten, Wijk bij Duurstede en Zwolle werd het verzoek van de minister van de Pekela, Tiel, Egeling, 'Brieven van een geneesheer', 244; Ruitenbeek, 'Zutphen', 54-55 45 Egeling, 'Brieven van een geneesheer', 245

46 Egeling, 'Wat wij willen', 1-5

47 Bijvoorbeeld in Winschoten in 1862 en in Amsterdam in 1864. Ook in vele kleinere gemeenten was geen Plaatselijke Commissie van Toevoorzigt bestond, verschenen na 1860 gezondheidscomopenlijk verzette tegen het denkbeeld van de gezondheidscommissies én geneeskundige die zich Ned. Weekb. Geneesk. sprak hij direct na het initiatief in Rotterdam de wagrschus Penn. In het bestaan van gezondheidscommissies gevaarlijk kon in Rotterdam de waarschuwing uit dat het 
regering worden gebruikt om niets meer op landelijk niveau te regelen. De verwachting dat wanneer er overal gemeentelijke commissies zouden zijn, een landelijke regeling vanzelf zou volgen, achtte hij weinig reeel gezien de historische ontwikkelingen in het buitenland. De geschiedenis in Frankrijk, Engeland en België liet juist zien dat een centrale regeling dikwijls zeer moeizaam en veelal pas tientallen jaren na ontplooiing van de plaatselijke initiatieven tot stand was gekomen. Penn, 'De instelling eener gezondheidscommissie'

48 Een mooi voorbeeld van het gebruik van de eerder beschreven gezondheidsthermometer is te vinden in een brief van de Plaatselijke Commissie van geneeskundig Toevoorzigt in Rotterdam van 26 september 1856, gericht aan Burgemeester en Wethouders van de stad. Een vergelijking van de sterfte in Rotterdam in het jaar 1855 met die in voorgaande jaren, leerde dat de gezondheidstoestand in de stad achteruit was gegaan. Een vergelijking met de sterfte in andere steden maakte duidelijk dat Rotterdam één van de ongezondste steden van Nederland was. De commissie beëindigde har brief met de wens, dat 'bij het gemeentebestuur de onwrikbare overtuiging moge gevestigd worden, dat het kwaad zo spoedig mogelijk moet worden gestuit'. 'Brief van de Plaatselijke Commissie van geneeskundig Toevoorzigt, aan H.H. Burgemeester en Wethouders, over de sterfte binnen Rotterdam', 443-451

49 Ministeriële circulaire, 30 april 1857 (nr. 138), vermeld in: Ali Cohen (red.), Handboek I, 235

50 Vogelzang, Drinkwatervoorziening,79-80

51. Een samenvatting in: Ned.Weekb.Geneesk. 5 (1855) 189-190 en 196-200; Ned. Weekb.Geneesk. $\sigma$ (1856) $430-432$ en $440-442$

52 Meer informatie over de moeilijke omstandigheden waaronder de Plaatselijke Commissie van geneeskundig Toevoorzigt in Amsterdam moest werken, is te vinden in: Verdoorn, Het gezondheidswezen, 294-327

53 Eerenbeemt, 'Wat leidde tot de woningwet', 518. Tussen 1851 en 1860 bestonden circa tien verenigingen 'ter verbetering der woningen van de arbeidende klasse', die verspreid over het land jaarlijks enkele tientallen woningen met twee vertrekken, voorzien van een privaat, gootsteen en ijzeren ledikant lieten bouwen.

54 'Wetsontwerpen tot regeling van: 1. de uitoefening der geneeskunst; 2. de uitoefening der artsenijbereidkunst en den handel in geneesmiddelen en in heelkundige werktuigen; 3 . het geneeskundig bestuur; 4 . het onderzoek naar de bekwaamheid van aanstaande geneeskunstoefenaren en apothekers, 3 augustus $1857^{\prime}$. Bijlagen Handelingen der Staten-Generaal 1856-1857, II, 1269-1299. Deze ontwerpen kwamen niet in behandeling en werden in de nieuwe zitting opnieuw ingediend (24 september 1857).

55 Bijlagen Handelingen der Staten-Generaal 1857-1858,II, 890-916

56 Ali Cohen, 'Eenige opmerkingen'

57 Penn, 'Opmerkingen omtrent de wetsontwerpen', 656

58 Het belangrijkste succes van het kabinet was de totstandkoming van een nieuwe Wet op het Lager Onderwijs op 13 augustus 1857 (Stb. 103). In artikel 4 van deze wet werd bepaald dat districts-schoolopzieners lokalen, die 'schadelijk voor de gezondheid waren', konden afkeuren. Maatstaven voor dit laatste werden echter niet opgegeven. Verder was een pokkenbriefje voor schoolkinderen niet meer bij wet verplicht. Nadat de wet was ingevoerd, traden steeds meer artsen toe tot de provinciale en plaatselijke schoolcommissies die toezicht op het onderwijs en de schoolgebouwen moesten houden. Met succes pleitten zij voor gemeentelijke en provinciale verordeningen ter aanvulling van de gebrekkige hygiënische bepalingen in deze wet. Tussen 1859 en 1875 voorzagen de Gedeputeerde Staten van alle provincies de schoolopzieners van aanvullende reglementen. In de jaren zestig en zeventig gaven artikel 4 en de provinciale reglementen aanleiding tot vele publikaties van leraren, ingenieurs en medici over luchtbederf, verwarming, hygiëne, schoolbanken, verlichting en oogafwijkingen. Bijvoorbeeld Allebé en Van Cappelle, Gezondheidsvereischten van schoolgebouwen, bedoeld als handboek voor de schoolopzieners. Andere artsen die zich na 1860 veelvuldig met de schoolhygiëne hebben bezig gehouden, waren Pous Koolhaas en Coronel. Bergink, Schoolhygiène, 21 e.v.

59 'Wetsontwerpen tot regeling van: 1 . het geneeskundig bestuur; 2 . de uitoefening der geneeskunst; 3. de uitoefening der artsenijbereidkunst en het verkoopen van geneesmiddelen; 4 . het onderzoek naar de bekwaamheid van hen die verlangen te worden toegelaten als artsen, apothekers en vroedvrouwen, 2 februari 1859'. Bijlagen Handelingen der Staten-Generaal 1858-1859, II, 801$815,1305-1333$

60 Heije, 'Adres aan de Tweede Kamer', 147

$61 \mathrm{~KB} 30$ mei 1859 nr. 55 in: Staatscourant, 2 juni 1859; ARA: Kabinet, inv. nr. 102

62 Tijds. NMG 5 (1854) I, 126-127

63 Tijds.NMG 6 (1855) I, 46-48 
64 In een brief van 14 mei 1858, schreef Heije aan het kamerlid Thorbecke dat Loncq beslist moest worden vervangen, wilde het ooit tot een herziening van de geneeskundige wetten komen. Als opvolger van Loncq beval Heije Penn aan. ARA: Thorbecke, inv. nr. 69

65 Tijds. NMG 7 (1856) I, 185

66 Penn, "Opmerkingen omtrent de wetsontwerpen", 649-651

67 Festen, 125 jaar Geneeskunst, 136

68. Delprat, 'Geschiedenis der Nederlandsche geneeskundige tijdschriften III', 78-81

69 Nederlandsch Tijdschrift woor Geneeskunde, tevenss orgaan der Nederlandsche Maatschappij tot bevordering der Geneeskunst. Comité van redactie: C. Gobee, J. Penn, G.E. Voorhelm Schneevoogt, J.W.R. Tilanus, J. Zeeman. Penn werd gérant (secretaris, penningmeester en eindredacteur) van het tijdschrift.

70 Delprat, De geschiedenis van de eerste 50 jaren van het Nederlandsch Tijdschrift voor Geneeskunde, 34-35 
1 Ali Cohen, 'Voorloopige mededeeling betreffende het voorkomen van diphteritis' en Van Cappelle, 'Bijdrage tot de geschiedenis van diphteritis'

2 Ministeriële circulaire, 24 december 1859 in: Bijvoegsel Stb. (1859) nr. 358

3 Ali Cohen, Algemeene gezondheid

4 Het lijkt erop dat Roëll meer in het algemeen zijn samenwerking met de NMG geheim wilde houden. Ook Roëlls medewerking aan het onderzoek van Coronel naar de armenverpleging mocht kennelijk niet bekend worden. Dit blijkt uit het feit dat Roüll aan Penn liet weten bijzonder onaangenaam getroffen te zijn door openbare uitlatingen van Coronel over diens samenwerking met het ministerie, in casu Roell. Roëlls ergenis was gewelkt, to meer daar de inrichting van de armenzorg politiek nog altijd zeer gevoelig lag. Bibliotheek KNMG: Stukken betreffende de wording van Wet: brief van Roëll aan Penn, 27 juni 1861

5 De stukken laten tegengestelde opvattingen zien van Heije en Donders inzake de eenheid van stand. Donders wees de gedachte af, dat niet alleen de studenten van de klinische scholen, maar ook die van de universiteiten een staatsexamen moesten afleggen, alvorens tot de praktijk te worden toegelaten. Donders was hiermee teruggekomen op zijn in 1857 ingenomen standpunt. Hij toonde zich nu voorstander van handhaving van de scheiding tussen gegradueerden en nietgegradueerden: medicinae doctores respectievelijk geneeskundigen met een staatsexamen. Heije daarentegen vreesde juist dat Roëll en Penn toch weer een stand van 'geneesmeesters' wilden handhaven, waaraan minder bevoegdheden zouden worden gegeven dan aan de gegradueerden. Roëll en Penn zochten telkens het compromis. Bibliotheek KNMG: Stukken betreffende de wording van Wet: brieven van Roëll aan Penn, 4 en 10 januari 1860

6 Bibliotheek KNMG: Stukken betreffende de wording van Wet. Ontwerpen van wet betreffende de uitoefening der geneeskunst en der artsenijbereidkunst bevinden zich ook onder deze stukken. Ik heb ze echter niet kunnen identificeren als werkstukken van Roëll en Penn uit 1860.

7 Bibliotheek KNMG: Stukken betreffende de wording van Wet: brief van Roëll aan Penn, 21 september 1861

8 Heije, 'Adres aan de Tweede Kamer', 145-149

9 In 1862 werd bovendien Evers, die op goede voet met Thorbecke stond, voorzitter van de Maatschappij.

10 Mogelijk heeft ook nog het kamerlid mr. M.H. Godefroi een rol gespeeld. Bibliotheek KNMG: Stukken betreffende de wording van Wet: brief van Roëll aan Penn, 4 januari 1860

11 ARA: Kabinet, inv. nrs. 117 en 118

12 'Wetsontwerpen tot regeling: 1. van het geneeskundig staatstoezigt; 2. der voorwaarden ter verkrijging der bevoegdheid van geneeskundige, apotheker, hulpapotheker en vroedvrouw; 3 . der uitoefening van de geneeskunst; 4. van de uitoefening der artsenijbereidkunst'. Bijlagen Handelingen der Staten-Generaal 1861-1862, II, 966-978. De ontwerpen werden niet meer in behandeling genomen en op 18 september 1862 opnieuw aangeboden. Over de in september 1862 ingediende wetsontwerpen werd door de rapporteurs der Tweede Kamer (betrokken bij de voorbehandeling) op 20 maart 1863 voorlopig verslag uitgebracht. Daarop volgde een nieuwe aanbieding van de wetsontwerpen in oktober 1863 met een nieuwe Memorie van Toelichting. In februari 1864 werd het tweede verslag van de rapporteurs uitgebracht. Dit leidde tot een verdere wijziging van de wetsontwerpen. Tijdens de slotbehandeling in maart 1865 bracht Thorbecke voor de derde maal wijzigingen in de wetsontwerpen aan. ARA: Medische Politie, inv. nrs. 46, 48, 49 53, 54: brieven en stukken betreffende de geneeskundige wetten, 1862-1865. Zie voor de memories van toelichting, de verslagen der rapporteurs, de memories van antwoord en het plenaire kamerdebat: Opwijrda, Geneeskundige wetten en Verwey, De geneeskundige wetgeving

13 Kerkhoff, 'Over de verhouding tussen gerechtelijke geneeskunde en openbare gezondheidsregeling', 14-15

14 Verkade, Overzicht der staatkundige denkbeelden van Thorbecke, 138-139

15 Verkade, Overzicht der staatkundige denkbeelden van Thobecke, 142-143

16 Opwijrda, Geneeskundige wetten, 63

17 Verkade, Overzicht der staatkundige denkbeelden wan Thorbecke, 269-270

18 Verkade, Overzicht der staatkundige denkbeelden van Thorbecke, 272

19 Opwijrda, Geneeskundige wetten, 103 en 118

20 Een algehele opheffing van de klinische scholen zou overigens niet alleen een vergroting van de opleidingscapaciteit van de faculteiten hebben vereist. Ook de toelatingseisen voor de medische 
faculteiten zouden moeten worden versoepeld. Het grootste deel van de medische studenten beschikte op dat moment immers niet over de vereiste gymnasiale vooropleiding. Toelating van studenten zonder gymnasiale opleiding zou volgens de hoogleraren het universitaire karakter van het onderwijs aan de medische faculteiten ernstig in gevaar brengen.

21 ARA: NMG, inv, nr. 12

22 Ned. Tijds, Geneesk. 6 (1862) 409-412,418, 449-455

23 Ned.Tijs. Geneesk 6 (1862) 419-421

24 Voor een samenvatting van en commentaar op de in 1862 verschenen adressen, artikelen en brochures, zie: Ali Cohen: 'Overzigt van den hoofdinhoud der adressen enz.' en 'Korte beoordeling' 25 Voor een meer gedetailleerde beschrijving van de gebeurtenissen, zie: Festen, 125 jaar Geneeskunst, 138-144; Klinkert, Verloskundigen en artsen, 38-58; Van Lieburg, 'De tweede geneeskundige stand", 450-453

26 ARA: NMG, inv, nrs. 78, 86, 110. Ali Cohen werd uit zijn functie van secretaris van de NMGafdeling Groningen gezet. Volgens de hoogleraren Van Deen en Baart de la Faille zou Ali Cohen buiten hun medeweten en van de overige leden van de afdeling een adhesiebetuiging namens de afdeling naar Zeeman hebben verstuurd.

27 Klinkert, Verloskundigen en artsen, 53

28 Opwijrda, Geneeskundige wetten, 295 e.v.

29 De Utrechtse hoogleraar in de heelkunde L.C. van Goudoever, die in 1865 voorzitter was, weigerde zijn handtekening onder een tweede adhesiebetuiging te plaatsen. Toen de overige leden van het bestuur voet bij stuk hielden en toch een adres met een positief oordeel naar de Tweede Kamer zonden, nam Van Goudoever tot grote ergernis van Voorhelm Schneevoogt ontslag als voorzitter. ARA: NMG, inv. nr.12

\section{Opwijrda, Geneeskundige wetten, 105}

31 Opwijrda, Geneeskundige wetten, 101. Deze opmerking van Thorbecke was maar ten dele juist. De minister ging namelijk voorbij aan het feit, dat ook in Engeland in de jaren veertig een heftige politieke strijd was gevoerd tussen sanitaire hervormers die een landelijke gezondheidswet voorstonden, en regering en parlement die het lokaal zelfbestuur en het privé-eigendom niet wilden aantasten ('War of the clean and dirty parties'). Dat de Engelse hervormers het uiteindelijk wonnen in 1848 was voornamelijk te danken aan de sociale en politieke agitatie van de Chartisten. Metz, 'Social thought', 270

32. Opwijrda, Geneeskundige wetten, 102

33 Opwijrda, Geneeskundige wetien, 60

34 Opwijrda, Geneeskundig wetten, 101

35 Verkade, Overzicht der staatkundige denkbeelden van Thorbecke, 33-38, 323-324

36 Verkade, Overzich der staatkundige denkbeelden van Thorbecke, 258

37 Opwijrda, Geneeskundige wetten, 91-92

38 Opwijrda, Geneeskundige wetten, 145 e.v. en 163 e.v.

39 Opwijirda, Geneeskundige wetten, 75

40 Opwijrda, Geneeskundige wetten, 189

41 Opwijrda, Geneeskundige wetten, 103

42 Opwijrda, Geneeskundige wetten, 112

43 Opwijrda, Geneeskundige wetten, 110.

44 Opwijrda, Geneeskundige wetten, 217

45 Met de invoering van de Wet tot regelling van het Hooger Onderwijs van 28 april 1876 (Stb. 102) vond een definitieve regeling van de opleiding tot geneeskundige plaats. Aan de gemeente Amsterdam werd toegestaan het Athenaeum Illustre tot universiteit in te richten.

46 Van Lieburg, 'De tweede geneeskundige stand', 448. Bovendien trok een groot aantal oudgedienden in de NMG zich terug uit bestuursfuncties. Velen van hen verlegden hun werkzaamheden naar het Staatstoezicht. Voorhelm Schneevoogt besteedde de laatste jaren van zijn leven aan de neuropathologie en het krankzinnigenwezen en leidde een enigszins teruggetrokken bestaan. Evers was al in 1864 door Thorbecke overgehaald het ambt van hoogleraar in de pathologie te Leiden te aanvaarden. Israels werd in 1867 benoemd tot de eerste hoogleraar in de openbare hygiëne en de geschiedenis der geneeskunde te Amsterdam. Zeeman trad in 1867 af als secretaris van de NMG. Heije had zich reeds in 1862 teruggetrokken.

47 Sikkel, 'Het ontstaan der Maatschappij', 1103 e.v.

$48 \mathrm{Te}$ denken valt aan het verstrekken van vergunningen tot vestiging als arts, de visitatie van apotheken, het verbieden van de verkoop van 'geheime geneesmiddelen', de gerechtelijke vervolging van onbevoegden, het verbeterde toezicht op de koepokinenting, het toezicht op de overlijdensverklaringen, de standaardisering van de vermelding der doodsoorzaken en de invoering 
van een nieuwe landelijke farmacopee. Nader onderzoek zal moeten leren of en in welke mate het Staatstoezicht er in is geslaagd alle nieuwe bepalingen werkelijk op te leggen aan de medische beroepsgroep, de apothekersstand en degenen die onbevoegd de geneeskunst uitoefenden of in geneesmiddelen handelden. 
1 Mulder, Adres, $22-23$

2 Ali Cohen, 'Een viertal adviezen', 513-515

3 Van TJselmuiden, Binnenlandse Zaken, 125-128

4 Coronel, secretaris geneeskundige raad Groningen-Friesland; Teixeira de Mattos, secretaris geneeskundige raad Noord-Holland; Pous Koolhaas, secretaris geneeskundige raad Zuid-Holland. Zie voor verdere gegevens over de personeelsbezetting van het Staatstoezicht: Querido, Een eeuw Staatstoezicht, 252-295 en de Verslagen aan den Koning van de bevindingen en handelingen van hes Geneeskundig Staatstoezigt

5 Hejje werd in 1853 lid van de Amsterdamse gemeenteraad, maar werd door verzet uit conservatieve kring in 1857 niet herkozen. In Groningen trad Baart de la Faille in 1853 tot de gemeenteraad toe. Ali Cohen daarentegen stelde zich vanaf 1851 iedere twee jaar zonder succes kandidaat. Hij werd pas in 1864 gekozen. De hoogleraar Mulder was in de jaren vijftig voornamelijk op grond van zijn conservatieve politieke denkbeelden lid van de Utrechtse gemeenteraad. Propaganda voor kandidaten die zich hadden ingespannen voor de gezondheid van de stad Utrecht bleef bij de gemeenteraadsverkiezingen van 1867 zonder resultaat. Bosschaert, Utrecht, 96. In Dordrecht duurde het tot 1863 voordat een bekende hygiënist in de gemeenteraad werd gekozen. Olvers, Dordrecht, 30-39. In de periode 1860-1880 werden onder anderen de volgende hygiënisten tot lid van een gemeenteraad gekozen: Penn, Allebe, Van Cappelle, en C.E. Heynsius te Amsterdam, die van 1874-1877 wethouder van openbare werken was, Ali Cohen in Groningen, Schermbeek in Utrecht, Delhez in Dordrecht, Maas in Schiedam, Evers in Leiden, Ballot in Rotterdam, Luyten in Gouda, Haakma Tresling in Winschoten.

6 Wet van 10 april 1869 (Stb. 65), houdende bepalingen betrekkelijk het begraven van lijken, de begraafplaatsen en de begrafenisregten. Alle begraafplaatsen kwamen onder toezicht van burgemeester en wethouders. Binnen vijftig meter afstand van een begraafplaats mochten geen gebouwen worden opgericht of putten gegraven. Iedere gemeente diende ten minste én algemene begraafplaats te hebben. De behandelend geneesheer van de overledene was verplicht een verklaring over de doodsoorzaak op te geven.

7 Een ontwerp van wet tot regeling van het veeartsenijkundig staatstoezicht en de veeartsenijkundige politie was al in 1868 door minister Heemskerk bij de Tweede Kamer ingediend, maar in verband met de val van het kabinet in hetzelfde jaar weer ingetrokken. Bijlagen Handelingen der Staten-Generaal, 1867-1868, II, 578-587. In het wetsontwerp van minister Fock, ingediend op 20 december 1868, ontbraken de in het eerste ontwerp opgenomen bepalingen omtrent het keuren van vlees voor de consumptie die door geneeskundigen sinds de jaren veertig vurig waren bepleit (een wet op de vleeskeuring kwam pas in 1919 tot stand). Bijlagen Handelingen der Staten-Generaal, II, 793-798. De Wet op het Veeartsenijkundig Staatstoezicht (Stb. 131) zou samen met de Wet van 8 juli 1874, regelende de uitoefening der veeartsenijkunst (Stb. 98), de Wet van 5 juni 1875, met bepalingen ter voorkoming van hondsdolheid $(S t b .110)$ en de Wet op de longziekten onder het rundvee (1878) een redelijk goed veeartsenijkundig staatstoezicht tot stand brengen. Bosman e.a. (red.), 'De veeartsenijkunde', passim. Hont, 'Abattoirs', 174-179; Vervoorn, Wergeving dierziektenbestrijding, passim

8 Querido, Een eeuw Staatstoezicht, 113

9 Verslag Staatstoezigt (1867), 18 en 200-202

10 Verslagen Staatstoezigt (1867), 14-27; (1868) 28-33; (1869) 33, 74, 89, 97, 106, 112-115 en 312; (1870) $10-12$; (1871) 29

11 Bijdragen tot de geneeskundige plaatsbeschrijving wan Nederland: A.A. Fokker, J.C. De Man en Berdenis Berlekom, Natuurkundige plaatsbeschrijving van Zeeland (1870); J.J. Bruinsma, De natuurkundige plaatsbeschrijving van Friesland (1872); H. van Hengel, Geneeskundige plaatsbeschrijving van het Gooiland (1875); D. Lubach, Natuurkundige plaatsbeschrijving van Overijssel (1875); J.J. Willems, Natuurkundige plaatsbeschrijving van Limburg (1881)

12 In de Verslagen Staatstoezigt, 1867-1872, wordt melding gemaakt van topografieên van onder andere West-Friesland, Wieringermeer, Terschelling, Vlielland, Edam, Alkmaar en omgeving, Haarlem, Meppel en meerdere plaatsen in Utrecht en Gelderland. Deze beschrijvingen zijn nooit door het Staatstoezicht uitgegeven. Mij is niet bekend of zij elders zijn verschenen.

13 De opkomst van de geografie en de demografie als zelfstandige vakgebieden na omstreeks 1870 maakte zulk onderzoek van geneeskundigen trouwens gaandeweg overbodig. CBS, Geschiedenis van
de statistiek, 22 e.v. 
14 Polijn Būchner, 'De gezondheidstoestand van Kampen'; Asman, 'Proeve eener geneeskundige plaatsbeschrijving van Leeuwarden'; Hanegraaf, Sterfte-statistiek van Arnhem; Kooperberg, Geneeskundige plaatsbeschrijvin van Leeuwarden; Egeling en Pareau, Sterfteciffers van 's-Gravenhage

15 In het mavolgende beperk ik me tot het noemen van enkele belangrijke publicaties en een aantal algemene kenmerken van de medische statistiek. Een gedetailleerde bespreking van de resultaten van het statistisch onderzoek tussen $1865-1900$ is te vinden bij: Van Poppel, 'Sociale ongelijkheid'. De na 1865 sterk verbeterde statistiek van het aantal vaccinaties en de beofenaars der geneeskunst en de toepassing van de statistiek in de ziekenhuizen laat ik buiten beschouwing.

16 Van Overbeek de Meijer \& Carsten, De Pokken-epidemie. Voor de cholera, zie hoofdstuk 4. Tot 1869 bewerkten de inspecteurs de sterftecijfers zelf. Daarna viel de bewerking van gegevens grotendeels onder de verantwoordelijkheid van de afdeling Statistiek van Binnenlandse Zaken.

17 CBS, Geschiedenis van de statistiek, 90-92

18 De tweede sterfte-atlas was in opzet gelijk aan de eerste, maar bevatte geen gegevens meer over dichtheid en welvaart der bevolking. Ondanks verzoeken daartoe, werd ook deze atlas niet door Binnenlandse Zaken bekostigd. Sterfte-kaarten over de jaren 1875-11889 verschenen wel op kosten van Binnenlandse Zaken in 1895. Sterfte-atlas van Nederland over 1860-1874; CBS, Geschiedenis van de statistiek, 92

19 Hanlo verzorgde het jaarverslag van de sterfte in Amsterdam tot aan 1887. Verder gaf hij samenvattingen van de mortaliteitsgegevens per provincie tot aan 1887. Egeling publiceerde zulke samenvattingen met betrekking tot veertien grotere steden tot aan 1891. Ali Cohen berichtte een enkele keer over de sterfte in Groningen. Vanaf 1866 verscheen tevens een groot aantal opgaven van de mortaliteit in Engelse, Franse en Duitse steden. Deze opgaven werden soms met elkaar en met Amsterdamse gegevens vergeleken.

20 Scheltema Beduin publiceerde in 1868 een vervolgstudie op het eerder besproken onderzoek van Egeling naar de sterfte in Amsterdam: Scheltema Beduin, 'Over de sterfte te Amsterdam'

21 Onnen, 'Onderzoek'; De Man, 'De afname der sterfte'; Carsten, 'Invloed van hygiënische maatregelen'; Carsten, 'Verbetering van den gezondheidstoestand'

22 Nadat Korösy zijn methode voor het Internationaal Statistisch Congres in 1876 had uiteengezet, werd deze in verscheidene Europese landen overgenomen. Korösy had in dat jaar grote Europese steden demografisch bewerkt. Hierbij gebruikte hij een standaardpopulatie bestaande uit vijf leeftijdsgroepen: jonger dan 1 jaar, 1-19 jaar, 20-39 jaar, $40-59$ jaar en ouder dan 60 jaar. J. Korösy, Welche Unterlagen hat die Statistik zu beschaffen um richtige Mortalitats-tabellen zu gewinnen?, Budapest: 1876; Statistique internationale des grandes villes, Budapest-Parijs: 1877. CBS, Geschiedenis van de statistiek, 46. Zeeman, 'Sterftestatistiek', 183. Saltet, Voordrachten, 58-62

23 Onnen, 'Onderzoek', 711

24 Ali Cohen, 'Rangorde van de voornaamste steden'

25 Carsten, 'Verbetering van den gezondheidstoestand'

26 Van Overbeek de Meijer, 'Verbetering van den gezondheidstoestand'

27 Bij de samenstelling van het Handboek stelde Ali Cohen zich het door de Duitse hygiënist L. Pappenheim uitgegeven Handbuch der Sanitdts-Polizey. Nach eigenen Untersuchungen bearbeitet, 3 Bd. Berlijn, 1858-1864, ten voorbeeld.

$28 \mathrm{Na} 1866$ vonden op initiatief van gemeentebesturen of particulieren kleine verbeteringen plaats: bevordering van de doorstroming van grachten, het plaatsen van grote regenbakken bij overheidsen kerkgebouwen, verkoop van water via waterwagens, de aanleg van 'standpijpen' in de armenbuurten, door de gemeente gesubsidieerde verstrekking van emmers water. Zoals eerder vermeld, beschikten Amsterdam en Haarlem al in 1853 over een drinkwaterleiding. In 1868 waren in Amsterdam 10.000woonhuizen en een groot aantal fabrieken, brouwerijen en openbare instellingen aangesloten. De leiding voorzag ook waterverkopers van water. Vogelzang, Drinkwatervoorziening, passim

29 Een bespreking van deze problemen is te vinden in hoofdstuk $\mathrm{V}$ van het Rapport drinkwater van de staatscommisie voor onderzoek van drinkwater.

30 In 1869 besloot de gemeenteraad van Rotterdam tot de anleg van een drinkwaterleiding. Door de lozing van faecale stoffen op de Maas sinds 1863, was het Maaswater minder geschikt voor consumptie geworden. De leiding kwam in 1874 gereed voor de buitenwijken waar de beter gesitueerden woonden. In Den Haag kwam in 1874 het eerste stuk van de drinkwaterleiding gereed. In deze plaatsen kon relatief gemakkelijk een leiding worden aangellegd. Leiden en Nijmegen volgden in 1878 en 1879. In Utrecht werd in 1868 en nog eens in 1876 de aanleg van een leiding afgewezen. Vogelzang, Drinkwatervoorziening,80-81, 163-166; Bosschaert, Utrecht, 110-111

31 Regionale drinkwaterprojecten werden pas mogelijk toen de overheid in 1909 subsidies ging verstrekken. In hetzelfde jaar werd een staatscommissie voor de drinkwatervoorziening ingesteld. 
Deze commissie werd sinds 1910 bijgestaan door het Rijksbureau voor de Drinkwatervoorziening, het latere Rijksinstituut voor de Drinkwatervoorziening. Halbertsma, 'Historische schets drinkwaterleidingen', 161-162; Vogelzang, Drinkwaterwooniening,4-5

32 Ali Cohen, 'Waterbederf' I (1871), II (1872), III (1874), IV (1881)

$33 \mathrm{~KB} 31$ januari 1824 , rakende de vergunning ter oprichting van sommige fabrijken en trafijken (Stb. 19); KB 26 september 1833, betreffende het toezigt op de stoomtoestellen (Stb. 58)

34 Wet van 2 juni 1875 , tot regeling van het toezigt bij het oprigten van inrigtingen, welke gevaar, schade of hinder kunnen veroorzaken (Stb. 95). Deze wet is tot 1952 van kracht gebleven.

35 Het gemeentebestuur kon bijvoorbeeld op grond van de Hinderwet het slachten van vee alleen in een openbaar slachthuis laten plaatsvinden. Van deze mogelijkheid werd vór 1900 alleen in Amsterdam en Rotterdam gebruik gemaakt. Hont, 'Abattoirs', 175-176

36 Op 28 juni $1876 \mathrm{kwam}$ nog tot stand de Wet, houdende maatregelen tegen het gevaar, hetwelk door den in-, door- en vervoer van vergiftigde stoffen kan ontstaan (Stb.150). Men had hierbij bijvoorbeeld het vervoer van arseenzuur per schip of trein en eventuele storting van deze stof in zee en tivieren op het oog. Zie ook: Verslag Staatstoezigt (1876) 14, 349-350 en bijlage G

37 Een uitvoerige studie van de niet-industriële vervuiling in Nederland en de rol van de inspectie bij de bestrijding ervan, is te vinden bij: Van Zon, Een zeer onfrisse geschiedenis

38 In 1863 werden op het achttiende Nederlandsch Landhuishoudkundig Congres de resultaten bekendgemaakt van een onderzoek naar de wijze waarop de vuilverwijdering was georganiseerd. Zie daarvoor: Van Zon, Een zeer onfrisse geschiedenis, 149

39 Van Zon, Een zeer onfrisse geschiedenis, 32-33, 73, 77, 87, 130-135, $149,152-153$

40 Ackerknecht, Virchow, 112-115; Sigerist, 'The value of health'

41 Verslag Staatstoezigt (1870) 564-634 (bijlage C). In juli 1871 door de Nederlandsche Maatschappij ter bevordering van Nijverheid bekroond

42 Ali Cohen, "Algemeene gezondheid en landbouw", 18

43 Een beschrijving van het Liernurstelsel is te vinden bij: Van Zon, Een zeer onfrisse geschiedenis, 101-107

44 Artikelen van Ali Cohen daarover verschenen tussen 1871 en 1884 in het Ned.Tijds.Geneesk., Hygieia, de Landbouwcourant en Agricultura.

45 Verslag Staatstoezigt (1876) 446-460 (bijlage D); (1877) 424-429. Rapportage van de gang van zaken in de afzonderlijke gemeenten wekte in elk geval de indruk dat men overal druk doende was verbeteringen aan te brengen. Zie bijvoorbeeld: Verslag Staatstoezigt (1876) 253-278

46 Van Zon, Een zeer onfrisse geschiedenis, 73

47 In Groningen bestond, zoals gezegd, al sinds 1822 een van gemeentewege geregelde tonnenophaaldienst voor de afvoer van faecaliën. In 1855 werd daar een gemeentelijke reinigingsdienst ingesteld. In Amsterdam was in 1847 de reiniging uitbesteed aan de Maatschappij ter Bevordering van de Landbouw en Landontginning, onder leiding van de medicus Sarphati. In 1869 stelde de gemeente Zwolle een reinigingsdienst in. Niet lang daarna volgden Leeuwarden (1870), Den Haag (1871), Deventer (1871), Delft (1871), Breda (1873), Rotterdam (1876), Utrecht (1876), Amsterdam (1877) en Nijmegen (1877). Na 1880 nam het aantal reinigingsdiensten langzaam toe. Van Zon, Een zeer onfrisse geschiedenis, 263

48 In 1863 was het spoelstelsel op beperkte schaal in Rotterdam ingevoerd, ondanks verzet van de plaatselijke gezondheidscommissie. Ook in Utrecht werd in 1864 een begin gemaakt met de aanleg van een gesloten riolering (spoelstelsel), maar dit werk stagneerde al spoedig. In 1870 werd in Leiden en Amsterdam begonnen met de aanleg van het Liernurstelsel, in 1873 gebeurde dat in Dordrecht. Het stelsel heeft in Dordrecht echter nooit enige betekenis voor de vuilverwijdering gehad. In alle genoemde gemeenten werd in de jaren zeventig ook het tonnenstelsel ingevoerd. Dit stelsel is op veel plaatsen tot omstreeks 1916 in gebruik geweest. Van Zon, Een zeer onfrisse geschiedenis, 85; Vogelzang, Drinkwaterwooniening,80-81 en 164; Bosschaert, Utrecht, 110 $49 \mathrm{C}$. W. von Nägeli, Die niederen Pilze in ihren Beziehungen zu den Infectionskrankheiten und der
Gesundheitspflege. München: 1877

50 Zie bijwoorbeeld de discussie in Amsterdam: Ned.Tijds.Geneesk. 22 (1878) I, 368-370 en de discussie in Rotterdam: Van Zon, Een zeer onfrisse geschiedenis, 89

51. Verslag Staatstoezigr (1878) 396-407 (bijlage A)

$52 \mathrm{Na} 1885$ werd in de grotere steden begonnen met de aanleg van het spoelsysteem. Anders dan in het buitenland werd het water vór 1900 zonder noemenswaardige zuivering op het oppervlakte53 Van Zon, Een zeer onfrisse geschiedenis, 150

54 Van den Eerenbeemt, 'Woontoestanden'; Brugmans, De arbeidende klasse, 157-159. De Jonge, Industrialisatie in Nederland, 196-199. De Regt, Arbeidersgezinnen, 24-26 en 177-179 
55 Van den Eerenbeemt, 'Wat leidde tot de woningwet 1901', 524; Brugmans, De arbeidende klasse, $160-161$

56 Gecit. bij Van den Eerenbeemt, 'Woontoestanden', 496

57 Van den Eerenbeemt, "Wat leidde tot de woningwet 1901',519; Brugmans, De arbeidende klasse, 160 en $247 ;$ Tijds. Gezondheidsl, de jaargangen $1867-1872$

58 Ali Cohen (red.), Handboek $I, 189$. Coronel gaf in hetzelfde handboek een uitvoerige samenvatting van het in die tijd verrichte 'chemisch-klimatologisch' onderzoek van de lucht in woon- en slaapvertrekken: Handboek I, 195-207 en 217-222

59 Allebe, 'Enquête naar den toestand der bewoonde kelders'. Een meer uitvoerige bespreking van de enquète in: Verdoom, Het gezondheidswezen, 228-230

60 Ali Cohen (red.), Handboek I, 255-256. De door Ali Cohen aangehaalde verslagen van de verenigingen in: Ned.Tijds. Geneesk 11 (1867) II, 111 en verder verspreid over een groot aantal jaargangen

61 Hygieia 1 (1874) nr. 19; Stratingh Tresling had al eerder van zich doen spreken door zijn publikatie over de bouw van arbeiderswoningen: Het bouwen van arbeiderswoningen (1873). Deze studie werd door de Nederlandsche Maatschappij ter bevordering van Nijverheid in 1872 bekroond.

62 Ali Cohen (red.), Handboek I, 187-249

63 Brugmans, De arbeidende klasse, 160

64 Ali Cohen (red.), Handboek I, 237

65 Van den Eerenbeemt, 'Wat leidde tot de woningwet 1901', 521 e.v.; Van der Weijde, 'De sociaal-culturele achtergronden'; Tellegen, 'Arbeiderswoningen'

66 Verslagen Staatstoezigt, de paragrafen 'Locaal Onderzoek' en 'Gebouwen en Inrigtingen'. Tevens: 'Overzigt van den toestand der slaapsteden', Verslag Staatstoezigt (1868) 388-425 (bijlage A); Egeling \& Carsten, 'Onderzoek van de kazernen', Verslag Staatstoezigt (1876) 461-478 (bijlage E)

67 Reeds vanaf 1870 stelden de geneeskundige raden 'regelen voor het bouwen van scholen' op. Deze werden aan de Gedeputeerde Staten aangeboden met het verzoek op grond hiervan nieuwe verordeningen in te voeren. Het verslag van een systematisch onderzoek onder leiding van de genceskundigen Allebé, Van Hengel, Penn en Teixeira de Mattos naar de toestand der scholen in Noord-Holland is te vinden in: Verzameling van Stukken (1879) 200-214

68 Lager Onderwijswet, 17 augustus 1878 (Stb. 127); Wet van 25 april 1879 (Stb.87). Een staatscommissie waarvan, behalve onderwijzers en bouwkundigen, Allebé en Coronel deel uitmaakten, kwam in 1879 met voorschriften omtrent de inrichting van schoolgebouwen: Rapport van de commissie benoemd bij $K B$ van 2 februari 1879 , no. 15. Het Anti-Revolutionair getinte zakenkabinet Van Lynden hield echter weinig rekening met dit rapport: het KB van 30 augustus 1880 (Stb. 167) ging veel minder ver dan de staatscommissie had voorgestell. De jaren daarop werden de bepalingen onder druk van de kerkelijke partijen verder afgezwakt. Zo werd in 1882 het bijzonder onderwijs van toezicht gevrijwaard. Na 1880 verschoof de belangstelling van geneeskundigen steeds meer van technisch-hygiënische naar medisch-hygiënische en pedagogische onderwerpen, zoals myopie, ooginfecties, schoolborden, schoolwandelingen, 'achterlijke kinderen', steilschrift. Bergink, 'Schoolhygiëne, 70-74; Van Tussenbroek, 'Schoolhygiëne', 49-52

$69 \mathrm{Er}$ werd jaarlijks ongeveer $f 2000,-$ op de rijksbegroting uitgetrokken voor subsidies aan vaccinatiebureaus. Verslag Staatstoezigt (1868) 141 en 252

70 Verslag Staatstoezigt (1868) 431

71 'Rapport van de commissie tot voorbereiding van eene wet tot beteugeling van epidemische ziekten, Verslag Staatstoezigt (1868) 430-442 (bijlage D)

72 De term 'besmettelijke oogziekte' werd hier gebruikt voor verschillende purulente aandoeningen van de oogleden die blindheid konden veroorzaken, zoals trachoma (infectie door chlamydia trachomatis, dikwijls gepaard gaande met een bacteriēle infectie), de ophtalmia granulosa (bacteriële infectie) en de ophtalmia neonatorum (meestal gonorroïsche of syfilitische infectie bij pasgeborenen).

73 'Ontwerp van wet, tot wering van besmetting door zeeschepen', Verslag Staatstoezigt (1871) 474476 (bijlage A). Het ontwerp was van toepassing op de gele koorts, cholera, tyfus en besmettelijke oogziekte en vreemd genoeg niet op de pest.

74 Verslag eener commissie uit de Tweede Kamer, 8-9 en 24

75 Cannegieter, 150 jaar Gezondheidswet, 86

76 Bijvoorbeeld in de ministeriële circulaire van 20 oktober 1871 , betreffende maatregelen tegen de cholera in: Bijvoegsel Stb. (1871) nr. 276

77 Bijlagen Handelingen der Staten-Generaal 1870-1871,II, $1900^{4}-1900^{8}$

78 Met de invoering van de Lager Onderwijswet in 1857 werd de sinds 1823 bestaande verplichting 
om schoolgaande kinderen te vaccineren, afgeschaft. Gemeentebesturen konden sindsdien zelf bepalen of zij de verplichting wilden handhaven.

79 Zowel de inspecteurs, als Thorbecke zelf en diverse kamerleden namen de Engelse gezondheidswetgeving uit de jaren zestig tot voorbeeld (Vaccination-act, Lodgement-act, Sanitary-act en de vervanging van de centralistische Public Health instanties uit de jaren veertig door gemeentelijke gezondheidsorganen). Het grote verschil met Nederland was echter dat in Engeland zulke wetten weliswaar door plaatselijke instanties werden uitgevoerd, maar dat die instanties rijksorganen waren en bovendien buiten de gemeentebesturen om gezondheidsmaatregelen met kracht van wet konden uitvaardigen. Thorbecke heeft deze vorm van geneeskundig bestuur altijd afgewezen.

80 Bijlagen Handelingen der Staten-Generaal 1872-1873, II, 54.2-54.3

81 Handelingen der Staten-Generaal 1872-1873, II, 261

82 Handelingen der Staten-Generaal 1872-1873,II, 263

83 Wet van 4 december 1872 , tot voorziening tegen besmettelijke ziekten (Stb. 134)

$84 \mathrm{~KB} 17$ april 1873 (Stb. 43): 'ontsmettingsreglement', gewijzigd bij KB 26 juli 1885 (Stb. 167). Volgens een KB van 16 oktober $1873(S t b .138)$ werd de Epidemiewet voor de duur van een jaar van toepassing verklaard op de dysenterie, aangezien die ziekte epidemische vormen aannam. Het jaar daarop werd dit besluit in een Wet veranderd en tevens mazelen aan de rij van ziekten toegevoegd waarop de Epidemiewet van toepassing was: Wet van 3 december 1874 (Stb, 188). Andere aanvullingen op de Epidemiewet waren: Wet van 28 maart 1877 (Stb. 36), Wet van 23 april 1879 (Stb. 73), Wet van 26 maart 1884 (Stb. 80), die de landelijke en plaatselijke overheid toestonden om bij de constatering van cholera, pest, gele koorts en pokken in binnen- en buitenland, allerlei quarantainemaatregelen te nemen.

85 Wet van 28 maart 1877 , tot wering van besmetting door uit zee aankomende schepen (Stb. 35)

86 Behalve de reeds genoemde ziekten werden ook vlektyfus, erisypelas en hospitaalgangreen als besmettelijke ziekten aangemerkt, waarbij afzondering der patiënten geboden was. Kinkhoest, favus en etterige en granulomateuse oogontsteking vereisten voorzichtigheid, maar geen geïsoleerde verpleging. Teringlijders behoefden niet to worden afgezonderd en dysenterielijders alleen ten tijde van een epidemie. Syfilis-patiënten kwamen om zedelijke redenen voor afzondering in aanmerking. 87 Het Diaconessenziekenhuis te Utrecht beschikte al in 1858 over een barak voor besmettelijke ziekten. In Maastricht was dat in 1866 en in Den Haag in 1872 het geval. $\mathrm{Na} 1872 \mathrm{kwam}$ het kosten van de gemeente strenger gemeentelijk toezicht te staan. Bij elke begraafplaats werd op besmettelijke ziekte".

88 De reeds sinds de jaren vijftig bestaande gemeentelijke bepalingen op de prostitutie, ter bestrij-
ding van syfilis en gonorrthoe, vormden schouwing blijft.

89 Gesubsidieerde vaccinatiebureaus bestonden in Amsterdam, Haarlem, Utrecht, Arnhem, initiatief van Binnenlandse Zaken een 'parc vacciner, Ommen en Maastricht. In 1873 werd op aan geneeskundigen en gemeentebesturen vaccinogène' in Utrecht opgericht dat kosteloos vaccine rijksinrichting, waarover de directeur van beschikbaar zou stellen. Dit 'parc" werd in 1886 een en 1890 verschenen soortgelijke inrichtingen achtereenvoljschool de leiding kreeg. Tussen 1875 Leeuwarden, Leiden, Maastricht en Nijmegen. Na 1887 gens in Haarlem, Arnhem, Groningen, meer voor. Broeksmit, De geschiedenis der pokken $1887 \mathrm{kwam}$ inenting met humane lymfe niet koepok-inenting', 138-143

90 Een topjaar was 1871 , met ruim 276,000 vaccinaties.

91 In 1876 werden 113 sterfgevallen genoteerd. In 1877

26,11 en 8 , terwijl de totale morbiditeit en mortaliteit sterk en 1879 waren dat er respectievelijk

92 Ali Cohen, 'Plaatselijke vereenigingen', 525-526

sies, als onderdeel van het statstoezicht, tot stand.

94 Olvers, Dordrecht, 24; Copier en Vant, tot stand.

95 Verzameling Stukken (1874) 39 .

96 Zie bijvoorbeeld Van der Kluit,

97 Broeksmit, De geschiedenis der, 'Zutphen", 126 en Ruitenbeek, 'Zutphen', 49

98 Brugmans, De arbeidende klasse, 223-245 99 Deze hadden Querido, Een eeuw Staatstoezicht, 125

maar de bewindsman leek niet van zins dit advies op te volgen. 100 Festen, 125 jaar Geneeskunst, 165

101 Coronel, 'De ligchamelijke ontwikkeling in verband tot den arbeid der kinderen' 
103 Bergink, Coronel, 37

104 Zie voor een meer uitvoerige beschrijving van de taken van de commissie: Reinsma, 'De commissie belast met het onderzoek naar den toestand der kinderen', 407

105 Zeeman schreef over het passeren van Coronel: Aan welke personen die taak door den minister werd toevertrouwd, laten wij daar, doch zeker is het, dat de geneeskundige leden dier commissie bij het op zich nemen van dien omvangrijke last niet enkel op zich zelven vertrouwenden, maar ook op de ondersteuning hunner collega's van de maatschappij in het bijzonder, welke op dat onderzoek bij herhaling had aangedrongen.' Coronel heeft aan deze uitnodiging geen gehoor gegeven. Ned.Tijds. Geneesk. 8 (1864) 419

106 Een bespreking van het rapport is te vinden bij: Brugmans, De arbeidende klasse, 236-238. De Vooys, 'De sterfte in Nederland', passim en Reinsma, 'De commissie 'belast met het onderzoek naar den toestand der kinderen"', 408-413. De door mij aangehaalde gegevens zijn op deze besprekingen gebaseerd.

107 De constatering bijvoorbeeld dat fabrieksarbeid geen bijzondere nadelige invloed op de volkgezondheid uitoefende omdat de mortaliteit in opkomende industrieplaatsen als Tilburg, Goor en Hellendoorn geen extra ongunstig beeld vertoonde, was een zinloze generalisatie. Zeker in het licht van het onderzoek dat Coronel reeds had verricht.

108 Het was niet alleen de vergelijking tussen de lokale bruto sterfte en levensomstandigheden, die de artsen tot dit oordeel bracht. Ook politieke motieven speelden een rol. Zeeman sprak in 1867 uit dat wettelijke bepalingen tot een beperking van de vrijheid van arbeid en individu zouden leiden. Men was het aan de Franse Revolutie verplicht om de vrijheid van arbeid, zowel als van loon en het individu, als richtsnoer voor de toekomst in het oog te houden. Ned.Tijds. Geneesk. 11 (1867) II, 204. En in het rapport zelf staat te lezen: 'Ingrijpen van overheidswege heeft geen zin. Er is nu eenmaal een maatschappelijke ongelijkheid. De laagste klassen zullen steeds het slachtoffer zijn, omdat zij de middelen missen zich omhoog te werken.' Reinsma, 'De commissie 'belast met het onderzoek naar den toestand der kinderen", 411

109 Brugmans, De arbeidende klasse, 256

110 Coronel, 'Een beroep op de goede gezindheid der Industrieelen', 19; Coronel, 'De zorg voor de gezondheid bij de verschillende beroepen', 262 en 305

111 Coronel, 'Een blik op de ontwikkeling der arbeidende klasse', 473-528

112 Wet van 19 september 1874 (Stb. 130). Overigens betuigde de NMG pas haar instemming met het wetsvoorstel van Van Houten, nadat het door de Kamer was veranderd in een simpel verbod op kinderarbeid onder de twaalf jaar.

113 Verslag Staatstoezigt (1867) 246

114 Verslag Staatstoezigt (1869) 361-362. Wel werden onder Fock nieuwe voorschriften op het gebruik van stoomketels van kracht: KB 28 mei 1869 , regelende het toezicht op stoomketels (Stb. 97)

115 Dit initiatief viel samen met het besluit van de NMG om een groot onderzoek naar de schadelijke invloed van de industrie op de gezondheid van de arbeiders in te stellen. Van dit plan is echter niets terecht gekomen.

116 Zie bijvoorbeeld: Verslag Staatstoezigt (1871) 202-226

117 Verslag Staatstoezigt (1871) 210 en 212

118 ' $\mathrm{Zij}$ staan daar als mummiën in onze eeuw van beschaving en vooruitgang, in eene eeuw, die zoo gaarne spreekt van humaniteit en philantropie". Coronel, 'De Hilversumsche industrie", 441

119 De uitdrukking 'sociale sterfteverschillen' kreeg bij Coronel voor het eerst de betekenis die in de epidemiologie van tegenwoordig nog steeds wordt gebruikt. Met de 'sociologische benadering van sterfteverschillen' wordt hier dan ook bedoeld de epidemiologie die is gebaseerd op statistische analyse van het verband tussen sterfte en ziekte enerzijds en de sociologische kenmerken van een klasse of stand (beroep, inkomen, levenswijze, uiterlijk) anderzijds.

120 Coronel, 'De ziekten der calicot-wevers'

121 Coronel maakte veel gebruik van de onderzoeksresultaten van Franse geneeskundigen zoals Villermé, Parent-Duchâtelet en Lévy alsmede van de chirurgijn en apotheker C. Turner Thackrah uit Leeds, de belangrijkste woordvoerder van de Engelse fabriekshervormers in het begin van de negentiende eeuw. Hun classificatie van beroepsziekten, en daarmee ook die van Coronel, was gebaseerd op die van de Italiaan B. Ramazzini. Deze publiceerde over beroepsziekten in 1700 het boek De morbis artificium diatribe, dat vele herdrukken en vertalingen heeft beleefd en door latere commentatoren aanzienlijk is uitgebreid. In 1822 is het werk opnieuw uitgebreid en van uitvoerig commentaar voorzien door de Franse geneeskundige P. Patissier. Het verscheen toen onder de titel Traité des maladies des artisans et de celles qui résultent des diverses professions. 
122 Coronel, 'De Hilversumsche industrie'; Coronel, 'Bevolking van Hilversum'. Dat Coronel juist Hilversum uitkoos, had mede te maken met het feit dat de daar werkzame arts J.F. van Hengel reeds enkele kleinere studies op dit terrein had verricht. Van Hengel, 'De gezondheidstoestand in de gemeente Hilversum' en Van Hengel, 'De Hilversumsche fabrieksarbeider'

123 Coronel onderscheidde aan de hand van beroep en "leefwijze en sociale welstand' vijf standen: de fabrieksarbeidersstand (waartoe hij cok de fabrikanten rekende), de daglonersstand (sjouwers), de landbouwstand, de neringdoende stand (winkeliers, dienstboden) en de burgers zonder beroep. Hij had de hoogte van het inkomen wel als uitgangspunt voor een sociale verdeling van de bevolking willen nemen, maar was daartoe niet in staat omdat er geen gegevens over de inkomens beschikbaar waren.

124 Coronel, 'De Leidsche wolfabrieken', Coronel, 'De diamantwerkers'

125 De negatieve reacties op zijn publikaties waren volgens hem het gevolg van het feit dat "de stellingen daarin verkondigd ten eenenmale indruischten tegen de destijds nog in volle bloei verkeerende Manchester school van het laissez faire'. Coronel, 'Een worstelstrijd van veertig jaar', 3. Enkele geneeskundigen, onder wie Zeeman, Van Cappelle en Israëls hebben zich inderdaad tegen Coronels politieke opvattingen gekeerd. Volgens Israëls was Coronels weergave van de toestanden in de fabrieken nogal overdreven en moest worden opgepast dat de 'openbare gezondheidsregeling niet belemmerend op de industrie inwerke'. Ned. Tijds. Geneesk. 12 (1868) II, 492

126 Deze vier categorieën waren: fabrieksarbeiders, dagloners, landbouwers en burgers. Van Hengel, Geneeskundige plaatsbeschrijving van het Gooiland

127 Zeer sprekend was de wijze waarop hij de ideale omstandigheden waarin het burgermanskind opgroeide tegenover het door ondervoeding en ziekte geplaagde leven van het arbeiderskind plaatste. Deze schets van sociale en hygiënische verschillen vulde F. Domela Nieuwenhuys later aan met vergelijkingen tussen het werkmansleven en het burgermansleven in: 'Eenige 'kiekjes' uit het werkmansleven', Recht voor Allen 4 (1882)

128 Ballot, 'Onderzoek naar de sterfte te Rotterdam'. Ballot had trouwens al in 1869 zijn twijfels geuit over de theorie van Von Pettenkofer: Ballot, 'Von Pettenkofer en het wezen der cholera'

129 Deze onderzoekingen waren ook wezenlijk anders, daar over een lange periode gezinnen, naar welstand onderverdeeld, werden gevolgd. Het ging hier dus om sterfte voor individuen per sociale klasse en niet meer om die op aggregraatniveau. Zie voor een bespreking van de periode na 1890: Van Poppel, 'Sociale ongelijkheid', 298 e.v.

130 Bleker, 'Die Stadt als Krankheitsfaktor', 124-125

131 Ballot baseerde zich op Fr. Oesterlens Handbuch der medizinischen Statistik. Tübingen: 1865

132 Voor de ontwikkeling van de voedingsfysiologie en voedingshygiëne, zie: De Knecht-Van Eekelen, Naar een rationele zuigelingenvoeding,45-62

133 Ned.THjds. Geneesk. 17 (1873) I 219

134 Haakma Tresling, 'Proeve eener beschrijving van de volksvoeding'; Haakma Tresling, 'Onderzoek naar de volksvoeding'; Coronel, 'De volksvoeding in Friesland'; Fokker, 'De volksvoeding in Zeeland'; Haakma Tresling, 'Vergelijking van de voeding van het werkwolk eener steenbakkerij'. Haakma Tresling, 'Rapport in hoofdzaak over de voeding'

135 H., 'De kindersterfte te Wissenkerke', 48

136 Coronel, 'De volksvoeding in Friesland', 108

137 Wet van 19 mei 1829 , strekkende om de vermenging van vergiftige of andere schadelijke zelfstandigheden in eet- en drinkwaren te beteugelen (Stb. 35)

138 Een in 1870 door de inspectie opgestelde ontwerp-strafwet tegen het vervalsen van levensmiddelen, heeft het parlement nooit bereikt. Verslag Staatstoezigt (1870) 555-563 (bijlage B)

139 In Amsterdam bestond tussen 1858 en 1867 een keuringsdienst van waren. Na 1867 waren er vier keurmeesters voor vlees en vis in gemeentelijke dienst en stond het scheikundig laboratorium van de hoogleraar in de chemie J.W. Gunning ter beschikking van iedereen die verdachte produkten wilde laten onderzoeken. In 1879 werd de keuringsdienst heropgericht. Ook in andere gemeenten vindt men melding van stadskeurmeesters voor vlees, vis en melk, die tevens vaak het
ambt van stadsveearts uitoefenden.

140 Bijvoorbeeld: Ali Cohen, 'Mededeelingen betreffende vragen: of het vleesch en de melk van parelzieke koeijen voor den mensch schadelijk is?'

141 In 1879 bestond een dergelijke melkinrichting in Amsterdam, Utrecht, Den Haag, Amhem, Delft, Groningen, Hilversum, Leiden en Rotterdam.

142 'Wetsontwerp houdende bepalingen tot het tegengaan van overmatigen arbeid en verwaarlozing
van kinderen, 23 april 1882*, Bijlagen

143 Bergink, 'Coronel. Zijn strijd voor de lingen der Staten-Generaal 1881-1882 II, [153. 1-3]

144 Bijlagen Handelingen der Staten General afschaffing van de kinderarbeid', 761 
145 Verslag Staatstoezigr(1883) 327-328,(1884) 327,329,340-342,(1887) 308-309 en bijlage A

146 'Wetsontwerp houdende bepalingen tot het tegengaan van overmatigen arbeid en verwaarlozing van jeugdige personen, 18 december $1887^{\prime}$, Bijlagen Handelingen der Staten-Generaal 1887-1888, II, $[77.1-6]$

147 Bijlagen Handelingen der Staten-Generaal 1888-1889, II, [53. 1-3]

148 Bijlagen Handelingen der Staten-Generaal 1888-1889, II, 53.4-53.9,53.37

149 Wet van 5 mei 1889 , houdende bepalingen tot het tegengaan van overmatigen en gevaarlijken arbeid van jeugdige personen en van vrouwen (Stb. 48)

150 Van der Woude, 'Bevolking en Gezin', 29-38

151 Van Overbeek de Meijer, 'Rede, gehouden op 26 maart 1887',557

152 Cannegieter, I50 jaar Gezondheidswet, 89-90

153 In 1887 werd Ruysch door minister Heemskerk tot Adviseur voor medische en veterinaire Politie' aangesteld. Ruysch was samen met Coronel in de jaren tachtig een van de belangrijkste voorvechters van een geneeskundige inspectie op de fabrieksarbeid. Na 1890 was hij de drijvende kracht achter de oprichting van een 'Veiligheidsmuseum' in Amsterdam en de organisatie van het Congres voor Openbare Gezondheidsregeling.

$154 \mathrm{Zie}$ bijvoorbeeld de verdediging van het Staatstoezicht tegen deze aanvallen door Overbeek de Meyer in: 'Rede, gehouden op 26 maart 1887 ' en 'De verbetering van den gezondheidstoestand sedert 1865 '

155 'Wetsontwerp tot wijziging der wet van 1 juni 1865 regelende het geneeskundig Staatstoezicht, 1 maart 1886', Bijlagen Handelingen der Staten-Generaal 1885-1886, II, [123. 1-7] 
1 Zie voor de kritiek op Quetelet in Duitsland: Hacking, 'Prussian numbers', 382-384; Norton Wise, 'How do sums count?', 398

2 Zie voor Quetelets invloed in Frankrijk en Engeland: Lécuyer, 'Probability in vital and social statistics'

3 Veel verder ging Farrs invloed overigens niet. Tal van andere verbeteringen die Farr in de bevolkingsstatistiek had doorgevoerd, zoals de berekening van de levensverwachting voor leeftijdsspecifieke groepen en van de bevolkingsdichtheid, zijn door de Nederlandse hygiënisten niet overgenomen.

4 Het nu volgende betoog over de statistiek is mede gebaseerd op inzichten uit de moderne wetenschapssociologie, zoals die te vinden zijn in: Stemerding, 'Latours antropologie van de wetenschap' en Latour, Science in action, met name hoofdstuk 6 'Centres of calculation'

5 Omgekeerd is het natuurlijk zo dat de hygiënisten de leer der volksziekten pas definitief hebben kunnen omvormen toen ook de politieke cultuur ten aanzien van de gezondheid van burgers veranderde. Nieuwe politieke opvattingen schiepen een maatschappelijk kader waarbinnen de nieuwe leer der volksziekten een politieke rol van betekenis kon spelen

6 Het is wellicht niet toevallig dat in die jaren stemmen opgingen om een patronagesysteem voor armen in te stellen. Kruithof, 'De deugdzame natie", 368. Zie voor een vergelijkbare ontwikkeling in Duitsland: Frevert, Krankheit als politisches Problem, 118 en 122-123

7 Kossmann, De Lage Landen, 133

8 De Wit, Thorbecke, 103-104

9 De Wit, Thorbecke, 135

10 Aan deze constatering moet een relativerende opmerking worden toegevoegd. Ik wil hier niet beweren dat de gezondheidsopvattingen van de hygiënisten ongewijzigd in de samenleving geaccepteerd zijn. Het valt aan te nemen dat maatschappelijke groeperingen (liberale burgerij, confessionelen, werkende stand, geneeskundigen, enz.) de idee van 'volksgezondheid' slechts hebben overgenomen woor zover dat in hun eigen denkschema's paste. De 'rationele hygiëne" van de hygiënisten is dus in het dagelijks leven omgevormd en selectief toegepast. De geschiedenis van dit proces van omvorming en selectie is een afzonderlijke studie waard

11 De volksklasse wend niet meer verantwoordelijk gehouden voor de toestand waarin het verkeercle en was ontslagen van allerlei dagelijkse verplichtingen (de kerkgang bijvoorbeeld). Daar stonden echter nieuwe verplichtingen tègenover: zij was gehouden de toestand als ongewenst te beschouwen en mee te werken aan genezing, niet alleen door de uitvoering van het hygiënisch programma toe te laten, maar ook door een opleiding te volgen, werk te zoeken, de huur op tijd te fabrieksarbeider of zorgzame huisvrouw. In, en zich op te werken tot nijvere handwerkman, (de officiële geneeskunde). Zie bijvoorbeeld: geval van ziekte moest men competente hulp zoeken 12 Deze opvatting wordt krachtig verdedig: De Regt, Arbeidersgezinnen, 175-176

voor vergelijkbare standpunten Metz, 'Paupers 258-259 13 Zie daarvoor: Coleman, Death is a social disease; La Berge, 'The early nineteenth- century

14 Kooij, 'Stad en Platteland', 98; Van der Woude, 'Bevolking en Gezin', 28; Brugmans, De

15 De Jonge, Industrialisatie in Nederland, 205

16 De Jonge, Industrialisatie in Nederland, 21 en 237; Brugmans, De arbeidende klasse, 72-73

17 De Jonge, Industrialisatie in Nederland, 26,97 en 265

18 Brugmans, De arbeidende klasse, 189

19 De Jonge, Industrialisatie in Nederland, 18-19; De Hen, 'De Industrialisatie van Nederland, 12

21 De Swaan heeft terecht opgemerkt dat de aanleg van een rioleringsstelsel en een drinkwa inspanning van de kapitaalkrachtige, gevestigde verdelingsprobleem. Alleen door een collectieve voorzieningen worden getroffen. Deze groepen waren groepen in de samenleving konden sanitaire inspanning, nadat de beter gesitueerden bij elkaaren volgens De Swaan echter pas bereid tot deze de minder gegoeden achterbleven in armenwijken. 'ruimtelijke segregatie' konden de bewoners van de deftigeor deze 'sociale homogenisering' en 
gen treffen in het vertrouwen dat hun goed gesitueerde buren erin zouden deelnemen en dat de armen er niet zonder bijdragen van zouden profiteren. De Swaan, 'Aantekeningen uit het ondergrondse', 337 en 345 e.v. 


\section{ARCHIVALIA}

\section{ALGEMEEN RIJKSARCHIEF TE 'S GRAVENHAGE (ARA)}

\section{Tweede Afdeling}

2.02.01:de archieven van de Algemene Staatssecretarie en van het Kabinet des Konings 1813-1840: Staatssecretarie 1813-1840,inv. nr. 3595 (SvS)

2.02.04:het archief van het Kabinet des Konings 1841-1897, inv. nr. 604 en 1193 (KdK)

2.04.08: het archief van het ministerie van Binnenlandse Zaken: afdeling Onderwijs, Kunsten en Wetenschappen 1848-1876(OKW)

2.04.21: het archief van het ministerie van Binnenlandse Zaken: afdeling Medische Politie 18501901 (Medische Politie)

2.04.26: Geheim- en Kabinetsarchief van het het ministerie van Binnenlandse Zaken 1814-1910: kabinetsarchief (Kabinet)

2.19.53:het archief van de Nederlandsche Maatschappij tot bevordering der Geneeskunst 1849-1942 (NMG)

2.21.161:verzameling van stukken afkomstig van mr. Johan Rudolf Thorbecke en van enige van zijn verwanten (Thorbecke)

\section{BIBLIOTHEEK KNMG, BIBLIOTHEEK VAN DE UNIVERSITEIT VAN AMSTERDAM}

Afdelling handschriften

Catalogusnummer C 63: Stukken betreffende de wording van de Wet tot regeling van de bevoegdheden der Geneeskunstoefenaren (Stukken betreffende de wording van Wet)

Catalogusnummer II E 38: J. Zeeman, Notulenboek van de commissie voor geneeskundige statistiek en topographie, 21 november 1848 - november 1851

\section{COLLECTIE L. ALI COHEN UTRECHT (Coll. Ali Cohen)}

In deze collectie bevinden zich brieven, redevoeringen en wetenschappelijke verhandelingen in handschrift alsmede tal van boeken en brochures van de hand van L. Ali Cohen. 


\section{GEDRUKTE BRONNEN EN LITERATUUR}

\section{Periodieken}

a Wekelijks en maandelijks geraadpleegde week- en maandbladen:

De Gezondheid. Tijdschrift voor den beschaafden stand. Uitgegeven door de Vereniging van voorstanders der Gezondheidsleer te Amsterdam, 1877-1880. Redactie: G.A.N. Allebé, L.J.Egeling,J.F. van Hengel, A.H. Isrälls, S. Stratingh Tresling

Het Repertorium. Tijdschrift woor de Praktisch-geneeskundige wetenschappen in al haren omvang, 1855-1856. Redactie: L. Ali Cohen (Repertorium)

Hygieia. Weekblad voor de Gezondheidsleer in Nederland, 1874-1876. Redactie: A.H. Israels

Nederlandsch Tijdschrift voor Geneeskunde. Tevens orgaan der Nederlandsche Maatschappij tot Bevordering der Geneeskunst, 1857-heden. Redactie bij de oprichting: C. Gobes, J. Penn, G.E. Voorhelm Schneevoogt, J.W.R. Tilanus, J. Zeeman. Wekelijks geraadpleegd tot 1880 (Ned.Tijds.Geneesk.)

Nederlandsch Weekblad voor Geneeskundigen, 1851-1856. Redactie: J.P. Gildemeester, A.H. Israëls, J. Penn, H. Riehm tot 1852, J.M. Schrant, J.W.R. Tillanus, J. Zeeman vanaf 1852 (Ned.Weekb.Geneesk.)

Nieuw Practisch Tijdschrift voor de Geneeskunde in al haren omvang, nieuwe reeks, 1849-1854. Redactie: L. Ali Cohen

Schat der Gezondheid. Een tijdschrift woor alle standen, tot bevordering van volkswelvaart, door verspreiding van eenvoudige beginselen van gezondheidsleer en openbare gezondheidsregeling en hunne toepassing op het individueel en maatschappelijk leven, 1858-1864. Redactie: L.J. Egeling en D. Lubach

Tijdschrift voor algemeene Gezondheids-regeling en Geneeskundige Politie, 1853-1854. Redactie: L.H. Verwey en C. Pruys van dler Hoeven (Tids. Gezondheidsregeling)

Tijdschrift der Nederlandsche Maatschappij tot Bevordering der Geneeskunst, 1850-1856. Redactie: J.N. Ramaer tot 1853, M. Dassen tot 1853, J.M. Schrant, J.J. Homoet, L. Lehmann en K.M. Giltay (Tijds.NMG)

Tijdschrift voor Gezondheidsleer. Tijdschrift voor alle standen ter bevordering van volkswelvaart en huiselijk geluk, 1867-1872. Redactie: C.P. Pous Koolhaas (Tijds. Gezondheidsleer)

b Overige geraadpleegde periodieken:

Archief voor Geneeskunde, 1841-1846

Bijdragen tot Geneeskundige StaatsregelingI-III, 1842-1845

De Gids. Nieuwe vaderlandsche letteroefeningen (opgericht in 1837) De Economist. Tijdschrift voor alle standen ter bevordering van volkswelvaart door verspreiding van

Geneeskundige Courant, 1847-1912. Geraadpleegd tot 1865

Het Nederlandsch Lancet. Tijdschrift voor de geneeskundige wetenschappen in haren geheelen omvang,
2 e serie, $1845-1856$ Practisch Tijdschrift voor de Geneeskunde in al haren omvang, 1823-1846. Met supplementbanden,
1823-1841

Wenken en Meeningen omtrent de Geneeskundige Staatsregeling en Algemeene Geneeskunde, 1838-
1840 


\section{Literatuur}

Acker Stratingh, G.A. \& Ali Cohen, L., 'Ontwerp van een plan voor eene geneeskundige plaatsbeschrijving van Nederland', Tjids.NMG 4 (1853) I, 236-243

Acker Stratingh, G.A.; Keiser M.J.; Tresling, P. \& Ankum, C.H. van, 'Bijdrage over de voedingsmiddelen in de stad of gemeente Groningen gebruikelijk', Tijds. NMG 5 (1854) I, 3-16

Ackerknecht, E.H., 'Beiträge zur Geschichte der Medizinalreform von 1848', Sudhoffs Archiv fiur Geschichte der Medizin 25 (1932) 61-109, 112-183

Ackerknecht, E.H., 'Hygiene in France, 1815-1848', Bull. Hist.Med. 22 (1948) 117-155

Ackerknecht, E.H., 'Anticontagionism between 1821 and $1867^{\prime}$, Bull. Hist.Med. 22 (1948) 562-593

Ackerknecht, E.H., 'Statistics: contributions of Lambert Adolphe Jacques Quetelet and Louis René Villerme', Bull. Hist.Med. 26 (1952) 317-329

Ackerknecht, E.H., Rudolf Virchow. Artzt, Politiker, Anthropologe. Stuttgart: F. Enke, 1957

Ackerknecht, E.H., Geschichte und Geographie der wichtigsten Krankheiten. Stuttgart: F. Enke, 1963

Aerts, R.; Calis, P.; Jacobi, T \& Relleke, J., De Gids sinds 1837. De geschiedenis van een algemeencultureel en literairtijdschrift. Den Haag: Nederlands letterkundig museum en documentatiecentrum- Amsterdam: Meulenhoff, 1987

'Algemeen rapport, uitgebragt door de Nederlandsche Maatschappij tot bevordering der Geneeskunst, omtrent het advies der Staatscommissie', Tijds. NMG 2 (1851) I, 15-25

'Algemeen rapport, uitgebragt door de Nederlandsche Maatschappij tot bevordering der Geneeskunst omtrent de Ontwerpen van Wet, enz., ingediend door de Staatscommissie, benoemd bij Koninklijke Besluiten van 25 juli en 4 augustus 1848',Tjds.NMG 3 (1852) I, 117-136

Ali Cohen, L., Nieuw statistisch geneeskundig Jaarboekje van het Koninkrijk der Nederlanden. Gorinchem: J. Noorduyn en Zn., 1847

Ali Cohen, L., Nieuw statistisch geneeskundig Jaarboek van het Koninkrijk der Nederlanden. Gorinchem: J. Noorduyn en Zn. 1848-1852

Ali Cohen, L., 'Studiën over de cholera asiatica, I en II', Nieuw Practisch Tijdschrift voor de Geneeskunde in al haren omvang (nieuwe reeks) 2 (1850) 7-19,65-80

Ali Cohen, L., 'Een woord over de noodzakelijkheid der statistische methode in de geneeskunde', Nieuw Practisch Tijdschrift voor de Geneeskunde in al haren omvang (nieuwe reeks) 2 (1850) 529 . 535

[Ali Cohen, L.], 'Professor G.J. Mulder en de Minister Thorbecke', Nieuwe Rotterdamsche Courant, 9 december 1851

Ali Cohen, L., 'Over openbare gezondheidsregeling, de gevolgen van hare verwaarlozing en de noodzakelijkheid van hare invoering hier te lande', Nieuw Practisch Tijdschrift voor de Geneeskunde in al haren omvang (nieuwe reeks) 4 (1852) 253-300

Ali Cohen, L.., 'Staat van de verordeningen, tegen wier overtreding straf is bedreigd, die gedurende 1855 in de verschillende gemeenten onzes landes zijn vastgesteld of afgekondigd', Het Repertorium (nieuwe reeks) 2 (1856) 520-523

Ali Cohen, L., 'Eenige opmerkingen betreffende de dezer dagen door de regering bij de Tweede Kamer der Staten Generaal ingediende ontwerpen van wet ter regeling van eenige onderwerpen uit het gebied der staatsgeneeskunde', Ned. Tijds. Geneesk. I (1857) 603-611,619-626

Ali Cohen, L., 'Gesteldheid van den bodem en cholera. Twee hoofdstukken uit de geschiedenis van de jongste cholera-epidemie te Kopenhagen', Ned.Tijds. Geneesk. 2 (1858) 161-168

Ali Cohen, L. (vert.), Choulant-Richter's Handboek der bijzondere ziektekunde en genezingsleer. Tweede, veel vermeerderde en verbeterde druk, naar de zesde, nogmaals omgewerkte Hoogduitsche uitgaaf. 2 vols. Groningen: J.B. Wollters, 1858-1860

Ali Cohen, L., 'Beknopt overzicht van den gezondheids- en ziektetoestand in de verschillende gemeenten der provincie Groningen, over het jaar 1858', Ned. Tijds. Geneesk. 3 (1859) 453-457

Ali Cohen, L., 'Hygiëne en economie. Hoe verbetering van stads-wateren zondere opofferingen, ja zelfs met 'geldelijk voordeel' voor de gemeenten kan plaats hebben', De Economist 8 (1859) 1-8, $423-425$

Ali Cohen, L., 'Statistiek overzigt van den toestand der gezondheid en ziekte van menschen en vee, benevens van het aantal geneeskunstoefenaren (ook veeartsen), van de verrigte koepokinentingen enz., in de verschillende gemeenten der provincie Groningen, over het jaar 1859', Ned.Tijds. Geneesk. 4 (1860) 611-617

Ali Cohen, L., Algemeene gezondheid en Fabryk-nijverheid. Het verband tussen beide, en de wijze waarop beider strijdige belangen kunnen worden overeengebragt.Rapport aan de Heeren Gedeputeerde Staten der provincie. 2 vols. Groningen: P. Noordhoff, 1860 
Ali Cohen, L., 'Algemeene gezondheid en landbouw. Het verzamelen en afvoeren van faecale stoffen en ander vuil in de steden, bepaaldelijk in ons vaderland', De Economist 10 (1861) Bijblad, 1-48

Ali Cohen, L., 'Voorloopige mededeeling betreffende het voorkomen van gevallen van diphteritis faucium in ons vaderland tot in den aanvang van $1861^{\prime}$,Ned.Tijds. Geneesk. 5 (1861) 184-185 en 241.

Ali Cohen, L., 'Beknopt overzicht van den toestand der tot de rubriek medische politie behoorende onderwerpen in de verschillende provinciën onzes lands, gedurende 1860', Ned. Tijds. Geneesk 6 (1862) 36-40

Ali Cohen, L.' 'Korte beoordeling van de voomaamste bedenkingen, die tot dus ver zijn in het midden gebragt tegen de op 20 juni door de regering bij de Tweede Kamer der Staten-Generaal ingediende vier ontwerpen van wet betreffende de geneeskundige aangelegenheden', Ned.Tijds.Geneesk 6 (1862) 675-693

Ali Cohen, L., 'Het verband tusschen de gesteldheid van den bodem en het heerschen van cholera', Ned. Tijds. Geneesk. 6 (1862) 67-70

Ali Cohen, L., 'Overzigt van den toestand der provincie Groningen en van hare verschillende gemeenten, over het jaar 1860 , met betrekking tot hetgeen onder de rubriek 'medische politie' pleegt gebragt te worden', Ned Tijds. Geneesk 6 (1862) 225-245

Ali Cohen, L., 'Overzigt van den hoofdinhoud der adressen, brochures enz., die over de aanhangige geneeskundige wetsontwerpen het licht zien', Ned.Tijds. Geneesk. 6 (1862) 459-461, 471-474,539$541,546-556,561-564,593-610,614-615,628-632$

Ali Cohen, L., 'Een viertal adviezen ten betooge, waarom men le in ons land bij het regelen der gezondheidsbelangen niet in algemeenheden kan vervallen en bij het buitenland te rade gaan; en $2 \mathrm{e}$ aan het geneeskundig toezigt de bevoegdheid tot handelen niet, althans niet dadelijk kon of kan verleenen', Ned.Tijds. Geneesk. 10 (1866) I, 513-520,593-594 Ali Cohen, L., 'Plaatselijke vereenigingen tot verbetering van de volksgezondheid', Ned.Tijds.-
Geneesk. 11 (1867)I, 225-226

Ali Cohen, L. (red.), Handboek der openbare gezondheidsregeling en der geneeskundige politie, met het oog op de behoefte en de wetgeving van Nederland. 2 vols. Groningen: J.B. Wolters, 1872

Ali Cohen, L., 'Waterbederf ten gevolge van aardappelmeel-fabricage', Ned. Tijds. Geneesk. 15 (1871) I, 637-644; 16 (1872) I, 609-614;18 (1874) I, 497-508; 25 (1881) I, 325-336

Ali Cohen, L., 'Faecaliën, volksgezondheid, landbouw en materiële welvaart. Rapport aan den geneeskindigen raad voor de provincie Noord-Holland, van de commissie voor het vraagstuk der
faecalia', Ned. Tijds. Geneesk. $18(1874) \mathrm{I}, 275-288$

Ali Cohen, L., 'Mededeelingen uit de jongste literatuur betreffende vragen: of het vleesch en de melk van de parelzieke koeijen voor den mensch al of niet schadelijk is ? en of de tuberculose van dieren op den mensch al of niet kan worden overgebracht ?', Ned. Tijds. Geneesk. 20 (1876)I,
$485-491 ; 21$ (1877) II, 138-152;24 (1880) I, 42-60

Ali Cohen, L., 'Rangorde van de voornaamste steden des lands, naar het algemeene verhoudingscijfer van hare sterfte tot hare bevolking, in de jaren 1873 tot en met $1878^{\prime}$, Ned. Tijds. Geneesk. 24
(1880) I, 31-32

Ali Cohen, L. \& Zeeman, J., 'De invloed van woning, stand en algemeene maatregelen', Ned.Tijds.
Geneesk. 11 (1867) II, 110-116

Allebé, G.A.N. \& Cappelle, H. van, De gezondheidsvereischten van schoolgebouwen, met toepassing

op de Lokalen der openbare armenscholen te Amsterdam. Haarlem: A.C. Kruseman, 1861
Allebe, G.A.N., 'Enquête naar den toestand der bewoonde kelders in de gemeente Amsterdam',
Ned. Tijds. Geneesk. 18 (1874) I, 165-175

Allema, J. \& Ringoir, D.J.B.,Amsterdam zonder GG en GD. Amsterdam: Stadsdrukkerij, 1975 5772

2619-2625 Anonymus, Ontwerp en Co., 1842 unus, Ontwerp van verbetering der geneeskundige wetgeving. Leiden: Hazenberg

Anonymus, 'Verslag wetenschappelijke sectie', NMG-tijds. I (1850) I, 72-77

Amtzenius, D.J.A., Brief over de wijze van ontstaan wan den Aziatischen braakloop te Scheveningen.
Amsterdam: Van der Vinne, 1832 .

Arntzenius, D.J.A., 'Noodzakelijkheid eener herziening in het onderwijs en de toelating onzer geneeskundigen', Bijdragen tot Geneeskundige StaatsregelingI (1842) 79-124

Natuurk. Verh. Prov. Utrechts Genootschap, nieuwe reeks (1870) II, eerste stuk 
Baart de la Faille, J., Advies over het rapport der raadscommissie, omtrent een voorstel van het Gezelschap van Groningsche Geneeskundigen, ter oprigting eener Gezondheids-Commissie. Groningen: 1855

Ballot, A.M., 'Over sterfteverhouding te Rotterdam', Ned.Tijs. Geneesk. 3 (1859) 113-121

Ballot, A.M., 'Invloed van het drinkwater op de verspreiding der cholera', Tijds. Gezondheidsleer 1 (1867) $145-155$

Ballot, A.M., 'Het drinkwater in eenige onzer steden uit een hygiënisch oogpunt beschouwd, vooral in betrekking tot de cholera', Ned.Tijds. Geneesk. 12 (1868) II, 175-248

Ballot, A.M., 'Von Pettenkofer en het wezen der cholera', Ned.Tijds. Geneesk. 13 (1869) I, 91-94

Ballot, A.M., Het voorstel tot den aanleg eener drinkwaterleiding te Rotterdam, uit een hygiénisch oogpunt beschouwd. Rotterdam: H. Nijgh, 1869.

Ballot, A.M., 'Onderzoek naar de sterfte te Rotterdam en hare oorzaken', Ned.Tijds.Geneesk. 17 (1873) II, 113-156

Banga, J., Verhandeling over de epidemische ziekte, welke omstreeks 1826 in de noordelijke provincièn der Nederlanden geheerscht heeft. Amsterdam: P. Meyer Warnars, 1828

Barrett, N.R., 'A tribute to John Snow, M.D. 1813-1858',Bull.Hist.Med.19 (1946) 517-535

Bax, C., Wergeving voor de genees-, heel-, vroed-en artsenijmengkunde in het Koningrijk der Nederlanden, of Verzameling van al de thans in vigueur zijnde Wetten, Reglementen en Instructien, daartoe enigszins betrekkelijk, of met dezelve in verband staande. Haarlem: F. Bohn, 1818

Berge, A.F. la, 'The Paris Health Council, 1802-1848',Bull.Hist.Med.49(1975) 339-352

Berge, A.F. la, 'The early nineteenth-century french public health movement: the disciplinary development and institutionalization of hygiene publique', Bull.Hist.Med. 58 (1984) 363-379

Berge, A.F. la, 'Edwin Chadwick and the French connection', Bull.Hist.Med. 62 (1988) 23-41

Bergink, A.H., Samuel Senior Coronel. Zijn betekenis voor de socialegeneeskunde in Nederland. Assen: Van Gorcum en Comp., 1960

Bergink, A.H., Schoolhygiëne in Nederland in de negentiende eeuw. Veendam: Marico meubelen, 1965

Bergink, A.H., 'C.P. Pous Koolhaas (1831-1893), voorloper van de Haagsche schoolartsen', Tijds. Sociale Geneesk. 44 (1966) 324-326

Bergink, A.H., 'Samuel Senior Coronel. Zijn strijd voor de afschaffing van de kinderarbeid in Nederland', Sociaal Maandblad Arbeid 22 (1967) 754-762

Beukers; H., 'Groei en ontwikkeling. De Leidse faculteit der geneeskunde in het derde kwart der negentiende eeuw' in: W. Otterspeer (red.), Een Universiteit herleeft. Wetenschapsbeoefening aan de Leidse Universiteit vanaf de tweede helft van de negentiende eeuw, Leiden: E.J. Brill/ Universitaire pers Leiden, 1984

Bierman, A.I., Van artsenijmengkunde naar artsenijbereidkunde. Ontwikkelingen van de Nederlandse farmacie in de negentiende eeuw. Amsterdam: Rodopi, 1988

Bijdragen tot de geneeskundige plaatsbeschrijving van Nederland. Uitgegeven door het Departement van Binnenlandsche Zaken. 5 stukken. 's Gravenhage: Van Weelden en Mingelen, 1870-1881

Bijdragen tot de kennis van den tegenwoordigen staat der provincie Groningen. 7 dln. Groningen: C.M. van Bolhuis Hoitsema, 1860-1874

Bijvoegsel tot het Staatsblad van het Koningrijk der Nederlanden. Dordrecht: A. Blussé; vanaf 1826: Gorinchem: J.Noorduyn en $\mathrm{Zn.} \mathrm{1813-1946.} \mathrm{Titel} \mathrm{varieert}$

Bik, J.G.W.F., Viff eeuwen medisch leven in een Hollandse stad. Assen: Van Gorcum en Comp., 1955

Bleker, J., 'Die Stadt als Krankheitsfaktor. Eine Analyse ärztlicher Auffassungen im 19. Jahrhundert', Medizinhistorisches Journal 18 (1983) 118-136

Bleker, J., 'Die historische Pathologie, Nosologie und Epidemiologie im 19. Jahrhundert', Medizin historisches Journal 19 (1984)1/2, 33-52

Bleker, J., 'Die Idee einer historischen Entwicklung der Krankheiten des Menschengeschlechts und ihre Bedeutung für die empirische Medizin des frühen 19. Jahrhunderts', Berichte zur Wissenschaftsgeschichte 8 (1985) 195-204

Blume, C.L., Over de Asiatische cholera, uit eigene waarnemingen en echte stukken. Amsterdam: C.G. Sulpke, 1831

Böhme, G., '1848 und die Nicht-Entstehung der Sozialmedizin', Kennis en methode 3 (1979) nr. 1 , 93-141

Boogaard, J.A., 'Verslag namens de commissie voor statistiek', Ned.Tijds. Geneesk. 3 (1859) 469-477

Boogaard, J.A., 'Model en toelichting der tabel voor geneeskundige sterfte-statistiek, op de algemeene vergadering der maatschappij tot bevordering der geneeskunst voorgesteld door hare commissie voor statistiek', Ned.Tijds. Geneesk. 6(1862) 502-505 

Boogaard, J.A., 'Bijdrage tot de militie-statistiek der provincie Zeeland', Ned.Tijds. Geneesk. 12
(1868)II, 303-325

Boogman, J.C., Rondom 1848. De poltitieke ontwikkeling van Nederland 1840-1858. Bussum: Unieboek, 1978

Boon Cz, A. van der, 'De sterfte te Zaandam gedurende de jaren 1850-1859",Ned.Tjds. Geneesk 6 (1862) $177-186$

Bordes, C. de, 'Verslag over de ziekten, welke in 1851 in Nederland geheerscht hebben', Tijds. NMG 4 (1853) I, 249-308

Bordes, C. de, Bespreking van Untersuchungen und Beobachrungen aber die Verbreitungsart der Cholera, nebst Betrachtungen aber Maßregeln derselben Einhalt zu thun door M. von Pettenkofer, Ned. Weekb. Geneesk. 5 (1855) 317-320

Bordes, C. de, 'Verslag over de volksziekten, welke in 1854 in Nederland hebben geheerscht', Tijds. NMG 7 (1856) 1, 229-304

Bordes, C. de, 'Bijdragen tot de theorie van Professor Von Pettenkofer, omtrent de oorzaak der verspreiding van de cholera asiatica', Ned. Weekb. Geneesk. 6 (1856) 331-334,341-344, 351-354

Bosman, M., e.a. (red.), 'De veeartsenijkunde ten tijde van de oprichting van de maatschappij', Diergeneeskundig Memorandum 34 (1987) nr. 4

Bosschaert, D., De stad Utrecht als medisch ontwikkelingsgebied (diss.). Rotterdam: Bronder, 1969 'Brief van de Plaatselijke Commissie van Geneeskundig Toevoorzigt, aan H.H. Burgemeester en Wethouders, over de sterfte binnen Rotterdam', Ned. Weekb. Geneesk. 7 (1856) 443-451

Broeksmit, C., De geschiedenis der pokken in Nederland van 1865 tot 1885. Rotterdam: J. de Jong, 1887

Broes van Dort, K., Bijdrage tot de kennis van de sterfie der gemeente Goes en van den gemiddelden en waarschijnlijken levensduur harer inwoners, gedurende het 30-jarigetijdvak 1830-1859. Goes: L. de Fouw, 1861

Brown, P.E., 'John Snow - The autumn loiterer', Bull.Hist.Med. 35 (1961) 519-528

Brugmans, I.J., De arbeidende klasse in Nederland in de 19e eeuw. Utrecht-Antwerpen: Het Spectrum, $1978^{I I}$

Buchner, W.S. [Büchner, W.F.], "Verhandeling over de middelen, ter voorkoming en beteugeling van de heerschende ziekten bij uitgestrekte droogmakerNatuurk.Verh.Holl.Maatsch. Wetensch. dl. 11 (1822) 3-76

Buchner, F.W., [Büchner, W.F.], Verhandeling over den invloed der Noord-Hollandsche droogmakerijen na 1608 op de gezondheid der ingezerenen. Utrecht: S. Altheer, 1826

Büchner, W.F., Bijdragen tot de geneeskundige topographie en statistiek van Gouda. Gouda: G.B. van Goor, 1842

Büchner, E.C.,Bijdragen tot de statistiek der sterfie in de gemeente Amsterdam, gedurende de laatste twaalfjaren. Amsterdam: C.G. van der Post, 1852

Büchner, E.C., 'Over den invloed der luchtgesteldheid op de sterfte, gedurende twaalf jaren, van 1841 tot 1852, in de gemeente Amsterdam", Tijs.NMG 5 (1854) II, 289-309

Budd, W., De Aziatische cholera te Bristol in 1866. Een voorbeeld hoe de cholera zelfs in groote steden kan geweerdworden. Vertaald door H. van Cappelle. 's Gravenhage: S. van Velzen, 1873

Bulloch, W., The history of bacteriology.(1938) Reprint New York: Dover Publications, 1979

Burns, C.R., 'The nonnaturals: A paradox in the Western concept of health', The Journal of Medicine and Philosophy 1 (1976) 3, 202-21.1

Bynum, W.F., 'Cullen and the study of fevers in Britain', 1760-1820 in: W.F. Bynum \& V. Nutton (eds.), Theories of fever from antiquity to the Enlightenment. Londen: Wellcome Institute for the History of Medicine, 1981

Canguilhem, G., Wissenschaftsgeschichte und Epistemologie. Frankfurt am Main: Suhrkamp, 1979

Canguilhem, G., La connaissance de la vie. Parijs: J. Vrin, $1980^{2}$

Cannegieter, D., 150 jaar Gezondheidswer. Assen: Van Gorcum en Comp., 1954 Cappelle, H. van, 'Iets over de sterfte der kinderen beneden de twee jaren te Amsterdam', Schat
der Gezondheid 1 (1858) 83-96

Cappelle, H. van, 'Verslag over de volksziekten, welke in 1857 in Nederland hebben geheerscht',

gedurende van, 'Bijdrage tot de geschiedenis der epidemie van diphteritis in Nederland, Cappelle, $H$. van, 'Bijdrage tot de geschiedenis. Tijds. Geneesk. 6 (1862) 565-590

Ned. Tijds. Geneesk. 7 (1863) 707-716 
Cappelle, H. van, 'Internationale Sanitaire Conferentie te Konstantinopel', Ned.Tjis. Geneesk 10 (1866) I, 369-374

Cappelle, H. van; Egeling, L.J.; Evers, J.C.G.; Gunning, J.W.; Penn, J. \& Heusde, A.C. van, De choleraepidemie in Nederland in 1866 en 1867. Uitgegeven door het Departement van Binnenlandsche Zaken. 's Gravenhage: Van Weelden en Mingelen, 1875

Cappers, W., 'Op zoek naar zekerheid omtrent de dood. Totstandkoming en uitvoering van de begrafeniswet van 1869 in Nederland', Groniek 20 (1987) 99, 98-109

Carsten, B., 'Invloed van hygiënische maatregelen op het sterftecijfer eener gemeente", Ned. Tijds. Geneesk. 26 (1882) I, 565-568

Carsten, B., 'Verbetering van den gezondheidstoestand der gemeente Numansdorp, ten gevolge van het inlaten van zoet water in kanalen en slooten, die vór dien tijd zout water bevatten', Ned.Tijds. Geneesk. 28 (1884) I, 180-182

Centraal Bureau voor de Statistiek, Geschiedenis van de statistiek in het Koninkrijk der Nederlanden (1902). Fotografisch herdruk, uitgegeven onder auspiciën van de studievereniging voor sociaaleconomische geschiedenis Amsterdam. Wageningen: Landbouwhogeschool, 1974

Cohen, D., 'Over de sterfteverhouding in Drenthe', Ned.Tids. Geneesk. 5 (1861) 497-498

Coleman, W., 'Health and Hygiene in the Encyclopédie: A Medical Doctrine for the Bourgeoisie', Journal of the History of Medicine 29 (1974) 1, 399-421

Coleman, W., Death is a social disease. Public health and political economy in early industrial France. Madison: the University of Wisconsin Press, 1982

Coleman, W., Yellow fever in the North. The methods of early Epidemiology. Madison: the University of Wisconsin Press, 1987

Comte, A., La science sociale. Présentation et introduction d'Angèle Kremer-Marietti. Parijs: Gallimard, 1972

Copier, R. \& Maanen, M. van, 'Effecten van de cholera in 1866/1867 op gemeentelijk en medisch terrein in Rotterdam'. Niet uitgegeven scriptie. Nederlandse lerarenopleiding Delft, afd. geschiedenis, 1983

Coronel, S.Sr., Middelburg, voorheen en thans. Bijdrage tot de kennis van den voormaligen en tegenwoordigentoestand van het armwezen aldaar. Middelburg: Van Benthem en Jutting, 1859

Coronel, S.Sr., 'De ziekten der calicot-wevers", Ned.Tijds. Geneesk 4 (1860) 497-506

Coronel, S.Sr., Gezondheidsleer toegepast op de fabrieksnijverheid. Een handboek voor industrielen, genees- en staathuishoudkundigen. Haarlem: De Erven Loosjes, 1861

Coronel, S.Sr., "Een beroep op de goede gezindheid der Industrieelen in Nederland', Schat der Gezondheid 4 (1861) 13-19

Coronel, S.Sr., "De Hilversumsche industrie. Een hygiènisch-sociale studie", Ned.Tijds. Geneesk. 6 (1862) 433-447

Coronel, S.Sr., 'De bevolking van Hilversum in verband tot hare industrie: eene statistische studie', Ned. Tijds. Geneesk. 6 (1862) 651-664

Coronel, S.Sr., 'De ligchamelijke ontwikkeling in verband tot den maatschappelijken toestand en den arbeid der kinderen', Schat der Gezondheid 5 (1862) 193-206

Coronel, S.Sr., 'De Leidsche wolfabrieken en haar invloed op de gezondheid der arbeiders', Ned.Tijds. Geneesk. 8 (1864) 225-239

Coronel, S.Sr., 'De diamantwerkers te Amsterdam. Eene hygiènische studie", Ned.Tijds.Geneesk. 8 (1864) 633-650

Coronel, S.Sr., 'Over het verhandelde in de 5de (historische en staatsgeneeskundige) sectie, gedurende 1862-1865',Ned.Tijds. Geneesk. 9 (1865) II, 377-382

Coronel, S.Sr., 'Een blik op de maatschappelijke en staatkundige ontwikkeling der arbeidende klasse in Engeland", De Gids 33 (1869) II, 473-528

Coronel, S.Sr., 'De zorg voor gezonde woningen' in: L. Ali Cohen (red.), Handboek der openbare gezondheidsregeling en der geneeskundige politie, met het oog op de behoefte en de wetgeving van Nederland 1. Groningen: J.B. Wolters, 1872

Coronel, S.Sr., 'De zorg voor de gezondheid bij de verschillende beroepen' in: L. Ali Cohen (red.), Handboek der openbare gezondheidsregeling en der geneeskundige politie, met het oog op de behoefte en de wetgeving van Nederland I. Groningen: J.B. Wolters, 1872

Coronel, S.Sr., 'De volksvoeding in Friesland', Ned. Tijds. Geneesk. 20 (1876) II, 103-129

Coronel, S.Sr., 'Een worstelstrijd van veertig jaar'. Transeript van niet uitgegeven, onvoltooide autobiografie. In eigen beheer 
Daalder, H. 'Politieke Instellingen en Politieke Partijen" in: F.L. van Holthoon (red.), De Nederlandse samenteving sinds 1815. Wording en samenhang. Assen-Maastricht: Van Gorcum en Comp., 1985

Daalen, R. van, 'Openbare hygiëne en prive-problemen: het ontstaan van de Amsterdamse gezondheidlszorg', Sociologisch Tijdschrift 9 (1983) 568-605

Daniëls, C.E., De kinderpok-inenting in Nederland, meerendeels naar onuitgegeven bescheiden bewerkt', Ned. Tijds. Geneesk. 19 (1875) II, 17-222

Daniëls, C.E., Levensschets van Dr. A.H. Israëls', Ned. Tijds. Geneesk. 28 (1884) I, 881-903,913-927

Dawber, Th.R., The Framingham study. The epidemiology of atherosclerotic disease. Cambridge, Massachusetts-Londen: Harvard University Press, 1980

Degen, H., 'München als Tagungsort der Gesellschaft Deutscher Naturförscher und Aerzte', Naturwissenschafiliche Rundschau 25 (1972) 10, 367-382

Delprat, C.C., 'Dr. A.F.H. Lespinasse', Gedenkboek der Nederlandsche Maatschappij tot bevordering der Geneeskunst bij haar viff-en-zeventigjarig bestaan. Amsterdam: 1924

Delprat, C.C., "Het ontstaan der Nederlandsche Maatschappij tot bevordering der Geneeskunst en haar rol bij de herziening der geneeskundige staatsregeling van 1818', Gedenkboek der Nederlandsche Maatschappij tot bevordering der Geneeskunst bij haar viff-en-zeventigjarig bestaan. Amsterdam: 1924

Delprat, C.C., 'De geschiedenis der Nederlandsehe geneeskundige tijdschriften van 1680 tot 1857, IIII', Ned. Tijds. Geneesk. 71 (1927) Ia, 3-116; Ib, 1711-1824; IIa, 13-86

Delprat, C.C., De geschiedenis van de eerste 50 jaren van het Nederlandsch Tijdschrift voor Geneeskunde 1857-1907. Haarlem: F. Bohn, 1932

Delprat, C.C., De wording en de geschiedenis wan het Genootschap ter bevordering van Natuur-, Genees-, en Heelkunde te Amsterdam. Amsterdam: A.H. Kruyt, z.j.

Dewhurst, K., Dr. Thomas Sydenham (1624-1689). his life and original writings. Londen: The Wellcome Historical Medical Library, 1966

Dijk, J.P. van, 'Doodsoorzakenclassificaties 1750-1950. Schets van de ontwikkeling van plaatselijke sterftelijsten lijsten tot een Internationale Classificatie van Doodsoorzaken'. Niet uitgegeven scriptie. Instituut voor sociaal-medische wetenschappen der Rijksuniversiteit Groningen (ISMWrapport 81-PO-27). Groningen, 1981

Dijk, J.P. van, 'Doodsoorzakenclassificaties van 1750 tot 1900', Tijds. Geschiedenis Geneesk, Natuurw., Wisk en Techniek 5 (1982) 4, 145-157

Domela Nieuwenhuis, F., 'Benige 'kiekjes' uit het werkmansleven' in: Een veldtocht tegen het kapitalisme, 1879-1904. Amsterdam: L. de Boer, 1904. Eerder verschenen in Recht voor Allen 4 (1882)

Drooglever Fortuyn, H.J.W., 'Statistiek van de Nederlandsche Maatschappij tot bevordering der Geneeskunst', Gedenkbouk der Nederlandsche Maatschappij tot bevordering der Geneeskunst bij haar viff-en-zeventig jarig bestaan. Amsterdam: 1924

Eerenbeemt, H.F.J.M. van den, "Woontoestanden van de volksklasse in de $19 \mathrm{e}$ eeuw", Spiegel Historiael II (1976)9, 494-501

Eerenbeemt, H.F.J.M. van den, 'Wat leidde tot de woningwet 1901 ', Spiegel Historiael 11 (1976)10, $517-525$

Eerenbeemt, H.F.J.M. van den, 'De 'blauwe dood' als impuls tot maatschappelijke vernieuwing', Economisch- en Sociaal-Historisch Jaarboek 47 (1984) 91-104.

Egeling, L.J., Bespreking van De werkzaamheden van het algemeen hygiënisch congres, gehouden te Brussel, 20-23 september 1852, door J. Zeeman, De Gids 17 (1853) II, 354-358.

Egeling, L.J., "Rapport van de commissie voor statistiek, 1855",Tijds. NMG 6 (1855) I, 175-179

Egeling, L.J., 'Een vlugtige blik op de vrijstelling van de nationale militie wegens Ligchaamsgebreken, verleend in de provincie Noord-Holland in de jaren $1841-1855^{\prime}$, Tijds. NMG 7 (1856) I, 206226

Egeling, L.J., 'Brieven van een geneesheer', De Economist 6 (1857) 240-245

Egeling, L.J., 'Wat wij willen. Een woord tot inleiding", Schat der Gezondheid $l$ (1858) 1-5

Egeling, L.J., 'Waterverversching te 's Gravenhage', Schat der Gezondheid I (1858) 381-384

Egeling, L.J., 'Rapport van de commissie voor statistiek, 1858', Ned. Tijds. Geneesk. 2 (1858) 481-489

Egeling, L.J., 'Gezondheid, ziekte en dood. Noodzakelijke gevolgen van bepaalde oorzaken', Schat der Gezondheid 2 (1859) 105-117

Egeling, L.J., "De afvoer van vuil uit de steden', Schat der Gezondheid 2 (1859) 372-383

Egeling, L.J., 'Bijdrage tot de kennis van den gezondheidstoestand der stad Amsterdam in de jaren 1856-1860',Ned. Tijds. Genieesk. 7 (1863) 577-591 
Egeling, L.J., 'Opgaven betreffende de sterfte en de geboorten in eenige groote gemeenten in het jaar $1869 \ldots 1891^{*}$, Ned.Tijds. Geneesk. $13(1869)$ en volgende jaargangen

Egeling, L.J., 'Geboorten en sterfte in 12 Nederlandse steden', Gezondheid 1 (1877) 87-90

Egeling, L.J., 'Sterfte en geboorte in eenige groote gemeenten in het jaar 1877', Gezondheid 2 (1878) 126-127

Egeling, L.J. \& Pareau, A.H., Sterftecijfers van de stad 's-Gravenhage over de jaren 1866-1884. 's Gravenhage: W.P. van Stockum en Zn., 1889

Elias, N., Het civilisatieproces. Sociogenetische en psychogenetische onderzoekingen. $2 \mathrm{dlm}$. Utrecht: Het Spectrum, $1983^{3}$

Evans, A., 'Pettenkofer revisited. The life and contributions of Max von Pettenkofer (1818-1901)', Yale Journ. of Biology and Med. 46 (1973) 3, 161-176

Evers, J.C.G., 'Programma uit naam der commissie geneeskundige politie en openbare gezondheidsregeling', Tijds. NMG 1 (1850)I, 224-233

Eyler, J., Victorian social medicine. The ideas and methods of William Farr. Baltimore: Johns Hopkins University Press, 1979

Eyler, J., 'The conceptual origins of William Farr's epidemiology. Numerical methods and social thought in the 1830's, Bull. Hist.Med.54(1980) Suppl., 1-21

Festen, H., 125 jaar geneeskunst en maatschappij. Geschiedenis van de Koninklijke Nederlandsche Maatschappij tot bevordering der Geneeskunst. Ter gelegenheid van het 125 jarig bestaan der Maatschap- pij, 1974

Fokker, A.A. \& Man, J.C. de, 'Proeve eener geneeskundige plaatsbeschrijving van de stad Middelburg, hoofdplaats der provincie Zeeland', Tijds.NMG 7 (1856) II, 41-136

Fokker, A.P., 'De volksvoeding in Zeeland', Ned.Tijds. Geneesk. 21 (1877) II, 195-240

Fokker, A.P., 'Een en ander over bacteriën', Ned. Tijds. Geneesk. 24 (1880) I, 453-460

Fokker, A.P., 'De beteekenis der organismen bij miltvuurinfectie', Ned.Tijds. Geneesk. 24 (1880) I, 709-716

Frevert, U., Krankheit als politisches Problem 1770-1880. Göttingen: Vandenhoeck und Ruprecht, 1984.

Galdston, 1., 'Social medicine and the epidemic constitution', Bull.Hist.Med. 25 (1951) 8-21

Geuns, J. van, 'Blik op onze tegenwoordige geneeskundige staatsregeling', Bijdragen tot Geneeskundige StaatsregelingI, (1842) 4-17,57-73

Geuns, J. van, 'Rapport aan den minister van Binnenlandsche Zaken van den hoogleraar J. van

Geuns, door de Nederlandsche regering gedelegeerd bij de Internationale Sanitaire Conferentie to Konstantinopel', Ned.Tijds. Geneesk. 10 (1866)I, 577-588

Giele, J., 'Arbeidersbestaan. Levenshouding en maatschappijbeeld van de arbeidende klasse in Nederland in het midden van de negentiende eeuw*, Jaarboek voor de Geschiedenis van Socialisme en Arbeidersbeweging in Nederland. Nijmegen: SUN, 1976

Godefroi, M.H., 'De ontbinding der commissie tot herziening der geneeskundige wetten en verordeningen', Ned.Weekb. Geneesk. 1 (1851) 195-197

Godefroi, M.J., 'De kindersterfte te 's Hertogenbosch beneden het eerste levensjaar over de jaren 1858-1867',Tijds. Gezondheidsleer 3 (1869) 97-104

Godefroi, M.J., 'Oud en nieuw uit de geschiedenis der geneeskunde', Ned.Tijds. Geneesk. 38 (1894) II, $1006-1017$

Gysel, M., 'Adolphe Quetelet (1796-1874), la statistique et la biométrie de la croissance', L'Orthodontie Française 45 (1974) 643-677

H., 'De kindersterfte te Wissenkerke op Noord-Beveland', Ned.Tijds. Geneesk. 19 (1875) I, 45-48

Haakma Tresling, Th., 'Proeve eener beschrijving van de volksvoeding in het arrondissement Winschoten', Ned.Tijds. Geneesk. 18 (1874) I, 593-618

Haakma Tresling, Th., 'Onderzoek naar de volkswoeding in Nederland', Ned.Tijds.Geneesk. 20 (1876) II, 1-53

Haakma Tresling, Th., 'Vergelijking van de voeding van het werkvolk eener steenbakkerij, en die eener landhoeve, in verband met die van het personeel van het armhuis te Winschoten', Ned. Tijds. Geneesk. 22 (1878) I, 293-306

Haakma Tresling, Th., 'Rapport in hoofdzalak over de voeding van de landmacht', Ned.Tijds.Geneesk. 31 (1887) II, 437-446 
Haan, J. de, 'Bacteriologische laboratoria en instituten in Nederland' in: Alers, C. e.a., De ziekenverpleging en de zorg woor de openbare gezondheid in de laatste 50 jaren. Amsterdam: F. van Rossen, 1899

Hacking, I., 'Prussian numbers 1860-1882' in: L. Krüger, L.J. Daston \& M. Heidelberger (eds.), The probabilistic revolution. Vol. I: Ideas in history. Cambridge, Massachusetts-Londen, England: The MIT Press, 1987

Hahneveld, G.T., 'Veranderingen in de pathologie 1840-1870' in: D. de Moulin (red.), Kracht en stof. De introductie van moderne natuurwetenschappelijke denkwijzen in de geneeskunde, zoals blijkt uit de medische vakbladen 1840-1870. Amsterdam: Rodopi, 1985

Haines, B., 'Inter-relations between social, biological and medical thought, 1750-1850: Saint-Simon and Comte", The British Journal for the History of Sctence vol. 11 (1978) $\mathrm{nr}$. 37, 19-35

Halbertsma, H.P.W., 'Historische schets der drinkwaterleiding in Nederland' in: Alers, C. e.a., De ziekenverplegingen de zorg woor de openbare gezondheid in de laatste 50 jaren. Amsterdam: F. van Rossen, 1899

Handelingen der Staten-Generaal, Verslag van de, 1847-1880. Vanaf 1846 jaarlijks uitgegeven als afzonderlijk 'Bijblad' van de Nederlandsche Staatscourant. 's Gravenhage: Algemeene Landsdrukkerij.

Hanegraaf, C.D.L., Sterfie-statistiek van de gemeente Alrnhem over het tijdvak 1866-1876. Uitgegeven door den Geneeskundigen Raad van de provinciën Gelderland en Utrecht. Arnhem: 1878

Hannaway, C., 'The Sociêté Royale de Médecine and epidemics in the Ancien Régime', Bull.Hist.Med. 46 (1972) 257-263

Have, H. ten, Geneeskunde en filosofie. De invloed van Jeremy Bentham op het medische denken en handelen (diss.). Lochem: De Tijdstroom, 1983

Heederik, G.J., Van kasboekregister tot burgerlijke stand. Medisch-demografische aspecten van de registratievan huwelijken, geboorte en sterfte (diss.). Meppel: Boom, 1973

Heije, J.P., 'Over geneeskundige staatsregeling', Archief voor Geneeskunde 3 (1843) 267-284

Heije, J.P., 'Een woord aan alle geneeskundigen', Archief voor Geneeskunde 5 (1846) 210-222

Heije, J.P., 'Adres aan de Tweede Kamer. Met uittreksel uit de handelingen der twaalfde algemeene vergadering', Ned.Tijds. Geneesk. 5 (1861) 145-149

Hen, P.E. de, 'De Industrialisatie in Nederland' in: F.L. van Holthoon (red.), De Nederlandse samenleving sinds 1815. Wording en samenhang. Assen-Maastricht: Van Gorcum en Comp., 1985

Hendriksz, P.; Beckers, P.L. \& Amtzenius, D.J.A., Algemeen Rapport der commissie tot het onderzoeken van den aard en de meest geschikte wijze van behandeling van den Aziatischen
braakloop. 's Gravenhage: 1832 Hengel, J.F. van, 'De gezondheidstoestand in de gemeente Hilversum gedurende het jaar 1859',
Schat der Gezondheid 3 (1860) 143-151

Hengel, J.F. van, 'De Hilversumsche fabrieksarbeider', Schat der Gezondheid 4 (1861) 321-340 Schat der Gezondheid 5 (1862) 97-108 Hengel, J.F. van, Geneeskundige plaatsbeschrijving van het Gooiland. Bijdragen tot de geneeskundige
plaatsbeschrijving van Nederland. Derde stuk. Uitgegeven door het Departement van Binnen-
landsehe Zaken. "s Gravenhage: Algemeene Landsdnukerij,

landsehe Zaken. 's Gravenhage: Algemeene Landsdrukkerij, 1875
,T. \& Karpf, D., Gesundheitserziehung - Gestern und Heute. Stuttgart: Gentner Verlag, z.j. [1982]
Henle, F.G.J., Von den Miasmen und Kontagien und von den miasmatisch-komtagion

Henle, F.G.J., Von den Miasmen und Kontagien und von den miasmatisch-kontagiösen Krankheiten
(1840). Inleiding door F. Marchand. Leipzing (11840). Inleiding door F. Marchand. Leipzig: Barth, 1910. Reprint Leipzig: Zentralantiquariaat
DDR, 1968 Hirsch, A. (Herausg.), Biografisches Lexicon der hervorragendenAerzte aller Zeiten und Völker. $8 \mathrm{dln}$.
München-Berlijn: Urban und Schwarzenberg, $1962^{3}$

Holthoon, F.L. van, 'De Armenzorg in Nederland' in: F.L. van Holthoon (red.), De Nederlandse samenleving sinds 1815. Wording en samenhang. Assen-Maastricht: Van Gorcum en Comp 1985

Holthoon, F.L. van, 'De genese van Thorbeckes organische staatsleer', Bijdragen en Mededelingen

betreffende de Geschiedenis der Nederlanden, deel 101 (1986) 2, 177-201
Hont, D., 'Abattoirs en vleeschkeuring" in: Alers, C. e.a., De ziekenverpleging en de zorg voor de
openbare gezondheid in de laatste 50 jaren. Amsterdam: F, van Rossen, 1899

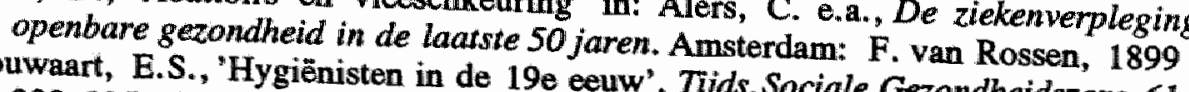
$308,335-349$

258-265, 295-

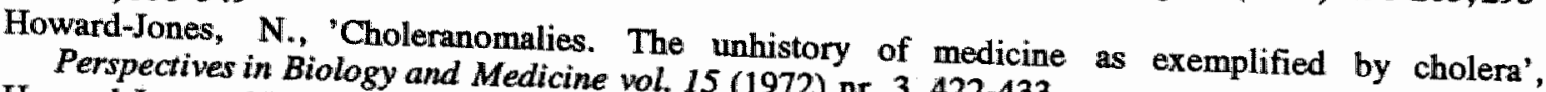

Howard-Jones, N., 'Gelsenkinchen tye vol. 15 (1972) nr. 3, 422-433 Max von Pettenkofer', British Med.Journal (1973) 1, 103-105 
Howard-Jones, N., 'Cholera nomenclature and nosology: a historical note", Bull. World Health Organisation 51 (1974) 317-324

Howard-Jones, N., The scientific backgrounds of the international sanitary conferences 1851-1938. Genève: WHO, 1975

Howe, G.M., Man, environment and disease in Britain (1972). Harmondsworth: Penguin Books, 1976

Huisman, F., 'Itinerant medical practitioners in the Dutch Republic: the case of Groningen', Tractrix. Yearbook for the History of Science, Medicine, Technology and Mathematics, vol. 1 (1989) 63-83

Huizinga, J., Verzamelde Werken VII. Universiteit, wetenschap en kunst. Haarlem: Tjeenk Willink en zoon, 1951

Idsenga, J., 'Mededelingen omtrent koepok-inenting in Nederland gedurende de laatste vijftig.jaren' in: Alers, C. e.a., De ziekenverpleging en de zorg voor de openbare gezondheid in de laatste 50 jaren. Amsterdam: F, van Rossen, 1899

Israëls, A.H., 'Over de sterfte der kinderen in de drie eerste levensjaren, gedurende de laatste dertig jaren te Amsterdam. Rapport, uitgebragt vanwege de commissie voor statistiek en geneeskundige topographie van de Geneeskundige Kring aldaar', Tijds.NMG $I$ (1850) II, 164194

Israëls, A.H., 'Rapport over de geneeskundige dienst, bij de onderscheidene diaconieën te Amsterdam', Tijds. NMG 4 (1853) I, 85-122

Israëls, A.H., 'Bijdragen tot de geschiedenis der lepra in de noordelijke Nederlanden', Ned.Tijds. Geneesk. I (1857) 161-175

Israëls, A.H., 'De geschiedenis der diphteritis beknopt medegedeeld', Ned.Tijds. Geneesk. 5 (1861) 203-218

Israëls, A.H., 'De sterfte der kinderen in de eerste drie jaren des levens te Amsterdam, in de jaren 1850-1859',Ned.Tijds. Geneesk. 6 (1862) 289-302

Israëls, A.H., 'De Hygiëne. Voordragt als inleiding tot zijne lessen, in de hygiëne gedurende den cursus 1871-1872',Ned. Tijds. Geneesk. 16 (1872) II, 123-141

Jacobi, H., 'Cholera in Noord-Holland', Ned.Tijds. Geneesk. 11 (1867) II, 117-143

Jonge, J.A. de, Industrialisatie in Nederland tussen 1850 en 1914 (diss. 1968). Nijmegen: SUN, 1976

Juffermans, P., Staat en gezondheidszorg in Nederland. Nijmegen: SUN, 1982

Jusatz, H.J., 'Die Bedeutung der medizinischen Ortsbeschreibungen des 19. Jahrhunderts fïr die Entwicklung der Hygiene' in: W. Artelt \& W. Rüegg (Herausg.), Der Ant und der Kranke in der Gesellschaft des 19. Jahrhunderts. Stuttgart: F. Enke, 1967

Kalmthout, P.J.C. van, 'Koortstypen in de $18 \mathrm{e}$ en $19 \mathrm{e}$ eeuw'. Niet uitgegeven scriptie. Instituut voor Geschiedenis der Geneeskunde Nijmegen, 1975

Keiser, M.J., Annotationes quasdam in febrem intermittentem, durante epidemia, praecipue Groningana 1826 et 1827 cum lienis morbo copulatam (diss.). Groningen: $M$. van Heyningen Bosch en Zn., 1830

Kerkhoff, A.H.M., Over de geneeskundige verzorgingvan het staatse leger (diss.). Nijmegen: R. Tissen e.a., 1976

Kerkhoff, A.H.M., 'Over de verhouding tussen gerechtelijke geneeskunde en openbare gezondheidsregeling' in: B.A.J. Cohen, D.J. van Lammeren, H.J. Leliefeld (red.), Inleiding tot de forensische geneeskunde. Raakvlakken tussen geneeskunst, gezondheidszorg en recht. Utrecht: Stichting voor sociale gezondheidszorg, 1989

Klinkert, J.J., Verloskundigen en artsen: verleden en heden van enkele professionele beroepen in de gezondheidszorg (diss.). Alphen a/d Rijn: Stafleu, 1980

Kluit, J. van der, 'Cholera in Zutphen', Oud-Zutphen 3 (1984) 2, 25-30

Knecht-Van Eekelen, A. de, Naar een rationele zuigelingenvoeding. Voedingsleer en kindergeneeskunde in Nederland 1840-1914. Nijmegen: Thieme, 1984

Knechtt-van Eekelen, A. de, 'Berichten over bacteriologie in het Album der Natuur' in: A.H.M.

Kerkhoff, A.M. Luyendijk-Elshout, M.J.D. Poulissen (red.), De novis inventis. Essays in the History of Medicine in honour of Daniel de Moulin. Amsterdam-Maarssen: Holland University Press, 1984

Knecht-van Eekelen, A. de, 'Abraham Pieter Fokker (1840-1906) en de serumtherapie bij difterie', Tijds. Gesch. Geneesk. Natuurw. , Wiskunde en Techniek 7 (1984) 161-171 
Knecht-van Eekelen, A. de, 'Een fysiologische geneeskunde" in: D. de Moulin (red.), Kracht en stof. De introductie van moderme natuurwetenschappelijke denkwijzen in de geneeskunde, zoals blijkt uit Nederlandsche medische vakbladen, 1840-1870. Amsterdam: Rodopi, 1985

Kooij, P., 'Gezondheidszorg in Groningen 1870-1914',Tijds. Sociale Geschiedenis 8 (1982) 112-155

Kooij, P., 'Stad en Platteland' in: F.L. van Holthoon (red.), De Nederlandse samenleving sinds 1815. Wording en samenhang. Assen-Maastricht: Van Gorcum en Comp., 1985

Kooperberg, Ph., Geneeskundige plaatsbeschrijving van Leeuwarden. 's Gravenhage: M. Nijhoff, 1888.

Korst, J.K. van der, Om liff en leven. Gezondheidszorg en geneeskunst in Nederland circa 1200-1960. Utrecht-Antwerpen: Bohn, Scheltema en Holkema, 1988

Kort, M. de, 'Over den aziatischen braakloop'. Niet uitgegeven scriptie. Nederlandse lerarenopleiding Delft, afd. Geschiedenis. 1983

Kossmann, E.H., De Lage Landen 1780-1940. Anderhalve eeuw Nederland en Belgiè. AmsterdamBrussel: Elsevier, 1984

Koster, W., Bespreking van Die niederen Pilze in ihren Beziehungen zu den Infectionskrankheiten und der Gesundheitspflege door C.W. von Nägeli, Ned.Tijds. Geneesk. 21 (1877) I, 1-16.

Koster, W., 'Het vrangstuk der specifieke bacteriën', Ned.Tijds. Geneesk. 21 (1877) I, 457-472

Kruithof, B., 'De deugdzame natie. Het burgerlijk beschavingsoffensief van de Maatschappij tot Nut van 't Algemeen tussen 1784 en 1860 ' in: B. Kruithof, J. Noordman \& P. de Rooy (red.), Geschiedenis van opvoeding en onderwijs. Nijmegen: SUN, 1982

Kühler, K.P.,Jan van Geuns. Zijn betekenis voor de geneeskundige wetenschap en het geneeskundig onderwijs (diss.). Leiden: De Jong, 1953

Kuhn, C.H., 'De morfologie der bacteriën', Ned.Tijds. Geneesk. 25 (1881) I, 705-706

Labruyère, W., G.J. Mulder 1802-1888(diss.). Leiden: J.J. Groen en Zn., 1938

Latour, B., Science in action. How to follow scientists and engineers through society. Milton Keynes: Open University Press, 1987

Lecuyer, B.P., 'Probability in vital and social statistics: Quetelet, Farr, and the Bertillons' in: L. Krüger, L.J. Daston \& M. Heidelberger (eds.), The probabilistic revolution. Vol. I: Ideas in history. Cambridge, Massachusetts-London, England: The MIT Press, 1987

Lenders, J., De burger en de volksschool. Culturele en mentale achtergronden van een onderwijshervorming in Nederland 1780-1850(diss.). Nijmegen: SUN, 1988

Lúnard, J., La médecine entre les pouvoirs et les savoirs. Histoire intellectuelle et politique de la médecine française au XIX $X_{-}^{e}$ siecle. Parijs: Aubier Montaigne, 1981

Lewis, R.A., Edwin Chadwick and the public health movement 1832-1854. Londen: Longmans Green, 1952

Lewis, F.M.M., "Dr. Marc d'Espines statistical nosology', Medical History 32 (1988) 301-313

Lieburg, M.J. van, 'Uit de medische stadsgeschiedenis van Rotterdam V. De cholera 1832-1853', Monitor 4 (1975) 5, 99-102

Lieburg, M.J. van, 'Geneeskunde en medische professie in het genootschapswezen van Nederland in de eerste helft van de negentiende eeuw', De Negentiende Eeuw 7 (1983) 123-145

Lieburg, M.J. van, 'De tweede geneeskundige stand (1818-1865). Een bijdrage tot de geschiedenis van het medisch beroep in Nederland', Tijdschrift voor Geschiedenis 96 (1983) 433-453

Lieburg, M.J. van, 'Van gildebus tot ziekenfonds: uit de voorgeschiedenis van de Stichting Ziekenfonds Rotterdam' in: M.J. van Lieburg (red.), Gilden, gestichten en gezondheidszorg. Vijftien opstellen over de medische stadsgeschiedenis van Rotterdam. Rotterdam: Stichting Ziekenfonds Rotterdam, 1984

Lieburg, M.J. van, 'Sympatische genezers, galvanisten en magnetiseurs te Rotterdam' in: M.J. van

Lieburg (red.), Gilden, gestichten en gezondheidszorg. Vijftien opstellen over de medische stadsgeschiedenis van Rotterdam. Rotterdam: Stichting Ziekenfonds Rotterdam, 1984

Lieburg, M.J. van, 'De Nederlandse medische tijdschriften en de wetenschappelijke geneeskunde 1840-1870' in: D. de Moulin (red.), Kracht en stof. De introductie van moderne natuurwetenschappelijke denkwijen in de geneeskunde, zoals blijkt uit Nederlandse medische vakbladen, 1840-1870. Amsterdam: Rodopi, 1985

Lindenboom, G.A., Dutch medical biography. A biographical dictionary of Dutch physicians and surgeons 1475-1975. Amsterdam: Rodopi, 1984 Lintsen, H.W., Ingenieurs in Nederland in de negentiende eeuw. Een streven naar erkenning en macht
(diss.). 's Gravenhage: M. Nijhoff, 1980 
Man, J.C. de, Over de statistiek der maandelijksche sterfte, of over den invloed der jaargetijiden op dezelve. z.p., z.j. [1848]

Man, J.C. de, 'Bijdrage tot de kennis der sterfte in Zeeland', Tijds.NMG 3 (1852) II, 195-232

Man, J.C. de, 'De afname der sterfte te Middelburg', Ned. Tijds. Geneesk. 26 (1882) I, 901-907

Man, J.C. de \& Broecke, J.C. van dem, De cholera asiatica in Zeeland, haar oorsprong en haar verspreiding gedurende de jaren 1832-1833 en 1848-1849. Middelburg: Abrahams, 1850

Man, J.C. de \& Fokker, A.A.,'Deziekenverpleging der behoeftigen', Tijds.NMG 4 (1853)II, 65-77

McDonald, J.C., 'History of quarantaine in Britain during the 19th century', Bull. Hist.Med. 25 (1951) 22-44

Melief, P.B.A.,De strijd om de amenzorg in Nederland 1795-1854 (diss.). Groningen-Djakarta: J.B. Wolters, 1955

Merkus Doornik, J.J.F.H.T., 'Verslag over de volksziekten, welke in 1856 in Nederland hebben geheerscht', Ned.Tijds. Geneesk. 3 (1859) 181-207

Metz, K.H., 'Social thought and social statistics in the early nineteenth century. The case of sanitary statistics in England', International Review of Social History 39 (1984) II, 254-273

Metz, K.H., 'Paupers and numbers: the statistical argument for social reform in Britain during the period of industrialisation" in: L. Krüger, L.J. Daston \& M. Heidelberger (eds.), The probabilistic revolution I: Ideas in history. Cambridge, Massachusetts-London, England: The MIT Press, 1987

Meulen, R.H.J. ter \& Widdershoven-Heerding, I., 'Het fysiologische ziektebegrip in de vroege Nederlandse psychiatrie' in: D. de Moulin (red.), Kracht en Stof. De introductie van moderne natuurwetenschappelijke denkwijzen in de geneeskunde, zoals blijkt uit Nederlandse medische vakbladen, 1840-1870. Amsterdam: Rodopi, 1985

Mijnhardt, W.W., Tot Heil van 't Menschdom. Culturele genootschappen in Nederland, 1750-1815 (diss.). Amsterdam: Rodopi, 1988

Moll, A., Handboek tot de leer der teekenen van gezondheid en ziekte. 2 vols. Amsterdam: C.G. Sulpke, $1826^{2}$

Moulin, D. de, 'Die Medizin zur Zeit der Regienung des Königs Wilhelm $I$ in den Niederlanden (1813-1840)',Janus 65 (1978) 21-44

Mulder, G.J., Verhandeling over de wateren en lucht der stad Amsterdam en aangrenzende deelen van ons vaderland. Amsterdam: C.G. Sulpke, 1827

Mulder, G.J., 'Handhaving der geneeskundige wetten in Nederland', Bijdragen tot Geneeskundige StaatsregelingI (1842) 18-25

Mulder, G.J., 'Besmettelijkheid der cholera', Nederlandsch Lancet 2e serie 4 (1848-1849) 278-294

Mulder, G.J., 'Aanspraak bij de opening der Tweede Algemeene Vergadering der Maatschappij tot bevordering der Geneeskunst', Tijds.NMG 1 (1850) I, 117-129.

Mulder, G.J., Open brief aan den heer Mr.J.R. Thorbecke. Rotterdam: H.A. Kramers, 1851

Mulder, G.J., 'Voorstel tot oprigting eener gezondheidscommissie te Utrecht', Ned. Weekb. Geneesk. 4 (1854) 383-388

Mulder, G.J., Adres aan zijne Excellentie den minister wan Binnenlandsche Zaken, betreffende het nieuwe geneeskundig Staats-bestuur. Rotterdam, 1866

Mulder, G.J., De Scheikundige middelen der Nederlandsche Regering tegen de verspreiding der cholera. Rotterdam: H.A. Kramers, 1866

Mulder, G.J., De natuurkundige methode en de verspreiding der cholera. Rotterdam: H.A. Kramers, 1866

Neurdenburg, M.G., Doodsoorzaak en statistiek. Amsterdam: Paris, 1929

Nierop, L. van, 'De aanvang der Nederlandsche Demographies', Economisch-Historisch Jaarboek 5 (1919)1, 192-208

Nieuw Nederlandsch Biografisch Woordenboek, P.C. Molhuysen, P.J. Blok, F.K.H. Kossmann (red.), 10 dlln. Leiden: A.W. Sijthoff, 1911-1937

Nieuwenhuys, C.J., Proeve eener geneeskundige plaatsbeschrijving der stad Amsterdam. 4 din. Amsterdam: Joh. van der Hey, 1816-1820

Norton Wise, M., 'How do sums count? On the cultural origins of statistical causality' in: L. Krüger, L.J. Daston \& M. Heidelberger (eds.), The probabilistic revolution I: Ideas in history. Cambridge, Massachusetts-Londen, England: The MIT Press, 1987 
Olvers, J.A.S.M.,Cholera en het gemeentebeleid in Dordrecht in de 19 e eeuw. Dordrecht: Gemeentelijke Archiefdienst, 1982

Onnen, M.F., Wenken betreffende de gesteldheid van Dordrecht in betrekking tot de gezondheid. Dordrecht: H.R. van Elk, 1867

Onnen, M.F., Onderzoek naar de werking van de maatregelen ter bevordering der volksgezondheid te Dordrecht, op het jaarlijksch gemiddelde sterftecijfer dier gemeente", Ned.Tijds. Geneesk 20 (1876) $1,709-720$

'Ontwerp van wet, tot regeling van hetgeen betrekkelijk is tot de uitoefening van de verschillende takken der Geneeskunst', Staatscourant 20 november 1844

Ontwerpen van Wet op het geneeskundig Staatsbestuur, ingediend door de Staatscommissie benoemd bij KB's wan 25 jull en 4 augustus, no.'s 64 en 50. 's Gravenhage: Algemeene Landsdrukkerij, 1851

Opwijrda, R.J., Geneeskundige wetten van 1 juni 1865 (Staatsblad no. 58-61). Met de daarover vooral in de Tweede Kamer der Staten-General gewisselde stukken en gehouden beraadslagingen. Nijmegen: Thieme, 1866

Overbeek de Meijer, G. van, 'Algemeene beschouwing over den aard en de werking van smetstoffen' in: L. Ali Cohen (red.), Handboek der openbare gezondheidsregeling en der geneeskundige politie, met het oog op de behoefte en de wetgeving van Nederland I. Groningen: J.B. Wolters, 1872

Overbeek de Mejjer, G. van, 'Rede, gehouden op 26 Maart 1887 in het groot-auditorium der Rijksuniversiteit Utrecht', Ned.Tijds. Geneesk, 31 (1887) I, 542-556

Overbeek de Meijer, G. van, 'Onderzoek en zuivering van drinkwater', Ned.Tijds.Geneesk. 31 (1887) II, 334-341

Overbeek de Meijer; G. van, 'Het vermogen der thans gebruikelijke gasvormige en vloeibare ontsmettingsmiddelen', Ned. Tijds. Geneesk. 32 (1888) II, 89 Overbeek de Meijer, G. van, 'Bacteriologisch onderzoek van drinkwater', Ned.Tijds. Geneesk. 32
(1888) II, 315-316

Overbeek de Meijer, G. van, "Verbetering van den gezondheidstoestand in Nederland sedert 1865', Ned.Tijds. Geneesk. 34 (1890) I, 34-39

Overbeek de Meijer, G. van \& Carsten, B., De Pokken-epidemie in Nederland in 1870-1873. Uitgegeven door het. Departement van Binnenlandsche Zaken. "s Gravenhage: Van Weelden en
Mingelen, 1875 Penn, J., "Geneeskundige Staatsregeling I-VII", Ned. Weekb. Geneesk. I (1851) 439-442, 449-453, 459-
464, 479-483,493-479,521-525; 2 (1852) 241-245 Penn, J., 'Het openbaar gezondheidswezen in Engeland', Ned. Weekb. Geneesk. 2 (1852) 345-348,
355-359

Penn, J., Bespreking van Bijdragen tot de statistiek der sterfte in de gemeente Amsterdam door E.C. Büchner, Ned. Weekb. Geneesk. 3 (1853) 52-57

Penn, J., 'Openbare gezondheidsregeling in Frankrijk', Ned. Weekb. Geneesk. 3 (1853) 79-82, 89-92 Penn, J., 'Over maatregelen ter wering en vermindering der epidemische cholera in Nederland',
Ned. Weekb. Geneesk. 3 (1853) 389-397

Penn, J., 'De instelling eener gezondheidscommissie to Rotterdam', Ned. Weekb. Geneesk. 4 (1854)
197-199, 207-210 Penn, J., "Over de openbare gezondheidsregeling in Engeland, Ned. Weekb. Geneesk.4 (1854) 329.
335, 373-376 Penn, J., 'Opmerkingen omtrent de ingediende wetsontwerpen tot regeling van de uitoefening der
geneeskunst enz.', Ned. Tijds. Geneesk. I (1857) 649-656

Penn, J. \& Ali Cohen, L., 'Rapport betreffende de maatregelen tot wering der cholera te nemen',
Staatscourant 8 en 9 april $1866,2-4$. Tevens Staatscourant 8 en 9 april $1866,2-4$. Tevens als bijlage IV opgenomen in: H. van Cappelle e.a.,
De cholercaepidemie in Nederland in

Pennink, J.J., Gezondheidseerland in 1866 en 1867 Algemeen. Amsterdam: Van Munster en Zn. Uitgegeven door de Maatschappij tot Nut van 't

Philips, R., Gezondheidszorg in Limburg. en Zn., Van der Hey en Zn., 1828 1940. Assen: Van Gorcum en Comp., 1980 en acceptatie van de gezondheidsvoorzieningen 1850

Polijn Büchner, 161-169 en zuigelingen- en kindersterfte in voor dood; het verband tussen sociaal-economische positie Geschiedenis \& (1982) 27, 231-281 
Pous Koolhaas, C.P.,De waterleidingte 's Gravenhage.'s Gravenhage: M. Nijhoff, 1865

Pous Koolhass, C.P., De cholera, haar ontstaan en hare bestrijding.'s Gravenhage: C. van Doorn en Zn., 1866

Pous Koolhaas, C.P., 'Een woord vooraf', Tijds. Gezondheidsleer 1 (1867) 1-4

Pous Koolhaas, C.P.,' Waterverversching', Tijds. Gezondheidsleer 2 (1868) 143-147

Pous Koolhaas, C.P., 'De rioolkwestie', Tijds. Gezondheidsleer 2 (1868) 35-39, 173-182

Pous Koolhaas, C.P.,De waterleiding en de bodemverontreiniging te 's Gravenhage. 's Gravenhage: C. van Doom en Zn., 1874

Pruys van der Hoeven, C.; Kaathoven, C.W.H. van \& Salomon, G., Geschiedverhaal van de choleraepidemie te Leiden in 1832. Leiden: C.C. van der Hoek, 1833

Pruys van der Hoeven, C., Anthropologisch Onderzoek. 4 dln., 2 vols. Leiden: E.J. Brill, 1851-1854

Querido, A., Een eeuw Staatstoezicht op de volksgezondheid. Den Haag: Staatsuitgeverij, 1965

Querner, H. \& Schipperges, H. (Herausg.), Wege der Naturforschung 1822-1972 im Spiegel der Versammlungen Deutscher Naturforscher und Aerzte. Berlijn-Heidelberg-New York: Springer Verlag, 1972

Ramaer, J.N., 'Geneeskundige stand en controle', Bijdragen tot Geneeskundige Staatsregeling III (1845) 91-119

Ramaer, J.N., 'Openingsrede van de tiende algemeene vergadering der Nederlandsche Maatschappij tot bevordering der Geneeskunst', Ned.Tijds. Geneesk. 2 (1858) 401-406

Rapport aan den minister wan Binnenlandsche Zaken, over desinfectie met betrekking tot de cholera, witgebracht door de algemeene cholera-commissie. 's Gravenhage: Van Weelden en Mingelen, 1866

Rapport aan den Koning van de commissie, benoemd bij Zijner Majesteits besluit van de l6den juli 1866 , no. 68, tot onderzoek van drinkwater in verband met de verspreiding van cholera en tot aanwijzing der middelen ter voorziening in zuiver drinkwater. "s Gravenhage: Van Weelden en Mingelen, 1868

Rapport van de commissie benoemd bij Zijner Majesteits besluit van 2 februari 1879, no. 15, tot voorlichting der regeringbij het ontwerpen van voorschriften ten ingevolge art. 4 en art. 87 der wet van 17 augustus 1878, no. 127. 's Gravenhage: W.P. van Stockum en $\mathrm{Zn}$., 1879

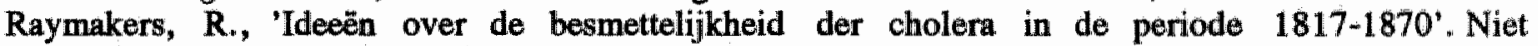
uitgegeven scriptie. Instituut voor Geschiedenis der Geneeskunde Nijmegen, 1979

Regt, A. de, Arbeidersgezinnen en beschavingsarbeid: ontwikkelingen in Nederland 1870-1940. Een historisch-sociologische studie (diss.). Meppel: Boom, 1984

Reinsma, R., 'De commissie "belast met het onderzoek naar den toestand der kinderen in fabrieken arbeidende' komt gereed met haar werk', Sociaal Maandblad Arbeid 22 (1967) 402-414

Riley, J.C., 'The medicine of the environment in eighteenth-century Germany', Clio Medica 18 (1983) $1 / 4,167-178$

Risse, G.B., 'Typhus fever in eighteenth-century hospitals: new approaches to medical treatment', Bull. Hist.Med. 59 (1985) 176-195

Romijn, W., Welvaart en gezondheid. Amsterdam: Algemeen ziekenfonds Ziekenzorg, 1955

Rosen, G., 'Disease and social criticism. A contribution to a theory of medical history', Bull.Hist.Med. 10 (1941) 5-15

Rosen, G., 'Problems in the application of statistical analysis to questions of health: 1700-1880', Bull. Hist.Med. 29 (1955) 27-45

Rosen, G., 'Disease, debility and death' in: H.J. Dyos \& M. Wolff (eds.), The Victorian city: images and realities.Londen-Boston: Routledge and Kegan Paul, 1973

Rosen, G., 'The fate of the concept of medical police' in: G. Rosen, From medical police to social medicine. Essays on the history of health care. New York: Science History Publications, 1974

Rosen, G., 'Cameralism and the concept of medical police' in: G. Rosen, From medical police to social medicine. Essays on the history of health care. New York: Science History Publications, 1974

Rosenberg, Ch., 'The cause of cholera: aspects of etiological thought in nineteenth century America", Bull.Hist.Med. 34 (1960) 331-354

Rotschuh, K.E., Konzepte der Medizin in Vergangenheit und Gegenwart. Stuttgart: Hippocrates, 1978.

Ruitenbeek, H., 'De Polsbroek. Een wijk in Zutphen. Haar ontwikkeling in de $19 \mathrm{e}$ eeuw'. Niet uitgegeven scriptie. Katholieke Universiteit Nijmegen, afd. Geschiedenis, 1983 
Rutten, W., 'Interventie, revolutie en het civilisatieproces. De inentingscampagne tegen pokken in de Batalfse Republiek' in: J. Dekker \& M. Doorman (red.), Papers ten behoeve van het Tircum Symposium. De groei van interventie. Maastricht: Rijksuniversiteit Limburg, 1989

Saltet, R.H., 'Ontsmettingen in Nederland' in: Alers, C. e.a., De ziekenverpleging en de zorg woor de openbare gezondheid in de laatste 50 jaren. Amsterdam: F. van Rossen, 1899

Saltet, R.H, Voordrachten over gezondheidsleer. Haarlem: F. Bohn, $1919^{2}$

Sasse, H.F.A., Gedachten over de Natuur en behandeling der ziekte, welke gedurende de jaren 18261828 te Groningen geheerschs heef, Groningen: J. Römelingh, 1828

Schadewaldt, H., 'Diaita - Methoden der Gesundheitsbelehrung historisch gesehen', Deutsches Aerzteblatt Aerziliche Mitteilungen 72 (1975) 50, 3437-3440, 72 (1975) 51, 3486-3490, 72 (1975) 52 , 3524-3527.

Scheltema, S.P., Over de warde der geneeskunde voor de maatschappij', Tijds.NMG 5 (1854) II, 49-62

Scheltema Beduin, L., 'Over de sterfte te Amsterdam, 1854-1865',Ned.Tijds.Geneesk. 12 (1868) II, $399-435$

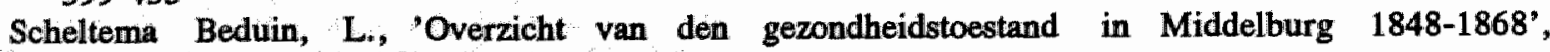
Ned.Tijds: Geneesk. 15 (1871) 1, 357-386

Scheltema Beduin, L., 'Rapport der commissie voor geneeskundige statistiek. De physieke en intellectueele ontwikkeling der militieplichtigen 1863-1889',Ned.Tijds. Geneesk. 35 (1891) II, 195205

Schick, J.W., 'Over de sterfteverhouding in verband tot hare oorzaken', Tijds. NMG 2 (1851) II, 3147

Schick, J.W., Over den gezondheidstoestand wan 's Gravenhage. 's Gravenhage: P.H. Noordendorp, 1852.

Schick, J.W., 'Rapport van den afgevaardigde der Maatschappij omtrent het Europeesch Congres voor Hygiene", Tids.NMG 3 (1852) I, 185-212

Schleurholts, L.J., Diss. pathologico-medica de effluviorium paludasorum, in regione inprimis Groningana, natura et efficacia noxia in corpus humanum. Groningen: C.M. van Bolhuis Hoitsema, 1830

Schmidt, F.J.I., "Beschouwingen over de waameming van de constitutio epidemica', Tijds.NMG I (1850) II, 49-68

Sigerist, H.E., "The value of health to a eity. Two lectures, delivered in 1873, by Max von Pettenkofer', Bull. Hist: Med. 10 (1941) 473-503,593-613

Sikkel, A., 'Het ontstaan der Nederlandsche Maatschappij ter bevordering der Geneeskunst en haar rol bij de herziening der geneeskundige statsregeling van 1818', Ned.Tijds. Geneesk. 46 (1902) I, 1079-1120

Sitter, W. de, Gezondheids-commissien. Groningen: H.R. Roelfsema, 1857

Smith, D.C., Medical science, medical practice, and the emerging concept of typhus in mideigthteenth century Britain' in: W. Bynum \& V. Nutton (eds.), Theories of fever from antiquity to the Enlightenment. Londen: Wellcome Institute for the History of Medicine, 1981

Snabilie, L.P.J., Praktische waarnemingen, nasporingen en aanmerkingen, betrekkelijk de verschijnselen, oorzaken, en geneeskundige behandeling van tusschenpoozende koortsen te Vissingen. Rotterdam: Wijnhoven Hendriksen, 1829

Staatkundig en staathuishoudkundig Jaarboekje 18 (1866)

Staatsblad van het Koningrijk der Nederlanden. 's Gravenhage: Algemeene Landsdrukkerij. Jaargangen 1813 e.v.

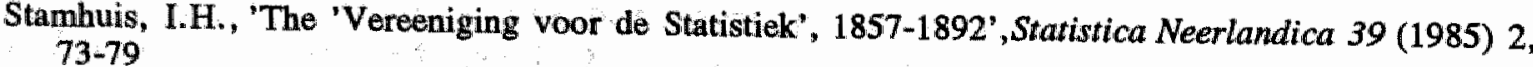

Stamhuis, I.H., Rehuel Lobatto (1797-1866). De bijdragen van een wiskundige aan de statistiek in Nederland in de negentiende eeuw. Amsterdam: Vakgroep Algemene Vorming, rapport nr.2. Vrije Universiteit, 1986

Stamhuis, I.H., 'Ciffers en Aequaties' en 'Kennis der Staatskrachten'. Statistiek in Nederland in de negentiende eum (diss.). Amsterdam: Rodopi, 1989

Stemerding, D., "Latours antropologie van de wetenschap. Planten, dieren en formules - classificaties in de achttiende ceuw' in: L. Boon \& G. de Vries (red.), Wetenschapstheorie: de empirische wending. Groningen: Wolters-Noordhoff, 1989

Sterfie-atlas van Nederland over 1841-1860. Uitgegeven door de Nederlandsche Maatschappij tot bevordering der Geneeskunst. Amsterdam: H.F. Bakels en Zn., 1866 
Sterfte-atlas van Nederland over de jaren 1860-1874. Uitgegeven door de Nederlandsche Maatschappij tot bevordering der Geneeskunst. Amsterdam: F. van Rossen, 1879

Stevenson, L.G., 'New diseases in the seventeenth century', Bull. Hist.Med. 39 (1965) 1-21

Stokvis, B.J., 'De cholera-sterfte bij de Israëlieten te Amsterdam', Ned.Tijds. Geneesk 11 (1867) II, 104-110

Stokvis, B.J., 'Toespraak bij het vijf-en-twintigjarig bestaan van den Geneeskundige Kring te Amsterdam', Ned. Tijds. Geneesk 17 (1873) I, 645-658

Stratingh, S.E., Groningen als woonplaats beschouwd. Eene bijdrage tot de geneeskundige plaatsbeschrijving van deze stad (diss.). Groningen: J.B. Wolters, 1858

Stratingh Tresling, S., Het bouwen van arbeiderswoningen.Haarlem: Loosjes, 1873

Stukken betreffende de herziening der geneeskundige wetten en verordeningen in 1841-1842. 's Gravenhage: Algemeene Landsdrukkerij, 1842

Sturmans, F., Epidemiologie. Theorie, methoden en toepassing. Nijmegen: Dekker en Van de Vegt, 1982

Susser, M., Epidemiology, health and society. New York-Oxford: Oxford University Press, 1987

Swaan, A. de, 'Aantekeningen uit het ondergrondse. Over de stedelijke waterhuishouding in de negentiende eeuw", Tijdschrift woor Geschiedenis 101 (1988) 337-351

Sybrandi, N.D., Verslagen van de ziekten welke gedurende het najaar van 1846 en 1847 binnen Amsterdam geheerscht hebben. 2 dln. Zwolle: 1847, 1848

Sybrandi, N.D.,' 'Verslag omtrent de ziekten, welke in de jaren 1847 en 1848 in Nederland hebben geheerscht', Tijds.NMG 1 (1850) I, 170-223

Sybrandi, N.D., 'Verslag omtrent de ziekten, welke in het jaar 1849 in Nederland hebben geheerscht, namens de commissie voor geneeskundige plaatsbeschrijving en volksziekten', Tijds. NMG 2 (1851)I, 169-336

Sybrandi, N.D., 'Verslag over de ziekten, welke in 1850 in Nederland hebben geheerscht, namens de commissie voor geneeskundige plaatsbeschrijving en volksziekten', Tijds.NMG 4 (1854) I, 364

Sybrandi, N.D., 'Verslag omtrent de ziekten, welke in 1853 in Nederland geheerscht hebben, namens de commissie voor geneeskundige plaatsbeschrijving en volksziekten', Tijds.NMG 6 (1855) I, 91-174

Sypkens Smit, J.H., Leven en werken van Matthias van Geuns m.d. 1735-1817(diss.). Assen: Van Gorcum en Comp., 1953

Taton, R. (éd.), Histoire généraledes sciences III, vol. I, Le XIX_e siècle. Parijs: Presses Universitaires de France, 1964-1969

Tellegen, J.W.C. 'Arbeiderswoningen en woninghygiène in Nederland' in: Alers, C. e.a., De ziekenverplegingen de zorg voor de openbare gezondheid in de laatste SO jaren. Amsterdam: F. van Rossen, 1899

Teixeira de Mattos, I., Verslag omtrent den ziektetoestand der stad Amsterdam in 1856 ... 1862, in verband met den geneeskundigen armendienst. Amsterdam: Stadsdrukkerij, 1857, 1858, 1860, $1861,1862,1863,1865$

Thijssen, H.F., Geschiedkundige beschouwingen der ziekten in de Nederlanden, in verband met de gesteldheid des lands en de leefwijze der inwoneren. Amsterdam: J. van der Hey en $\mathrm{Zn} ., 1824$

Timmer, M. \& Hansma, J., 'Social medicine in Western Europe 1848-1972', Tijds. Soc. Geneesk. 53 (1975) 11, Supplement nr. 1

Tsouyopoulos, N., Andreas Röschlaub und die romantische Medizin. Stuttgart: G. Fischer, 1982

Tsouyopoulos, N., 'Das Menschenbild der modernen Medizin und seine wissenschaftstheoretischen Voraussetzungen", Der Mensch in die Wissenschaften wom Menschen. Beiträge des XII. Deutschen Kongresses für Philosophie in Innsbrück, 29 Sept.- 3 Okt. 1981. Innsbruck: Solaris, 1983

Tsouyopoulos, N., 'German philosophy and the rise of modern clinical medicine', Theoretical Medicine 5 (1984) 345-357

Tussenbroek, C. van, 'Schoolhygiëne in Nederland' in: Alers, C. e.a., De ziekenverpleging en de zorg voor de openbare gezondheid in de laatste 50 jaren. Amsterdam: F. van Rossen, 1899

Tuske, D., 'Inhaltliche und methodische Entwicklungstrends der Gesundheitserziehung von der Renaissance bis zum ausgehenden 19. Jahrhundert', NTM-Schriftereihe Gesch..Naturw., Technik, Med. Leipzig 13 (1976) 1, 16-36 
Verdoorn, J.A., Het gezondheidswezen te Amsterdam in de 19e eeuw. Nijmegen: SUN, 1981

Verkade, W., Owerzicht der staakkundige denkbeelden van Johan Rudolph Thorbecke (1798-1872). Amhem: Van Loghum Slaterus, 1935

Verslag van de in het jaar 1826 te Groningen waargenomene ziekten, gegeven door de Plaatselijke Commissie van Geneeskundig Toevoorzigt aan de regering der stad Groningen. Groningen: J. Oomkens, 1828

Verslag over de ziekten, welke in het jaar 1849 ...1866 binnen Amsterdam geheerscht hebben. Namens de 6 de commissie an den Geneeskundige Kring door den secretaris dier commissie uitgebragt. C. de Bordes, over de jaren 1849-1851. 3 stn. Amsterdam: J. Noordendorp, 1850-1852; J.M. Fuchs, over 1852 en 1853. Amsterdam: J. Noordendorp, 1853-1854; H. van Cappelle over 1853 en 1854 en G.H. Saltet over 1856. Amsterdam: Metzler en Basting, 1855-1857; H. Fabius over 1857 en 1858, Amsterdam: Metzler en Basting, 1858 en 1859

Verslag eener commissie wit de Tweede Kamer der Staten Generaal over de verslagen van het Geneeskundig Staatstoezigt in de jaren 1866 en 1867, uitgebragtin de zitting van 10 november 1869 en goedgekeurd in de zitting van 15 Maart 1870. 's Gravenhage: Algemeene Landsdrukkerij, 1870

Verslag aan den Kaning van de bevindingen en handelingen van het Geneeskundig Staatstoezigt, 18661902. "s Gravenhage: Van Weelden en Mingelen, 1867-1903

Vervoorn, D.J., Wetgeving inzake dierziektenbestrijding. Ontwikkeling-doelstelling-resultaten.Openbare les. Utrecht: 1973

Verwey, L.H., De geneeskundige wetgeving in 1865 tot stand gebragt door Mr. J.R. Thorbecke. Rotterdam: H. Nijgh, 1865

Verzameling van Wetten, Besluiten en Reglementen betrekkelijk de burgerlijke Geneeskundige Dienst in het Koningrijk der Nederlanden. 's Gravenhage: J.B. Beekman, 1836

Verzameling van Stukken betreffende het Geneeskundig Staatstoezigt in Nederland. Uitgegeven door de inspecteurs en adjunct-inspecteurs voor het Geneeskundig Staatstoezigt. $19 \mathrm{dln}$. Den Haag: M.J. Visser, 1865-1888

Virchow, R., Mitreilungen uber die in Oberschlesien herrschende Typhus-Epidemie (1849); Die Not im Spessart. Eine medizinisch-geografisch-historische Skizze. (1852) Fotoreprint Darmstadt: Wissenschaftliche Buchgesellschaft, 1968

Virchow R. \& Leubuscher R.(Herausg.), Die medicinische Reform. Eine wochenschrift. Fotoreprint C. Kirsten \& K. Zeisler (Herausg.), Dokumente der Wissenschaftsgeschichte. Berlijn: AkademieVerlag, 1983

Visker, H., 'De openbare gezondheid in Delft, in het bijzonder de cholera-epidemieën'. Niet uitgegeven scriptie. Nederlandse lerarenopleiding Delft, afd. Geschiedenis, 1981

Vogelzang, 1. Drinkwatervoorziening van Nederland voor de aanleg van de drinkwaterleiding (diss.). Utrecht: Joh. Mulder, 1956

Vondelen, J.M. van, 'Een heldere geest tussen krankzinnigen. Ramaer als geneesheer'. Niet uitgegeven scriptie. Katholieke Universiteit Nijmegen, afd. Geschiedenis, 1986

Voorhelm Schneevoogt, G.E., 'Over de afzonderlijke uitoefening der Genees- en der Heelkunde', Bijdragen tot Geneeskundige StaatsregelingI (1842) 26-45

Voorhelm Schneevoogt, G.E., De heerschende ziektegesteldheid te Amsterdam, gedurende 1844-1846. z.p., z.j. [Amsterdam, 1847]

Voorhelm Schneevoogt, G.E., Bespreking van Over den gezondheidstoestand van 's Gravenhage door J.W. Schick, De Gids 16 (1852) II, 522-525

Voorhelm Schneevoogt, G.E., 'Hygieine', De Gids 25 (1861) I, 508-555

Vooys, A.C. de, 'De opkomst van de medische geografie in Nederland', Geografisch Tijdschrift 4 (1951) 1-8

Vooys, A.C. de, 'De sterfte in Nederland in het midden van de 19e eeuw. Een demografische studie', Tijds.Kon.Ned.Aardrijksk. Genootschap (tweede reeks) deel LXVIII (1951) 3, 233-271

Waardenburg, J.G., "Verslag over de ziekten, welke in 1852 in Nederland geheerscht hebben, namens de commissie voor geneeskundige plaatsbeschrijving en volksziekten', Tijds.NMG 5 (1854) I, 169-234

Waardenburg, J.G., 'Verslag over de volksziekten, welke in 1855 in Nederland hebben geheerscht', Ned. Tijds. Geneesk. 2 (1858) 345-366

Weijde, H. van der, 'De sociaal-culturele achtergronden', Spiegel Historiael 11 (1976) 10, 561-566

Weindling, P., 'Was social medicine revolutionary? Rudolf Virchow and the revolutions of 1848', Bull. Soc. Hist.Med. (1984) nr. 34, 13-18

Weiner, D. , 'Le Droit de l'homme à la Santé: une belle idée devant l'Assemblée constituante 17901791', Clio Medica 5 (1970) 208-223 
Weiner, D., 'Public health under Napolleon: the Conseil de salubrite de Paris, 1807-1815', Clio Medica 9 (1974) 271-284

Weispfenning, I., 'Pettenkofers Gesundheitswirtschaftslehre. Ein Meilenstein in der Entwicklung des öffentlichen Gesundheitswesens', Sudhoffs Archiv fur Geschichte der Medizin, Beiheft 24 (1984) 146-154

Wit, C.H.E. de (red.), Thorbecke en de wording van de Nederlandse natie. Nijmegen: SUN, 1980

Woelderink, B., 'De cholera epidemie van 1866 in Rotterdam', Rotr.Jaarb. 7e reeks 2 (1964) 302-318

Wohl, A.S., Endangered lives: public health in Victorian Britain. Cambridge, Massachusetts: Harvard University Press, 1983

Wolstenholme, G., 'Governments may damage your health', Journ. Royal Society of Physicians of London vol. 19 (1985) 17-22

Woud, A. van der, Het lege land. De ruimtelijke orde van Nederland 1798-1848. Amsterdam: Meulenhoff, 1987

Woude, A.M. van der, 'Bevolking en Gezin in Nederland' in: F.L. van Holthoon (red.), De Nederlandse samenleving sinds 1815. Wording en samenhang. Assen-Maastricht: Van Gorcum en Comp., 1985

Usselmuiden, P.G. van, Binnenlandse Zaken en het ontstaan van de moderne bureaucratie in Nederland 1813-1940(diss.). Kampen: Kok, 1988

Zeeman, J., 'Programma vanwege de commissie voor geneeskundige statistiek in Nederland", Tijds.NMG 1 (1850) I, 161-169

Zeeman, J., 'Het algemeen hygiènisch congres', Ned.Weekb. Geneesk. 2 (1852) 435-438, 445-449, $455-459,465-470,479-482,489-493,505-509,515-520$

Zeeman, J., 'Verslag namens de commissie voor geneeskundige statistiek', Tijds. NMG 5 (1854) I, $59-84$

Zeeman, J., 'Verslag namens de commissie voor statistiek', Tijds.NMG 6 (1855) I, 3-22

Zeeman, J., 'Pathologie der Cholera', Ned. Weekb. Geneesk. 5 (1855) 314-317, 325-328, 335-337

Zeeman, J., 'Verslag namens de commissie voor statistiek', Ned.Tijds. Geneesk. 1 (1857) 481-493

Zeeman, J., 'De sterfte beschouwd in verband met rijkdom en armoede', Ned.Tijds. Geneesk. 3 (1859) $121-124$

Zeeman, J., "Geschiedenis van de cholera gedurende 1859 in Nederland', Ned.Tijds. Geneesk. 4 (1860) 675-718

Zeeman, J., 'Verslag en voorstel namens de commissie voor geneeskundige statistiek', Ned.Tijds. Geneesk. 5 (1861) 340-342

Zeeman, J., 'Rapport van de commissie voor statistiek over de lotelingen van de provincie Groningen van 1836-1861' ,Ned. Tijds. Geneesk. 5 (1861) 691-723

Zeeman, J., 'Verslag van de commissie voor statistiek', Ned.Tijds. Geneesk. 12 (1868) II, 357-365

Zeeman, J., 'Sterfte-statistiek' in: Alers, C. e.a., De ziekenverpleging en de zorg voor de openbare gezondheid in de laatste 50 jaren. Amsterdam: F. van Rossen, 1899

Zon, H. van, Een zeer onfrisse geschiedenis. Studies over niet-industriële vervuiling in Nederland, 18501920 (diss.). Groningen: 1986 


\section{The Hygienists. Doctors, the State and the Health of the Nation in the Netherlands 1840-1890}

This study describes a distinct group of medical practitioners in the Netherlands in the years 1840 to 1890 , who adopted the view that the health of the nation is determined by the state of public health. Their scientific publications aimed at demonstrating this connection. They participated in a network of organizations involved in public health research and worked for the improvement of public hygiene and for the introduction of preventive medical legislation. Furthermore, they became active in political and social organizations and acceded into government bodies. In this study these doctors will be referred to as sanitary reformers or hygienists.

One of the theses to be developed in this book is that the hygienists played an essential part in replacing the old medical notions of the Ancien Régime by a new medical paradigm. This shift is placed in the context of the socio-political developments which took place after 1848: the transition from the traditional class-ridden society to a modern, liberal and unified state. Municipal autonomy was to play an essential part in this modern state, created in 1848 by the Minister of Internal Affairs, J.R. Thorbecke. It was the middle classes in particular, including doctors and other members of the liberal professions, who supported this development. They wished to acquire an important place in society, till then dominated by the aristocracy.

General dissatisfaction amongst doctors with their position in society and with the poor state of the population's health led to the formation of the Dutch Society for the promotion of Medicine (NMG) in 1849. The hygienist movement rose in parallel to this. The 1848 revolution liberated new energy amongst the middle-classes. In Germany doctors sided with the revolution in the conviction that corrupt and decayed regimes were responsible for the poor state of the nation's health. Their attitude had a great impact on the Dutch medical profession.

During the same period, all of Europe was visited by a cholera epidemic. The 1832 epidemic, which was countered by quarantine measures and philanthropic care, had had a disastrous outcome. This stimulated many doctors to approach the nation's health in a new way, in which public health care alone was stressed. The hygienists were not just ready for new medical ideas; they were also convinced that only political reform along liberal-democratic lines could create the necessary conditions for hygienic reform. Political and medical reform were inseparable.

Politically the hygienists were on the side of the doctrinaire liberals and their leader Thorbecke. Both the liberals and the hygienists stressed the importance of municipal autonomy. Thorbecke considered it of the utmost importance for the vitality of society that the state did not impose all kinds of regulations from above. The hygienists also believed that in the first instance a local, that is municipal, health policy should be developed. Central government would intervene only if local policy failed to improve public health.

This attitude towards the nation's health radically contradicted the technocratic-statist model, propagated by G.J. Mulder, professor at the University of 
Utrecht and well-known conservative opponent of Thorbecke. He advocated a medical profession strongly tied to the central government and more political power for medical professors. His thoughts owed much to French Bonapartism. In the Netherlands, however, his political concept failed to attract the support of either voters or doctors.

The hygienists were moderate enough to cooperate closely with Thorbecke. During the 1848 revolution some of them had proclaimed that only higher wages and the emancipation of the working class could improve the nation's health. After 1850, however, the hygienists embraced the more conservative 'Bodentheorie' of Max von Pettenkofer, professor of hygiene in Germany. He considered soil pollution as the main cause of epidemics and outlined a series of technical measures intended to combat this pollution.

In addition to Pettenkofer, the hygienists took their inspiration from the Belgium mathematician and statistician L.A.J. Quetelet. Quetelet's starting point was that under normal conditions social and biological data such as bodylength, criminality, suicide, intellectual capacities and mortality, were distributed amongst the people in a 'normal distribution'. Variations in a negative sense had to have a cause, which could be removed by political measures.

According to Quetelet, statistics was an important expedient in serving social progress. Based on these thoughts, the British sanitary reformer William Farr developed the so-called biometer. He calculated a 'physiological' death-rate of 17 per thousand. Higher municipal death rates were due to poor policy-making in the field of public health. According to Farr, in this case local authorities must change their policy. Following in the footsteps of Farr, the Dutch hygienists published the first Dutch atlas of mortality in 1865 .

\section{A new reality}

The statistical publications of the hygienists did not just present an objective description of reality. Statistics created a specific order within this reality. Firstly, through statistics the hygienists placed all civilians on an equal level. For the hygienist-statistician a death always carried the same weight. The death from cholera of an upper-class civilian or a poor man increased the death rate equally. How the different classes shared in this mortality, was of no relevance when the biometer was employed.

Secondly, the hygienists considered the mortality rate in the same way as the value of a thermometer, expressing the consequences of pathogenic, local environmental and life conditions. Mortality and morbidity were represented on maps, together with geographic data and details of sanitary conditions. Diseased places in the country or in a city could be recognized at a glance, and, following on from this, a comparison of death rates reflected the quality of sanitary conditions.

Through statistics the hygienists also created a new political order. In an unhealthy area measures to guarantee the quality of drinking water and the hygiene of soil and air had been insufficient. In other words, an area with a high death rate was also one where the benefits of preventive medicine and modern hygienic techniques had been insufficiently employed.

By using statistics in epidemiology the hygienists connected disease, the cause of disease, individuals, politics and society in an unprecedented manner. Disea- 
ses were the expression of poor management of the environment, a result of lack of civilization and faulty policy-making. Thus, diseases were symptoms of poor leadership. This statistically demonstrated connection between disease and policy placed disease and individuals in a new relationship, for, in many cases, the connection implied that civilians died through no fault of their own. Henceforth, civilians dying of an epidemic disease should be considered as victims of those obstructing 'progress'. According to the hygienists, precisely this reality, created by statistics, had to be the central issue in the debate on the nation's health.

\section{The power of statistics}

Statistics became the most important research tool, because statistics, unlike existing methods of research, offered a clear perspective on a programme to improve the nation's health. Statistics transformed epidemiology into a practical science with great social benefit.

According to the hygienists, the dragging discussion on the question as to whether cholera and other diseases were contagious was not relevant. This discussion had produced very few results in the preceding period. Thoughts about the nature and the life cycle of infectious matter and about the pathophysiological process in the human body had remained merely theoretical constructions. In other words, around 1850 scientific research had become deadlocked.

In opposition to this discussion, the hygienists put forward 'objective' measurements and empirical research. Statistics met their need to frame an inductive science of epidemics, just as the natural sciences fulfilled their wish to give pathology and therapy an inductive basis. The microscope and the pathologicalanatomical atlas were the most important expedients in clinical medicine, statistics and topography in epidemiology. Consequently, statistics created the possibility of arguing 'scientifically' at a time when the ultimate causes of epidemics were shrouded in mystery. Without seeking out hidden causes (for example, the contagion), one could study correlations between a number of aspects of the 'hygiena publica' and the appearence of common diseases. With this, epidemiology was transformed into a science which directed the social and political activity of both doctors and politicians.

Within ten years statistics came to dominate epidemiology. The success of statistics was based on three properties: the increase in scale in the number of data, standardization, and the facilitation of the process of dissiminating data in different directions.

Firstly, after 1850 statistical research was done by a nationally coordinated network of doctors, capable, after a short time, of publishing surveys of mortality and of various diseases for the country as a whole, the provinces and municipalities. These surveys for their part revealed geographic differences in health. Changes in the state of health could now be clearly detected over the years. A community where initially the local investigator had been his own master, was now, so to speak, carried off to the offices of the Ministry of Internel Affairs, where it became possible to obtain a good overview and to predict future developments. Henceforth, the Ministry came to function as a scientific centre stimulating new research and revealing new facts. Already after a few years one 
could draw some general conclusions about the cause of common diseases. Thus, from the very organization of statistics the hygienists gave a stimulus to a cycle of accumulation of knowledge, leading to an enlargement of research. They possessed knowledge on the state of health in each part of the country. This knowledge accorded more scientific status to the hygienists, who also came to be the government's most important 'suppliers of health knowledge'.

Secondly, statistical research initiated a standardization of research procedures. The effects of demographic changes on the death rate were calculated along established lines. The Dutch Society for the Promotion of Medicine also set up a protocol for topographical studies. Up until the 1880 s this protocol was based on Pettenkofer's 'Bodentheorie'.

Another standardization took place in the field of the definition of diseases. The hygienists rejected the contagionistic presumptions and the traditional method of describing species and genera morborum and of classifying diseases according to outward aspects, which all characterized early ninetheenth-century epidemiology. In their view the previous conception of disease was wrongly ontological. Diseases were not entities which could flourish and die following environmental changes, but were caused by disturbed anatomical and physiological relations in the body itself. From the 1850 s onwards the NMG, therefore, classified most diseases following their anatomical localization or the assumed causal physiological disorder. Consequently, there was a decrease in possible causes of death.

Through this standardization, statistical reports could be shaped following a fixed scheme of classification of diseases and causes of death. Thus, statistics changed medical knowledge, not only by increasing the amount of data on common diseases, but also by producing other and more stationary data: mortality and morbidity listings were based on a generally accepted classification of diseases.

Following the introduction of a fixed procedure for research and a fixed scheme for presenting data, one could classify large amounts of data as comparablle numbers, formulas, plain conceptions and brief texts. The state of health of an area could be compared with that of other areas at a glance; there were more possibilities for surveying health than ever before.

Finally, through statistics, the hygienists produced knowledge that could be more easily disseminated than the knowledge of their predecessors. Within the network of hygienists and in political circles the numbers could speak for themselves. After 1850 one observed changes in the country's health, without the observer being known. The hygienists put their analysis of the state of health in the form of lists and numbers presenting them as objective and true. Consequently, the hygienists succeeded in placing 'the nation's health' in the centre of the political debate on health care.

The political effects of the statistical rhetoric soon became noticeable. Members of parliament and ministers made increasing use of statistical facts in disputes with opponents. Ever more frequently facts came to stand in opposition to opinions. Ever more the discussion on the nation's health was dominated by the hygienists' 'positive science'. Consequently; for the political and social groups who had participated in this debate since the eighteenth century, the capacity to offer an analysis of their own decreased. Statistics now had the final word: differences in mortality between countries, cities and quarters existed year after 
year; these differences were structural and resulted from social conditions. Thus; through their statistical intervention, the hygienists diminished the possibilities for negotiating about facts in the field of public health.

\section{New legislation}

The introduction of the new medical laws in 1865 marked a time of triumph for the hygienists, because these laws fully confirmed their opinions. The introduction of uniform medical qualification provided equal quality health care for everyone. In addition, the government allocated more responsibility to the local authorities.

The 1865 State Health Inspectorate Act was not much more than a basic law intended to encourage local authorities to fulfill their responsibilities. Its main device was the stimulation of research on public health. Local authorities should take the results of this research seriously and act accordingly. Only if the municipalities obviously failed in this, did a 'douce violence' from the central government become justified to some extent. The scientific research, that was so vital to this scheme, was to be carried out by fourteen (adjunct) inspectors and by the members of seven medical councils of the State Health Inspectorate. Most of them had been hygienists since 1850 . They started a research programme con brio and at the same time recommended improvements. They also proposed several amendments in the law.

Since they based their reasoning on Pettenkofer's 'Bodentheorie', environmental protection played an important part in their activities. They aimed at the improvement of ground and surface water, though without much effect. For the purpose of the removal of faeces, a cheap pail-closet system was propagated. They turned against the so-called flushing system, so successful in later years. However, no new legislation was obtained in this field. With respect to drinking water, water works were opposed, as long as these would benefit the better-off only. According to the hygienists, the cleaning up of ground water was a better means of improving drinking-supplies, because this would benefit every citizen.

On a local level, the hygienists did not achieve much. Although much research still remains to be done, it seems clear that the hygienists seldom succeeded in convincing the local authorities of the necessity of governmental intervention. The hygienists came into conflict with the old liberal view that the authorities were not responsible for establishing a sound system of public hygiene. The great sanitary reforms would be carried out by another generation in another political context.

The fact that the Dutch hygienists accomplished so little in comparison, for example, with their British counterparts should be explained. It is argued that sanitary measures had by necessity been more drastic in Great Britain, because the growth of industrial cities had taken place much earlier than in the Netherlands.

The significance of the hygienists does not so much lie in the area of the concrete legislation and local regulations that they helped to achieve. Rather, they succeeded in putting public health on the political agenda. Moreover, they raised many sanitary problems and produced solutions, which were built upon after 1880. More important, however, was their contribution in the dissemination 
of new medical theories and a new way of thinking about the nation's health, breaking with the paradigms of the old class-ridden society and fitting in with the liberal-democratic state that was created in 1848. At the same time, the hygienists acquired the doctors' support - albeit not unanimously - for the new order. In a sense, the hygienists successfully encouraged Dutch doctors to participate in an emancipation movement of the learned middle classes in society. The hygienists, therefore, can be considered as the doctors who politically and socially worked out Thorbecke's 1848 legislation in the field of medicine. 
Acker Stratingh, G. (1804-1876)

Alexander, F.S. (1784-1844)

Ali Cohen, L. (1817-1889)

Ali Cohen, Ch. (1859-1913)

Alison, W.P. (1790-1859)

Andel, A.H. van (1836-1905)

Amtzenius, D.J.A. (1807-1848)

Baart de la Faille, J. (1795-1867)

Bake, H.A. (1754-1805)

Bakhuizen van den Brink, R.C. (1810-1865)

Balen Blanken, G.C. van (1827-1903)

Ballot, A.M. (1823-1874)

Banga, J. (1786-1877)

Baumhauer, M.M. von (1816-1878)

Beckers, P.L. (1789-1851)

Beijerink, J.A. (1800-1874)

Benoiston de Chateauneuf, L.F.(1776-1856)

Bentham, J. (1748-1832)

Berdenis van Berlekom, J.P. (1832-1903)

Bertillon, J. (1851-1922)

Berzelius, J.J. (1779-1848)

Billroth, Th. (1829-1894)

Bismarck, O. von (1815-1898)

Blaupot ten Cate, S. (1807-1884)

Blom Coster, T.H. (1817-1904)

Boerhaave, H. (1668-1738)

Bogaert, E.A.G. van den (1828-1880)

Boissier De Sauvages, F. (1706-1767)

Boogaard, J.A. (1823-1877)

Boogaard, J.F. (1831-1883)

Boon Czn., A. van der (1812-1886)

Bordes, C. de (1817-1858)

Bosch Kemper, jhr. G. de (1841-1912)

Bosch Kemper, jhr. J. de (1808-1876)

Boudin, J.C.M.F.(1806-1867)

Breda, J.G.S van (1788-1867)

Broecke, J.C. van den (1799-1870)

Broers, H.J. (1815-1876)

Broers, J.C. (1795-1847)

Büchner, E.C. (1812-1882)

Büchner, W.F. (1780-1855)

Budd, W. (1811-1880)

Cappelle, H. van (1825-1890)

Carsten, B. (1829-1892)

Chadwick, E. (1800-1867)

Cohen, D. (1815-1896)

Cohn, F. (1828-1898)

Comte, A. (1798-1857)

Coronel, S.Sr. (1827-1892)

Coulon, J. Vitringa (1767-1843)

Damman de Witt, J.H. (1820-1900)

Damme, M.H. (1819-1889)

Deen, I. van (1815-1869)

Delden Szn., P. van (1819-1914)

Dellhez, J.A. (1816-1885) 
Delprat, C.C. (1854-1934)

Domela Nieuwenhuis, F. (1846-1919)

Donders, F.C. (1818-1889)

Donker Curtius, D. (1791-1863)

Donkersloot, N.B. (1813-1890)

Doorn van Westcappelle, H.J. baron van (1786-1853)

Dorn Seiffen, I. (1818-1898)

Dort, K. Broes van (1816-1867)

Dozij, J.P. (1838-1906)

Duparc, H.M. (1817-1905)

Egeling, L.J. (1824-1892)

Engels, F. (1820-1895)

Espine, M. d' (1806-1860)

Evers, J.C.G. (1818-1886)

Fabius, H. (1827-1893)

Farr, W. (1807-1883)

Fock, C. (1828-1910)

Fokker, A.A. (1810-1878)

Fokker, A.P. (1840-1906)

Forster, J. (1844-1910)

Fracastorius, H. (1487-1553)

Frank, J.P. (1745-1821)

Fuchs, J.M. (1819-1900)

Geertsema Czn., J.H. (1816-1908)

Geuns, J, van (1796-1832)

Geuns, J. van (1808-1880)

Geuns, M. van (1735-1817)

Gobbelschroy, P.L.J. Servais van (1784-1850)

Gobée, C. (1804-1857)

Godefroi, M.H. (1813-1882)

Godefroi, M.J. (1819-1895)

Goeman Borgesius, H. (1849-1917)

Goudoever, L.C. van (1820-1894)

Griesinger, W. (1817-1868)

Groen van Prinsterer, jhr. P.J. (1764-1837)

Groshans, G.Ph.F.(1814-1874)

Guérin, J.R.G. (1803-1886)

Guizot, F.P.G. (1787-1874)

Gunning, J.W. (1827-1900)

Haakma Tresling, Th. (1834-1907)

Hall, F.A. baron van (1791-1866)

Hallier, E. (1831-1904)

Hanegraaf, C.D.L. (1819-1880)

Hanlo, J.G.M. (1831-1897)

Hanou Jzn., J. (1811-1881)

Harbaur, F.J. (1760-1824)

Harting, P. (1813-1885)

Hasselt, A.W.M. van (1814-1902)

Haussmann, G.E. baron (1809-1891)

Heemskerk Azn., J.H. (1818-1897)

Heemstra, S. baron van (1807-1864)

Heije, J.P. (1809-1876)

Hendriksz, P. (1779-1843)

Hengel, J. van (1811-1892)

Henle, F.G.J. (1809-1885)

Hesselink, H.G. (1836-1901) 
Heusde, A.C. van (1816-1899)

Heynsius, A. (1831-1885)

Heynsius, C.E. (1822-1880)

Hippocrates (460-370 v.Chr.)

Hirsch, A. (1817-1892)

Hoeven, J. van der (1802-1868)

Hofstede Crull, P. (1797-1870)

Homoet, J.J. (1818-1908)

Houten, S. van (1837-1930)

Huet, G.D.L. (1831-1891)

Hufeland, C.W. (1792-1836)

Huizinga, D. (1840-1903)

Huizinga, J. Menno (1850-1913)

Idzerda, W.H. (1816-1881)

Imans, M. (1821-1900)

Ingenhousz, A.F.J.(1812-1886)

Isensee, L.Th.E. (1807-1845)

Israëls, A.H. (1822-1883)

Jacobi, H. (1833-1892)

Jenner, E. (1749-1823)

Jonckbloet, W.J.A. (1817-1885)

Kappeyne van de Coppello, J. (1822-1895)

Kapteyn, H.P. (1839-1914)

Keiser, M.J. (1806-1893)

Kempenaer, J.M. de (1793-1870)

Ketwich Verschuur, J.A. (1822-1882)

Kiehl, W.F.P.(1798-1876)

Klep, M.C. (1818-1881)

Koch, R. (1843-1910)

Kock, H.M. baron de (1779-1845)

Korösy, J. (1844-1906)

Koster, W. (1834-1907)

Kuhn, C.H. (1848-1926)

Lespinasse, A.F.H.de (1819-1881)

Leubuscher, R. (1821-1861)

Levoir, L.C.H. (1832-1908)

Lévy, M. (1809-1877)

Liebig, J. von (1803-1873)

Liernur, Ch.T. (1828-1893)

Lister, J. (1817-1912)

Lobatto, R. (1797-1866)

Lodewijk Napoleon, koning (1778-1846)

Loncq jr., C.J. (1815 - ?)

Loncq, G.J. (1810-1887)

Lotsij, J.S. (1808-1863)

Lubach, D. (1815-1902)

Lulofs, H.J. (1806-1875)

Luyten, A. (1815-1899)

Lynden van Sandenburg, C.Th. baron van (1826-1885)

Maanen, F.J. van (1777-1861)

Maas, A. (1811-1869)

Magendie, Fr. (1783-1855)

Man, J.C. de (1818-1909)

Marc, C.C.H. (1771-1841)

Merkus Doornik, J.J.F.H.T.(1825-1906) 
Meursinge Hzn., A. (1819-1893)

Modderman, A.E.J. (1838-1885)

Molewater, J.B. (1813-1864)

Moll, A. (1786-1843)

Mulder; G.J. (1802-1880)

Nägeli, C.W. von (1817-1891)

Napoleon III, keizer (1808-1873)

Neumann, S. (1819-1908)

Nieuwenhuys, C.J. (1775-1837)

Nuijens, W.J.F.(1823-1894)

Oesterlen, Fr. (1812-1877)

Onnen, M.F. (1809-1877)

Oosterbaan, G. (1884-1926)

Overbeek de Meijer, G. van (1831-1918)

Pacini, F. (1812-1883)

Pappenheim, L. (1818-1875)

Parent-Duchâtelet, A. (1780-1836)

Pasteur, L. (1821-1895)

Patissier, P. (1791-1863)

Penn, J. (1821-1890)

Pennink, J.J. (1795-1877)

Pettenkofer, M. von (1818-1901)

Pijnappel, M.W. (1854-1921)

Plantenga, B.P.B. (1870-1955)

Polijn Büchner, H. (1814-1887)

Post, A.E. (1841-1917)

Potgieter, E.J. (1808-1875)

Pous Koolhaas, C.P. (1831-1893)

Pruys van der Hoeven, C. (1792-1871)

Quetelet, L.A.J.(1796-1874)

Ramaer, J.N. (1817-1887)

Rammzzini, B. (1633-1714)

Rappard, jhr. A.G.A.van (1799-1869)

Reenen, G.C.J. van (1818-1893)

Remak, R. (1815-1865)

Riehm, C.H. (1822-1852)

Ringeling, H.G. (1856-1931)

Roëll, C.C. (1814-1863)

Rogier, Ch. (1800-1885)

Rokitansky, C. (1804-1878)

Rombach, K.A. (1812-1891)

Roosenburg, J. (1823-?)

Royen, I.A. van (1800-1868)

Ruys van Beerenbroek (na 1895 Ruys de Beerenbrouck), jhr. G.L.M.H. (1842-1926)

Ruysch, W.P. (1847-1920)

Saint-Simon, H. de (1760-1825)

Saltet, G.H. (1825-1858)

Saltet, R.H. (1853-1927)

Sarphati, S. (1813-1866)

Scheltema Beduin, L. (1833-1892)

Schermbeek, Th.A. van (1810-1882)

Schick, J.W. (1818-1853)

Schimmelpenninck van der Oye van der Poll, W.A. baron (1800-1872)

Schleurholts, L.T. (1806-1870) 
Schnurrer, F. (1784-1833)

Schrant, J.M. (1823-1864)

Schwann, Th. (1810-1882)

Simon, J. (1816-1904)

Simons, G. (1802-1868)

Sitter, W. de (1820-1889)

Six, jhr. W. (1829-1908)

Snabilie, L.P.J.(1797-1865?)

Snellen, H. (1834-1908)

Snoep, J.P. (1815-1882)

Snow, J. (1813-1858)

Sonsbeeck, H. van (1796-1865)

Southwood Smith, Th. (1788-1861)

Staring, W.C.H. (1808-1877)

Stokvis, B.J. (1834-1902)

Stork, H.W. (1808-1877)

Stratingh Tresling, S. (1831-1897)

Stratingh, S.E. (1833- ?)

Straub, M. (1855-1916)

Suringar, G.C.B. (1802-1874)

Süssmilch, J.P. (1708-1767)

Swinderen, Th. van (1784-1851)

Sybrandi, N.D. (1816-1886)

Sydenham, Th. (1624-1689)

Szokalski, V.F. (1811-1891)

Tets van Goudriaan, jhr. J.G.H. van (1812-1885)

Teixeira de Mattos, I. (1821-1904)

Thackrah, C.T. (1795-1833)

Thiersch, K. (1822-1895)

Thorbecke, J.R. (1798-1872)

Thijssen, H.F. (1830-1915)

Tienhoven, G.P. van (1836-1901)

Tillanus, C.B. (1796-1870)

Tillanus, J.W.R. (1823-1914)

Tour van Bellinchave, M.W. du (1835-1908)

Varrentrapp, J.G. (1809-1886)

Verspijck, H.L. (1825-1902)

Verwey, L.H. (1816-1875)

Villemin, J.A. (1827-1892)

Villermé, L.R. (1792-1863)

Virchow, R. (1821-1902)

Vissering, S. (1818-1888)

Vogt, K. (1817-1895)

Voit, K. von (1831-1908)

Vollenhoven, C. (1778-1849)

Voorhelm Schneevoogt, G.E. (1814-1871)

Vries Reilingh, D. de (1800-1879)

Vries Robbé, A.A.C. de (1814-1881)

Vrolik, W. (1801-1863)

Westerhoff, R. (1801-1874)

Willem I, koning (1772-1843)

Willem II, koning (1792-1849)

Willem III, koning (1817-1890)

Willems, J.J. (1834-1869?)

Wintgens, W. (1818-1895)

Witt Hamer, H.M. de (1811-1895)

Wurfbain, C.L. (1837-1904)

Zeeman, J. (1824-1905) 
Eddy Houwaart werd geboren op 12 februari 1953 te 's-Gravenhage. Na het Gymnasium B studeerde hij geneeskunde in Groningen waar hij in 1981 zijn artsdiploma behaalde. In 1983 voltooide hij de opleiding tot huisarts.

Van 1983 tot 1989 is hij als wetenschappelijk assistent verbonden geweest aan het Instituut voor de Geschiedenis der Geneeskunde van de Katholieke Universiteit Nijmegen.

Vanaf 1989 is hij werkzaam als Universitair Docent bij de vakgroep Geschiedenis van de Faculteit der Algemene Wetenschappen van de Rijksuniversiteit Limburg.

Hij publiceerde in verschillende tijdschriften op het terrein van de geschiedenis der geneeskunde en van de sociale geneeskunde. Sinds 1983 is hij secretaris van de Stichting Gezondheid en Politiek die verantwoordelijk is voor de uitgave van het Tijdschrift voor Gezondheid en Politiek. 